UNITED STATES DEPARTMENT OF THE INTERIOR

J. A. Krug, Secretary

GEOLOGICAL SURVEY

W..E. Wrather, Director

Professional Paper 210

\title{
SHORTER CONTRIBUTIONS TO GENERAL GEOLOGY
}

1946

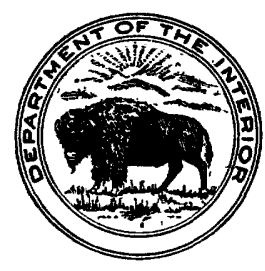

UNITED STATES

GOVERNMENT PRINTING OFFICE

WASHINGTON : 1947 



\section{CONTENTS}

[The letters in parentheses preceding the titles are those used to designate the individual papers]

(A) Tertiary Foraminifera from St. Croix, Virgin Islands (published in September 1946) September 1946)

(C) Reptilian fauna of the North Horn formation of central Utah (published in January 1947)

(D) Bulimina and related foraminiferal genera (published in $\frac{1}{1947)}$ )

Page

\section{ILLUSTRATIONS} Plates 1-2. Flora of the Forkston coal
3. View of badland area of the North Horn
formation looking toward North Horn formation looking toward North Horn

4. Two views of quarry showing bones in

5-10. Skeletal parts of Alamosaurus sanjuanensis

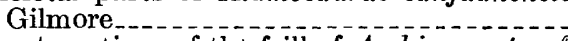

11. Crest portions of the frill of Arrhinoceratops? utahensis Gilmore

12. Median portion of skull of Arrhinoceratops? utahensis_....................... _.

13. Epoccipital bones tentatively referred to Arrhinoceratops? utahensis...........

14. Parts of ceratopsian skull and a hadrosaurian femur. .....................

15. Terebralina, Turritina, and Buliminella....

16. Buliminella.

17. Buliminella, Buliminoides, and Ungulatella.

18. Rohertina and Pseudobulimina-- U

19, 20. Butimina

21. Bulimina and Butiminella

22-28. Bulimina

29. Bulimina, Butimina (Desinobulimina), Neobulimina, Globobulimina

30. Buliminella, Bulimina, Globobulimina.-.-.

31. Fossils from the Avent and McRae wells in Mississippi and a new Venericardia from Uvalde County, Tex

32-33. Fossils from the Avent well in Mississippi- 192, 194
FigURE 1. Generalized geologic map of St. Croix . .....

2. Cross section of central part of St. Croix, showing location of test wells with reference to the geologic features................

3. Reconstruction of Lacoea seriata Read, n. sp., to show gross morphology

4. Chevrons of Alamosaurus sanjuanensis Gil-

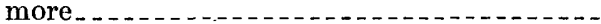

5. Outlines of sternal plates of Alamosaurus sanjuanensis............................

6. Left scapula and coracoid of Alamosaurus sanjuanensis............................

7. Forelimbs of Alamosaurus and Apatosaurus viewed from in front. .............

8. Right humerus of Alamosaurus sanjuanensis viewed from in front. . . . . . . . . .

9. Right radius and ulna of Alamosaurus sanjuanensis shown as found articulated ......

10. Right metacarpus of Alamosaurus sanjuanensis . . . . . . . . . . . . . . . . . . . . . .

11. Coossified ischia of Alamosaurus sanjuanensis viewed from above.

12. Incomplete skull of Arrhinoceratops? utahensis Gilmore viewed from the right side........

13. Geologic map of North Horn area, Emery County, Utah...........................

\section{INSERT}

Distribution of species of Foraminifera in three wells on St. Croix 

UNITED STATES DEPARTMENT OF THE INTERIOR

J. A. Krug, Secretary

GEOLOGICAL SURVEY

W. E. Wrather, Director

Professional Paper 210-A

\title{
TERTIARY FORAMINIFERA FROM ST. CROIX VIRGIN ISLANDS
}

\author{
BY \\ J. A. CUSHMAN \\ WITH \\ A NOTE ON THE GEOLOGY \\ BY \\ D. J. CEDERSTROM
}

Shorter contributions to general geology, 1946

(Pages 1-17)

UNITED - STATES

GOVERNMENT PRINTING OFFICE

WASHINGTON : 1946

For ealo by the Superintendent of Documenta, U. S. Government Printing Office, Washington 25, D. C.

Price 20 cents 
CONTENTS

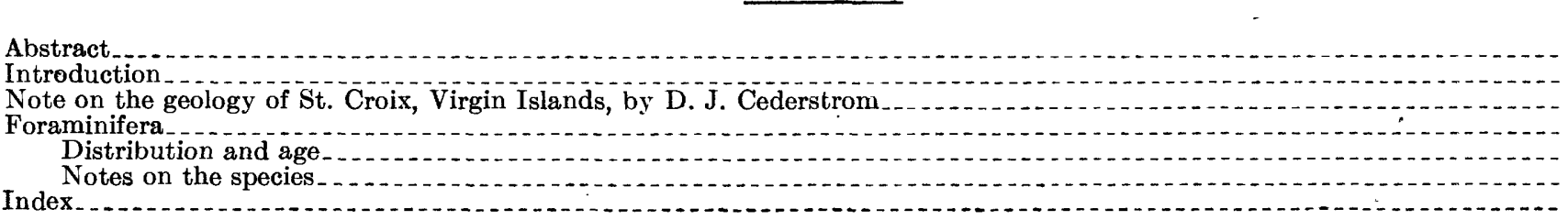
Page

Abstract

Cederstrom

Note on the geology of St. Croix, Virgin Islands, by D. J. Cederstrom

Distribution and age

\section{ILLUSTRATIONS}

FIG URE 1. Generalized geologic map of St. Croix

Page

2. Cross section of central part of St. Croix, showing location of test wells with reference to the geologic features...

\section{INSERT}

Distribution of species of Foraminifera in three wells on St. Croix 


\title{
Tertiary Foraminifera from St. Croix, Virgin Islands
}

\author{
By J. A. Cushman
}

\section{ABSTRACT}

This paper records the Foraminifera found in three wells drilled on the island of St. Croix, V. I. The spc cies and varieties found total 103 forms, of which 5 were originally described from this material. Two of the wells and the upper part of the third appear to eut Miocene rocks. The lower part of the third well appears to have reached Oligocene rocks.

\section{INTRODUCTION}

This paper is based on the Foraminifera found in the cuttings from three test wells drilled in the winter of 1938-39 on the island of St. Croix, V. I. These wells were drilled as part of a program of test drilling for ground water financed by the Public Works Administration and were located on lands owned by the United States Government that have been put to economic use by the Virgin Islands Co., a quasi-government corporation. The wells were drilled by the rotary, clay-seal method, and much mixing of material from lesser depths with that of greater depths has taken place. It is believed, however, that valuable data have been obtained from the cuttings and that the results are well worth recording.

The geographic and geologic setting of the wells is described by D. J. Cederstrom, of the Geological Survey, who made a study of the geology and groundwater conditions of the island, supervised the test drilling, and collected the cuttings on which this paper is based.

\section{NOTE ON THE GEOLOGY OF ST. CROIX, VIRGIN ISLANDS}

\section{By D. J. Cederstrom}

The island of St. Croix lies about 95 miles southsoutheast of San Juan, P. R., and is one of the Virgin Islands group, of which St. Thomas, St. John, and St. Croix belong to the United States. The island is about 21 miles long. The western part is about 6 miles wide, but the eastern part tapers to a width of less than 1 mile at the eastern end.

The western part of the island is made up of a mountainous area on the north and a rolling plain on the south. The eastern part of the island is mountainous. (See fig. 1.) The mountainous areas are composed of limestones, breccia, tuff, and volcanic flows of Cretaceous age, strongly folded, metamorphosed, and intruded by dioritic rocks of early Tertiary(?) age. The rolling plain flanking the northern range of mountains is underlain by Tertiary sediments chiefly soft white or creamy marls with intercalated somewhat more consolidated thin-bedded white limestone strata. These beds are gently folded along axes that trend west-southwest. The test drilling revealed that these limy strata are underlain by a gray clay and included limestone conglomerate whose maximum thickness is unknown. ${ }^{1}$ In test well No. 1 , the location of which is shown in figure 1, a thickness of 1,400 feet of this formation was penetrated. In test well No. 2 the gray clay is underlain by a basal limestone conglomerate, as shown in the accompanying $\log$ of the well and in the diagram, figure 2 .

The older Upper Cretaceous rocks making up the mountainous areas, referred to by $K e m p^{2}$ as the Mount Eagle series, are referred to now as the Mount Eagle volcanics. The marly Tertiary rocks exposed at, the surface of the rolling plain were named the Kingshill series by Kemp. ${ }^{3}$ They are now referred to as the Kingshill marl. The dark clays and included conglomeratic material found below the light colored Kingshill marl have been named by the writer ${ }^{4}$ the Jealousy formation.

Much has been written on the geology of St. Croiv. by Danish, German, Swedish, and American geologists. Most of the reports written before 1927 are reviewed. by Kemp in the publication referred to above. The report by Vaughan ${ }^{5}$ on the stratigraphy. of St. Croix is of especial interest to students of paleontology. Foraminifera and other fossils are listed in his report that were found in samples taken from outcrops at Evening: Hill and Montpelier, 1 mile and 3 miles, respectively, northwest of Christiansted; at Annas Hope, 2 miles southwest of Christiansted; and near Wheel of Fortune Estate, 1 mile south of Frederiksted. Vaughan found that the strata at Evening Hill and Montpelier are probably late Oligocene in age, although they may possibly be assigned to early Miocene. At Annas Hope the horizon was determined to be very low in the Miocene, and near Wheel of Fortune the strata were assigned tc the middle Oligocene.

The main geologic features of the island of St. Croix are outlined.in two papers. ${ }^{6}$

\footnotetext{
1 Cederstrom, D. J., Notes on the physiography of st. Croix, V. I.: Am. Jour. Sci., vol. 239, pt. 2, No. 8, pp. 553-576, 1941.

Kemp, J. F., Introduction and review of the literature on the geology of the

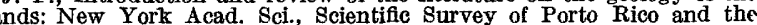
Virgin Islands, vol. 4, pt. 1, p. 49, 1926.

o Cederstrom, D..J., op. cit., p. 557, the Virgin Islands of the United States and of Culebra and Vieques Islands, and notes on eastern Porto Rico: Washington Acad. Sci Jour. vol, 13, pp 303-317, 1923 .

Cederstrom, D. J., Notes on the physiography of St. Croix, V. I.: Am. Jour. Sci., vol. 239, pt. 2, No. 8, pp. 553-576, 1941; Geology and ground-water resourees of St. Croix, V. I.: U. S. Ceol. Survey Water-Supply Paper-(in preparation).
} 


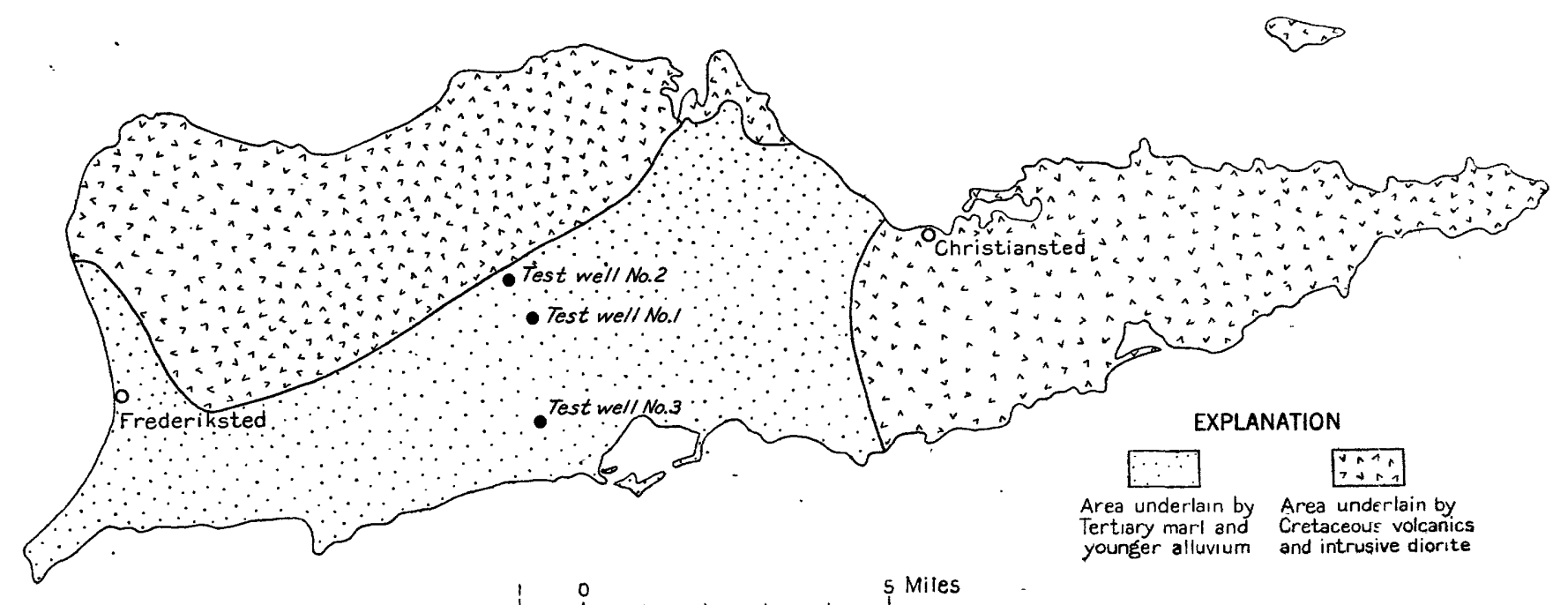

FIQURE 1,-Generalized geologic map of St. Croix, V, I.

The logs of the three wells, from which the material used in this paper were derived, are as follows:

Test well No. 1, 500 yards east-northeast of Bethlehem

\begin{tabular}{|c|c|c|}
\hline & $\begin{array}{c}\text { Thickness } \\
\text { (feet) }\end{array}$ & $\begin{array}{c}\text { Depth } \\
\text { (feet) }\end{array}$ \\
\hline Yellow marl_ & 18 & $0-18$ \\
\hline arse sand. & 4 & $18-22$ \\
\hline$x=$ & 3 & 22 \\
\hline llow marl & 83 & $25-108$ \\
\hline $\begin{array}{l}\text { Greenish gray clay (thin, hard Jayers of } \\
\text { limy rock at } 728,732,762,770,778 \text {, and }\end{array}$ & & \\
\hline onglomerate-boulders of older, hard rock & 987 & $108-1,095$ \\
\hline on & 16 & 1,09 \\
\hline ray cla & 85 & $1,111-1,196$ \\
\hline $\begin{array}{l}\text { onglomerate } \\
\text { ray clay, with hard streaks at } 1,291\end{array}$ & 5 & $1,196-1,201$ \\
\hline ind $1,448 \mathrm{ft}$. & 305 & $1,201-1,506$ \\
\hline
\end{tabular}

Test well No. 2, 300 yards west of great-house at Jealousy

Yellow marl (contains hard, limy layers, each a few inches in thickness, at 81, 83, 84,85 , and $88 \mathrm{ft}$.) . . 91

Gray clay

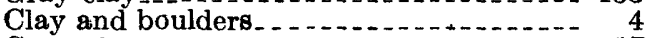

Gray clay

Gray and black clay containing a considerable amount of rounded pebbles and small boulders ............... 10

Gray clay containing a variable but small amount of sand and pebbles........... 143

Hard limestone conglomerate............ 61

Hard basement rock. . . . . . . . . . . . . . . 11

$0-91$
$91-224$
$224-228$
$228-245$

$245-255$

$255-398$
$398-459$
$459-470$

Test well No. 8, at Fair Plain, five-eighths of a mile west of Anguilla

Fine sand, gradually becoming a coarse gravel with depth Clay, somewhat sandy or gravelly Coarse sand and gravel (water bearing) -.Sand and gravel (water bearing)

Yellowish marl

Limestone . . . . . .

Yellowish to white marl

Limestone and marl

Yellowish marl

Blue clay
0-33

$33-57$

$57-62$

62-70

70-73

73-162

162-167

$167-185$

185-195

195-208

208-225

\section{FORAMINIFERA}

\section{By J. A. Cushman \\ DISTRIBUTION AND AGE}

Foraminifera are numerous in the wel' cuttings, 103 forms having been recognized. As noted above, the manner of drilling of the three wells ras such that much mixing of materials was possible. Only the level of first appearance of a species is therefore significant, that is, the highest level in the wells, for lower appearances may be merely the effect of mixing.

The distribution of the species in each well is shown on the accompanying chart. On the following pages notes are given on the distribution of the species in the samples, and their known occurrences elsewhere for comparison.

The age of the samples from test well No. 2 and test well No. 3 and from the upper part of tast well No. 1 seems to be definitely Miocene. The low er part of test well No. 1 contains species that are known to occur particularly in the Oligocene, and from these species it is inferred that the well penetrated the Oligocene.

\section{NOTES ON THE SPECIES \\ Family TEXTULARIIDAE \\ Genus TEXTULARIA Defrance, 1824}

Textularia leuzingeri Cushman and Renz

Textularia leuzingeri Cushman and: Renz, Cushman Lab. Foram. Research Contr., vol. 17, p. 3, pl. 1, figs. 2a-c, 1941.

Cushman and Stainforth, Cushman Lab. Foram. Research Special Pub. 14, p. 15, pl. 1, figs. 19, 20, 1945.

Cushman and Todd, Cushman Lab. Joram. Research Special Pub. 15, p. 3, pl. 1, figs. 6a, b, 1945.

Test of medium size, broadly rounded at the initial end, sides in the adult nearly parallel, strongly compressed toward the periphery, which is subacute; chambers numerous, low and broad, the early ones indistinct, later ones with the anterior pcrtions strongly raised, concave posteriorly; sutures indistinct, nearly straight, oblique; wall rather coarsely arenaceous, surface somewhat roughened; aperture a n rounded opening in the median line at the base of the apertural face. Length, $0.60-0.90 \mathrm{~mm}$; breadth 0.45-0.50 mm.; thickness $0.25 \mathrm{~mm}$. 

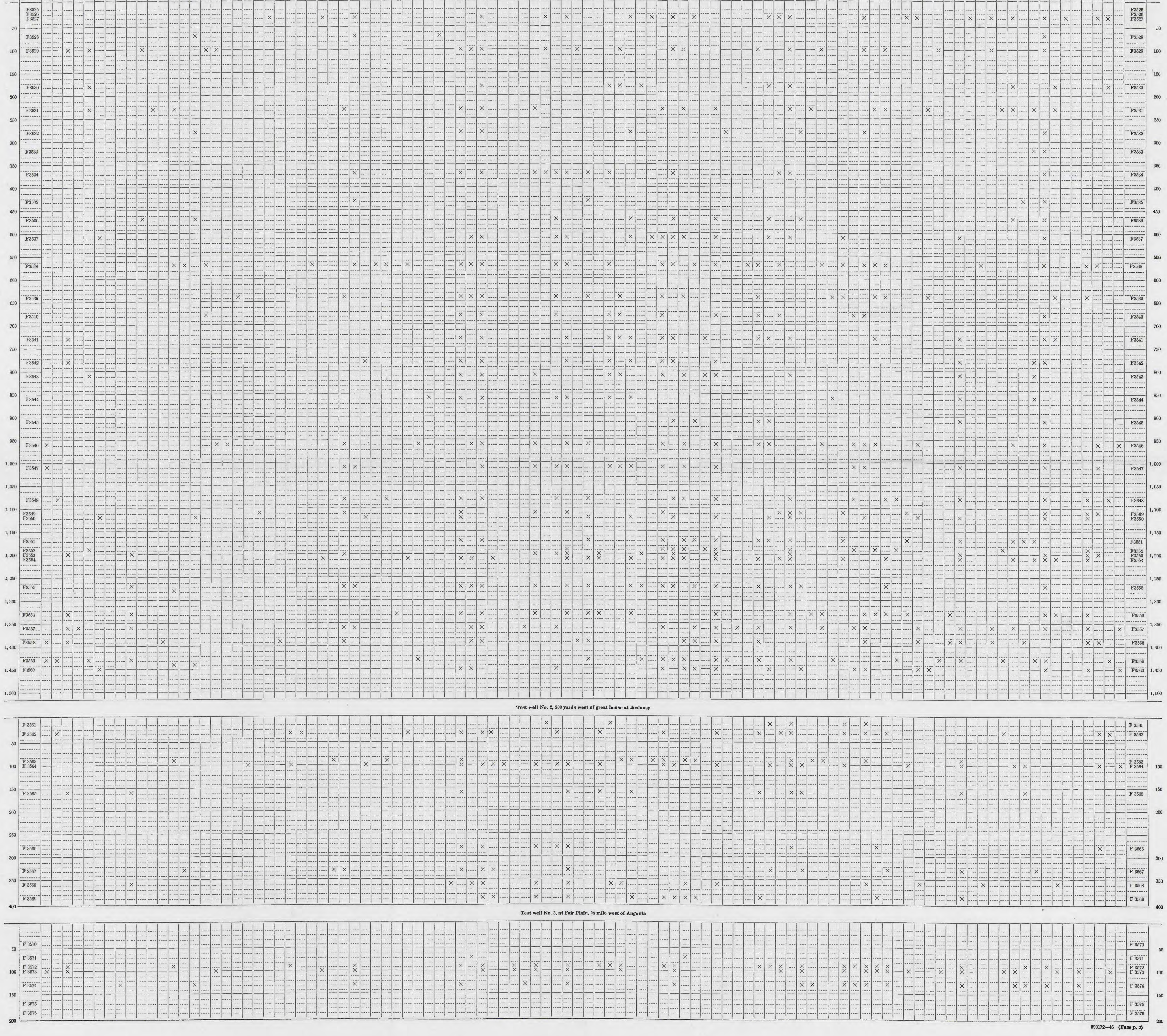


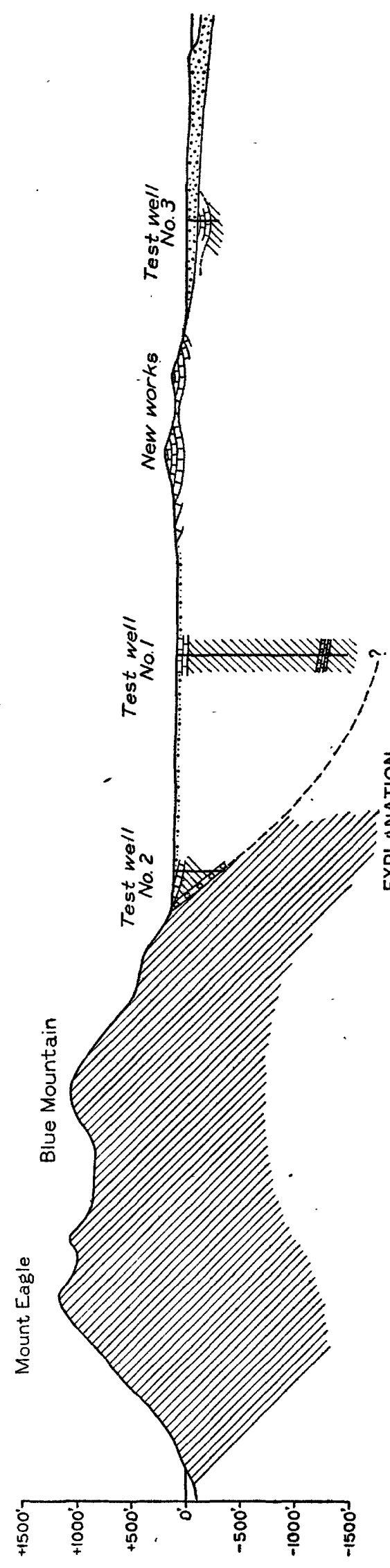

Specimens referable to this species, described from Venezuela, are rare in test well No. 1 at $960,1,02$ ?, 1,390 , and 1,430 feet and in test well No. 3 at 100 feet. The species occurs in Venezuela in beds ranging from the upper Oligocene to the middle Miocene, in t] $\mathrm{e}$ Oligocene Cipero formation of Trinidad, and in the Miocene of Buff Bay, Jamaica.

\section{Genus VULVULINA D'Orbigny, 1826}

Vulvulina spinosa Cushman var. miocenica Cushman

Vulvulina spinosa Cushman var. miocenica Cushman, Cushman Lab. Foram. Research Contr., vol. 8, p. 80, pl. 10, fig. $10,1932$.

Coryell and Rivero, Jour. Paleontology, vol. 14, p. 325, pl. 41, fig. 1, 1940 .

Cushman and Todd, Cushman Lab. Foram. Researeh Special Pub. 15 , p. 4 , pl. 1, fig. 10, 1945 .

Vulvulina capreolus Cushman [not D'Orbigny], Cushman Lab. Foram. Research Contr., vol. 5, p. 80, pl. 12, fig. 6, 1929.

Vulvulina capreolus D'Orbigny var. spinosa Nuttall, Jour. Paleontology, vol. 6, p. 6, 1932.

This variety occurs in the Miocene of Jamaica, Haiti, Trinidad, Venezuela, and Ecuador. It is present in test well No. 1 at 1;090 and 1,430 feet. A single immature specimen from test well No. 2 at 30 feet may belong to this variety.

\section{Family VALVULINIDAE \\ Genus KARRERIELLA Cushman, 1933}

Karreriella bradyi (Cushman)

Karreriella bradyi Cushman, Cushman Lab. Foram. Researoh Special Pub. 8, p. 135, pl. 16, figs. 6-11, 1937.

Coryell and Rivero, Jour.'Paleontology, vol. 14, p. 326, pl. 43, fig. 5, 1940 .

Franklin, Jour. Paleontology, vol. 18, p. 307, pl. 44, fịs. $16 a, b, 1944$.

Cushman and Todd, Cushman Lab. Foram. Research Special Pub. 15, p. 8, pl. 1, fig. 20, 1945.

Gaudryina pupoides H. B. Brady [not D'Orbigny], Challenger Rept., Zoology, vol. 9, p. 378 , pl. 46, figs. $1-4,1884$.

Gaudryina bradyi Cushman, U. S. Nat. Mus. Bull. 71, pt. 2, p. 67, text figs. $107 \mathrm{a}-\mathrm{c}, 1911$.

Gaudryina globulifera Galloway and Morrey [not Reuss], Bu'. Am. Paleontology, vol. 15 , No. 55, p. 33, pl. 5, figs. 3, 4, 1929.

This species is widely distributed and ranges from th ? Oligocene to the Recent. The records in the Miocene are from Ecuador, Haiti, Jamaica, and Egypt. In the material from St. Croix it is present in all three wells. Only a few of the references are given above.

\section{Genus SCHENCKIELLA Thalmann, 1942 \\ Schenckiella ef. S. petrosa (Cushman and Bermúdez)}

A single specimen from test well No. 1, at a depth of 1,360 feet, is very similar to this species, described from the Eocene of Cuba and recorded from th: Oligocene of Cuba and Trinidad.

\section{Family MILIOLIDAE \\ Genus QUINQUELOCULINA D'Orbigny, 1826 Quinqueloculina venusta Karrer}

Quinqueloculina venusta Karrer, Akad. Wiss. Wien Sitzungsbe-. vol. 58 , pt. 1, p. 147, pı. 2, fig. 6,1868 .

Cushman, U. S. Geol. Survey Bull. 676, pp. 23, 70, pl. 28, fig. 3 ; pl. 29, fig. 2, 1918 .

Miliolina venusta (Karrer) H. B. Brady, Challenger-Rep+., Zoology, vol. 9, p. 162, pl. 5, figs. 5, 7, 1884 .

Flint, U. S. Nat. Mus. Rept. for 1897, p. 289, pl. 44, fig. 2, 1899. 
This species has already been recorded from the Miocene of the eastern Coastal Plain region of the United States. It is present in test well No. 1 at depths ranging from 100 to 1,430 feet.

Quinqueloculina seminula (Linné)

This species has been widely recorded. Single specimens from test well No. 1, at 1,120 and 1,450 feet, may be referred to it.

\section{Quinqueloculina lamarckiana D'Orbigny}

A single slightly broken specimen with angular periphery is similar to this species.

\section{Genus SPIROLOCULINA D'Orbigny, 1826}

Spiroloculina obscura Cushman and Todd

Spiroloculina grateloupi D'Orbigny [not Terquem, 1878], Annales sci. nat., vol. 7, p. 298, 1826.

Terquem, Soc. géol. France Mém., 3d ser., vol. 2, p. 155, pl. 16 (24), figs, 6 a, b, 1882.

Fornasini, Accad. sci. Ist. Bologna Mem., ser. 6, vol. 1, p. 4, pl. 1, figs. 3a, b, 1904 .

Spiroloculina obscura Cushman and Fodd, Cushman Lab. Foram. Research Special Pub. 11, p. 20, pl. 1, figs. 8a, b; pl. 3, figs. 22-25, 1944.

This species was named from the Miocene of France and also recorded from the Eocene of France. A single specimen from test well No. 1 at 520 feet is of the general form of this species.

\section{Genus SIGMOILINA Schlumberger, 1887}

Sigmoilina schlumbergeri A. Silvestri

A single specimen from test well No. 3 at 130 feet is typical. The species has been recorded from the Miocene of Haiti by Coryell and Rivero (Jour. Paleontology, vol. 14, p. 324, 1940) and the Miocene of Jamaica by Palmer (Bull. Am. Paleontology, vol. 29, No. 115, p. 31,1945 ) and by Cushman and Todd (Cushman Lab. 'Foram. Reseârch Special Pub. 15, p. 11, pl. 2, fig. 3, 1945).

\section{Genus TRILOCULINA D'Orbigny, 1826}

\section{Triloculina gracilis D'Orbigny}

Triloculina gracilis D'Orbigny, in De la Sagra, Historia física, política y natural de la isla de Cuba, Foraminifères, $p$. 181 , pl. 11, figs. 10-12, 1839 .

Cushman, Carnegie Inst. Washington Pub. 311, p. 74, 1922; U. S. Nat. Mus. Bull. 104, pt. 6, p. 59, pl. 14, figs. 4a-c, 1929 .

Cushman and Wickenden, U. S. Nat. Mus. Proc., vol. 75, art. 9, p. 3, pl. 1, figs. 3a-c, 1929 .

Cushman and Ponton, Florida Geol. Survey Bull. 9, p. 53, pl. 6, figs. 8, 9, 1932 .

Slender specimens referred to this species are present in test well No. 1 from 1,200 to 1,430 feet and in test well No. 2 at 160 and 360 feet. The species was originally described from the West Indian region, and it has been recorded from the Miocene Chipola formation of Florida.

\section{Genus PYRGO Defrance, 1824}

\section{Pyrgo depressa (D'Orbigny)}

This is a species of rather deep, cool waters. Single typical specimens are present in material from test well No. 1 at 100 and 480 feet. It occurred also in late
Tertiary material from the Georges Bank in the western Atlantic Ocean (Cushman, Geol. Soc. America Bull., vol. 47 , p. 430 , pl. 4 , fig. 10,1936 ).

\section{Pyrgo murrhina (Schwager)}

Biloculina murrhina Schwager, Novara-Exped., Geol. Theil, vol. 2, p. 203, pl. 4, figs. $15 \mathrm{a}-\mathrm{c}, 1866$.

Pyrgo murrhina Cushman, U. S. Nat. Mus. F ill. 104, pt. 6, p. 71 , pl. 19, figs. $6,7,1929$.

Cushman and Jarvis, Jour. Paleontology, vol. 4, p. 357, pl. 32, figs. 7a, b, 1930 .

Coryell and Rivero, Jour. Paleontology, vo' 14, p. 324, pi. 43 , fig. 9, 1940.

Cushman and Stainforth, Cushman Lab. Foram, Research Special Pub. 14, p. 21, pl. 2, fig. 22, 1945.

Cushman and Todd, Cushman Lab. Foram. Research Special Pub. 15, p. 12, pl. 2, fig. 5, 1945.

This is another species of fairly deep vrater. It has already been recorded from the Miocene of Jamaica and Haiti and the Oligocene of Trinidad.

\section{Family LAGENIDAE \\ Genus ROBULUS Montfort, 1808}

A few specimens of Robulus, nearly all of them young stages and therefore difficult to identify with any degree of certainty, are perhaps referable to $R$. americanus (Cushman), and one or two others to $R$. catenulatus (Cushman).

\section{Genus PLANULARIA Defrance, 1894}

Planularia cf. P. venezuelana Hedh erg

This species was described from the upper Oligocene of Venezuela. A single specimen was found in the sample from test well No. 1 at a depth of 1,390 feet.

\section{Genus MARGINULINA D'Orbigny, 1826 \\ Marginulina glabra D'Orbigny}

A number of specimens may be referred to this species, and as usual the specimens show a wide $r \cdot$ nge of variation. In test well No. 1 the specimens were found at depths of $230,520,1,270$, and 1,430 feet; in test well No. 2 at 90 feet; and in test well No. 3 at 90 feet.

\section{Marginulina cf. M. dubia Neugeboren}

A specimen from test well No. 1 at 590 feet seems fairly typical; another from test well No. 2 at 330 feet is less typical. The species has been recorded from the Miocene of Florida and elsewhere.

\section{Genus DENTALINA D'Orbigny, 18ra \\ Dentalina communis D'Orbigny}

In the Florida Miocene this species seems confined to the Choctawhatchee formation. It occurs also in the Miocene Gatun formation of the Panama Canal Zone and in the Miocene of Buff Bay, Jamaica. In test well No. 1 the occurrences are at $70,280,480$, 1,120 , and 1,430 feet, and in test well No. 3, at 130 feet.

Dentalina consobrina D'Orbigny var. emaciata Reuss

Records include the Miocene Shoal River formation of Florida and Yorktown formation of Vir rinia. Specimens are present in test well No. 1 at 100,580 , and 690 feet. 
Dentalina cf. D. mucronata Neugeboren

Specimens resembling this species are from test well No. 1 at 100 and 920 feet and test well No. 3. at 100 feet.

Dentalina cf. D. isidroensis Cushman and Renz

A single incomplete specimen from test well No. 1, at 960 feet, closely resembles this species, described from the Miocene of Venezuela.

\section{Genus NODOSARIA Lamarck, 1812}

Nodosaria vertebralis (Batsch)

A single typical megalospheric specimen from test well No. 1 at 640 feet is the only record from these wells.

Genus PSEUdograndolina Cushman, 1929

Pseudoglandulina laevigata (D'Orbigny) var. occidentalis Cushman

A single specimen from test well No. 2 at 100 feet is the only representative of this variety. It has been recorded from the late Tertiary of Georges Bank, in the western Atlantic Ocean.

\section{Pseudoglandulina gallowayi Cushman}

Records for this species include the Miocene of Ecuador, Trinidad, and California and the Oligocene of Trinidad. A single specimen was found in test well No. 1 at 1,110 feet.

\section{Genus SARACENARIA Defrance, 1824}

Saracenaria acutauricularis (Fichtel and Moll)

This species is known from the Miocene of Trinidad, Venezuela, and Haiti, and from the Miocene Choctawhatchee and Shoal River formations of Florida. The only specimen in the present material is from test well No. 1 at 24 to 30 feet.

\section{Genus LINGULINA D'Orbigny, 1826}

\section{Lingulina seminuda Hantken}

This species has been recorded from the Miocene of Buff Bay, Jamaica. A single specimen was found in test well No. 1 at a depth of 1,390 feet.

\section{Genus LAGENA Walker and Jacob, 1798}

A number of species of this genus, mainly represented by single specimens, were found in the material from St. Croix. Larger series of most of them are needed to show possible variation, and they are not here specifically identified.

\section{Family POLYMORPHINIDAE}

Genus GUTTULINA D'Orbigny, 1839

\section{Guttulina irregularis (D'Orbigny)}

Globulina irregularis D'Orbigny, Foraminifères fossiles du bassin tertiaire de Vienne, p. 226, pl. 13, figs. 9, 10, 1846.

Guttulina irregularis Cushman and Ozawa, U. S. Nat. Mus. Proc., vol. 77, art. 6, p. 25, pl. 3, figs. 4, 5: pl. 7, figs. 1, 2, 1930.

Cushman, Florida Geol. Survey Bull. 4, p. 33, 1930.

Cushman and Ponton, Florida Geol. Survey Bull. 9, p. 64 , pl. 9, figs, $10-12,1932$.

Cushman, U. S. Geol. Survey Prof. Paper 181, p. 24, pl. 9, figs. 13-16, 1935 .

This species has been recorded from the Miocene of Florida as well as from most of the Tertiary of the Gulf
Coastal Plain area. It is present in test well No. 2 at depths of 30 and 100 feet and in test well No. 3 at a depth of 90 feet.

\section{Guttulina lactea (Walker and Jacob)}

(For references to this species see Cushman and Ozawa, U. S. Nat. Mus. Proc., yol. 77, art. 6, p. 43, 1930.)

This widely distributed species has been recorded from the Miocene of Florida (Cushman and Ponton, Florida Geol. Survey Bull. 9, p. 65, pl. 9, figs. 15a, b, 1932), where it occurs in the Shoal River and Chipola formations. The only occurrence in the St. Croix material is in test well No. 2 at a depth of 30 feet.

\section{Guttulina caudata D'Orbigny}

This species, like the preceding, has been recorded from the Miocene of Florida, from both the Shoal River and Chipola formations (Cushman and Ponton, Florida Geol. Survey Bull. 9, p. 65, pl. 9, figs. 16, 17, 1932). It is present in test well No. 1 at a depth of 580 feet.

\section{Genus PYRULINA D'Orbigny, 1839}

\section{Pyrulina albatrossi Cushman and Ozawa}

Pyrulina albatrossi Cushman and Ozawa, U. S. Nat. Mus. Proc., vol. 77, art. 6, p. 58, pl..15, figs. 1-3, 1930 .

Cushman, Florida Geol. Survey Bull. 4; p. 34, 91. 5, firs. $17,18,1930$.

Cushman and Ponton, Florida Geol. Survey Bull. 9, p. 66, 1932.

Cushman and Cahill, U. S. Geol. Survey Prof. Paper 175-A, p. 18, pl. 6, figs. 5a, b, 1933.

This species is known from the Miocene of the Coastal Plain region of the United States. The types are Recent from a station off Cuba.

\section{Genus PSEUDOPOLYMORPHINA Cushman and Ozawa, 1928}

Pseudopolymorphina dumblei (Cushman and Applin)

Polymorphina compressa D'Orbigny var. dumblei Cushman and Applin, Am. Assoc. Petroleum Geologists Bull., vol. 10, p. 173, pl. 9, figs. 4, 5, 1926.

Pseudopolymorphina dumblei Cushman and Ozawa, U. S. Nat. Mus. Proc., vol. 77, art. 6, p. 97, pl. 25, figs. 1a, b, 1930. Cushman, Florida Geol. Survey Bull. 4, p. 35, pl. 6, fig. 5, 1930.

Cushman and Ponton, Florida Geol. Survey Bull. 9, p. 67, 1932 .

Ellisor, Am. Assoc. Petroleum Geologists Bull., vol. 17, no. 11, pl. 7, fig. 2, 1933.

Cushman and Cahill, U. S. Geol. Survey Prof. Paper 175-A, p. 19, pl. 6, figs. $10 \mathrm{a}, \mathrm{b}, 1933$.

Cushman, U. S. Geol. Survey Prof. Paper 181, p. 29, pl. 10, figs. 14, 15, 1935.

Although first described from Eocene deposits, in which it is found at various localities, the form also occurs in the Miocene Shoal River and Chipola formations of Florida, and in the Miocene St. Marys and Calvert formations of Maryland. It was found in material from test well No. 2 at depths of 90 and 330 fest.

\section{Family NONIONIDAE}

Genus NONION Montfort, 1808

\section{Nonion pompilioides (Fichtel and Moll)}

(For references see Cushman, U. S. Geol. Survey Prof. Paper 191$, p. $19,1939$.

This species is recorded from the Miocene of Ecuador, Venezuela, Trinidad, and Haiti, from the late Tertiary 
of Georges Bank in the western Atlantic Ocean, and from the American Pliocene and Oligocene. Specimens are present in samples from test well No. 1 at depths of 230 to 1,390 feet and from test well No. 3 at 330 feet.

Nonion affine (Reuss)
(For references see Cushman, U. S. Geol. Survey Prof. Paper
191, p. 9, 1939.)

This species is common in the Oligocene of Europe and has been recorded from the Miocene of Venezuela and Ecuador. It is also recorded from California in formations of similar age. It occurs in test well No. 1 at depths ranging from 24 to 1,360 feet and in test well No. 3 from 90 to 130 feet.

\section{Nonion grateloupi (D'Orbigny)}

(For references see Cushman, U. S. Geol. Survey Prof. Paper 191, p. 21, 1939.)

This species was described from the West Indian region. In the American Miocene it occurs in the Choctawhatchee, Shoal River, Oak Grove, and Chipola formations of Florida; the Choptank and Calvert formations of Maryland; and the Yorktown formation of Virginia. The specimens from St. Croix are in some features similar to Nonion extensum (Cushman). The few specimens are from test well No. 1 at depths of 780 and 1,120 feet and from test well No. 2 at 100 feet.

Nonion medio-costatum (Cushman)

(For references see Cushman, U. S. Geol. Survey Prof. Paper 191, p. 15, 1939.)

This species, known from the Miocene Monterey shale of California, is represented by a single typical specimen from test well No. 1 at a depth of 580 feet.

Genus ELPHIDIOM Montfort, 1808

Elphidium sagrai (D'Orbigny)

(For references see Cushman, U. S. Geol. Survey Prof. Paper 191, p. 55, 1939.)

This species was originally described from the shore sands of Cuba and is widely distributed in the general West Indian region. It occurs in the Miocene in Cuba, Puerto Rico, and Jamaica; in the Choctawhatchee, Chipola, and Oak Grove formations of Florida; and in the Duplin marl of North Carolina. It is found in test well No. 1 at depths of 580 and 1,090 feet and in test well No. 2 at 90 feet.

\section{Family HETEROHELICIDAE}

\section{Genus PLECTOFRONDICULARIA Liebus, 1903}

Plectofrondicularia jarvisi Cushman and Todd

Plectofrondicularia vaughani Cushman and Jarvis [not Cushman], Jour. Paleontology, vol. 4, p. 361, pl. 33, fig. 4, 1930.

Cushman, Cushman Lab. Foram. Research Special Pub. 5, pl. 26, fig. 27, 1933.

Coryell and Rivero, Jour. Paleontology, vol. 14, p. 341, pl. 42, fig. 28,1940 .

Cushman, Foraminifera, 3rd Ed., Key; pl. 26, fig. 27, 1940. Plectofrondicularia jarvisi Cushman and Todd, Cushman Lab. Foram. Research Special Pub. 15, p. 38, pl. 6, fig. 4, 1945.

This species was described from the Miocene of Buff Bay, Jamaica, and it occurs in the Miocene of Haiti. A typical specimen was found in test well No. 1 at a depth of 1,330 feet.

\section{Plectofrondicularia hedbergi Cushnirn}

Plectofrondicularia californica Hedberg [not Cushman and Stewart], Jour. Paleontology, vol. 11, p. 675, pl. 91, fig. 7, 1937.

Plectofrondicularia hedbergi Cushman, Cushman Lab. Foram. Research Contr., vol. 19, p. 90, pl. 16, fig. 1, 1943.

Test compressed, elongate, sides nearly parallel for most of their length, broad faces flattener or slightly concave, periphery keeled with an additional lateral keel at either side near the margin; chambers numerous, biserial in early stages, uniserial in the adult and increasing rapidly in height, in the adult higher than broad; sutures limbate, slightly depressed; wall smooth, except for a central costa for most of the length of the test and occasionally other less developed ones at each side. Length $0.50-0.60 \mathrm{~mm}$; breadth $0.20 \mathrm{~mm}$.

This species, . described from the upp $\mathrm{r}$ Oligocene Carapita formation of Venezuela, has b?en confused with Plectofrondicularia californica Cushman and Stewart. It differs from that species in the smaller size, nearly parallel sides throughout, more elongate median costa, and much higher chambers.

Specimens comparable to those from Venezuela were found in test well No. 1 at 580 and 1,210 feet and test well No. 2 at 30 feet.

\section{Plectofrondicularia sp.}

A few specimens of a species somewhat similar to the preceding but. with a tapering test, lower chambers, more costae, and the broad faces distinctly concave, were found in test well No. 1 at 1,430 feet. Not enough specimens are available to warrant description, although the species appears to be undescribed.

\section{Family BULIMINIDAF}

Genus BUITMINELLA Cushman, 1811

Buliminella subfusiformis Cushman

This species was described from the Miocene of California, but also occurs in the Miocene Choctawhatchee, Shoal River, and Oak Grove frrmations of Florida, and in the Duplin marl of North Carolina. It is found in test well No. 1 at 870 feet.

\section{Buliminella brevior Cushman}

This species has been known previourly only from the Miocene of California. It occurs in typical form in test well No. 1 at a depth of 70 feet.

\section{Buliminella elegantissima (D'Orbigny)}

This species is known from a wide range in the American Tertiary. It occurs in the Mincene of both the east and west coasts of America. Tl a only record in the present material is from test well No. 2 at 360 feet.

\section{Genus BULIMINA D'Orbigny, $1 \& ? 6$ Bulimina ovula D'Orbigny}

Bulimina ovula D'Orbigny, Voyage dans l'Amérixue méridionale, vol. 5, Foraminifères, p. 51, pl. 1, figs. 10, 11, 1839.

Cushman and Parker (part), Cushman Lab. Foram. Re search Contr., vol. 16, p. 10, pl. 2, figs. 1314 (not fig. 15), 1940 .

This species was described from Recent material off Chile and Peru. It has been recorded from the Mio- 
cene of California and seems to be common in the well samples from St. Croix. Specimens were found in test well No. 1 from 100 feet to the bottom of the well; in test well No. 2 from 30 to 330 feet; and in test well No. 3 from 90 and 130 feet.

\section{Bulimina striata D'Orbigny var. mexicana Cushman}

Bulimina inflata Seguenza var. mexicana Cushman, U. S. Nat. Mus. Bull. 104, pt. 3, p. 95, pl. 21, fig. 2, 1922.

Bulimina inflata Flint [not Seguenza] (part), U. S. Nat. Mus. Rept. for 1897, p. 291, pl. 37, fig. 5, 1899.

Cushman and Jarvis, Jour. Paleontology, vol. 4, p. 362, pl. 33, fig. 5, 1930.

Bulimina striata D'Orbigny var. mexicana Cushman and Parker, Cushman Lab. Foram. Research Contr., vol. 16, p. 16, pl. 3, fig. 9, 1940 .

Cushman and Todd, Cushman Lab. Foram. Research Special Pub. 15, p. 40, pl. 6, fig. 10, 1945.

The types are from an Albatross station in 210 fathoms in the Gulf of Mexico. The variety has been recorded from the Miocene of Buff Bayy, Jamaica. In test well No. 1 it is present from 100 to 1,450 feet, in test well No. 2 at 360 feet, and in test well No. 3 at 62 to 70 feet.

\section{Bulimina alazanensis Cushman}

Bulimina alazanensis Cushman, Jour. Paleontology, vol. 1, p. 161, pl. 25, fig. 4, 1927.

Palmer and Bermúdez, Soc. cubana historia nat. Mem., vol. 10, p. 286, 1936 .

Bermúdez, Soc. cubana historia nat. Mem., vol. 11, p. 341, 1937.

Parker and Bermúdez, Jour. Paleontology, vol. 11, p. 514, pl. 58, figs. 5a-c, 1937.

Cushman and Stainforth, Cushman Lab. Foram. Research Special Pub. 14, p. 40, pl. 6, fig. 2, 1945:

This species was originally described from the Oligocene Alazan shale of Mexico. It is common in the samples from St. Croix. In test well No. 1 it ranges from 24 to 1,390 feet; in test well No. 2 , from 30 to 390 feet; and in test well No. 3, from 90 to 100 feet.

\section{Genus ENTOSOLENIA Ehrenberg, 1848}

\section{Entosolenia marginata (Walker and Boys)}

A number of specimens referable to this species are present in the well samples, from test well No. 1 at 1,210 feet and test well No. 2 at 30, 100, 330, and 390 feet. As usual in any series referred to this species, there is a wide range of variation in the width of the keel.

\section{Entosolenia squamosa (Montagu)}

A single specimen from test well No. 2 at 100 feet is typical.

\section{Entosolenia orbignyana (Seguenza) var. trinitatensis (Nuttall)}

Rather typical specimens of this variety, described by Nuttall from Trinidad, are present in test well No. 3 at 90 and 100 feet.

\section{Entosolenia orbignyana (Seguenza) var. elliptica Cushman}

Well characterized specimens of this variety are present in test well No. 1 at 230,480, and 1,360 feet and in test well No. 3 at 130 feet.

$$
690172-46-2
$$

Entosolenia sp.

Numerous other species, mostly represented by sircle specimens in the St. Croix material, are difficult to identify positively, and are merely noted here.

\section{Genus VIRGUIINA D'Orbigny, 1826}

\section{Virgulina implicata Cushman}

Virgulina implicata Cushman, Cushman Lab. Foram. Research Contr., vol. 19, p. 90, pl. 16, figs. 3a, b, 1943.

Test elongate, slender, strongly twisted; early portion triserial, remainder of the test biserial, slightly fusiform; chambers distinct, slightly inflated, increaring gradually in height as added; sutures distinct, sligl tly depressed; wall smooth, coarsely perforate; apert'1re broadly rounded, at the base of the last-formed chamber. Length up to $0.40 \mathrm{~mm}$; ; diameter $0.12 \mathrm{~mm}$.

This species was described from material from a depth of 230 feet in the Bethlehem Test well No. 1, at a locality 500 yards east-northeast of Bethleham, Island of St. Croix, V. I. It differs from Virgulina delmonteensis Cushman and Galliher in its more slender, more strongly twisted test, and larger, more rounded aperture. It is common in the well samples, in test well No. 1 from 90 feet at intervals to 1,270 feet, and in test well No. 2 at 100, 280,360, and 390 feet.

\section{Genus BOIIVINA D'Orbigny, 1839}

\section{Bolivina tortuosa H. B. Brady}

Bolivina tortuosa H. B. Brady, Quart. Jour. Micr. Sci., vol. 21 , p. 27, 1881; (part), Challenger Rept., Zoology, vo . 9, p. 420 , pl. 52, figs. 31,32 (not figs. 33, 34), 1884 .

Egger, $\mathbf{K}$. bayer, Akad. Wiss., Math.-naturh. Abt., A bh., Kl. 2, vol. 18, pt. 2, p. 298, pl. 8, figs. 43, 44 (part), $18 \lessdot 3$.

Millett, Royal Micr. Soc. Jour., p. 543, 1900.

Chapman, Linnean Soc. Jour., Zoology, vol. 28, p. 187, 1900; p. 382 (list), 1902.

Sidebottom, Royal Micr. Soc. Joùr., 1918, p. 127.

Cushman, Carnegie Inst. Washington Pub. $342, \mathrm{p} .18, \mathrm{pl}$. 5 , figs, $4,5,1924$.

Heron-Allen and Earland, Royal Micr. Soc. Jour., 1924, p. 145; Linnean Soc. Jour., Zoology, vol. 35, p. 621, 1924

Yabe and Hanzawa, Japanese Jour. Geology and Geogranhy, vol. 4, p. 50 (list), 1925 (1926).

Hanzawa, Japanese Jour. Geology and Geography, vcl. 4, p. 40 (table), 1925 (1926).

Macfadyen, Egypt Geol: Survey, 1930, p. 57, 1931.

Cushman and Parker, U. S. Nat. Mus. Proc., vol. 80, art. 3 , p. 16, pl. 3, figs. 22a, b, 1931.

Bermúdez, Soc. cubana historia nat. Mem., vol. 9, p. 195, 1935.

Cushman, Cushman Lab. Foram. Research Special Pub. 9 , p. 133, pl. 17, figs. 11-19, 1937 .

Cushman and MeGlamery, U. S. Geol. Survey Prof. Paper 189-D, p. 107, pl. 25, figs. 13, 21, 1938.

Palmer, Soc. cubana historia nat. Mem., vol. 14, p. 301, 1940.

Cushman, Smithsonian Misc. Coll., vol. 99, no. 9, p. 10, 1941 ; U. S. Nat. Mus. Bull. 161, pt. 3 , p. 20 , pl. 7 , figs. $1 \mathrm{a}, \mathrm{b}, 1942$

Cushman and MoGlamery; U. S. Geol. Survey Prof. Ртрег $197-B$, p. 70,1942 .

Cushman and McCulloch, Allan Hancock Pacific Exped., vol. 6, No. 4, p. 220, pl. 27, figs. 12a, b, 1942.

Macfadyen, Geol. Mag., vol. 79, p. 136 (list), 1942.

Palmer, Bull. Am. Paleontology, vol. 29, no. 115, p. 48, 1945.

Cushman and Todd, Cushman Lab. Foram. Reser.rch Special Pub. 15, p. 44, pl. 7, fig. 6, 1945.

The American records for this species as a fossil are from the Oligocene of Alabama and Cuba and the

\section{$+$}


Miocene of Jamaica. It occurs in the Miocene of Egypt, where numerous other species occur that are identical with those of the Miocene of tropical America.

Specimens are rare but occur in test well No. 1 at depths of 24 to 30,100 , and 370 feet, and in test well No. 2 at a depth of 10 feet.

\section{Bolivina pisciformis Galloway and Morrey}

Bolivina pisciformis Galloway and Morrey, Bull. Am. Paleontology, vol. 15 , no. 55, p. 36, pl. 5, figs. $10 \mathrm{a}$, b, 1929.

Cushman, Cushman tab. Foram. Research Contr., ivol. 5, p. 93, pl. 13, fig. 26, 1929.

Palmer and Bermúdez, Soc. cubana historia nat. Mem.; vol. 10, p. $289,1936$.

Cushman, Cushman Lab. Foram. Research Special Pub. 9, p. 92 , pl. 11, figs. 20,21, 1937.

Kleinpell, Miocene stratigraphy of California, p. 279, pl. 4, fig. 10, Tulsa, 1938.

Renz, 8th Am. Sci. Congress Proc., pp. 546, 553 (lists), 1942.

This species is known from the Miocene of Ecuador, Venezuela, Trinidad, and California and the Oligocene of Cuba and Trinidad. It is present in test well No. 1 from 370 to 1,450 feet and in test well No. 2 from 30 to 280 feet.

Bolivina pisciformis Galloway and Morrey var. optima Cushman Bolivina pisciformis Galloway and Morrey var. optima Cushman, Cushman Lab. Foram. Research Contr., vol. 19, p. 91, pl. 16, figs. 2a, b, 1943 .

The variety differs from the typical form in having the early one-third or one-half of the test with numerous longitudinal costae, the later portion of the test smooth. It was described from material at a depth of 520 feet in the Bethlehem test well No. 1 , at a locality 500 yards east-northeast of Bethlehem, St. Croix, V. I. The main characters of sutures and chambers are like those of typical $B$. pisciformis, but the ornamentation of the early portion is distinctive. Specimens are common in the samples from St. Croix.

\section{Bolivina pisciformis Galloway and Morrey var.}

Two specimens with spinose periphery seem in other essential characters very much like this species. In the peripheral spines they resemble $B$. difformis (Williamson) and $B$. pygmaea H. B. Brady, but not in their main characters. Full description must await more specimens. These single specimens are from test well No. 1 at 100 and 1,390 feet.

\section{Bolivina marginata Cushman}

Bolivina marginata Cushman, U. S. Geol. Survey Bull. 676, p. 48 , pl. 10, fig. 1, 1918; Cushman Lab. Foram. Research Contr., vol. 1, pt. 2, p. 30 , pl. 5, figs. 5a, b, 1925; vol. 2, pt. 3, p. 54, 1926; Florida Geol. Survey Bull. 4, p. 45 pl. 8 , figs. 9a, b, 1930 .

Cushman and Laiming, Jour. Paleontology, vol. 5, p. 110, pl. 12, figs. 6-8, 1931 .

Cushman and Parker, Cushman Lab. Foram. Research Contr., vol. 7, p. 9, pl. 2, fig. 1, 1931.

Cushman and Ponton, Florida Geol. Survey Bull. 9, p. 81, 1932.

Barbat and von Estorff, Jour. Paleontology, vol. 7, p. 171, pl. 23, figs. 14d, b, 1933 .

Cushman and Cahill, U. S. Geol. Survey Prof. Paper 175-A, p. 25 , pl. 8, figs. $9 a, b, 1933$.

Woodring, Bramlette, and Kleinpell, Am. Assoc. Petroleum Geologists Bull., vol. 20, p. 141 (list), 1936.

Cushman, Cushman Lab. Foram. Research Special Pub. 9, p. 86, pl. 10, figs. 4-6, 1937.
Kleinpell, Miocene stratigraphy of California, p. 275, pl. 9, fig. 2; pl, 12, fig. 7, Tulsa, 1938.

Ellisor, Am. Assoc. Petroleum Geologists Rull., vol. 24, no. 3 , pl. 5 , figs. $22 \mathrm{a}, \mathrm{b}, 1940$.

Cushman and Todd, Cushman Lab. Foram. Re search Contr.; vol. 17, p. 30, pls. 7, 8, 1941.

Renz, 8th Am. Sei. Congress Proc., pp. 553, $55^{\circ}$ (lists), 1942.

LeRoy, Colorado School of Mines Quart., vol. 39, no. 3, p. 29, pl. 1, figs. 34-37, 1944.

Weaver, Washington Univ. [Seattle] Pub. in Goology, vol. 6, no. 1, p. 23. (list), 1944 .

This is a common species in the Miocen of Florida and is confined largely to the middle part, the Ecphora, Arca, and Yoldia zones of the Choctawhatchee formation and all three zones of the Shoal River formation. It also occurs in the Duplin marl of North Carolina and in the Miocene of Louisiana, California, Venezuela, Trinidad, and central Sumatra.

\section{Bolivina alata (Segúenza)}

(For references see Cushman Lab. Foram. Resaarch Special Pub. 9, p. 106, 1937, and Special Pub. 15, p. 42, 1945.)

Specimens referable to this species have been recorded from the late Tertiary of Georges Bank, in the western Atlantic Ocean, in a fauna closely related to that of the Miocene of the West Indian region. The species is present in test well No. 1 from 1,200 to 1,330 feet, in test well No. 2 from 30 to 160 feet, and in test well No. 3 at 90 feet.

Bolivina plicatella Cushman var. mera Cushmar and Ponton

Bolivina plicatella Cushman var. mera Cushman and Ponton, Florida Geol. Survey Bull. 9, p. 82; pl. 12, fizs. 4a, b, 1932. Bermudez, Soc. cubana historia nat. Mem., vol. 9, p. 195, 1935.

Cushman, Cushman Lab. Foram. Research S recial Pub. 9, p. 90, pl. 11, figs. 5-8, 1937.

Cushman and MeGlamery, U. S. Geol. Survev Prof. Paper 189-D, p. 108, 1938.

This species was described from the Miocene of Florida, occurring only in the lower part, tho Oak Grove sand and Chipola formation. It was also found in the Oligocene of Alabama. In the St. Croix "rell samples it is present at various depths as follows: test well No. 1,180 to 1,020 feet; test well No. 2,10 and 360 feet; and test well No. 3 , at 90 feet.

\section{Bolivina acerosa Cushman}

Bolivina acerissa Cushman, Cushman Lab. Formm. Research Special Pub. 6, p. 54, pl. 8, figs. 1a, b, 1936; Special Pub. 9, p. 94, pl. 12, figs. 11-13, 1937.

Palmer, Soc. cubana historia nat. Mem., vol. 14, p. 297, pl. 52, fig. 1, 1940 .

This species was described from the Miorene Gurabo formation of Santo Dominica and has beon recorded from the Oligocene of Cuba. It was founc? in test well No. 1 from 100 to 1,020 feet; test well No. 2 at 90 and 360 feet; and test well No. 3 at 90 and 100 feet.

\section{Bolivina mantaensis Cushman}

Bolivina mantaensis .Cushman, Cushman Lab. Fo-am. Research Contr., vol. 5, p. 92, pl. 13, figs. 27a, b, 1929; Special Pub. 9, p. 91, pl. 11, figs. 25, 26, 1937.

Bolivina applinae Galloway and Morrey [not P] 'mmer], Bull. Am. Paleontology, vol. 15, No. 55, p. 35, pl. 5, figs. $9 a, b$. 1929. 
This species occurs in the Miocene of Ecuador and Venezuela. It is present in numerous samples from test well No. 1, from 24 to 1,330 feet; in test well No. 2, at 90,160 , and 390 feet.

\section{Bolivina tongi Cushman}

Bolivina tongi Cushman, Cushman Lab. Foram. Research Contr., vol. 5, p. 93, pl. 13, figs. 29a, b, 1929.

Nuttall, Jour. Paleontology, vol. 6, p. 21, pl. 5, fig. 4, 1932.

Palmer and Bermúdez, Soc. cubana historia nat. Mem., vol. 10, p. 290, 1936.

Cushman, Cushman Lab. Foram. Research Special Pub. 9, p. 92 , pl. 12, figs. $7,8,1937$.

Palmer, Soc. cubana historia nat. Mem., vol. 14, p. 300, 1940.

This species was originally described from the lower Miocene of Venezuela. It has been recorded from the Oligocene of Mexico by Nuttall and from the Oligocene of Cuba by Palmer and Bermúdez. It is present in test well No. 1 at 180,1,200,1,270, and 1,430 feet.

\section{Genus REUSSELLA Galloway, 1933}

\section{Reussella miocenica Cushman}

Reussia spinulosa Cushman [not Reuss], Florida Geol. Survey Bull. 4, p. 48, pl. 8, fig. 17, 1930 .

Cushman and Ponton (part), Florida Geol. Survey Bull. 9 p. 84, pl. 12, figs. 14, 16 (?) (not fig. 15), 1932.

Cushman and Cahill, U. S. Geol. Survey Prof. Paper 175-A, p. 27, pl. 9, figs, 1a, b, 1933.

Reussella miocenica Cushman, Cushman Lab. Foram. Research Contr., vol. 21, p. 36, pl. 6, figs. 19, 20, 1945.

Cushman and Todd, Cushman Lab. Foram. Research Special Pub. 15, p. 49, pl. 7, fig. 22, 1945.

This species has been recorded from various parts of the Miocene of Florida and South Carolina and from the Miocene of Buff Bay, Jamaica. The specimens from St. Croix are few and spinose. They are present in test well No. 1 at 24 to 30 feet and 520 feet; test well No. 2 at 90 feet; and test well No. 3 at 100 feet.

\section{Genus UVIGERINA D'Orbigny, 1826}

\section{Uvigerina rustica Cushman and Edwards}

Uvigerina hispida Galloway and Morrey [not Schwager], Bull. Am. Paleontology, vol. 15, no. 55, p. 39, pl. 6, fig. 3, 1929. Cushman, Cushman Lab. Foram. Research Contr., vol. 5 , p. 95, pl. 13, fig. 35, 1929 .

Uvigerina auberiana Nuttall [not D'Orbigny], Quart. Jour. Geol. Soc., vol. 84, p. 94, pl. 6, fig. 16, 1928.

Uvigerina rustica Cushman and Edwards, Cushr:an Lab. Foram. Research Contr., vol. 14, p. 83, pi. 14, tig. 6, 1938.

Palmer, Soc. cubana historia nat. Mem., vol. 15, p. 184, pl. 15, fig. 19, 1941.

Renz, 8th Am. Sci. Congress Proc., pp. 546, 548, 560 (lists), 1942.

Cushman and Stainforth, Cushman Lab. Foram. Research Special Pub. 14, p. 47, pl. 7, fig. 13, 1945 .

Cushman and Todd, Cushman Lab. Foram. Research Special Pub. 15, p. 50, pl. 7, fig. 26, 1945.

This species was described from material from Venezuela that is probably of early Miocene age. The species has been recorded from Trinidad, Ecuador, Cuba, and Jamaica. It is common in test well No. 1, from 230 to 1,450 feet; in test well No. 2, from 30 to 390 feet; and in test well No. 3 at 90 feet.

\section{Uvigerina auberiana D'Orbigny}

Uvigerina auberiana D'Orbigny, in De la Sagra, Historia físjca, política y natural de la isla de Cuba, Foraminifares, p. 106 , pl. 2 , figs. $23,24,1839$.

Cushman, U. S. Nat. Mus. Bull. 104, pt. 4, p. 163, pl. 42,' figs. 3, 4, 1923; Cushman Lab. Foram. Research Contr. vol. 5 , p. 95, pl. 13, fig. 36, 1929; Florida Geol. Surrey Bull. 4, p. 49, pl. 9, fig. 7, 1930 .

Cushman and Ponton, Florida Geol. Survey Bull. 9, p. 86, 1932.

Cushman and Cahill, U. S. Geol. Survey Prof. Paper 175-A, p. 27, pl. 9, fig. 3, 1933 .

Cushman, Geol. Soc. America Bull., vol. 47 , p. 423 , pl. 2, figs. 18a, b, 1936.

Cushman and Todd, Cushman Lab. Foram. Research Contr. vol. 17 , p. 44 , pl. 13 , figs. $4,5,1941$.

D'Orbigny described this species from the region of Cuba. It is rare in the Miocene Choctawhatchee and Shoal River formations of Florida. Specimens from the lower Miocene of Venezuela and from the late Tertiary of Georges Bank, in the western Atlantic Ocean, are probably also to be referred here. $T$. is species is common in the well samples from St. Crcix, . occurring in test well No. 1 from 24 to 1,430 feet, test well No. 2 from 100 to 390 feet, and test well No. 3 from 90 to 130 feet.

\section{Uvigerina ef. $U$. hispido-costata Cushman and Todd}

A number of specimens are similar to, although smaller than, this species described from-the Miocene of Buff Bay,'Jamaica, and known from the West Indian region. In the well samples it is present in test well No. 1 at 100 feet and is then common from 520 feet to the bottom of the well at 1,450 feet, in test well No. 2 at 90 feet and 360 feet, and in test well No. 3 from 62 to 70 feet.

\section{Uvigerina carapitana Hedberg}

Uvigerina carapitana Hedberg, Jour.' Paleontology, vol. 11, p. 677 , pl.' 91 , fig. 20,1937 .'

Cushman and Edwards, Cushman Lab. Foram. Research Contr., vol. 14, p. 82, pl. 14, fig. 2, 1938.

Palmer, Soc. cubana historia nat. Mem., vol. 15, p. 182, 1941. Renz, 8th Am. Sci. Congress Proc., pp. 546, 557 (lists), 1942.

This species was described originally from the Oligocene Carapita formation of Venezuela, and similar specimens occur in the upper Oligocene of Cuba and the Oligocene and Miocene of Trinidad. It is present in test well No. 1 at 24 to 30,580 , and 920 feet, and from there more frequently to the bottom of the well at 1,450 feet; and in test well No. 2 at 90 and 390 feet

\section{Uvigerina gallowayi Cushman}

Uvigerina gallowayi Cushman, Cushman Lab. Foram. Research Contr., vol. 5, p. 94, pl. 13, figs. 33, 34, 1929.

Cushman and Edwards, Cushman Lab. Foram. Research Contr., vol. 14, p. 75, pl. 13, figs. 8, 9, 1938 .

Kleinpell, Miocene stratigraphy of California, p. 294, pl. 5, figs. 1, 2, 5, Tulsa, 1938.

Cushman and Todd, Cushman Lab. Foram. Research Contr., vol. 17, p. 45 , pl. 13, fig. 11, 1941 .

Galloway and Heminway New York Acad. Sci., Sci. Survey Porto Rico and Virgin Ids., vol. 3, pt. 4, p. 429, pl. 33, fig. 8, 1941.

Cushman and Simonson, Jour. Paleontology, vol. 18, p. 270, pl. 32, figs. 18, 19, 1944.

Weaver, Washington Univ. [Seattle] Pub. in Geology, vol. 6 , no. 1, p. 25 (list), 1944.

Cushman and Stainforth, Cushman Lab. For am. Research Special Pub. 14, p. 48, pl. 7, fig. 14, 1945.

Cushman and Todd, Cushman Lab. Foram. Research Special Pub. 15, p. 49, pl. 7, fig. 24, 1945. 
This species is known from the lower Miocene or possibly upper Oligocene of Ecuador and Venezuela, the Oligocene and Miocene of California, the Oligocene of Puerto Rico and Trinidad, and the Miocene of Buff Bay, Jamacia. Rather typical material occurs in test well No. 1 at 740,820 , and 1,190 feet.

\section{Genus SIPHOGENERINA Schlumberger, 1883}

\section{Siphogenerina lamellata Cushman}

Siphogenerina lamellata Cushman, U. S. Geol. Survey Bull. 676, p. 55, pl. 12, fig. 3, 1918; U. S. Nat. Mus. Proc., vol. 67, art. 25 , p. 10, pl. 1, fig. 13, 1926; Florida Geol. Survey Bull. 4, p. 49 , pl. 9, fig. 10 , 1830 .

Cushman and Ponton, Florida Geol. Survey Bull. 9, p. 86, 1932.

Cushman and Cahill, U. S. Geol. Survey Prof. Paper 175-A, p. 28 , pl. 9, fig. 4, 1933 .

Cole, Florida Geol. Survey Bull. 16, p. 18 (list), pl. 1, fig. 1, 1938.

Ellisor, Am. Assoc. Petroleum Geologists Bull., vol. 24, No. 3, pl. 4, 'fig. 6 , 1940.

Renz, 8th Am. Sci. Congress Proc., pp. 554, 557 (lists), 1942.

This species was found in test well No. 1 from 230 to 1,450 feet, and in test well No. 2 at 30,100 , and 360 feet.

\section{Siphogenerina cf. S. senni Cushman and Renz}

Single specimens from test well No. 1 at 280 and 1,430 feet are close to this species described from the Miocene of Venezuela.

\section{Siphogenerina basispinata Cushman and Jarvis}

Siphogenerina basispinata Cushman and Jarvis, Cushman Lab. Foram. Research Contr., vol. 5, p. 13, pl. 3, figs. 4, 5, 1929.

Cushman and Stainforth, Cushman Lab. Foram. Research Special Pub. 14, p. 49, pl. 8, fig. 3, 1945.

A single specimen from 1,360 feet in test well No. 1 is very similar to this species, described from Trinidad, probably from the early Tertiary.

\section{Siphogenerina multicostata Cushman and Jarvis}

Siphogenerina multicostata Cushman and Jarvis, Cushman Lab. Foram. Research Contr, vol. 5, p. 14, pl. 3, fig. 6, 1929.

Cushman, Cushman Lab. Foram. Research Contr., vol. 5, p. 95, pl. 13, fig. 38, 1929.

Hadley, Bull. Am. Paleontology, vol. 20, no. 70A, p. 17, pl. 2, fig. 8, 1934.

Kleinpell, Miocene stratigraphy of California, p. 302, pl. 5, fig. 7, Tulsa, 1938.

Galloway and Heminway, New York Acad. Sci., Sci. Survey Porto Rico and Virgin Ids., vol. 3, pt. 4, p. 435, pl. 34, figs. 3, 4, 1941.

Renz, 8th Am. Ści. Congress Proc., pp. 545, 546, 548, 560 (lists), 1942

Weaver, Washington Univ. [Seattle] Pub. in Geology, vol. 6, no. 1 , p. 25 (list), 1944.

Cushman and Stainforth, Cushman Lab. Foram. Research Special Pub. 14, p. 49, pl. 8, fig. 1, 1945.

This species was described from Trinidad and has been recorded from the Miocene of Venezuela and California and from the Oligocene of Cuba, Puerto Rico, and Trinidad. Typical specimens of this species are present in test well No. 1 at 580 feet.
Siphogenerina multicostata Cushman and Jarvi^ var. optima Cushman

Siphogenerina multicostata Cushman and Jarvis var. optima Cushman, Cushman Lab. Foram. Research Contr., vol. 19 , p. 91 , pl. 16, figs. $9,10,1943$.

This variety differs from the typical form in the finer costae and the uniserial chambers, which tend to be in an irregular line. It was described from material at a depth of 90 feet in the Fair Plain test well No. 3, five-eighths of a mile west of Anguilla, St. Croix, V. I.

The variety was found in test well No. 1 from 100 to 1,430 feet; in test well No. 2 at 30,160 , and 390 feet; and in test well No. 3 at 90 feet.

\section{Genus ANGULOGERINA Cushman, 19^ฑ}

Angulogerina occidentalis (Cushman)

Uvigerina angulosa Cushman [not Williamson], Carnegie Inst. Washington Pub. 311, p. 34, pl. 5, figs. 3, 4, 1922.

Uvigerina occidentalis Cushman, U. S. Nat. Mus. Jull. 104, pt. 4, p. $169,1923$.

Angulogerina occidentalis Cushman, Florida Geol. Survey Bull. 4 , p. 50 , pl. 9 , figs. $8,9,1930$.

Cole, Florida Geol. Survey Bull. 6, p. 44, pl. 2, fig. 5, 1931.

Cushman and Laiming, Jour. Paleontology, vol. 5, p. 112, pl. 12, figs. 15, 16, 1931 .

Cushman and Ponton, Florida Geol. Survey Bull. 9, p. 86, 1932.

Palmer and Bermúdez, Soc. cubana historia nat. Mem., vol. 9, p. 249, 1935.

This species, described from Recent material of the West Indian region, where it is commc $\mathrm{n}$, has been found in the Miocene. The records include the Calvert formation of Maryland, the Yorktown formation of North Carolina and Virginia, the Duplin marl of North Carolina, and the Choctawhatchee formation of Florida. It has been recorded also from the Tertiary of Cuba and the Miocene of California. In the well-samples from St. Croix it is present in test well I $J^{\top}$. 1.almost throughout the series of sediments penetrated from 24 to 1,450 feet, in test well No. 2 from 10 to 330 feet, and in test well No. 3 at 90 feet.

\section{Genus TRIFARINA Cushman, 1983 \\ Trifarina bradyi Cushman}

Scattered specimens in the well samples s sem identical with this species, as figured from the Miocene of Venezuela (Cushman, Cushman Lab. Forem. Research Contr., vol. 5, p. 96, pl. 13, fig. 39, 1є29) and the Oligocene of Trinidad (Cushman and Stainforth, Cushman Lab. Foram. Research Special P. 1 b. 14, p. 50, pl. 8, fig. 4, 1945). These are present in test well No. 1 at the following depths: 24 to $30, £ 70,580,690$, 1,110 , and 1,210 feet; in test well No. 2 at 30 feet; and in test well No. 3 at 90 and 100 feet.

\section{Family ELIIPSOIDINIDAE}

Genus PLEUROSTOMELLA Reuss, $18^{\circ} \cap$

Pleurostomella alternans Schwager

In the American Miocene this species has been recorded from Ecuador, Venezuela, Trinidad, and Haiti. Specimens are fairly common in the well ramples from St. Croix, being present almost throughout all three wells. 


\section{Pleurostomella brevis Schwager}

This species is not so common as the preceding species but occurs at scattered levels in all three wells. It has been recorded from the Miocene of Trinidad and Jamaica and the Oligocene of Cuba.

\section{Genus NODOSARELLA Rzehak, 1895}

\section{Nodosarella subcylindrica Cushman}

Nodosarella subcylindrica Cushman, Cushman Lab. Foram. Research Contr., vol. 19, p. 91, pl. 16, figs. 4, 5, 1943.

Cushman and Stainforth, Cushman Lab. Foram. Research Special Pub. 14, p. 53, pl. 9, fig. 4, 1945.

Test small, elongate, subcylindrical, slightly tapering; early stages biserial, adult uniserial; chambers distinct, slightly inflated, those in the adult uniserial portion higher than broad; sutures distinct, slightly depressed; wall 'smooth, finely perforate; aperture terminal, narrow, with a slightly overhanging lip. Length 0.55 $0.65 \mathrm{~mm}$.; diameter $0.10-0.12 \mathrm{~mm}$.

This species was described from material at a depth of 90 feet in the Jealousy test well No. 2, 300 yards west of great-house at Jealousy, St. Croix, V. I. It differs from Nodosarella pacifica Cushman in the much smaller size and higher chambers. It also occurs in test well No. 1 at $230,740,1,330,1,360$, and 1,450 feet and in test well No. 3 at 90 and 130 feet, and has been recorded from the Oligocene Cipero formation of Trinidad.

\section{Nodosarella robusta Cushman}

Nodosarella robusta Cushman, Cushman Lab. Foram. Research Contr., vol. 19, p. 92, pl. 16, fig. 8, 1943.

Cushman and Stainforth, Cushman Lab. Foram. Research Special Pub. 14, p. 53, pl. 9, figs. 1, 2, 1945.

Test of medium size, elongate, subcylindrical; biserial stage very short; chambers distinct, very slightly inflated, overlapping, broader than high except the final chamber; sutures fairly distinct, slightly if at all depressed; wall smooth and polished; aperture terminal, a narrow opening with a distinctly overhanging lip. Length 1.10-1.25 mm.; diameter 0.28-0.35 $\mathrm{mm}$.

This species was described from material at a depth of 100 feet in the Bethlehem test well No. 1, at a locality 500 yards east-northeast of Bethlehem, St. Croix, V. I.

This species differs from Nodosarella pacifica Cushman in the typically shorter, stouter test, and more strongly overhanging lip. It occurs in test well No. 1 at intervals from 100 to 1,360 feet and in test well No. 2 at 90 feet.

\section{Genus ELIIPSONODOSARIA A. Silvestri, 1900}

\section{Ellipsonodosaria subspinosa Cushman}

Ellipsonodosaria sp. Cushman and Jarvis,- Cushman Lab. Foram. Research Contr., vol. 10, pl. 10, figs. 4, 5, 1934. Ellipsonodosaria subspinosa Cushman, Cushman Lab. Foram. Research Contr., vol. 19 , p. 92, pl. 16, figs. $6,7,1943$. Cushman and Stainforth, Cushman Lab. Foram. Research Special Pub. 14, p. 56, pl. 9, figs. 9, 10, 1945.

Test elongate, subcylindrical, slightly tapering, greatest breadth near the apertural end; chambers distinct. strongly inflated, increasing gradually in size as added; sutures distinct, strongly depressed; wall with short stout spines, either entirely covering the chamber or in the early stages confined to the lower portion of the chamber wall; aperture with a subcylindrical neck and distinct lip with an inwardly projecting tooth. Length 2.50-3.25 m.m.; diameter 0.35-0.90 mm.

This species was described from the Oligocene Cipero formation of Trinidad, originally designated as "lov'er middle Miocene, Green clay, Cipero section" (see Cushman and Stainforth, Cushman Lab. Foram. Researsh Special Pub. 14, p. 7,1945 ). It differs from Ellipsonodosaria mappa Cushman and Jarvis in the more elongate, tapering test, and the surface ornamentation of short spines. It occurs in test well No. 1 at 640,870 , and 1,430 feet.

\section{Ellipsonodosaria cf. E. gracilis Palmer and Bermúdez}

A number of specimens are curved and typically he.ve a row of spines near the base of the chamber, two characters which apparently distinguish this species, described by Palmer and Bermúdez from the Oligocene of Cuba (Soc. cubana historia nat. Mem., vol. 10, p. 236, pl. 18 , figs. $8,9,1936$ ). In the later stages of the spesimens from St. Croix, however, additional spines are found on the upper part of the chambers and in some specimens these nearly cover the chamber. Specimens are found in all three wells.

\section{Ellipsonodosaria verneuili (D'Orbigny)}

A number of specimens, variable in size and amount of inflation of the chambers, seem to belong to this specias. The species has already been recorded from the Miocene of Ecuador, Venezuela, Trinidad, and Jamaica. It is present in test well No. 1 from 690 to 1,450 feet, and in test well No. 3 at 90 and 130 feet.

\section{Family ROTAITIDAE \\ Genus GYROIDINA D'Orbigny, 1826 \\ Gyroidina soldanii D'Orbigny}

Material referred to this species needs much more study, as a glance at the figures. of the specimens referrad to it will show. The species has been recorded from the Miocene of Ecuador, Colombia, Venezuela, Trinidrd, Puerto Rico, Costa Rica, and California, as well as from the late Tertiary of the Georges Bank in the western Atlantic Ocean. What seem to be typical specimens rre present with a wide range in all three of the wells on St. Criox.

Gyroidina soldanii D'Orbigny var. altiformis R. E. and K. C. Stewart

This variety has been recorded from the Miocene of Haiti (Coryell and Rivero, Jour. Paleontology, vol. 14, p. 337, pl. 43, figs. 19a-c, 1940) and the Miocene of Buff Bay, Jamaica (Cushman and Todd, Cushman Leb. Foram. Research Special Pub. 15, p. 57, pl. 9, figs. 3a, b, 1945). Although not as common as the typical for'n, specimens referable to the variety are present in test well No. 1 at 230 to 1,330 feet, test well No. 2 at 280 and 390 feet, and in test well No. 3 at.90 and 100 feet. 
Genus EPONIDES Montfort, 1808

Eponides umbonata (Reuss)

Very typical specimens similar to those recorded from the Miocene of Ecuador and Venezuela (Cushman Lab. Foram. Research Contr., vol. 5, p. 98, pl. 14, figs. 8a-c, 1929) were found in material from all three wells.

\section{Genus SIPHONINA Reuss, 1850}

\section{Siphonina pulchra Cushman}

This species was described from the Miocene of Cuba and has been recorded from the Miocene of Haiti and Jamaica and from the late Tertiary of Georges Bank in the western Atlantic Ocean. Specimens occur only in test well No. 1 at 1,090, 1,190, and 1,430 feet.

\section{Siphonina tenuicarinata Cushman}

This species, originally described from the Oligocene Alazan formation of Mexico, has been recorded from Eocene to Miocene. It occurs in the lower Miocene of Venezuela, Trinidad, Haiti, Puerto Rico, and Mexico. A few specimens are found in all three wells in St. Croix.

\section{Family CASSIDULINIDAE}

Genus PULVINULINeLIA Cushman, 1926

Pulvinulinella culter (Parker and Jones)

This species has been recorded from the Miocene of Ecuador, Venezuela, and Trinidad. A few specimens occur at scattered depths in test well No. 1 and test well No.2. All the specimens have a very strong keel.

\section{Genus CASSIDULINA D'Orbigny, 1826}

\section{Cassidulina crassa D'Orbigny}

A few specimens may belong to this species. The aperture, however, is more elongate than in the typical form and considerable variation is shown in the series of specimens. The species has already been recorded from the Miocene of Venezuela, Florida, North Carolina, Virginia, and Maryland, and from the late Tertiary of Georges Bank in the western Atlantic Ocean. There are also records from the Oligocene. Specimens are present only in test well No. 1 at 230 , 640 , and 1,450 feet.

\section{Cassidulina laevigata D'Orbigny}

A very few specimens may be referred to this species. They most closely resemble the specimens with very elongated aperture figured by Macfadyen from the Miocene of Egypt (Egypt Geol. Survey, 1930, p. 63, pl. 2, figs. $6 \mathrm{a}, \mathrm{b}, 1931)$. Specimens occur in test well No. 1 at 100 and 1,430 feet and test well No. 3 at 100 feet.

\section{Cassidulina laevigata D'Orbigny var. carinata Cushman}

This variety has been recorded widely in the American Miocene but is very rare in the present material, occurring only in test well No. 1 at 1,330 and 1,390 feet.

\section{Cassidulina subglobosa H. B. Brady}

This species is the most common member of the genus in the well-samples, occurring in all three wells in a large number of the samples with a wic's range. In the American Miocene it has been recorded from Cuba, Jamaica, Puerto Rico, Costa Rica, Ecuadcr, Venezuela, Trinidad, and California.

\section{Cassidulina carapitana Hedberg}

This species, described from the upper Oligocene of Venezuela (Jour. Paleontology, vol. 11, F. 680, pl. 92, figs. 6a, b, 1937), is represented in the present material by a single specimen from test well No. 1 at 24 to 30 feet. It has also been recorded from the Oligocene of Cuba and Trinidad.

\section{Genus CASSIDULINOIDES Cushman, 1927}

Cassidulinoides bradyi (Norman)

This species has been recorded from the Miocene of Florida and Jamaica and the Oligocene of Trinidad. Adult specimens are present in test well No. 1 at 580 feet and in test well No. 2 at 360 feet. A few specimens, perhaps representing young stages, are present also in some of the other samples.

\section{Genus EHREN Bergina Reuss, 18E?}

Ehrenbergina bradyi Cushman

Coryell and Rivero have recorded this species from the Miocene of Haiti (Jour. Paleontology, vol. 14, p. 342 , pl. 44, figs. 22a-c, 1940). It may bo the same as the form I have identified as E. trigona (Goës) from the late Tertiary of Georges Bank in the western Atlantic Ocean (Geol. Soc. America Bull., vol. 47, p. 425, pl. 3, figs. 9a, b, 1936). Scattered specimers are present in test well No. 1 at 24 to $30,100,1,360$, and 1,390 feet.

\section{Family ChILOSTOMELLIDAE}

\section{Genus CHILOSTOMELIA Reuss, 18 ho}

Chilostomella oolina Schwager

The only previous American Miocene record for this species rests on a single broken specimen from the Choctawhatchee formation of Florida. It has been recorded also from the Oligocene of ${ }^{\top T}$ enezuela by Hedberg.

Single typical specimens are present in test well No. 1 at $230,1,190$, and 1,430 feet; test well No. 2 at 30 feet; and test well No. 3 at 100 feet.

\section{Genus PULLENIA Parker and Jones, 1862 \\ Pullenia bulloides D'Orbigny}

(For references see Cushman and Todd, Cushman Lab. Foram. Research Contr., vol. 19, p. 13, 1943.)

Under this name have been grouped those specimens that are nearly spherical and show little if any sign of compression. The species occurs in the late Tertiary of the Georges Bank in the western Atlantic Ocean, in the Miocene near Manta, Ecuador, and in the Miocene of Egypt. It is present in test well No. 1 from 24 to 1,360 feet and in test well No. 3 at 100 and 130 feet. 
Pullenia quinqueloba (Reuss)

(For references see Cushman and Todd, Cushman Lab. Foram. Research Contr., vol. 19, p. 10, 1943.)

This species is usually recorded with the preceding and represents a more compressed test. In the well samples such forms are present in test well No. 1 at $440,1,170,1,210,1,360$, and 1,390 feet; test well No. 2 at 100 and 160 feet; and test well No. 3 at 90 and 130 feet.

\section{Genus SPHAEROIDINA D'Orbigny, 1826}

-

\section{Sphaerởilina bulloides D'Orbigny}

It is probable that there is little difference between this species and $S$. variabilis Reuss. Specimens from the well samples seem to be identical with those, figured as $S$. variabilis, from the Miocene of Ecuador, Venezuela, and Trinidad, and with those, figured as S. bulloides, from the Miocene of Puerto Rico and Jamaica and from the late Tertiary of Georges Bank in the western Atlantic Ocean. Specimens are present in test well No. 1 at numerous depths from 230 to 1,430 feet, and in test well No. 2 at 330 feet.

\section{Family GLOBIGERINIDAE}

This family is now being intensively studied in a monographic way and the species from St. Croix, which are represented by abundant specimens, will be included in those studies. No attempt has been made to deal with them in this report.

\section{Family GLOBOROTALIIDAE}

Genus GLOBOROTALIA Cushman, 1927

\section{Globorotalia menardii (D'Orbigny)}

This species is abundant in nearly all the wellsamples from St. Croix. It occurs also in the Miocene of Florida and elsewhere. Studies now under way on this and related species may show that these Miocene forms are separable from the Recent ones. With $G$. menardii, in the St. Croix material, are other species of this genus, but all need special study and comparison with those of other areas before satisfactory determinations can be made.

\section{Family ANOMAIINIDAE}

\section{Genus ANOMALINA D'Orbigny, 1826}

\section{Anomalina flintii Cushman}

Anomalina ammonoides Flint [not Reuss], U. S. Nat. Mus. Rept. for 1897 , p. 335 , pl. 78, fig. 4,1899 .

Anomalina fintii Cushman, U. S. Nat. Mus. Bull. 104, pt. 8, p. 108 , pl. 18, figs. $5 a-c, 1931$.

Coryell and Rivero, Jour. Paleontology, vol. 14, p. 334, pl. 44, figs. 8a-c, 1940.

The types of this species are from stations off Cuba. The species occurs in the Miocene of Haiti and is present in typical form in the well material from St. Croix. Specimens occur in test well No. 1 at intervals from 180 to 1,330 feet, in test well No. 2 at 360 feet, and in test well No. 3 at 100 feet.

\section{Genus PLANULINA D'Orbigny, 1826 \\ Planulina cf. P. ariminensis D'Orbigny}

A single specimen from test well No. 1 at 24 to ?? feet is close to this species and similar to that figured from the Miocene of Haiti (Coryell and Rivero, Jour. Paleontology, vol. 14, p. 337; pl. 44, figs. 7a-c, 1940).

Genus IATICARININA Galloway and Wissler, 1927

\section{Laticarinina bullbrooki Cushman and Todd}

Laticarinina bullbrooki Cushman and Todd, Cushman Lab. Foram. Research Contr., vol. 18, p. 19, pl. 4, figs. 8, 9, 1942.

Cushman and Stainforth, Cushmon Lab. Foram. Researsh Special Pub. 14, p. 73, pl. 15, figs. 2a, b, 1945.

Cushman and Todd, Cushman Lah. Foram, Research Srecial Pub. 15, p. 70, pl. 12, fig. 5, 1945.

Single immature specimens of this species are present in test well No. 3 at 100 and 130 feet. The species occurs in the Miocene and Oligocene of Trindad ard the Miocene of Buff Bay, Jamaica.

\section{Genus CIBICIDES Montfort, 1808}

Cibicides mississippiensis (Cushman)

A number of specimens seem much more like this species than like $C$. americanus. They are all from test well No. 1 and largely from the lower part of that well. The species was described from the Oligocene of Mississippi and seems to be more characteristic of that part of the section than of the Miocene.

\section{Cibicides americanus (Cushman)}

A few specimens from St. Croix apparently belong to this species but they are rare and are scattered throughout the well sections.

Cibicides pseudoungerianus (Cushman) var. io Cushman

Cibicides pseudoungerianus (Cushman) var. io Cushman, U. S. Nat. Mus. Bull. 104, pt. 8, p. 125, pl. 23, figs. 1, 2, 1931 .

Palmer and Bermúdez, Soc. cubana historia nat. Mem., vol. 9, p. $257,1935$.

Cibicides io Coryell and Rivero, Jour. Paleontology, vol. 14, p. 334 , pl. 44, figs. $11 \mathrm{a}-\mathrm{c}, 1940$.

Galloway and Heminway, New York Acad. Sci., Sri. Survey Porto Rico and Virgin Islands., vol. 3, pt. 4, p. 392 , pl. 22, figs. 4a-c, 1941 .

Rather typical specimens of this form, described from Recent material dredged off Florida, occur in the well samples. They are from test well No. 1 at 24 to $30,180,1,090$, and 1,430 feet; test well No. 2 at 30 feet; and test well No. 3 at 100 feet. It has been recorded from the Miocene of Cuba, Haiti, and Puer ${ }^{+} \circ$ Rico.

\section{Cibicides illingi (Nuttall)}

Truncatulina illingi Nuttall, Geol. Soc. London Quart. Jour., vol. 84 , p. 99, pl. 7, figs. 11, 17; text fig. 5, 1928.

This species was described from the lower Miocene or upper Oligocene of Trinidad. Typical specimens are present in the well samples; in test well No. 1 at $960,1,360$, and 1,450 feet; and in test well No. 2 at 100 feet. 



\section{INDEX}

$\boldsymbol{A}$

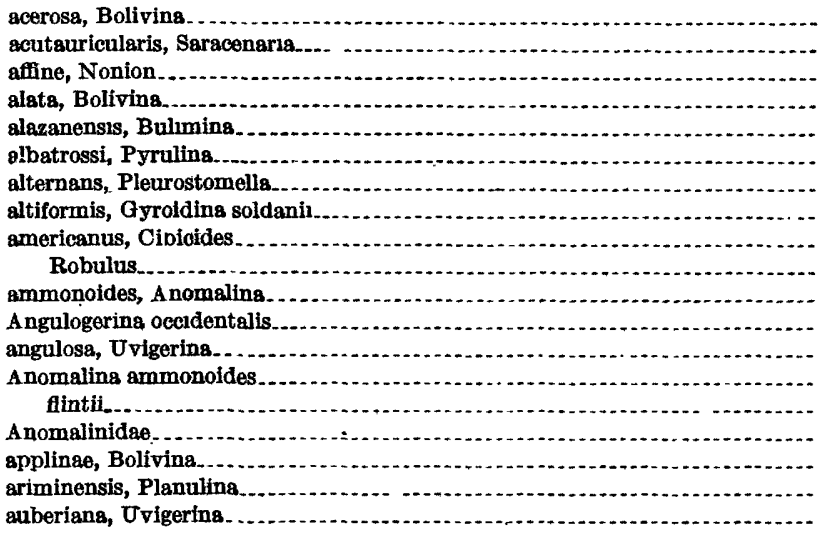

\section{B}

basispinsts, Siphogenerins

Hloculina murrhina

Bolivina acerosa

alata

applinae.

difformis

mantaensis.

marginata

pisciformis

optıms.

每

pygmaea.

tongi.

tortuosa

bradyi, Cassidulinoides

Ehrenbergina.

Gaudryins.

Karreriella

Trifarins

brevior, Buliminella

brevis, Pleurostomelis

Bulimina alazanensis

inflata.

$$
\text { mexicana }
$$

ovuls.

striats mexicans

Buliminells brevior

elegantissima

subfusiformis

Buliminidre

bullbrooki, Laticarinins

bulloides, Pullenia.

Sphaeroldins

californica, Plectofrondicularis

capreolus, Vulvulina. spinosa, Vulvulina.

carapitans, Cassidulins.

Uvigerina.

carinata, Cassidulina laevigata

Cassidulina carapitans.

crassa.

Jaevigata

carinata.

subglobosa.
Cassidulinidae

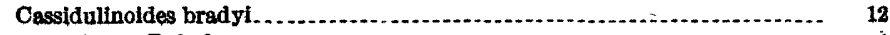

catenulatus, Robulus

caudata, Guttulina

Cederstrom, D. J., Note.on the geology of St. Croix, V. I................... 1-2

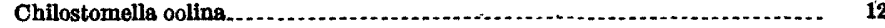

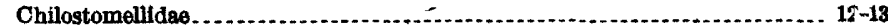

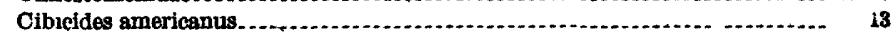

illingi

$10 \ldots \ldots+\ldots . . .13$

mississippiensis_................................................................ 13

pseudoungerianus io.

communis, Dentalins

compressa dumblel, Polymorphins

culter, Pulvinulinella

delmonteensis, Virguling

Dentalins communis

consobrina emaclats.

isidroensis.

mucronata.

depressa, Pyrgo

difformis, Bolivins

dubia, Marginulina

dumblei, Polymorphina compresss

Pseudopolymorphina.

Ehrenbergins bradyi

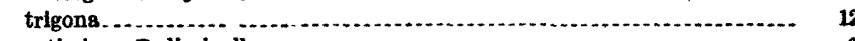

elegantissima, Buliminella...............

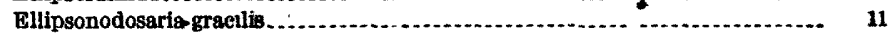

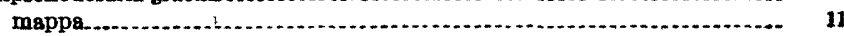

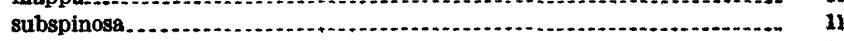

verneuili_.................................................................. 11

sp

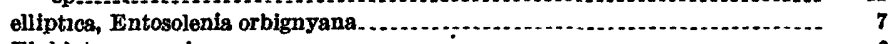

Elphiaium sagrai

emaciate, Dentalina consobrina

Entosolenia marginata.

trinitatensis.

squamosa.

7

Eponides umbonata

extensum, Nonion

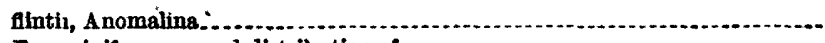

- $\mathbf{C}$

gallowayi, Pseudoglanduling

Uvigerina.

Gaudryina bradyi.

globulifers

pupoides.

Geology of the aree

glabra, Marginulina

Glonigerinidar.

Globorotalia menardii

Globorotalidas.

globulifers, Gaudryina.

.


Globulina irregularis

Page

racilis, Ellipsonodosaria Triloculina

grateloupi, Nonion

Spiroloculina

Guttulina caudata

irregularis

lactea

Gyroidina soldanii

soldanii altiformis

hedbergi, Plectofrondicularia

.

Heteroheliciaae.

hispida, Ovigerina

hispido-costata, Uvigerina

illingi, Cibicides.

Truncatulma..

implicata, Virgulins

mflata, Bulimina

mexicana, Bulimina

io, Cibucides

Cibicides pseudoungerianus

irregularis, Globulina

Guttulina.

isidroensis, Dentalina

jarvisi, Plectofrondicular ia......

Jealousy formation, occurrence of

K

Karreriella bradyi.

Kingshill marl, occurrence of

lactea, Guttulina

laevigata, Cassidulina

carinata, Cassidulina

occidentalis, Pseudoglandulina

Lagena .

Lagenidae .

lamarckıans, Quinqueloculing

lamellata, Siphogenerina

Laticarinina bullbrooki

leuzingerl, Textularia

Lingulina seminuda

Location of the area

\section{M}

mantaensis, Bolivina.

mappa, Ellipsonodosari

marginata, Bolivina

Entosolenia

Marginulina dubia

glabra.

medio-costatum, Nonio

menardil, Globorotalia

mera, Bolivina plicatella

mexicana, Bulimina inflata

Bulimina striata.

Míliolidae.

Miliolina venusta

miocenica, Reussella

Vulvulina spinosa

mississippiensis, Cibicides

Mount Eagle volcanics, occurrence of

mucronata, Dentalina

multicostata, Siphogenerina

optima, Siphogenerina

murrhina, Biloculina

Pyrgo

N

o

abscura, Spiroloculina

occidentalis, Angulogerina

Pseudoglandulina laevigata

Uvigerina

oolina, Chilostomella

optima, Bolivina pisciformis

Siphogenerina multicostata

orbignyana elliptica, Entosoleuia

trinitatensis, Entosolenia

ovula, Bulimins

$\mathbf{P}$

pacifica, Nodosarella.

petrosa, Schenckiella

pisciformis, Bolivina

optima, Bolivina.

Planularia venezuelana

Planulina ariminensis

Plectofrondicularia californica

hedbergi.

jarvisi.

vaughani

sp.....

Pleurostomella alternan

brevis.

plicatella mera, Bolivina

Polymorphina compressa dumblei

Polymorphinidae

pompilioides, Nonion

Pseudoglandulina gallowayi

laevigata occidentalis

Pseudopolymorphina dumblei

pseudoungerianus io, Cibicides

pulchra, Siphonina.

Pullenia bulloides

quimqueloba

Pulvinulinella culter

pupoides, Gaudryina

pygmaea, Bolivina.

Pyrgo depressa

murrhina.

Pyrulina albatrossi

8-9

Quinqueloculina lamarekiana

seminula.

venusta.

\section{Q}

Reussella miocenica

Reussia spinulosa

Robulus americanus

catenulatus.

robusta, Nodosarella

Rotaliidae.

rustica, Uvigerina

sagrai, Elphidium

Saracenaria acutauricularis

Schenckiella petrosa

schlumbergeri, Sigmoilina.

Page
11
11
11
5
6
6
6
6
$5-6$
$5-6$

(́)

age

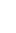


minuda, Linguling

seminula, Quinqueloculina

senni, Siphogenerina

Sigmoilina schlumbergeri:

Siphogenerina basispinata

lamellata.

multicostata.

optima

senni...

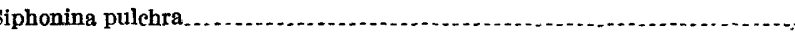

tenuicarinata.

soldanii, Gyroidins

altiformis, Gyroiding

Sphaeroidina bulloides

variabilis

spinosa, Vulvuling cepreolus

miocenica, Vulvulina

spinulosa, Reussia

Spiroloculina obscura

grateloupi...

squamosa, Entosolenia.

striata mexicana, Bulimina

subeylindrica, Nodosarella

subfusiformis, Buliminella

subglobosa, Cassidulina

subspinosa, Ellipsonodosaria

\section{$\mathbf{T}$}

tenuicarinata, Siphonina

15.

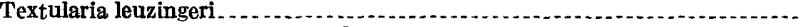

Textularidae
tongi, Bolivina

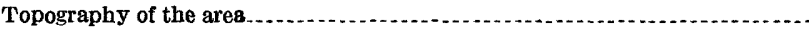

tortuosa, Bolivina

Trifarina bradyi.

trigons, Ehrenbergina.

Pare

12

Triloculina gracilis........................................................... 4

trinitatensis, Entosolenia orbignyana

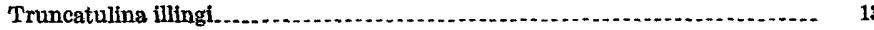

\section{U}

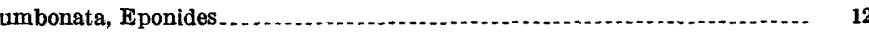

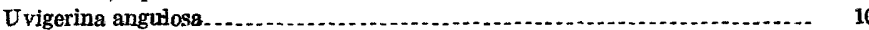

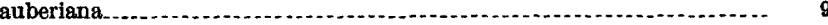

carapitana $\ldots$

gallowayi

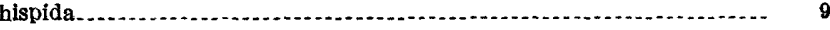

hispido-costata

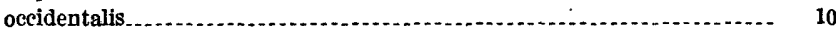

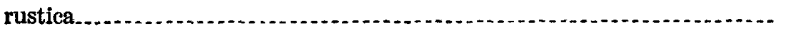

V

Valvulinidae . . . . .

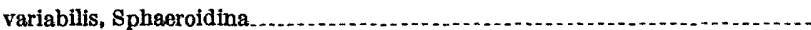

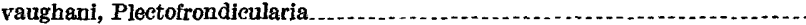

venezuelana Planularia

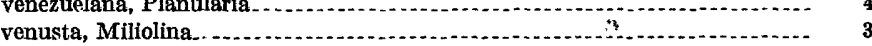

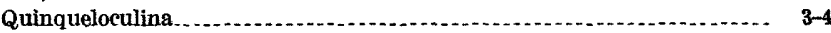

verneuili, Ellipsonodosaria................................................ 11

vertebralis, Nodosaria

Virgulina delmonteensis. implicats

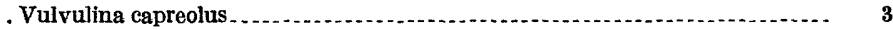

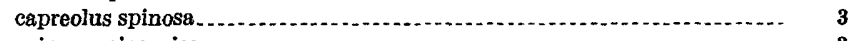
spinosa miocenica

Wells, logs of . 
,

-

. 
UNITED STATES DEPARTMENT OF THE INTERIOR

J. A. Krug, Secretary

GEOLOGICAL SURVEY

W. E. Wrather, Director

Professional Paper 210-B

\section{A PENNSYLVANIAN FLORULE FROM THE FORKSTON COAL \\ IN THE DUTCH MOUNTAIN OUTLIER NORTHEASTERN PENNSYLVANIA}

BY

CHARLES B. READ

Shorter contributions to general geology, 1946

(Pages 17-28)

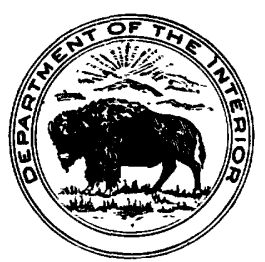

UNITED STATES

GOVERNMENT PRINTING OFFICE

WASHINGTON : 1946

For sale by the Superintendent of Documents, U. S. Government Printing Office, W ashington, D. C. Price 15 cents 


\section{CONTENTS}

Abstract_...

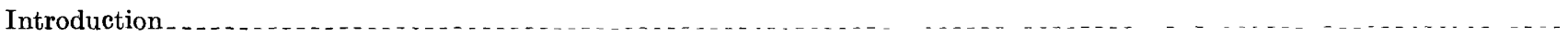

Position of the fossil plants.

Composition of the florule and age of associated strata

Description of fossils.

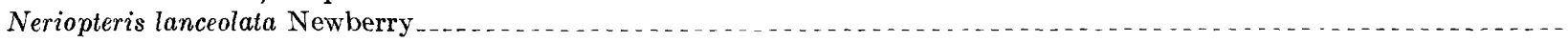

Archaeopteridium bellasylviana Read, n. sp

Mariopteris sp

Neuropteris sp

Cordaites sp_.

Cardiocarpon phillipsi Read, n. sp

Index.

\section{ILLUSTRATIONS}

I'aye 17 17 17 18 18 18 18 20

21

Plates 1-2. Flora of the Forkston coal

Facing . . . 


\title{
A FLORULE FROM THE FORKSTON COAL IN THE DUTCH MOUNTAIN OUTLIER, NORTHEASTERN PENNSYLVANIA
}

\author{
By Charles B. Read
}

\begin{abstract}
Dutch Mountain is an outlier of Pennsylvanian strata situated some 15 miles north of the west end of the Northern Anthracite coal field. The Forkston coal, semianthracite in rank and in the midst of a great conglomeratic sandstone, has been mined on Dutch Mountain for many years. From the roof of this coal at several points collections of fossil plants have been obtained. There are Lacoea seriata Read, I. gen. and n. sp., Neriopteris lanccolata Newberry, Archaeopteridium bellasylriana Read, n. sp., Mariopteris sp., Neuropteris sp., Cordaites sp., 'asdiocarpon phillipsi Read n. sp. The age of this flora is lower Pennsylvanian, and it is believed to indicate approximate rontemporaneity of the Forkston coal with coal-bearing strata near the position of the lower portion of the Connoquenessing sandstone member of the Pottsville formation of the Allegheny Plateau, the Nuttall sandstone member of the Sewell formation of West Virginia, and perhaps the Makanda sandstone and the sandstone immediately below the Tarter coal in Illinois. It is believed that this flora will aid in the difficult problem of establisling correlations between the anthracite region of eastern Pennsylvania and the great areas of Pennsylvanian strata of the Allegheny Plateau.
\end{abstract}

\section{INTRODUCTION}

Dutch Mountain is one of several small outliers of Pennsylvanian strata that lie north of the western part of the Northern Anthracite coal fields, in Northeastern Pennsylvania. It is in Forkston and North Branch townships, Wyoming County, about 15 miles northwest of Wilkes-Barre, 15 miles due north of the western end of the Northern Anthracite field, and 3 miles southwest of the village of Forkston. From their position in the drainage basin of Mehoopany Creek these outliers are sometimes spoken of as the "Mehoopany coal basins."

The Mehoopany basins are the easternmost of the remnants of Pennsylvanian strata that are scattered from. western Wyoming County across Sullivan, Bradford, Lycoming, and Tioga Counties to the northern Allegheny Plateau region of Clinton and Potter Counties, in which there are more continuous areas of the "Coal Measures." Because of its position, linking the anthracite basins of the eastern part of the State with the great area of the Allegheny Plateau in the west, this chain of outliers has been of interest to stratigraphers from the time of the early Pennsylvania surveys. Unfortunately, exposures in most of the basins are poor, and they have not furnished the data that an inspection of the State maps would lead one to expect.

In Dutch Mountain, as well as in several of the other $689523-46$ areas, small coal mines have been operated intermittently for many years. During the time of his activity as a collector, in the latter half of the past century, R. D. Lacoe obtained a very interesting lot of forsil plants from mines in the Forkston coal in Dutch Morntain. While engaged in field work in Pennsylvanie, in 1938, H. A. Swenson, of the Geological Survey, and the writer paid a brief visit to the Mehoopany coal basins to investigate the occurrence of the fossils. It is the purpose of this paper to record the observations made and to describe the available collection of plants.

\section{POSITION OF THE FOSSIL PLANTS}

As is stated above, Dutch Mountain is a small crea of Pennsylvanian rocks preserved in a syncline and situated 15 miles north of the west end of the Nortlern Anthracite coal field. Outcrops are poor, owing to the heavy cover of timber and to the mantle of glacial debris. Coal has been mined at a number of points near the top of Dutch Mountain, where a few hundred acres of coal is preserved. At the time of the writer's risit only one mine was in operation.

A section of the Pennsylvanian rocks could not, be measured in the region, owing to the poor exposures. It was, however, possible to obtain a few facts regarding their occurrence. The Forkston coal, a semianthracite, is a rather variable bed, ordinarily maintaining a thickness of 3 feet or a few inches less, but in a fow places increasing to about 4 feet, and at others becoming too thin to mine. It is underlain by a few inches to 4 feet of dark-gray carbonaceous, root-traversed, massive to irregularly bedded siltstone and underclay that contain occasional fernlike pinnules and large Cordaites leaves. The roof, at points where it was seen in the one mine entered, was sandstone or conglomerate. Miners report, however, that in some of the old workings a few inches to a foot of silty gray shale lies between the coal and the sandstone.

Under the Forkston coal and its associated root bed is a conglomeratic sandstone, exposures of which are rery poor but sufficient to indicate a thickness of about 200 feet. Above the coal some 50 feet of conglomerate is present and in at least two air shafts that have been driven through the upper conglomerate a thin coal has been encountered about 20 feet above the Forkston bed. Details of this upper coal bed are not available. 
The florule here described comes from the roof of the Forkston coal at points in several drift mines not now in operation.

\section{COMPOSITION OF THE FLORULE AND AGE OF THE ASSOCIATED STRATA}

The composition of the Forkston florule is as follows :

\author{
Lacoea seriata Read, n. gen., n. sp. \\ Neriopteris lanceolata Newberry. \\ Archaeopteridium bellasylviana Read, n. sp. \\ Mariopteris sp. \\ Neuropteris sp. \\ Cordaites sp. \\ Cardiocarpon phillipsi Read, n. sp.
}

As shown by the list, the number of species is small. Only seven forms are known and but four of these are specifically identifiable. The significance of these four is great, however, from the riewpoint of the stratigraphic paleontologist. Thus Neriopteris lanceolata Newberry and a form closely related to Archaeopteridium bellusylviana, A. stricta (Andrews) (n. comb.), are known from strata associated with the lower part of the Connoquenessing sandstone member of the Pottsville formation in southern Ohio and with the Nuttall sandstone member of the Sewell formation in the Kanawha-New River Valley of West Virginia. In addition, a close relative of $A$. bellasylviana, $A$. plumosum White, is known from rocks in the zone just above the Makanda sandstone in southern Illinois.

Lacoea seriata is known in sandstone above the Sharon coal in the Youngstown region of northeastern Ohio and in shale just under the Connoquenessing sandstone member of the Pottsville formation in Jackson County, Ohio. Cardiocarpon phitlipsi is a type of seed common in the strata under the Quakertown coal and associated with the lower part of the Commoquenessing sandstone.

It thus appears that the data in hand indicate the equivalence of the Forkston coal to coal-bearing strata at the approximate position of the lower part of the Connoquenessing sandstone of the northern Allegheny Plateau and the Nuttall sandstones of the West Virginia region. Approximate correlation with the $\mathrm{Ma}$ kanda sandstone of southern Illinois or beds just above it is also suggested.

As regards the position of the Forkston floral zone in the general section of the anthracite region, it appears possible to establish it, but pending a more detailed study of the sequence a report on this must be deferred. It may be said, however, that the zone appears to be present near the base of the Pennsylvanian section in the Northern Anthracite field and completely absent in the Southern Anthracite field.

\section{DESCRIPTION OF FOSSILS \\ Genus LACOEA Read, n. gen.}

Characters at present those of the single species, Lacoea seriata. The generic name is in honor of the collector of the type specimens, R. D. Lacoe.

Lacoea seriata Read, n. sp.

Plate 1, figures 1-14

The most abundant recognizable fossils in the Forkston collection are the flattened impression" and incrustations of a rather remarkable type of fructification. As usually seen on the bedding planes of the dark-gray sandy shale, these are roughly oval to ovate and show a considerable range in size. However, it is relatively rare to find one larger than 2 centimeters in diameter. The general appearance of typical individuals is seen in plate 1 , figures $1-10,13$. It is evident that some specimens are globular and others somewhat cupshaped. In all a notable feature is the more or less asymetrical base. The form of the base differs considerably in the several specimens and, as will be shown farther on in this paper, is dependent upon the position of the body with reference to other similar organs. The main part of the fossil just above the base in many specimens is somewhat lenticular in transverse section, a feature indicating that its cross section was circular prior to fossilization. A very obvious character is the surface patterns, which in the better-praserved individuals is male up of abundant small rhomboidal or diamond-shaped areas (pl. 1, figs. 3 and 5, particularly) ranging from 1 to 2 millimeters in lengtl and usually half as broad as long. These are closery spaced and are arranged in what appear to be close spirals. Normally they stand in relief, with shallow depressions or furrows between. The general effect of the pattern is, in fact, superficially similar to that of a fragment of some small Lepidodendron stem that has lost its foliage.

Fringing distal parts of the structure is a lacinate border of variable width (pl. 1, figs. $2,3,5,6,10,13$ ), usually a centimeter or more across. The tissues that made up this fringe were evidently rather thin and delicate, if the present vague limits and the lack of relief may be taken as criteria.

The cupular organs just briefly descrilnd are borne in pinnate aggregates of 10 or more pairs and are seated on short perlicels attached to slender rachises. Some of these aggregates are seen in plate 1 , figures 11,12 , and 14. It is apparent that the cupules are crowded on the axis, so that a strobilus is simulated. A notable feature is the small size of the individual structures in those specimens in which they are attached as compared to those detached. That the large and small individuals are identical in structure is seen by their form as well 
as by their superficial rhomboidal markings. The dif-' ference in size will be more fully treated in connection with the interpretation of the fossils.

The specific name refers to the seriate or serrate fringe at the apex of the specimen.

Interpretation.-The interpretation of Lacoea seriata and the reconstruction of its aspect before crushing and fossilization demand some thought. If it is recalled that the specimens were derived from a region of rather considerable crustal deformation, one in which the strata have been subjected to a great rleal of pressure, as evidenced by the very high rank of the coal, ${ }^{1}$ it will be clear that the lenticular cross section of the ovate body ( $\mathrm{pl}$. 1, fig. 9) of the Lacoea specimens is evidence of an original rounded form. Thus it would appear that the structures were originally sphaeroidal or cupular, with a constricted brim, although without any definite radial symmetry (pl. 1, figs. 1. 7, 9, particularly). This striking lack of radial symmetry was noted in an earlier paragraph and is undoubtedly related to the grouping of the structures into dense strobiluslike aggregates. However, the individual bodies are two-ranked on the axis rather than in whorls or in spirals. In consequence it is rather clear that the axis upon which these bodies are borne is a rachis rather than a stem.

A point that has been made in connection with the grouping of the specimens is that those that are assembled. in the pinnate aggregates are much smaller than those that are detached. (See pl. 1, fig. 14, in which a group as well as an isolated structure may be seen.) Likewise, although this was not brought out earlier, the detached bodies differ considerably in size. The writer is of the opinion that the strobiluslike groups of these bodies represent the young or decidedly immature state and that, with enlargment of the individual structures and elongation of the rachis upon which they were borne, the strobiluslike masses became less rigid and the individual bodies were easily detached. Hence it is only in the very young specimens that large aggregates are found. As to the difference in size of the individual specimens, it is certainly related in part to their macurity and probably in part to their position on the rachis; that is to say, it is quite probable that the basally placed structures tended to be larger than these situated apically.

As regards the individual bodies, they seem almost certainly to represent the spore-bearing or pollen-bearing organs of some early gymmosperm, probably a seed fern, or pteridosperm. The rhomboidal surface markings are apparently the basal ends of sporangia or pollen sacs seen slightly obliquely. From their size and position it is believed tha they were situated on a convex or

\footnotetext{
: The Forkston coal is classified as semianthracite.
}

subspherical receptacle, from which they radiated upward and possibly slightly outward.

The relationship of the membranaceous fringe or border to the sporangia is not clear. The fringe may be an extensiun of the ends of the sporangia, for similar fringes have been observed in Potoniea adiantiformis Zeiller. Or, as seems more likely, it may represent the extension beyond the receptacle proper of a sterile sheath enclosing the sporangia. The distal part of this sheath is either normally laciniate or else frays readily.

Because of its bearing on the morphology of the Forkst on specimens it is necessary to bring into the dis'ussion a specimen from the horizon of the lower part of the Connoquenessing sandstone near Youngstown, Ohio. The aspect of this specimen is seen in plate 1 , figure 4. As compared with the individuals just reviewed, the Ohio fragment is relatively uncrushed. In form it is obconical or funnel-shaped. The sides, in the region of marked downward tapering, are slightly concave. The dimensions of the specimen are approximately 2 by 2 centimeters. The upper 0.5 to 1.0 centimeter forms a sort of rim that is deeply torn at irregular intervals. the tearing being due beyond doubt to abrasion, or some other cause related to its preservation. This part is otherwise structureless and presents no characteristic markings. It evidently represents a rather thin sheathing tissue for the structures next to be described.

Below the rim are seen here and there, almost to the base of the organ, rhomboidal markings similar to these noted in the specimens of Lacoea seriata from the Forkston coal. At the very base these markings are absent, and the surface is covered with a thin unmarked carbonaceous layer. It is apparent that the point of attachment has been broken off, and the base is seen to be somewhat frayed.

The interpretation of this uncrushed specimen is rather simple. The obconical structure is a cupule of rather delicate tissue that is readily disorganized and that leaves at most only a film of carbon if preserved. Traces of this sheath are seen at the apex of the cupule and also at the base. In the markedly tapering part of the structure (the obconical part) are closely spaced rhomboidal or possibly saclike areas. It is evident that these are the bases of elongate, cylindrical sporangia attached regularly around the concave inner surface of the cupule. The rhomboidal rather than circular form of the bases of the sporangia is due in part to the oblique course of the rows of sporangia across the walls of the cupule, and in part to the crowding of the bases and at the same time their alinement in regular spirals. To bring out these relationships as well as the general morphology of the structure, a sketch incorporating the writer`s ideas is presented in figure 3 . On the left 
are shown the surface features reconstructed from the fossil, and on the right a part of the outer receptacle has been cut away to show the attachment of the individual sporangia.

Comparisons.-In the Carboniferous strata of this country, particularly the Pennsylvanian, a great variety of polleniferous organs pertaining to pteridosperms occur, and these are known in collections. Many of them have been acquired by the Geological Survey during field work done in comection with stratigraphic

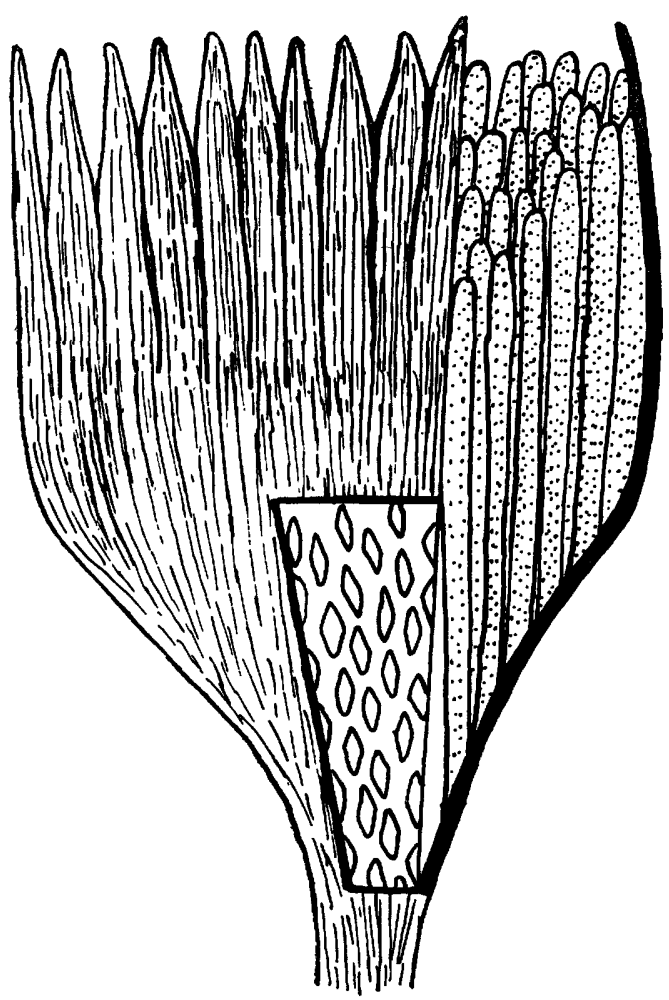

Figure 3.-Reconstruction of Lacoea seriata Read, n. sp., to show gross morphology.

studies of the upper Paleozoic rocks, and others have been acquired by the United States National Museum. Unfortunately most of these remain undescribed.

One of the best known of these fossil polleniferous organs is Whittleseya elegans Newberry, elucidated by the recent efforts of T. G. Halle. ${ }^{2}$ A typical specimen of this species is shown in plate 2 , figure 10 . As ordinarily seen these appear as flattened, fan-shaped, leaflike organs somewhat suggestive of Ginkgo leaves. In fact, W. elegans was originally assigned to the Ginkgoales. It appears, however, that this flat structure is a crushed cup, the walls of which are formed by closely spaced tubular sporangia extending the length of the cup. Thus Lacoea seriata differs markedly from $W$.

\footnotetext{
2 Halle, T. G., The structure of certain fossil- spore-bearing organs believed to belong to pteridosperms: $K$. svenska vetensk. akad. Handl.,
} ser. 3, Band 12, No. 6, pp. 17-24, 1933. elegans in the solid nature of the aggregate $\mathrm{c} f$ sporangia and likewise in the presence of a receptacle.

Lacoea seriata, in its features of gross norphology, is perhaps closer to Dolerotheca or to Potoniea. These are spore-bearing organs without a hollow central area, the sporangia extending to the center of the body. In Doterotheca there is a ground mass of tissue between the sporangia, whereas in Potoniea the sporangia are free save for a leaflike sheath on the exterior of the whole synangium. In neither form does th ore seem to be a structure entirely comparable to Lacosa, with the rhomboidal sporangia bases spirally arrenged on a concave receptable and a long raylike sterile sheath.

No pollen grains have been observed in the material of Lacoea seriata, nor could any be expected in fossils found in strata that have undergone such intense pressure as is evidenced by the high rank of the coal.

\section{Genus NERIOPTERIS Newberry}

\section{Neriopteris lanceolata Newberry}

1873. Neriopteris lanceolata Newberry, Ohio Geol. Survey Rept., vol. 1, pt. 2, p. 381, pl. 45, figs. 1-3.

The Forkston collection contains occasional fragments of a large, long-pinnuled fern that is beyond doubt referable to Neriopteris lanceolata Newberry. The plant is of the alethopteroid type, with long, strapshaped leaflets or pinnules, the apices of which are acute and set at somewhat less than a right angle to the axis of the pinna. These pinnules are attached across approximately their own breadth to the rachis of the pinna, the base of the pinnule being decurrent and the upper margin tending to curve slightly downward, following the proximal one. As the pinnules are very closely set, the lamina is thus contimuous from one pinmule to the next. The venation is of the alethopteroid type, a heavy midrib extending the complete lengtl of the pinnule and giving off, at an acute angle, secondaries that immediately curve sharply to pass to the margin at approximately a right angle, forking once or twice. At the base of the pinnules the midrib or primary vein is slightly decurrent on the rachis. The material is too poor to illustrate, but there can be no doubt regarding its identity.

The writer has recently examined the type specimen of Neriopteris lanceolata Newberry, which is in the collection of the New York Botanical Garden. It will be recalled that in Newberry's original description the pinnules were said to be basally constricted. In the figures accompanying his description they were shown to be attached across a narrow zone immediately adjacent to the midrib, and their bases were rounded. Actually the type specimen does not show these featuras but agrees very closely with the Forkston plant, in which the pin- 
nules are attached across the whole breadth of the base and are slightly decurrent.

According to present data, this species, though extremely rare, is of considerable importance stratigraphically. It is known at several localities in eastern Ohio, where it occurs either in the extreme upper part of the Sharon shale or in the lower part of the Connoquenessing sandstone, most commonly in the latter. It is generally, but not invariably, associated with species of the genus Cannophyllites.

Neriopteris lanceolata Newberry is perhaps similar in some respects to the plant that was called Taeniopteris? missouriensis by White. ${ }^{3}$ The systematic position of White's species is still in doubt, but there is no question regarding the similarity of the plants from Pennsylvania and those from Missouri. The Missouri plant is distinguished, however, by its somewhat more widely spaced pinnules, set more commonly at a right angle to the rachis, and by the more open venation.

Another form to which there is a certain degree of similarity, although probably superficial, is Protoblechnum wongii Halle, ${ }^{4}$ from the Shilhotse series in central China. P. wongii shows, however, a somewhat different type of venation, oblique rather than at right angles, and it has somewhat more flabellate pinnules. The similarity in form probably is best regarded as a sort of homeomorphy whereby widely separated groups may show a similar external form.

According to Jongmans, ${ }^{5}$ the American species that White referred to Taeniopteris? missouriensis should more properly be placed in Macralethopteris, the genotype of which is $M$. hallii Jongmans and Gothan, from deposits of Stephanian age in Java. From the figures given by Jongmans and Gothan one cannot be at all sure regarding this determination. At all events, in considering a name for these large, long-pinnuled Alethopteris-like plants the genus Neriopteris must be noted and its relationships to similar plants must be determined.

\section{Genus ARCHAEOPTERIDIUM Kidston}

Archaeopteridium bellasylviana Read, n. sp.

Plate 2, figures 6-9

Main divisions of the frond unknown, the secondary pinnae short, linear-lanceolate and acute, with a narrow lineate rachis. Pinnules alternate, small, short, close, tending to overlap, obliquely set, rhomboidal to ovate, 6 to 15 millimeters long, 3 to 6 millimeters wide, the widest point being situated below the middle; pinnules usually obtusely rounded at the apex, broadly attache.l

\footnotetext{
${ }^{3}$ White, David, Fossil flora of the Lower Coal Measures of Missouri : U. S. Geol. Survey Mon. 37, pp. 140-144, pl. 40, figs. 1-7, 1899 .

Halle, T. G., Palaeozoic plants from central Shansi : Palaeontologica Sinica, ser. A, vol. 11, fasc. 1. pp. 135-138, pls. 35-36; pl. 64, fig. 12, 1927.

5 Jongmans, W. J., and Gothan, Walther, Die Paläobotanischen Ergebnisse der Djambi-Expedition 1925: Jaarb. nijnwezen Ned.-Indië 1930, Verh., pt. 2, pp. 130-132, 1935.
}

(the attachment about one-half the width of the pinnule), slightly decurrent, the border nearly straight for about two-thirds of the length on the lower side, but arched strongly on the upper side. Proximal basal pinnules heteromorphous. Nervation distinct, coarse, apparently derived from the rachis, and radiating, th nerves forking once or twice in passing nearly straigl t to the margins of the pinnule.

The specific name is derived from the settlement of Bellasylvia, southwest of Dutch Mountain.

The fragmentary condition of the fossils here described and the gritty nature of the matrix prevent th 9 illustration of large parts of the pinnae. Likewise it has been impossible to determine all the features of the apical parts of the pinnules. It is possible that they may be denticulate, as are the numerous species of Archaeopteris from the Devonian, with which this material was originally identified.

The general aspect of the pinnae of this species is seen in plate 2 , figure 6 , which illustrates a specimen with rather crowded pinnules. A phase with slightly narrower and somewhat less crowded pinnules is seen in plate 2, figures 8 ; in this latter specimen there is a tendency toward a more erose or denticulate margin $\mathrm{cn}$ the pinnules. An inferior, basal, heteromorphous pinnule is shown in figure 9 .

Archaeopteridium bellasylviana is perhaps comparxble to A. tschermaki Stur from Bohemia. ${ }^{6}$ The latter has more cuneate, crowded pinnules attached across tl o entire base, and the general habit of the frond is closer to that generally found in the genus Rachopteris.

\section{Genus MARIOPTERIS Zeiller Mariopteris sp.}

Several specimens in the collection are referable to a species of Mariopteris. However, these fragments are scarcely sufficient to warrant specific reference. Tl best preserved specimen is a pinna approximately 6 centimeters long and narrowly lanceolate. The pin. nules are rather variable in shape but in general are triangular, and from their attitude with reference to the rachis of the pinna it is evident that they were rathor lax. The venation is partly obliterated by the coarse grains of the matrix, but where seen it is typical of the group $M$. muricata, to which the form evidently belongs.

Mariopteriis sp. recalls, in some measure, a form from the Eastern Interior coal field of Illinois, recently studied and described under the name $M$. speciosu (Lesquereux) White. ${ }^{7}$ This latter species has a pin-

\footnotetext{
6 Stur, D. R. J., Beiträge zur Kenntniss der Flora der Vorwelt. Band 1, Die Culm-Flora; K.k. geol. Reichsanstalt Abh., Band 8, Heft 1, pp. 57-60, pl. 12, fig. 1 ; pl. 16, fig. $1,1875$.

7 Lesquereux, Leo, Description of the coal flora of the Carboniferous formation in Pennsylvania and throughout the United States: Pennsylvania 2d Geol. Survey Rept. Progress P, vol. 1, pp. 216-217, 1E80 (under Pseudopecopteris speciosa Lesquereux).
} 
nule rather similar in form and of the same size. However, the Forkston species does not bear the sparingly serrate margins observed in the Illinois plant. M. speciosa is known from the Battery Rock coal horizon and in consequence is about the age of the Sharon coal and its correlatives in the Appalachian region.

\section{Genus NEUROPTERIS Brongniart}

Neuropteris sp.

A few fragments of a Neuropteris in the Dutch Mountain collection may be identical with $N$. tenuifolia, but the material is not sufficient to determine the relationships. The fossils are isolated pinnules and very fragmentary pinnae, highly macerated and with venation obliterated by the relatively coarse grains of the matrix.

\section{Genus CORDAITES Unger}

Cordaites sp.

Throughout the collection there are abundant fragments of Cordaites leaves, all greatly macerated, and all with the details of the venaticn obliterated by the coarse matrix. It is impossible to form any very close idea regarding the size or relative proportions of the leaves.

\section{Genus CARDIOCARPON Brongniart \\ Cardiocarpon phillipsi Read, n. sp. \\ Plate 2, figures 1-3}

Seeds very large, some of them as much as 4 centimeters in length and 3.5 centimeters in width including wing, of which the wing makes up about 10.5 centimeter on either side of the seed proper, about 1 centimeter at the chalazal end, and 0.5 centimeter at the micropylar end. Form of the seed with wing somewhat orbicular to oval, and of seed alone distinctly orbicular, with the base slightly modified to a truncate or even cordate shape and the apex tending to be slightly pointed. Details of seed coats or divisions of the testa not distinct. Wing deeply incised apically in the vicinity of the micropyle, the slit running to the apex of the seed in a distinct $\mathrm{V}$ directed to the upper end of the micropyle.

The specific name was chosen in honor of Mr. Ben Phillips, who was associated with Lacoe in making the collection from the Forkston coal.

The general aspect of Cardiocarpon phitlipsi is seen in plate 2, figures 1-3. A very large number of specimens of this seed are known, and those figured have been selected to illustrate the diagnostic features as seen in the whole range. It is apparent at the outset that one of the most characteristic features of this species is its large size. In fact, in this country such large forms of Cardiocarpon as C.phillipsi are rarely encountered. It is notable, as has been pointed out by White ${ }^{8}$ in a paper read before the Geological Society of America but published only in abstract, that these large species occur at a rather definite horizon and are commonly associated with the remains of Cannophyllites spp. (originally known as Megalopteris) in the Appalachian region and also in the Eastern Interior coal field. The narrow range of these seeds is about the position of the lower portion of the Connoquenessing sandstone in the northern Appalachians, the Nuttall sandstones of New River. and the sandstone underlying the Tarter coal in the Illinois region. Elsewhere the flora is not well known owing to its inability to compete in other than a very narrow range of environments.

Although the apices of these seeds are slightly pointed, they do not show the acute and prominent tips that characterize so many species of this genus. The seeds tend to be orbicular rather than to assume the cordate or heart-shaped outline commonly seen.

It is clear that this seed must have been markedly flattened even in its original form. $\mathrm{Tl}$ e residue is slight, and in none of the specimens examined has there been any evidence that the impression showed marked relief when originally made, prior to compaction of the enveloping sediments.

As has been previously stated, the number of species of these very large Cardiocarpons is relstively small. They include Cardiocarpon baileyi. Dawson ${ }^{9}$ and $C$. newbirryi Andrews, ${ }^{10}$ both of which difer markedly from $C$. phitlipsi in seed form and in the proportions of the wings; $C$. samaraeforme. Newberry, ${ }^{11}$ whose seed is similar in size and form but has a rather different type of wing; and $C$.ingens Lesquereux (pl. 2, fig. 4 ),,$^{12}$ which approaches very closely the form and size of $C$. phitlipsi, but differs in the wings, which are narrower, basally not so broad, and very deeply cut at the micropylar end.

Remarkable for its size, which is perhaps the largest known in the genus, is Cardiocarpon akroni Read, n. sp. (pl. 2, fig. 5), from the uppermost part of the Sharon shale near Akron, Ohio. This species has fully twice the breadth of $C$. phillipsi or $C$. ingens. The illustration is introduced to indicate the wide range of size of the genus and, with the figure of $C$. ingens. for comparison with $C$. phitlipsi.

\footnotetext{
${ }^{8}$ White, David, Megalopteris and the giant-winged cardiocarps (abstract) : Geol. Soc. America Bull., vol. 44, pt. 1, p. 213, 1933.

a Dawson, J. W., Acadian geology, 3d ed.. p. 555, text fig. 194D, 1878

${ }^{10}$ Andrews, E. B., Descrintions of fossil plants from the Coal Measures of Olio : Ohio Geol. Survey Rept., vol. 2, pt. 2, Paleontclogy, pp. 425-426, pl. 46. fig. 2,1875 .

11 Newberrs. J. S.. Descriptions of foesil plants from the Coal Measures of Ohio: Ohio Geol. Survey Rept., vol. 1, pt. 2, Paleontology, p. 375, pl. 43 , fig. 11,1873 .

12 Lesquereux, Leo, Botanical and paleontological report on the geological State survey of Arkansas, in Owen, D. D., Fecond report of a geological reconnaissance of the middle and southern counties of Arkansas, p. 311, pl. 4, figs. 4-4a, 1860.
} 
PLATES 1-2 


\section{PLATE 1}

Figures 1-3, 5-10, 13. Lacoea seriata Read, n. sp., individual synangia from the Forkston coal in Dutch Mountain, Pa., showing features of gross morphology. In figure 1 a large synangium shows the rhomboidal surface markings particularly well. Figures $2,3,5,6,8$, and 9 illustrate the membranaceous sheath extending as a fringe far beyond the globular to cupular synangium. Note in figures $3, \mathbf{5}, 8,9$, and 10 the rhomboidal scars left by the bases of sporangia attached obliquely to the plane of the surface exposed, Cotypes, U. S. Nat. Mus. 26217, 26219, 26251, $26213,26235,26256,26252,26214,1626,26247$.

4. Lacoea seriata Read, n. sp., an uncrusherl specimen from the lower portion of the Connoquenessing sandstone near Youngstown, Ohio, illustrating the cupular nature of the polleniferous synangia. U. S. Nat. Mus. 26261.

11, 12, 14. Lacoea seriata Read, n. sp., strobiluslike aggregates of the synangia from the Forkston coal in Dutch Mountain, Pa. Note the crowded, rigid, biseriate arrangement. Cotypes, U. S. Nat. Mus. 26242, 262.1. 
GEOLOGICAL SURVEY

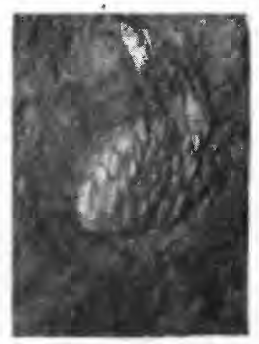

1

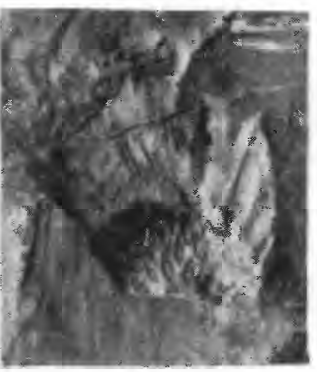

5

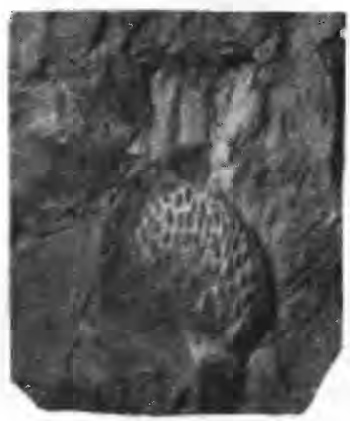

9

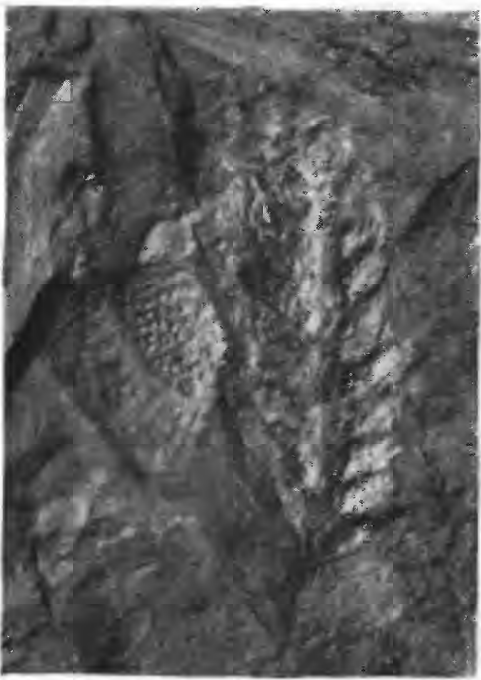

12
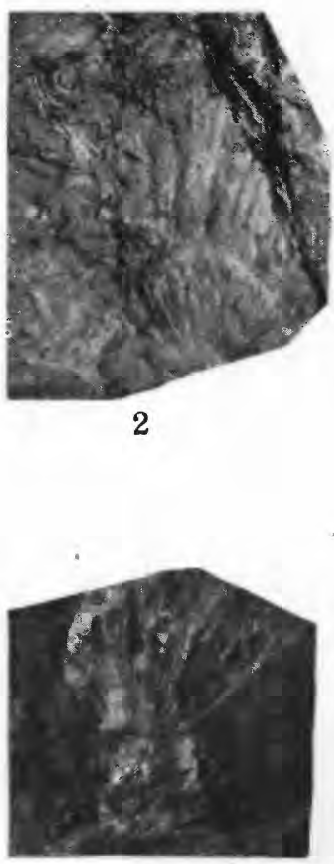

6

PROFESSIONAI PAPER 210 PLATE 1
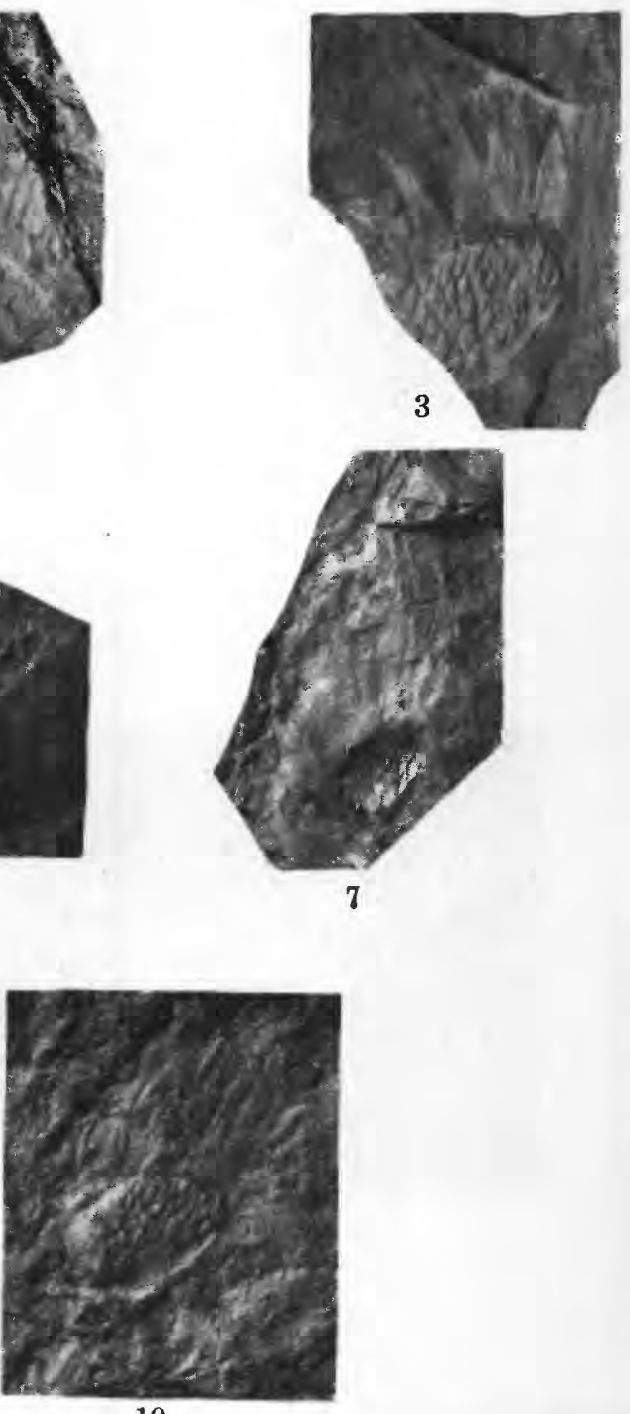

10

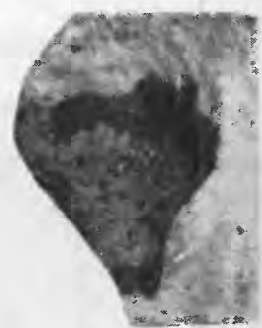

4

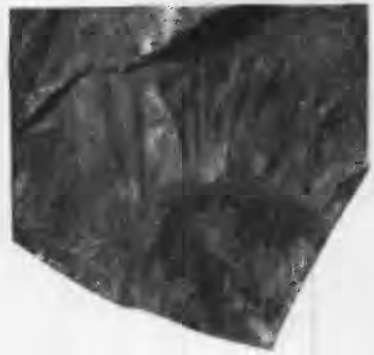

8

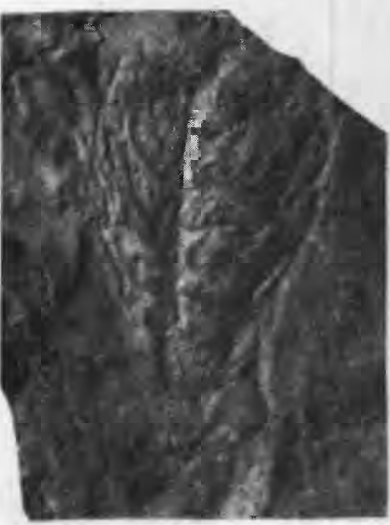

11

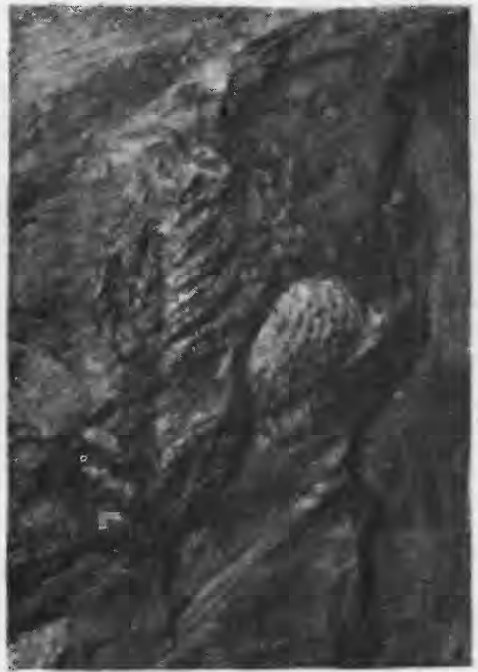

14

FLORA OF THE FORKSTON COAL. 
GEOLOGICAL SURVEY

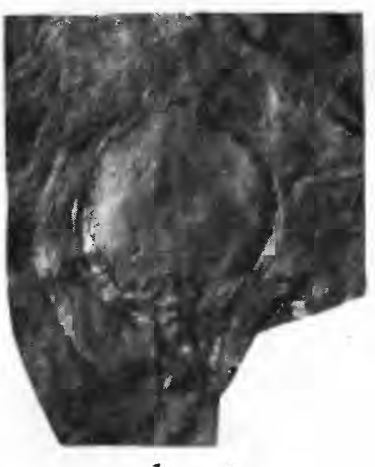

1

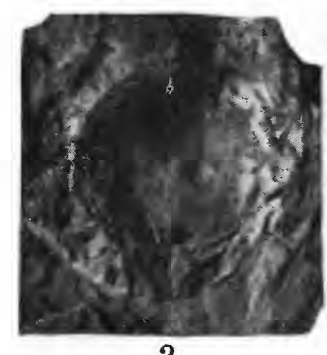

2
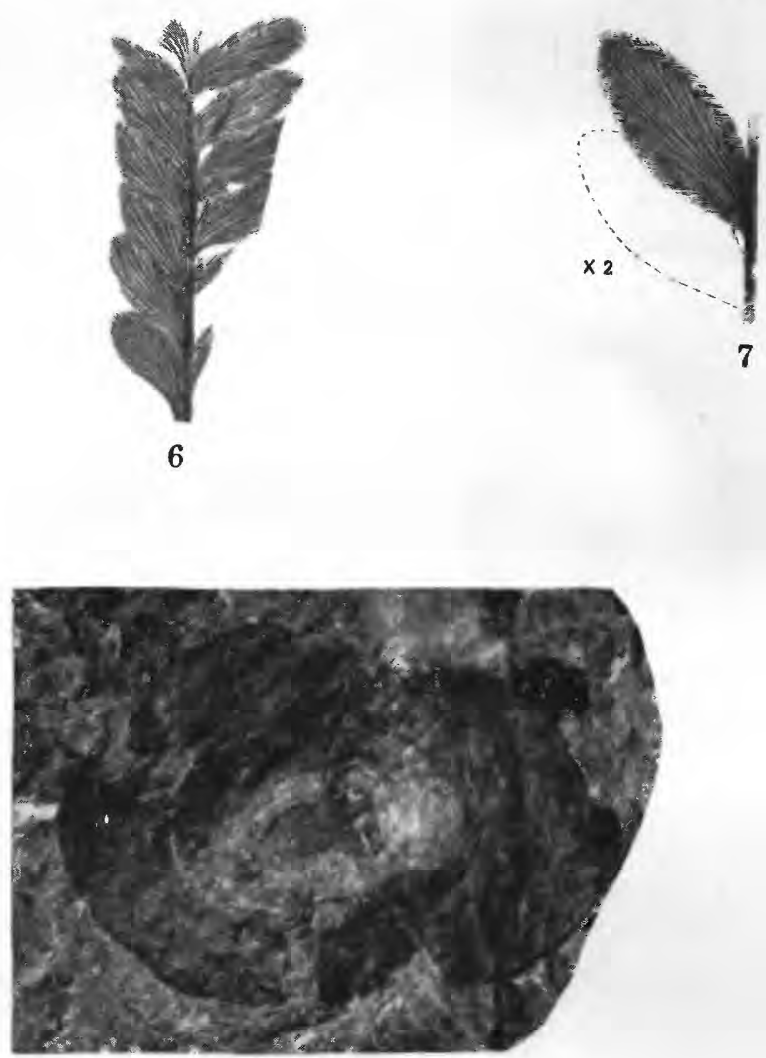

5
PROFESSIONAL PAPER 210 PLATE 2
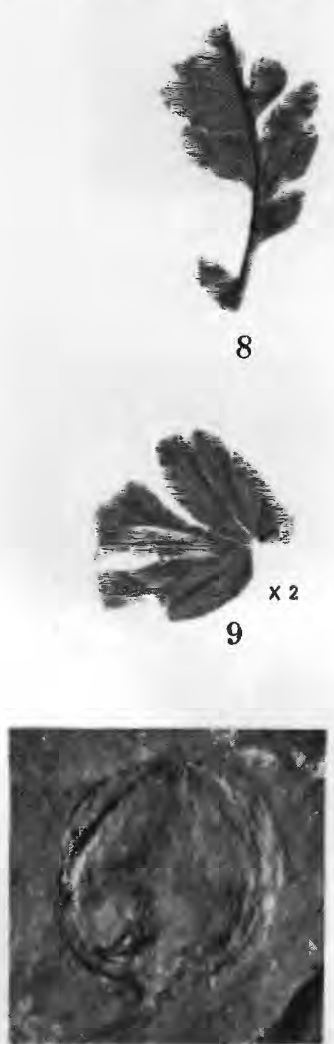

3

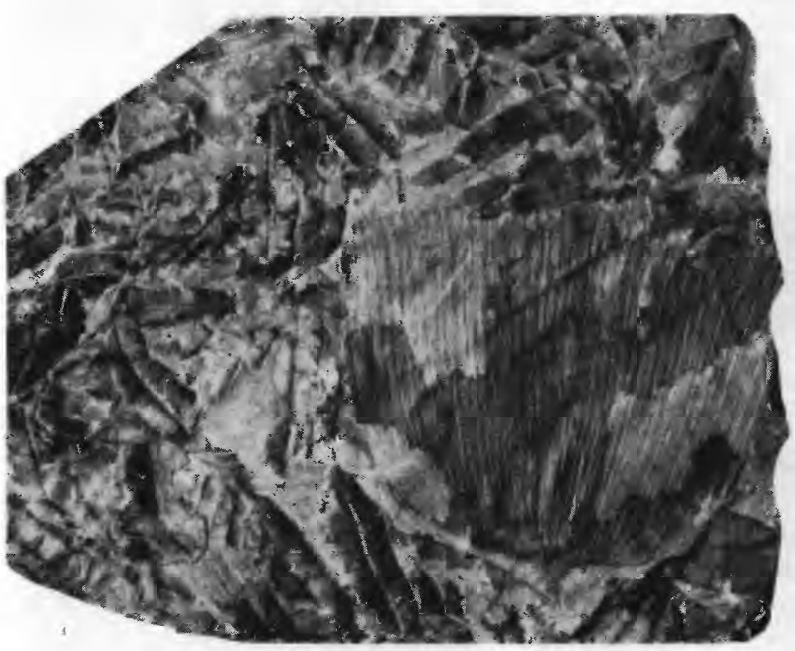

10

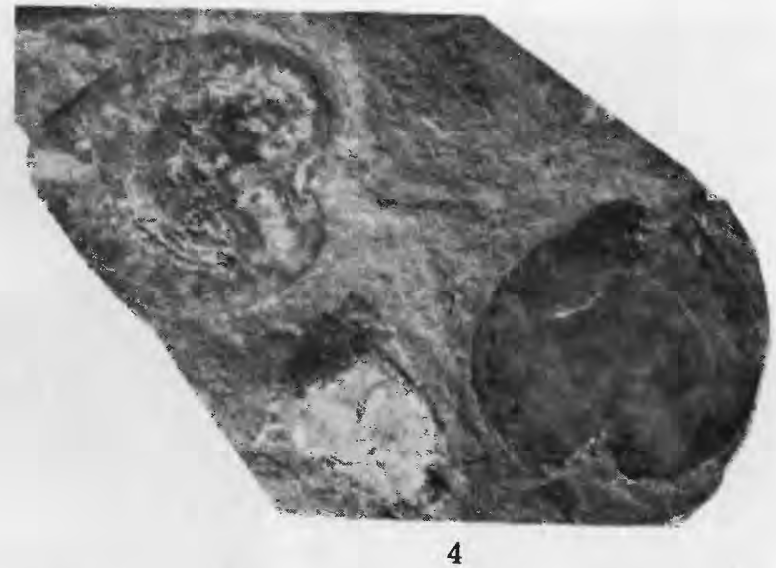

4

FLORA OF THE FORKSTON COAI. 


\section{PLATE 2}

Figures 1-3. Cardiorarpon phillipsi Read, n. sp., showing the large size and the form of the seeds, Forkston coal, Dutch Mountain, Pa. Cotypes. U. S. Nat. Mus, 25391, 25390, 25396.

4. Cardiocarpon ingens Lesquereux, typical specimens of this species introduced for comparison with $C$. phillipsi. Coalbearing Bloyd shale. Morrow gromp, at Lemons coal bank, Washington County, Ark. U. S. Nat. Mus. 25417.

5. Cardiocarpon akroni Read, n. sp., an extremely large spccies of Cardioctipon introduced to show the size that sone species of this group attain. Sharon shale near Akron. Ohio. Holotype. U. S. Nat. Mus. 25382.

Figures 6-9. Archaeopteridium bellusyliuma Read, n. sp., two pinnae (figs. 6 and 8 ) and details of a typical pinnule and a heteromorphous pinnule (figs. 7 and $9, \times 2$ ). Forkston coal in Dutch Mountain, Pa. Cotypes in U. S. Nat. Mus 10. Whittleseya elegans Newberry, a specimen from the upper sharon shale near Akron, Ohio, introduced for comparison with Lacoea seriata. U. S. Nat. Mus. $188+3$. 



\section{INDEX}

Abstract.....

adantiformis, Potoniea

Age of the florule

akroni, Cardiocarpon

Archaeopteridium bellasylviana

tschermaki _._. 21

baileyi, Cardiocarpon__._. 22

bellasylviana, Archaeopteridium _._. 21, pl.

Cannophrllites, association of Neriopteris lanceolata with

Cardiocarpon akroni

baileyi

ingens _.

newberryi-_.

phillipsi .

Composition of the florule

Cordaites sp

Dolerotheca sp

Dutch Mountain, stratigraphic relations of

elegans, Whittleseya

Page

17

18

22

2

1

2

21

22

22

22

2

22

18

20

17
pl. 2

0, pl. 2

17, 18

21

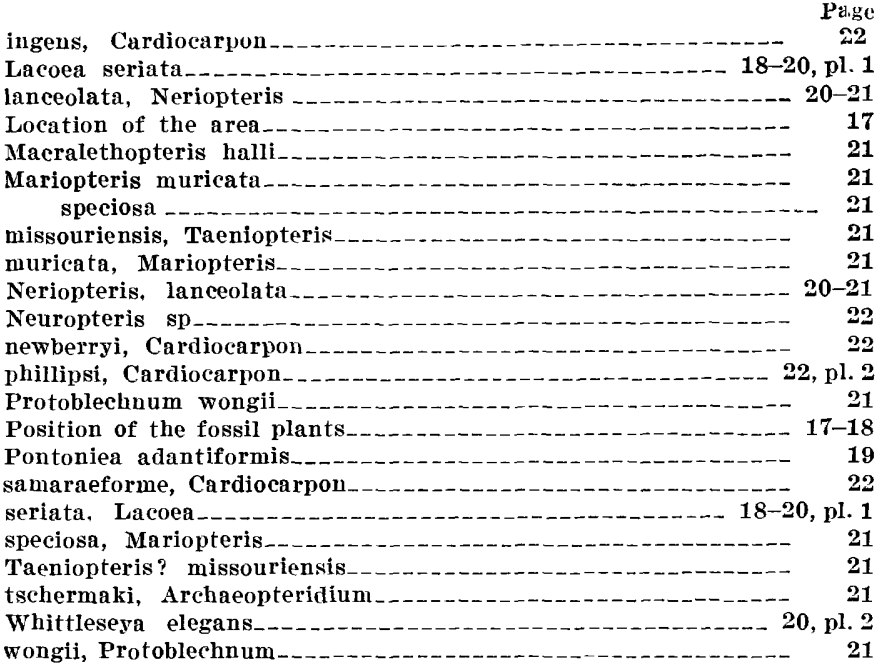


. 
UNITED STATES DEPARTMENT OF THE INTERIOR

J. A. Krug, Secretary

GEOLOGICAL SURVEY

W. E. Wrather, Director

Professional Paper 210-C

\title{
REPTILIAN FAUNA \\ OF THE NORTH HORN FORMATION \\ OF GENTRAL UTAH.
}

BY

\author{
CHARLES W. GILMORE
}

Shorter contributions to general geology, 1946

(Pages 29-53)

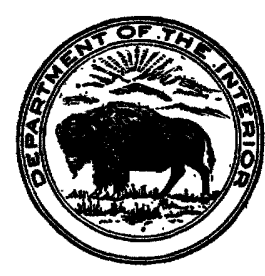

UNITED BTATES

GOVERNMENT PRINTING OFFICE

WASHINGTON : 1946 


$$
5 \cdot
$$




\section{CONTENTS}

Abstract

Part 1. Osteology of Alamosaurus, a sauropod dinosaur from the Upper Cretaceous.

Introduction

Family Titanosauridae Lydekker Genus Alamosaurus Gilmore................... Alamosaurus sanjuanensis Gilmore........

Details of the skeletal parts......................................

The tail . . . . . . .

Caudal vertebrae...............................

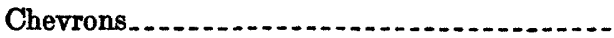

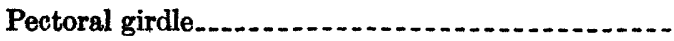

Sternal plates......................................

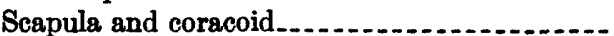

The forelimb. . .

Humerus . . . . . . .

Radius and ulna.................................

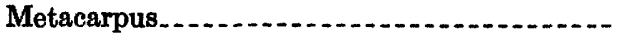

The pelvic region

The skeletal parts in place

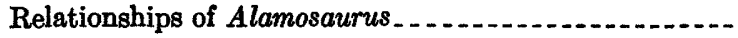

Part 2. Description of a new species of the Ceratopsia.....-

Introduction.

Available ceratopsian specimens

Family Ceratopsidae Marsh......................

Genus Arrhinoceratops Parks.................

Arrhinoceratops? utahensis Gilmore, n. sp.-

Description of the specimens.

Squamosal

Parietal

Supraorbital horn
Page
Part 2. Description of a new species of the CeratopsiaCon.

Description of the specimens-Con.

Jugal

Quadratojugal

Lachrymal.

Epijugal.

Quadrate...........................................

Epoccipitals..............

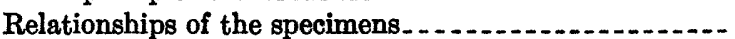

Part 3. Review of vertebrate fauna of the North Horn formation

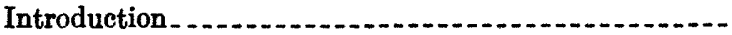

Faunal List,

Class Reptilia ........

Order Dinosauria.

Suborder Sauropoda Marsh Family Titanosauridae Lydekker..... Suborder Ceratopsia Marsh .............. Family Hadrosauridae Cope........... Family Deinodontidae Brown........

Order Sauria Family Polyglyphanodontidae Gilmore

Family undetermined.....................

Order Rhynchocephalia.......................

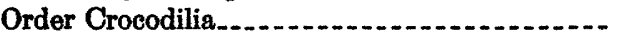

Order Chelonia

Class Pisces..........

Index $\ldots$
Pagi?

45

46

46

48

46

46

46

$4 \varepsilon$

$4 \Omega$

$4 \Omega$

$5 C$

$5 C$

$5 C$

$5 C$

$5 C$

51

51

51

5]

5

$5\rfloor$

$5]$

59

5

5 i

\section{ILLUSTRATIONS}

Prate 3. View of badland area of the North Horn formation looking toward North Horn Mountain from the south............

4. Two views of quarry showing bones in place .

5-10. Skeletal parts of Alamosaurus sanjuanensis Gilmore...

11. Crest portions of the frill of Arrhinoceratops? utahensis Gilmore

12. Median portion of skull of Arrhinoceratops? utahensis

13. Epoccipital bones tentatively referred to Arrhinoceratops utahensis

14. Parts of ceratopsian skull and a hadrosaurian femur

Fiqurs 4. Cherrons of Alamosaurus sanjuanensis Gilmore

5. Outlines of sternal plates of Alamosaurus sanjuanensis . .

6. Left scapula and coracoid of Alamosaums sanjuanensis

7. Forelimbs of Alamosaurus and Apatosaurus viewed from in front

8. Right humerus of Alamosaurus sanjuanensis viewed from in front

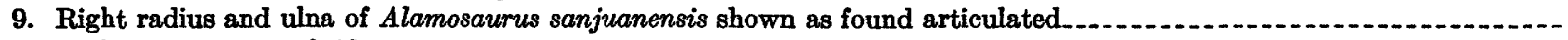

10. Right metacarpus of Alamosaurus sanjuanensis .

11. Coossified ischia of Alamosaurus sanjuanensis viewed from above

12. Incomplete skull of Arrhinoceratops? utahensis Gilmore viewed from the right side.........

13. Geologic map of North Horn area, Emery County, Utah. 


$$
\bullet
$$

$$
\text { - }
$$




\title{
REPTILIAN FAUNA OF THE NORTH HORN FORMATION OF GENTRAL UTAH
}

\author{
By Charles W. Gilmore ${ }^{1}$
}

\begin{abstract}
In Part 1 a sauropod dinosaur from the lower part of the North Horn formation in central Utah, represented by 30 procoelous caudal vertebrae, with chevrons, and the ischia, right forelimb, scapula, coracoid, and sternal plates, is referred to the species Alamosaurus sanjuanensis Gilmore. This specimen substantiates a previous discovery of sauropod remains in New Mexico and establishes definitely the presence of the family Titanosauridae in the Upper Cretaceous

of North America. It also supplies new data on skeletal feature, of the late sauropods.

In Part 2, a new species, assigned tentatively to the genus Arrhincceratops Parks, and other ceratopsian specimens from the North Horm formation of central Utah are described.

In Part 3, the reptilian forms of the fauna are reviewed, and correlation with other Upper Cretaceous faunas is briefly discussed.
\end{abstract}

\section{PART 1. OSTEOLOGY OF ALAMOSAURUS, A SAUROPOD DINOSAUR-FROM THE UPPER CRETACEOUS}

\section{INTRODUCTION}

In a brief note ${ }^{2}$ attention has recently been directed to the discovery of a partial skeleton of a large sauropod dinosaur in the Upper Cretaceous of central Utah. It is proposed to give here a detailed discussion of its relationships. Its geologic occurrence has been described by E. M. Spieker. $^{3}$

The general appearance of the area on which the specimen was found is shown on plate 3 and close views of the quarry on plate 4 . The broader relationships of the locality are shown on the map included by Spieker in his description of the Wasatch Plateau. ${ }^{4}$

The discovery of the specimen by the 1937 Smithsonian Paleontological Expedition is of more than ordinary interest: (1) It substantiates the authenticity of the original discovery that sauropod dinosaurs may be found in the Upper Cretaceous of North America; (2) it demonstrates the presence of a member of the family Titanosauridae in North America; (3) it permits for the first time an adequate diagnosis of the genus Alamosaurus; and (4) it strongly suggests that the North Horn formation may be the equivalent in age of the Ojo Alamo formation of New Mexico.

\footnotetext{
1 Late Curator of Vertebrate Paleontology, U. S. National Museum. This paper is a product of informal cooperation between the Geological Survey and the U. S. National Museum and is published by permission of the Secretary, Smithsonian Institution.

2 Gilmore, C. W., Sauropod dinosaur remains in the Upper Cretaceous: Bcience, new ser., vol. 87 , no. 2257 , p. $299,1938$.

Spieker, E. M., Late Mesozoic and early Cenozoic history of central Utah: U. S. Geol. Survey Prof. Paper 205-D, pp. 134-135, 1946.

4 Spieker, E. M., The Wasatch Plateau coal field, Utah: U. S. Geol. Survey Bull. 819, pl. 32, 1931 .

5 Lydekker, R., Contributions to a knowledge of the fossil vertebrates of Argentina, 1, The dinosaurs of Patagonia: Paleontología Argentina, t. 2, Mus. de La Plata Anales (unnumbered) p. 3, 1893.

6 Lydekker, R., Notices of new and other Vertebrata from Indian Tertiary and secondary rocks: India Geol. Survey Rec., vol. 10, pp. 38-41, 1877.

7 Deperet, Charles. Note sur les dinosauriens sauropodes et théropodes du Crétacé supérieur de Madagascar: Soc. géol. France, вér. 3, t. 24, p. 192, 1896.
}

\section{Family TITANOSAURIDAE Lydekker}

In view of the fact that the Titanosauridae hav" hitherto not been positively recognized as occurring in North America, a brief review of the family seems ap. propriate.

The term Titanosauridae was proposed by Lydekker ${ }^{5}$ in 1893 to include the sauropodous dinosaurs described by him from India and South America. At that time ho provisionally defined the family as follows:

Sauropodous dinosaurs in which the caudal vertebrae, with th? exception of the first, are procoelus, the presacrals opisthocoelus, and the lumbars without lateral cavities; the superior extremitiea of the chevron bones being open.

The family Titanosauridae has since become the reposi * tory of practically all the Cretaceous sauropod dinosaur" that have been described. In many instances these assign. ments rest primarily on the presence of similar procoelus caudal vertebrae. If correctly 'referred, representative? of this family have been reported from India, ${ }^{6}$ Indo-China, Madagascar, ${ }^{7}$ Egypt, ${ }^{8}$ Transylvania, ${ }^{9}$ southern France, ${ }^{\text {,n }}$ Isle of Wight, ${ }^{11}$ Brazil, ${ }^{12}$ Patagonia, ${ }^{13}$ South Africa, ${ }^{14}$ and North America. ${ }^{15}$ Thus it would appear that the Titano. sauridae have the widest geographical range of any known family of the Dinosauria.

8 Stromer, E, Ergebnisse der Forschungsreisen Prof. E. Stromers in den Wusten Ägyptens, II. Wirbeltierreste der Baharte-Stufe (unterstes Cenoman) 11. Sauropoda: Bayer. Akad. Wiss., Math.-naturwiss. Abt., Abh., neue Folge, Heft 10, 1932.

9 Nopsca, Francis, On the geological importance of the primitive reptilian fauna of the uppermost Cretaceous of Hungars; with a description of a new tortoise (Kallokibotion): Geol. Soc. London Quart. Jour., vol. 79, p. 107, 1923.

10 Depéret, Charles, op. cit., p. 176.

11 Lydekker, R., On certain Dinosauriae vertebrae from the Cretaceous of India and the Isle of Wight: Geol. Soe. London Quart. Jour., vol. 43, pp. 156$160,1887$.

12 Huene, Friedrich von, Los saurisquios y ornitisquios del Cretáceo Argentinc. Mus. La Plata Anales, ser. 2. t. 3, p. 167, 1929.

13 Lydekker, R., op. cit. (Paleontología Argentina, t. 2), p. 1, 1893.

14 Broom, $R$, On the occurrence of an opisthocoelian dinosaur (Alogosaurv: bauri) in the Cretaceous beds of South Africa: Geol. Mag., dec. 5, vol. 1, pr. 445-447, 1904.

15 Gilmore, C. W., A new sauropod dinosaur from the Ojo Alamo formation of New Mexico: Smithsonian Misc. Coll., vol. 72, no. 14, 1922 . 
Huene ${ }^{16}$ was the first to assign the genus Alamosaurus to the Titanosauridae, an assignment proved correct by the specimen here discussed.

From the information furnished by the Utah specimen, in conjunction with a review of the literature, the definition of the family Titanosauridae may now be amplified as follows:

First caudal vertebra with biconvex centrum; other caudals strongly procoelous; neural arches on most of the caudals attached to the anterior half of the centrum; caudals without lateral cavities; presacrals opisthocoelus; 5 or 6 vertebrae in sacrum; all chevron bones open at articular end; pubes not narrowing distally; ischia short and wide, without especial distal thickening.

The following genera have been included in this family: Titanosaurus, India, Indo-China, and South America; Argyosaurus, Laplatasaurus, Antarctosaurus, Campylodon, all from South America; Macrurosaurus, England; Hypselosaurus, Aepyosaurus, both from southern France; Aegyptosaurus, Egypt; Algosaurus, South Africa; and Alamosaurus, New Mexico.

When more complete specimens are found, it is quite probable that some of these genera will be shown to have other family affiliations.

\section{Genus alamosaurus Gilmore}

Alamosaurus Gilmore, Smithsonian Misc. Coll., vol. 72, no. 14, pp 1-9, pls. 1-2, 1922.

Genotype: Alamosaurus sanjuanensis Gilmore.

The genus Alamosaurus was established on a meager specimen collected by John B. Reeside, Jr., from the Ojo Alamo formation, Upper Cretaceous, in New Mexico. The type material consists of two bones, a left scapula and a right ischium, somewhat incomplete and perhaps pertaining to two individuals. The rather unusual procedure of founding a genus on such scanty evidence was justified on the ground that this was the first authentic record of the occurrence of sauropodous dinosaur remains in the Upper Cretaceous of North America. Fortunately, the specimen found in Utah has a scapula and both ischia preserved, thus permitting the fullest possible comparison to be made.

The present specimen is in close agreement with the type in all important particulars, and as the slight differences observed could not be considered of specific importance, I refer this specimen to Alamosaurus sanjuanensis.

Contributory evidence of the correctness of this conclusion is furnished by a second specimen from the type area-No. 15658, United States National Museum. This specimen consists of approximately the twenty-first caudal centrum and a caudal neural spine collected in 1916 by John B. Reeside, Jr., from a shale bed 3 to 8 feet above the base of the Ojo Alamo formation, in Barrel Springs Arroyo, west of the road, 1 mile south of Ojo Alamo,
N. Mex. These bones are in perfect agre 'ment with the caudal vertebrae of the Utah specimen, down to the smallest details. Thus it is shown that these typically procoelous caudal vertebrae also may be found in the same formation as the type materials on which the genus Alamosaurus was established and to that extent verify the identification of the Utah specimen with the meager materials from New Mexico. For the first time an adequate diagnosis of the skeletal characteristics of the genus Alamosaurus is possible.

Diagnosis: First caudal vertebra with biconvex centrum; other caudals procoelous; spines of anteriorly caudal vertebrae relatively short; neural arches arising from the. anterior half of the centra; prezygapophyses long, with articular faces looking more strongly inward than upward; transverse processes on first eight caucals, stout and raking backward; 25 chevrons, the first carried by caudal 1 , none bridged across at the articular en 1 ; scapula with blade regularly widening from the narrowest diameter upward, blade wide throughout; spine at right angles to longest axis of scapula; ischia short, narrowing but little distally, joined along median line for their full length; humerus long in relation to length of radius and ulna; ulna with short, stout olecranon process; five metacarpels; stout, first and second subequal in length; sternal bones very large.

\section{Alamosaurus sanjuanensis Gilmore}

Alamosaurus sanjuanensis Gilmore, Smithsonian Misc Coll. vol72, no. 14, pp. 1-9, pls. 1-2, 1922.

Specimen: United States National Museum 15560. Consists of 30 articulated caudal vertel wae, beginning with the first; 25 chevrons; 2 ischia, righ ${ }^{+}$somewhat incomplete; left scapula and coracoid; right humerus, ulna, radius, and metacarpus articulated; 2 ste"nal plates and parts of 3 ribs. Although not collected, the sacrum was observed in the field, and evidence was noted that the complete sacrum consisted of 5 vertebrae. Found by George B. Pearce, June 15, 1937.

Locality: Southwest toe of North Horn Mountain, Manti National Forest, Emery County, $\mathrm{U}^{\prime} \mathrm{h}$.

Horizon: Lower part of North Horn fo"mation, Upper Cretaceous.

\section{DETAILS OF THE SKELETAL PARTS}

\section{THE TAIL}

Caudal vertebrae

The tail is represented by 30 consecutive vertebrae, beginning with the first and retaining all the chevrons. In place, the tail showed a slight displacement between the ninth and tenth vertebrae but other xise formed an articulated series. All tail vertebrae, except caudal 1, are strongly procoelous. None of the centr have lateral 
cavities. The anterior caudals are relatively long; short centra, such as are found in Camarasaurus, Apatosaurus, and Diplodocus, are lacking.

The first caudal in Alamosaurus is characterized by its biconvex centrum, a feature found elsewhere among the Reptilia only in the Crocodilidae. Viewed from the front this centrum is subrectangular in outline, with the greatest diameter vertically. The anterior ball is more evenly rounded than the posterior and projects prominently forward from the centrum. (See pl. 5, fig. 1.)

The neural arch is low, restricted fore and aft, and arises wholly from the anterior half of the centrum. The diapophyses are thin, winglike processes that spring about equally from the sides of the centrum and arch, extending outward nearly at right angles to the bone. Both processes are slightly incomplete, but the right one gives a fairly good idea of its main features. (See pl: 8, fig. 1.) The upper border slopes steeply downward and outward from the level of the prezygapophyses as a thin plate, being thickened only along the ventral border. The extreme outer end is missing on both processes.

The prezygapophyses are lacking, except for their thin bases adjacent to the spine. These are deep dorsoventrally and indicate that the missing articular faces looked more strongly inward than upward. Superiorly they are braced by the supraprezygapophyseal laminae. Additional support is given by the supradiapophyseal lamina that terminates near their superior borders. The postzygapophyses are somewhat beneath the base of the spine. Their articular faces are poorly defined.

The spine on caudal 1 is badly distorted by crushing, which somewhat obscures its structure. It is composed primarily of prezygapophyseal, postzygapophyseal, prespinal, and postspinal laminae. The spine viewed from the front gradually widens from the base upwards. (See pl. 8, fig. 1.) The prespinal and postspinal laminae have their surfaces rugosely roughened throughout the greater part of their lengths. The prespinal is the more prominently developed. There is only slight evidence of emargination of the top of the spine. On the lower posterior angle chevron facets are developed. Anterior to these facets the median surface is flattened, with little indication of the lateral ridges that form such a conspicuous feature in the most posterior vertebrae.

Caudals two to thirty may be discussed as a group. From the table of measurements on page 32 it will be noted that the centra gradually decrease in length posteriorly as far as the thirteenth; beyond which they gradually lengthen for a few vertebrae and then progressively shorten to the end of the series. The last two show a more rapid reduction in size than those before, suggesting a near approach to the whiplash that probably was present, as in the South American Titanosaurus australis.

The centra have a pronounced ball on the posterior end with a deep cup on the anterior. Viewed endwise (see pl.
8) caudal 2 is higher than wide, 'which proportion pers" back to caudal 12. The fourteenth shows subequal dis neters, and the remaining 'members of the series are witen than high.

The chevrons are articulated intercentrally; and the articular facets are clearly observable posteriorly as far as caudal 18.

The inferior caudal surfaces, posterior to caudal 1 , are rudely rectangular in outline, but slightly expanded at either end. Commeneing with caudal 2 the conspicums feature of the ventral view-is the pair of lateral rid wes developed on either side of the centrum. Anteriorly the begin 60 to 70 millimeters posterior to the lip of the cip and terminate posteriorly at the beginning of the ball; at the posterior termination of each ridge the ends are obhiquely truncated, thus forming facets for the articulation of the chevron. These ridges become progressiv ly less and less conspicuous posteriorly, practically disappearing on caudal 14. Although chevrons persist as far as caudal 25, distinct facets for their articulation apprar for the last time on caudal 18. The median longitudinal channel; which is such a conspicuous feature of the vontral surface on the anterior third of the tail, has all $k t$ disappeared on the posterior members; on the eighteer th centrum all that remains are shallow median depressions at either end, and these persist to the last of the verteb-al series but become shallower and less well defined in the posterior caudals. On the anterior ventral end of caud als 29 and 30 a decided median noteh appears in the border of the cup. (See pl. 8.)

Except on the first caudal the transverse processes are heavy, rounded, and blunt, and they project outwerd and backward, springing about equally from the aroh and the top of the centrum. These processes gradually decrease in length posteriorly, disappearing after caudal 8 . The next four vertebrae have raised, roughened reetangellar areas (see pl. 6) in lieu of transverse processes, and from caudal 13 to 26 these areas are replaced by a rais $9 d$ longitudinal ridge. The ridges gradually decrease in stro from front to back, disappearing entirely on caudal 27.

The prezygapophyses are strongly developed throughout the caudal series and were probably functional as far back as caudal 23 . They regularly increase in size from the first to the thirtieth. In the anterior caudals the presvgapophyses are deep dorso-ventrally, are exceptionally long, and strongly overhang the ends of the centra. Th?y appear to have a downward curve, an appearance die largely to the convex contour 'of their upper borders. $T$ " articular faces look more strongly inward than upward. On the anterior vertebrae the prezygapophyses are strengthened superiorly by supraprezygapophyseal lan'inae and inferiorly by the walls of the neural arch. T laminae largely disappear posterior to caudal 13. Nenr caudal 13 the prezygapophyses are long and fingerlile, becoming progressively shorter posteriorly until on caudal 
27 their anterior ends terminate within the end of the centrum. (See pl. 7, fig. 27.) On many vertebrae one prezygapophysis is shorter than its opposite fellow.

The postzygapophyses are at the base of and slightly beneath the spine and face outward and slightly downward. From first to last these articular facets are poorly defined.

The spine on the caudals is composed primarily of the prezygapophyseal, postzygapophyseal, prespinal, and postspinal laminae. Except for the prezygapophyseal, these laminae largely disappear as distinct structures near caudal 7.

The neural arches throughout the series arise from the forward half of the centrum and are present on all 30 vertebrae.

The spines of the anterior caudals are relatively short, contrasted with the attenuated spines corresponding in Apatosaurus and Diplodocus. They rapidly decrease in height posteriorly and disappear as separate structures near caudal 15 , in this respect most nearly resembling those of Brachiosaurus. The spines are simple, none having emarginate tops as in Apatosaurus and Diplodocus.

In comparison with Titanosaurus australis the caudal vertebrae of Alamosaurus are simple and rectangular, viewed from the side, with a squarely truncated upper extremity. The tops of the spines are transversely widened on the first nine vertebrae, but more especially on the first six. In the anterior caudal spines the anterior and posterior surfaces are strongly rugose, probably in connection with the attachment of strong interspinous ligaments. At the base of the spines both front and back are deep pits leading into the interior of the bone, and these continue posteriorly as far as the eighteenth vertebra.

Caudals 5 and 6 are coossified by their centra. (See pl. 5, figs. 5 and 6.) There is little distortion of the bones, and very little extraneous bony matter extends over the joint. It is in no way comparable to the lesion on the sauropod caudals described and illustrated by Moodie, ${ }^{17}$ but the union may have been brought about by a slight injury.

The outstanding features of the caudal region of Alamosaurus sanjuanensis may be summarized as follows:

Caudal 1 with strongly convex ends.

Caudals 2 to 30 strongly procoelous.

Neural spines arising from the anterior half of centra.

Spines of anterior caudals relatively short, diminishing rapidly in height posteriorly.

Transverse processes only on caudals 1 to 8 .

Functional zygapopyhses ending 'on caudal 25.

First caudal chevron bearing.

The type caudal vertebrae on which the genus Titanosaurus was established were considered by Lydekker to belong to the postmedian part of the tail, but comparison with the articulated caudals of Alamosaurus indicates

17 Moodie, R. L., Two caudal vertebrae of a sauropodous dinosaur exhibiting a pathological lesion: Am. Jour. Sei., 4th ser., vol. 41, pp. 530-531, fig. 1, 1916. they pertain to the anterior half. The caud $\$$ figured by Lydekker ${ }^{18}$ belongs about at the thirteenth or fourteenth from the proximal end of the tail. It is distin ruished from the Alamosaurus eaudals by its much smallor size, more compressed centrum, and sharper definition of the chevron facets. Except for their smaller size, the caudal vertebrae of Titanosaurus blandfordi, illustrated on plate 7 of Lydekker's paper, cited above, bear a closer resemblance to the Alamosaurus caudals than do those of $T$. indicus.

Although the forward position of the neur-1 arches distinguishes the caudals of this animal from all other North American Sauropoda, this feature is found also in the genus Titanosaurus.

Measurements of caudal vertebrae, in millimeters

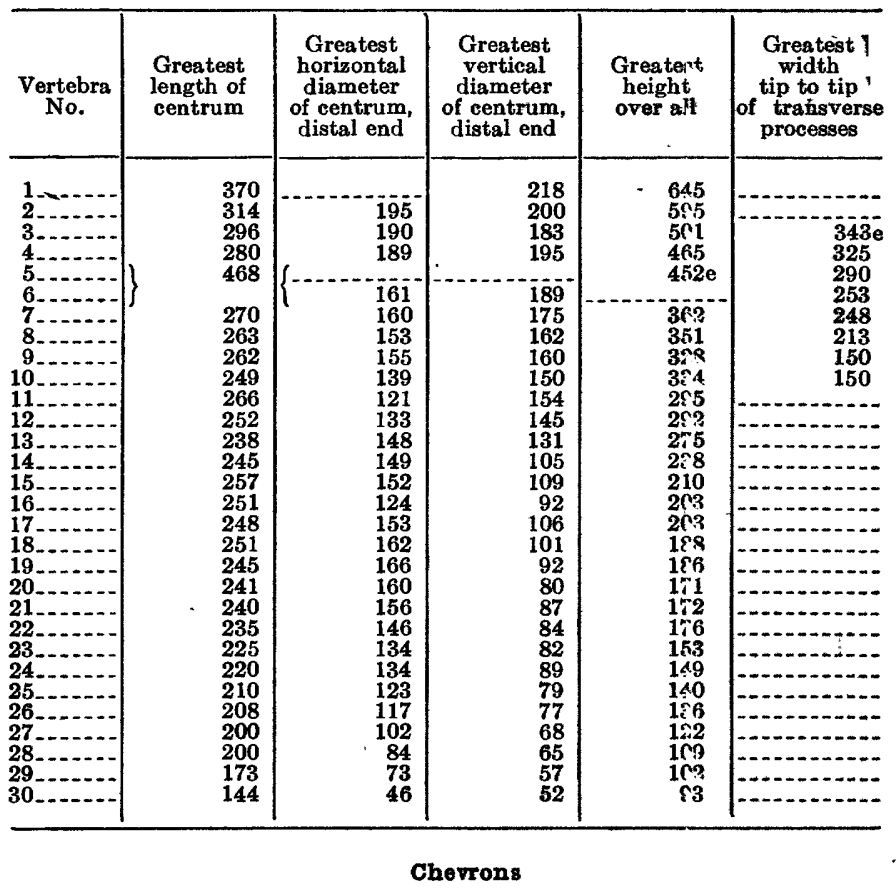

Commencing with caudal 1, intervertel-al chevron bones are present as far back as the twenty-fifth, which, from its small size, is probably the last of $t]$ ? series. For the sake of clearness in discussing the chevions they are enumerated with the vertebrae, the most anterior numbered one. All were found articulated, and their arrangement here may be considered as positively dotermined.

In having a chevron on caudal 1, Alamssaurus is in accord with Apatosaurus but differs from Diplodocus, in which the first chevron is carried on the se cond caudal.

In this series (see fig. 4) there are three auite distinct types of chevron bones. Nos. 1 to 15 are typically reptilian but open above the haemal canal, the two arms uniting below to form a laterally compressed spine that widens somewhat toward the distal end. Nos. 16 to 18 have the upper portion of chevron joined below but lack

18 Lydekker, R., Fossil Reptilia and Batrachia: Palaeontoloria Indica, ser. 4, Indian pre-Tertiary Vertebrata, vol-1. pt. 3, pl. 4, figs. 1, 2, 1879. 


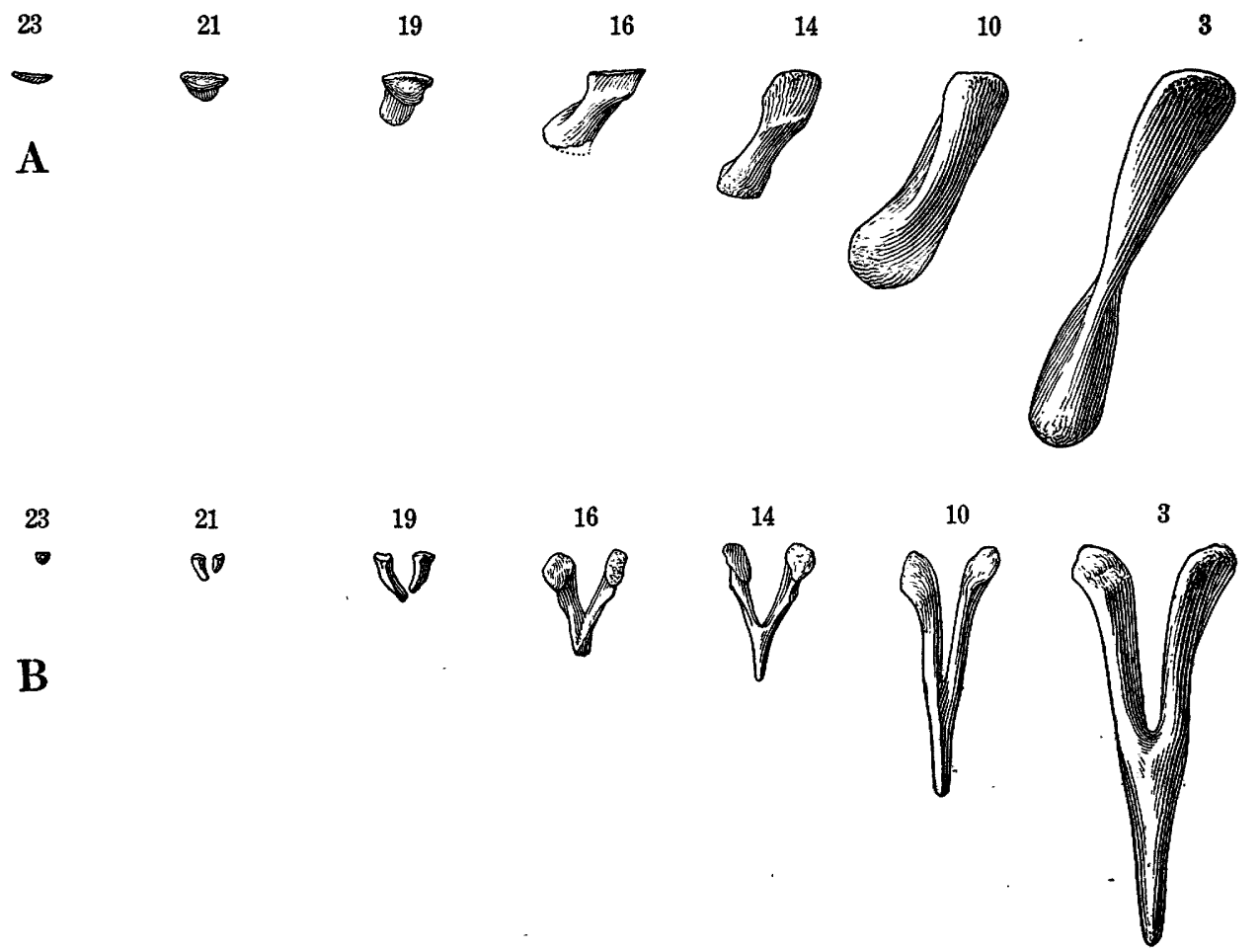

Figune 4.-Chevrons of Alamosaurus sanjuanensis Gilmore (U. S. Nat. Mus. 15560). A, Lateral view; B, posterior view, Nas. 3, 10, 14, 16, 19, 21, and 23 refer to position in the series. All one-tenth natural size.

a spine. Nos. 19 to 25 have the two halves of chevron separate. The first type gradually diminishes in length posteriorly until in the sixteenth chevron little remains except the cojoined arms. In the succeeding chevrons the articular ends are the last features to lose their identity. Even where the two halves are separate the form of the articular end is retained in the anterior pairs, but succeeding this type are elongated, subrounded, ossiclelike elements that were attached on their flattened sides to the outer lower angles of the vertebrae. These paired elements not only differ in size, but also in shape. The last, or twenty-fifth, chevron consists of a single elongated, rounded ossiclelike bone. Chevrons 7 to 17 display a lack of symmetry that is unique. On these chevrons the posterior border of the right arms, just before their junction to form the spine, is noticeably in advance of the left side. This is probably an individual peculiarity, for none of the bones gives indication of being injured or diseased.

The outstanding features of the chevrons are the great size of the haemal opening and the fact that none is bridged across with bone on the articular end. In Diplodocus the anterior chevrons have the haemal opening much reduced in size, whereas in Alamosaurus these openings are deep, constituting one-half the total length of the bone. Although retaining considerable depth, in chevrons 4 to 10 , inclusive, these openings are somewhat less than one-half of the total length of the bone. From chevron 10 posteriorly, however, owing to progressive shortening of the spines, the haemal canal again becomes more than one-half the total length of the bone. The longest chevrons; 4 and 5, have a greatest length of about 403 millimeters

PECTORAL GIRDLE

The pectoral girdle is represented in this specimen by the left scapula and coracoid and both sternal plates, all in an excellent state of preservation.

Sternal plates

The sternal plates, as shown in plate 9 , were found side by side not far removed from their proper relationship to the other parts of the skeleton. These pairec plates are elongate, with concave outer borders, bluntly pointed in front, and with "broad squarely truncatec ${ }^{\prime}$ posterior extremities.

The smooth, slightly concave side apparently is the upper or visceral surface and the slightly convex side the lower or outer surface. The lower surface near the outer anterior border is marked by a sharp ridge that extendr backward from the proximal end. At the anterior end this ridge stands out prominently from the surface of the bone and leans strongly toward the outer side of the plate. Its truncated anterior end contributes to the beveled. roughened articular surface of the coracoid, and in 8 posterior direction it rapidly recedes in height to merge. into the thickened portion of the plate. The sternal at the point of articulation with the coracoid has a greatest. thickness of about 110 millimeters.

The smooth, outer concave border of the bone is thin. but it thickens rapidly inward. The broad, truncate. 


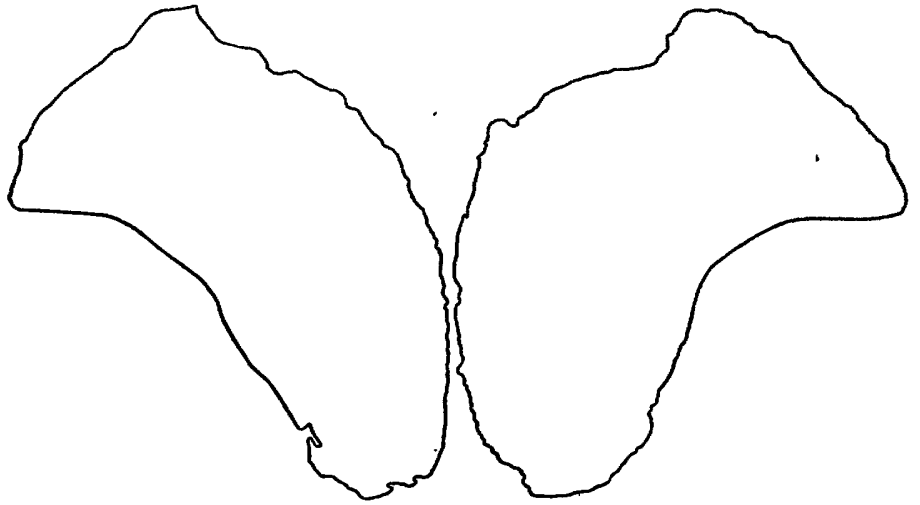

Fradre 5.-Outlines of sternal plates of Alamosaurus sanjuanensis Gilmore (U. S. Nat. Mus. 15560) showing their probable relationships in the artieulated sternum. One-twentieth natural size.

posterior end is thickened on the outer third, but gradually becomes thinner toward the inner edge. The thickened portion of this end gives faint indication of indentures for the attachment of the cartilaginous sternal ribs. The irregular inner border for one-half the length of the plate is thin, but the anterior half becomes increasingly thickened as it approaches the coracoidal articular facet.

These paired plates are asymmetrical to the extent that the left plate is longer and narrower than the right. This same asymmetry is also noted in a pair of sternal bones (U. S. Nat. Mus. 13786) of Camarasaurus lentus preserved in the National Museum collections. In general outline and in other particulars these elements are in fairly close agreement. In size the sternal plates of $A l a-$ mosaurus (fig. 5) are the largest sternal plates that have ever come to my attention, the right sternal, which is the longest, measuring nearly $31 / 2$ feet in length (approximately 1 meter).

In outline the plates resemble those of Brachiosaurus more closely than those of Apatosaurus, Barosaurus, or Camarasaurus.

The proper articulation of these elements in the sauropod skeleton has occasioned much perplexity and much difference of opinion as to which is the anterior end. The position of the present plates in the quarry-the heavy, thickened ends facing forward-confirms the correctness of Professor Marsh's determination of the position of the sternals in a specimen of Apatosaurus excelsus. ${ }^{19}$ Additional evidence that this is the correct position is furnished by a specimen of Camarasaurus lentus (U. S. Nat. Mus. 13786), which had the sternals preserved in situ between the ribs of the two sides, both of them with the heavy, more pointed end forward. In this connection it is now quite evident that Hatcher ${ }^{20}$ and Holland ${ }^{21}$ were in error in their interpretation of the sternals of Diplodocus. The

19 Marsh, O. C., Dinosaurs of North America: U. S. Geol. Survey 16th Ann. Rept., pl. 22, fig. 1, 1896.

20 Hatcher, J. B., Diplodocus Marsh; its osteology, taxonomy, and probable habits, with a restoration of the skeleton: Carnegie Mus. Mem., vol. 1, no. 1, p. 39, fig. 12, 1901 heavy thickened end which they regarded as posterior is quite certainly the anterior end.

The relationship of one plate to the other along the median line also offers some perplexities, but the position of the plates as found in the ground, with th? forward inner borders nearly in apposition, is probab'y the correct articulated position of the elements. In this position they would be as shown in figure 5, with a deep triangularshaped cleft between their posterior ends, such as would be the relation of the sternals of Diplodocus if the position advocated by Hatcher and Holland were reversed. This position, furthermore, puts the thickened anterior borders nearly in apposition instead of the thinner posterior borders. By experiment it was determined that if the posterior halves of these bones were joined along the median line the articular facets for the cracoids would be approximately 4 feet apart, which would provide a chest measurement all out of proportion to the known dimensions of these large sauropod skeletons.

\begin{tabular}{|c|c|c|}
\hline & Right & Left \\
\hline $\begin{array}{l}\text { Greatest over-all length } \\
\text { Greatest width at posterior end } \\
\text { Greatest width at center. }\end{array}$ & $\begin{array}{r}1,015 \\
600 \\
518\end{array}$ & $\begin{array}{r}1,071 \\
552 \\
465\end{array}$ \\
\hline
\end{tabular}

Scapula and coracoid

The left scapula coossified with the coracoid was recovered in an almost complete state of preservation, the coracoid lacking some of its anterior border, as shown in figure 6. In size these bones rival those of the largest of the sauropod dinosaurs, measuring abcrit 76 inches, approximately 2 meters, from end to end. The blade is especially wide throughout its length. From its narrowest

21 Holland, W. J., The osteology of Diplodocus Marsh, with special reference to the restoration of the skeleton of Diplodocus carnegiei Hatcher: Carnegie Mus. Mem., vol. 2, no. 6, p. 256, fig. 25, 1906. 


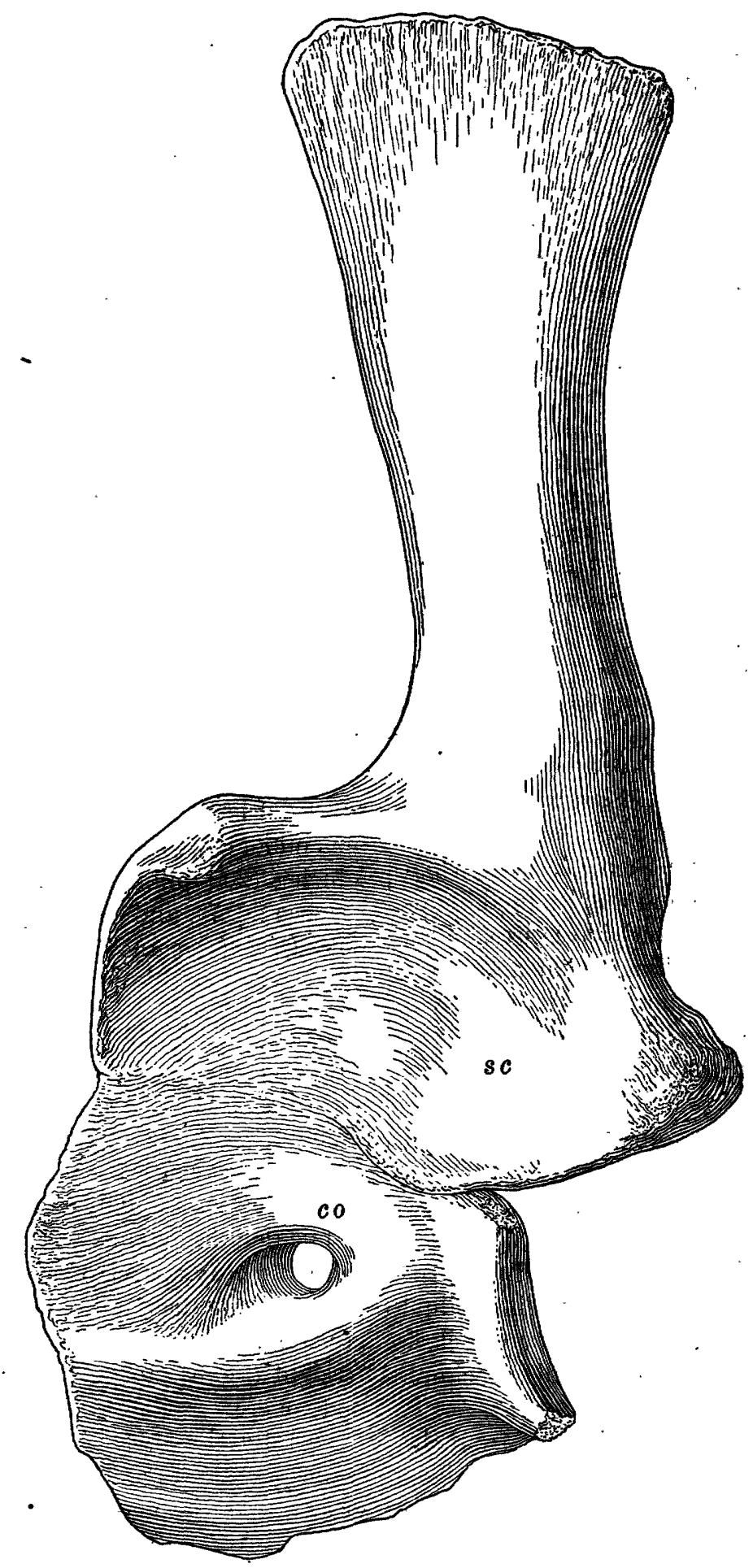

Fraune 6. -Left scapula and coracoid of Alamosaurus sanjwanenses Gilmore (U. S. Nat. Mus 15560), lateral view: co, coracoid; se, scapula. One-tenth natural s'ze. 
diameter it gradually widens from below upwards, as in the type. There is no special expansion of the anterior border of the blade, as in Camarasaurus and Titanosaurus, or of both upper borders, as in Haplocanthosaurus and Diplodocus, its closest resemblances being with the scapula of Cetiosaurus oxoniensis. The great width of the blade as a whole at once distinguishes it from the scapula of Apatosaurus. The posterior border is sinuous, with an abrupt downward turn of the thickened portion above the glenoid fossa. The upper, or suprascapular, end is thickened transversely and gently convex anteroposteriorly. Its surface is rugosely roughened, probably for the attachment of the suprascapular cartilage.

The spine is prominent and extends forward to the border, being placed at right angles to the longitudinal axis of the bone. This ridge is much thickened and along the side toward the coracoid the bone is deeply excavated, forming a muscle fossa of great extent. The opposite side of the spine slopes sharply off to the border. In this respect it differs from the type scapula of Alamosaurus sanjuanensis, which has a more gradual slope to this edge, as shown in plate 10, figure 1 . On the internal side the scapula and coracoid are concave from end to end, thus conforming to the shape of the thorax.

In the formation of the glenoid fossa the coracoid and scapula contribute. about equally. The sutural union of these two bones is so fully fused that their line of coalescence is difficult of detection. The coracoid has the usual subrectangular outline, its vertical and longitudinal diameters being about subequal. The outer side is irregularly convex, the inner concave. Approaching the glenoid fossa this border rapidly thickens. The bone is perforated by a large elliptical foramen that passes diagonally backward through the bone, emerging on the inner side close to the coraco-scapular suture.

In general the scapula closely resembles the type of Alamosaurus sanjuanensis, differing only in a few details, such as having a more sinuous posterior border, a more rapid slope from the thickened spine upward to the border, and slightly smaller size. None of the differences observed could be considered as more than individual variation, and for that reason, substantiated by the close resemblance of the ischia to the paratype, this specimen is referred to Alamosaurus sanjuanensis.

The scapula of Alamosaurus is quite different from the scapulae of Titanosaurus australis as figured and described by Huene. ${ }^{22}$ In view of the close resemblances found in the other bones, the total dissimilarity of the scapulae and coracoids of these two species leads me to question the validity of the association of the South American scapulae with the Titanosaurus skeleton, especially since the corresponding bones assigned to the genus Laplatasaurus, ${ }^{23}$ except for size, bear a much closer resemblance

\footnotetext{
22 Huene, Friedrich von, Los saurisquios y ornitisquios del Cretaceo Argentino: Mus. La Plata Anales, ser. 2, t. 3, pp. 36-37, pl. 9, 1929.
}

to the North American material. Because of the scattered occurrence of the South American material-, the differences in the scapulae would suggest an accidental interchange of skeletal parts.

Comparative measurements of scapulae, in milimeters

\begin{tabular}{l|r|r}
\hline & U. S. Nat. Mus. & U. S. Nat. Mus. \\
\hline Greatest over-all length of scapula & $1,948+$ & \\
and coracoid. & 1,475 & 1,700 \\
Greatest length of scapula_- & 815 & 820 \\
Greatest breadth of scapula.-. & 290 \\
Least diameter of blade._-_. & \\
Greatest diameter of upper or dis- & 490 & 450 \\
tal end. & & \\
\hline
\end{tabular}

THE FORELIMB

The right forelimb, including the foot, was found articulated as shown in plate $4, A$. It consists of the somewhat incomplete humerus, perfect radius and ulna, and five articulated metacarpals. As found in the quarry the forelimb measured about 9 feet (approximately 2.75 meters) from the proximal end of the humerus to the distal end of the metacarpus. Its outstanding characteristic is the great length of the humerus relative to that of the radius and ulna. In comparison, a radius and an ulna of Apatosaurus of lengths almost identical with those of the specimen under discussion are associated with a humerus that is 8 inches (200 millimeters) shorter than that of Alamosaurus (see fig. 7), and this proportional differerse obtains in both Diplodocus and Camarasaurus.

\section{Humerus}

When found, the humerus was protruding from the outcrop, and much of the anterior face of the proximal end and the entire inner angle had been eroded away, though the bone otherwise was excellent'y preserved. The head is centrally placed, forming a rounded prominence that is especially conspicuous in its porterior aspect.

The deltoid extends well down on the outer side of the shaft, is heavy, and overhangs the center of the shaft. This feature has quite certainly been exaggerated by crushing. The outer side of the humerus is unusually straight (fig. 8), not widening out as in most, other sauropod genera.

Distally the shaft terminates on the outer side in an inconspicuous radial condyle, set off by a longitudinal groove upon its anterior face. The ulnar ecndyle is likewise weakly defined. Viewed from the distal end the humerus is subrectangular in outline, witl the median posterior border deeply and broadly hollowed out by the anconeal fossa. Viewed laterally the distal end shows a slight inclination forward. Both articular end - are rugosely roughened.

\footnotetext{
23 Idem, pl. 23, figs. 1, 2.
} 

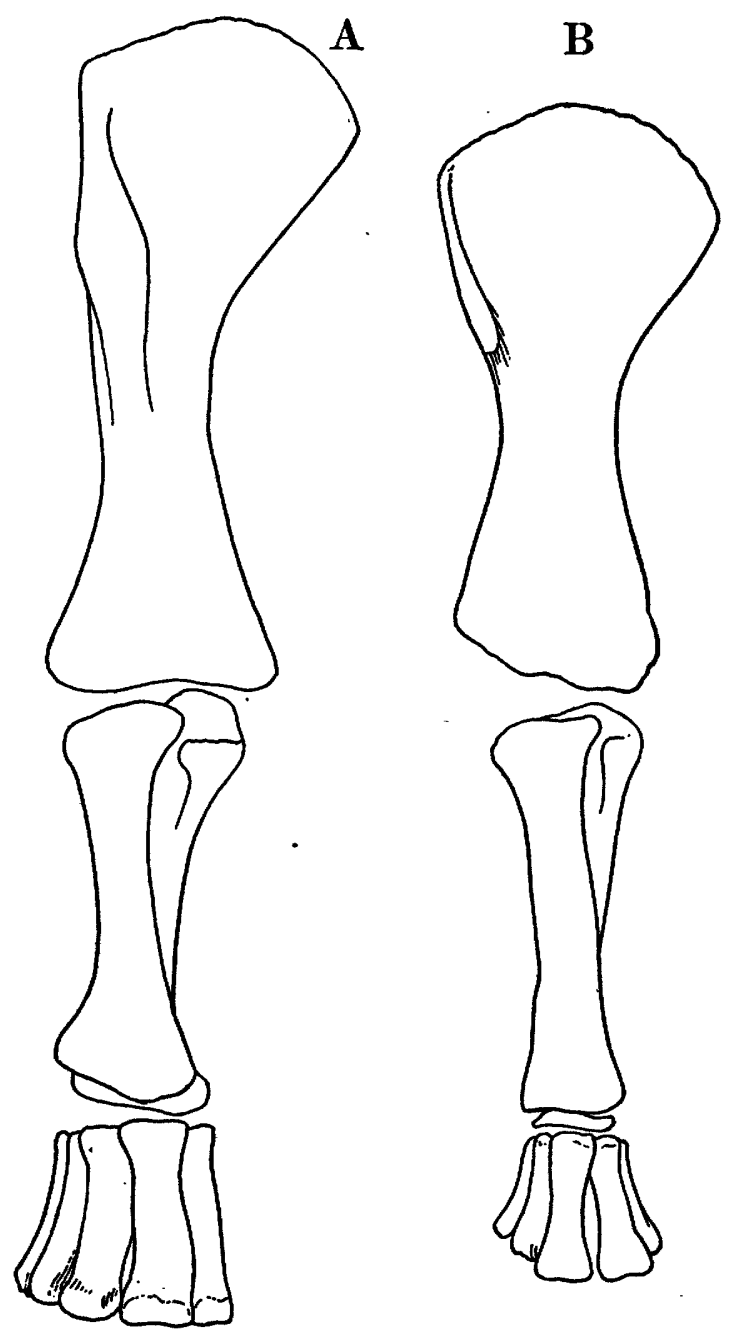

Fradre 7.-Fore limbs of Alamosaurus and A patosaurus, viewed from the front. $A$, Alamosaurus sanjuanensis (U. S. Nat. Mus. 15560); $B, A$ patosaurus louisea (C. M 3018). Both about one-twentieth natural size.

\section{Measurements of humerus}

Millimeters

Greatest length

1,360

Greatest transverse diameter, distal end

Least transverse diameter of shaft.

\section{Radius and ulna}

The ulna is longer and heavier than the radius. It differs from most other sauropod ulnae in developing a stout, blunt olecranon process, which stands up prominently behind the articular surface for the humerus, as shown in figure 9. The ulna of Aegyptosaurus barharijensis Stromer, ${ }^{24}$ a true member of the Titanosauridae, shows a somewhat similar blunt olecranon process. Posterior to the projection just described, and separated from it by a narrow notch, is a second, lesser projection. Viewed from the proximal end the ulna has the usual subtriangular out-

\footnotetext{
24 Stromer, E., Ergebnisse der Forschungsreisen Prof. E. Stromers in den Wüsten Ägyptens. II. Wirbeltierreste der Baharie-Stufe (unterstes Cenoman). 11. Sauropoda: Bayer. Akad. Wiss., Math.-naturwiss. Abt., Abh., neue Folge, Heft 10, pl. 1, fig. 2a, 1932.
}

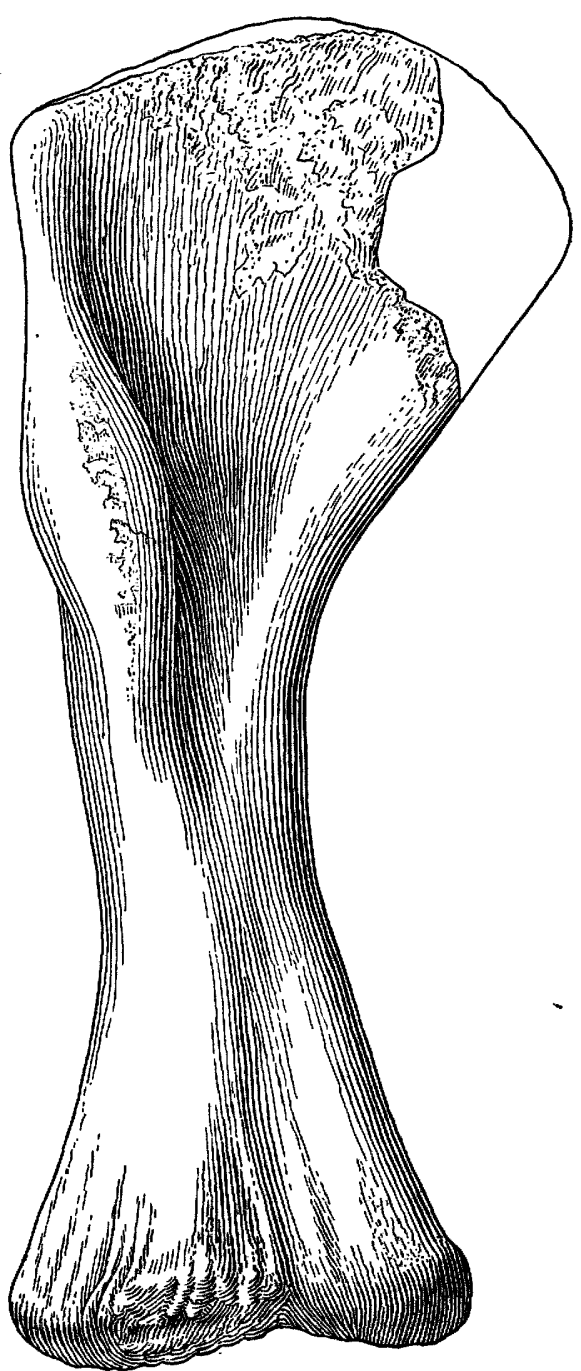

FIGURE 8.-Right humerus of Alamosaurus sanjuanensis Gilmore (U. S. N'at Mus. 15560), viewed from the front. One-tenth natural size.

line, being hollowed out in front for the reception of t1 ? head of the radius. The distal end is reniform in outline, with the concave side looking inward and backwarl. This end is heavier than that of the radius and mo"e expanded than the angularly rounded end of the ulna of Apatosaurus. The proximal half of the inner surface is hollowed out both longitudinally and anteroposteriorly.

The radius has a slightly constricted, bowed shaft, with ends about subequal. The upper articular end is slightly concave, the lower convex; the surfaces of both are rugosely roughened. In the articulated position in which there bones were found the shaft of the radius partly crossas that of the ulna, as shown in figure 9.

In discussing the various bones found in the "Sauropod bed" at Bara Simla, India, Huene and Matley ${ }^{25}$ reached certain conclusions as to their association that in the light

${ }^{25}$ Huene, Friedrich von, and Matley, C. A., The Cretaceous Saurisehia and Orinthischia of the central provinces of India: Palaeontologia Indica, new s?r. vol. 21, Mem. 1, pp. 31-32, 1933. 

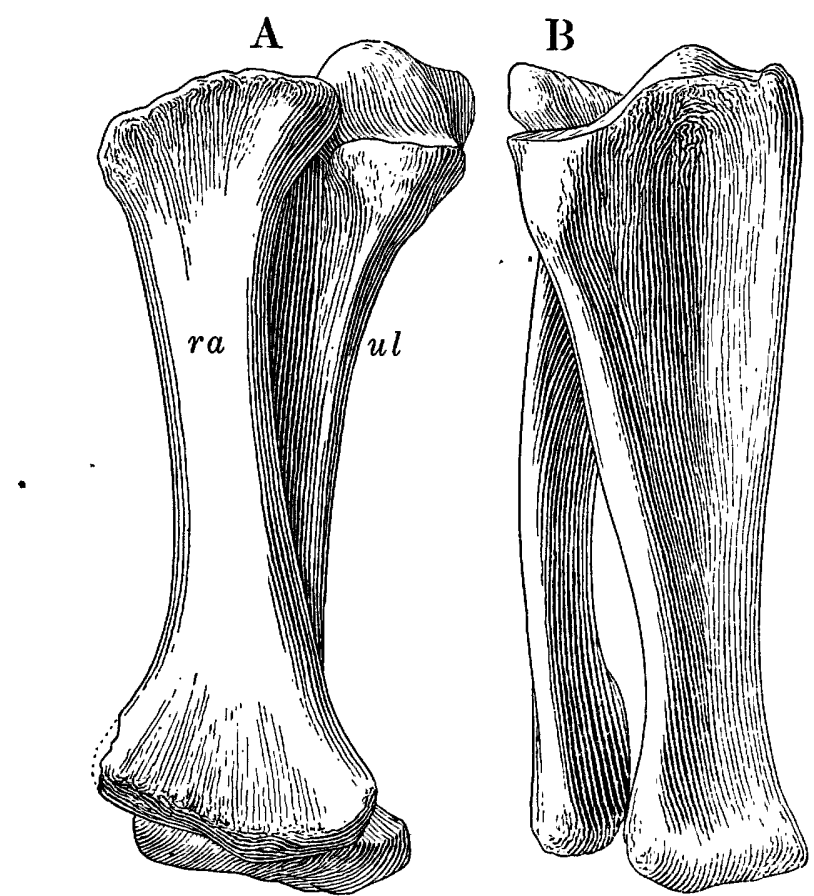

FrGURE 9.-Right radius and ulna of Alamosaurus sanjuanensis (U. S. Nat. Mus. 15560 ), shown as found articulated. $A$, Viewed from the front; $B$, lateral view. One-tenth natural size.

of the articulated forelimb of Alamosaurus seem to be in error. On the basis of proportionate lengths, Huene and Matley concluded that the lower-limb bones were too short for the length of the humerus. If the same ratio obtains between the two segments of the forelimb as in Alamosaurus, the radius and ulna assigned to the Indian form are somewhat overlong instead of being too short, as shown by the measurements given below:

Length of forelimb of Alamosaurus, in millimeters

\begin{tabular}{|c|c|c|c|}
\hline & $\begin{array}{l}\text { Length of } \\
\text { humerus }\end{array}$ & $\begin{array}{l}\text { Length of } \\
\text { ulna }\end{array}$ & $\begin{array}{l}\text { Length of } \\
\text { radius }\end{array}$ \\
\hline $\begin{array}{l}\text { Alamosaurus } \\
\text { Indian specimens. }\end{array}$ & $\begin{array}{l}1360(=1) \\
1034(=1)\end{array}$ & $\begin{array}{l}885(=0.65) \\
790(=0.76)\end{array}$ & $\begin{array}{l}800(=0.59) \\
780(=0.75)\end{array}$ \\
\hline
\end{tabular}

Although the difference in measurements of the Indian specimens seems to indicate that these bones do not pertain to a single individual, they are at least close enough to warrant the suggestion that in all probability the segments of the forelimb bones of Titanosaurus and Antarctosaurus had approximately the proportions of the forelimb of Alamosaurus.

\section{Measurements of ulna and radius}

Millimeters

Greatest length of ulna

Transverse diameter of ulna at proximal end

Transverse diameter of ulna at distal end

Transverse diameter of ulna at middle of shaft.

Greatest length of radius .

Greatest transverse diameter of radius at proximal end....

Greatest transverse diameter of radius at distal end ........

Least transverse diameter, middle of shaft.
Motacarpus

The metacarpus of Alamosaurus, consisting of five elements, was found articulated, and, except for the badly abraded anterior surfaces of metacarpals I and II (metacarpals I and II, fig. 10), all are in a good sts.te of preservation. There was no indication of ossified carpal bones. In order to preserve the precise relationships of these articulated foot bones, they were prepared in deep relief, but this procedure has the disadvantage of leaving their posterior sides partly hidden in the matrix.
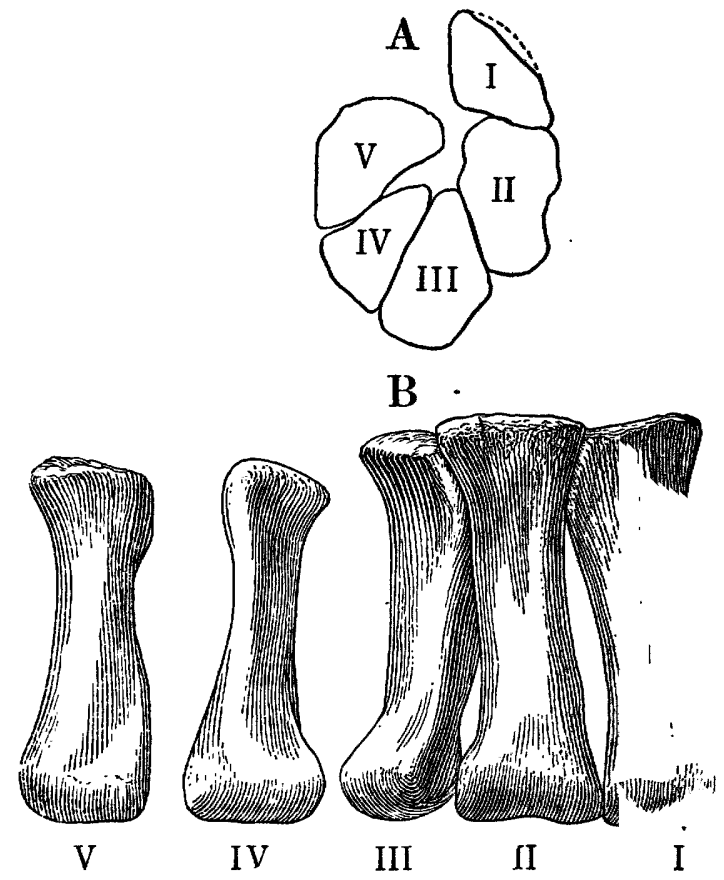

Fradre 10.-Right metacarpus of Alamosaurus sanjuanensis Gilmore (U. S. Nat. Mus. 15560). A, Proximal ends of metacarpals as found articulated; $B$, metacarpals, with the exception of III, viewed from the front; I, II, III, $I V$, and $V$ indicate metacarpals one to five, respectively. One-sixth natural size.

In articulated position the metacarpals interlock at their proximal ends (see fig. 10) forming a semicircle, a structure with a stability that conforms well to the great weight they are called upon to support. The metacarpus as preserved has the arc of this semi-circle flattened, so that metacarpals IV and $V$ lie directly behind the other elements. Thus, in preparing figure 73, I, II and III were drawn as found articulated, and IV and V separately from a direct front view of each, in order to show more clearly their relative proportions.

The metacarpals of Alamosaurus are elongated; I and-II, the longest of the series, are subequal in length, the remaining metacarpals becoming progressively shorter toward the outside of the manus.

The anterior face of metacarpal I in this snecimen has been so badly planed off by erosion that its contours have been largely destroyed. The posterior si le, however, is in good preservation. This surface between the expanded 
ends gradually widens from above downward. On the proximal half of the external side this bone presents a flattened, beveled triangular surface that forms the chief articular contact for metacarpal II. Viewed from the end the distal extremity is rectangular in outline with the greatest diameter transverse. The articular surface of this end extends well upward on both anterior and posterior faces, being about subequal in extent. This description of the distal end of metacarpal I would apply equally well to the other metacarpals with the exception of $\mathrm{V}$, which has the most robust distal end of any of the series.

Metacarpal II, which has the same length as I, may be distinguished by the subreniform outline of the proximal end. The greatest diameter of this extremity is anteroposterior. The external concave side of this end articulates with the internal side of metacarpal III. Viewed from the front, the shaft is transversely constricted above its midlength, but regularly widens from this point to the distal end, especially along the external side.

Metacarpal III is slightly shorter than II but more slender. The proximal end is triangular in outline, narrowing to an acute angle posteriorly. In a lateral view the shaft grows regularly wider from the distal third upward. In articulated position the proximal end is closely wedged in between metacarpals II and IV. (See fig. 10.)

Metacarpal IV, as shown in the table of measurements, is intermediate in length between III and V. The shaft is slightly twisted, thus bringing the planes of the two ends, viewed from the front, slightly out of alignment. Between the expanded ends the shaft is moderately constructed transversely. Viewed laterally the shaft widens regularly from the distal third upward. The proximal end is triangular in outline.

Metacarpal V is nearly as long as IV and equally stout. The proximal end is subrectangular in outline, with the longest diameter transverse. In articulated position little more than one-half of the anterior surface at the proximal end is in articulation with metacarpal IV.

\begin{tabular}{l|r|r|r}
\multicolumn{4}{|c}{ Measurements of metacarpals, in millimeters } \\
\hline Metacarpal & $\begin{array}{c}\text { Greatest } \\
\text { length }\end{array}$ & $\begin{array}{c}\text { Greatest } \\
\text { diameter } \\
\text { of proximal } \\
\text { end }\end{array}$ & $\begin{array}{c}\text { Greatest } \\
\text { transverse } \\
\text { diameter of } \\
\text { distal end }\end{array}$ \\
\hline I & 410 & 151 & 142 \\
\hline III & 409 & 160 & 131 \\
IV & 390 & 165 & 104 \\
V & 370 & 140 & 137 \\
\hline
\end{tabular}

Among the Sauropoda the metacarpals of Alamosaurus are exceeded in length only by those of Brachiosaurus brancai Janensch. ${ }^{26}$ In Brachiosaurus, metacarpal II is the longest, reaching a length of 634 millimeters, or more than 8 inches (200 millimeters) longer than metacarpal $\mathrm{I}$, the longest in the Alamosaurus foot. The Alamosaurus metacarpals have relatively stouter shafts, and their proximal ends differ from those of Brachiosaurus in outline and relative proportion. The manner of articulation, however, of the metacarpals in these two genera is r?markably similar.

The foot clearly demonstrates the erect columnar position of the metacarpals in the articulated manus and shows them to have been arranged in a semicircular position, a relationship made possible by the triangular form of the proximal ends of metacarpals II, III, and IV, is shown in figure $10 \mathrm{~A}$. Because of the decrease toward the outside in the lengths of the metacarpals, it is quite arparent that the metacarpus had a correspondingly slanting position.

The proportionate lengths of the metacarpals are quite unlike those of such sauropods as Apatosaurus and Camcrasaurus, in which the lateral elements are shortest. This would seem to indicate for Alamosaurus a foot in which tr 9 supported weight is more evenly distributed on the sepsrate toes than in Apatosaurus and Camarasaurus. It might also imply a different digital formula, but unfontunately none of the phalangial bones were preserved with this specimen.

\section{THE PELVIC REGION -}

Of the bones of the pelvic region, only the ischia wer: collected. The sacrum was noted in the field, and it ar. peared to consist of five vertebrae.

The coossified ischia were found in articulation with remnants of the ilia and pubes. The left ischium is fractured below the articular end, and this part is turned urward at nearly right angles to the main part of the bone. Otherwise it is nearly complete. The right element lacks the articular ends for the ilium and pubis, but in betweer. a part of the acetabular border still remains.

The ischia are thoroughly coalesced for their full length along the median line. The exact outline of the antericr border is somewhat uncertain, either because this border has been telescoped or because the overlying bone is a narrow portion of the pubes that has slipped by the articulation and rests upon the ischia. If the latter, it indicates the pubes were closely joined across the entire antericr border of the ischia, thus entirely closing the pelvis frorn below.

The ischia are relatively short and broad with littl? expansion of their distal ends. Viewed from above, th? conjoined ischia are broadly concave from side to sid? (see fig. 11), becoming more gutterlike distally. The outer borders are thickened, rounded, and strongly concave.

${ }^{26}$ Janensch, W., Das Handskelett von Gigantosaurus robustus und Branchisaurus brancai aus den Tendaguru-Schichten Deutsch-Ostafrika: Centralbl. Mineralogie, 1922 , no. 15 , pp. $464-480$. 


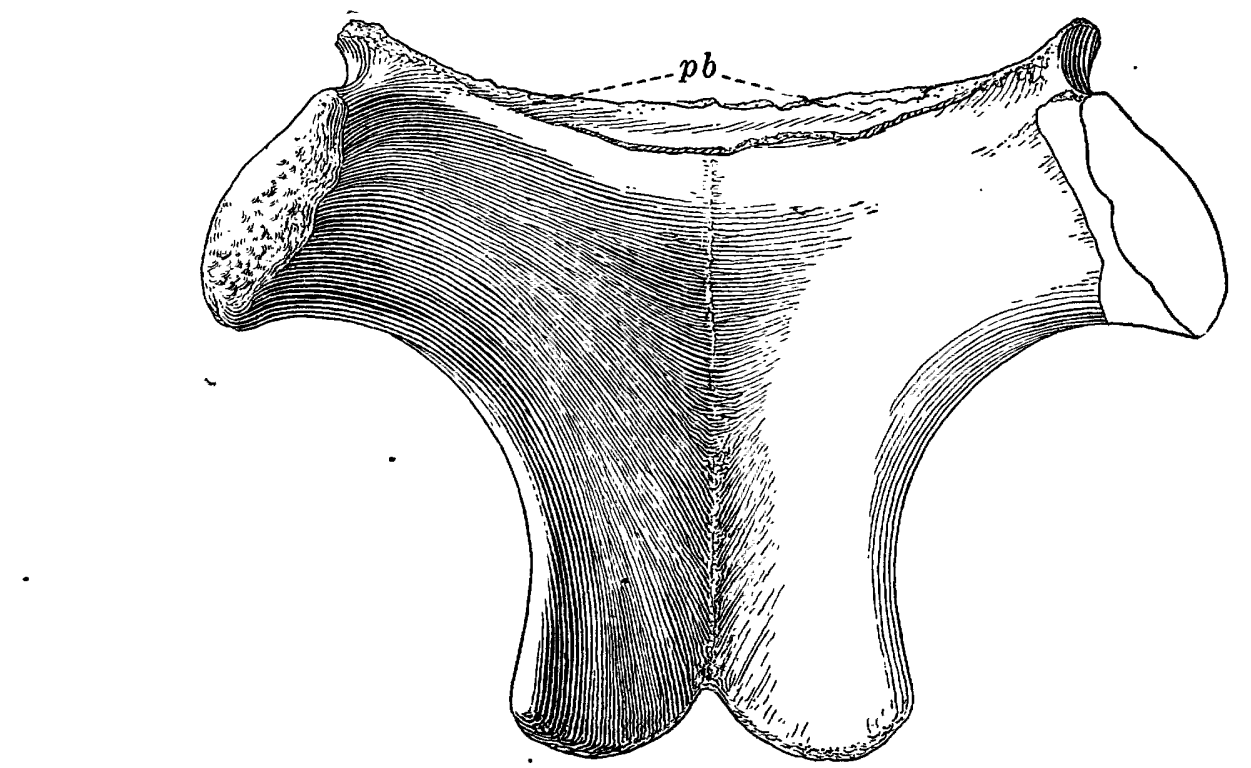

Figure 11.-Coossified ischia of Alamosaurus sanjuanensis Gilmore (U. S. Nat. Mus. 15560), viewed from above. pb, indicates what appears to be an overlap of the pubes. One-tenth natural size.

sweeping outward and upward to the heavy expanded end for articulation with the ischiac peduncle of the ilium. The acetabular border is relatively wide, its concave surface looking outward and forward when articulated. The upper anterior angle is thickened, with a rugosely roughened surface for articulation with the pubis. The anterior border becomes gradually thinner toward the median line. Transversely, the ventral side of the conjoined ischia is slightly convex. The distal ends are but little thickened and may have formed a broad notch on the median line, but the slightly damaged condition of this border leaves uncertainty on this point.

Among the various sauropod ischia with which these bones were compared the closest resemblance was found with the paratype of Alamosaurus sanjuanensis ${ }^{27}$ from the Upper Cretaceous of New Mexico. These bones so closely resemble one another in all of their principal features that no doubt is left of their generic identity. Comparison shows at once that the original description of the Alamosaurus ischium erred in interpretation of the border for the pubic articulation. What appears to be a complete rugose border is now recognized as an incomplete broken edge, and the complete bone would have quite a different shape on this side. Next to Alamosaurus the ischium of Titanosaurus australis, as illustrated and described by Huene, ${ }^{28}$ is of the same general type, differing in having a much narrower shaft.

Measurements of ischia

Millimeters

Width across distal end of coossified ischia, about_..._._. 395 Length at center..... Greatest thickness at distal end

27 Gilmore, C. W., A new sauropod dinosaur from the Ojo Alamo formation of New Mexico: Smithsonian Misc. Coll., vol. 72, no. 14, pl. 2, 1922.

\section{THE SKeletal PARTS IN PLAC?}

The specimen of Alamosaurus sanjuanensis described was an isolated skeleton, that is, there were no bones of other animals found intermingled with it; thus all parts recovered are certainly those of a single individual. The skeleton was semi-articulated, the dorsal virtebrae protruding from a lens of soft, yellowish, friable sandstone. These bones lay practically on the surface and were so disintegrated that no attempt was made to collect them. They formed an articulated series in line with the sacrum, and what had been a complete pelvis was present, but bottom side up. Detached and some 2 feet distant from the last sacral was the first caudal, beginning an articulated series to the tenth vertebra. Between the ninth and tenth was a slight dislocation, but from this point to the thirtieth, the tail with all the chevrons remsined in articulated sequence. Most of the ribs lay on either side and at right angles to the dorsal part of the vertebral column, those of the right side, in order and regularly spaced. The left scapula and coracoid were parallel to the column, but on the right side; whereas the complete art: sulated right forelimb, including the foot, was on the left side (pl. $4, A$ ) and at right angles to the vertebral column. The very large sternal plates were shifted to one side (pl. $4, B$ ), but their proper relationship to one another was maintained. The position of the pelvis, sternal plates, anc' ribs clearly indicated that the carcass when entombed was lying on its back.

Of the articulated pelvis, only the ischia were sufficiently well preserved to be worth collecting. No tree was found of the hind limbs, and the neck and skull must long since have been eroded away and destroyed.

28 Huene, Friedrich von, Los saurisquios y ornitisquoios del Cretáceo Argentino: Mus. La Plata Anales, ser. 2, t. 3, pl. 14, figs. 2a, 3b-e, 1929. 


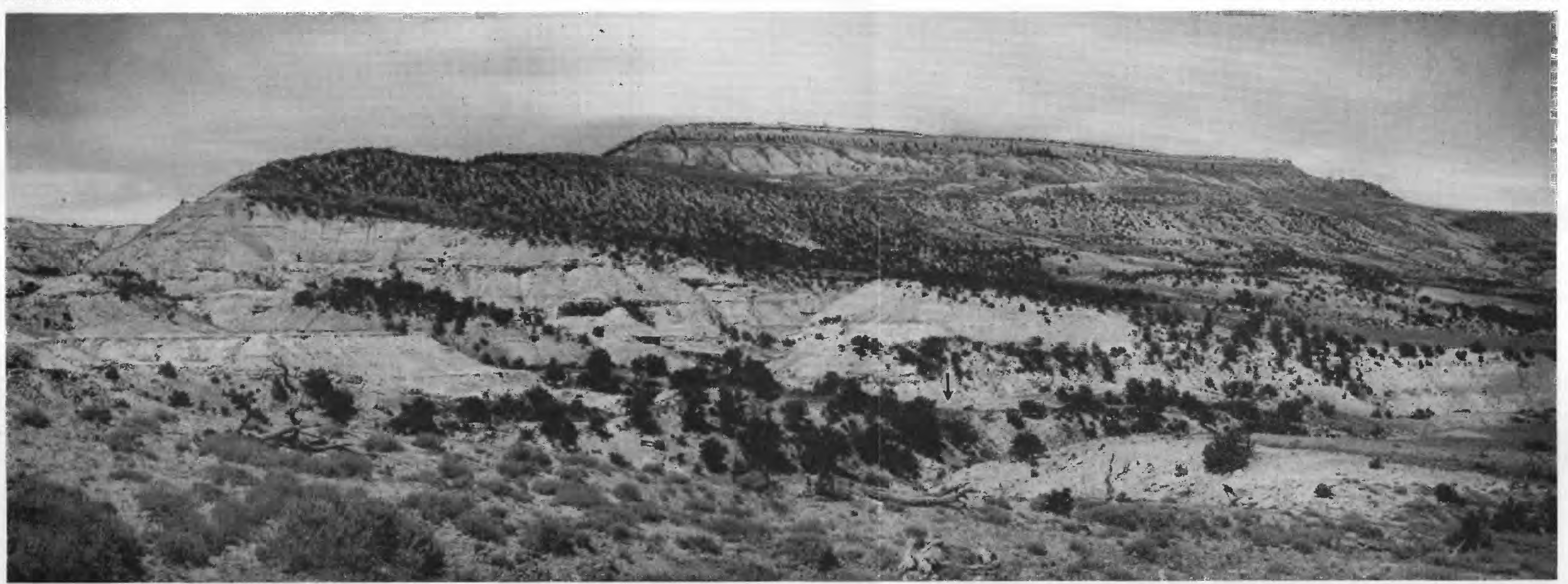

VIEW OF BADLAND AREA OF THE NORTH HORN FORMATION LOOKING TOWARD NORTH HORN MOUNTAIN FROM THE SOUTH. Shows the location of the Alamossurus quarry (indicated by the arrow in the middle foreground). Photograph by E. M. Spieker. 


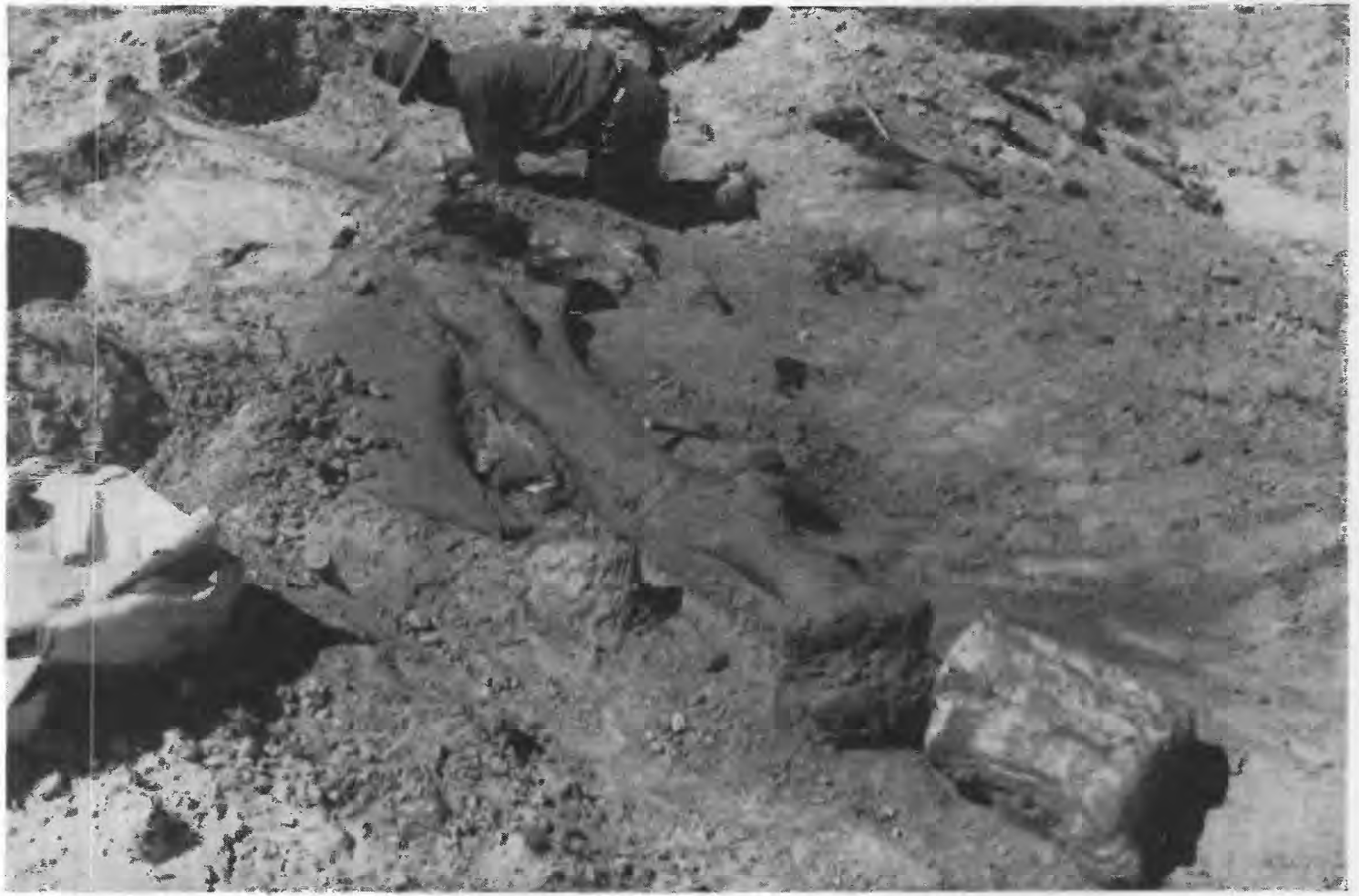

A. THE ARTICULATED FORELIMB OF ALAMOSAURUS SANJUANENSIS GILMORE IN PLACE.

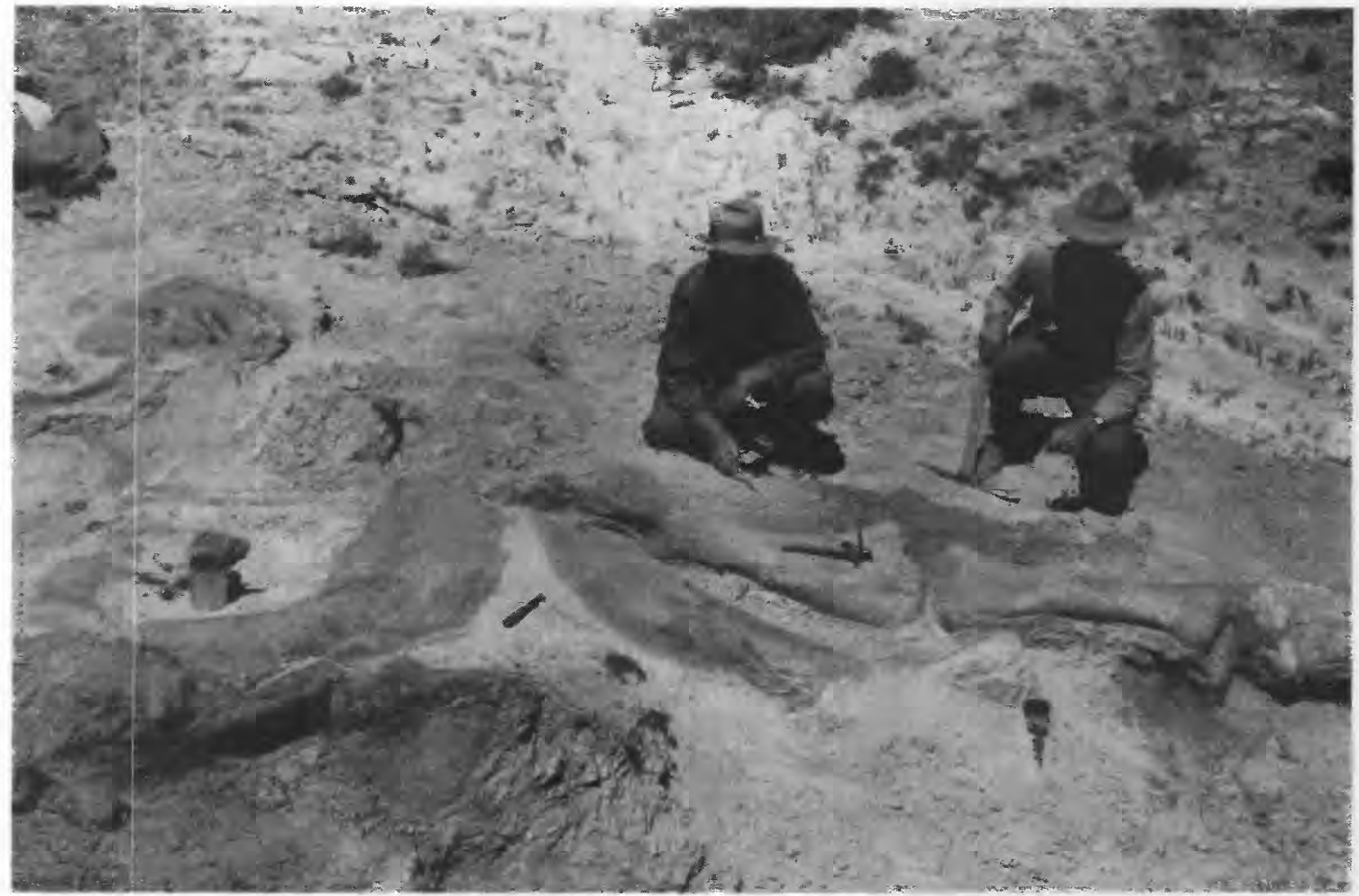

B. THE STERNAL PLATES OF ALAMOSAURUS SANJUANENSIS GILMORE AS THEY WERE FOUND. 


\section{RELATIONSHIPS OF ALAMOSAURUS}

It is clearly evident that Alamosaurus represents one of the larger members of the Sauropoda. The markedly procoelus character of the caudal vertebrae at once distinguishes this genus from all the better known sauropodous dinosaurs of North America, and indicates that its family affliations are with the Titanosauridae. It should be mentioned, however, that Diplodocus and Brachiosaurus, and to a lesser degree Apatosaurus, have a few anterior caudal vertebrae that might be called procoelus, which are soon superseded by those of amphiplatan style, not present in Alamosaurus.

Among all North American sauropod genera the preserved elements of Alamosaurus compare most favorably with Brachiosaurus, and although these two genera can be adequately distinguished, the several points of resemblance suggest a relationship whose implications, because of the paucity of our knowledge of the Alamosaurus skeleton, cannot be fully weighed at this time.

The most apparent of these common features are an elongated humerus; a stout and lengthened metacarpus; relatively short, simple spines of the anterior caudal region; a lack of pleurocoels in the caudal centra; wide ischia without distal expansion; and very large, somewhat similarly shaped sternal plates.

Of the genera assigned to the family Titanosauridae, most of which are inadequately known, Alamosaurus appears to have its closest affinities with the genus Titanosaurus of India. Insofar as one can determine from the illustrations and description of the meager type materials, the Indian Titanosaurus and the North American Alamosaurus seem to be generically identical, yet it must be kept in mind that other parts of the skeleton might display points of distinction. In fact, the South American Titanosaurus, australis, known from more adequate specimens, appears, because of its much smaller size and differer ses found in the scapula and coracoid, to be readily distinguishable from Alamosaurus. This fact, coupled vith the wide geographical separation, leads to a decisior to continue the use of the term Alamosaurus to denote the North American representative of the Titanosauridae.

Huene has shown that Titanosaurus australis has a Diplodocus-like skull and dentition, but whether $A l a-$ mosaurus has a similar development of the crani'm, as yet we have no evidence.

Little is known of evolutionary trends in the Sauropoda, and it is therefore difficult to fix the phylogenetic value of the last of the Sauropoda. Altogether Alamosauris is a type that shows no such marked specialization as do the Diplodocidae.

The neural spines of the anterior caudals are simple, not bifid, and the centra are without pleurocoels. T] 1 re may have been an extension of the distal end of the tail into a long whiplash, as in T. australis, but as yet we bave no evidence of this part of the skeleton. It would appear that in the elongation of the humerus and the metacarnus some specialization is shown, but here again the lact of knowledge concerning the proportions of the hind linbs leaves us in doubt as to whether the trend was in the direction of the Brachiosauridae or otherwise. 


\section{PART 2. DESCRIPTION OF A NEW SPECIES OF THE CERATOPSIA}

\section{INTRODUCTION}

The first recognizable ceratopsian fossils to be discovered in the North Horn formation were found in 1935 by Messrs. E. M. Spieker and J. B. Reeside, Jr., in the vicinity of North Horn Mountain, Emery County, Utah. Additional and better-preserved specimens were collected there by the 1937 and 1939 Smithsonian Paleontological Expeditions, and, in all, skeletal parts of 11 individuals are now available. The incompleteness of these specimens, especially the lack of certain critical skull parts, leaves much to be desired for a study of the material, but the discoveries have greatly extended the known geographical range of the Ceratopsia, and one of these specimens is sufficiently complete to be tentatively assigned as a new species to the genus Arrhinoceratops Parks.

\section{AVAILABLE CERATOPSIAN SPECIMENS}

The following specimens, all in the United States National Museum have been studied:

1. No. 15583. Partly disarticulated skull consisting of the right squamosal, jugal, lachrymal, supraorbital, postfrontal, one supraorbital horn core, right quadrate, and both quadratojugal bones. Posterior median part of frill, tentatively associated.

2. No. 15875. Right squamosal and a considerable part of the median part of the frill.

3. No. 16169. Articulated median part of a very large skull, including one complete brow horn and part of the other. Parts of both squamosals.

4. No. 16572. Posterior and median parts of the so-called parietal bone.

5. No. 16577. Palatal part of a skull, with the articulated lower parts of the jugals, epijugals, and quadrates. Small parts of both articulated squamosals are also present. All discarded except right quadrate and epijugal.

6. No. 16574. Left dentary, with a few poorly preserved teeth.

7. No. 16575. Right dentary, teetb all missing.

8. No. 15665. Right pubis.

9. No. 16576. Left pubis.

10. No. 16168. Left humerus.

11. No. 16573. Crest (median) of frill.

\section{Pamily CERATOPSIDAE Marsh}

\section{Genus ARRHINOCERATOPS Parks}

The genus Arrhinoceratops was established by Parks ${ }^{29}$ on a well-preserved skull from the Edmonton formation, which skull he characterized as follows:

Supraorbital horn cores large, directed outwards and forward; nasal horn core absent; facial region short; crest relatively large, subquadrate, flat; squamosal long; parietals with oval fontinelles of moderate size; anterior process of jugal unusually long.

\footnotetext{
29 Parks, W. A., Arrhinoceratops brachyops, a new genus and species of Ceratopsia from the Edmonton formation of Alberta: Toronto Univ. studies, geol. eer., no. 19 , pp. 5-15, pls. 1-2, 1925 .
}

The incompleteness of the present skull renders its generic assignment to Arrhinoceratops somewhat conjectural, but the presence of a thin, flattened, subquadrangular crest; a large supraorbital horn core that is directed strongly forward; and a long wide squamosal are features in accord with the type. A more complete specimen might prove the species to be distinct from Arrhinoceratops, but for the present a tentative assignment to that genus appears to be the more logical course.

\section{Arrhinoceratops? utahensis Gilmore, n. sp.}

Type: U. S. Nat Mus. 15583. The articulated right squamosal, quadrate, quadratojugal, postorkital, supraorbital horn core, postfrontal, lachrymal, jug ?l, and epijugal. Provisionally associated is a considergble portion of the posterior part of a parietal. Collected by G. B. Pearce, July 9, 1937.

Paratype: U. S. Nat Mus. 15875. A righ $\uparrow$ squamosal and the posterior part of the parietal. Collected by E. M. Spieker and J. B. Reeside, Jr., 1935.

Type locality: For the type, west side of $]^{\top}$ orth Horn Mountain (see fig. 13, locality 6); for the paratype, southwest spur of North Horn Mountain (see fig. 13. locality 8), Manti National Forest, Emery County, Utah.

Horizon: Upper Cretaceous part of the I'orth Horn formation.

\section{DESCRIPTION OF THE SPECIMENS}

The specimen selected as the type was found disarticulated and in association with the following: skull and skeletal elements, some of which may pertain to this individual: Pair of lower jaws; fragmentary parts of a maxillary, premaxillary, and pterygoid; 13 enoccipitals; posterior parts of three parietals; coossified atlas, axis, and third cervical; 5 dorsal vertebrae; 1 cervical rib, 8 thoracic ribs, and numerous fragments. There scattered bones were found in a small area about 8 br 15 feet in extent, and at the time of collection all were thought to pertain to a single individual. Preparatior. however, disclosed the presence of the posterior parts of three frill crests, indicating as many individuals and thus making it impossible to associate properly many of $t \mathrm{l}$ : scattered bones.

The question of which of the three parietal : pertain to the type is to some extent solved on the evic'ence of the paratype. This specimen, U. S. Nat. Mus. 15875, which has a squamosal like that of the type, has nuuch of the posterior half of the parietal associated with it. This bone 
resembles in all essential particulars two of the parietal parts found with the type. On the basis of the above association it would appear to be fair to assume that one of these bones pertained to the type skull. For purposes of description, all three will be used, as they are practically identical.

\section{SQUAMOSAL}

The squamosal is one of the characteristic bones of the ceratopsian cranium, and its proportionate length at once determines to what family of the Ceratopsia a specimen belongs. The squamosal of the present specimen is long and relatively wide, and is therefore referable to the long-crested line, of which Chasmosaurus, Pentaceratops, Anchiceratops, Arrhinoceratops, Triceratops, and Torosaurus are members.

The squamosal of the present specimen is broad anteriorly, narrowing posteriorly. The external surface for some distance inside the border is gently concave, then becomes convex, with another concave area paralleling the parietal border. At the posterior end this external surface is flattened, and the anterior end is gently convex from side to side. The parietal border on the posterior half is much thickened, with the usual smooth, vertical face, but more anteriorly it appears to overlap the border of the parietal. In advance of midlength, this bone presents a rounded inner edge that for a distance of 230 millimeters gives no evidence of having been in contact with another bone. Lull ${ }^{30}$ calls attention to a Chasmosaurus skull in which the parietal does not have a continuous squamosal border and a similar condition might explain the rounded nonsutural section in the present skull.

The external surfaces of both squamosals of the type and paratype are covered with the usual vascular impressions. That the outer border was ornamented by a series of epoccipital bones is indicated by one on the border of the type (see epoc in fig. 12). Given the regular quota of articulated epoccipitals, the frill would have a scalloped border.

The right squamosal bone is preserved with the paratype (U. S. Nat. Mus. 15875) and also with a referred specimen (U. S. Nat. Mus. 16169) collected in 1939. The first mentioned has the almost complete right element present, while the other has the anterior half of the right and the posterior two-thirds of the left preserved. In shape and other proportions there is the closest agreement among all three bones. The referred specimen (U. S. Nat. Mus. 16169 ) is larger than the others, and the external surface of the squamosal of the paratype is more profusely ornamented with vascular impressions, but otherwise all are closely similar.

${ }^{30}$ Lull, R. S., A revision of the Ceratopsia or horned dinosaurs: Peabody Mus. Nat. History Mem., vol. 3, pt. 3, p. 25, 1933.

\section{PARIETAL}

The term parietal as used here comprises the median part of the crest that lies between the squamosals, thus returning to the use of the original designation of Marsh for this part of the ceratopsian skull. This procedure is adopted here to conform to present-day usage and thus avoid confusion in description, although the evidence does not yet seem conclusive that the median part of the frill is the parietal.

The parietal of Arrhinoceratops? utahensis is represented by the posterior parts from three individuals, of which the paratype, U. S. Nat. Mus. 15875, is mcst complete. The other two were found in association with the type, but which of these pertains to that specimon is uncertain. All three have a portion of the left squamosal border preserved, as shown in plate 11. The squamosal border of the paratype, as preserved, measures 523 millimeters in length. None of the specimens shows the complete transverse width between the squamosal bordens, but measurements made from the midline indicate a total width between parieto-squamosal sutures of abo't 1,200 millimeters; thus the complete frill would have the proportions of that of a large Triceratops. Both specimens found with the type have portions of the sutural border for the squamosal preserved, but both have comparatively smooth upper and lower surfaces, as contrasted with the longitudinal vascular sinuses that ornament at least one surface of the paratype.

The extreme thinness of the parietal is one of the outstanding characteristics of the Arrhinoceratops skull. In the present specimens, exclusive of the squamosal borders, which have a greatest thickness of 24 millimeters, the maximum thickness of 18 millimeters is s.ttained about 40 millimeters anterior to the posterior border, and from that point forward the whole bone gradually thins toward the broken anterior edge, which in places is less than 3 millimeters thick. This extreme thinness of the incomplete anterior borders strongly suggests that they participated in the formation of the boundaries of the frill fontanelles. In fact, one small anterior projection on the parietal of U. S. Nat. Mus. 15583 appears to have a finished edge. If correctly interpreted, it shows the posterior rim of the fontanelle to be $2 ? 5$ millimeters anterior to the posterior margin of the frill.

In the original description of Arrhinoceratops brachyops, Parks ${ }^{31}$ notes that "there is some evidence of sutures running back from the fontanelles to the posterior margin. Such sutures would indicate the existence of an interparietal bone." From these remarks it is evident that Parks observed an obscure condition in the type skull that is in accord with the features found in one of the present specimens. The incomplete parietal that has be?n

s1 Parks, W. A., op. cit., p. 12, 1925. 


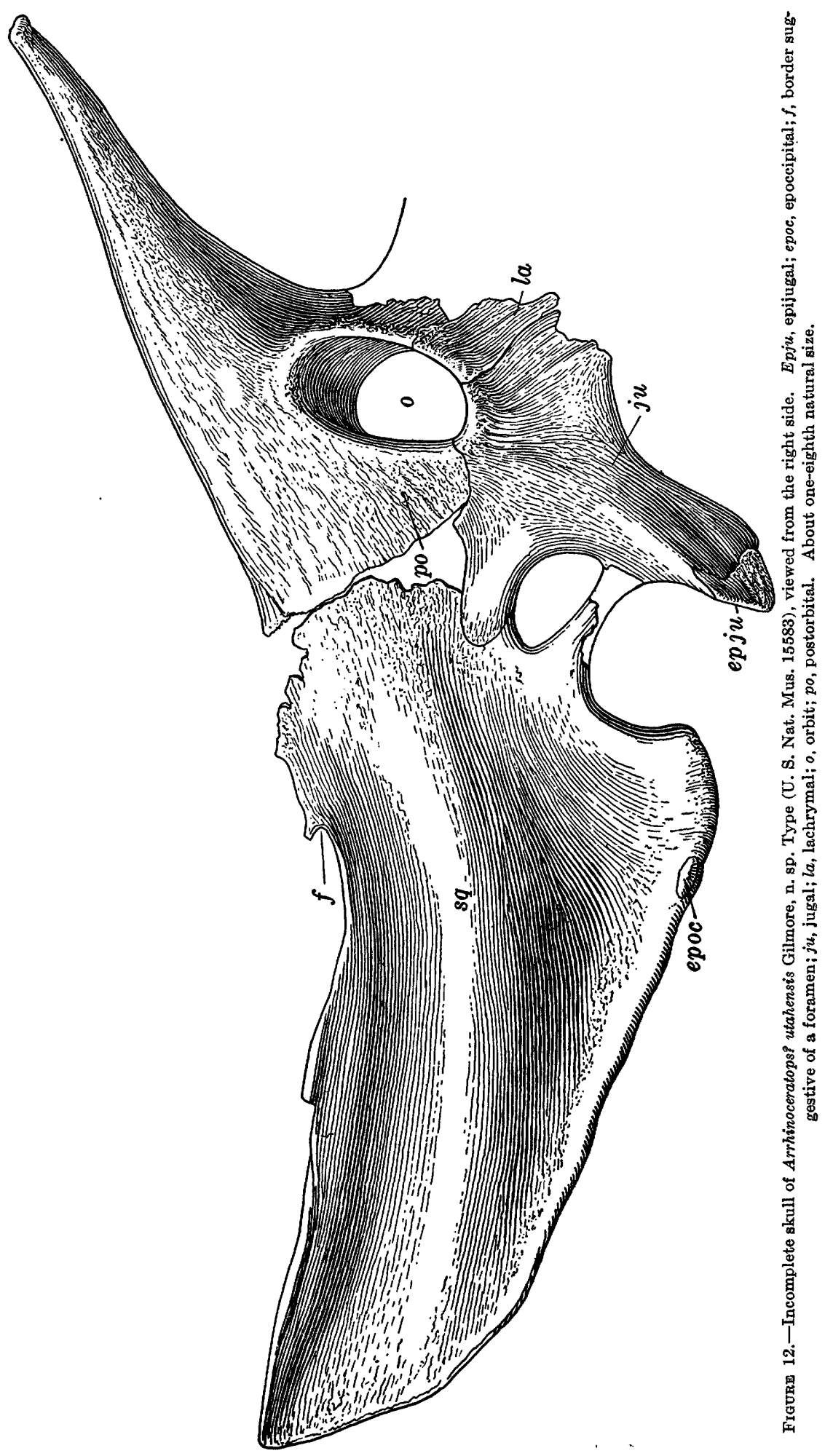

provisionally assigned to the type (see pl. 12, fig. 1) differs from the others in having two longitudinal pseudosutural divisions on either side of the midline that converge slightly in an anterior direction. It was first thought these represented true sutural separations corresponding to those noted by Parks in the type of Arrhinoceratops brachyops. The later discovery of similar divisional edges separating longitudinally the two halves of a ceratopsian squamosal and the presence of a similar division on the right side of the midline of the parietal of U.S. Nat. Mus. 16572 that 
is divergent in an anterior direction seems to indicate these are not true sutures and thus denies the existence of a distinct element in this part of the ceratopsian frill.

The unusual and misleading character of these pseudosutural divisions of the parietal deserves a detailed description. These are not fractures of the bone, but are natural separations that run in a straight line. On the right side the posterior part of the lateral border presents a flat vertical face that in the grain of the bone has a striking similarity to the sutural surfaces between the hyo-hypoplastral bones in certain trionychid turtles. More anteriorly the upper half of the edge projects outward and overlaps a corresponding projection of the lower edge of the adjacent section, thus making a lap joint. On the opposite side of the median section of the parietal, this condition is reversed, the lower half of the border forming the projecting edge and thus underlapping the contiguous portion of the upper. There is no indication of these lines of separation in either of the other two parietals (U. S. Nat. Mus. .15583 and 15875). (See pl. 11.) From this evidence it would seem that a similar condition must have existed in the skull studied by Parks, which misled him into concluding that he was dealing with a true suture.

The complete transverse extent of this median section of the parietal measured between the lateral edges at the posterior border is 333 millimeters. The surfaces of this bone are smooth, except for a few vascular depressions on the ventral side. The median frill region of specimen U. S. Nat. Mus. 15875 has one surface, presumably the ventral, sculptured by deep vascular sinuses, the deeper ones having a longitudinal direction, as in Arrhinoceratops brachyops.

\section{SUPRAORBITAL HORN}

The right supraorbital horn core, coalesced with the postorbital and supraorbital bones, is preserved almost in its entirety, lacking only the tip, which was lost before interment. (See fig. 12.) This horn core is moderately stout, tapers, is compressed laterally, and is elliptical in cross section throughout the great part of its length, as in Torosaurus. It appears quite probable that some of this transverse flattening may be attributed to postmortem deformation. The horn core rises well forward above the orbit, is strongly inclined anteriorly, and differs from the brow horns of Arrhinoceratops brachyops in being only slightly inclined outward. The regular forward curve of the basal half of the horn core is reversed in the upper half, thus bringing about an upward tilt at the tip. The surface of the horn core is covered with the usual vascular impressions, and there is obscure indication of sulcation, extending downward for a short distance from the tip on the anterior side. The orbit lies under the-anterior margin of the horn, as in Pentaceratops.
Comparative measurements of supraorbital horns in millimeters

\begin{tabular}{|c|c|c|c|}
\hline - & $\begin{array}{c}\text { Type of } \\
\text { Arrhino- } \\
\text { ceratops? } \\
\text { utahensis } \\
\text { (U. S. Nat. } \\
\text { Mus. 15583) }\end{array}$ & $\begin{array}{c}\text { Type of } \\
\text { Arrhino- } \\
\text { ceratops } \\
\text { brachyops }\end{array}$ & $\begin{array}{c}\text { Specimen } \\
\text { U. S. Ngt. } \\
\text { Mus. } 16169\end{array}$ \\
\hline Greatest length from upper median & $510^{1}$ & & 710 \\
\hline $\begin{array}{l}\text { Greatest length measured along upper } \\
\text { convex margin. }\end{array}$ & 570 & 555 & 760 \\
\hline $\begin{array}{l}\text { Greatest length measured along lower } \\
\text { concave margin. }\end{array}$ & 485 & 460 & 655 \\
\hline Girth at base. & 495 & 425 . & 612 \\
\hline
\end{tabular}

1 Estimated.

Specimen U. S. Nat. Mus. 16169, which is provisionally identified as pertaining to Arrhinoceratops? utahensis, is considerably larger than the type. It has the right supraorbital horn core preserved in almost its entirety (see pl. 12) and the detached basal half of the left. The right horn is of the same slender, tapering form as that of the type, but it stands more erect, and is nearly 8 inches longer. It differs further in having a distinct sulcus extending downward from the tip for more than half its length, the depth of which has been exaggerated by crushir?. Sulcated horns in the Ceratopsia are rare, and Lull ${ }^{32}$ is of the opinion that their presence or absence is of lit'le significance. However, the presence of sulcation in the brow horns of all the Arrhinoceratops specimens known at the present time suggests a certain constancy in $\mathrm{tl}^{\text {is }}$ genus that may have some meaning.

JUGAL

The right jugal is completely preserved, although it was found detached from the other skull elements. $T$. precise agreement of the sutural borders with those of the lachrymal and postorbital leaves no doubt that it pertains to the same individual as the supraorbital horn core $c^{\prime} \mathrm{s}-$ scribed above. In its more slender proportions, and esperially the more restricted expansion of the proximal end, it differs markedly from the more robust jugal of Arrhinoceratops brachyops. In fact, the jugal of that species differs so much from those of other ceratopsians as to lead one to wonder if its outline has been correctly interpreted. If correctly delimited, it furnishes important features for distinguishing Arrhinoceratops brachyops from the species here described.

The jugal under description has a truncated anterior process that joins the maxillary, contrasting with the long and tapering process in Arrhinoceratops brachyops. Likewise, the posterior proeess that joins the squamosal is much shorter and narrower. The greatest length of the present jugal from the orbital border to the distal end is 373 millimeters, and its greatest width from the maxillary contact to the squamosal border is 355 millimeters. $T^{*}$ ? thickened orbital border contributes 65 millimeters to the inferior rim of the orbit. 


\section{QUADRATOJUGAL}

Both quadratojugal bones of U. S. Nat. Mus. 15583 are preserved, but they are not quite complete. In articulated position the quadratojugal is imposed between the lower internal side of the jugal and the lower outer side of the quadrate. A heavy, downwardly projected process articulates with the epijugal by rugose suture. The quadratojugal may have contributed to the formation of the lower border of the infratemporal fossa, as in Triceratops, but this feature cannot be positively determined, as, unfortunately, both quadratojugals are imperfect in this respect. In Monoclonius the quadratojugal does not participate.

\section{LACHRYMAL}

The lachrymal is triangular in outline, with a heavy expanded end that contributes to the anterior rim of the orbit. It is united closely with the upper border of the anterior branch of the jugal by a longitudinally grooved, sutural articulating border. The upper anterior border is deeply excavated, leaving a slender anterior process that extends between the jugal and nasal.

\section{EPIJUGAL}

The right epijugal was found detached, but its sutural contact with the jugal clearly indicates that it pertains to specimen U. S. Nat. Mus. 15583. In position it articulates on the lower outer extremity of the jugal, extending prominently outward, backward and downward. (See fig. 12.) Its outer end is bluntly pointed, upper surface shallowly concave, and ventral surface strongly convex. A triangular, cupped, articular end projects inward below the level of the jugal to meet a thickened, rounded projection from the quadratojugal. The outer surfaces are covered with the usual vascular markings. In shape and proportions the present bone has a close likeness to the epijugal of Arrhinoceratops brachyops.

\section{QUADRATE}

A right quadrate found in this same assemblage may quite certainly be assigned to the type, as indicated by the close articulation of the sutural surfaces with the quadratojugal and epijugal bones. The end of the quadrate that articulates with the lower jaw has a greatest transverse diameter of 115 millimeters, a greatest anteroposterior diameter of 41 millimeters, and a greatest length of about 355 millimeters.

\section{EPOCCIPITALS}

Thirteen detached epoccipital bones were found in this quarry, of which about half represent complete elements. Eight of these, although differing somewhat in size, are relatively large and closely resemble one another in shape.

Since these eight peripheral elements resemble the epoccipitals found attached to the squamosal of the type and to the parietal of the paratype, it is ass imed that all pertain to Arrhinoceratops? utahensis. These elements are elongated and have a sharp outer edge and a raised median apex, as shown in plate 13 , figures 1 to 5 . Their external surfaces are ornamented with vascular imprassions which suggest that in life they probably had a horny, skinlike covering. Their inner borders are hollowed out longitudinally to conform better to the rounded borders of the squamosal and parietal, along whose periphary they were arranged. With the epoccipitals in positior. the border of the frill must have had a scalloped form.

The five smaller epoccipitals are slender (see pl. 13, fig. 1), triangular in cross section, and lack the median apex. Their surfaces also lack vascular markings. Their position on the frill is not known at this tim?.

\section{RELATIONSHIPS OF THE SPECIMITNS}

The incompleteness of the type materials and especially the lack of critical parts has made it difficult to reach a satisfactory conclusion as to the true relationships of the specimen under discussion. As mentioned proviously, the squamosal indicates the affinity of the spesies with the long-crested group of the Ceratopsia. The grater relative width of the posterior portion of the squamos? ceratops? utahensis distinguishes it from the corresponding element in Chasmosaurus, Pentaceratops, and Torosaurus, all of which have the posterior extremity of this bone narrow and tapering. In general outline and proportions the squamosal of Arrhinoceratops? utahensis has its nearest counterpart in Triceratops, but the presence of fenestrae in the frill satisfactorily distinguishes them. That the affinities of the present form do not lie with the genus Anchiceratops is indicated not alone by differences in the form of the squamosal bones, but also by $t \mathrm{t}:$ absence in the Utah specimen of the heavy epoccipital processes on the parietal that form such a prominent feature of the Edmonton genus. Meager though the evidence may be, this brief review appears to show that the snecimen here discussed cannot be satisfactorily included in any of the above-mentioned genera. Of the known members of the long-crested Ceratopsia only Arrhinocerctops remains to be considered.

The presence in the Utah specimen of a flat quadrangular frill crest having an extremely thin parictal part perforated by fenestrae, and of well-develop $\$$, sulcated, supraorbital horns that curve strongly forward are features held in common with the skull on which Parks established the genus Arrhinoceratops. $\mathrm{O}^{\text {n the other }}$ hand, important differences appear in the jugal bones of the two specimens. In fact, the jugal of the Parks specimen differs so decidedly from those of ceratopsians in general that I am led to believe he must have erred in delimiting it. If such an assumption proves to be true, the observed differences in outline and proportions of the jugals of the two species have no special sigrificance. 
In view of the above facts it is proposed to refer the differences found in the brow hom cores. In this speries North Horn ceratopsian provisionally to the genus these horns curve strongly forward but with slight outArrhinoceratops, as the species Arrhinoceratops? utahen- ward inclination, while in Arrhinoceratops brachyops they sis, which may be distinguished from the genotype by $\mid$ turn strongly outward. 


\section{PART 3. REVIEW OF VERTEBRATE FAUNA OF THE NORTH HORN FORMATION}

\section{INTRODUCTION}

A new locality for Mesozoic reptiles was made known through the discovery by E. M. Spieker in 1934 of fragments that could be identified as dinosaurian. This locality, in the vicinity of North Horn Mountain (see fig. 13), Manti National Forest, Emery County, Utah, was again visited in 1935 by Spieker and J. B. Reeside, Jr., who were successful in obtaining specimens that could be positively identified as pertaining to ceratopsian and hadrosaurian dinosaurs. These fossils definitely indicated the Upper Cretaceous age of the lower member of the sequence that Spieker has since named the North Horn formation.

In anticipation of opening up a new field for horned and other dinosaurian specimens and also in the hope of obtaining materials that would more accurately date the beds in which the fossils are found, the Smithsonian Institution in 1937 sent an expedition under my direction to investigate the area. The success of the first expedition brought about the organization in 1938, 1939, and 1940 of field parties in the same area under the leadership of C. L. Gazin.

The localities near North Horn Mountain, where important specimens have been found by the field parties, are all clearly indicated on the geologic map. (See fig. 13.) This map is based, with modifications, on Geological Survey topographic sheets, and was drawn by Dr. Gazin, through whose kindness it is presented herein.

Locality 3 in the Dragon Valley has been referred to as the "lizard locality," number of lizard specimens that have been found there. Dinosaurian specimens in this same area were found both above and below the lizard horizon, and a few characteristic caudal vertebrae of Alamo:aurus were found at the same level. All the vertebrate specimens came from a large depressed block of Uppe." Cretaceous sediments that had been dropped by the north-south faults traversing this area. The precise relationship of this bone-bearing level to the fossil-bearing zone around North Horn Mountain has not been determined, but the presence of Alamosaurus remains in both strongly suggests that they are at about the same lovel in the formation.

The specimens found on the west side of North Horn Mountain were considered by Spieker from examination in the field to be at about the same level in t] ? formation as those from locality 1 on the southwest side.

With the exception of Champsosaurus and Crocodylus remains, which alșo may be found in the overlying Paleocene strata, all dinosaurian and other reptilian fossils found in this area have come from tl ? lower $\mathbf{8 5 0}$ feet of the North Horn formation, which consists of variegated shales and sandstones that are conglomeratic in places. One fragmentary dinosaur specimen found in place a short distance from locality 1, lit not collected, was of interest in being at the lowest level in the formation at which a vertebrate was found. This specimen was estimated to be less than 200 feet above the top of the Price River formation, which outcrops in this section.

\section{FAUNAL LIST}

A study of the fossil materials accumulated by these four expeditions has resulted in the establishment of the faunal list given below. For ready comparison a Fauna of the North Horn formation

Dinosauria:

Alamosaurus sanjuanensis Gilmore.

Arrhinosaurus? utahensis Gilmore.

Ceratopsian, gen. and sp. indet.

Hadrosaurian (large).

Hadrosaurian (small).

Deinodont (large).

Deinodont (small).

Sauria:

Polyglyphanodon sternbergi Gilmore.

Paraglyphanodon utahensis Gilmore.

Rhynchocephalia:

Champsosaurus sp.

Crocodilia:

Crocodylus sp.

Chelonia:

Basilemys sp.

Adocus sp.

Compsemys sp.

Pisces:

Aspideretes sp.

Lepisosteus sp.

list of the fauna of the Ojo Alamo sandstone is placed beside it.

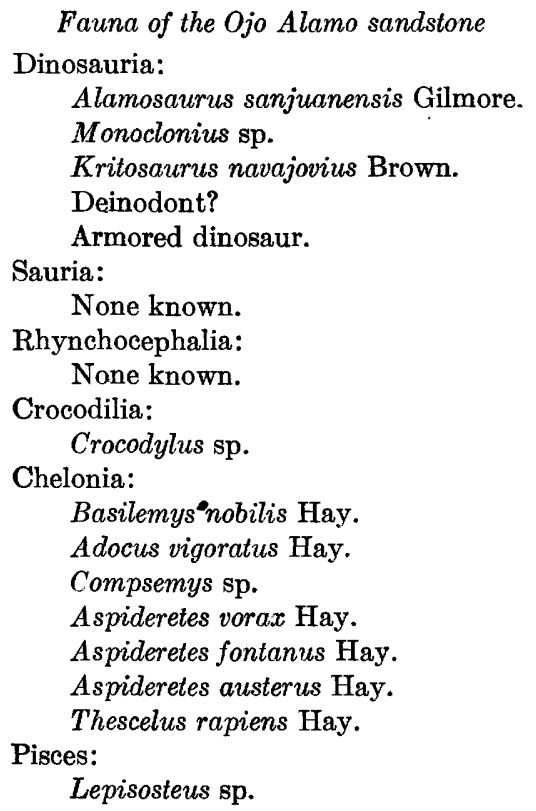

${ }^{33}$ Gazin, C. L., The mammalian fasnas of the Paleocene of central Utah, with notes on the geology: U. S. Nat. Mus. Proc., vol. 91, no. 3121, p. 7, fig. 1, 1941. 

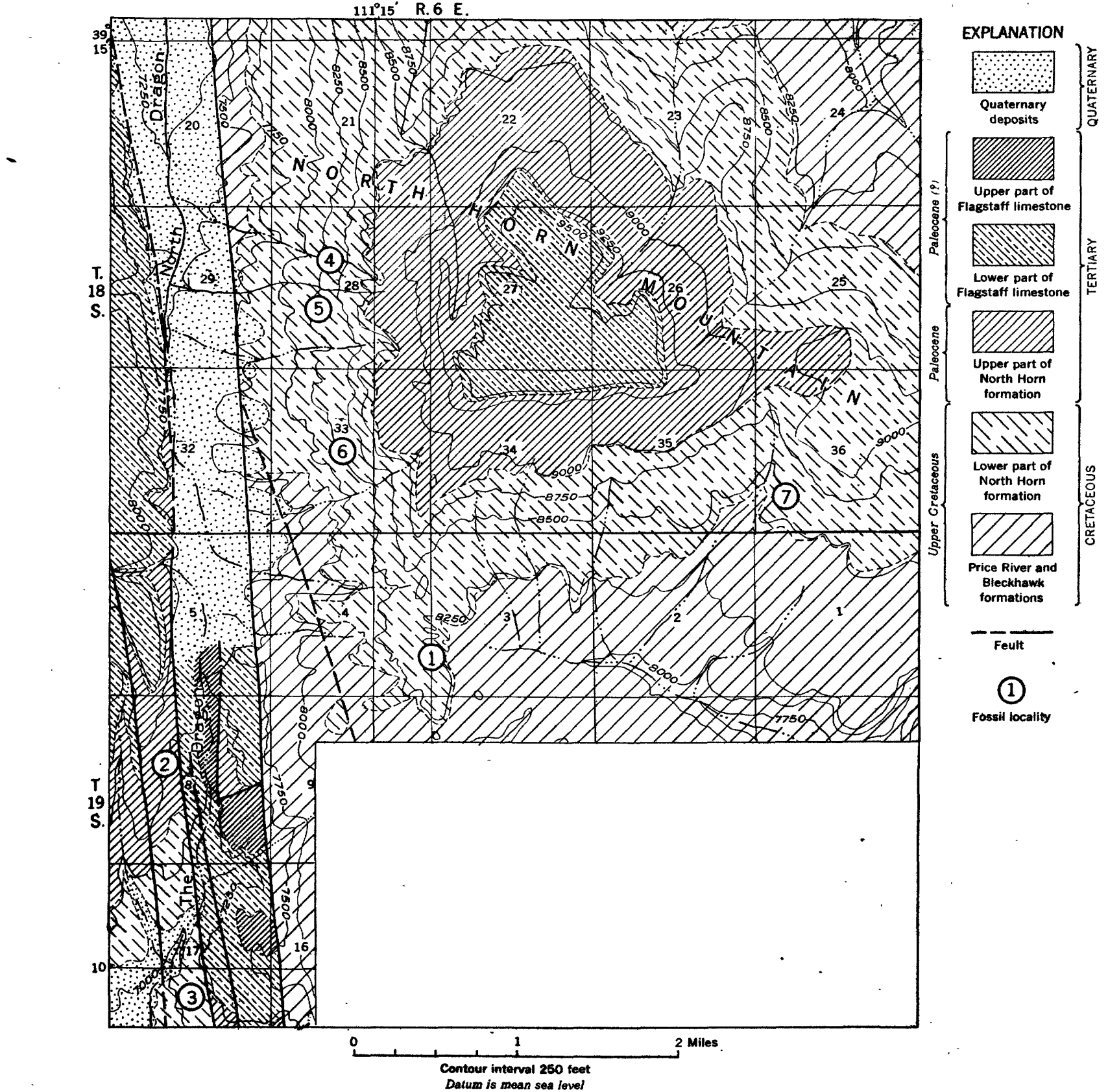

Fraurn 13.-Geologic map of the region around North Horn Mountain, Emery County, Utah, showing localities where specimens were found: (1) Alamosaurss san juanensis, skeleton (U. S. Nat. Mus. 15560); (2) Paleocene mammal locality; (3) lizard locality; (4) ceratopsian skull (U. S. Nat. Mus. 16169); (5) type of Arrhinoc. eratops? utahensis (U. S. Nat. Mus. 15583); (6) hadrosaurian femur locality; (7) ceratopsian (U. S. Nat. Mus. 16577). Map drawn by C. L. Gasin.

The fauna of the North Horn formation, as shown, consists almost entirely of reptiles. Five different orders are now recognized. Of these the Dinosauria are the most significant; they pertain to well-known groups whose geologic history is well understood, and they definitely indicate that the beds in which the fossils are found are of Upper Cretaceous age. Until recently the large sauropod, Alamosaurus sanjuanensis, had been found in association with horned dinosaurs (Ceratopsia), duck-billed dinosaurs (Hadrosauridae), and carnivorous dinosaurs (Deinodontidae) only in the Ojo Alamo sardstone of the San Juan Basin in New Mexico. This \& $9-$ sociation strongly indicates the equivalence in age of the North Horn formation and the Ojo Alamo sandstone, and the conclusion is further strengthened by the presence in both formations of four genera of turtles, a fish, and a crocodile. The fragmentary condition of the fish and the crocodile renders them of little importance individually, but collectively they are of value in showing the similarity of the faunas of the two formations. 
Recent discoveries ${ }^{34}$ made in the Big Bend of the Rio Grande, Tex., show the presence in that area, also, of sauropod dinosaurs in association with Upper Cretaceous Ceratopsia and Hadrosauridae.

In order to present as complete a picture of the North Horn fauna as available materials will permit, each of the known members is briefly reviewed below, and new information resulting from the latest collecting is incorporated. In addition to the recognized genera and species there are a few fragmentary specimens identifiable only as to order or family, and these are briefly discussed.

\section{Class REPTILIA}

\section{Order DINOSAURIA}

\section{Suborder SAUROPODA Marsh}

\section{Family TITANOSAURIDAE Lydekker}

The large sauropod Alamosaurus sanjuanensis Gilmore was fully discussed on pages 29 to 41 , and it is only necessary herein to mention the finding of new materials. Two caudal centra found by the 1939 expedition at the lizard locality, St 12 sec. 17, T. 19 S., R. 6 E., in the South Dragon Valley, and from the same level as one of the specimens of Polyglyphanodon, somewhat extend the-geographical range of Alamosaurus. The large size and the procoelous character of these median caudal centra at once establish their identity as pertaining to the genus Alamosaurus.

A second specimen consisting of two very large thoracic ribs was collected from a small patch of badland exposures on the west side of the South Dragon Valley (NE1/4 sec. 12, T. 19 S., R. 5 E.). These are certainly the ribs of a sauropod dinosaur, and in all probability they record the occurrence of a third individual of $A l$ amosaurus within this general area.

\section{Suborder CERATOPSIA Marsh}

In addition to the specimens of Arrhinoceratops? that form the subject matter of part 2 of this paper, several other fragmentary ceratopsian specimens were collected by the 1937 and 1939 expeditions.

The most important of these is the palatal part of a skull (U. S. Nat. Mus. 16577) articulated with the incomplete maxillaries and distal portions of the jugals, epijugals, quadrates, and anterior portions of both squamosals. This specimen was found by G. F. Sternberg on the west side of North Horn.Mountain (SW $1 / 4$ Sec. 36, T. 18 S., R. 6 E.). Very large hornlike epijugals (see pl. 14, fig. 3), large coossified epoccipitals on the anterior border of the squamosal bones, and a more open squamosal-jugal notch appear to show its distinctness from Arrhinoceratops. The large size of the epijugals suggests relationship to Pentaceratops, a Kirtland genus that might be expected to occur here, but lack of other diagnostic parts in the present specimen does not permit verification of this. The chief interest in the specimen lies in the fact thet it indicates the presence in the fauna of a second, as yet undetermined ceratopsian.

Intermingled with the bones of the typ? of Arrhinoceratops? utahensis were parts of the frill of an individual that may represent a third type of ceratopsian. These materials include a median portion of the frill crest, a considerable section of the median bar of the frill, and a portion of its anterior end showing the supratemporal fossa. No direct contacts between there three frill parts have been found, but their relative positions in the quarry were such as to suggest strongly that they belonged to one individual. Furthermore, the relative thickness of the broken ends, as well as tha contours of contiguous parts, are in complete harmony with such a conclusion. These detached parts, arranged in relative sequence, are illustrated in plate 14, figures 1 and 2.

The crest portion shows a divisional partitioning of the parietal as in the type of Arrhinoceratops? utahensis. A pseudosutural edge on the right side of the parietal is the counterpart of those in the type of Arrhinoceratops? utahensis, with the exception that it runs forward and outward. Thus, if the opposite sutural edge, which is missing, should have the same course, they would be divergent, whereas in Arrhinoceratops? $u^{\text {rahensis they }}$ converge in an anterior direction. This crest portion thickens on the median line, and on the dcrsal side, 100 millimeters anterior to the free margin, a low, rounded boss marks the midline. (See pl. 14, fig. 2.) In front of this boss the surface slopes downward $\mathrm{cn}$ either side. The broken anterior end has a thickness of 25 millimeters. The under side is regularly conerve from side to side, the surface being marked by a few vascular impressions. The free border is slightly undulating and shallowly concave from side to side as contrasted with the convex border of the parietal of Arrhinoceratops? utahensis. The undulations may be the coossified epoccipital bones.

The median, or bar, portion of the frill (pl. 14, fig. 4) measures 490 millimeters in length. Th? bone as a whole is roof-shaped, with a heavy, rounded median ridge. Viewed laterally, the crest of this ridge is undulating, owing to a series of longitudinal swellings arranged one in front of the other. The bone thins out away from the midline. On the right sida for a short space near midlength is what appears to be a finished edge. If this interpretation is correct, it would be a portion of the inner border of the right fenestra, and would indicate the median bar to have a width of approximately 226 millimeters between the fenestrae, thus resembling Arrhinoceratops and Torosaurus, rather than the very narrow bar of Chasmosaurus or Anchiceratops.

\footnotetext{
A Brown, Barnum, oral communication.
} 
The anterior end of the parietal has a rounded median ridge with steep lateral sides and a relative thickness of the bone that agree with the corresponding features of the anterior end of the median part described above and that give every indication that the two parts belong together. On the left side the outline of the supratemporal fossa is distinctly indicated.

These three frill parts, with some allowance for the missing connecting pieces, have a combined length from end to end of about 984 millimeters, thus indicating an individual having about the same frill proportions as the type of Arrhinoceratops? utahensis. The greater thickness of the frill portions, the concave medianposterior border, the rounded median boss on the dorsal surface are all features that show the probable distinctness of this specimen from Arrhinoceratops. The available materials are too meager for generic designation and furthermore there is the possibility that this type of development may pertain to the ceratopsian with the large epijugals, previously mentioned, of which at the present time there is no information regarding the frill.

In the collections there are six other individuals of the Ceratopsia, each represented by a single bone. These are a left humerus (U. S. Nat. Mus. 16168), a right pubis (U. S. Nat. Mus. 15665), a left pubis (U. S. Nat. Mus. 16576), a right dentary (U. S. Nat. Mus. 16575), a left dentary (U. S. Nat. Mus. 16574), and the posterior half of an ilium. These bones are of no special significance, as genera in the Ceratopsia cannot be determined from any of them. They do permit the suggestion, however, that in this area ceratopsian dinosaurs may have been more abundant than members of the Hadrosauridae, whereas in most other Upper Cretaceous faunas the latter usually predominate in number of specimens.

\section{Family HADROSAURIDAE Cope}

A complete right femur, U. S. N. M. 16318, collected in 1939 from locality 7 (see fig. 13), is the only evidence obtained of the presence in this fauna of one of the larger representatives of the Hadrosauridae. In size it would be comparable to Kritosaurus or Parasaurolophus of the Ojo Alamo and Kirtland formations, respectively. This femur (see pl. 14, fig. 1) has a greatest length over all of 1,122 millimeters.

That a much smaller member of the Hadrosauridae exists in this fauna is indicated by an articulated ulna, radius and partial forefoot, U. S. N. M. 13808. In size it pertains to an animal smaller than Procheniosaurus. This specimen was collected in 1935 on the southwest spur of North Horn Mountain, only a few yards from the site of the partial skeleton of Alamosaurus sanjuanensis discovered in 1937. (See fig. 13, loc. 1).

as Gilmore, C. W., New fossil lizards from the Upper Cretaceous of Utah: Smithsonian Misc. Coll., vol. 99, no. 16, pp. 1-2, 1940.

\section{Family DEnTODOWTIDAE Brown}

The presence of canivorous dinosaurs in the North Horn formation is show by the finding of several characteristic teeth, a large claw pertaining to the manus, and the distal half of a lateral metatarsal. These rere not found in association, and it is therefore assumed that each pertained to a separate individual. Althongh none of the parts is adequate for generic determination, each is sufficiently diagnostic to indicate the occurrence here of a carnivorous dinosaur of the size of the Upper Cretaceous Gorgosaurus.

\section{Order SAURIA}

\section{Family POLYGLYPEANODONTIDAE Gilmore}

Nearly complete and partially articulated skeletons of Polyglyphanodon sternbergi Gilmore enabled me to describe its skeletal anatomy. ${ }^{36}$ Altogether, the remains of nearly 50 individuals of Polyglyphanodon have now 1 æen assembled, thus making it the best known of all North American lizards. These specimens came from one small area (S. $1 / 2$ sec. 17, T. 19 S., R. 6 E.) located in the cer tral part of the South Dragon Valley and referred to in this paper as the lizard locality (fig. 13, loc. 3).

Since no fossil lizards are known in the Ojo Alamo or Kirtland formations at the present time, this new lizard has no significance for correlation.

\section{FAMILY UNDETERMINED}

The lizard Paraglyphanodon utahensis Gilmore also had been described. ${ }^{36}$ It was based on a maxil $7 x y$ bone found in association with specimens of Folyglyphanodon. A specimen, U. S. Nat. Mus. 16357, consisting of an anterior end of a right dentary containing six teeth, was collected by the 1939 expedition. These six teeth occupy a space 4 millimeters in len $x$ th, and, as in the upper series, increase in size from front to back. The most anterior tooth is very small, and the tops of all appear to have been much worn, thus obscuring the details of their structure. Two specimens collected in 1940 have the skulls and a few vertel rae preserved. All came from the lizard locality and from practically the same geologic level.

\section{Order RHYNCHOCEPHALIA}

The record of Champsosaurus in the North Horn formation rests upon the half of a vertebral centrum picked up on the surface on the south side of North Horn Mountain. Since this aquatic reptile has a long geologic range it is of little significance for correlation.

\section{Order CROCODILIA}

A single characteristic vertebral centrum picked up on the surface shows that extinct Crocodilia were present in this fauna.

36 Gilmore, C. W., op. cit., p. 3. 


\section{Order CHEIONA}

The turtles are represented by scattered fragments that with one exception were found loose on the ground.

A fragmentary part of a carapace of Basilemys associated with a few limb and foot bones was found in place at the lizard locality in the South Dragon Valley. The characteristic sculpturing on the fragments of carapace permits recognition also of the presence of Adocus,
Compsemys, and Aspideretes. All four genera are present also in the Ojo Alamo.

\section{Class PISCES}

A single bony lozenge-shaped scale of a ganoid fish from the North Horn formation is referred, according to the usual practice, to the genus Lepisost?us. 


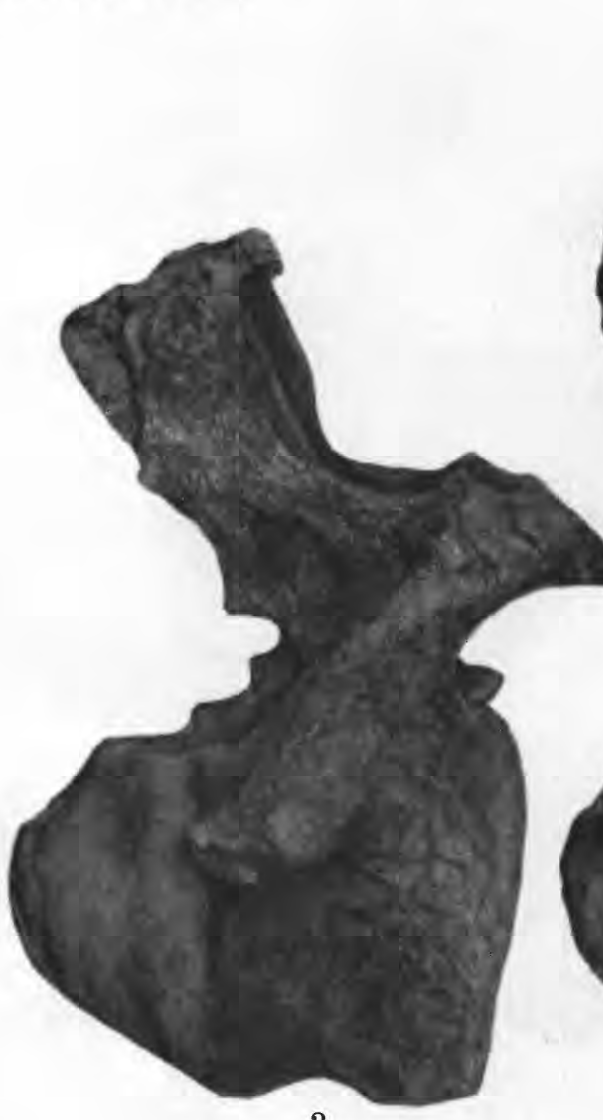

3
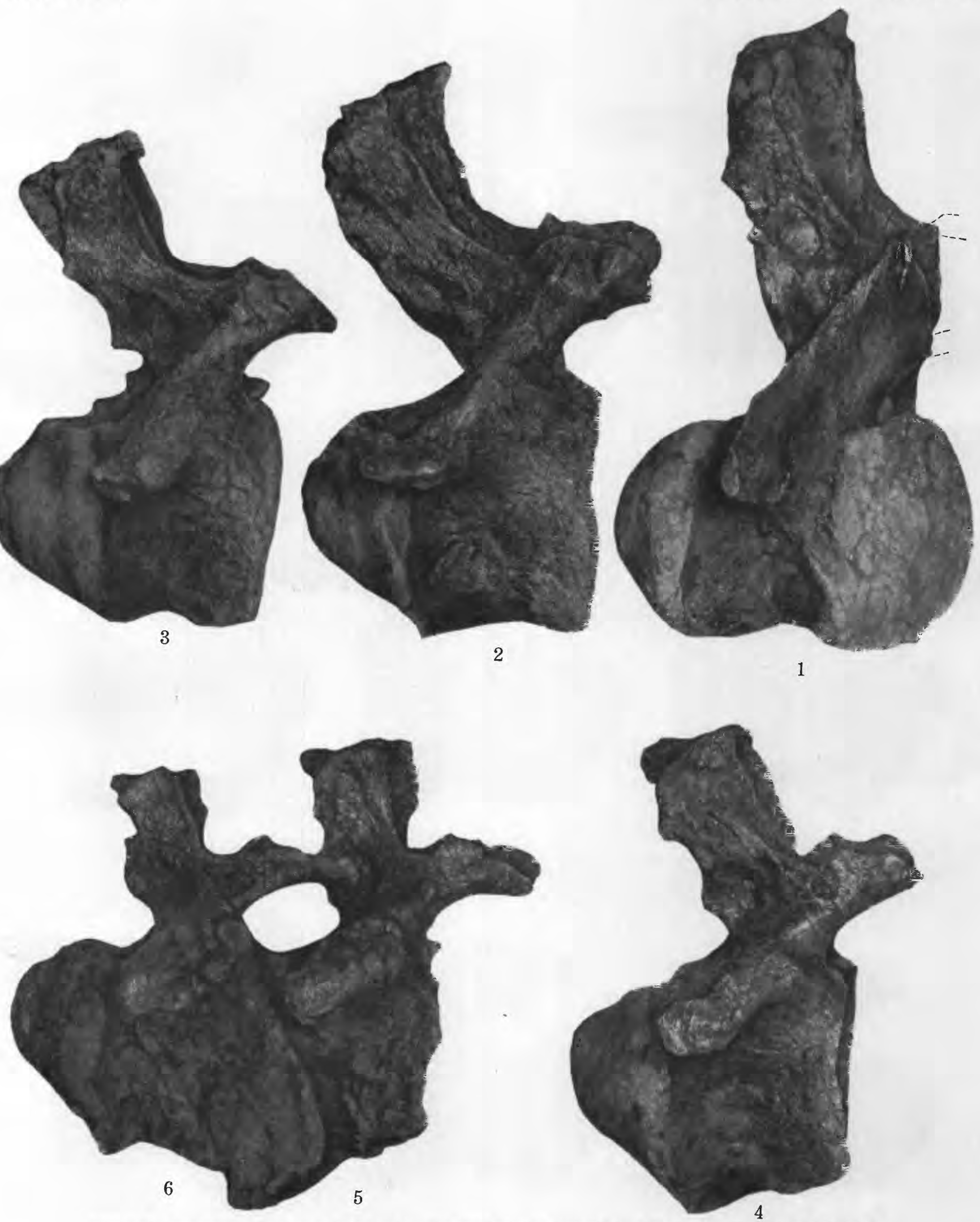

CAUDAL VERTEBRAE 1 TO 6 OF ALAMOSAURUS SANJUANENSIS GILMORE (U. S. NAT. MUS, 15560), LATERAL VIEW. About one-fifth natural size. 

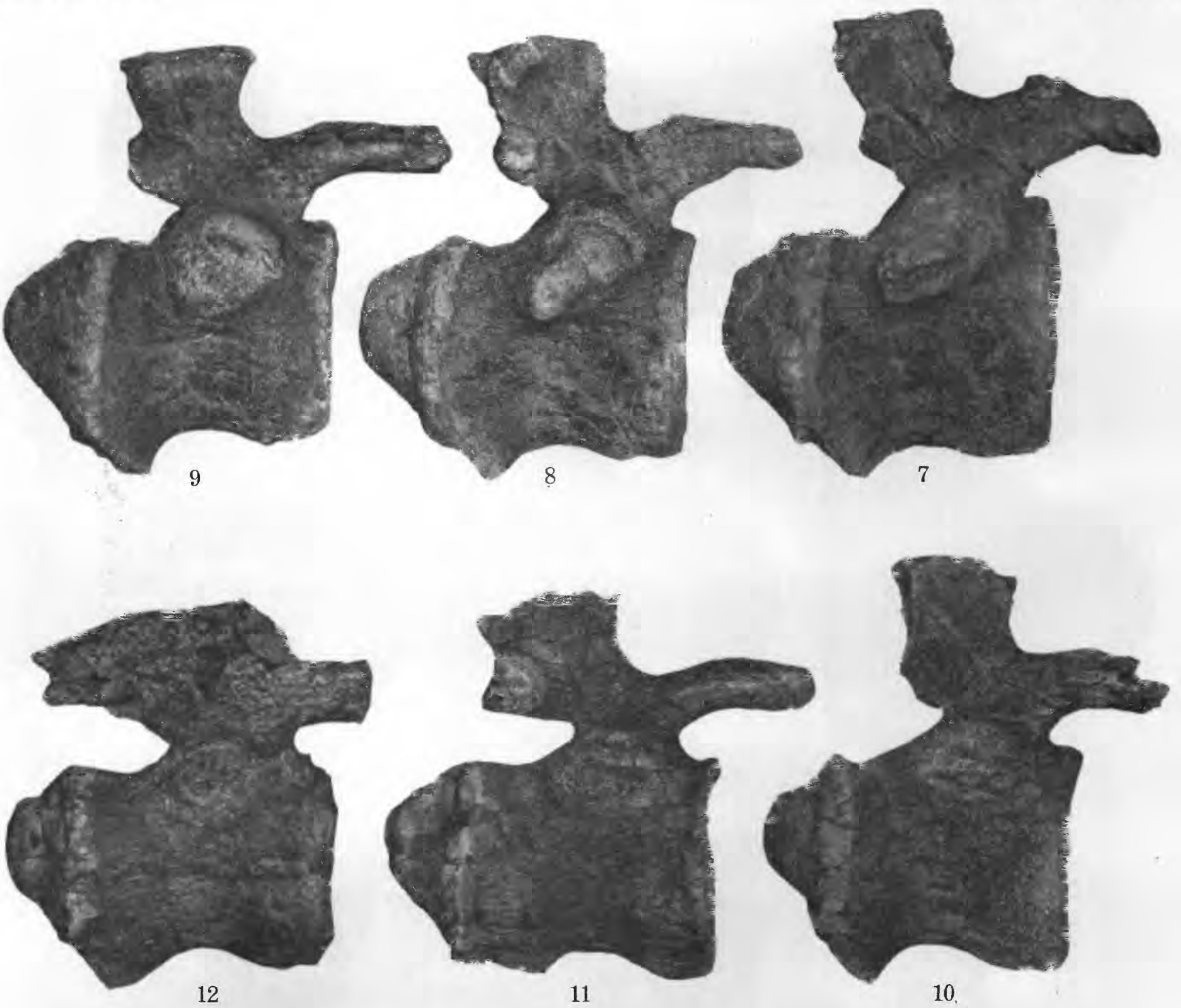

11
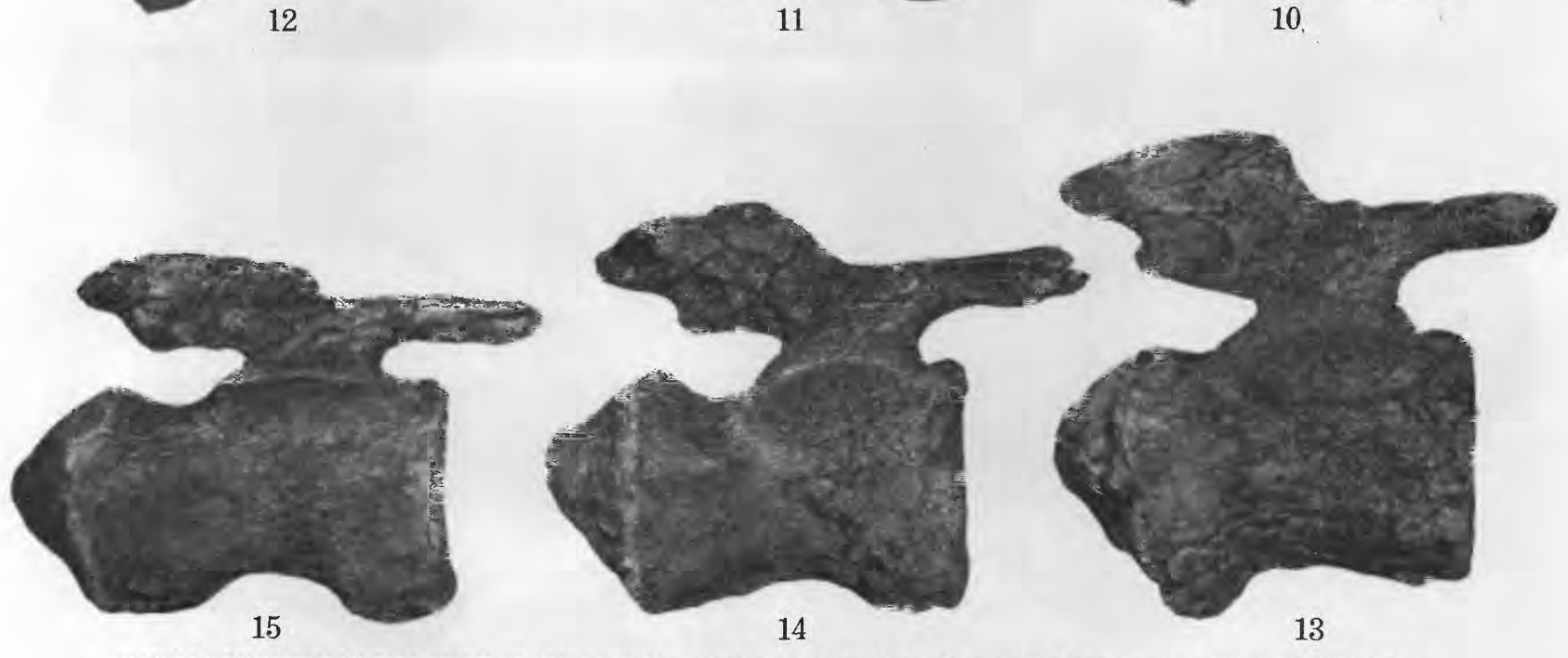

CAUDAL VERTEBRAE 7 TO 15 OF ALAMOSAURUS SANJUANENSIS GILMORE (U. S. NAT. MUS. I5560), LATERAL VIEW. About one-fifth natural size. 

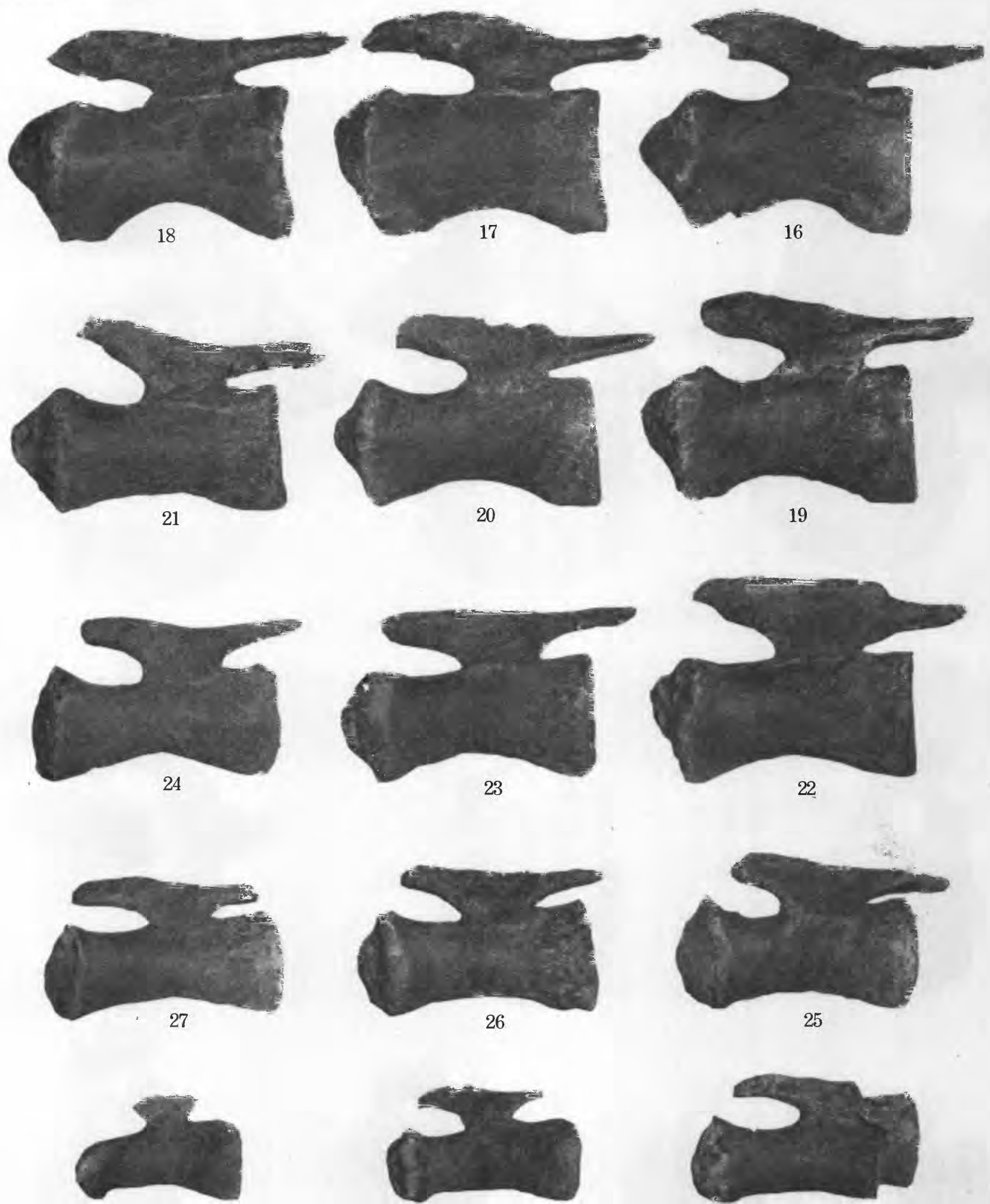

29

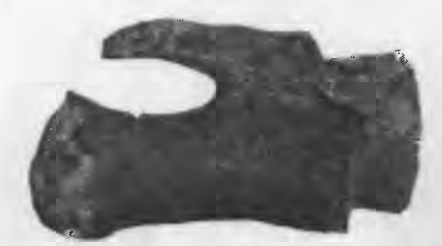

28

CAUDAL VERTEBRAE 16 TO 30 OF ALAMOSAURUS SANJUANENSIS GILMORE (U. S. NAT. MUS. 15560), LATERAL VIEW.

About one-fifth natural size. 

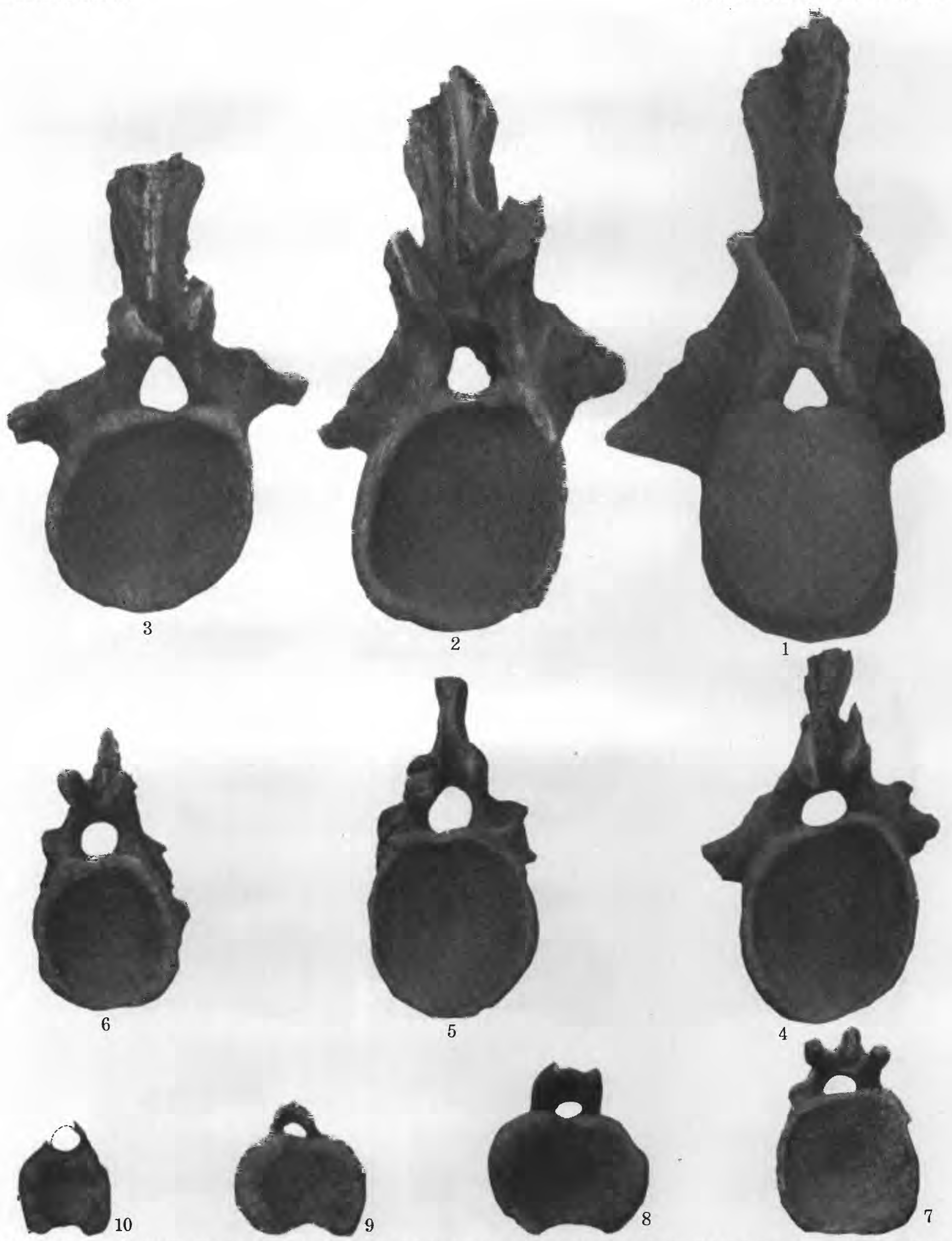

CAUDAL VERTEBRAE OF ALAMOSAURUS SANJUANENSIS GILMORE (U. S. NAT. MUS. 15560), ANTERIOR VIEW. About one-fifth natural size.

$$
\begin{array}{rr}
\text { FIGURE 1. CAUDAL } 1 . & \text { FIGURE 6. CAUDAL } 13 . \\
\text { 2. CAUDAL 2. } & \text { 7. CAUDAL } 16 . \\
\text { 3. CAUDAL 4. } & \text { 8. CAUDAL } 23 . \\
\text { 4. CAUDAL } 7 . & \text { 9. CAUDAL } 27 . \\
\text { 5. CAUDAL } 10 . & \text { 10. CAUDAL } 30 .
\end{array}
$$



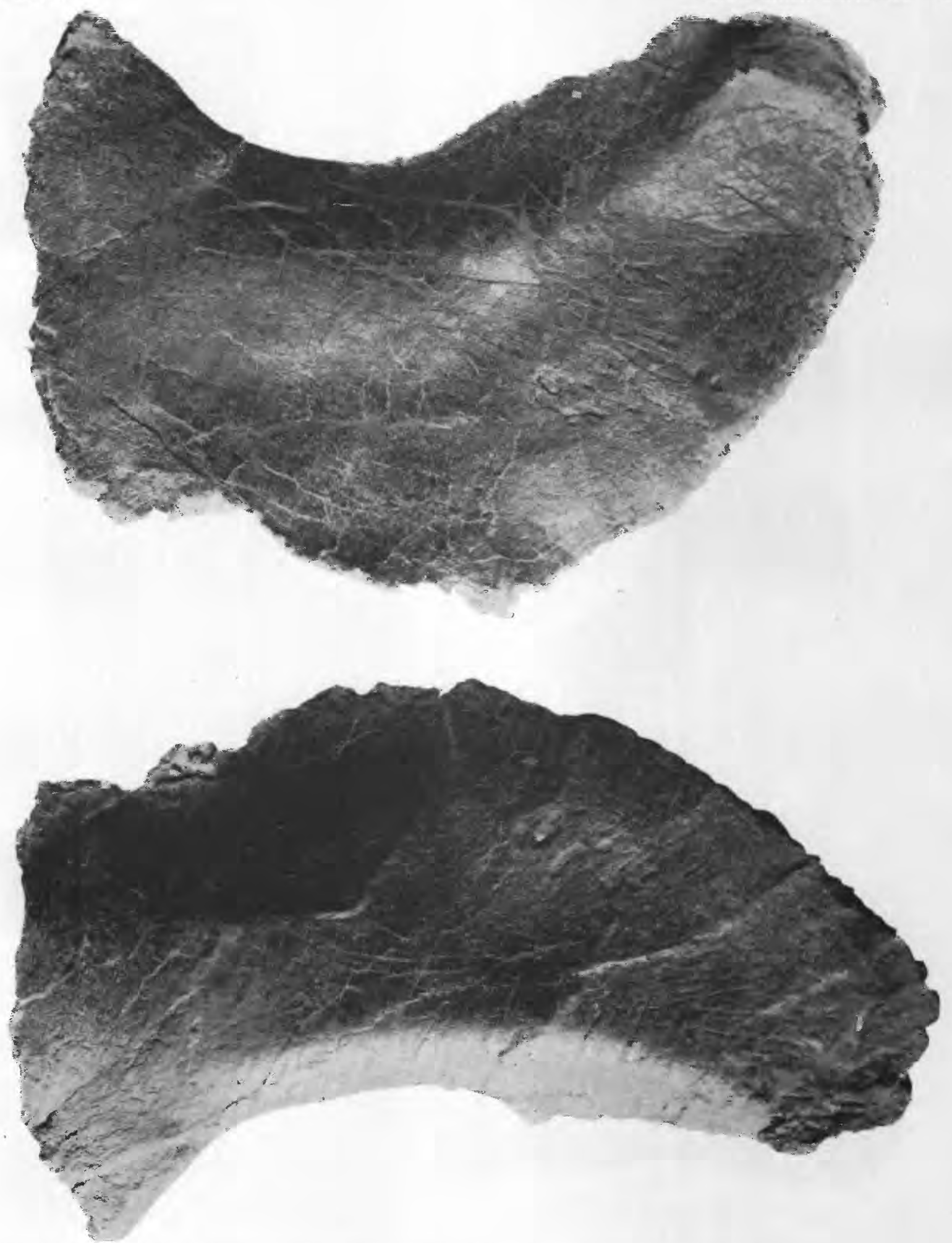

STERNAL PLATES OF ALAMOSAURUS SANJUANENSIS GILMORE (U. S. NAT. MUS. 15560), VENTRAL VIEW.

Ahout one-seventh natural size. 

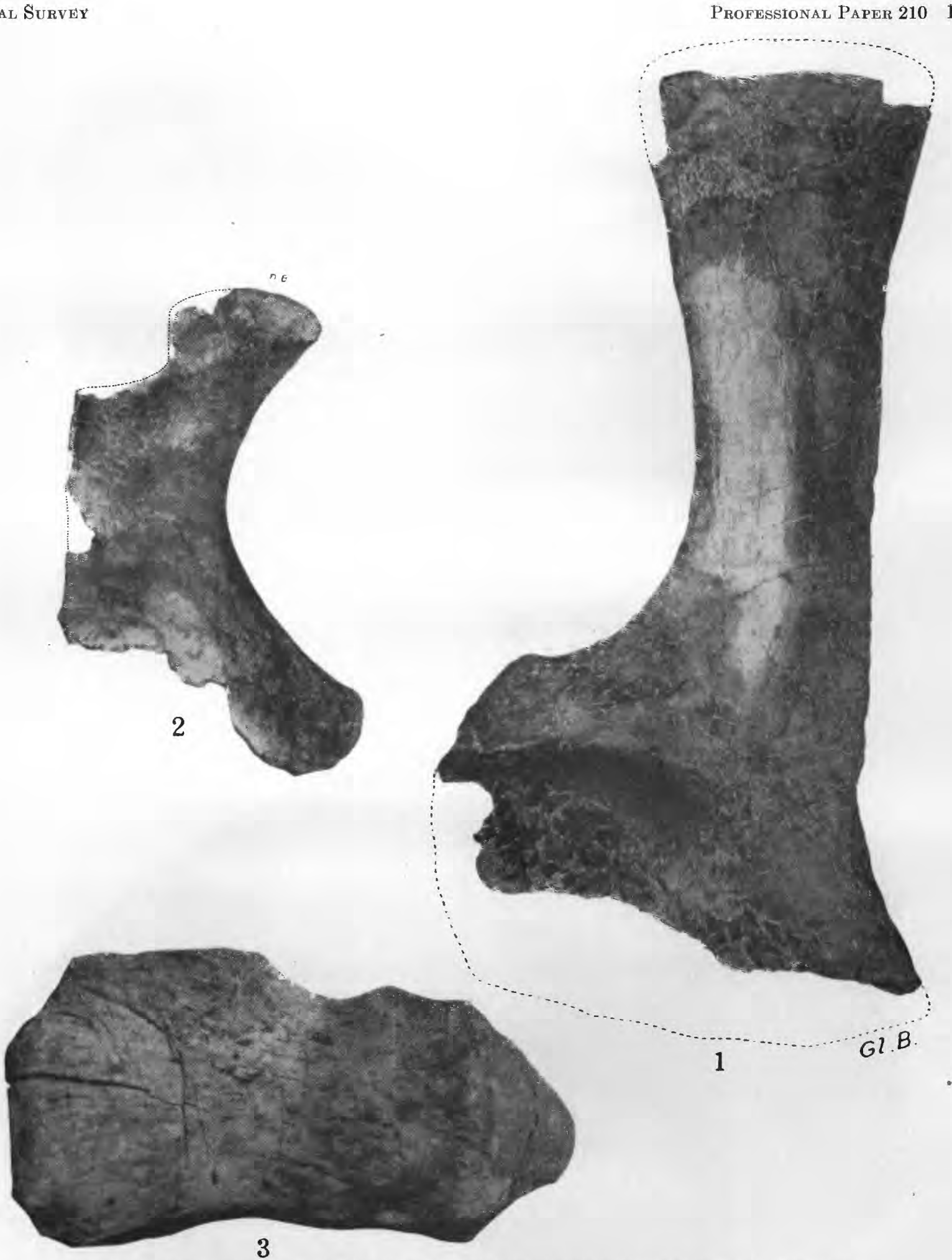

FIGURE 1. LEFT SCAPUI.A OF AL.AMOSAURUS SANIJUANENSIS GIIMORE, TYPE (U. S. NAT. MUS. 10186). About one-seventh natural size.

FIGURE 2. RIGHT ISCHIUM OF ALAMOSAURUS SANJUANENSIS GILMORE, PARATYPE (U. S. NAT. MUS. 10487). About one-tenth natural size.

FIGURE 3. CAUDAL CENTRUM OF ALAMOSAURUS SANJUANENSIS GILMORE (U. S. NAT. MUS. 15658), LATERAL VIEW. About 0.42 natural size. 

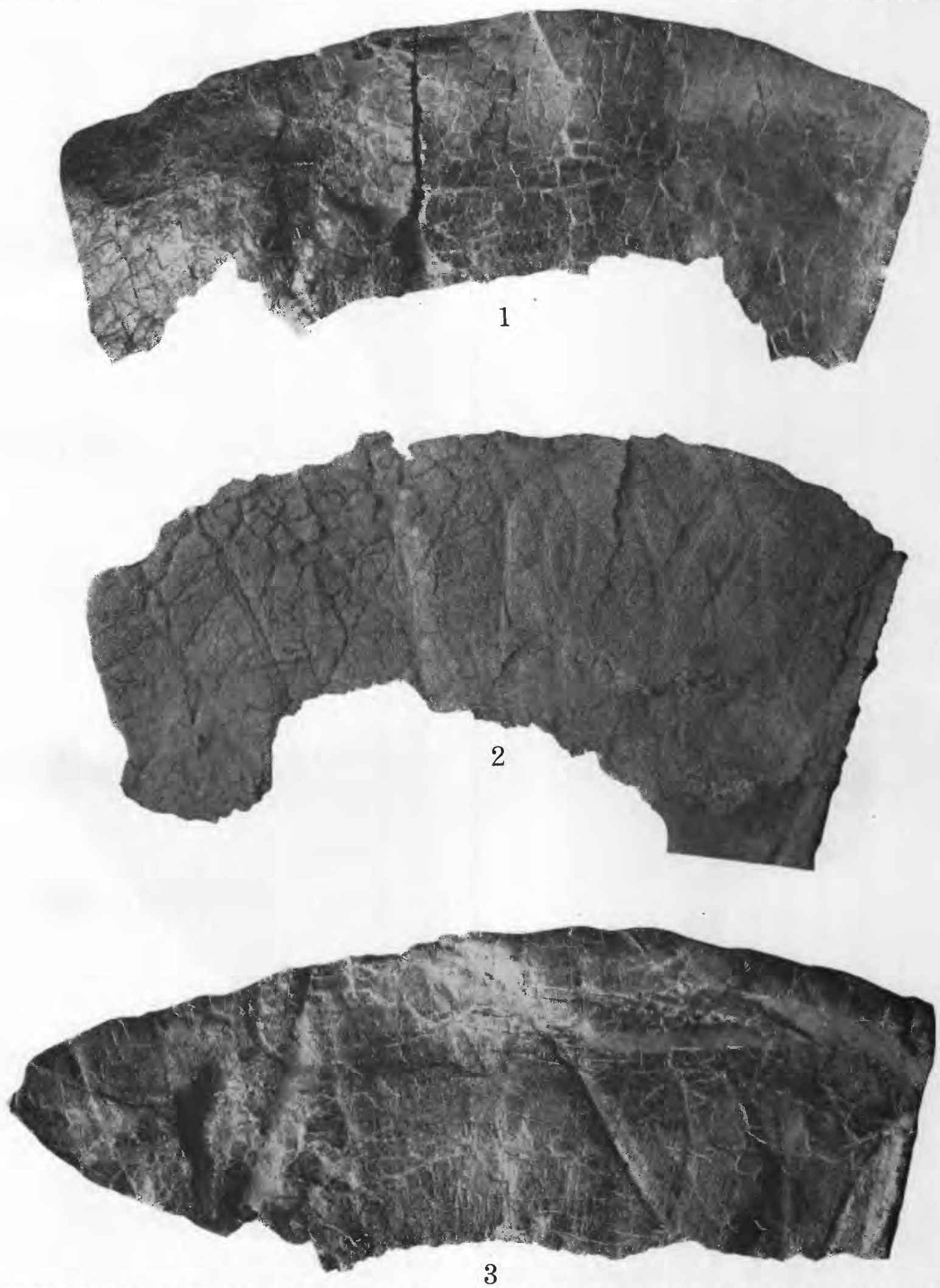

CREST PORTIONS OF THE FRILL OF ARRHINOCERATOPS? UTAHENSIS GILMORE, N. SP., VIEWED FROM THE TOP.

FIGURE 1. TYPE (U. S. NAT. MUS. 15583),

FIGURE 2. PARATYPE (U. S. NAT. MUS. 15875).

FIGURE 3. U. S. NAT. MUS. 16573

All ahout one-fourth natural size. 


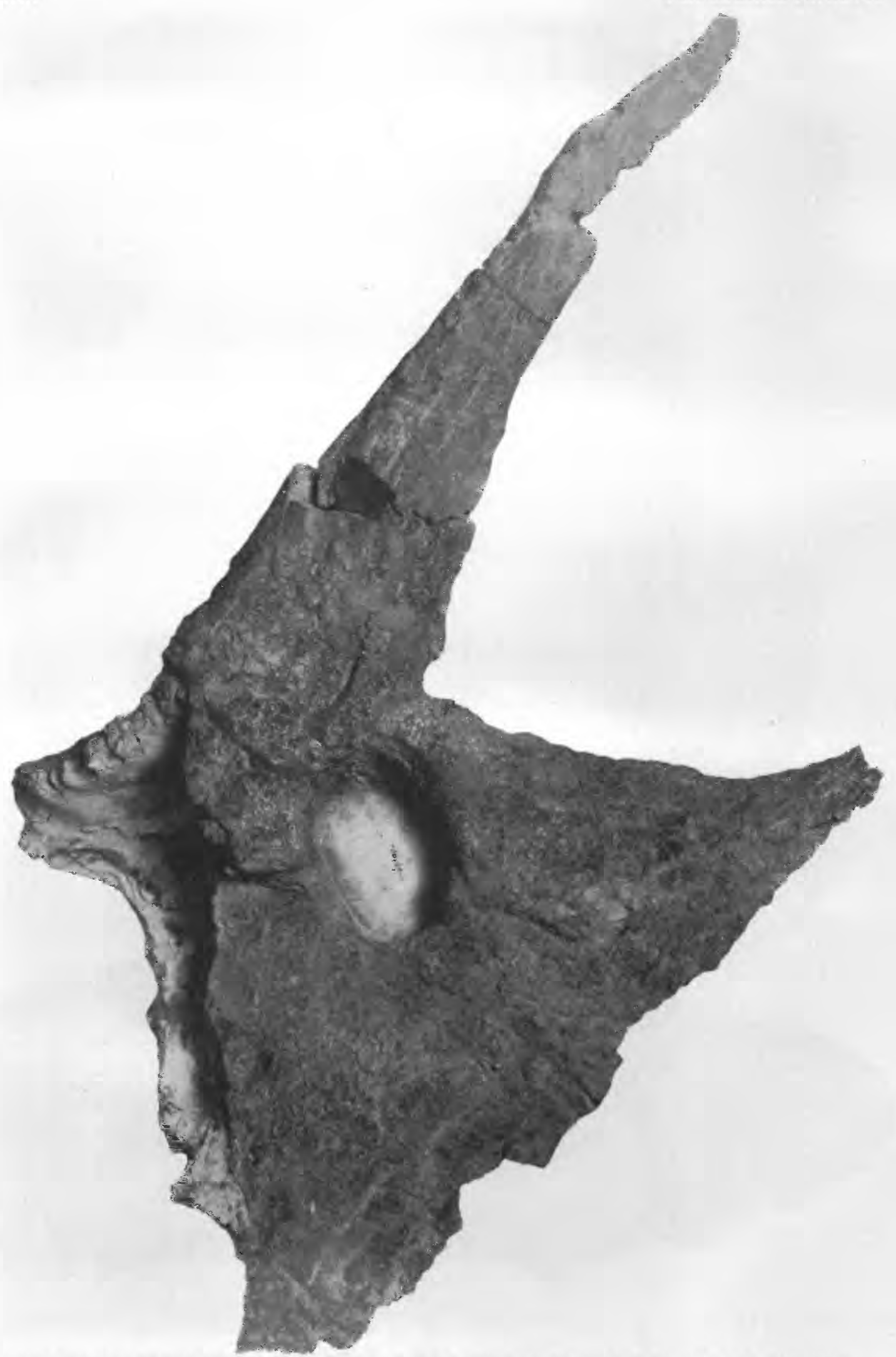

MEDIAN PORTION OF THE SKULL OF ARRHINOCERATOPS? UTAHENSIS GLMORE, N. SP., (U. S. NAT. MUS. 16169). About one-fifth natural size. 

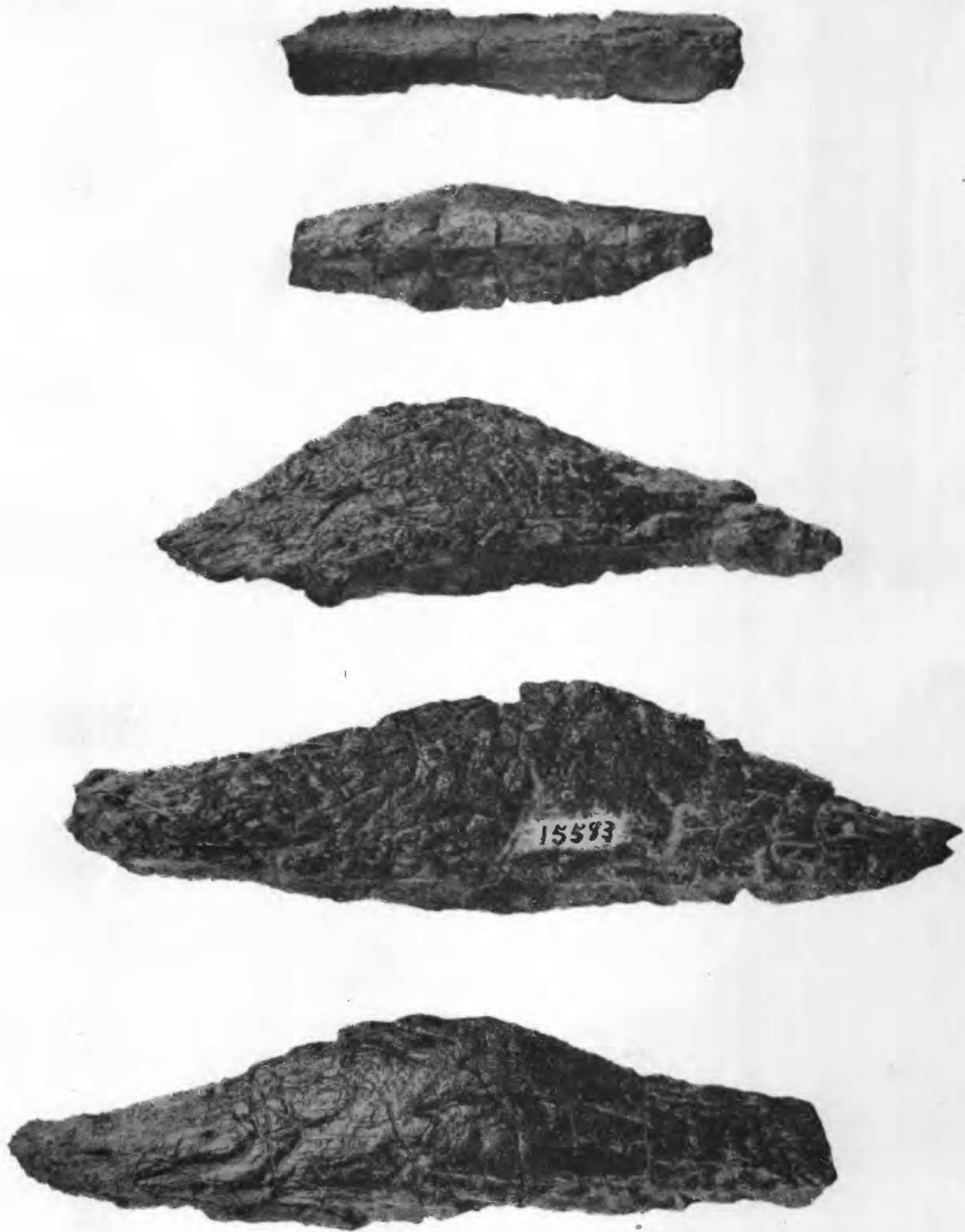

EPOCCIPITAL BONES TENTATIVELY REFERRED TO ARRHINOCERATOPS? UTAHENSIS GILMORE, N. SP. Natural size. 

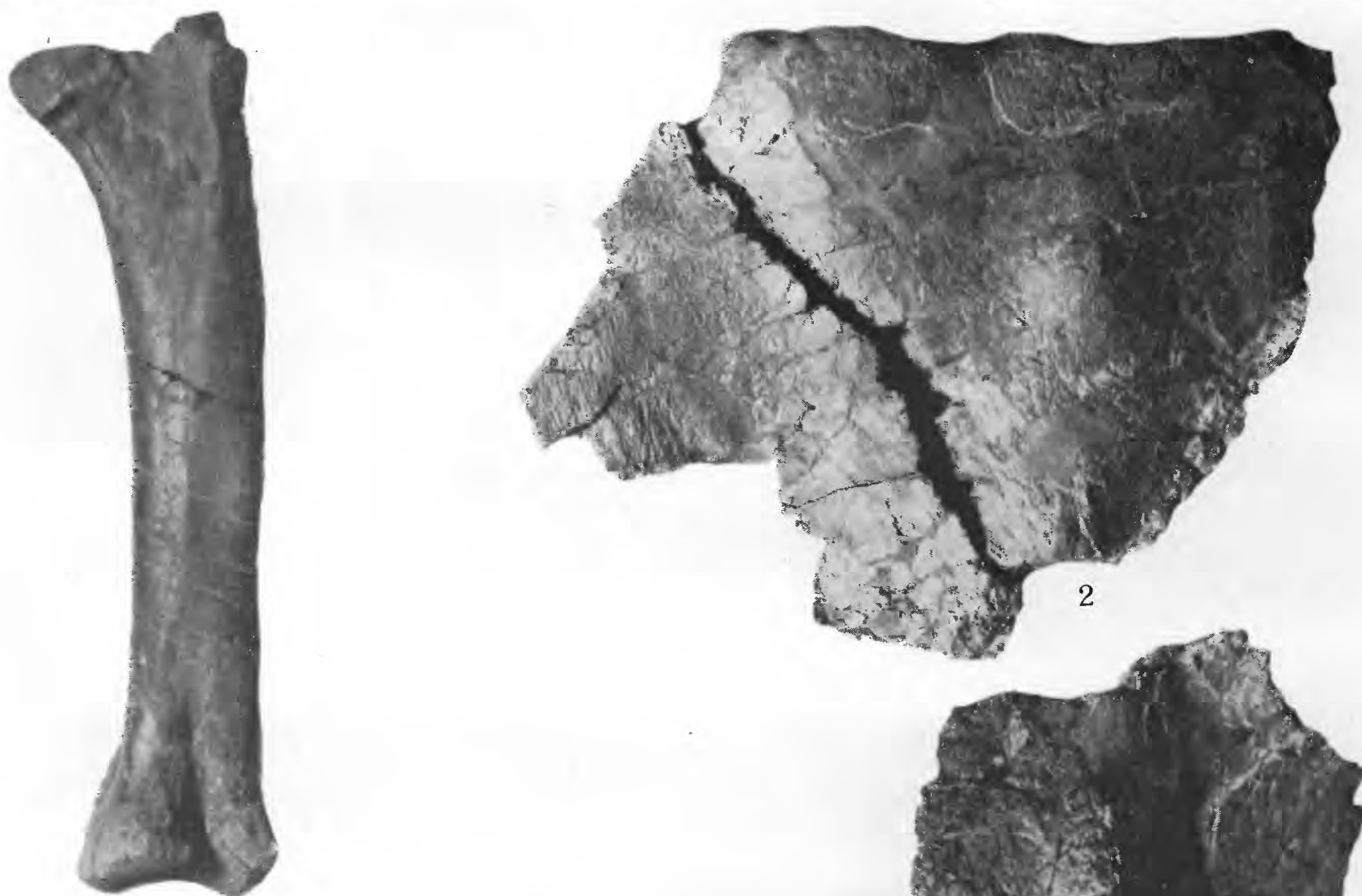

1

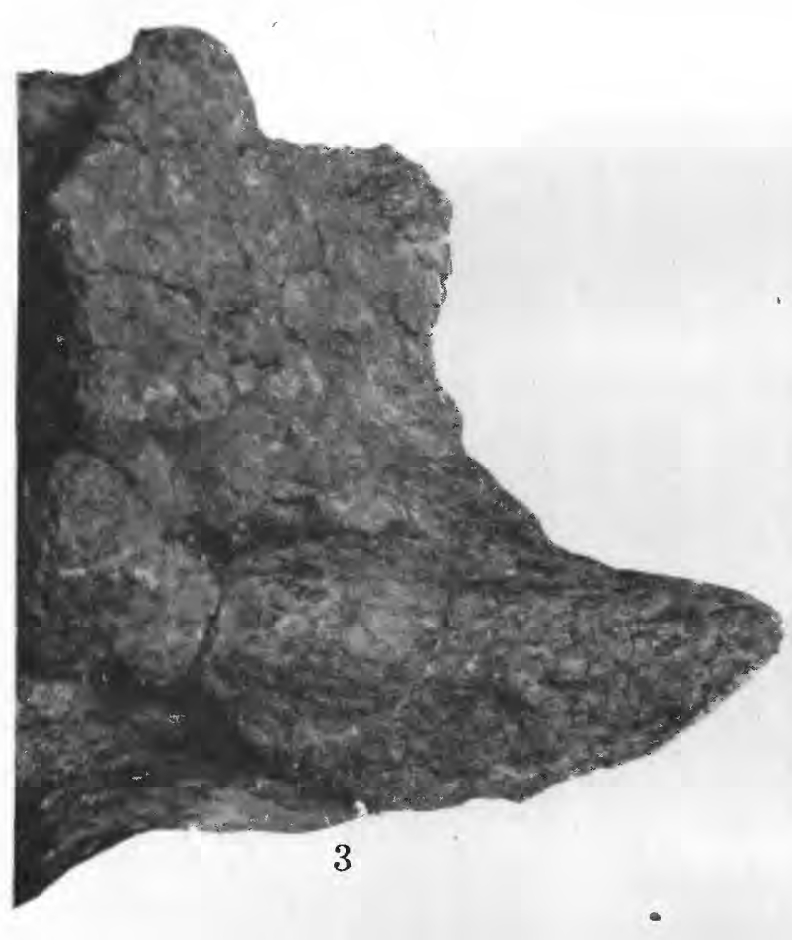

2
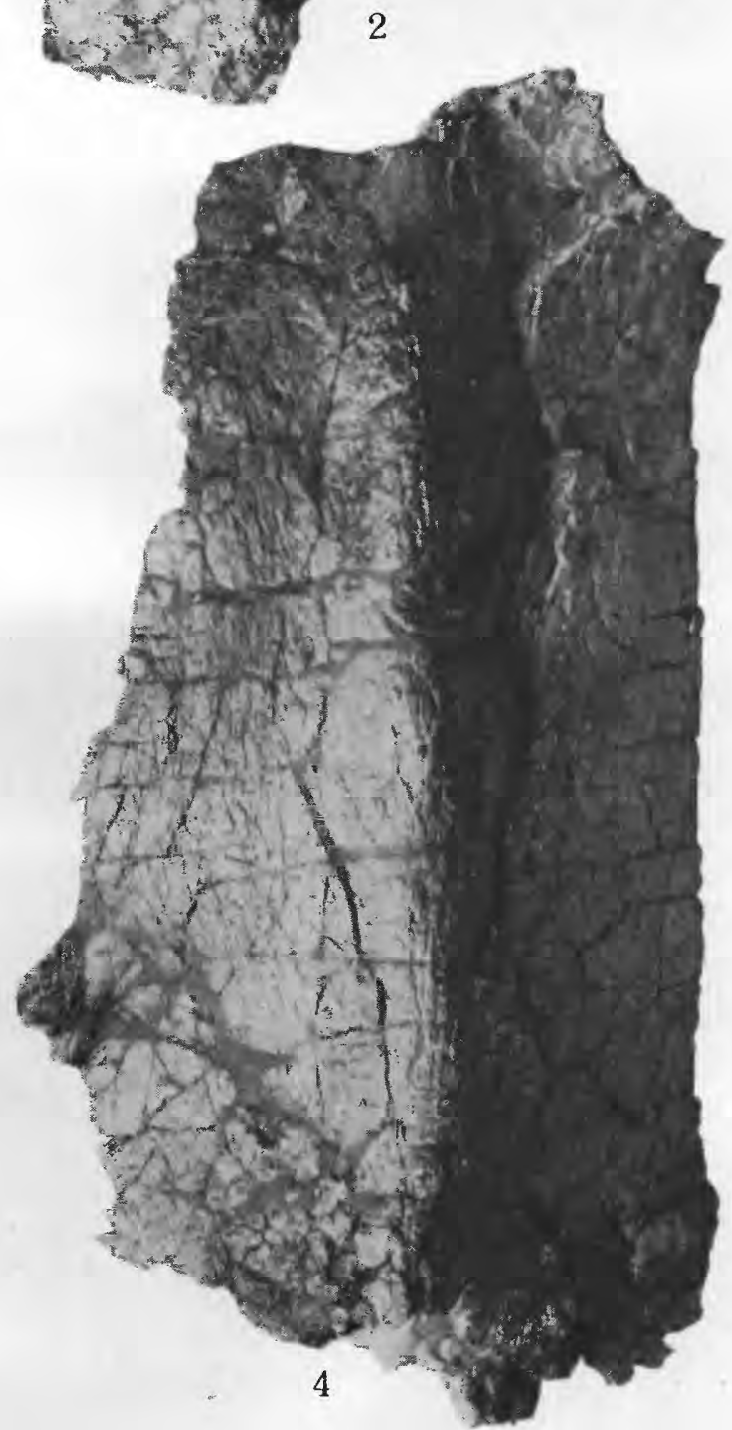

FIGURE 1. RIGHT FEMUR OF HADROSAURIAN DINOSAUR (U. S. NAT. MUS. 16318), BACK VIEW.

About one-tenth natural size.

FIGURE 2. MEDIAN PORTION OF CERATOPSIAN PARIETAL (U. S. NAT. MUS. 16573), TOP VIEW.

About one-third natural size.

FIGURE 3. LEFT EPIJUGAL OF CERATOPSIAN SKULL (U. S. NAT. MUS. 16577), FRONT VIEW

Ahout two-fifths natural size.

FIGURE 4. CREST PORTION OF CERATOPSIAN PARIETAL (U. S. NAT, MUS. 16573), TOP VIEW.

About one-third natural size. 


\section{N D E X}

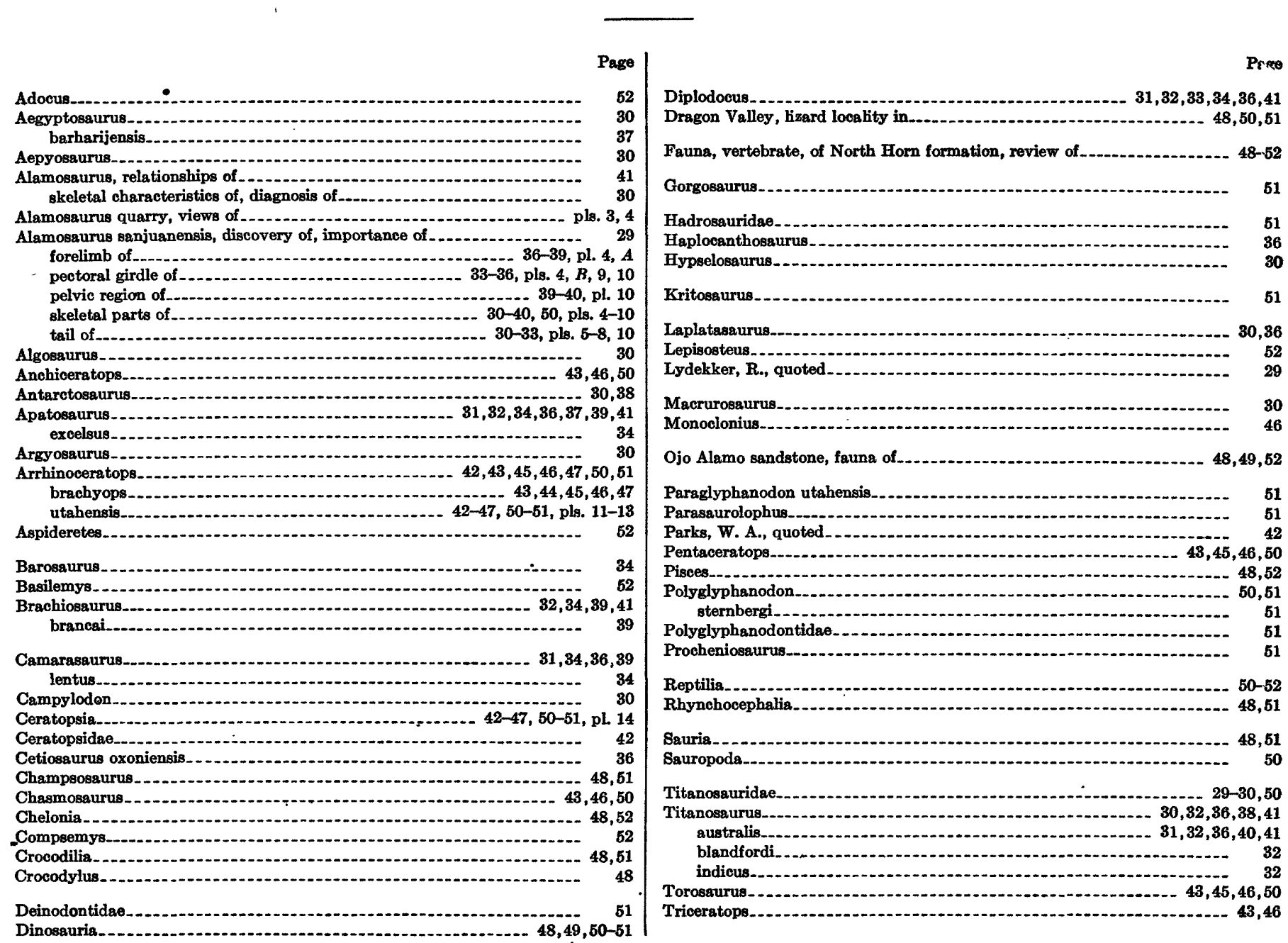




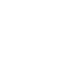



UNITED STATES DEPARTMENT OF THE INTERIOR

J. A. Krug, Secretary

GEOLOGICAL SURVEY

W. E. Wrather, Director

Professional Paper 210-D

\section{BULIMINA AND RELATED FORAMINIFERAL GENERA}

BY

JOSEPH A. CUSHMAN and FRANCES L. PARKER

Shorter contributions to general geology, 1946

(Pages 55-160)

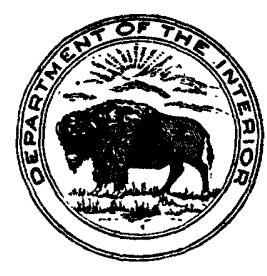

UNITED STATES

GOVERNMENT PRINTING OFFICE

WASHINGTON : 1947 


\section{CONTENTS}

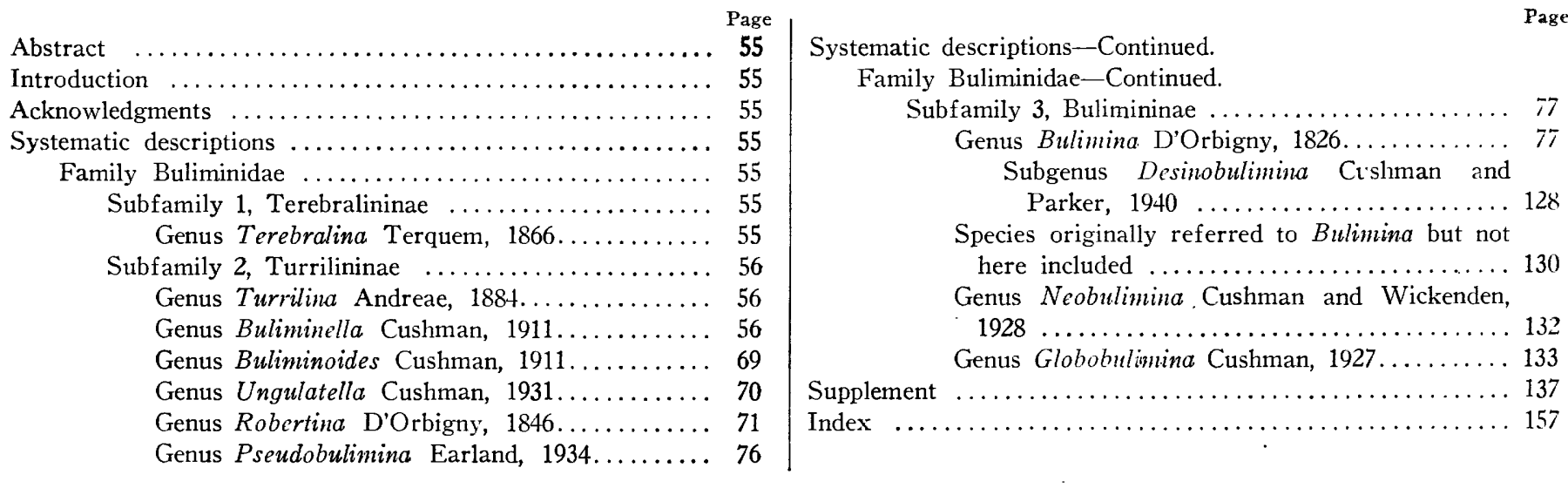

\section{ILLUSTRATIONS}

Plate 15. Terebralina, Turrilina, and Buliminella ..... 140

16. Buliminella ........................ 142

17. Buliminella, Buliminoides, and Ungulatella .... $14+4$

18. Robertina and Pseudobulimina ............. 146

19, 20. Bulimina
$.148,150$
Plate 21. Buliminia and Buliminella ............ 152

22-28. Bulimina $\ldots \ldots \ldots .154,156,158,160,162,164,166$

29. Bulimina, Bulimina (Desinobulimina), Neobulimina, Globobulimina ................. 168

30. Buliminella, Bulimina, Globobulimira ....... 170 


\title{
BULIMINA AND RELATED FORAMINIFERAL GENERA
}

\author{
By Joseph A. Cushman and Frances L. Parker
}

\begin{abstract}
This paper describes and illustrates the species belonging to the genera of the first 3 subfamilies of the Family Buliminidae, the Terebralininae, Turrilininae, and Bulimininae except Entosolenia. In the Terebralininae the genus Terebralina includes 1 species. In the Turrilininae the genus Turrilina includes 2 species, Buliminella 49 species and varieties, Buliminoides 1 species, Ungulatella 4 species, Robertina 19 species, and Pseudobulimina 3 species. In the Bulimininae the genus Bulimina includes 196 species and varieties, the subgenus Desinobulimina 5 species; 97 other species assigned originally to Bulimina have been assigned to other genera or are indeterminate. Neobulimina includes 4 species, Globobulimina 9 species and varieties. Four species are new and one new name is proposed. Twenty-one species and varieties described since this work was completed are listed in a supplement.
\end{abstract}

\section{INTRODUCTION}

The genus Bulimina is represented by many species from the Jurassic to the present time. Other related genera, nine in number, forming the first three subfamilies of the Foraminiferal family Buliminidae, are also includeci here. The genus Entosolenia is not included, as without recourse to the actual types it is very difficult to place many of the species.

A study has been made of the older types, where available, and of other species topotype material has often been examined As a result a great majority of the described species has been studied from actual material. Original figures and descriptions are given for most of the other species for which actual material is not available. During the several years that this study has been carried on, numerous short papers have been published giving descriptions and figures of new species and varieties as well as notes on the older species. Most of the records for the genera and species will be found in the references. References in the literature that are without figures usually have not been included unless original material or material from the same area has been available.

\section{ACKNOWLEDGMENTS}

Our thanks are due particularly to Miss Ann Shepard for her careful and accurate drawings of many of the species and redrawing of many of the types of the older species, the results of which appear in the accompanying plates; to Miss Anna Laura Dorsey for help in making up the plates and checking the manuscript; and to Miss
Alice E. Cushman for the typing of portions of the mantscript.

Our thanks are due also to Dr. John B. Reeside, Jr., Chief of the Section of Paleontology and Stratigraphy of the Geological Survey, for making possible the completion of this work as part of the regular work of the Survey.

We are indebted to many co-workers for sending us material from various regions. Mr. Bradford C. Adams sent us very fine series of Bulimina and related forms from the Tertiary of California. Material from Venezuela was received from Dr. Hollis Hedberg, from Trinida from Mr. P. W. Jarvis and Dr. H. H. Renz, and from Cuba from Dr. Pedro J. Bermúdez. Our thanks are due to Mr. Arthur Earland of England, Dr. A. Franke $c^{f}$ Germany, Mr. W. J. Parr of Australia, Dr. Shoshiro Hanzawa of Japan, and many others for valuable material yielding specimens of Bulimina and other related genera.

\section{SYSTEMATIC DESCRIPTIONS \\ Family BULIMINIDAE \\ Subfamily 1. TEREBRALININAE}

Test in an elongate, close spiral, not divided.into chanbers; all calcareous, perforate; aperture rounded, sulterminal.

\section{Genus TEREBRALINA Terquem, 1866}

Terebralina Terquem, Sixième mémoire sur les foraminifères du Lias, p. 473, 1866.

Cushman, Cushman Lab. Foram. Research Contr., vol. 3, p. 65, 1927; idem, Special Pub. 1, p. 243, 1928; idem, Special Pub. 4, p. 216, 1933.

Genotype, Terebralina regularis Terquem.

Test consisting of a proloculum and elongate, undivided, tubular, second chamber in an elongate close spiral; wall calcareous, perforate ; aperture rounded, terminal. Jurassic. There is a single species known.

\section{Terebralina regularis Terquem}

Plate 15, figure 1

Terebralina regularis Terquem, Sixième mémoire sur les foraminifères du Lias, p. 473, pl. 19, fig. 3, 1866.

Cushman, Cushman Lab. Foram. Research Special Pub. 1, pl. 35, fig. 6; pl. 37, fig. 1, 1928; idem, Special Pub. 4, p' 22, fig. 1, 1933; idem, Special Pub. 5, pl. 22, fig. 1, 1933. 
Test elongate, a close spiral about the vertical axis, undivided into chambers, circular in transverse section; wall calcareous, perforate, smooth; aperture rounded, subterminal, the apertural end somewhat contracted and prolonged.

The types are from the Jurassic, lower Lias, "les Bossons (près de Nohant, Indre)", France. It is recorded as very rare.

\section{Subfamily 2. TURRILININAE}

Test an elongate, close spiral, divided into chambers, usually more than three to a whorl, lines of the spiral very distinct.

\section{Genus TURRILINA Andreae, 1884}

Turrilina Andreae, Abh. geol. Specialkarte Elsass-Lothringen, vol. 2, pt. 3, p. 120, 1884.

Cushman, Cushman Lab. Foram. Research Contr., vol. 3, p. 65, 1927; idem, Special Pub. 1, p. 246, 1928; idem, Special Pub. 4, p. 217, 1933.

Bulimina (part) of authors.

\section{Genotype, Turrilina alsatica Andreae.}

Test an elongate, close spiral; chambers three or more in a whorl, spiral suture deep and continuous; wall calcareous, perforate; aperture at basal margin of chamber, broad, little if at all twisted. Jurassic? to Recent?

In this genus the spiral suture is very strongly marked, more so than those between the chambers.

Certain species that have been placed in this genus evidently belong elsewhere. The species referred to by White and others as "Turrilina trochoides (Reuss)" (White, Jour. Paleontology, vol. 3, p. 46, pl. 5, fig. 4, 1929) does not belong here. Sandidge has described and figured a species, "Turrilina angulata", from the Cretaceous (Am. Midland Nat., vol. 13, p. 198, pl. 19, figs. 7, 8, 1932) which should not be included in this genus.

\section{Turrilina alsatica Andreae}

\section{Plate 15 , figure 3}

Turrilina alsatica Andreae, Abh. geol. Specialkarte Elsass-Lothringen, vol. 2, pt. 3, p. 120, pl. 8, figs. 18, 19, 1884.

Cushman, Cushman Lab. Foram. Research Special Pub. 5, pl. 27, figs. 3a-c, 1933.

Test small, $11 / 2$ to 2 times as long as broad, rapidly tapering, greatest breadth formed by the last whorl, initial end subacute; chambers distinct, inflated, 3 to a whorl, increasing rapidly but uniformly in size as added; sutures distinct, the spiral suture very distinct and depressed; wall smooth; aperture low and broad, at the base of the apertural face, with a distinct margin. Length 0.20 to $0.25 \mathrm{~mm}$. ; diameter 0.15 to $0.18 \mathrm{~mm}$.

The types of this species are from the Oligocene of Alsace. We have specimens from Andreae's locality of
Lobsann and from other localities in the middle Oligocene of Germany.

\section{Turrilina andreaei Cushman}

Plate 15, figure 2

Turrilina andreaei Cushman, Cushman Lab. Foram. Research Special Pub. 5, pl. 27, figs. 2a, b, 1933.

Bulimina acicula Andreae (not Costa, 1856), Al '. Specialkarte Elsass-Lothringen, vol. 2, pt. 3, p. 277, pl. 12, fig. 13, 1884.

Paalzow, Offenbacher Ver. Naturkunde Ber., 1912-24, p. 65, pl. 1, fig. 6, 1912.

Turrilina acicula Cushman, Cushman Lab. Foram. Research Contr., vol. 3, p. 67, pl. 14, fig. 2, 1927; Scc. sci. Seine-etOise Bull., ser. 2, vol. 9, p. 52, pl. 2, fįs. 5a, b, 1928; Cushman Lab. Foram. Research Special Pub. 4, p1. 22, fig. 2,1933 .

Test elongate, spiral, conical, 3 to 5 whorls in the adult. greatest width formed by the last whorl; chambers distinct, only slightly inflated, 5 or 6 in the adult whorl; sutures distinct, the spiral suture partictlarly so and more depressed than those between the clambers; wall smooth; aperture a high, arched opening at the base of the truncated or somewhat concave apertural face, with a slight lip. Length 0.25 to $0.40 \mathrm{~mm}$., diameter 0.10 to $0.15 \mathrm{~mm}$.

This species is known from the Oligocene of AlsaceLorraine from the material described by Andreae, from the Mainz Basin recorded by Paalzow, and from Ormoy in France recorded by Cushman.

\section{Genus BULIMINELLA Cushman, 1911}

Buliminella Cushman, U. S. Nat.. Mus. Bull. 71, pt. 2, p. 88, 1911; idem, Bull. 104, pt. 3, p. 108, 1922 ; Cushman Lab. Foram. Research Contr., vol. 3, pt. 1, p. 65, 1927; idem, Special Pub. 1, p. 246, 1928; idem, Special Pub. 4. p. 217, 1933.

Genotype Bulimina elegantissima d'Orbigny.

Test an elongate, close spiral, the spiral s'iture distinct; chambers 3 or usually more in a whorl; wall calcareous, perforate; aperture elongate, loop-shaped, very slightly twisted. Cretaceous to Recent.

Species are numerous in this genus, the earliest of which appear in the Cretaceous. Most species are smooth and the ornamentation, when it occurs, is re'atively simple in comparison with the ornate character of many species of Bulimina. As a rule the species are re'atively shortlived and make good index fossils.

\section{Buliminella obtusa (D'Orbigny) Cushman and Parker}

Plate 15, figure 4

Bulimina obtusa D’Orbigny, Soc. Géol. France Mém., ser. 1, vol. 4, p. 39, pl. 4, figs. 5, 6, 1840; Prodrome de Paléontologie, vol. 2, p. 282, No. 1399, 1850.

Buliminella obtusa Cushman and Parker, Cushm»n Lab. Foram. 
Research Contr., vol. 10, p. 28, pl. 5, figs. 1 a, b, 1934; idem., vol. 12, p. 6, pl. 2, figs. la-c, 1936.

.Brotzen, Sveriges geol. undersökning, ser. c, no. 396, p. 131, pl. 8, figs. 2a, b, 1936.

Test large, slightly tapering, almost twice as long as broad, consisting of 4 to 5 whorls; chambers 4 to a whorl, the last-formed chamber constituting slight, lobular projection; sutures flush with the surface, slightly limbate, appearing as somewhat darkened lines; wall smooth, polished, coarsely perforate; aperture loop-shaped, with a depressed area extending down from it along the suture bounding the apertural face. Length $0.71 \mathrm{~mm}$., diameter $0.42 \mathrm{~mm}$.

This species was described from the Upper Cretaceous of Meudon and Sainte Germaine in the Paris Basin, and of England. We have specimens which may be referred to this species from Bougival, France.

It seems possible that this form may represent a variant of Buliminella laevis (Beissel), but lack of evidence makes it advisable to keep the two species separate for the present.

\section{Buliminella imbricata (Reuss) Cushman and Parker}

\section{Plate 15, figure 5}

Bulimina imbricata Reuss, Haidinger's naturwiss. Abl., vol. 4, p. 22, pl. 3, fig. 7, 1851.

Franke, Preuss geol. Landesanstalt Abh., n. ser., vol. 111, p. 159, pl. 14, fig. 20, 1928.

Buliminella imbricata Cushman and Parker, Cushman Lab. Foram. Research Contr., vol. 10, p. 31, pl. 5, figs. 19a, b, 1934; idem., vol. 12, p. 6, pl. 2, figs. 2a-c, 1936.

Test small, somewhat tapering, usually twice as long as broad, with about 4 whorls; chambers 4 to a whorl; sutures distinct, dark, spiral suture slightly depressed; others flush with the surface; wall smooth, very coarsely perforate, somewhat polished; aperture comma-shaped, almost at the apex of the apertural face, which is somewhat rounded. Length 0.18 to $0.28 \mathrm{~mm}$., diameter 0.12 to $0.16 \mathrm{~mm}$.

The species was described from the Upper Cretaceous, Senonian, of Lemberg, Galicia. Our specimens from Lemberg are very much smaller than those described by Reuss. In other respects, however, they appear very similar and it seems best to refer them to this species. One of them is figured here. A few other specimens were found in the Senonian of Germany.

The form is broader and less tapering than Buliminella pusilla (Brotzen).

\section{Buliminella laevis (Beissel) Cushman and Parker}

Plate 15, figure 6

Bulimina laevis Beissel, Preuss. geol. Landesanstalt Abh., n. ser., vol. 3, p. 66 , pl. 12, figs. 39-43, 1891.
Buliminella laevis Cushman and Parker, Cushman Lab. Foram. Research Contr., vol. 12, p. 6, pl. 2, figs. 3a-c, 1936.

Brotzen, Sveriges geol. undersökning, ser. c, no. 465, p. 45, 1945.

Bulimina elegans Heron-Allen and Earland (not D'Orbigny), Royal Micr. Soc. Jour., p. 409, pl. 6, fig. 11, 1910.

Bulimina ovulum Franke (not Reuss), Geol. pal. Instit. Univ. Greifswald Abh., vol. 6, p. 25, pl. 2, fig. 17, 1925; Preus: geol. Landesanstalt Abh., n. ser., vol. 111, p. 157, pl. 14, fig. 14, 1928.

Test large, about $14 / 5$ times as long as broad, consistin? of 3 or more whorls; chambers 4 to a whorl, very slightly inflated; sutures slightly depressed, especially in the earlie $r$ whorls, giving the test an irregular appearance, usuall: flush with the surface in the last whorl; wall smootl, finely perforate, sometimes polished; aperture commeshaped, broad at the base, near the apex of the apertural face, in some specimens with a small depression extendin? down from it along the base of the last-formed chamber, sometimes as far as the suture joining the second ant third chambers; also in a few specimens a very short, depressed area extending up from the base of the aperture along the same suture. Length 0.54 to $0.91 \mathrm{~mm}$., diameter 0.42 to $0.48 \mathrm{~mm}$. (The occasional dwarfed specimens which are found at some localities were not used in compiling these measurements).

The species was described from Friedrichsberg, nea.r Aachen, Germany. It is common in the Upper Cretaceous, Senonian, of Europe and England. Various authors. including Reuss himself, in later papers have confused this form with Bulimina ovulum Reuss (Bulimina reussi Morrow), which is distinctly a Bulimina. It is a large* species than Buliminella cushmani Sandidge and differs from it in the shape of the aperture and the size and shafe of the apertural face.

\section{Buliminella pusilla (Brotzen) Cushman and Parker Plate 15 , figure 7 ; plate 21 , figure 5}

Bulimina pusilla Brotzen, Sveriges geol. undersökning, ser. c, no. 396 , p. 127 , pl. 8 , fig. 4 ; text fig. $44,1936$.

Test small, slender, slightly tapering, about $2 \frac{1}{4}$ times as long as broad, consisting of 4 whorls; chambers 4 to a whorl, fairly distinct; sutures slightly depressed; wall smooth, coarsely perforate; aperture loop-shaped, near the apex of the test. Length $0.20 \mathrm{~mm}$., diameter $0.09 \mathrm{~mm}$.

The above description is given of a single syntype $c^{+}$ the species sent by Dr. Brotzen. It was originally describe-1 from the Upper Cretaceous, lower Senonian, of Eriksdal, Sweden. We have one other specimen similar to this form from Lubitsch, Czechoslovakia.

The species differs from Buliminella imbricata (Reuss) is being much more slender and more tapering, and in having the broadest part of the test near the apex. 


\section{Buliminella carseyae Plummer}

Plate 15, figure 8

Bulinina compressa Carsey (not Bailey, 1851), Texas Univ. Bull. 2612, p. 29, pl. 4, fig. 14, 1926.

Buliminella carseyae Plummer, Texas Univ. Bull. 3101, p. 179, pl. 8, fig. 9, 1931.

Cushman, Jour. Paleontology, vol. 6, p. 340, 1932.

Cushman and Parker, Cushman Lab. Foram. Research Contr., vol. 12, p. 8, pl. 2, figs. 6a-c, 1936.

Loetterle, Nebraska Geol. Survey Bull., 2d ser., Bull. 12, p. 37, pl. 5, figs. 10a, b, June, 1937.

Cole, Florida Dept. Cons. Geol. Bull. 16, p. 35 (list), pl. 4, fig. 2, 1938.

Cushman, Cushman Lab. Foram. Research Contr., vol, 20, p. 12, pl. 2, fig. 24 ; p. 93, pl. 14, fig. 10, 1944; U. S. Geol. Survey Prof. Paper 206, p. 119, pl. 50, figs. 17-20, 1946.

Buliminella hofkeri Brotzen, Sveriges geol. undersökning, ser. c, no. 396 , vol. 30 , no. 3 , p. 129 , pl. 8 , fig. 3 ; text fig. 45,1936 .

Test ovate, about twice as long as broad, initial extremity bluntly pointed; chambers about four in each mature whorl, turgid, smooth; sutures distinctly depressed, disposed at a strong angle to the elongate axis of the test; aperture small, comma-shaped, in a strong depression on the septal face and overhung by a sharp projection of the apex of the last chamber and marked by a minute and very narrow apertural flap extending down the long side of the septal face. Length $.39 \mathrm{~mm}$; diameter $.22 \mathrm{~mm}$.Plummer.

The types of this species are from the Upper Cretaceous, upper part of the Taylor formation, on right bank of Onion Creek near bridge at Moore and Berry's Crossing, $81 / 2$ miles in a straight line southeast of the capitol in Austin, Texas.

The species is found in the Upper Cretaceous Navarro group, and the Taylor and Austin formations of Texas. It occurs rarely in the Navarro but is very widespread and abundant in the Taylor. In the Austin the form is not so common and is usually smaller and somewhat shorter in proportion to its length than the typical form. We have specimens also from the Turonian and Senonian of Germany and from the Upper Cretaceous of Gravesend, England. These forms have been referred by Brotzen to the new species Buliminella hofkeri. As they appear to us to be in every way identical with the American form, which Brotzen notes that he had no opportunity of seeing, his species is placed in the synonymy under Mrs. Plummer's.

The species is related to Buliminella laevis (Beissel) but is much smaller and shows much more inflation of the chambers.

\section{Buliminella carseyae Plummer var. plana Cushman and Parker}

Plate 15, figure 9

Buliminella carseyae Plummer var. plana Cushman and Parker, Cushman Lab. Foram. Research Contr., vol. 12, p. 8, pl. 2, figs. 7a-c, 1936.
Cushman and Hedberg, idem, Contr., vol. 17, p. 94, pl. 22, figs. 26a-c, 1941.

Cushman and Todd, idem, Contr., vol. 19, p. 65, pl. 11, fig. 20, 1943.

Cushman, U. S. Geol. Survey Prof. Paper 206, p. 120, pl. 50. figs. $16,21,22,1946$.

Test small, about $11 / 2$ times as long as broad, consisting usually of 4 whorls, the last-formed whorl constituting at least half the test; chambers distinct, somewhat inflated; sutures distinct, depressed; wall smooth, perforate; aperture comma-shaped. Length 0.18 to $0.24 \mathrm{~mm}$., diameter 0.10 to $0.15 \mathrm{~mm}$.

This variety was described from the Upper Cretaceous Navarro formation on the San Antonio road. 6 miles east of Castroville, Bexar County, Texas. Our specimens are from the Navarro or formations of equivalent age in the Gulf Coast region of the United States and from the Upper Cretaceous of Columbia.

The variety differs from the typical form in the smaller size of the test and the lesser inflation of the chambers.

\section{Buliminella cushmani Sandidge \\ Plate 15, figures 10,11}

Buliminella cushmani Sandidge, Jour. Paleontology, vol. 6, p. 280, pl. 42, figs. 18, 19, 1932.

Cushman and Parker, Cushman Lab. Foram. Research Contr., vol. 12 , p. $8,1936$.

Cole, Florida Dept. Cons. Geol. Bull. 16, p. 24 (list), pl. 2, fig. 14, 1938.

Cushman and Deaderick, Jour. Paleontology, vol. 18, p. 337, pl. 53, fig. 5, 1944.

Applin and Jordan, idem, vol. 19, p. 132, 1945.

Cushman, U. S. Geol. Survey Prof. Paper 206 p. 119, pl. 50, fig. $15,1946$.

Test medium, tapering, widest portion about $2 / 3$ of the length from the initial end, usually consisting of 4 whorls; chambers distinct, 4 to a whorl, slightly irflated in the first 3 whorls; sutures distinct, spiral suture slightly depressed, others flush with the surface, usually darker in color than the rest of the test; wall smooth, finely perforate; aperture loop-shaped, near apex of the apertural face, which is flaring and somewhat flattened. Specimens from the Upper Cretaceous Kemp clay on a branch of Mustang Creek, 1 mile west-southwest of Noack, 900 feet downstream from road, Williamson County, Texas. Length 0.34 to $0.50 \mathrm{~mm}$., diameter 0.22 to $C .24 \mathrm{~mm}$.

The types of the species are from the Upper Cretaceous Ripley formation in an exposure at the mouth of Boguechitto Creek, Alabama. We have no topotype material, but there seems little doubt that our specimens may be referred to Sandidge's species. This species occurs in the Upper Cretaceous of the Gulf Coast area cf the United States in the Saratoga chalk, Corsicana marl, Kemp clay, Marlbrook marl, and Prairie Bluff formation. It occurs also in the Upper Senonian of Germany ant France. 
Sandidge describes the species as very similar to Buliminella carseyae but differing from it in being smaller and more compact, with less inflated chambers and more gracefully curving sutures. It is also similar to Buliminella laevis (Beissel), but is smaller, has a broader apertural face and a broader, less curved aperture.

\section{Buliminella vitrea Cushman and Parker}

Plate 15, figure 12

Buliminella vitrea Cushman and Parker, Cushman Lab. Foram. Research Contr., vol. 12, p. 7, pl. 2, figs. 4a-c, 1936.

Cushman, U. S. Geol. Survey Prof. Paper 206, p. 119, pl. 50, fig. 14, 1946.

Test small, about $11 / 2$ times as long as broad, slightly tapering, consisting of 3 to 4 whorls, the last-formed whorl constituting more than half the test; chambers distinct, slightly inflated; sutures distinct, depressed; wall partially transparent, coarsely perforate; aperture commashaped. Length 0.16 to $0.25 \mathrm{~mm}$., diameter 0.08 to 0.15 $\mathrm{mm}$.

The species was described from the Upper Cretaceous Selma chalk at a locality 2 miles west of Guntown, Mississippi. It occurs in the Selma chalk of the eastern Gulf region and at one locality in the upper Austin of Texas.

The species resembles Buliminella imbricata (Reuss), but differs from.it in the more curving sutures, the greater inflation of the chambers, and the transparency of the test.

\section{Buliminella fabilis Cushman and Parker}

\section{Plate 15, figure 13}

Buliminella fabilis Cushman and Parker, Cushman Lab. Foram. Research Contr., vol. 12, p. 7,•pl. 2, figs. 5a-c, 1936.

Cushman, U. S. Geol. Survey Prof. Paper 206, p. 119, pl. 50, fig. 13, 1946.

? Buliminella imbricata Cushman (not Reuss), idem, vol. 7, p. 42, pl. 5, figs. 10a-c, 1931.

Test small, about twice as long as broad, tapering, consisting of 4 to 5 whorls, the last-formed whorl taking up about two-thirds of the test; chambers distinct, those in the last whorl very slightly inflated; sutures distinct, slightly depressed; wall smooth, perforate; aperture loopshaped, near apex of test. Length 0.16 to $0.20 \mathrm{~mm}$.. diameter 0.08 to $0.10 \mathrm{~mm}$.

The species was described from the Upper Cretaceous, lower part of the Taylor formation, in the bank of small stream, 45 feet north of Hillsboro-Corsicana road, 14.2 miles east of Hillsboro, Texas. It occurs in the Taylor, Austin, and Eagle Ford formations of Texas.

The form is very close to Buliminella pusilla Brotzen, but as we have only a single specimen of the latter, kindly sent by Dr. Brotzen, it seems best not to combine the two.

\section{Buliminella colonensis Cushman and Hedberg}

Plate 15, figures 14,15

Buliminella colonensis Cushman and Hedberg, Cushman Láb. Foram. Research Contr., vol. 6, p. 65, pl. 9, figs. 6, 7, 1930.

Cushman, U. S. Geol. Survey Prof. Paper 206, p. 120, pl. 50, figs. 23, 24, 1946.

Test medium, nearly as broad as long, at least in the microspheric form, initial end pointed, apertural end broadly rounded; chambers 5 or 6 in the last-formed whorl, elongate, rather uniformly increasing in size as added, very slightly inflated; sutures distinct, very slightly depressed; wall smooth; aperture broadly comma-shaped, the greatest breadth at the inner end of the aperture. Length up to $0.40 \mathrm{~mm}$., diameter $0.35 \mathrm{~mm}$.

The types of the species are from the Upper Cretaceo's Colon shale in the Department of Escuque, State of Trujillo, Venezuela. The species occurs also in the Uppar Cretaceous Velasco shale and Mendez formation of Mexico.

The species is most closely related to Buliminella cushmani Sandidge but differs from it in having fewer whorls and in tapering more rapidly.

\section{Buliminella fusiforma Jennings}

Plate 30 , figure 2

Buliminella fusiforma Jennings, Bull. Am. Paleontology, vol. 23, no. 78 , p. 30 , pl. 3 , fig. $18,1936$.

Test fusiform, initial end pointed, apertural end rounded; about three whorls to a test, the last forming 80 per cent of the test; four chambers to a whorl; sutures distinct, depressed, spiral suttre much more strongly depressed than transverse; aperture virguline, in a depression in the septal face forming a strong angle with the axis of the test. Length $0.21-0.32 \mathrm{~mm}$; width, $0.18 \mathrm{~mm}$ Jennings.

This species was described from the Upper Cretaceo's Navesink marl of New Jersey.

Buliminella irregularis (Terquem) Cushman and Parker

Plate 15 , figure 16

Bulimina irregularis Terquem, Soc. Géol. France Mém., ser. 3, vol. 2, p. 112, pl. 12(20), figs. 1a, b, 1882.

?Bulimina scalariformis Terquem, idem, p. 114, pl. 12(20), fig. 13.

Buliminella irregularis Cushman and Parker (part), Cushm»n Lab. Foram. Rèsearch Contr., vol. 13, p. 68, pl. 9, figs. $6 \varepsilon-\mathrm{c}$ (not figs. 7a-c), 1937.

van Bellen, Geol. Stichting Mededeelingen, ser. C-V, No. 4, p. 45 , pl, 4, fig. 11, 1946.

Test small, elongate, tapering from the initial end to the greatest breadth made by the last-formed whorl, abo'it 3 times as long as broad, initial end with an acerose spine; chambers distinct, slightly inflated, almost 4 in the adult whorl, increasing very gradually in size as added; sutures distinct, slightly depressed, somewhat limbate; 
wall smooth, except above the aperture, where there are numerous radiating lines or slight ridges running down into the apertural face; aperture very small, broadly loopshaped, at the inner margin of the apertural face, which is strongly depressed and has a rounded lip. Length of Terquem's specimen $0.37 \mathrm{~mm}$., diameter $0.16 \mathrm{~mm}$. Length of our specimen $0.35 \mathrm{~mm}$., diameter $0.14 \mathrm{~mm}$.

The species was described from the Eocene, Vaudancourt, Paris Basin, France. We have a single specimen from the sand of Chaméry, in the Paris Basin.

This species may be distinguished by its tapering test, basal spine, and the depressed apertural face with the radiating ridges.

\section{Buliminella turbinata (Terquem) Cushman and Parker}

Plate 15, figures $18-21$

Bulimina turbinata Terquem, Soc. Géol. France Mém., ser. 3, vol. 2, p. 113, pl. 12(20), figs. 6, 7, 1882.

Bulimina ovula Terquem (not D'Orbigny), idem, p. 113, pl. $12(20)$, fig. 5.

Buliminella turbinata Cushman and Parker, Cushman Lab. Foram. Research Contr., vol. 13, p. 68, pl. 9, figs. 8a-c, 9a-c, 1937.

Test small, about twice as long as broad, somewhat fusiform, initial end subacute, last-formed whorl composing the greater part of the test; chambers distinct, 6 or 7 to $\dot{a}$ whorl, elongate and narrow, slightly, if at all, inflated; sutures distinct, usually flush with the surface, slightly limbate; wall smooth, finely perforate; aperture loop-shaped, in a distinct depression on the apertural face, which is otherwise somewhat rounded and formed of clear shell material. Length of Terquem's specimens 0.50 to $0.52 \mathrm{~mm}$., diameter 0.24 to $0.30 \mathrm{~mm}$. Length of our specimens 0.30 to $0.35 \mathrm{~mm}$, diameter 0.10 to $0.15 \mathrm{~mm}$.

Terquem records the species are rare in the Eocene at Vaudancourt, Paris Basin, France. We have specimens from several localities of the Calcaire grossier inférieur and lower Lutétian of the Paris Basin. A single specimen was found in the Oligocene Stampian at Lounandière, France.

The last-formed whorl of this species composes a far greater proportion of the test than that of either Buliminella intorta (Terquem) or B. glomerata Cushman and Parker and the spiral suture is not depressed. The test is more tapering than that of the former species, and the chambers are somewhat narrower than those of the latter.

\section{Buliminella flexa (Terquem) Cushman and Parker}

Plate 16, figure 1

Bulimina flexa Terquem, Soc. Géol. France Mém., ser. 3, vol. 2, p. 115 , pl. $12(20)$, fig. $15,1882$.

Test small, slender, slightly tapering, with a rounded initial end, consisting of 3 or 4 whorls ; chambers distinct, 4 to a whorl; sutures distinct, flush with the surface; wall smooth, finely perforate; aperture small. loop-shaped, placed toward the top of the apertural face, which is formed of clear shell material. Length of figured specimen $0.30 \mathrm{~mm}$, diameter $0.13 \mathrm{~mm}$.

The species was described from the Eocene Septeuil, Paris Basin, France. We have specimens from several localities in the Paris Basin.

This form has fewer chambers to the whorl than Buliminella intorta (Terquem), and the spiral suture is not depressed.

\section{Buliminella intorta (Terquem) Cushman and Parker}

Plate 15, figure 17

Bulimina intorta Terquem, Soc. Géol. France Mém., ser. 3, vol. 2, p. 115, pl. 12(20), fig. 16, 1882.

Bulimina pulchra Terquem (part), idem, p. 114, pl. 12(20), fig. 10 (not figs. 8, 9, 11, 12).

Buliminella irregularis Cushman and Parker (not Bulimina irregularis Terquem) (part), Cushman Lab. Foram. Research Contr., vol. 13, p. 68, pl. 9, figs. 7a, b (not figs. 6a-c), 1937.

Test small, somewhat fusiform, consisting of about 3 whorls; chambers distinct, 5 to a whorl, narrow; sutures distinct, spiral suture depressed, others flush with the surface, darker in color than the rest of the test; aperture small, loop-shaped, on the apertural face, wlich is rounded and does not extend down the side of the test. Length of figured specimen $0.25 \mathrm{~mm}$., diameter $0.10 \mathrm{~mm}$.

The species was described from the Eorene, Septeuil, Paris Basin, France. We have material frcm Chaméry in the Paris Basin.

This form has narrower, more curving chambers than Buliminella flexa (Terquem), and the spiral suture is depressed.

\section{Buliminella conulus (Terquem) Cushman and Parker}

Plate 16, figure 2

Bulimina conulus Terquem, Soc. Géol. France Mém., ser. 3, vol. 2, p. 116, pl. 12(20), fig. 17, 1882.

Cushman and Parker, Cushman Lab. Foram Research Contr., vol. 13, p. $73,1937$.

Test conical, pyramidal, rounded at the top, slender and obtuse at the bottom, straight on the sides, covered with very fine perforations arranged in vertical lines, formed of 5 whorls, not projecting, with transverse sutures, the first very close, the last widely separated; chambers smooth, quadrangular, sutures linear, curved; aperture round, in an ovally pointed depression, surrounded by a thick border. Length $0.53 \mathrm{~mm}$., diameter $0.18 \mathrm{~mm}$.

This description is a translation of Terauem's description of the species from the Eocene of Septeuil, Paris Basin, France. We have no typical material. 


\section{Buliminella pupa (Terquem) Cushman and Parker}

Plate 16, figure 3

Bulimina pupa Terquem, Soc. Géol. France Mém., ser. 3, vol. 2, p. 116, pl. 12(20), figs. $18 \mathrm{a}, \mathrm{b}, 1882$.

Bulimina striato-punctata Terquem, idem, p. 116, pl. 12(20), fig. 19.

Buliminella striato-punctata Cushman and Parker, Cushman Lab. Foram. Research Contr., vol. 13, p. 69, pl. 10, figs. 3a-c, 1937.

Test small, elongate, $21 / 2$ to 3 times as long as broad, sides in the middle portion nearly straight and parallel, initial end subacute, apertural end somewhat truncate; chambers distinct, very slightly inflated, usually 3 to a whorl, with the final chambers somewhat offset from the others; sutures distinct, very slightly curved, very slightly depressed, usually dark in color; wall with rather coarse punctae arranged in longitudinal lines, the bottom part of the test, and sometimes more, ornamented by faint costae; aperture elongate, rounded, at the inner margin of the last-formed chamber in a distinct depression of the apertural face. Length 0.30 to $0.60 \mathrm{~mm}$., diameter 0.12 to $0.16 \mathrm{~mm}$.

The types are from the Eocene at Vaudancourt, Paris Basin, France. The species occurs at several localities in the Paris Basin.

It seems probable that $B$. pupa and $B$. striato-punctata of Terquem should be combined, as specimens resembling the figures of both are found in the same species. The form may be differentiated from others by the punctate test and the faint striations or costae, which are sometimes barely visible unless viewed with cross lighting.

Buliminella semi-nuda (Terquem) Cushman and Parker

Plate 16, figures 4,9

Bulimina semi-nuda Terquem, Soc. Géol. France Mém., ser. 3, vol. 2, p. 117, pl. 12(20), fig. 21, 1882.

Bulimina obliqua Terquem (not D'Orbigny), idem, p. 118, pl. 12(20), fig. 23.

Cushman and Parker, Cushman Lab. Foram Research Contr., vol. 13, p. 73, 1937.

Bulimina terquemiana Heron-Allen and Earland, Royal Micr. Soc. Jour., 1911, p. 314, p1. 9, figs. 13, 14.

Buliminella semi-nuda Cushman and Parker, Cushman Lab. Foram. Research Contr., vol. 13, p. 70, pl. 10, figs. 4a-c, 5a-c, 1937.

Buliminella terquemiana Cushman and Parker, idem, p. 71, pl. 10, fig. 7.

Test of medium size, about $11 / 2$ times as long as broad, initial end acute, often with a short, stout spine, greatest breadth at about the middle, rapidly tapering, the lastformed whorl constituting the greater part of the test; chambers indistinct, 6 to 8 in the adult whorl, increasing very gradually in size as added; sutures indistinct, narrow, usually not depressed except for the spiral suture; wall ornamented by numerous, irregular, longitudinal costae which often fade out and become almost untraceable in the upper portion of the test; aperture rounded, in a distinct depression of the inner margin of the broad:" flaring apertural face, which is ornamented with fine, radiating ridges. Length of figured specimens $0.33 \mathrm{~mm}$., $0.45 \mathrm{~mm}$.; diameter $0.20 \mathrm{~mm}$., $0.27 \mathrm{~mm}$.

The species was described from the Eocene at Septeuil, Paris Basin, France. It occurs at several localities in the middle Eocene of the Paris Basin, France. We have one specimen from the Ocala limestone, east bank of the Flint River, Mitchell County, Georgia The form described $1 y$ Cushman as Buliminella elegantissima (D'Orbigny) ver. semi-nuda (Terquem) (U. S. Nat. Mus. Bull. 104, pt. 3, p. 108, pl. 23, fig. 5,1922 ) is very similar except for the initial end, which is more rounded; it has well defined costae that extend to the top of the test and was recorded from the Recent material at Albatross sta. D2358 in the Caribbean. Bermúdez records this same form from a Recent locality north of Cuba (Soc. cubana hist. nat. Mem., vol. 9, p. 193, 1935). Brady's species of the same name (Challenger Rept., Zoology, vol. 9, p. 403, pl. ¿0, figs. 23, 24, 1884) from the Indo- Pacific may represent this variant, although figure 23 pictures a smooth form that should possibly be referred to Buliminella madagcscariensis (D'Orbigny).

Bulimina terquemiana Heron-Allen and Earland, recorded as "fossil" from Selsey Bill, England, has be $n$ combined with this species, as a study of the Paris Basin specimens of $B$. semi-nuda in appropriate cross-lighting shows invariably that instead of extending only acrcss the bottom half of the test the costae are continuo's throughout the test. The specimens of $B$. semi-nuda show a gradation from the faintly costate forms to those having well-developed costae that can be easily seen. $T$ : costae and the broadly flaring apertural.face differenticte this species from others.

\section{Buliminella pulchra (Terquem) Cushman and Parker}

\section{Plate 16, figures 5, 6}

Bulimina pulchra Terquem (part), Soc. Géol. France Mém., ser. 3, vol. 2 , p. 114 , pl. $12(20)$, figs. $8,9,11,12$ (not fig. 10), 1882.

Buliminella pulchra Cushman and Parker (not Tolmachoff), Cushman Lab. Foram. Research Contr., vol. 13, p. 69, pl. 10, figs. 1, 2, 1937.

Test small, about $21 / 2$ times as long as broad, composed of 3 or 4 whorls, the last forming about two-thirds of the surface of the test; chambers distinct, slightly, if at all, inflated, 5 or 6 in the adult whorl, fewer in the earlier whorls, increasing very slightly in size as added; sutures distinct, spiral suture depressed, especially in the microspheric form, others usually flush with the surface; wall smooth, very finely perforate; aperture an elongate open- 
ing, in a depression at the inner margin of the last-formed chamber, placed toward the upper part of the apertural face, which is narrow and extends well down the side of the test. Length 0.40 to $0.45 \mathrm{~mm}$., diameter 0.18 to $0.20 \mathrm{~mm}$.

The species was described from the Eocene at Septeuil, Paris Basin, France. It is very common in the Paris Basin material. A single specimen was found in the Eocene from Kressenberg, Germany. It occurs also in the London clay at Barton, England.

The species differs from Buliminella intorta (Terquem) in having broader chambers and a longer apertural face that extends down the side of the test.

\section{Buliminella alabamensis Cushman}

Plate 16, figure 7

Buliminella alabamensis Cushman, Cushman Lab. Foram. Research .Contr., vol. 2, p. 32, pl. 4, figs. 8a, b, 1926; U. S. Geol. Survey Prof. Paper 181, p. 34, pl. 13, figs. 6a, b, 1935.

Test small, ovate, broadest in front view slightly above the middle, initial end pointed, apertural end broadly rounded, somewhat obliquely truncated, whole test of $1 \frac{1}{2}$ to 2 coils; chambers fairly distinct, not inflated; sutures distinct but not depressed; apertural face with a very large open area somewhat broadening toward the base which reaches to at least the middle of the test; wall very thin and transparent. Length $0.22 \mathrm{~mm}$.-Cushman.

The species was described from the upper Eocene at a locality a quarter of a mile west of Water Valley, Choctaw County, Alabama. It is not known elsewhere.

This species may be easily recognized by the peculiar opening in the apertural face.

\section{Buliminella robertsi (Howe and Ellis) Martin}

\section{Plate 16, figure 8}

Bulimina robertsi Howe and Ellis, in Howe, Louisiana Dept Cons. Geol. Bull. 14, p. 63, pl. 8, figs. 32, 33, 1939.

Buliminella robertsi Martin, Stanford Univ. Publ., Univ. Ser., Geol. Sci., vol. 3, no. 3, p. 9 (list), 1943.

Cushman and Herrick, Cushman Lab. Foram. Research Contr., vol. 21, p. 64, pl. 10, fig. 15, 1945.

Cushman and Todd, idem, Contr., vol. 21, p. 94, pl. 15, fig. 12, 1945.

Bulimina guayabalensis Cushman and Thomas (not Cole), Jour. Paleontology, vol. 4, p. 38, pl. 3, figs. 6a, b, 1930.

Test very small, ovate in side view, subcircular in end view, composed of numerous short chambers which are coiled slightly more than three chambers to the whorl, wall thick, smooth; sutures only slightly depressed; aperture a low arched slit at the base of the last chamber.-Howe and Ellis.

Length of holotype $0.16 \mathrm{~mm}$., diameter $0.11 \mathrm{~mm}$.

The types are from the Eocene Cook Mountain formation, St. Maurice, Winn Parish, Louisiana. We have material from the Eocene Claiborne formation of Texas, and from the Atlantis cores 12-36 and 21-38 taken off the northeast coast of the United States. It has been recorded from the Eocene Lodo formatior of California and $\mathrm{McBean}$ formation of Georgia.

The shape of the chambers, the number of chambers to a whorl, and the marked spiral suture are the characteristics which indicate that this species belongs in the genus Buliminella. It may be differentiatef by its small, relatively round (in transverse section) test, and by the low, arched aperture.

\section{Buliminella basistriata Cushman and Jarvis Plate 16, figure 10}

Buliminella basistriata Cushman and Jarvis, Cushman Lab. Foram. Research Contr., vol. 5, p. 11, pl. 2, figs. 17-19, 1929.

Renz, Proc. 8th Amer. Sci. Congress, p. 541 (list), 1942.

Test small, somewhat fusiform, tapering from the greatest width near the apertural end; chambers distinct, 4 to a whorl, slightly inflated; sutures distinst, slightly depressed; wall, except for the basal portion, smooth, finely perforate, basal portion with very fine striations; aperture large, in a small depression on the apertural face, which is small and rounded. Length 0.30 to $0.40 \mathrm{~mm}$., diameter $0.15 \mathrm{~mm}$.

The types are from the Eocene Mount Moriah beds of Vistabella Quarry, Trinidad. Similar specinens are found in the lower Miocene of the Maracaibo Basin, Venezuela, and the Tertiary of Santa Elena, Ecuador.

This species is much smaller than Buliwinella subfusiformis Cushman, the chambers are less inflated, and the last-formed whorl makes up a greater prcportion of the test.

\section{Buliminella basistriata Cushman and Jarvis var. nuda Howe and Wallace}

Plate 16, figure 11

Buliminella basistriata Cushman and Jarvis var. nuda Howe and Wallace, Louisiana Dept. Cons. Geol. Bull. 2, p. 60, pl. 11, fig. 4, 1932.

Cushman, Cushman Lab. Foram. Research Special Pub. 16, p. 22, pl. 4, fig. 30, 1946.

Buliminella subfusiformis Ellisor (not Cushman), Am. Assoc. Petroleum Geologists Bull., vol. 17, pl. 3, fig. 1, 1933.

Variety differing from the typical in the lack of ornamentation of the initial end.

The types are from the Eocene Jackson formation, Danville Landing, Ouachita River, Catehoula Parish, Louisiana. The variety occurs also in the Jackson group of Texas.

\section{Buliminella grata Parker and Bermúdez}

Plate 16, figure 12

Buliminella grata Parker and Bermúdez, Jour. F`leontology, vol. 11 , p. 515 , pl. 59 , figs. $6 a-c, 1937$.

Bermúdez, Soc. cubana hist. nat. Mem., vol. 11, p. 342, 1937. 
Cushman and Siegfus, Cushman Lab. Foram Research Contr., vol. 15, p. 27, pl. 6, figs. 14a, b, 1939; San Diego Soc. Nat. History Trans., vol. 9, no. 34 , p. 411 , pl. 16, figs. $37 \mathrm{a}, \mathrm{b}$, 1942.

Cushman and Stainforth, Cushman Lab. Foram. Research Special Pub. 14, p. 40, pl. 6, fig. 1, 1945.

Test of medium size, slightly longer than broad, tapering rapidly; consisting of 2 or 3 whorls; chambers 4 to a whorl; sutures distinct, broad, flush with the surface, usually incised to give a scalloped effect (especially noticeable when wet); wall smooth, finely perforate; aperture rounded, with small, narrow, radial depressions extending from it. Length 0.24 to $0.46 \mathrm{~mm}$, diameter 0.18 to $0.38 \mathrm{~mm}$.

The types are from the Eocene at Loma Principe, cut between Calle $\mathrm{F}$ and Avenida de los Presidentes, 20 meters west of José M. Gómez monument, Havana, Cuba. Besides the Eocene of Cuba the species occurs in the Eocene of California: in a small canyon, 50 feet stratigraphically above the top of a massive sandstone on the south slope of hill 2217 (Cholame quadrangle), about half a mile east of Tar Canyon, Kings County; and in the Kreyenhagen shale, Garza Creek, Fresno County. It also occurs in the Oligocene Cipero formation of Trinidad.

This species is much larger than Buliminella robertsi (Howe and Ellis) and has incised sutures.

\section{Buliminella grata Parker and Bermúdez var. spinosa Parker and Bermúdez}

.Plate 16 , figure 13

Buliminella grata Parker and Bermúdez var. spinosa Parker and Bermúdez, Jour. Paleontology, vol. 11, p. 516, pl. 59, figs. 7a-c, 1937.

Bermúdez, Soc. cubana historia nat. Mem., vol. 11, p. 343, 1937.

Variety differing from the typical form in its larger size and in the presence of short, thick, blunt spines in the lower part of the test, often covering the entire test of young specimens. Length 0.48 to $0.78 \mathrm{~mm}$., diameter 0.40 to $0.66 \mathrm{~mm}$.

The types are from the Eocene, north side of Elevador in Noroña, north of Guanajay, on railroad, Pinar del Rio Province, Cuba. It is not known elsewhere.

\section{Buliminella westraliensis Parr}

\section{Plate 16, figures 14,15}

Buliminella westraliensis Parr, Royal Soc. West Australia Jour., vol. 24 , p. 80 , pl. 2 , figs. $3,4,1937-38$.

Test elongate, subcylindrical, more or less twisted in contour, initial end blunt, apertural end rounded; chambers numerous, long and narrow, added obliquely and arranged in a spiral series of about two and a half coils in the adult; sutures distinct, wall smooth; aperture elongate and narrow, in a semi-circular depression just below the end of the test. Length up to $0.40 \mathrm{~mm}$; diameter $0.1 \mathrm{~mm}$.-Parr.

The types are from the Eocene, King's Park bore no. 1, 755 feet, Perth, Western Australia. We have no typical material.

\section{Buliminella obtusata Cushman}

Plate 16, figures 16,17

Bulininella obtusata Cushman, Cushman Lab. Foram. Resear $\mathrm{h}$ Contr., vol. 5, p. 42, pl. 7, figs. 8a, b, 1929.

Cushman and Parker, idem, vol. 13, p. 39, pl. 4 figs. 8, 9a, b, 1937.

Cushman and Todd, idem, vol. 22, p. 91, pl. 15, figs. 21, 22, 1946.

Test elongate, between 2 and 3 times as long as broad, usually not more than 2 whorls; chambers numerous, 7 or more in the last whorl; sutures distinct, flush with the surface except for the spiral suture, which may be dapressed, somewhat limbate; aperture in a slight depression of the apertural face, which is large and concave, gradually depressed to its deepest at the aperture. Length 10 to $0.46 \mathrm{~mm}$., diameter up to $0.20 \mathrm{~mm}$.

The types are from the Oligocene Byram marl, Byram, Mississippi. The species occurs in the Oligocene Vicksburg group and Red Bluff formation of Mississippi; in the Miocene, upper Burdigalian of France, and at Nus:dorf in the Vienna Basin, Austria; and the Pliocene of Antwerp, Belgium.

This species differs from Buliminella elegantissima (D'Orbigny) in being less fusiform, with a more flarir? apertural face, and broader chambers.

\section{Buliminella choctawensis Cushman and McGlamery}

Plate 16, figures 18,19

Buliminella choctarensis Cushman and McGlamery, U. S. Geol. Survey Prof. Paper 189-D, p. 107, pl. 25, figs. 11, 16, 1938.

Test elongate, subcylindrical, of rather uniform dianeter throughout, composed of about 3 whorls; chambers distinct, not inflated, 6 to 8 in the adult whorl, rather uniform in shape throughout; sutures distinct, the spirr 1 suture slightly depressed, the others flush with the su"face; wall slightly roughened, rather coarsely perforate; aperture an arched, semicircular opening at the base of the apertural face, in the adult sometimes more elongate and terminal. Length 0.30 to $0.40 \mathrm{~mm}$., diameter 0.08 to $0.10 \mathrm{~mm}$.

The species was described from the Oligocene limestone 2 or 3 feet above water level, Choctaw Bluff, Alabama River, Alabama. It is not known elsewhere.

This form may be differentiated by its very slender, elongate test, and the rather coarse perforations. 
Buliminella madagascariensis (D’Orbigny) var. spicata Cushman and Parker

Plate 16, figure 20

Bulimina elegantissima D'Orbigny var. apiculata Chapman (not Egger), Linnean Soc. London Jour., Zoology, vol. 30, p. 31, pl. 4, fig. 77, 1907.

Sidebottom, Royal Micr. Soc. Jour., 1918, p. 23, pl. 3, fig. 11.

Buliminella elegantissima (D'Orbigny) var. apiculata Cushman, Carnegie Inst., Washington Pub. 342, p. 25, 1924.

Buliminella apiculata Cushman, Cushman Lab. Foram. Research Contr., vol. 5, p. 44, pl. 7, figs. 6, 7, 1929.

Cushman and Parker, Cushman Lab. Foram. Research Contr., vol. 13, p. 39, pl. 4, figs. 10a, b, 1937.

Buliminella madagascariensis (D'Orbigny) var. spicata Cushman and Parker, (in Cushman), U. S. Nat. Mus. Bull. 161, pt. 3, p. 8, pl. 3, figs. 5, 6, 1942.

Cushman and Todd, Cushman Lab. Foram. Research Contr., vol. 2, p. 91, pl. 15, figs. 23, 24, 1946.

Variety differing from the typical form in its somewhat larger size, and in the presence of a stout, basal spine. Length 0.40 to $0.72 \mathrm{~mm}$., diameter 0.24 to $0.38 \mathrm{~mm}$.

The types are from the Oligocene, Grice's Creek, Balcombe Bay, Kackeraboite Creek, and Altoona Bay Coal Shaft, Victoria, Australia. We have typical material. The variety occurs also in the Oligocene Byram marl, Byram, Mississippi; in the Miocene and Recent of Australia; and in the Recent of the Fiji and Samoan Islands.

This variety has been given a new name because of the priority of Egger's Bulimina ovata D'Orbigny var. apiculata (1895).

There is a great variation in size. The Recent specimens are especially large and bear a close resemblance to Buliminella spinigera Cushman. They differ, however, in lacking the high polish of the latter, in having more numerous, more distinct chambers, and a less regular shape.

\section{Buliminella barbati Cushman and Simonson}

Plate 30, figure 1

Buliminella barbati Cushman and Simonson, Jour. Paleontology, vol. 18, p. 197, pl. 32, figs. 10a-c, 1944.

Test fusiform, $2 \frac{1}{2}$ to 3 times as long as broad, of. 3 to 4 whorls, greatest breadth usually at or below middle, initial end rounded, last whorl much constricted at apertural end; chambers distinct, little if at all inflated, about 5 to a whorl; sutures very slightly depressed; wall smooth; aperture broadly loop-shaped in an obliquely truncate apertural face. Length, $0.30-0.33 \mathrm{~mm}$; diameter, $0.15 \mathrm{~mm}$.

This species differs from $B$. brevior Cushman in the more elongate form, larger number of whorls, rounded base, and more truncate apertural face.-Cushman and Simonson.

The types of this species are from the Oligocene Tumey formation of Fresno County, California.

\section{Buliminella subfusiformis Cushman}

Plate 16, figure 21

Buliminella subfusiformis Cushman, Cushman Lab. Foram. Research Contr., vol. 1, pt. 2, p. 33, pl. 5, fig. 12, 1925.

Cushman, Stewart and Stewart, San Diego Soc. Nat. History Trans., vol. 6, p. 64, pl. 4, figs. 8a, b, 1930.

Cushman and Laiming, Jour. Paleontology, vol. 5, p. 106, pl. 11, figs. 14a, b, 1931.

Cushman and Parker, Cushman Lab. Foram. Research Contr., vol. 7, p. 8, pl. 1, fig. 29, 1931.

Barbat and von Estorff, Jour. Paleontology, vol. 7, p. 171, pl. 23, figs. 9a, b, 1933.

Kleinpell, Miocene stratigraphy of California, p. 251, pl. 9, fig. 8; pl. 22, fig. 5(?), Tulsa, 1938.

LeRoy, Natuurk. tijdschr. Ned-Indië, vol. 93, pt. 6, p. 243, pl. 5, figs. 16-18, 1939.

Schenck and Childs, Stanford Univ. Publ., Univ. Ser. Geol. Sci., vol. 3, no. 2, p. 26 (list), 1942.

LeRoy, Colorado School of Mines Quart., vol. 39, no. 3, p. 25, pl. 1, fig. 19, 1944.

Weaver, Washington Univ. [Seattle] Pub. in Geology, vol. 6, no. 1, p. 23 (list), 1944.

Buliminella curta Cushman (not Cushman, 1925), Florida Geol. Survey Bull. 4, p. 43, pl. 8, fig. 4, 1930.

Cushman and Cahill, U. S. Geol. Survey Prcf. Paper 175-A, p. 23, pl. 7, fig. 15, 1933.

Test elongate, fusiform, basal end poirted, apertural end somewhat rounded; chambers distinct, 4 in a whorl, inflated; sutures distinct, depressed, slightly curved; wall smooth, with medium sized perforations; aperture very small, in a depression of the apertural face which is small, rounded, and does not extend very far down the side of the test. Length up to $0.62 \mathrm{~mm}$., diameter up to $0.20 \mathrm{~mm}$.

The types are from the Miocene Monterey shale, sec. 24, T. 28 S., R. 14 E., M.D.M., San Luis Obispo County, California.

Kleinpell records the species from the lower Zemorrian to the upper Mohnian in the Miocene of California. It occurs also in the Choctawhatchee, Shoal Kiver, and Oak Grove formations of Florida, and in the Duplin marl of North Carolina. Le Roy records it from the Miocene of Central Sumatra.

This species differs from Buliminella curta Cushman in being more fusiform, more elongate, and in having a much smaller, more terminal apertural fare. The adult test has more whorls and more inflated -chambers than $B$. bassendorfensis Cushman and Parker.

\section{Buliminella curta Cushman}

Plate 16, figure 22

Buliminella curta Cushman, Cushman Lab. Foram. Research Contr., vol. 1, pt. 2, p. 33, pl. 5, fig. 13, 1925.

Cushman and Laiming (part), Jour. Paleontology, vol. 5, p. 106, p1. 11, fig. 16 (not fig. 15), 1931.

Cushman and Ponton, Florida Geol. Survey Bull. 9, p. 75, 1932. 
Cushman and LeRoy, Jour. Paleontology, vol. 12, p. 125, p1. 22, figs. 17a-c, 1938.

Kleinpell, Miocene stratigraphy of California, p. 248, pl. 7, fig. 3 ; pl. 15, fig. 4; pl. 16, fig. 8, Tulsa, 1938.

Ellisor, Am. Assoc. Petroleum Geologists Bull., vol. 24, pp. 439, 444 (lists), pl. 4, fig. 4, 1940.

Weaver, Washington Univ. [Seattle] Pub. in Geology, vol. 6, p. 23 (list), 1944.

Test tapering from the broadest part in the lastformed whorl, initial end pointed, apertural end broadly rounded, consisting of about 5 whorls; chambers distinct, inflated, about 4 to a whorl; sutures distinct, depressed; wall smooth, with medium sized perforations; aperture small, in a depression of the apertural face which is semicircular extending somewhat down the side of the test. Length 0.45 to $0.50 \mathrm{~mm}$., diameter $0.25 \mathrm{~mm}$.

The types are from the Miocene Monterey shale, sec. 24, T. 28 S., R. 14 E., M.D.M., San Luis Obispo County, California. Kleinpell records the species from the lower Zemorrian to the lower Delmontian in the Miocene of California. It occurs also in the Chocawhatchee marl, Shoal River and Oak Grove formations of Florida and is recorded by Miss Ellisor from the Miocene in a well core, Baldwin County, Alabama. Very similar specimens were found in the Recent deposits at Guide sta. 20(24), Lat. $43^{\circ} 05^{\prime} \mathrm{N}$., Long. $125^{\circ} 01^{\prime} \mathrm{W}$., in 640 fathoms, and in the Pliocene of Castel Arquato, Italy.

This species very closely resembles Buliminella subfusiformis Cushman, possibly is a variation of that form, It is shorter, more tapering, and has a broader, longer apertural face.

\section{Bulimịnella curta Cushman var. basispinata R. E. and K. C. Stewart}

Plate 16, figure 23

Buliminella curta Cushman var. basispinata R. E. and $\mathrm{K}$. C. Stewart, Jour. Paleontology, vol. 4, p. 63, pl. 8, fig. 6, 1930.

Cushman and Parker, Cushman Lab. Foram. Research Contr., vol. 14, p. 59, pl. 10, fig. 10, 1938.

Buliminella inconstans (Egger), var. basispinata Coryell and Mossman, Jour. Paleontology, vol. 16, p. 243, pl. 36, fig. 46, 1942.

Variety differing from the typical form in its larger size and the presence of short, blunt spines on the initial portion of the test. Length $0.80 \mathrm{~mm}$., diameter $0.30 \mathrm{~mm}$.

The types are from the Pliocene, upper part of the Pico shales, Kalorama Canyon, Ventura County, California. The variety is found also in the Pliocene, Repetto Hills, Los Angeles, California, and in Cañada de Aliso, Ventura County, California, in gray siltstone 5,320 feet stratigraphically above the base of the first Pico sandstone, 2.7 miles S. $78^{\circ} \mathrm{E}$. of La Crosse Junction. We have specimens from the Recent material at Guide sta. 20 (24), Lat. $43^{\circ} 05^{\prime} \mathrm{N}$., Long. $125^{\circ} 01^{\prime} \mathrm{W}$. It is also recorded from the Pliocene Charco Azul formation of Panama.

\section{Buliminella brevior Cushman}

Plate 16, figure 24

Buliminella brevior Cushman, Cushman Lab. Foram. Research Contr., vol. 1, pt. 2, p. 33, pl. 5, fig. 14, 1925.

Kleinpell, Miocene stratigraphy of California, p. 247, pl. 12, fig. 10, Tulsa, 1938.

Hanna and Hertlein, State of Calif. Div. of Mines, Bull, 118, fig. 67 [plate] fig. 22, 1941.

Test short, broad, fusiform, the last-formed whorl constituting about three-fourths of the test; chambers distinct, about 5 to a whorl, inflated; sutures distinct, depressed; wall smooth, with perforations of medium size; aperture in a depression of the apertural face that is narrow and extends down the side of the test. Length $0.50 \mathrm{~mm}$., diameter $0.30 \mathrm{~mm}$.

The species was described from the Miocene Monterey shale, sec. 24, T. 28 S., R. 14 E., M.D.M., San Luis Obispo County, California. Kleinpell records it from the upper Zemorrian to the lower Delmontian of the Miocene of California.

This species is more fusiform than Buliminella curta Cushman, the chambers are more inflated, the last-formed whorl composes a far greater proportion of the test, and the apertural face is longer. The chambers are more inflated and the apertural face is much narrower than in $B$. madagascariensis D'Orbigny.

\section{Buliminella californica Cushman}

Plate 17 , figure 1

Buliminella californica Cushman, Cushman Lab. Foram. Resea-ch Contr., vol. 1, pt. 2, p. 33, pl. 5, fig. 15, 1925.

Kleinpell, Miocene stratigraphy of California, p. 247, Tulsa, 1938.

Buliminella curta Cushman and Laiming (not Cushman) (part), Jour. Paleontology, vol. 5, p. 106, pl. 11, fig. 15 (not fig. 16), 1931.

Buliminella aff. $B$. californica Kleinpell, Miocene stratigraphy of California, p. 248, Tulsa, 1938.

Test elongate, narrow, slightly fusiform with almost parallel sides, initial end subacute, consisting of 5 or 6 whorls ; chambers distinct, about 4 to a whorl, very slightly inflated; sutures distinct, limbate, spiral suture somewhat depressed; wall smooth, with medium sized perforations; aperture in a depression near the top of the apsrtural face, which is otherwise rounded and small in size. Length 0.50 to $0.55 \mathrm{~mm}$., diameter $0.15 \mathrm{~mm}$.

The types are from the Miocene Monterey shale, sec. 24, T. 28 S., R. 14 E., M.D.M., San Luis Obispo County, California. Kleinpell records the species from the upper Luisian and lower Mohnian of the California Miocene. 
It occurs also at Los Sauces Creek, Ventura County, California, in beds of Saucesian and upper Zemorrian age. We have specimens from one locality in the Eocene, Cantua Creek, Fresno County, California, 150 feet below the base of the Temblor formation.

This species has less inflated chambers and is more slender than Buliminella subfusiformis Cushman, and the sutures are more limbate.

\section{Buliminella glomerata Cushman and Parker, n. name}

\section{Plate 17, figure 2}

Buliminella pulchra Tolmachoff (not Terquem), Carnegie Mus. Ann., vol. 23, p. 305, pl. 40, fig. 28, 1934.

Palmer, Bull. Am. Paleontology, vol. 29, no. 115, p. 46, 1945.

Test regularly spiral, of three volutions, the last of which occupies about three-fourths of the whole height of the test. Sutures well marked between the last whorl and the previous one, rather indistinct in earlier stage. The final whorl has five or six chambers separated from each other by distinct sutures. Surface shining, smooth. Aperture elongate, slightly curved. Length about $0.3 \mathrm{~mm}$., the greatest thickness about $0.2 \mathrm{~mm}$.-Tolmachoff.

The type is from the Miocene on the Atrato River, Colombia, South America. We have no typical material. Mrs. Palmer has recently recorded it from the Miocene Bowden marl of Jamaica.

Tolmachoff relates this species to Buliminella turbinata (Terquem) saying that it differs from Terquem's first figure in having fewer chambers in the last whorl and from the second figure in being less slender. He says that the last whorl of his species is smaller than that of $B$. colonensis Cushman and Hedberg, but that the two have very much the same general shape.

As Terquem's "Bulimina pulchra" described in 1882 is a Buliminella, a new name is here proposed for Tolmachoff's species.

\section{Buliminella dubia Barbat and Johnson}

Plate 17, figures 3,4

Buliminella dubia Barbat and Johnson, Jour. Paleontology, vol. 8, p. 13, pl. 1, figs. 14, 15, 1934.

Kleinpell, Miocene stratigraphy of California, p. 249, pl. 16, fig. 7, Tulsa, 1938,

Test spiral, consisting of about three and one-half whorls, tapering or fusiform, greatest width near apertural end, initial end pointed, apertural end rounded, periphery slightly lobulate; chambers distinct, about four in a whorl, almost as broad as long, more or less inflated; spiral suture not very distinct, other sutures wellmarked, slightly depressed; wall calcareous, smooth, very finely perforate; aperture comma-shaped, located in a depression of the last-formed chamber. Length $0.31 \mathrm{~mm}$.; width $0.17 \mathrm{~mm}$.

This species has fewer chambers than Buliminella curta, and the chambers are broader in proportion to their length.-Barbat and Johnson.

This species was described from the Miocene Reef Ridge shale, Leland Stanford Junior Univ. no. 696, Ohio
Oil Company well, Bearstate no. 23, Belridge field, Kern County, California, McKittrick quadrangle, sec. 30, T. 28 S., R. 21 E., M.D.M., depth 2,266-2,286 fest. Kleinpell records it from the lower Mohnian to the lower Delmontian of the Miocene of California. We have no typical material. One specimen in our collection, from the Pliocene in the Cañada de Aliso, Ventura County, California, in gray siltstone 3,200 feet stratigraphically above the base of the first Pico sandstone, 2.4 miles S. $88^{\circ} \mathrm{E}$. of $\mathrm{La}$ Crosse Junction, is probably referable to it.

This species is apparently much smaller than the others described from the Miocene of California.

\section{Buliminella henryana Cushman and Klrinpell}

Plate 17, figure 5

Buliminella henryana Cushman and Kleinpell, Cushman Lab. Foram. Research Contr., vol. 10, p. 4, pl. 1, figs. 11a, b, 1934.

Kleinpell, Miocene stratigraphy of California, p. 250, pl. 20, figs. 8, 15, 16, Tulsa, 1938.

Test comparatively short, about twice as long as broad, the periphery somewhat lobulate; chambers distinct, four or five in the adult whorl, of rather uniform shape but increasing gradually in size and length as added; sutures distinct, very slightly depressed, somewhat limbate, especially toward the upper end; wall smooth, finely perforate; aperture an elongate; comma-shaped opening in a depression of the somewhat obliq iely truncated apertural face. Length $0.40 \mathrm{~mm}$; breadth $0.20 \mathrm{~mm}$.-Cushman and Kleinpell.

The species was described from the Miocene Monterey shale, Henry Ranch, Graves Creek, San Luis Obispo County, California. It is not known elsewhore.

The authors describe this species as resembling Buliminella californica Cushman but having a shorter, stouter test, and more inflated chambers.

\section{Buliminella bassendorfensis Cushman and Parker}

\section{Plate 17, figure 6}

Buliminella bassendorfensis Cushman and Parker, Cushman Lab. Foram. Research Contr., vol. 13, pp. 40, 53, pl. 4, figs. 13a, b, 1937; idem, p. 53.

Test elongate, fusiform, $21 / 2$ times as long as broad. consisting of about 5 whorls; chambers distinct, about 4 to a whorl, somewhat inflated; sutures distinct, depressed, somewhat limbate; wall smooth, fine ${ }^{1} y$ perforate; aperture at the top of the apertural face, which is small and rounded. Length $0.55 \mathrm{~mm}$., diameter $0.20 \mathrm{~mm}$.

The types are from the Miocene, south side of Alsea Bay, Lincoln County, Oregon (Loc. A. 198, see Schenck. Univ. California, Dept. Geol. Sci. Pub., Bull., vol. 18, no. 1 , p. 33, Nov. 30, 1928). The species is not known elsewhere.

This species is similar to Buliminella subfusiformis 
Cushman but has longer, less inflated chambers. It is more fusiform, with more inflated chambers than $B$. californica Cushman.

\section{Buliminella semihispida Kleinpell}

Plate 17 , figure 7

Buliminella semihispida Kleinpell, Miocene stratigraphy of California, p. 250, pl. 20, figs. 8, 15, 16, Tulsa, 1938.

Test short, broad, composed of about two whorls, the lastformed whorl of many distinct chambers; sutures distinct, slightly depressed; wall finely perforate, lower half of test covered with numerous short, thick, blunt spines; aperture at base of slightly concave face of ultimate chamber. Length, $0.75 \mathrm{~mm}$.; breadth, $0.50 \mathrm{~mm}$.-Kleinpell.

The species was described from the Miocene Monterey shale (sample N-49), near Naples, Santa Barbara County, California. We have no typical material.

\section{Buliminella multicamera Cushman and Parker}

Plate 17 , figures 8,9

Buliminella multicamera Cushman and Parker, Cushman Lab. Foram Research Contr., vol. 14, p. 60 , pl. 10, figs. 11, 12, 1938.

Test elongate, about $2 \frac{1}{2}$ times as long as broad, tapering, greatest width toward the apertural end which is truncate, initial end rounded; chambers numerous, very elongate, with a slight tendency toward becoming irregularly biserial, little, if at all, inflated; sutures distinct, limbate, not depressed; wall smooth, very finely perforate; aperture rounded, slightly elongate, in a rather deep depression in the center of the base of the apertural face which is somewhat flaring and extends well down the side of the test. Length 0.40 to $0.45 \mathrm{~mm}$., diameter 0.15 to $0.18 \mathrm{~mm}$.

The types are from the Pliocene of Castel Arquato, Italy. We have specimens of Recent age from the Mediterranean off Port Said, from the Red Sea, and from Madagascar. They do not show the biserial chambers but are otherwise similar.

The species has narrower chambers than Buliminella madagascariensis (D'Orbigny), and is less fusiform, with a broader apertural face, than $B$. elegantissima (D'Orbigny).

\section{Buliminella elegantissima (D'Orbigny) Cushman}

\section{Plate 17, figures $10-12$}

Bulimina elegantissima D'Orbigny, Voyage dans l'Amérique méridionale, vol. 5 , pt. 5 , Foraminifères, p. 51 , pl. 7 , figs. $13,14,1839$.

Williamson, Recent Foraminifera of Great Britain, p. 64, p1. 5, figs. 134, 135, 1858.

Schlumberger, Feuille jeunes nat., vol. 12, pl. 1, fig. 14, 1881.

H. B. Brady, Challenger Rept., Zoology, vol. 9; p. 402, pl. 50, figs. 20-22, 1884.
Reade, Geol. Mag., dec. 4, vol. 7, pp. 100, 101 (lists), p1. 5, fig. $6,1900$.

Sidebottom, Manchester Lit. Philos. Soc. Mem. and Prcc., vol. 49, no. 5, p. 11, pl. 2, fig. 6, 1905.

Bagg, U. S. Geol. Survey Bull. 513, p. 38, pl. 9, figs. 8a-c, 1912.

Heron-Allen and Earland, Discovery Repts., vol. 4, p. 3:1, pl. 8, figs. 35-37, 1932.

Buliminella elegantissima Cushman, U. S. Nat. Mus. Proc., vol. 56, p. 606, 1919; idem, Bull. 100, vol. 4, p. 168, 1921; Cushman Lab. Foram. Research Contr., vol. 1, pt. 2, p. 40, pl. 6 , figs. 5a, b, 1925.

Cushman and Wickenden, U. S. Nat. Mus. Proc., vol. 75, art. 9, p. 8, pl. 3, figs. 12a, b, 1929.

Cushman and Kellett, idem, vol. 75, art. 25, p. 6, pl. 3 figs. $1-3,1929$.

Cushman, Stewart and Stewart, San Diego Soc. Nat. History Trans., vol. 6, p. 64, pl. 4, figs. 7a, b, 1930.

Cushman, Florida Geol. Survey Bull. 4, p. 42, pl. 8, figs. 2, 3, 1930 .

Cole, idem, Bull. 6, p. 39, pl. 2, fig. 8, 1931.

Cushman and Parker, U. S. Nat. Mus. Proc., vol. 80, art. 3, p. 13, pl. 3, figs. 12, 13, 1931.

Howe and Wallace, Louisiana Dept. Cons. Geol. Bull. 2, p. .61, pl. 11, fig. 3, 1932.

Cushman and Ponton, Florida Geol. Survey Bull. 9, p. 75, 1932.

Cushman, Cushman Lab. Foram. Research Special Pub. 4, pl. 22, fig. 3, 1933; idem, Special Pub. 5, pl. 27, figs. 4a, b, 1933.

Cushman and Cahill, U. S. Geol. Survey Prof. Paper 175-A, p. 23, pl. 7, figs. 13, 14, 1933.

Barbat and Johnson, Jour. Paleontology, vol. 8, p. 12 pl. 1 , figs. 12, 13, 1934.

Bermúdez, Soc. cubana hist. nat. Mem., vol. 9, p. 193, 1935. Cushman, Geol. Soc. America Bull., vol. 47, p. 431, 1936.

Chapman and Parr, Australasian Antarctic Exped., ser. C, vol. 1, pt. 2, p. 79, 1937.

Kleinpell, Miocene stratigraphy of California, p. 249, pl. 16, fig. 10, Tulsa, 1938.

Cushman and Henbest, U. S. Geol. Survey Prof. Paper 196-A, pl. 9, fig. 20, 1940.

Cushman and Parker, Cushman Lab. Foram. Research Cont"., vol. 16, p. 21,1940 .

Hanna and Hertlein, State of Calif., Div. of Mines Bull. 118, p. 178, fig. 67 [plate], figs. 5-7, 1941.

Macfadyen, Geol. Mag., vol. 79, p. 135, 1942.

Cushman, Cushman Lab. Foram. Research Special Pub. 12, p. 27 , p1. 3, figs. 43, 44, 1944; idem, Contr., vol. 21, p. 7 , pl. 2, fig. 6, 1945.

Buliminella cf. $B$. elegantissima Cushman and Ponton, Cushman Lab. Foram. Research Contr., vol. 8, p. 67, pl. 8, figs. 20, 21, 1932.

Cushman and McGlamery, U. S. Geol. Survey Prof. Papar 189-D, p. 107, pl. 25, fig. 15, 1938.

Palmer, Soc. cubana hist. nat. Mem., vol. 14, p. 294, 1940.

Test small, fusiform, consisting of 2 or 3 whorls, initial end bluntly pointed in the megalospheric form, much sharper in the microspheric; chambers distinct, 7 to 10 in the final whorl, narrow, slightly inflated; sutures dis- 
tinct, slightly depressed, somewhat curved; wall smooth, finely perforate; aperture elongate, narrow, placed near the top of the apertural face, which is narrow, somewhat depressed, and flaring, extending well down the side of the test. Length of specimens from off Payta, Peru, 0.23 to $0.40 \mathrm{~mm}$.; diameter 0.13 to $0.18 \mathrm{~mm}$.

The species was described from Recent material off Payta, Peru; Cobija in Bolivia; and off Valparaiso, Chile. It is a very widely ranging form, both vertically and horizontally. It is known from the Eocene Wilcox group of Alabama and Jackson group of Texas and Louisiana; the Oligocene Meson formation of Mexico, and Oligocene beds at Choctaw Bluff, Alabama; and the Miocene deposits of the Coastal Plain of the eastern United States. It was recorded by Kleinpell from the Whiterock Bluff shale (uppermost part at type locality), Monterey shale at the type locality, basal Margarita formation in San Luis Obispo County, and sample E92, Reliz Canyon, Monterey County, California. It is known from the Pliocene San Pedro formation and beds in Humboldt County, California; the Pliocene of Florida; Pleistocene beds in England and Florida; and the Recent seas along the east and west coasts of South America, Falkland Islands, Dry Tortugas, Antigua, British Isles, Mediterranean, Philippine Islands, and off British Columbia. It is also recorded from the late Tertiary of the Georges Bank canyons in the western Atlantic Ocean.

This species may be distinguished by its small, fusiform test and numerous, narrow chambers.

\section{Buliminella elegantissima (D'Orbigny) Cushman var. cochlea Wiesner}

Plate 17, figure 13

Buliminella elegantissima (D'Orbigny) .var. cochlea Wiesner, Deutsche Sïdpolar-Exped., vol. 20, Zoology, p. 124, pl. 19, fig. 237, 1929.

Wiesner describes this variety as having an open corkscrew type of coiling.

The types are from sta. 56, 385 meters, Lat. $66^{\circ} 2^{\prime}$ S., Long. $89^{\circ} 38^{\prime} \mathrm{W}$.

It seems very possible that this variety represents the microspheric form of Buliminella elegantissima (D'Orbigny) but as we have no specimens to verify this point the two forms have not been combined.

\section{Buliminella elegans (D’Orbigny) Cushman and Parker}

Plate 17 , figure 14

Bulimina elegans D'Orbigny, Annales sci. nat., vol. 7, p. 270, no. 10, Modèles, no. 9, 1826.

Cushman and Parker, Cushman Lab. Foram. Research Contr., vol. 14 , p. 93 , p1. 16 , fig. $13,1938$.

The type of the species is from the Recent, Rimini, Italy. It probably belongs to the genus Buliminella, as a model has the characteristic apertural face and spiral suture of that genus. The details are too indefinite, however, for any known material to be definitely referred to it.

\section{Buliminella punctata (D'Orbigny) Cushman and Parker}

Plate 17, figure 31

Bulimina punctata D’Orbigny, Annales sci. nat., vol, 7, p. 270 , no. 11, 1826.

Fornasini, Accad. sci. Ist. Bologna Mem., ser. 5, vol. 9, p. 374, text fig. 6, 1901.

Cushman and Parker, Cushman Lab. Foram. Research Contr., vol. 14, p. 93, pl. 16, fig. 14, 1938.

The type is from the Recent, Rimini, Italy. We have no material referable to the species but it seems probable that it should be placed in this genus.

\section{Buliminella madagascariensis (D'Orbigny) Cushman and Parker}

Plate 17 , figures $15-17$

Bulimina madagascariensis D'Orbigny, Annales sci. nat., vol. 7, p. 270 , no. 17,1826 .

Fornasini, Accad. sci. Ist. Bologna Mem., ser. 6, vol. 5, p. 47, pl. 1, figs. 13, 13a, 1908.

Cushman and Parker, Cushman Lab. Foram. Research Contr., vol. 14, p. 94, pl. 16, figs. 19, 20, 1938.

?Bulimina elegantissima D'Orbigny var. fusiformis Sidebottom (not Williamson), Royal Micr. Soc. Jour., 1918, p. 23, pl. 3, figs. 8-10.

Bulimina elegantissima Heron-Allen and Earland (not D'Orbigny), Linnean Soc. London Jour., Zoology, vol. 35, p. 620, pl. 35, figs. $23,24,1924$.

Bulimina seminuda Heron-Allen and Earland (not Terquem), Discovery Repts., vol. 4, p. 351, pl. 8, figs. 38-41, 1932.

Buliminella apiculata (Chapman) var. hebetata Cushman and Parker, Cushman Lab. Foram. Research Contr., vol. 13, p. 40 , pl. 4 , figs. $11,12,1937$.'

Test composed of 2 or 3 whorls, small, tapering in the microspheric form, almost cylindrical in the megalospheric; chambers fairly numerous, 6 to 8 in the adult whorl, distinct: sutures distinct, somewhat limbate, flush with the surface; wall smooth, polished, finely perforate; aperture rounded, with a tooth-like process extending up over it, near the top of the apertural face, which is convex around the outside and depressed towart the aperture. Length of figured specimens 0.33 to $0.55 \mathrm{~mm}$., diameter 0.20 to $0.25 \mathrm{~mm}$.

The type is from the Recent of Madagascar. The species occurs in the Oligocene of Australia, and in the Byram marl, Byram, Mississippi, and in the Recent seas near Australia, New Zealand, and Madagasçar. One very similar specimen was found off the coast of Brazil. It has been recorded also from off the Falkland Islands.

It has been found that the Recent form: are identical with the fossil forms, and for that reason D'Orbigny's 
name must be used. The species is very variable in shape, but the number of chambers to a whorl, their size, and shape all remain the same. The peculiar tooth-like projection over the aperture is an important characteristic. The chambers are broader than those of Buliminella obtusata Cushman, and the apertural face does not extend so far down the side of the test as in that species. The test is less fusiform than that of $B$. clegantissima D'Orbigny, the apertural face is more flattened, and the chambers are broader.

\section{Buliminella spinigera Cushman}

Plate 17, figures 18,19

Buliminella spinigera Cushman, U. S. Nat. Mus. Bull. 104, pt. 3, p. 113, pl. 23, figs. $1-4,1922$.

Test large, fusiform, the initial end terminated by a long, stout spine, apertural end rounded; chambers indistinct, 6 or 7 in the adult whorl; sutures indistinct, flush with the surface, limbate; wall very smooth, highly polished, very finely perforate; aperture near the top of the broad, flat apertural face, with a flat plate-like tooth extending up over it. Length (including spine) 0.43 to $0.80 \mathrm{~mm}$., diameter 0.23 to $0.43 \mathrm{~mm}$.

The types are from Albatross sta. D2677, in 478 fathoms, off the coast of North Carolina. The species is known only from this locality and one other Albatross station in this region.

This species is somewhat larger than Buliminella madagascariensis (D'Orbigny) var. spicata Cushman and Parker, has less distinct, somewhat fewer chambers, and a much more highly polished wall.

\section{Buliminella milletti Cushman}

Plate 17, figures 20, 21

Buliminella milletti Cushman, Cushman Lab. Foram. Research Contr., vol. 9, p. 78, pl. 8, figs. 5, 6, 1933 ; U. S. Nat. Mus. Bull. 161, pt. 3, p. 7, pl. 3, figs. 1-4, 1942.

Bulimina eleganissima var. Sidebottom, Manchester Lit. Philos. Soc. Mem. and Proc., vol. 49, no. 5, p. 11, pl. 2, figs. 7-12; pl. 3, figs. 1, 2, 1905.

Test small, tapering, initial end bluntly rounded, increasing in diameter toward the apertural end, consisting of 2 or 3 whorls; chambers distinct, 4 or more making up the last whorl, slightly inflated; sutures distinct, flush with the surface or slightly depressed, especially the spiral suture, slightly limbate; wall smooth, very finely perforate; aperture a semi-elliptical opening at the base of the apertural face which is broadly rounded, with slight ridges running into the depressed area at the center. Length $0.30 \mathrm{~mm}$., diameter 0.15 to $0.20 \mathrm{~mm}$.

The types are from Mokaujar Anchorage, Fiji. The species occurs at various localities in the Fiji Islands; Pago Pago Harbor, Samoa; Zanzibar; Montego Bay,
Jamaica; the Dry Tortugas; and St. Johns, Antigua. It has been reported by Sidebottom from the Island of Delos.

The species is larger, more tapering, and has fewewhorls than Bulininella parallela Cushman and Parker.

\section{Buliminella parallela Cushman and Parker}

Plate 17 , figure 22

Buliminella parallela Cushman and Parker, U. S. Nat Mus. Proc., vol. 80, art. 3, p. 13, pl. 3, figs. 15a-c, 1931.

Bermúdez, Soc. cubana hist. nat. Mem., vol. 9, p. 193, 1935. ? Bulinina elegantissina D'Orbigny var. compressa Millett (nct Bailey), Royal Micr. Soc., Jour., 1900, p. 277, pl. 2, fig. 5. ?Bulimina elegantissima Millett (not D'Orbigny), idem, p. 276 pl. 2 , fig. 4.

Test elongate, slender, the sides usually nearly parallet for most of their length, both ends broadly rounded, nearly circular in transverse section, consisting of $3 \mathrm{o}^{\circ}$ more whorls; chambers distinct, 5 or more in each whorl, not much, if at all, inflated; sutures distinct, the spiral suture somewhat irregularly crenulate, slightly limbate, flush with the surface; wall smooth, polished, very finely perforate; aperture rounded, with very slightly raised costae running in toward it on the surrounding depressed area of the apertural face, which is small and rounded. Length $0.25 \mathrm{~mm}$., diameter 0.08 to $0.10 \mathrm{~mm}$.

The types are from the Recent deposits off Ilha $\mathrm{Pa}$ queta, Rio de Janeiro Harbor, Brazil. The species occurs in the Recent seas near Dry Tortugas; St. Johns, Antigua; off the north coast of Cuba; at two localities in Rio de Janeiro Harbor; and at one locality in the Falkland Islands. Millett's specimens from the Malay Archipelagis are questionably placed here.

The species differs from Buliminella milletti Cushman in its more slender, parallel sided test, greater number of whorls, and smaller size.

\section{Genus BULIMINOIDES Cushman, 1911}

Buliminoides Cushman, U. S. Nat. Mus. Bull. 71, pt. 2, p. 90 , 1911; Smithsonian Misc. Coll., vol. 77, no. 4, p. 36, 1925; Cushman Lab. Foram. Research Contr., vol. 3, pt. 1, p. 65, 1927; idem, Special Pub. 1, p. 246, 1928; idem, Specia1 Pub. 4, p. 217, 1933; U. S. Nat. Mus. Bull. 161, pt. 3, p. $\varepsilon_{\text {, }}$ 1942.

Bulimina (part) of authors.

\section{Genotype Bulimina williamsoniana H. B. Brady.}

Test subcylindrical, elongate, spirally twisted; chambers in a spiral, several chambers in a whorl, largely obscured by the heavy longitudinal costae; wall calcareous, perforate; aperture terminal, central, circular, in a depression at the end of the test. Recent.

A single species is known, rather widely distributed in the Indo-Pacific and rare in the Gulf of Mexicc., It is not known as a fossil. 
Buliminoides williamsoniana (H. B. Brady) Cushman

Plate 17, figures 23, 24

Bulimina williamsoniana H. B. Brady, Quart. Jour. Micr. Sci., vol. 21, p. 56, 1881; Challenger Rept., Zoology, vol. 9, p. 408, pl. 51, figs. 16, 17, 1884.

Millett, Royal Micr. Soc. Jour., 1900, p. 279, pl. 2, fig. 8.

Bagg, U. S. Nat. Mus. Proc., vol. 34, p. 136, 1908.

Heron-Allen and Earland, Zool. Soc. London Trans., vol. 20, p. 641, 1915; British Antarctic Exped., Zoology, vol. 6, p. $130,1922$.

Buliminoides williamsoniana Cushman, U. S. Nat. Mus. Bull. 71, pt. 2, p. 90, text fig. 144, 1911; Carnegie Inst. Washington Pub. 311, p. 31, pl. 3, fig. 7, 1922; U. S. Nat. Mus. Bull. 104, pt. 3, p. 113, 1922; Cushman Lab. Foram. Research Special Pub. 4, pl. 22, fig. 5, 1933; idem, Special Pub. 5, pl. 27, figs. 6, 7, 1933.

Bermúdez, Soc. cubana hist. nat. Mem., vol. 9, p. 194, 1935.

Cushman and Parker, Cushman Lab. Foram. Research Contr., vol. 16, p. 22, 1940.

Cushman, U. S. Nat. Mus. Bull. 161, pt. 3, p. 8, pl. 3, figs. $7-9,1942$.

Test elongate, subcylindrical, composed of numerous chambers which are not distinct when viewed from the surface; wall ornamented with longitudinal costae, usually somewhat spirally twisted, running from the initial end to the apertural face and across it to the aperture itself, making a radiate pattern; aperture small, circular, terminal, in the center of the depressed apertural face. Length up to $0.80 \mathrm{~mm}$., diameter 0.18 to $0.22 \mathrm{~mm}$.

This is mainly an Indo-Pacific species but occurs rarely in the western tropical Atlantic. Indo-Pacific records are as follows: From the Challenger stations given by Brady, "Port Stephens and Port Jackson, New South Wales, 2-10 fathoms; off Levuka, Fiji, 12 fathoms; off the New Hebrides, 125 fathoms; Torres Strait, 155 fathoms; Humboldt Bay, Papua, 37 fathoms; Nares Harbor, Admiralty Islands, 17 fathoms." Millett records it from two localities in the Malay region, and Bagg from a single Albatross station, H4694, in 865 fathoms, and Cushman from H2922, in 268 fathoms, both off the Hawaiian Islands. Heron-Allen and Earland record it from the Kerimba Archipelago, off the eastern coast of Africa. Cushman records it from off Samoa in 9 to 50 fathoms. Heron-Allen and Earland record it also from "Spirits Bay, near North Cape, New Zealand, in 11-20 fathoms," and " 7 miles $E$. of North Cape, New Zealand, in 70 fathoms". We have a very typical specimen from $\mathrm{Al}$ batross sta. D5230, 118 fathoms, between Bohol and Leyte, Philippines.

In the Atlantic it has been recorded by Cushman from off the Dry Tortugas, Florida, and by Bermúdez from off the north coast of Cuba.

There are a number of other species that show this same general distribution in the Atlantic and Pacific.

Yabe and Asano have described a new species from the Pliocene of Java as Buliminoides bantamensis (Tohoku
Imp. Univ. Sci. Repts., 2d ser., Geol., vol. 19, p. 121, pl. 17 , fig. 20, 1937) but no specimens have been available for comparison.

\section{Genus UNGULATELLA Cushman, 1931}

Ungulatella Cushman, Cushman Lab. Foram. Research Contr., vol. 7, p. 81, 1931; idem, Special Pub. 4, p. 217, 1933; idem, Contr., vol. 10, p. 102, 1934.

Genotype, Ungulatella pacifica Cushmar.

Test with the early portion conical and probably consisting of a series of spirally coiled chambers, later chambers uniserial, forming an elongate, subcylindrical test, or somewhat compressed toward the apertural end; wall calcareous, rather coarsely perforate; aperture a loopshaped opening in the flattened or som:what concave terminal face. Recent, Pacific.

This genus is probably derived from Buliminella or Buliminoides by the development of uniserial chambers in the adult stage. From what is known of the species it probably has developed in very recent times in the IndoPacific region. No fossil forms are known.

\section{Ungulatella pacifica Cushman}

Plate 17 , figures 25,26

Ungulatella pacifica Cushman, Cushman Lab. Foram. Research Contr., vol. 7, p. 82, pl. 10, figs. 11, 12, 1931 ; idem, Special Pub. 4, pl. 22, fig. 6, 1933; idem, Special Pub. 5, pl. 27, figs. 8a-c, 1933; idem, Contr., vol. 10, p. 102, pl. 13, figs. 3, 4, 1934.

Test elongate, the early portion abruptly tapering, later portion in front view with the sides nearly parallel, in side view somewhat progressively compressed toward the apertural end; chambers in the adult uniserial, low and broad, becoming somewhat oblique in the apertural face, flattened or slightly concave; sutures distinct, very slightly limbate, flush with the surface; wall with numerous, comparatively large and distinct perforations except on the apertural face, which is smooth; aperture somewhat comma-shaped, at or near the ventral side of the apertural face. Length $0.35 \mathrm{~mm}$., diameter 0.12 to $0.14 \mathrm{~mm}$., thickness at the apertural end 0.08 to $0.10 \mathrm{~mm}$.

The types are from shallow water off the Island of Rangiroa in the south Pacific, where it is fairly common. The shape of the early portion and the aperture show that it is probably derived from the Buliminella group.

\section{Ungulatella peregrina Cushman}

Plate 17, figure 27

Ungulatella peregrina Cushman, Cushman Lab. Foram. Research Contr., vol. 10, p. 102, pl. 13, figs. 5a-c, 1934.

Test short and broad, much compressed, initial end with a large, stout spine, remainder of test composed of a spirally coiled tube, the last 1 or 2 whorls tending to 
show partial divisions into half coils, attached face much flattened and oblique, concave in the middle, with an outer flange-like rim; suture marked by a raised, sharp ridge, representing the peripheral flange at that stage; wall roughened on the outer side of the coils, very smooth and polished on the apertural face; aperture apparently opening on the open umbilical area. Length $0.20 \mathrm{~mm}$., diameter $0.15 \mathrm{~mm}$.

The types of this species are from off the Island of Rangiroa in the south Pacific, and it has not been recorded elsewhere. The species is small and scale-like, and with its prominent initial spine and raised ridges is easily distinguished.

\section{Ungulatella conoides Cushman}

Plate 17, figures 28, 29

Ungulatella conoides Cushman, Cushman Lab. Foram. Research Contr., vol. 10, p. 102, pl. 13, figs. 6, 7, 1934.

Test small, short and broad, conical, initial end pointed, with a large, stout, solid spine, greatest breadth of test at the apertural end which is somewhat expanded into a flaring lip or flange, sides of the test uneven in length, making the flattened, apertural end at a decided angle to the elongate axis; sutures mostly indistinct; wall very closely perforate, or even slightly papillate, the pores often partially arranged in lines, giving a peculiar ornate appearance to the surface; apertural face smooth and polished, slightly concave, especially in the middle, which has a circular depression; last-formed whorl often partially subdivided into two half coils. Length $0.15 \mathrm{~mm}$., diameter 0.15 to $0.20 \mathrm{~mm}$.

The types of this species are from off the Island of Rangiroa in the south Pacific. It has not been recorded elsewhere.

\section{Ungulatella capistra Cushman}

\section{Plate 17 , figure 30}

Ungulatella capistra Cushman, Cushman Lab. Foram. Research Contr., vol. 10, p. 103, pl. 13, figs. 8a-c, 1934.

Test with the main portion a broad cone, but with a thin, high flange rising even above the initial end which is smooth and rounded, the coiled chamber seeming to be partially divided toward the end into portions half a coil in length, apertural face smooth, the central portion concave; wall coarsely perforate on the exterior of the sides. Length, including flange, $0.25 \mathrm{~mm}$., diameter, including flange, $0.30 \mathrm{~mm}$.

The types are from off the Island of Rangiroa in the south Pacific and the species has not been recorded elsewhere.

This is a very peculiar form with the flange very highly developed.

\section{Genus ROBERTINA D'Orbigny, 1846}

Robertina D'Orbigny, Foraminifères fossiles du bassin tertiaire de. Vienne, p. 202, 1846.

Cushman, Cushman Lab. Foram. Research Contr., vol. 3, p 65, 1927 ; idem, Special Pub. 1, p. 246, 1928; idem, Special Pub. 4, p. 218, 1933.

Cushman and Parker, idem, Contr., vol. 12, p. 92, 1936.

Glaessner, Studies in micropaleontology, vol. 1, fasc. 1, p. 23. 1937.

Cushman, U. S. Nat. Mus. Bull. 161, pt. 3, p. 9, 1942.

Bulimina (part) of authors

Cassidulina (part) of authors.

Genotype, Robertina arctica D'Orbigny, 1846.

Test an elongate, close spiral, the spiral suture distinct; chambers several in each whorl, in microspheric young like Buliminella, later forming a double series; wall calcareous, finely perforate; apertures 2 in number, the primary one elongate, loop-shaped, at basal margin of the chamber, extending into the apertural face, the secondary one at the basal margin extending between the last-formec chambers of the upper and lower series, usually smaller than the primary one. Eocene to Recent.

The genus is variable, even within the limits of $\bar{c}$ species. The best criteria for establishing a species are the position and angle of the primary aperture, the number of chambers to a whorl, and their shape. The genus has developed along two main lines from the Eocene forms, one with few chambers, compact and close coilec' with more or less straight sides; the second with many chambers, and a more open coil, which is much more twisted.

This genus has been placed by Glaessner close to Ceratobulimina in a new family Ceratobuliminidae. Its early stages, however, are very similar to Buliminella anc' it seems to have developed from that genus. The primary opening, as described here, has been questioned by Glaessner, who describes it as a fold extending down to the previous chamber. A study of Robertina arctica D'Orbigny and other species, however, seems to show that this opening is a definite aperture into the chamber and that the species is related to Buliminella.

\section{Robertina wilcoxensis Cushman and Ponton}

\section{Plate 18 , figure 1}

Robertina wilcoxensis Cushman and Ponton, Cushman Lab. Foram. Research Contr., vol. 8, p. 66, pl. 8, figs. 19a, b, 1932.

Cushman and Parker, idem, Contr., vol. 12, p. 96, pl. 16, figs 13a, b, 1936.

Cushman and Garrett, idem, Contr., vol. 15, p. 82, pl. 14, fig. 16, 1939.

Cushman and Todd, idem, Contr., vol. 18, p. 36, pl. 6, figs. 22, 23, 1942.

Cushman, idem, Contr., vol. 20, p. 42, pl. 7, fig. 9, 1944; Am Jour. Sci., vol. 242, p. 11, pl. 1 fig. 17, 1944. 
Test about twice as long as broad, slightly compressed, fusiform, greatest breadth slightly above the middle, initial end sharply pointed and evenly tapering, apertural end narrowed; chambers slightly inflated, about 5 pairs in the adult whorl, increasing rather rapidly but evenly in size as added; sutures slightly, if at all, depressed, very slightly limbate; wall smooth, very finely perforate; aperture narrow, running about one-third of the way across the apertural face, about in the vertical axis of the test, secondary aperture slight. Length 0.30 to $0.40 \mathrm{~mm}$., diameter 0.15 to $0.18 \mathrm{~mm}$.

The types of this species are from the Eocene Wilcox group in a railroad cut 1 mile north of Ozark, Alabama. It occurs also at Woods Bluff, Clarke County, Alabama, and in the Paleocene, Naheola formation of Alabama.

This species is smaller than Robertina angusta (Cushman) and is more pointed at the ends. It probably represents the ancestral form of that species. This form and $R$. ovigera (Terquem) furnish the oldest records of the genus.

\section{Robertina mcguirti Howe}

Plate 18, figure 2

Robertina mcguirti Howe, Louisiana Dept. Cons. Geol. Bull. 14, p. 82, pl. 8, figs. 23, 24, 1939.

Test elongate, narrow, apparently composed of about two whorls, but only a very small portion of the initial whorl visible; chambers numerous, distinct; sutures distinct, slightly limbate, in some views faintly depressed; wall smooth; aperture a high slit in a depression of the apertural face extending upward from the base of the chamber. Length $0.26 \mathrm{~mm}$., breadth $0.11 \mathrm{~mm}$.- Howe.

The types are from the Eocene Cook Mountain formation, left bank of Saline Bayou beneath the Louisiana and Arkansas Railroad bridge at St. Maurice, sec. 15, T. 9 N., R. 6 W., L.M., Winn Parish, Louisiana. We have no typical material.

\section{Robertina plummerae Cushman and Parker}

\section{Plate 18, figure 3}

Robertina plummerae Cushman and Parker, Cushman Lab. Foram. Research Contr., vol. 14, p. 73, pl. 13, figs. 1a, b, 1938.

Howe, Louisiana Dept. Cons. Geol. Bull. 14, p. 82, pl. 8, figs. 43, 44, 1939.

Test almost $21 / 2$ times as long as broad, greatest breadth at the middle, initial end subacute, apertural end tapering, rounded; chambers, 6 pairs in the final whorl, increasing gradually in size as added; sutures distinct, slightly depressed; wall smooth; aperture elliptical, short, supplementary aperture almost as large. Length 0.46 to $0.66 \mathrm{~mm}$., diameter 0.20 to $0.24 \mathrm{~mm}$.

The types are from the Eocene Crockett formation of the Claiborne group, Shipp's Ford on the Colorado
River, 33/4 miles due east of Smithville, Rastrop County, Texas. Howe records it from the Eocene Cook Mountain formation in Louisiana.

This species differs from Robertina wilcoxensis Cushman and Ponton in being longer, more twisted, less ovate in shape, and in having a larger secondary aperture.

\section{Robertina ovigera (Terquem) Cushman and Parker}

\author{
Plate 18, figure 4 .
}

Bulimina ovigera Terquem (part), Soc. Géol. France Mém., ser. 3, vol. 2, p. 108, pl. 11(19), figs. 17, 20 (not figs. 18, 19), 1882.

Robertina ovigera Cushman and Parker, Cushman Lab. Foram. Research Contr., vol. 12, p. 98, pl. 16, figs. 15a, b, 1936.

Cushman and Todd, idem, Contr., vol. 21, p. 16, pl. 4, fig. 4, 1945.

Test nearly twice as long as broad, greatest breadth toward the apertural end which is broadly rounded, initial end subacute, rapidly tapering; chambers somewhat inflated, about 5 pairs in the adult whorl, increasing rather rapidly but regularly in size as added; sutures distinct, slightly depressed; not limbate; wall smooth, finely perforate; aperture elongate, narrow, slightly curved, running less than half way into the apertural face; supplementary aperture small, low. Length 0.29 to $0.34 \mathrm{~mm}$., diameter 0.15 to $0.20 \mathrm{~mm}$.

Terquem describes this species as rare in the Eocene calcaire grossier of the Paris Basin, at Vaudancourt and Septeuil. We have specimens from Grignon, Mouchy, Fontenay, and St. Félice in the Paris Basin.

This species is very variable, but the general characters seem to remain the same. It is smaller than the other known species.

\section{Robertina washingtonensis Brek}

Plate 30 , figures 3,4

Robertina washingtonensis Beck, Jour. Paleontology, vol. 17, p. 604, pl. 107, figs. 17, 19, 24, 1943.

Test nearly three times as long as broad, initial end sharply pointed, evenly tapering, fusiform, greatest breadth slightly above middle; chambers slightly inflated; 5 pairs in ad :1t whorl, increasing in size as added; sutures moderately depressed; wall smooth, very finely perforate; aperture narrow, comma-shaped, extending about two-thirds of way across apertural face, slightly oblique to vertical axis of test, supplementary aperture indistinct. Length, $0.57 \mathrm{~mm}$.; breadth, $0.20 \mathrm{~mm}$.

The general shape and chamber arrangemert of this species is similar to $R$. wilcoxensis Cushman and Ponton (1932, p. 66, pl. 8, figs. 19a, b) except that it is narrower. Its aperture, however, is more than twice as long, and is curved, and oblique to the long axis of the test.-Beck.

The types of this species are from the Eocene of Cowlitz River, Lewis County, Washingten. 


\section{Robertina germanica Cushman and Parker}

Plate 18, figure 5

Robertina germanica Cushman and Parker, Cushman Lab. Foram. Research Contr., vol. 14, p. 73, pl. 13, figs. 2a, b, $193 \dot{8}$.

Robertina angusta Cushman and Parker (not Cushman) (part), Cushman Lab. Foram. Research Contr., vol. 12, p. 96, 1936.

Test twice as long as broad, initial end bluntly pointed, apertural end flattened; chambers, 7 to 8 pairs in the final whorl, slowly increasing in size as added; sutures distinct, slightly limbate, not depressed; wall smooth; aperture narrow, elliptical, reaching about halfway into the apertural face, supplementary aperture deeply cut, narrow. Length 0.46 to $0.83 \mathrm{~mm}$, diameter 0.22 to 0.40 inm.

The types are from the lower Oligocene of Calbe, near Magdeburg, 'Germany. The species is found also in the lower Oligocene of Brundhorst, near Bünde and Weinkeine near Alzey, Mainz Basin, Germany.

This species resembles Robertina angusta (Cushman) but differs from it in its greater length in proportion to its breadth, more pointed initial end, and its slightly more twisted test.

\section{Robertina angusta (Cushman) Cushman and Parker}

Plate 18, figure 6

Buliminella subteres (H. B. Brady) var. angusta Cushman, U. S. Geol. Survey Prof. Paper 129-F, p. 127, pl. 29, figs. 8, 9, 1922 ; idem, Prof. Paper 133, p. 24, 1923.

Howe, Jour. Paleontology, vol. 2, p. 174 (list), 1928.

Cushman, Cushman Lab. Foram. Research Contr., vol. 5, p. 42, pl. 7, fig. 4, 1929.

Cushman and Ponton, Florida Geol. Survey Bull. 9, p. 76, pl. 11, figs. 9a, b, 1932.

Robertina angusta Cushman and Parker, Cushman Lab. Foram. Research Contr., vol. 12, p. 96, pl. 16, figs. 11a, b, 1936.

Cushman and McGlamery, U. S. Geol. Survey Prof. Paper 197-B, p. 70, pl. 5, fig. 15, 1942.

Cushman and Frizzell, Cushman Lab. Foram. Research Contr., vol. 19 , p. 85 , pl. 14 , fig. $15,1943$.

Test usually more than twice as long as broad, irregularly fusiform, initial end somewhat more pointed than the apertural; chambers, about 7 pairs in the final whorl, increasing rather slowly in size as added, all of one series meeting in the median line on the ventral side; sutures distinct, limbate, not depressed; wall smooth; aperture elongate, elliptical, almost closed near the base, more open toward the inner end, which reaches more than halfway across the apertural face; supplementary aperture very small and low. Length 0.32 to $0.60 \mathrm{~mm}$, diameter 0.22 to $0.34 \mathrm{~mm}$.

The types are from the Oligocene Mint Spring marl, Chickasawhay River, 11/4 miles southwest of Boice, Mississippi. The species also occurs in the Oligocene Red
Bluff clay, Byram marl, and Chickasawhay marl of Mississippi, and the Lincoln formation of Washington. Les: typical. specimens occur in the Twiggs clay member of the Barnwell formation of Georgia. Specimens from the Miocene of Florida seem to be very close to this species.

As in the other early species, Robertina wilcoxensis, the aperture is broader than in most later species and the supplementary aperture relatively inconspicuous.

\section{Robertina declivis (Reuss) Cushman and Parker}

Plate 18 , figure 7

Bulimina declivis Reuss, Akad. Wiss. Wien Sitzungsber., vol. 48, pt. 1 , p. 55 , pl. 6 , figs. 70 a, b; pl. 7 , fig. 71,1863 ; idem vol. 62, pt. 1, p. $48+$, 1870 (Von Schlicht, Foram. Septarienthones Pietzpuhl, pl. 23, figs. 8-12, 1870).

Robertina declivis Cushman and Parker, Cushman Lab. Foran Research Contr., vol. 12, p. 94, pl. 16, figs. 5a, b, 1936.

Beck, Jour. Paleontology, vol. 17, p. 604, pl. 107, figs. 1, 7, 25, 1943.

Test somewhat longer than broad, broadly fusiform, initial end subacute, apertural end broadly rounded; chambers distinct, inflated, 4 to 5 pairs in the adult whorl, increasing rapidly in size as added; sutures distinct, depressed; wall smooth, polished; aperture elongate, distinctly curved, secondary aperture very distinct, often nearly as broad as the primary. Length $0.41 \mathrm{~mm}$., diameter $0.22 \mathrm{~mm}$.

The types are from the Oligocene Septarienthon of Offenbach, Germany. We have specimens from the middle Oligocene at Hermsdorf, near Berlin, Germany. Reuss also records this species from a few other German Ol:gocene localities. It has been recently recorded from the Eocene of Cowlitz River, Lewis Co., Washington.

\section{Robertina austriaca Reuss}

Plate 18 , figures 8,22

Robertina austriaca Reuss, Akad. Wiss. Wien Denkschr., vol. 1, p. 375, p1. 47, fig. $15,1850$.

Cushman and Parker, Cushman Lab. Foram. Research Cont:-, vol. 12, p. 94, pl. 16, figs. 2, 3, 1936.

Test broadly conical, only slightly longer than broad, not much compressed, expanding only slightly toward tr? apertural end, initial end either very bluntly pointed or rounded; chambers slightly inflated, about 5 pairs in tr: final whorl: sutures distinct, slightly depressed; wall very finely perforate, smooth; aperture elongate, slight'y curved, and obliquely placed at the base of the apertural face, with a secondary aperture at the basal margin. Length 0.46 to $0.55 \mathrm{~mm}$., diameter 0.31 to $0.32 \mathrm{~mm}$.

Reuss described this species from the Miocene at Grinzing, near Vienna. We have specimens from the Miocene of Perchtoldsdorf and Baden, Vienna Basin; Austria. 
Robertina imperatrix (Karrer) 'Cushman and Parker

Plate 18, figures 9,10

Bulimina imperatrix Karrer, Akad. Wiss. Wien Sitzungsber., vol. 57, pt. 1, p. 176, pl. 4, fig. 11, 1868.

Robertina imperatrix Cushman and Parker, Cushman Lab. Foram. Research Contr., vol. 12, p. 95, pl. 16, figs. 6, 7, 1936.

Glaessner, Studies in Micropaleontology, vol. 1, fasc. 3, p. 24, pl. 2, fig. 30, 1937.

Test longer than broad, fusiform, greatest breadth at about the middle, initial end acute, tapering, apertural end broadly rounded; chambers distinct, very slightly inflated, 5 or 6 pairs in the last-formed whorl, increasing rapidly in size as added; sutures distinct, very slightly, if at all, depressed, strongly limbate; wall smooth, polished; aperture elongate, narrow, running at least halfway into the apertural face, secondary aperture distinct, elongate, nearly as broad as the primary. Length 0.41 to $0.60 \mathrm{~mm}$., diameter $0.30 \mathrm{~mm}$.

The types are from the Miocene of Kostej, in the Banat region of Hungary. The species is not known elsewhere.

\section{Robertina californica Cushman and Parker}

Plate 18, figure 11

Robertina californica Cushman and Parker, Cushman Lab. Foram. Research Contr., vol. 12, p. 97, pl. 16, figs. 14a, b, 1936.

Test nearly twice as long as broad, initial end subacute, tapering, apertural end broadly rounded; chambers only slightly inflated, increasing gradually in size in the final whorl, which consists of 8 or more pairs, all the chambers of one series reaching the middle line on the ventral side; sutures strongly limbate, little, if at all, depressed; aperture very narrow, elongate, running more than halfway into the apertural face, little, if at all, curved; supplementary aperture elongate, low. Length 0.32 to $0.64 \mathrm{~mm}$., diameter 0.14 to $0.31 \mathrm{~mm}$.

The types are from the Pliocene of Santa Barbara, California. The species occurs also in Pliocene material from Timms Point, San Pedro, California.

This species is related to, and probably the ancestral form of, Robertina charlottensis Cushman, differing from that species in the more regular form and outline, less twisted elongate axis, and less prominent spire.

\section{Robertina arctica D'Orbigny}

Plate 18, figure 12

Robertina arctica D'Orbigny, Foraminifères fossiles du bassin tertiaire de Vienne, p. 203, pl. 21, figs. 37, 38, 1846.

Schlumberger, Feuille jeunes nat., vol. 12, pl. 2, fig. 2, 1881.

Cushman, Cushman Lab. Foram. Researç Special Pub. 1, p. 246 , pl. 35 , figs. $13,14,1928$; idem, Special Pub. 4, pl.
22, fig. 4, 1933; idem, Special Pub. 5, p'. 27, figs. 10a, b, 1933.

Earland, Discovery Repts., vol. 10, p. 123, pl. 5, figs. 52, 53, 1934.

Cushman and Parker, Cushman Lab. Foram. Research Contr., vol. 12, p. 93, pl. 16, figs. 1a, b, 1936.

Bulimina subteres Goës (not H. B. Brady), K. svenska. vetensk. akad. Handl., vol. 25, no. 9, p. 46, pl. 9, figs. 445-453, 1894.

Test in a loose spiral, generally conical, expanding toward the apertural end, initial end bluntly pointed; chambers arranged in a double series in each whorl, giving an alternating appearance to the dorsal side, numerous, as many as 12 to 15 in the final whorl in the adult; sutures distinct, usually not depressed; wall very finely perforate, smooth; aperture a straight or slightly curved, slit-like opening in the middle of the base of the apertural face, nearly at right angles to the line of the base of the chamber; secondary aperture distinct, but shorter than the primary. Length 0.44 to $0.56 \mathrm{~mm}$., diameter 0.26 to $0.28 \mathrm{~mm}$.

D'Orbigny described this species from the Arctic, north of Siberia. The species is common in the collections made by Capt. R. A. Bartlett off northasest Greenland. Like certain other Arctic species this one seems to occur also in the Antarctic.

\section{Robertina charlottensis (Cushman) Cushman \\ Plate 18, figure 14}

Cassidulina charlottensis Cushman, Cushman Lab. Foram. Research Contr., vol. 1 , pt. 2, p. 41, pl. 6, figs. 6, 7, 1925 ; idem, Contr., vol. 1, pt. 3, p. 53, pl. 8, figs. 17, 18, 1925.

Robertina charlottensis Cushman, idem, Specirl Pub. 5, pl. 27, figs. 9a, b, 1933.

Cushman and Parker, idem, Contr., vol. 12, p. 97, pl. 16, figs. 12a, b, 1936.

Test about twice as long as broad, strongly spiral, greatest breadth at about the middle, in front view one side nearly straight, the other strongly convex, initial end subacute, rapidly tapering, apertural end obliquely rounded, truncate; chambers slightly, if at all, inflated, increasing gradually and regularly in size as added, 9 or more pairs in the final whorl, all those on one side reaching the median line on the ventrel side; sutures strongly limbate; aperture elongate, somewhat open, running halfway into the apertural face of the test, slightly curved; supplementary aperture elongate, low. Length nearly up to $1.00 \mathrm{~mm}$., diameter $0.55 \mathrm{~mm}$.

This species was described from Queen Charlotte Sound, in 20-25 fathoms.

It is evidently derived from Robertina californica Cushman and Parker and is a still more specialized species, with the whorls strongly marked. It also seems related to R. subteres ( $H$. B. Brady) but is broader and larger, with more chambers to a whorl. 
Robertina subcylindrica (H. B. Brady) Cushman and Parker

Plate 18, figure 13

Bulimina subcylindrica (H. B. Brady), Quart. Jour. Micr. Sci., vol. 21, p. 56, 1881; Challenger Rept., Zoology, vol. 9, p. 404, p1. 50, figs. 16a, b, 1884.

Millett, Royal Micr. Soc. Jour., 1900,.p. 277, pl. 2, fig. 6.

Sidebottom, idem, 1918, p. 122, pl. 3, fig. 7.

Robertina subcylindrica Cushman and Parker, Cushman Lab. Foram. Research Contr., vol. 12, p. 95, pl. 16, figs. 10a, b, 1936.

Chapman and Parr, Australasian Antarctic Exped., ser. C, vol. 1, pt. 2, p. 79, 1937.

Thalmann, Eclogae geol. Helvetiae, vol. 30, p. 341, 1937.

Cushman and Parker, Cushman Lab. Foram. Research Contr., vol. 16 , p. 22, 1940.

Cushman, U. S. Nat. Mus. Bull. 161, pt. 3, p. 9, pl. 3, figs. 14a, b, 1942.

Test subcylindrical, broadly rounded at both ends, about 4 pairs of chambers in the last-formed whorl, the chambers of the lower series much more elongate than those of the upper ones, somewhat inflated; sutures distinct, slightly depressed, somewhat limbate; wall smooth, thin, translucent; aperture comparatively short, narrow, nearly in the line of the elongate axis; supplementary aperture very inconspicuous. Length $0.50 \mathrm{~mm}$., diameter $0.24 \mathrm{~mm}$.

Brady's types of this species were from Challenger sta. 120 , off Pernambuco, Brazil. It has been recorded from the Indo-Pacific and Australian regions. We have a typical specimen from 98 fathoms, off the Big King, New Zealand, and one specimen from off the Philippines.

\section{Robertina translucens Cushman and Parker}

\section{Plate 18, figure 15}

Robertina translucens Cushman and Parker, Cushman Lab. Foram. Research Contr., vol. 12, p. 99, pl. 16, figs. 8a, b, 1936.

Test somewhat longer than broad, rather regularly fusiform, greatest breadth at about the middle, initial end subacute, apertural end rounded; chambers distinct, very slightly inflated, about 4 pairs in the last-formed whorl, very rapidly increasing in size as added, the next to the last chamber in the apertural view pinched out from the median line by the preceding chamber of its series; sutures distinct, somewhat limbate, slightly if at all depressed; wall smooth, translucent; aperture elongate, distinctly curved, nearly in the elongate axis of the test, secondary aperture very small and inconspicuous. Length 0.40 to $0.52 \mathrm{~mm}$., diameter 0.20 to $0.25 \mathrm{~mm}$.

The types are from Recent material from 1,000 fathoms, off southwest Ireland. The species occurs also southwestward to the eastern coast of the United States, and southward to Brazil.

This species differs from Robertina arctica D'Orbigny in the fewer chambers to the whorl, much more rounded chambers, more strongly curved and less oblique aperture, and in the great extension of the chambers toward the base.

\section{Robertina bradyi Cushman and Parker}

Plate 18, figure 16

Robertina bradyi Cushman and Parker, Cushman Lab. Foram. Research Contr., vol. 12, p. 99, pl. 16, figs. 9a, b, 1936.

Thalmann, Eclogae geol. Helvetiae, vol. 30, p. 341, 1937.

Bulimina subteres H. B. Brady (part), Challenger Rept. Zoology, vol. 9 , p. 403 , pl. 50 , fig. 18 (not fig. 17), 1884.

Buliminella subteres Cushman (not $\mathrm{H}$. B. Brady), U. S. Nat. Mus. Bull. 71 , pt. 2, p. 89 , text fig. 142, 1911; U. S. Nat. Mus. Bull. 104, pt. 3, p. 110, pl. 22, figs. 3-5, 1922.

Buliminella subteres (H. B: Brady) var. Cushman, idem, p. 112 , pl. 22, fig. 6, 1922.

Test somewhat longer than broad, fusiform, initial end bluntly pointed, apertural end broadly rounded; chambers slightly inflated, 4 to 5 pairs in the last-formed whorl, increasing rapidly in size as added, the next to the last chamber in the series with the apertural chamber meeting the median line; sutures distinct, slightly depressed, strongly limbate; wall smooth, polished, fairly thick; aperture very elongate, open, only slightly curved in the median line of the axis, supplementary aperture short. fairly high. Length 0.35 to $0.50 \mathrm{~mm}$., diameter 0.24 tc $0.30 \mathrm{~mm}$.

The types are from Recent material at Albatross sta. D2150, 382 fathoms, Caribbean Sea, Lat. $13^{\circ} 34^{\prime} 45^{\prime \prime} \mathrm{N}$. Long. $81^{\circ} 21^{\prime} 10^{\prime \prime} \mathrm{W}$. The species ranges south to the coast of Brazil.

This species differs from Robertina arctica D'Orbigny in the fewer chambers, much broader form, more elongate and more open aperture. It differs from $R$. translucens Cushman and Parker in the apertural view, by the muck shorter chambers, and in having the chamber before the apertural chamber meeting the median line instead of being pinched out.

\section{Robertina oceanica Cushman and Parker, n.sp.}

Plate 18, figure 18

Bulimina declivis H. B. Brady (not Reuss), Challenger Rept., Zoology, vol. 9, p. 404, pl. 50, figs. 19a, b, 1884.

?Egger, K. bayer. Akad. Wiss. Abh., cl. 2, vol. 18, p. $29 \mathrm{C}$, pl. 8, figs. 64, 65, 1893.

Sidebottom, Royal Micr. Soc. Jour., 1918, p. 122, pl. 3, figs. 4-6.

Test slightly longer than broad, very broadly fusiform, initial end subacute to rounded, apertural end broadl! rounded; chambers distinct, much inflated, 3 to 4 pair: in the adult whorl, increasing very rapidly in size as added; wall smooth, polished; aperture elongate, distinctl:" curved, narrow; secondary aperture very distinct, about 
half as long as the primary. Length 0.70 to $0.80 \mathrm{~mm}$., breadth 0.55 to $0.60 \mathrm{~mm}$.

Holotype (Cushman Coll. No. 35847), from Recent material at 75 fathoms, off North Cape, New Zealand.

Brady's figured specimen is from a Challenger station off the $\mathrm{Ki}$ Islands in the Pacific and Sidebottom's were from off Australia. We have specimens from other localities off New Zealand. A single specimen from off the Philippines seems to be very close to this species.

This species has been included under Reuss' name, as given above, but is a broader, more inflated form, with deeper sutures and more inflated chambers.

\section{Robertina parkeri (Terquem and Terquem) Cushman and Parker}

\section{Plate 18 , figure 17}

Bulimina parkeri Terquem and Terquem, Soc. Zool. France Bull., vol. 11 , p. 334 , pl. 11, fig. $19,1886$.

Robertina parkeri Cushman and Parker, Cushman Lab. Foram. Research Contr., vol. 16, p. 22, 1940.

This species was described from the region south of Norway. It is evidently a Robertina, but we have no material that seems identical with it. The type figure is given on our plate.

\section{Robertina subteres (H. B. Brady) Cushman and Parker}

Plate 18, figure 19 .

Bulimina subteres H. B. Brady, Quart. Jour. Micr. Sci., vol. 21, n.ser., p. 55, 1881.

Wright, Belfast Nat. Field Club Proc., 1880-81, App., p. 180, pl. 8, figs. 2, 2a, 1882 .

H. B. Brady (part), Challenger Rept., Zoology, vol. 9, p. 403, pl. 50, fig. 17? (not fig. 18).

Bulimina presli Reuss var. elegantissima Parker and Jones, Philos. Trans., vol. 155 , p. 374, pl. 15, figs. 12-17, 1865.

Robertina convoluta Cushman and Parker (not Williamson), Cushman Lab.- Foram. Research Contr., vol. 12, p. 94, pl. 16, figs. 4a, b, 1936.

Thalmann, Am. Midland Naturalist, vol. 28, p. 464, 1942.

Test elongate, $21 / 2$ times as long as broad, slightly compressed, initial end somewhat pointed; chambers distinct, slightly inflated, 6 or 7 pairs in the final whorl, rather elongate and narrow; sutures distinct, very slightly depressed, strongly limbate; wall smooth, polished, translucent; aperture elongate, narrow, slightly curved, the upper end slightly expanded; supplementary aperture at the base very narrow, inconspicuous. Length $0.39 \mathrm{~mm}$., diameter $0.16 \mathrm{~mm}$.

In his notes on this species published in 1881 Brady refers the figures of Parker and Jones to his species and again in the synonymy of the Challenger Report. This form is common about the British Isles and in the north Atlantic and may be taken as typical of this species. He mentions its relationship as close to Robertina arctica D'Orbigny. Our figured specimen is from the coast of Ireland. There has been much confusion in regard to this species, as the figures shown under $B$. subteres in the Challenger Report of specimens from the south Pacific are not of the same species as that from the north Atlantic.

We referred the figured specimens to "Robertina conroluta (Williamson)," but that species is different and will be discussed separately.

\section{Genus PSEUDOBULIMINA Earland, 1934}

Pseudobulimina Earland, Discovery Repts., vol. 10, p. 133, 1934. Bulimina (part) of authors.

Genoholotype, Bulimina chapmani Heron-Allen and Earland.

Test free, consisting of two series of chambers of very different dimensions, rapidly increasing in size and arranged side by side in a helicoid spiral of more than one convolution ; wall calcareous, perforate; aperture a narrow opening at the inner edge of the chamber, with a longer opening in the apertural face. Eocene to Recent.

This peculiar form is in some respects similar to Robertina, particularly in the apertural characters. It may possibly be related to the Cassidulinidae.

Glaessner places this genus and Robertina in his new family Ceratobuliminidae. He states that the so-called primary aperture in this and Robertina is not a true aperture but a fold connecting with the previous chamber, but our studies of Robertina arctica do not confirm this.

\section{Pseudobulimina chapmani (Heron-Allen and Earland) Earland}

Plate 18 , figure 20

Bulimina chapmani Heron-Allen and Earland, British Antarctic Exped., Zoology, vol. 6, p. 130, pl. 4, figs. 18-20, 1922.

Robertina chapmani Wiesner, Deutsche Süd-Polar-Exped., vol. 20, Zool., p. 124, pl. 20, fig. 239, 1929.

Pseudobulimina chapmani Earland, Discovery Repts., vol. 10, p. 134, pl. 6, figs. 11-14, 1934.

Chapman and Parr, Australasian Antarctic Exped., ser. C, vol. 1, pt. 2, p. 80, 1937.

Glaessner, Studies in micropaleontogy, vol. 1, fasc. 3, p. 23, pl. 2, figs. 23, 24, 1937.

Test free, perforate, helicoid, consisting of a double series of chambers, arranged in a rapidly-increasing spiral, the outer series being largely predominant and increasing in size much more rapidly than the inner series. Sutural lines flush, but often thick, and showing as bands of clear shell-substance. The oral face of the final chamber flat, containing the aperture, which is a wellmarked cleft, running halfway across the septal face. Size (across oral face) : Length up to $.80 \mathrm{~mm}$; breadth up to $.60 \mathrm{~mm}$; thickness up to $.50 \mathrm{~mm}$.- Heron-Allen and Earland.

The species was described from the Antarctic and has been since recorded several times from tlat region. We 
have no material. Heron-Allen and Earland refer the specimen figured from the Antarctic, by Chapman as "Bulimina seminuda Terquem" to their species. (Chapman, British Antarctic Exped., Geol., vol. 2, p. 29, pl. 2, figs. 9a, b, 1916.)

\section{Pseudobulimina glaessneri Howe and Roberts}

Plate 18, figure 21

Pseudobulimina glaessneri Howe and Roberts, in Howe, Louisiana Dept. Cons. Geol. Bull. 14, p. 81, pl. 11, figs. 9-11, 1939.

Cushman and Todd, Cushman Lab. Foram. Research Contr., vol. 21 , p. 20 , pl. 4, figs. 19, 20, 1945.

Test spirally coiled, with a double set of chambers which show both dorsally and ventrally; 10 or 11 chambers in the last coil; wall thick and shiny as in Ceratobulimina; early sutures flush with the surface, later ones depressed; aperture an oblique slit in the apertural face. Holotype, length $0.40 \mathrm{~mm}$; thickness $0.16 \mathrm{~mm}$.Howe and Roberts.

The types of this species are from the Eocene Cook Mountain formation, left bank of Saline Bayou beneath Louisiana and Arkansas Railroad bridge at St. Maurice, Winn Parish, Louisiana.

The type figures, given on our plate, do not give clear details of the structure of this species, and it is questionably placed in this genus until more is known concerning its detailed structure. Similar forms were found in the Eocene Lisbon formation of Monroe County, Alabama.

\section{Pseudobulimina convoluta (Williamson)}

\section{Cushman and Parker}

Bulimina pupoides D'Orbigny var. convoluta Williamson, Recent Foraminifera of Great Britain, p. 63, pl. 5, figs. 132, 133, 1858.

Bulimina convoluta H. B. Brady, Challenger Rept., Zoology, vol. 9, p. 409, pl. 113, figs. 6a, b, 1884.

Egger, K. bayer. Akad. Wiss. Abh., cl. 2, vol. 18, p. 288, pl. 8, figs. 83, 84, 1893.

Millett, Royal Micr. Soc. Jour., 1900, p. 279, pl. 2, fig. 9.

Buliminella convoluta Cushman, U. S. Nat. Mus. Bull. 104, pt. 3, p. 109, pl. 18, figs. 4, 5, 1922.

Pseudobulimina convoluta Glaessner, Studies in micropaleontology, vol. 1, fasc. 3, p. 23, pl. 2, figs. 26, 27, 1937.

Brotzen, Sveriges geol. undersökning, ser. c, no. 451 , p. 37 , text figs. 12, 16, 1942.

Thalmann, Am. Midland Naturalist, vol. 28, p. 464, 1942.

No definite description of this species can be given, as the original figure by Williamson is too obscure to provide information on details. It is also probably not correctly drawn. The figures given by Brady in the Challenger Report of specimens obtained from Torres Strait are probably not of a species identical with that of Williamson and perhaps do not belong to Pseudobulimina. The species is evidently rare in the region of the British Isles to judge by our examination of material from that area. Other references are given above, but it is very doubtful if they all refer to one species or whether they really belong to this genus. In some respects they resemble Cushmanella. Few of them show the primary aperture well developed. Glaessner has placed these forms with Ceratobulimina and described the family Ceratobuliminidae, which contains a varied group of genera, the close relationships of which seem very questionable. The group needs much detailed study.

\section{Subfamily 3. BULIMININAE}

Test spiral, usually triserial, becoming involute and finally, in Entosolenia, single chambered; wall calcareous, finely perforate; aperture loop-shaped, the larger end away from the inner margin (or rounded in Entosolenia), usually with a distinct tooth and internal tube or trough connecting the chambers (or in Entosolenia free at the inner end).

In this study Entosolenia has not been included, as many of the species are difficult to place until the actual types can be examined for their internal structure.

\section{Genus BULIMINA D'Orbigny, 1826}

Bulimina D'Orbigny, Annales sci. nat., vol. 7, p. 269, 1826.

H. B. Brady, Challenger Rept., Zoology, vol. 9, p. 397, 1884. Chapman, The Foraminifera, p. 172, 1902.

Cushman, U. S. Nat. Mus. Bull. 71, pt. 2, p. 76, 1911; Smithsonian Misc. Coll., vol. 77, no. 4, p. 35, 1925.

Galloway and Wissler, Jour. Paleontology, vol. 1, p. 73, 1927.

Cushman, Cushman Lab. Foram. Research Contr., vol. 3, pt. 1, p. 65, 1927; idem, Special Pub. 1, p. 247, 1928.

White, Jour. Paleontology, vol. 3, p. 46, 1929.

Cushman, Cushman Lab. Foram. Research Special Pub. 4, p. 220, 1933; U. S. Nat. Mus. Bull. 161, pt. 3, p. 10, 1942.

Pleurites Ehrenberg, Mikrogeologie, 1854.

Cucurbitina Costa, Accad. pontaniana Atti, vol. 7, pt. 2, p. 363, 1856.

Genotype, Bulimina marginata D'Orbigny.

Test an elongate spiral, generally triserial; chambers inflated, spiral suture more or leśs obsolete; wall calcareous, perforate; aperture loop-shaped, with a tooth or plate at one side and an internal spiral trough connecting through the chambers between the apertures. Jurassic to Recent.

The earliest occurrence of the genus is in the Jurassic. The species there are simple, so far as can be made out from the figures and descriptions. In the Upper Cretaceous the species become ornate, and the same types of ornamentation persist in the species of the present oceans. For the most part the ornamentation consists of longitudinal costae or ridges, sometimes continuous over the whole length of the test but more usually broken at the sutures. Spines are frequently developed at the basal border of the chambers and at the initial end. 
Many of the species are relatively short-lived and make good index fossils. Some species have wide geographic distributions but are distinctly restricted, so far as is known, at the present time.

\section{Bulimina antiqua Terquem and Berthelin}

Plate 19, figure 1

Bulimina antiqua Terquem and Berthelin, Soc. Géol. France Mém., ser. 2, vol. 10 , pt. 3 , p. 65 , pl. 5, fig. 16,1875 .

Cast of pyrite, elongate, narrow, straight, composed of 3 vertical series, containing 6 whorls of spherical chambers. Very rare. Length $0.26 \mathrm{~mm}$; diameter $0.09 \mathrm{~mm}$.-Terquem and Berthelin (translated).

The species was described from the lower Lias of Essayles-Nancy, France.

No specimens referable to this species were found in available collections. It is more than possible that the form is not a Bulimina. The original figure is reproduced.

\section{Bulimina incurva Terquem}

Plate 19, figures 2, 3

Bulimina incurva Terquem, Cinquième Mémoire sur les foraminifères du système oolithique, p. 387 , p1. 45 , figs. 10,11 , 1883.

Test elongate, smooth, obtuse at both ends, consisting of an oblique spire, twisted, of 5 or 6 whorls; chambers projecting, round, arranged in 3 straight or curved rows, increasing regularly. Length (of figured specimens) $0.28,0.32,0.38 \mathrm{~mm}$; ; diameter 0.14 , $0.12,0.22 \mathrm{~mm}$.-Terquem (translated).

The species was described from the Jurassic, $A m$ monites parkinsoni zone, Fontoy, France.

Terquem's figures are reproduced. Three specimens were found in Jurassic material from Metz, France, which may be tentatively referred to this species. One of these is figured. The later chambers do not show the inflation of Terquem's species, and the chambers are not spherical.

\section{Bulimina intricata Terquem}

Plate 19, figure 4

Bulimina intricata Terquem, Cinquième mémoire sur les foraminifères du système oolithique, p. 388, p1. 45, figs. 14a, b, 1883.

Test elongate, oval, smooth, tapering, rounded at the initial end, consisting of an indistinct spire, with more or less numerous whorls, the early chambers flat, overlapping, very small and numerous, later ones more or less inflated, round. Length $0.29 \mathrm{~mm}$., diameter $0.16 \mathrm{~mm}$.-Terquem (translated).

The types are from the Jurassic, Ammonites parkinsoni zone, Fontoy, Moselle, France.

We have no typical material. Terquem's figures are reproduced.

\section{Bulimina muricata Terquem}

Plate 19, figures 5,6

Bulimina muricata Terquem, Cinquième mémoire sur les foraminifères du système oolithique, p. 388, pl. 45, figs. 12, 13, 1883.

Test elongate, conical, almost circular in transverse section, smooth, obtuse at both ends, formed of a straight. spire of 4 to 6 whorls, chambers in 2 or 3 rows, projecting, more or less involute, the last sometimes regularly oval. Length $0.26,028 \mathrm{~mm}$; diameter $0.17,0.16 \mathrm{~mm}$.-Terquem (translated).

The types of the species are from the Jurassic, Ammonites parkinsoni zone of Fontoy, Moselle, France.

We have no material referable to the species. Terquem's figures are reproduced.

\section{Bulimina prima Terquem}

Plate 19, figures 7-9

Bulimina prima Terquem, Cinquième mémoire sur les foraminifères du système oolithique, p. 387, pl. 45, figs. 7-9, 1883.

Test elongate, conical, smooth, inflated at the apertural end, more or less tapering, obtuse at the initial ent, consisting of a straight spire, composed of 4 to 7 whorls, chambers projecting, inflated, rounded, arranged in 3 rows, increasing regularly. Length $0.31,0.32,0.37 \mathrm{~mm}$; diameter $0.16,0.14,0.14 \mathrm{~mm}$.-Terquem (translated).

The types are from the Jurassic, Ammonites parkinsoni zone, Fontoy, Moselle, France. We have no typical material. Terquem's figures are reproduced.

\section{Bulimina nannina Tappan}

Plate 19, figure 10

Bulinina nannina Tappan, Jour. Paleontology, vol. 14, p. 116, pl. 19, figs. 4a, b, 1940; idem, vol. 17, p. 507, pl. 81, fig. 15, 1943.

Test minute, triserial, chambers inflated, last series much larger than the earlier chambers, final pair of chambers forming one-half the test; sutures distinct, depressed; wall calcareous, smooth; aperture loop-shaped, in the face of the last formed chamber. Length of holotype, $0.21 \mathrm{~mm}$; breadth, $0.14 \mathrm{~mm}$.-Tappan.

The types are from the Lower Cretaceous Grayson formation, lower part of zone 1, Grayson Bluff on Denton Creek, $31 / 2$ miles northeast of Roanoke, 2 miles by road east of the Fort Worth-Denton highway, Denton County, Texas. The species has also been recorded from the Lower Cretaceous Duck Creek formation of Oklahoma and Texas.

Bulimina nannina was originally compared with " $B$. or'ula Reuss" (B. reussi Morrow) but was distinguished as being smaller, with more gradually increasing chambers. It is very close to B. reussi Mor -ow var. navarroensis Cushman and Parker, but is less tapering and has a more rounded initial end. 


\section{Bulimina brevis D'Orbigny}

Plate 21, figure 3

Bulimina brezis D’Orbigny, Soc. géol. France Mém., ser. 1, vol. 4, p. 41, pl. 4, figs. 13, 14, 1840; Prodrome de paléontologie, vol. 2 , p. 282 , No. $1402,1850$.

Cushman and Parker, Cushman Lab. Foram. Research Contr., vol. 10, p. 28, 1934.

Egger, K. bayer. Akad. Wiss. Abh., cl. 2, vol. 21, pt. 1, p. 49, pl. 15, figs. 42, 43, 1899.

Bulimina intermedia Reuss (part), Haidinger's Naturwiss. Abh., vol. 4, p. 23, pl. 3, fig. $11,1851$.

Egger, K. bayer. Akad. Wiss. Abh., cl. 2, vol. 21, pt. 1, p. 51, pl. 15, figs. 3, 4, 1899.

Bulimina murchisoniana Franke (not D'Orbigny), Geol. pal. Inst. Univ. Greifswald Abh., vol. 6, p. 27, pl. 2, figs. 22a, b, 1925 ; Preuss. geol. Landesanstalt Abh., n. ser., vol. 111, p. 160, pl. 14, figs. 22a, b, 1928.

Test almost as long as broad, 2 or 3 whorls, the lastformed whorl making up about three-fourths of the test; chambers few, earlier ones indistinct, those of last whorl distinct, inflated; sutures distinct, depressed in last whorl, earlier sutures indistinct; wall coarsely perforate, smooth; aperture long, comma-shaped, near the apex of the test. Length of figured specimen $0.88 \mathrm{~mm}$., diameter $0.72 \mathrm{~mm}$.

The types of the species are from the Upper Cretaceous near Meudon, Saint-Germain, and Sens of the Paris Basin, France. We have no material from D'Orbigny's localities, but specimens from Gravesend, England, appear to be identical. The species occurs also at various localities in the Senonian of Germany.

The original reference to Bulimina brevis was made by D'Orbigny in 1826 (Annales sci. nat., vol. 7, p. 270, no. 13, 1826) with Rimini, Italy, given as the type locality. At this time the name was merely listed, with no specific description. In 1840 D'Orbigny gave the name to a Cretaceous form, described, and figured it. His earlier listing of the Rimini species, together with Fornasini's later reproduction of D'Orbigny's unpublished figure (Accad. sci. Ist. Bologna Mem., ser. 5a, vol. 9, p. 6 , text fig. 7, 1901) therefore, must be discarded in favor of the Upper Cretaceous form, as the latter was the first valid application of the specific name.

The species resembles Bulimina intermedia Reuss, from the Turonian of Germany, but is much larger, with fewer whorls, and with the aperture differing both in position and shape. It differs from $B$. murchisoniana D'Orbigny, of which we have only one questionable specimen, in the less marked inflation of the last-formed chambers, in having less depressed sutures, in the position and shape of the aperture, and in its somewhat larger size.

\section{Bulimina murchisoniana D'Orbigny}

Plate 19, figure 11

Bulimina murchisoniana D'Orbigny, Soc. géol. France Mém., ser. 1, vol. 4, p. 41, pl. 4, figs. 15, 15, 1840; Prodrome de paléontologie, vol. 2, p. 282 , no. $1403,1850$.
Cushman and Parker, Cushman Lab. Foram. Research Contr., vol. 10 , p. 29 , pl. 5, figs. 7a, b, 1934.

Fahrion, Paleontographica, Suppl., 2. Reihe, pt. 2, no. 2, p. 199, 1937.

Macfadyen, Geol. Mag., vol. 79, p. 139, 1942.

Test large, rounded; chambers distinct, last-formed chambers inflated, corresponding chambers of each whorl aligned; earlier sutures indistinct, later ones depressed; wall slightly rough, almost papillate; aperture indistinct, placed at the suture joining the second and third chambers, loop-shaped. Length of figured specimen $0.70 \mathrm{~mm}$., diameter $0.64 \mathrm{~mm}$.

The types are from the Upper Cretaceous, of SaintGermain, Paris Basin, France, and of England.

One specimen was found in material from Gravesend, England, which may be referred to this species. It is figured here. A discussion of the resemblance of this species to Bulimina intermedia Reuss will be found under the latter species and need not be repeated here. It also bears some resemblance to $B$. brevis D'Orbigny. D'Orbigny recognized this and in his description says that it is related to $B$. brevis by its rounded chambers and short form. He adds that this species can be distinguished by its elongate spire, which is pointed and not obtuse. and by its chambers, which are more widely separated throughout and are arranged in three rows.

\section{Bulimina amphicona Von Hagenow}

Bulinina amphicona Von Hagenow, Neues Jahrb., 1842, p. 570.

Cushman and Parker, Cushman Lab. Foram. Research Contr., vol. 10, p. 36, 1934.

Test conically pointed at both ends, sharper at the upper end, regularly coiled; chambers inflated as in Helix, their junction, in a zigzag line, visible on only one side of the test.

Von Hagenow's description is summarized. The species was described from the Upper Cretaceous of Rügen. The description is not sufficiently full to identify any specimens we have with the species and no figures are given.

\section{Bulimina tumida Reuss}

Bulimina tumida Reuss, Geogn. Skizzen Böhmen, vol. 2, pt. 1, p. 215,1844

Cushman and Parker, Cushman Lab. Foram. Research Contr., vol. 10, p. 29, 1934.

Test about as long as broad, broadly egg-shaped, very tumid, apertural end truncated, initial end pointed, distinctly coiled, with 4 whorls, each with 3 chambers; chambers of the last portion inflated, with deep sutures; the earlier chambers one-third to one-fourth the size of the later, less inflated, sutures indistinct, the last whorl making up the larger portion of the test; aperture a straight opening, at right angles to the last spiral suture. Length one-fourth to 1 line (? 0.5 to $2.1 \mathrm{~mm}$.) 
The species is related to Bulimina murchisoniana D'Orbigny.

The original description of Reuss is summarized above. The species was described from the Upper Cretaceous Plänerkalk of Kuschlin and Kosstitz, Bohemia. No figures were given.

\section{Bulimina intermedia Reuss}

Plate 19, figures $12-15$

Bulimina intermedia Reuss, Die Verstein. böhm. Kreide, pt. 1, p. 37, pl. 13, fig. 71, 1845 ; Paleontographica, vol. 20, pt. 2, p. $108,1874$.

Bulinina murchisoniana Reuss (not D'Orbigny), Die Verstein. böhm. Kreide., pt. 1, p. 37, pl. 8, figs. 69, 72; pl. 13, fig. 70, 1845 ; in Geinitz, Grundr. Verstein., p. 672 , pl. 24, fig. 61 , 1845-6.

Test of medium size, rapidly tapering, consisting of 3 to 5 whorls; chambers distinct, those of the last whorl much inflated and occupying about half the test, corresponding chambers in each whorl aligned; sutures distinct, slightly depressed; wall coarsely perforate; aperture loopshaped, either directly at, or very slightly above, the suture joining the second and third chambers. Length of specimens from Luschitz 0.34 to $0.54 \mathrm{~mm}$., diameter 0.30 to $0.42 \mathrm{~mm}$.

We have a few specimens from the Upper Cretaceous Plänermergel of Luschitz, Bohemia, Reuss' type locality, as well as specimens from Kosstitz and other Turonian localities of Germany and Bohemia.

In the Naturhistorisches Museum in Vienna specimens of this species, named by Reuss and presumably from Luschitz, were seen and drawings of two of the specimens are reproduced here (pl. 19, figs. 14, 15). This form is close to Bulimina murchisoniana D'Orbigny and it is possible that it should be placed in the synonymy under this species, but as we have only one specimen of the latter from the Senonian of Gravesend, England, it seems best to keep the species separate. Reuss describes $B$. murchisoniana from Kosstitz but does not give this locality for $B$. intermedia. Our specimens from there, however, agree well with those seen in Vienna, and two of them are figured here (pl. 19, figs. 12,13). A study of Reuss' figures of D'Orbigny's species shows that he may have misunderstood the form. In comparing the two he describes $B$. intermedia as not having such deeply cut sutures, and in a later paper (Palaeontographica, vol. 20, pt. 2 , p. 108,1874 ) he describes it as a shorter, stouter form of $B$. murchisoniana. Actually it is a smaller form, the largest specimen being considerably less than twothirds of a millimeter, the length given by D'Orbigny for his species.

\section{Bulimina cenomana D'Orbigny}

Bulimina cenomana D'Orbigny, Prodrome de paléontologie, vol. 2, p. 185 . No. 759,1850 .
Cushman and Parker, Cushman Lab. Foram Research Contr., vol. 10 , p. $36,1934$.

Species close to $B$. Frotea, but shorter and more rugose-D'Orbigny (translated).

The types are from the Upper Cretace uus, Le Mans, France. The species was not figured.

\section{Bulimina sarthacensis D'Orbigny}

Bulimina sarthacensis D'Orbigny, Prodrome de paléontologie, vol. 2, p. 185 , no. $760,1850$.

Cushman and Parker, Cushman Lab. Foram. Research Contr., vol. 10 , p. $36,1934$.

Species related to $B$. rugosa, but larger and more pupoid.D'Orbigny (translated).

D'Orbigny's brief description of the spicies, from the Upper Cretaceous, Cenomanian, of Le Mans, France, in the absence of figures is wholly inadequate, especially as there seem to be no other references to "B. rugosa" in the literature.

\section{Bulimina acuta Reuss}

Plate 19, figure 16

Bulimina acuta Reuss, Haidinger's Naturwiss. Abh., vol. 4, pt. 1, p. 38 , pl. 3, fig. 8,1851 .

Cushman and Parker, Cushman Lab. Foram. Research Contr., vol. 10, p. 31, pl. 5, fig. 21, 1934.

Test $21 / 2$ times as long as broad, very slightly tapering, consisting of 4 to 5 whorls; chambers indistinct, not inflated; sutures indistinct, very slightly cepressed; wall smooth, coarsely perforate; aperture narrow, loop-shaped. at apex of test. Length of figured specimen $0.52 \mathrm{~mm}$. diameter $0.20 \mathrm{~mm}$.

The types are from the Upper Cretacecus, upper Senonian, of Lemberg, Galicia.

The species resembles Bulimina kickaporensis Cole but is smaller, with fewer whorls, and is muck more coarsely perforate. Only two specimens were found in material from Lemberg. A larger suite of specimens might show a greater resemblance to Cole's species.

\section{Bulimina parva Franke}

Plate 19, figure 17

Bulimina parva Franke, Preuss. geol. Landesans'alt. Abh., n. ser., vol. 111, p. 157, pl. 14, fig. 13, 1928.

Test small, tapering, consisting of 4 to 5 whorls; chambers fairly distinct, those of the last-formed whorl making up at least half of the test; sutures slightly depressed; wall smooth, perforate, somewhat polished; aperture loopshaped, at apex of test. Length of figured specimen 0.24 $\mathrm{mm}$., diameter $0.13 \mathrm{~mm}$.

The species was described from the Upor Cretaceous, upper Senonian, Himmelberg, near Ahlen, Germany. Our 
figured specimen is from Mersch, near Hamm, Germany. It is smaller than some of the specimens found. The species is fairly common in the Senonian of Germany.

This form differs from Bulimina reussi Morrow in its smaller size, narrower test, and the lack of inflation of the last-formed chambers. It is longer in proportion to its width than B. exigua Cushman and Parker, and the last-formed whorl makes up a far greater proportion of the test.

\section{Bulimina minuta (Marsson) Cushman}

Plate 21, figure 4

Tritaxia minuta Marsson, Naturwiss. Ver. Neu-Vorpommern Rügen Mitt., Jahrb. 10, p. 162, pl. 4, figs. 31a-d, 1878.

Bulimina minuta Cushman (not Hantken), Cushman Lab. Foram. Research Special Pub. 7, p. 29; 1937.

Bulimina marssoni Cushman and Parker, idem, Contr., vol. 16, p. 46 , pl. 8 , fig. 17,1940 .

Test small, triangular in transverse section, consisting of 5 whorls, rapidly tapering; chambers indistinct, meeting in a zigzag line on the somewhat concave sides; sutures slightly depressed, dark in color; wall coarsely perforate, smooth; aperture loop-shaped, at apex of test. Length of figured specimen $0.28 \mathrm{~mm}$., diameter $0.12 \mathrm{~mm}$.

This species was described from the Upper Cretaceous, Senonian, of Rügen. It has not been recorded elsewhere.

The specimens used for study were compared to Marsson's type in Vienna in 1932 by Cushman. The species resembles B. rudita Cushman and Parker but differs from it in its smaller size, more regular character, smooth wall, and less depressed sutures.

\section{Bulimina exigua Cushman and Parker}

Plate 19, figure 18

Bulimina exigua Cushman and Parker, Cushman Lab. Foram. Research Contr., vol. 11, p. 99, pl. 15, figs. 7a, b, 1935.

Cushman, U. S. Geol. Survey Prof. Paper 206, p. 122, pl. 51, fig. 18, 1946.

Test very small, about twice as long as broad, gradually tapering, usually consisting of 5 whorls; chambers distinct, overlapping, somewhat inflated ; sutures distinct, depressed throughout, forming a slight angle with the horizontal; wall smooth, perforate; aperture rounded. Length 0.10 to $0.17 \mathrm{~mm}$., diameter 0.08 to $0.11 \mathrm{~mm}$.

The types of the species are from the Upper Cretaceous Brownstown marl (near base), Paris-Clarksville highway, 1.85 miles southeast of Bagwell, Texas. It occurs also in the lower part of the Taylor marl and the Austin chalk and its equivalents in Texas.

The species resembles most closely Bulimina reussi Morrow var. navarroensis Cushman and Paker but differs from it in its smaller size, in having the last-formed chambers less inflated, and in the more gradual increase in the size of the chambers towards the apertural end.

\section{Bulimina kickapooensis Cole}

Plate 19, figures 19,20

Bulimina kickapooensis Cole, Florida Dept. Cons. Geol. Bull. 16, p. 45 , pl. 3, fig. 5, 1938.

Cushman and Hedberg, Cushman Lab. Foram. Research Contr., vol. 17, p. 94, pl. 22, figs. 28a-c, 1941.

Cushman and Deaderick, Jour. Paleontology, vol. 18, p. 337, pl. 53, fig. 7, 1944.

Cushman, U. S. Geol. Survey Prof. Paper 206, p. 123, pl. 51. figs. 11, 12, 14; pl. 66, fig. 12, 1946.

?Bulimina elegans Chapman (not D'Orbigny), Quart. Jour. Geol. Soc., vol. 48, p. 516 (list), pl. 15, fig. 9, 1892.

?Egger, K. bayer. Akad. Wiss. Abh., cl. 2, vol..21, pt. 1, p. 50, pl, 15, fig. 44, 1899.

? Bulimina obtusa Egger (not D’Orbigny), K. bayer. Akad. Wiss. Abh., cl. 2, vol. 21, pt. 1, p. 50, pl. 15, fig. 51, 1899.

Bulimina quadrata Cushman and Parker (part) (not Plummer), Cushman Lab. Foram. Research Contr., vol. 11, p. 100, pl. 15, figs. 13, 14 (not 12, 15, 16), 1935.

Test about $21 / 2$ times as long as broad, megalospheric form tapering very slightly, microspheric rapidly, consisting of 5 or 6 whorls; chambers numerous, distinct, slightly inflated, sharply angled; sutures distinct, slightly depressed; wall smooth, perforate; aperture loop-shaped at apex of test, with a thin, plate-like tooth. Length of holotype $0.72 \mathrm{~mm}$., diameter $0.28 \mathrm{~mm}$.

The types are from the Upper Cretaceous, upper part of Taylor marl, branch of Kickapoo Creek, 1200 feet south of public road, 1.8 miles northwest of Annona, Red River County, Texas. The species occurs in formations of Navarro age in Arkansas, Tennessee and Texas; those of Taylor age in Texas; in the deep well in Florida cited by Cole; and in the Upper Cretaceous of Colombia. It also occurs questionably in the Moreno shale of California. It is found in the Senonian of Germany.

This species was named by Cole from specimens described by Cushman and Parker (Cushman Lab. Foram. Research Contr., vol. 11, p. 100, 1935). Cole designated the specimens figured by Cushman and Parker on plate 15 , figures 13,14 and 16 . Figure 16, however, represents quite a different form from the others and is here referred to Bulimina aspera Cushman and Parker; it is smaller, having less sharply angled, more inflated chambers, with the wall of the earlier chambers somewhat roughened, and usually with one or more terminal spines. B. kickapooensis closely resembles $B$. (Desinobulimina) quadrata Plummer but does not have the terminal aperture.

\section{Bulimina kickapooensis Cole var. pingua Cushman and Parker}

Plate 19, figures 21,22

Bulimina kickapooensis Cole var. pingua Cushman and Parker, Cushman Lab. Foram. Research Contr., vol. 16, p. 44, pl. 9, figs. 13, 14, 1940. 
Cushman and Hedberg, idem, vol. 17, p. 95, pl. 22, fig. 29, 1941.

Cushman and Todd, idem, vol. 19, p. 66, pl. 11, figs. 24a, b, 1943.

Cushman, U. S. Geol. Survey Prof. Paper 206, p. 123, pl. 51, figs. 8,9 ; pl. 66, figs. 15, 16, 1946.

This variety differs from the typical form in being shorter and broader, and in having more inflated chambers and more depressed sutures. Length 0.50 to 0.67 mm., diameter 0.30 to $0.35 \mathrm{~mm}$.

The variety was described from the Upper Cretaceous Corsicana marl, Mexia highway at forks of Wortham road, 2.8 miles east southeast of Cooledge, Limestone County, Texas. It also occurs at other localities in the Corsicana marl, in the Kemp clay of Texas, and in the Prairie Bluff chalk of Mississippi. It has been recorded from the Colon formation, Santander del Norte, Colombia. It occurs in great abundance at some localities and serves as an excellent marker.

\section{Bulimina taylorensis Cushman and Parker}

Plate 19, figures 23, 24

Bulimina taylorensis Cushman and Parker, Cushman Lab. Foram. Research Contr., vol. 11, p. 96, pl. 15, figs. 3a, b, 1935.

Cushman, U. S. Geol. Survey Prof. Paper 206, p. 123, pl. 52, figs. 1, 2, 1946.

Test small, slightly tapering, about $1 \frac{1}{2}$ times as long as broad in the megalospheric form, in the rare microspheric form twice as long as broad: 4 to 5 whorls in the megalospheric form, more in the microspheric; chambers fairly distinct, overlapping; sutures deep, their presence, except in the last-formed whorl, chiefly indicated by the sharp undercutting of the chambers; wall finely perforate, with irregular costae spaced rather far apart, causing an irregular fluting of the sharp margins of the chambers, the initial end of the test with one or more spines; aperture an elongate, loop-shaped opening, with a distinct lip, at the inner margin of the last-formed chamber. Length 0.27 to $0.32 \mathrm{~mm}$, diameter 0.20 to $0.21 \mathrm{~mm}$.

The types are from the Upper Cretaceous, upper part of Taylor formation, branch of Kickapoo Creek, 1200 feet south of the public road, 1.8 miles northwest of Annona, Red River County, Texas. The species is found only in the upper Taylor.

It is a distinctive form and bears no close resemblance to any other Upper Cretaceous species.

\section{Bulimina triangularis Cushman and Parker}

Plate 19, figure 25

Bulimina triangularis Cushman and Parker, Cushman Lab. Foram. Research Contr., vol. 11, p. 97, pl. 15, figs. 4a, b, 1935.

Cole, Florida Dept. Cons. Geol. Bull. 16, p. 35 (list), pl. 4, fig. $1,1938$.
Cushman, Cushman Lab. Foram. Research Contr., vol. 20, p. 93, pl. 14, fig. 11, 1944.

Cushman, U. S. Geol. Survey Prof. Paper 276, p. 122, pl. 51, fig. 23, 1946.

Test small, $1 \frac{1}{3}$ times as long as broad, triangular in transverse section with rounded angles and slightly concave sides, consisting of about 5 whorls; chambers indistinct; sutures very indistinct, showing only as slightly darkened lines; wall of the bottom half of the test covered with short, irregular, longitudinal ridges which sometimes become slightly spinose, the upper half of the test smooth. coarsely perforate; aperture loop-shaped, with a slight lip. Length 0.21 to $0.28 \mathrm{~mm}$, diameter 0.15 to $0.17 \mathrm{~mm}$.

The types are from the Upper Cretaceous Taylor formation, 3.9 miles east of Farmersville, Collin County, Texas, on the Greenville road. The species is found in the upper beds of Taylor age in Texas, Mississippi, and Alabama, with a single occurrence in the Corsicana marl of Texas. It has been recorded by Cole from a deep well in Florida in material of Taylor age. From Germany we have specimens of Senonian age.

The species is larger than Bulimina rudita Cushman and Parker, is shorter in proportion to its length, has less distinct and fewer chambers, and is ornamented only on the lower part of the test.

\section{Bulimina referata Jennings}

Plate 30, figure 7

Bulimina referata Jennings, Bull. Am. Paleonto'ogy, vol. 23, no. 78, p. 31, p1. 3, figs. 21a, b, 1936.

Test minute, elongate, triangular in cross-section; four or more whorls, three chambers to a whorl; chambers stort; sutures distinct, depressed; wall smooth; aperture virguline and fairly large. Length, from $0.15-0.25 \mathrm{~mm}$; width, 0.09-0.15 mm.Jennings.

This species was described from the Up er Cretaceous Mt. Laurel sand and Navesink marl of New Jersey. We have not seen type material but it resembles Bulimina triangularis Cushman and Parker.

\section{Bulimina rudita Cushman and Parker}

Plate 19, figure 26

Bulimina rudita Cushman and Parker, Cushman Lab. Foram. Research Contr., vol. 12, p. 45, 1936.

Cushman, U. S. Geol. Survey Prof. Paper 2)6, p. 122, pl. 51, fig. 24, 1946.

Bulimina ornata Cushman and Parker (not Egger), Cushman Lab. Foran. Research Contr., vol. 11, p. 97, pl. 15, figs. $4 a, b, 1935$.

Test small, triangular in transverse sertion with the angles rounded and the sides distinctly conave, occasionally slightly twisted on its axis, consisting of 5 or 6 whorls; chambers distinct, somewhat inflated, arranged in 
regular series, with the adjacent series meeting in a zigzag line; sutures distinct, depressed, sigmoid, slanting at an angle of $45^{\circ}$ with the horizontal; wall, except for the central portion of the chambers in the last-formed whorl, covered with. short spines, perforate; aperture loop-shaped, with a slight lip. Length 0.20 to $0.26 \mathrm{~mm}$., diameter 0.11 to $0.16 \mathrm{~mm}$.

The types of the species are from the Upper Cretaceous Taylor formation, Paris highway, 1.8 miles east of Deport, Red River County, Texas. It is fairly common at several localities in the Austin and Taylor formations of Texas, in the Prairie Bluff chalk of Mississippi, and in the Selma chalk of Alabama, Mississippi, and Tennessee.

This species is unique and bears little resemblance to other species of the genus.

\section{Bulimina pectinata Cushman and Parker}

Plate 19 , figure 27

Bulimina pectinata Cushman and Parker, Cushman Lab. Foram. Research Contr., vol. 16, p. 45, pl. 8, figs. 20a-c, 1940.

Cushman, U. S. Geol. Survey Prof. Paper 206, p. 123, pl. 52, fig. 10, 1946.

Test medium, triangular in transverse section, somewhat twisted on its axis, broadest part near the apertural end, initial end bluntly pointed; consisting of about 6 whorls; chambers made somewhat indistinct by the ornamentation, except in the central part of the sides of the test; sutures indistinct except at the sides, flush with the surface, somewhat darker in color than the rest of the test; wall ornamented along the edges of the chambers by a bluntly toothed border which gives a somewhat fringed appearance to the test, finely perforate; aperture loop-shaped, at apex of test. Length of adult specimens 0.32 to $0.38 \mathrm{~mm}$., diameter 0.18 to $0.20 \mathrm{~mm}$.

The types are from the Upper Cretaceous, upper part of Taylor marl, road cut, east bank, near crest of hill, 14.4 miles south of Paris, 0.9 mile north of Lake City, Delta County, Texas. The species has been found only at the type locality.

The form resembles no other species. It is somewhat similar in shape to Bulimina rudita Cushman and Parker, but tapers less rapidly and is easily differentiated by the fringe-like ornamentation.

\section{Bulimina aspera Cushman and Parker}

Plate 19, figures 28-30; plate 21, figures 1,2

Bulimina aspera Cushman and Parker, Cushman Lab. Foram. Research Contr., vol. 16, p. 44, pl. 8, figs. 18, 19, 1940.

Cushman and Todd, idem, Contr., vol. 19, p. 66, pl. 11, figs. 22, 1943.
Frizzell, Jour. Paleontology, vol. 17, p. 349, pl. 57, fig. 1, 1943.

Cushman, U. S. Geol. Survey Prof. Paper 206, p. 121, pl. 51, figs. 7, 10, 13, 15, 16, 1946.

Bülimina pupoides Carsey (not D'Orbigny), Univ. Texas Bull. 2612, p. 29, pl. 4, fig. 3, 1926.

Plummer, idem, Bull. 3101, p. 180, pl. 9, fig. 15, 1931.

?Sandidge, Jour. Paleontology, vol. 6, p. 280, pl. 43, fig. 1, 1932.

Bulimina obtusa Cushman and Church (not D'Orbigny), California Acad. Sci. Proc., ser. 4, vol. 18, p. 513, pl. 39, fig: 17-19, 1929.

Cushman, Tennessee Geol. Survey Bull. 41, p. 47, p1. 7, figs 17, 18, 1931; Jour. Paleontology, vol. 5, p. 309, pl. 35, fig: 15a, b, 1931.

Bulimina subornata Sandidge (not H. B. Brady), Jour. Paleortology, vol. 6, p. 280, pl. 43, fig. 2, 1932.

?Bulimina elongata Sandidge (not D'Orbigny), Jour. Paleortology, vol. 6, p. 281, pl. 43, fig. 3, 1932.

Bulimina quadrata W. Berry and Kelley (not Plummer), U. S. Nat. Mus. Proc., vol. 76, art. 19, p. 5, pl. 2, fig. 7, 1929.

Cushman and Parker (part), Cushman Lab. Foram. Research Contr., vol. 11 , p. 100 , pl. 15 , figs. $12,15,16$ (not figs. 13 , 14), 1935.

Bulimina kickapooensis Cole (part), Florida Dept. Cons. Geo'. Bull. 16, p. 45, 1938.

Test medium, 2 or more times as long as broad, slightly tapering, consisting of 4 to 5 whorls, initial end bluntly pointed, sometimes with 1 or 2 short basal spines; chambers joined at an angle of about $90^{\circ}$ or less, slightly in flated; sutures distinct, slightly depressed; wall of initial part of test somewhat roughened, perforate, with th: perforations often arranged in regular lines; apertur? elongate, at apex of test, with a small, plate-like toott. Length of specimens fom type locality 0.38 to $0.50 \mathrm{~mm}$., diameter 0.16 to $0.26 \mathrm{~mm}$.

The types are from the Upper Cretaceous, upper part of Taylor formation, 6.15 miles from Kaufman on the road to Crandall, Kaufman County, Texas. The specie: is very widespread, occurring in the Upper Cretaceous sediments of Taylor and Navarro ages thoughout the Gulf Coast region of the United States. It is also recorded from the Upper Cretaceous Mal Paso shale of Peru.

The specimens from the upper part of the Navarro group differ from those of the lower part of the Navarro and from the Taylor formation in not having the small initial spines; in other respects they appear to be identical. The species differs from Bulimina pupoides D'Orbigny in the angled character of the chambers, in the much slighteinflation of the chambers, and in the shape of the test, which tapers less and has a more blunt initial end. It differs from B. kickapooensis Cole in the smaller size, greater inflation of the chambers, in the roughened early portion of the test, and in the usual presence of one or two short spines. 


\section{Bulimina reussi Morrow}

Plate 19, figure 31 ; plate 20 , figures $1-5$

Bulinina reussi Morrow, Jour. Paleontology, vol. 8, p. 195, pl. 29, fig. 12, 1934.

Cushman and Parker, Cushman Lab. Foram Research Contr., vol. 11, p. 99, pl. 15, figs. 8a, b, 10, 1935.

Cushman and Hedberg, idem, Contr., vol. 17, p. 95, pl. 22, figs. 30a-c, 1941.

Frizzell, Jour. Paleontology, vol. 17, p. 350, pl. 57, fig. 2, 1943.

Cushman and Deaderick, idem, vol. 18 , p. 337 , pl. 53 , fig. 6 , 1944.

Cushman, Cushman Lab. Foram. Research Contr., vol. 20, p. 12, pl. 2, fig. 25, 1944; U. S. Geol. Survey Prof. Paper 206 , p. 120 , pl. 51 , figs. $1-5,1946$.

Bulimina ovulum Reuss (not ovnla D'Orbigny), Geog. Skizzen Böhmen, vol. 2, pt. 1, p. 215, 1844; Die Verstein. böhm. Kreide, pt. 1, pl. 8, fig. 57 ; pl. 13, fig. 73, 1845-6.

Alth, Haidinger's Naturwiss. Abh., vol. 3, p. 264, pl. 13, fig. $18,1850$.

Reuss, idem, vol. 4, p. 38, pl. 3, fig. 9, 1851.

Cushman and Parker, Cushman Lab. Foram. Research Contr., vol. 10, p. 29, pl. 5, figs. 10, 11, 1934.

Bulimina murchisoniana Cushman (not D'Orbigny), Jour. Paleontology, vol. 5, p. 309, pl. 35, figs. 14a, b, 1931; Jour. Paleontology, vol. 6, p. 340, 1932.

Bulimina brevis Franke (not D'Orbigny), Geol. pal. Inst. Greifswald Abh., vol. 6, p. 25, pl. 2, fig. 18, 1925; Preuss. geol. Landesanstalt. Abh., n. ser., vol. 111, p. 157, pl. 14, fig. 12, 1928.

Cushman, Cushman Lab. Foram. Research Contr., vol. 7, p. 40 , p1. 5 , figs. 9a-c, 1931 .

Bulimina ventricosa Brotzen, Sveriges geol. undersökning, ser. c, no. 396, p. 124, pl. 8, figs. 1a-c, text figs. 42, 43, 1936.

Bulimina lwowensis Brotzen, idem, p. 126.

Test small, ovate, globular, subcircular in transverse section with greatest breadth above the middle, tapering evenly to a rather sharply rounded initial end; chambers triserial throughout, obscure, enlarging very rapidly in size as they are added; sutures very slightly depressed; wall smooth, very finely perforate; aperture small, subterminal. Height $0.28 \mathrm{~mm}$.; breadth $0.16 \mathrm{~mm}$.Morrow.

The species was described by Reuss from the Upper Cretaceous Plänermergel of Luschitz, Rannay, and Brozan in "Bohemia". The form has a wide range of occurrence both geographically and stratigraphically. It is found in the Upper Cretaceous of Europe ranging from the Turonian to the upper Senonian. In North America it occurs in formations of Navarró, Taylor, and Austin ages throughout the Gulf Coast region. It is also found in the Niobrara formation of Kansas, Velasco shale of Mexico, and Upper Cretaceous of Colombia and Peru. The forms found in the Austin chalk are usually shorter and broader than those occurring higher in the section.

A study has been made of specimens from various Turonian localities of "Bohemia" and from Senonian localities of Sweden, Germany, and England, and it does not seem to us advisable to subdivide the group as some authors have tried to do. Brotzen names two new species from this group. The first, Bulimina zentricosa, represents in our opinion a form so close to Reuss' species that it is difficult to separate the two. A suite of specimens sent by Brotzen shows tendencies towards a shorter type of test with fewer whorls, but many Turonian specimens may be found so close to it that ve have found it impossible to differentiate them; at best, evolution towards a different form may be at work: B. lwowensis, the name given by Brotzen to Reuss' citation of $B$. ovulum (in Haidinger's Naturwiss. Abh., vol. 4, p. 38, pl. 3, fig. 9, 1851) from the Senonian of Lemberg, Germany, also seems to represent the same species. A specimen from Lemberg that agreed exactly with Reuss' figure agrees almost exactly with one of Brotzen's syntypes of $B$. ventricosa and also with Turonian specimens.

The species lacks the trihedral character of Bulimina trihedra Cushman, has a shorter, less tapered test, and less inflated chambers.

\section{Bulimina reussi Morrow var. navarmoensis Cushman and Parker}

Plate 20, figure 6

Bulimina reussi Morrow var. navarroensis Cushman and Parker, Cushman Lab. Foram. Research Contr., vol. 11, p. 100, pl. 15, figs. 11a, b, 1935.

Cushman and Todd, idem, vol. 19, .p. 66, pl. 11, fig. 21, 1943.

Cushman, U. S. Geol. Survey Prof. Paper 206, p. 121, pl. 51, fig. 6, 1946.

This variety differs from the typical form in the smaller size of the test, in the much slighter inflation of the last-formed chambers, and in the much smaller proportion of the whole test which these chambers form. Length 0.16 to $0.25 \mathrm{~mm}$., diameter 0.10 to $0.13 \mathrm{~mm}$.

The types are from the Upper Cretareous Navarro formation, chalky marl member, San Marcos River, half a mile below Martindale, Caldwell County, Texas. It occurs in formations of Navarro age including. the Selma chalk of Tennessee, the Kemp clay, Corsicana marl, and Neylandville marl of Texas.

This variety is very easily differentiated from the typical Bulimina reussi Morrow by its mu:h smaller size.

\section{Bulimina prolixa Cushman and Parker}

Plate 20 , figures 7,8

Bulimina prolixa Cushman and Parker, Cushman Lab. Foram. Research Contr., vol. 11, p. 98, pl. 15, figs. 5a, b, 1935.

?Toulmin, Jour. Paleontology, vol. 15, p. 508, pl. 80, fig. 27, 1941.

Cushman and Todd, Cushman Lab. Foram. Research Contr., vol. 19, p. 66, pl. 11, fig. 23, 1943.

Schenck, Jour. Paleontology, vol. 17, p. 62, 1943.

Cushman and Deaderick, idem, vol. 18, p. 337, pl. 53, fig. 8 , 1944. 
Cushman and Goudkoff, Cushman Lab. Foram. Research Contr., vol. 20, p. 58, pl. 10, fig. 1, 1944.

Cushman, U. S. Geol. Survey Prof. Paper 206, p. 122, pl. 51, figs. 19-22, 1946.

Bulimina puschi Cushman (not Reuss), Tennessee Geol. Survey Bull. 41, p. 47, p1. 7, figs. 19a, b, 1931; Cushman Lab. Foram. Research Contr., vol. 7, p. 42, pl. 5, figs. 11a-c, 1931.

Bulimina speciosa Brotzen, Sveriges geol. undersökning, ser. c, no. 396, p. 128, pl. 8, fig. 5, 1936.

Test long and narrow, about $21 / 2$ times as long as broad, tapering very slightly throughout the entire length, triangular in transverse section with the angles broadly rounded, often somewhat twisted on its axis toward the initial end, consisting of 6 to 7 whorls; chambers distinct, those of successive whorls placed directly over each other with adjacent series meeting in a zigzag line; sutures distinct, very slightly depressed; wall smooth, coarsely perforate; aperture elongate, placed well above the junction of the second and third chambers. Length 0.25 to $0.27 \mathrm{~mm}$., diameter 0.11 to $0.12 \mathrm{~mm}$.

The types of the species are from the Upper Cretaceous Selma chalk, New Corinth highway, $131 / 2$ miles east of Selmer, McNairy County, Tennessee. It is found in formations of Navarro and later Taylor ages in Texas, Arkansas, Tennessee, and California. We have specimens also from the Upper Cretaceous of the Gotzreuther Graben, near Siegsdorf, Germany. Doubtful specimens have been recorded from the Eocene Salt Mountain limestone of Alabama.

As was pointed out in an earlier paper, this species has been wrongly identified in the United States as Bulimina puschi Reuss. Brotzen in his description of $B$. speciosa definitely states that it is identical with the Tennessee form described by Cushman as $B$. puschi.

\section{Bulimina arkadelphiana Cushman and Parker}

Plate 20, figures 9,10

Bulinina arkadelphiana Cushman and Parker, Cushman Lab. Foram. Research Contr., vol. 11, p. 96, pl. 15, figs. 1a, b, 2, 1935.

Cushman, U. S. Geol. Survey Prof. Paper 206, p. 124, pl. 52, figs. 3, 4, 1946.

Test small to medium, the megalospheric form considerably smaller than the microspheric, tapering, consisting of about 5 whorls in the megalospheric form, 8 in the microspheric; chambers numerous, later ones inflated; sutures distinct, deep; wall, except for the last 3 chambers, covered with sharp spines, especially at the margins of the chambers, the last formed whorl with spines at the margins of the chambers and with only an occasional spine above, finely perforate; aperture typically elongate, with a small lip. Length 0.33 to $0.50 \mathrm{~mm}$., diameter 0.23 to $0.30 \mathrm{~mm}$.
The types are from the Upper Cretaceous Arkadelphia clay, 6 miles north by west of Hope, Hempstead County, Arkansas. The species was found at several localities in the Arkadelphia clay.

This form differs from Bulimina cooperensis Cushman in having longer spines and no costae.

\section{Bulimina tortilis Reuss}

Plate 20, figure 14

Bulimina tortilis Reuss, Akad. Wiss. Wien Sitzungsber, vol. 44. pt. 1, p. 338, pl. 8, figs. 3a, b, 1861 (1862).

Cushman and Parker, Cushman Lab. Foram. Research Contr., vol. 10, p. 31, pl. 6, figs. 1a, b, 1934.

Uvigerina tortilis Egger, $\mathrm{K}$. bayer. Akad. Wiss. Math.-naturh. Abt., Abh., K1. 2, vol. 21, pt. 1, p. 133, pl. 15, figs. 52-54. 1899.

A peculiar, small species, pyramidal, three-sided, the sides concave, the ridges somewhat blunt, the whole test slightly twisted, composed of 5 whorls, the earliest small, the later increasing gradually in size; chambers semicircular, the earliest indistinct, the later rapidly increasing in size and strongly arched; aperture short, narrowly elliptical, beginning below the short, truncate end of the last-formed chamber and running down the flat side of the chamber. Maximum length $0.52 \mathrm{~mm}$.

A summary of Reuss' description is given above. The species was described from the Upper Cretaceous, "Senonian Greensands" of New Jersey. We have no specimens which can be identified with it. Egger figures a similar form from the Cretaceous of Europe.

\section{Bulimina velascoensis (Cushman) White}

Plate 20, figure 11

Gaudryina velascoensis Cushman, Cushman Lab. Foram. Research Contr., vol. 1, p. 20, pl. 3, fig. 7, 1925; Am. Assoc. Petroleun Geologists Bull. vol. 10, p. 587, pl. 16, fig. 9, 1926; Jour. Paleontology, vol. 1, p. 149, pl. 28, fig. 2, 1927.

Bulimina velascoensis White, Jour. Paleontology, vol. 3, p. $5 \mathrm{C}$, pl. 5, fig. 3, 1929.

Cushman, U. S. Geol. Survey Prof. Pajper 206, p. 124, pl. 52, fig. 8, 1946 .

Test almost twice as long as broad, broadest toward the apertural end, early portion somewhat triangular in transverse section, later portion with the angles broadly. rounded in transverse section, consisting of about 7 whorls; chambers indistinct except in the later portion of the test; sutures indistinct, very slightly depressed; wall perforate, with the fairly large perforations often arranged in longitudinal lines, giving the impression of faint striations; aperture elongate, loop-shaped, with a slight lip.

The types are from the Upper Cretaceous Velasco shale, Tamalte Arroyo, Hacienda El Limon, San Luis 
Potosi, Mexico. The species appears to be characteristic of the Velasco shale.

The form described and figured by White in some respects resembles Bulimina tabascoensis Galloway and Morrey, but the triangular character of the early portion of the test and the similarity of size make it more probable that it should be referred to this species.

\section{Bulimina incisa Cushman}

Plate 20, figures 12,13

Bulimina incisa Cushman, Am. Assoc. Petroleum Geologists Bull., vol. 10, p. 592, pl. 17, figs. 9a, b, 1926.

Cushman, U. S. Geol. Survey Prof. Paper 206, p. 124, pl. 52, fig. 7, 1946.

Bulimina declivis Galloway and Morrey (not Reuss), Jour. Paleontology, vol. 5, p. 351 , pl. 40, figs. 8, 9, 1931.

Test small, oval, circular in transverse section, greatest breadth toward the apertural end, initial end rounded, consisting of 4 to 5 whorls; chambers comparatively few, distinct, especially the later chambers; sutures distinct, usually depressed toward the apertural end, usually darker in color than the rest of the test, broad, the basal edge of each chamber with numerous reentrants, which are apparently cut in along the suture lines; wall of last whorl smooth, early portion often with occasional spines, some specimens showing faint, longitudinal lines; aperture broadly oval, at apex of test. Length of holotype 0.46 $\mathrm{mm}$., diameter $0.30 \mathrm{~mm}$.

The types are from the Upper Cretaceous Velasco shale in well samples from Hacienda El Limon, Vera Cruz, Mexico. It occurs also at other localities in the Velasco shale of Mexico.

This species is related to Bulimina tuxpamensis Cole but is much smaller. The sutures are more strongly marked and have larger reentrants cut in from them. It may be differentiated also by the spinose character of the initial portion of the test. The original description does not refer to these spines, but a study of the holotype reveals their presence. The holotype is refigured, together with a specimen from the Tamesí formation, Tantoyuquita, on the Rio Tamesí, Mexico.

\section{Bulimina trihedra Cushman}

Plate 20, figure 15

Bulimina trihedra Cushman, Am. Assoc. Petroleum Geologists Bull., vol. 10, p. 591, pl. 17, figs. 6a, b, 1926; Jour. Paleontology, vol. 1, p. 160, pl. 27, fig. 5, 1927.

Cushman and Parker, Cushman Lab. Foram. Research Contr., vol. 11, p. 100, pl. 15, figs. 9a, b, 1935.

Cushman, U. S. Geol. Survey Prof. Paper 206, p. 122, pl. 51, fig. 17, 1946.

Test small, distinctly trihedral, angles rounded, sides nearly flat or slightly convex; chambers numerous, distinct, inflated, somewhat higher than broad; sutures dis- tinct, depressed; wall smooth and polished, very finely perforate; aperture an elongate, oval-shaped opening with a slight lip, near the apex of the test. Lencth of holotype $0.43 \mathrm{~mm}$., diameter $0.23 \mathrm{~mm}$.

The types of the species are from the Upjer Cretaceous Velasco shale, Hacienda El Limon, Vera Cruz, Mexico (M. hole Z, 105 feet, Marland Oil Company of Mexico). It occurs also in the Upper Cretaceous Annona chalk of Texas, and the middle part of the Selma chalk of Mississippi.

This species most closely resembles Bulimina reussi Morrow, but differs from it in its trihedral character, longer, more tapered test, and in its more inflated and more numerous chambers.

\section{Bulimina trinitatensis Cushman and Jarvis}

Plate 20, figures 16,17

Bulimina trinitatensis Cushman and Jarvis, Cushman Lab. Foram. Research Contr., vol. 4, p. 102, pl. 14, figs. 12a, b, 1928; U. S. Nat. Mus. Proc., vol. 80, art. 14, p 44, pl. 13, figs. $4 a, b, 1932$.

Cushman, U. S. Geol. Survey Prof. Paper 2)6, p. 124, pl. 52, fig. 9, 1946.

Test somewhat longer than broad, rounded in transverse section, consisting of about 5 whorls ; chambers distinct, with the lower border extended into an overhanging plate marked on the upper side by an irregular network of reticulate areas, the outer angles enfing in short spines ; wall coarsely perforate, the upper fart of the lastformed chamber smooth; aperture comma-shaped, usually near the apex of the test. Length of holotype $0.54 \mathrm{~mm}$., diameter $0.34 \mathrm{~mm}$.

The types are from the Upper Cretaceous of Lizard Springs, near Guayaguayare, southeastern Trinidad. It occurs also in a well sample from Lizard Springs and in the Velasco shale of Mexico.

The species is very distinct. It differs from Bulimina taylorensis Cushman and Parker in its larger size, more distinct chambers, and the definite reticulation of the wall of the chambers.

\section{Bulimina spinata Cushman and Campbell Plate 20, figure 21}

Bulimina spinata Cushman and Campbell, Cushman Lab. Foram. Research Contr., vol. 11, p. 72, pl. 11, fig. 11, 1935.

Test triserial, short and broad, rapidly enlarging from the acute, initial end to the greatest breadth formed by the last whorl; chambers distinct, strongly inflated, enlerging rapidly as new whorls are developed, each undercut at the base, leaving a distinct ridge near the lower margin; sutures distinct, depressed; wall of the early chambers with numerous, distinct, spinose projections running back onto the chamber wall as raised costae, becoming greatly reduced, and disappearing on the main body of the chamber, last-formed whorl of chambers with the wall smooth; aperture, an elongate, narrow opening, running into the base of 
the last-formed chamber, with a trace of a lateral tooth. Length $0.50 \mathrm{~mm}$.; diameter $0.35 \mathrm{~mm}$.-Cushman and Campbell.

The species was described from the Upper Cretaceous Moreno shale, at a depth of 4500 feet in well, 1 mile north of Tracy, California. Similar forms are found in the Velasco shale of Mexico.

\section{Bulimina laddi Cushman and Hedberg}

\section{Plate 30, figure 5}

Bulimina laddi Cushman and Hedberg, Cushman Lab. Foram. Research Contr., vol. 17, p. 94, pl. 22, figs. 27a-c, 1941.

Cushman, U. S. Geol. Survey Prof. Paper 206, p. 124, pl. 66, fig. 11, 1946.

Test about three times as long as broad, fusiform, consisting of about three whorls, initial end tapering to a point, with a short but distinct spine; chambers distinct, somewhat inflated, rounded, increasing rapidly in height as added, those of the last-formed whorl in the adult making up nearly two-thirds of the size of the test; sutures distinct, depressed; wall smooth, perforate; aperture narrow, elongate, with a slight lip. Length $0.50-0.55 \mathrm{~mm}$. diameter $0.18-0.20 \mathrm{~mm}$.

This species differs from $B$. kickapooensis Cole in the more slender form, higher and narrower chambers, and pointed, spinose initial end.-Cushman and Hedberg.

The types are from the Upfer Cretaceous, upper zone of the Colon formation, Quebrada Mito Juan, Colombia.

\section{Bulimina petroleana Cushman and Hedberg}

Plate 30, figure 6

Bulimina petroleana Cushman and Hedberg, Cushman Lab. Foram. Research Contr., vol. 17, p. 95, pl. 22, figs. 31a-c, 1941.

Cushman and Goudkoff, idem, vol. 20, p. 59, pl. 10, fig. 2, 1944.

Cushman, U. S. Geol. Survey Prof. Paper 206, p. 125, p1. 66, fig. $13,19+6$.

Test about $1 \frac{1}{2}$ times as long as broad, consisting of 6-8 whorls, the greatest diameter above the middle formed by the last whorl of chambers which makes up about half the test, rapidly tapering to the subacute initial end which occasionally has a short spine; chambers distinct, inflated in the later portion, increasing rapidly in size as added; sutures distinct, later ones strongly depressed; wall of the earlier portion ornamented with numerous fine costae, last whorl usually smooth; aperture broadly loop-shaped. Length 0.40-0.45 mm.; diameter $0.25 \mathrm{~mm}$.

This species differs from $B$. arkadelphiana Cushman and Parker, in the more regularly tapering test, the very fine costae and the unornamented last whorl.-Cushman and Hedberg.

The types are from the Upper Cretaceous Colon formation, Quebrada La Petrolea, Colombia. Besides occurring in both zones of the Colon formation, this species also occurs in the Upper Cretaceous of California.

\section{Bulimina limbata White}

\section{Plate 20, figure 19}

Bulimina limbata White, Jour. Paleontology, vol. 3, p. 48, pl. 5, figs. 9a, b, 1929.
Cushman, U. S. Geol. Survey Prof. Paper 206, p. 124, pl. 52, fig. 5, 1946.

Test large, triangular in transverse section, with a rounded apertural end, consisting of about 6 whorls; chambers angular, curved, with raised sutures giving the effect of a series of arches; sutures distinct, strongly raised; aperture loop-shaped, at apex of test. Length of figured specimen $0.84 \mathrm{~mm}$, diameter $0.62 \mathrm{~mm}$.

-White described this species from the Upper Cretaceous Mendez formation, 900 meters west of Internatioral Petroleum Company's well Cacalilao no. 75, Mexico, and from the uppermost beds of the Papagallos shale. We have specimens also from the Velasco shale of Mexico.

\section{Bulimina mendezensis White}

Plate 20, figure 20

Bulimina mendezensis White, Jour. Paleontology, vol. 3, p. 49, pl. 5, fig. 10, 1929.

Cushman, U. S. Geol. Survey Prof. Paper 206, p. 124, pl. 52 , fig. 6, 1946.

Test broadly oval; wall smooth, last chambers relatively large; characterized by a relatively large, round aperture, with a number of slight folds radiating from it. Height of type specimen, C.55 $\mathrm{mm}$; greatest diameter, $0.35 \mathrm{~mm}$.-White.

The species was described from the Upper Cretacec'is Mendez shale of Mexico, where it is rare.

The type specimen has been lost, and it is impossible to compare the available specimens with it. We heve material which agrees well with the figure and description, except that the folds radiating from the aperture are less pronounced.

\section{Bulimina globocapitata Chapman}

Plate 20, figure 18

Bulimina globocapitata Chapman, New Zealand Geol. Survey, Paleontology, Bull. 11, p. 38, pl. 8, figs. 16a, b, 1926.

Test minute, consisting of a sharply tapering aboral series, which rapidly enters into an inflated subglobular terminal series with typical bulimine segments. The aboral end is usually strongly curved or twisted to one side. Surface smooth or polished. Len rth of holotype, $0.38 \mathrm{~mm}$; greatest width, $0.27 \mathrm{~mm}$.-Chapman.

Chapman's species is from the Upper Cretaceous and Eocene of New Zealand. We have no material that can be referred to it. Copies of the original figures are given and it seems probable that the specimen figured is an abnormal one.

\section{Bulimina callahani Galloway and Morrey}

Plate 20, figures 22, 23

Bulimina callahani Galloway and Morrey, Jour. Paleontology, vol. 5, p. 350, pl. 40, fig. 6, 1931.

Martin, Stanford Univ. Publ., Univ. Ser., Geol. Sci., vol. 3, no. 3 , p. 9 (list), 1943. 
Bulimina cf. B. callahani Kelley, Am. Assoc. Petroleum Geologists Bull., vol. 27, p. 8 (list), 1943.

Test robust, ovate; apical end with an angle of about $90^{\circ}$; apertural end rounded; chambers 6 to 8 , very little inflated, rapidly increasing in size as added; sutures very little depressed, not limbate; surface of apical end ornamented with numerous, small costae which disappear in the last two or three chambers, and which curve and join others; between the costae are small ridges, giving a reticulate or coarsely punctate appearance; the apertural end is smooth excepting for medium-sized punctae; aperture a broad and short virguline opening, rarely with short tooth. Length, $0.31 \mathrm{~mm}$.; breadth, $0.24 \mathrm{~mm}$.

This species is differentiated from all other described species of the genus by its ornamentation. It resembles $B$. velascoensis (Cushman) but the early portion is conical rather than pyramidal, the striae are stronger, reach higher but are less regular, and in having the cross bars between the striae.-Galloway and Morrey.

The species was described from the "Upper Cretaceous" near Puenta Piedra, on the Rio Puscatan, 19 kilometers south of Macuspana, Tabasco, Mexico.

We have, from a Mexican locality described as exhibiting reworked Papagallos shale, one specimen that is similar to a specimen in Galloway and Morrey's type slide. It differs in having less well defined costae and a more pointed initial end. It is figured, together with a copy of the original figure.

The species is recorded from the Eocene of California.

\section{Bulimina tabascoensis Galloway and Morrey}

Plate 20, figure 24 ; plate 21 , figure 6

Bulimina tabascoensis Galloway and Morrey, Jour. Paleontology, vol. 5, p. 352, pl. 40, fig. 11, 1931.

Test robust, pyriform, apical end bluntly pointed, apertural end inflated; chambers six to eight, slightly inflated, rapidly increasing in size as added; wall thick, coarsely perforate; surface of apical end covered with about sixteen short, obscure costae which fade out in the last third of the test; aperture a broad comma-shaped opening on the inner face of the last chamber. Length, 0.2-0.35 mm.; breadth, 0.14-0.28. mm. Common.

This species differs from $B$. buchiana (D'Orbigny) in having a wider angle at the apical end, less regular costae, and more rounded apical end. It differs from $B$. velascoensis (Cushman) in not being triangular, the sutures are distinct, and the costae are coarser. It differs from $B$. callahani $\mathrm{n}$. $\mathrm{sp}$. in the finer but more regular costae, making the surface sculpture much less ornate. It might be considered as a variety of $B$. callahani.-.-Galloway and Morrey.

The species was described from the Cretaceous(?), near Puenta Piedra, on the Rio Puscatan, 19 kilometers south of Macuspana, Tabasco, Mexico. We have two specimens from the Velasco shale of Mexico that resemble this species. One of these is figured here and a copy of the original figure is also given.

\section{Bulimina ezoensis Yokoyama}

Plate 20, figure 25

Bulimina ezoënsis Yokoyama, Palaeontographica, vol. 36, p. 190, pl. 24, figs. 5a-c, 1890 .
Test broadly fusiform, rounded at both ends, rounded in transverse section; chambers of last-formed whorl inflated, the 2 last-formed making up the greater part of the test, sharply separated by deep sutures, covering about two-thirds of the preceding chambers; apertural face oval, with a comma-shaped aperture; rall polished. Length of largest specimen $1.60 \mathrm{~mm}$.

A summary of Yokoyama's description is given. The species was described from the "Cretaceous" of Poronai and Ezo, Japan. As there is no typical material available it is impossible to verify the age.

\section{Bulimina schwageri Yokoyama}

Plate 20, figures 26-28

Bulimina schwageri Yokoyama, Palaeontographica, vol. 36, p. 190, pl. 24, figs. 6a, b, 7a, b, 8a, b, 1890.

Test ellongate, cylindrical, rounded at the sides, the smaller chambers giving an irregular apparance; early chambers rounded, inflated, increasing rapidly, later ones uniform, in 2 rows about the elongate axis; sutures deeply excavated; aperture oblique, comma-shaped, in a depression of the high, semicircular apertural face.

A summary of Yokoyama's description of the species from the "Cretaceous" of Ezo and Poronai, Japan, is given. The age is questionable, but a lack of topotype material makes it impossible to verify it. The species appears to be identical with Bulimina elongata D'Orbigny.

\section{Bulimina baccata Yokoyama}

Plate 20, figure 29

Bulimina baccata Yokoyama, Palaeontographica, vol. 36, p. 190, pl. 24, figs. 9a-c, 1890.

Test an elongate oval spiral, increasing rapidly in size from the early stage to the later rounded clambers, which appear to be sharply separated by the deaply depressed sutures; apertural face semicircular, the aperture, in the specimens examined, not clearly defined. Bulimina baccata may be distinguished from previously described species by its more inflated chambers and their more rapid increase in size.

A summary of Yokoyama's original description is given. The species was described from tho "Cretaceous" of Ezo, Japan. There is some question as to whether the material is actually Cretaceous or not, but as we have no material a definite decision cannot be made.

\section{Bulimina capitata Yokoyama}

Plate 20, figure 30

Bulimina capitata Yokoyama, Palaeontographica. vol. 36, p. 190 , pl. 24, fig. 10, 1890.

Test with nearly spherical chambers distinguished from previously described Buliminas by the rapidly taper- 
ing initial end, the large size of the last-formed chamber. which makes up a large proportion of the test, and the triangular shape of the test. The test is characteristically curving, the later chambers increasing rapidly in size, but not to the extent seen in Bulimina baccata Yokoyama. The apertural face is large, semicircular, and obliquely placed, but the aperture itself was not observed. Length $0.26 \mathrm{~mm}$.

This is a summary of Yokoyama's description of a form from the "Cretaceous" of Ezo and Poronai, Japan. Lack of material makes a definite determination of age impossible.

\section{Bulimina polymorphinoides Yokoyama}

Plate 20, figure 31

Bulimina polynorphinoides Yokoyama, Palaeontographica, vol. 36, p. 191, pl. 24, fig. 11, 1890.

Test broadly fusiform, both ends bluntly pointed, resembling in general a narrow, Polymorphina-like form, distinguished from Bulinina capitata by the lateral position of the broadly elongate chambers, the pointed upper end, and the aperture which broadens at the lower end. This form has a rounded transverse section, a polished wall, and consists of very rapidly increasing, inflated, elongate, oval chambers, the last 2 making up the greater part of the test. The sutures are indistinct in the early stages, more distinct in the later portion. The aperture is small and comma-shaped. Length 0.15 to $0.25 \mathrm{~mm}$.

Yokoyama's description of the species from the "Cretaceous" of Ezo, Japan is summarized. Lack of material makes it impossible to check the age, which is questionable.

\section{Bulimina truncana Gümbel}

Plate 21, figures 7,8

Bulimina truncana Gümbel, K. bayer. Akad. Wiss. Abh., cl. 2, vol. 10 , p. 644 , pl. 2, figs. 77a, b, 1870 .

Hantken, K. ungar. geol. Anstalt. Mitt. Jahrb., vol. 4, p. 61 , pl. 7, fig. 5, 1881.

Protescu, Soc. Nat. Roumania, Pub. 11, p. 26, pl. 4, figs. 11-13, 1932.

Cushman and Parker, Cushman Lab. Foram. Research Contr., vol. 13, p. 66, pl. 9, fig. 3, 1937.

Colom, Inst. Invest. Geol., Num. 2 Estudios Geologicos, p. 70, pl. 4, figs. 83, 84, 1945.

?Bulimina rostrata Cushman (not $\mathrm{H}$. B. Brady), Cushman Lab. Foram. Research Contr., vol. 5, p. 94, pl. 13, fig. 32, 1929.

Bulimina corrugata Cushman (not Cushman and Siegfus), Cushman Lab. Foram. Research Contr., vol. 15, p. 64, 1939.

Test small, about $1 \frac{1}{2}$ times as long as broad, very rapidly tapering to the acute, initial end, somewhat triangular in transverse section, apertural end obliquely truncate; chambers indistinct, little if at all inflated, regularly triserial; sutures indistinct; wall ornamented by 10 to 12 longitudinal, acute costae, running from the initial end to the base of the smooth, last-formed chamber, independent of the sutures and chambers; aparture broadly loop-shaped, with a slight lip. Length up to $0.40 \mathrm{~mm}$., diameter up tỏ $0.20 \mathrm{~mm}$.

The types are from the Eocene of Hammer, Bavaria. The species is found in the Clavulina szaboi beds of Hantken, near Budapest, Hungary. We have specimens from the Eocene of Biarritz, France which are somewhat larger and more slender than the typical. It occurs in the Eocene of the Atlantis cores 12-36 and 21-38 taken off the eastern coast of the United States. The specimens in the former have been recorded as Bulimina corrugata Cushman and Siegfus.

A comparison of this species with Bulimina alazanensis. Cushman is given under the latter species.

\section{Bulimina truncana Gümbel var. angusta Grzybowski}

Bulimina truncana Gümbel var. angusta Grzybowski, Akad. umi॰j., Wydz. Mat.-Przyr., Rozpr. vol. 9, p. 189, pl. 2, fig. 11 [pl. 1 in text], Krakow, 1894.

The types of the variety are from the Eocene? of Dukla, Hungary. The figures are so poor that a posit've identification is impossible. It is impossible even to state definitely to what genus they should be referred, although the character of the aperture and the arrangement of the chambers are apparently not bulimine.

Bulimina truncana Gümbel var. denticulata Protescu

Bulimina truncana Gümbel var. denticulata Protescu, Soc. Nat. Roumania, Pub. 11, p. 26, pl. 4, fig. 16, 1932.

In addition to our examples of Bulinina truncana Gümbe ${ }^{1}$ a few specimens are found which differ from the typical by the larger, shorter test, formed of more inflated chambers, or namented with longitudinal costae which stop half way up the test and are terminated at the bottom by spines.-Protescu (translated).

The types of the variety are from the Eocene of the Tintea region (District Prahova), Roumania. We have no material referable to it. The figure given is almost unrecognizable.

\section{Bulimina simplex Terquem}

Plate 21, figure 9

Bulimina simplex Terquem, Soc. géol. France Mém., ser. 3, vol. 2, p. 109, pl. 11(19), figs. 23, (24?), 1882.

Cushman and Parker, Cushman Lab. Foram. Research Contr., vol. 13, p. 67, pl. 9, fig. 4, 1937.

Cushman and Todd, idem, vol. 21, p. 17, pl. 4, fig. 5, 1945.

Test of medium size, elongate, tapering from the actute initial end to the greatest breadth at the last-form:d whorl, about $2 \frac{1}{2}$ times as long as broad, consisting of 5 or 6 whorls in the adult; chambers distinct, inflated, 
regularly triserial, increasing rather uniformly in size as suded; sutures distinct, depressed; wall smooth, very finely perforate; $;$ aperture large, somewhat quadrate, with a slight tooth and a slight, but definite, lip, in a distinct depression of the apertural face. Length of Terquem's figured specimens $0.29 \mathrm{~mm}$., $0.30 \mathrm{~mm}$.; diameter $0.14 \mathrm{~mm}$., $0.18 \mathrm{~mm}$.. Length of our specimens 0.30 to $0.40 \mathrm{~mm}$., diameter 0.13 to $0.17 \mathrm{~mm}$.

The types of the species are from the Eocene of the Paris Basin at Vaudancourt. We have specimens from various localities of the Paris Basin. The figured specimens are from Cuise La Motte. Specimens that appear identical were found in the Eocene Lisbon formation of Monroe Co., Alabama.

The form is very close to Bulimina elongata D'Orbigny but differs from it in the regular triserial arrangement of the chambers, the broader aperture, and in the shape of the test, which is usually more tapering, with a broader apertural end. The two species both occur in the Eocene of the Paris Basin but are easily differentiated by the above characteristics.

\section{Bulimina longiscata Terquem}

Plate 21, figures 10,11

Bulimina longiscata Terquem, Soc. géol. France Mém., ser. 3, vol. 2, p. 109, pl. 11(19), figs. 25, 26, 1882.

Cushman and Parker, Cushman Lab. Foram. Research Contr., vol. 13, p. 72, 1937.

Test elongate, straight, slightly conical, rounded at the ends, with subparallel sides, consisting of 5 indistinct whorls; chambers short, inflated; aperture funnel-shaped. Length of figured specimens $2.00 \mathrm{~mm}$., $0.58 \mathrm{~mm}$; diameter $0.54 \mathrm{~mm}$., $0.16 \mathrm{~mm}$.-Terquem (translated).

The types are from the Eocene of the Paris Basin at Vaudancourt. We have no typical material.

Terquem's description of the aperture as "funnelshaped" suggests that the form may belong to the UV vigerina group. Terquem's figures are reproduced here.

\section{Bulimina obscura Terquem}

Plate 21, figure 12

Bulimina obscura Terquem, Soc. géol. France Mém., ser. 3, vol. 2, p. 111, pl. 11(19), figs. 32a, b, 1882.

Cushman and Parker, Cushman Lab. Foram. Research Contr., vol. 13, p. 72, 1937.

Test conical, smooth, subangular at the bottom, wider at the top, all the whorls and chambers indistinct, the last 4 chambers rounded on the top; aperture round, very small, in a round depression without a definite edge. Length $0.61 \mathrm{~mm}$., diameter 0.44 mm.-Terquem (translated).

The types are from the Eocene of the Paris Basin at Vaudancourt. We have no material referable to the species.

It seems doubtful if this species belongs to the genus Bulimina. Terquem's figures are reproduced.

\section{Bulimina oviformis Terquem}

Plate 21, figure 13

Bulimina oviformis Terquem, Soc. géol. France Mém., ser. 3, vol. 2, p. 112, pl. 12(20), fig. 3, 1882.

Cushman and Parker, Cushman Lab. Foram. Research Contr., vol. 13, p. 72, 1937.

Test regularly oval, rounded at the top, narrcw and obtuse at the bottom, composed. of 4 whorls with non-infleted chambers; chambers curved; sutures filiform, indistinct; ape-ture an elongate slit, placed in a cavity at the front. Length $0.64 \mathrm{~mm}$.; diameter $0.36 \mathrm{~mm}$.-Terquem (translated).

The types are from the Eocene of the Paris Basin at Septeuil. We have no material referable to the species. Terquem's figure is reproduced.

\section{Bulimina glanduliformis Terquem}

Plate 21, figure 15

Bulimina glanduliformis Terquem, Soc. géol. France Mém., ser. 3, vol. 2, p. 113, pl. $12(20)$, fig. 4, 1882 .

Cushman and Parker, Cushman Lab. Foram. Research Contr., vol. 13, p. 72, 1937.

Test oval, glandular in shape, equally rounded at the ends, curved on the sides, polished, translucent, consisting of indistinct whorls; chambers smooth, curved, the 2 chambers surrounding the aperture slightly projecting at the top; aperture linear, in a depression which is oval at the top and pointed at the bottom, placed in the middle of the front side of the test. Length 0.48 $\mathrm{mm}$.; diameter $0.21 \mathrm{~mm}$.-Terquem (translated).

The types are from the Eocene of the Paris Basin at Septeuil.

The figure given by Terquem is reproduc?d, though it is poor and obviously inaccurate.

\section{Bulimina splendens Terquem}

Plate 21, figure 14

Bulimina splendens Terquem, Soc. géol. France Mém., ser. 3, vol. 2, p. 117 , pl. $12(20)$, fig. $20,1882$.

Cushman and Parker, Cushman Lab. Foram. Research Contr., vol. 13, p. 73, 1937.

Test incomplete, elongate, white, polished, translucent, ornamented with very fine, numerous perforations, rounded at the top, with straight sides, composed of projecting, oval chambers; aperture quadrate, in an oblique depression, ovally pointed, placed at the front of the apertural face. Length $0.42 \mathrm{~mm}$; diameter $0.16 \mathrm{~mm}$.-Terquem (translated).

The types are from the Eocene of the Paris Basin at Septeuil.

The single specimen described by Terqu'm is inadequate for definite identification. His figure is reproduced.

\section{Bulimina decorata Terquem}

Plate 21, figure 16

Bulimina decorata Terquem, Soc. géol. France Mém., ser. 3, vol. 2, p. 117, pl. 12(20), fig. 22, 1882. 
Cushman and Parker, Cushman Lab. Foram. Research Contr., vol. 13, p. 73, 1937.

Test regularly oval, rounded at the top and obtuse at the bottom, curved on the sides, ornamented by fine, curved costae, consisting of indistinct whorls; chambers inflated, projecting, depressed, irregularly arranged; aperture rounded, placed between two chambers. Length $0.54 \mathrm{~mm}$; diameter $0.35 \mathrm{~mm}$.-Terquem (translated).

The types are from the Eocene of the Paris Basin at Septeuil. We have no typical material. -

It is possible that the form is a variation of Bulimina tenuistriata Terquem. His figure is reproduced.

\section{Bulimina tenuistriata Terquem}

Plate 21, figure 17

Bulimina temistriata Terquem, Soc. géol. France Mém., ser. 3, vol. 2 , p. 118 , pl. $12(20)$, figs. $24,25,1882$.

Cushman and Parker, Cushman Lab. Foram. Research Contr., vol. 13 , p. 70 , pl. 10, figs. 6a-c, 1937.

Test of medium size, tapering, the initial end subacute or slightly rounded, apertural end broadly truncate, about $11 / 2$ times as long as broad; chambers in early portion indistinct and slightly inflated, in later one distinct, more inflated; sutures, except in the later portion, indistinct, slightly depressed in the later portion; wall ornamented by fine lines or ridges, usually parallel to the middle longitudinal line of the chamber, those of each chamber distinct from adjacent ones; aperture small, in a distinct depression of the apertural end of the test. Length of Terquem's figured specimens $0.50 \mathrm{~mm}$., $0.54 \mathrm{~mm}$.; diameter $0.35 \mathrm{~mm}$., $0.36 \mathrm{~mm}$. Length of our specimens 0.34 to $0.45 \mathrm{~mm}$, diameter 0.20 to $0.30 \mathrm{~mm}$.

The types are from the Eocene of the Paris Basin at Vaudancourt. We have specimens from several localities in the Paris Basin.

The species bears no close resemblance to any other. Some of the characteristics approach Buliminella, namely the four-chambered whorl and the character of the aperture, but the complete absence of a spiral suture makes it inadvisable to place it in that genus.

\section{Bulimina trigona Terquem}

Plate 21, figure 18

Bulimina trigona Terquem, Soc. géol. France Mém., ser. 3, vol. 2, p. 110 , pl. 11(19), figs. $28,29,1882$.

Cushman and Parker, Cushman Lab. Foram. Research Contr., vol. 13, p. 67 , p1. 9, fig. $5,1937$.

Cushman and Todd, idem, Contr., vol. 21, p. 17, pl. 4, fig. 6, 1945.

Test nearly twice as long as broad, regularly triserial, rather regularly tapering from the subacute initial end to the greatest breadth formed by the last 2 chambers, periphery rounded; chambers distinct, inflated, increasing rapidly in height and size as added, the last whorl in front view making up nearly the whole surface of the test; sutures distinct, depressed; wall smooth; aperture a rounded opening, somewhat longer than broad, with a slight lip, narrowest at the base of the apertural face. Length 0.42 to $0.58 \mathrm{~mm}$., diameter 0.28 to $0.35 \mathrm{~mm}$.

The types are from the Eocene of the Paris Basin at Vaudancourt. We have specimens from Vaudancourt and Beauves which agree in size and character with Terquem's species, with the exception of the aperture, which, in his figure, is quite obviously inaccurately drawn. The species occurs in the Eocene Lisbon formation of Morroe Co., Alabama.

The rapidly tapering test, the regularly arranged chambers, and the large proportion of the test occupied by the last whorl differentiate this form.

\section{Bulimina bellardii Hantken}

Bulinina bellardii Hantken, Ertek. Termész. köreböl, vol. 13, p. 27, pl. 2, figs. 2a, b, 1883; Math. Naturwiss. Ber. Ungarn., vol. 2, p. 148, 1884.

The species was described from the Eocene, Clavulina szaboi beds of Hungary. We have no typical material.

\section{Bulimina “minuta Hantken"}

Bulimina minuta Hantken (not Marsson), Ertek. Termész. köreböl., vol. 13, p. 28, pl. 1, figs. 6a, b, 1883; Math. Naturwiss. Ber. Ungarn., vol. 2, p. 148, 1884

Hantken figures this species from the Eocene Clavulina szaboi beds of Hungary. We have no material referable to it. The name is a homonyn of $B$. minuta (Marsson) 1878 , but it does not seem desirable to replace it now.

\section{Bulimina selseyensis Heron-Allen and Earland}

Plate 21, figures 19, 20

Bulimina selseyensis Heron-Allen and Earland, Royal Micr. Soc. Jour., 1911, p. 313, pl. 10, figs. 1, 2.

The authors describe this species as similar to Uvigerina selseyensis but state that it has the Bulimina type of aperture and a broader, stouter test, consisting of "four or five convolutions of heart-shaped chambers arranged around a spiral axis," and that it has deeply undercut sutural lines. The length is given as $0.25 \mathrm{~mm}$., diameter $0.20 \mathrm{~mm}$. ("nearly").

The species is described from shore-sands of Se'sey Bill, England, and as Eocene in age. We have no material referable to it.

The structure of the test seems to be entirely uvige-ine with the exception of the aperture.

\section{Bulimina versa Cushman and Parker}

$$
\text { Plate 21, figures 21, } 22
$$

Bulimina versa Cushman and Parker, Cushman Lab. Foram. Research Contr., vol. 16, p. 47, pl. 8, figs. 15a-c, 16a-c, 1940. 
Test small, triangular in transverse section, with rounded angles and slightly concave sides, somewhat twisted about the vertical axis, with a small, well developed, basal spine; chambers distinct, somewhat inflated; sutures distinct, depressed; wall of first half of test very finely costate, latter half coarsely perforate, almost punctate in appearance; aperture small, loopshaped, at apex of test. Length 0.25 to $0.30 \mathrm{~mm}$., diameter 0.12 to $0.15 \mathrm{~mm}$.

The types are from Eocene, Montian, Les Moulineaux, Department of Seine, France. The species is not known elsewhere.

The triangular character of the test, the finely costate initial end, and the basal spine make it easy to recognize this form.

\section{Bulimina eccentrica Cushman and Parker \\ Plate 21, figure 23}

Bulimina eccentrica Cushman and Parker, Cushman Lab. Foram. Research Contr., vol. 16, p. 46, pl. 8, figs. 12a-c, 1940.

Test of medium size, slightly less than twice as long as broad, tapering, with the widest portion at the middle of the last-formed whorl, initial end bluntly rounded, consisting of 4 whorls, the last-formed whorl making up at least $2 / 3$ of the test; chambers distinct, those of early whorls not inflated, the last whorl very much inflated, so the sudden increase in diameter between the early whorls and the last is very marked; sutures distinct, those of last whorl depressed; wall smooth, rather coarsely perforate; aperture large, broadly loop-shaped. Length of holotype $0.65 \mathrm{~mm}$., diameter $0.25 \mathrm{~mm}$.

The types of this species are from the Eocene, Calcaire Grossier inférieur, St. Félice, Department of Oise, France. It occurs at many localities in the Paris Basin Eocene.

The species is easily differentiated from others by the sudden inflation of the last-formed whorl.

Bulimina thanetensis Cushman and Parker, n.sp.

Plate 21, figure 26

Test long, slender, slightly tapering, initial portion somewhat angled with rounded angles, consisting of 6 to 8 whorls of regularly arranged chambers, test somewhat twisted on its elongate axis; chambers distinct, angled, very slightly inflated; sutures distinct, slightly depressed; wall transculent, coarsely perforate; aperture elongate, narrow, at the apex of the test. Length up to $0.43 \mathrm{~mm}$., diameter up to $0.25 \mathrm{~mm}$.

Holotype (Cushman coll. no. 35855) from the Eocene, Thanet beds, Pegwell Bay, England. Besides the type locality we have one specimen from the Eocene of Gotzreuther Graben, Germany.
The species is much more elongate and slender than Bulimina tuberculata Egger, is more rounded in transverse section, has less globular chambers, and a smaller aperture on the smaller, more narrow apertural end. The wall, though coarsely perforate, does not have the punctate character of Egger's species.

\section{Bulimina arkadelphiana Cushman and Parker var. midwayensis Cushman and Parker}

Plate 21, figures 24,25

Bulimina arkadelphiana Cushman and Parker var. midwayensis Cushman and Parker, Cushman Lab. Foram. Research Contr., vol. 12, p. 42, p1. 7, figs. 9, 10, 1936.

Cole, Florida Dept. Cons. Geol. Bull. 16, p. 3? (list), pl. 1, fig. 14, 1938.

Kline, Mississippi Geol. Survey .Bull. 53, p. 77, pl. 7, fig. 9, 1943.

Bulimina aculcata Plummer (not D'Orbigny), Univ. Texas Bull. 26+4, p. 73, pl. 4, fig. 3, 1927.

This variety differs from the typical form in the more inflated and higher last-formed whorl, and in the presence of a basal spine.

The types are from the Paleocene Midway formation, road cut south of Reservoir, $31 / 2$ miles southeast of Corsicana, Texas. The species is found at soveral localities in the Midway formation.

\section{Bulimina cacumenata Cushman and Frrker}

Plate 21, figure 27

Bulimina cacumenata Cushman and Parker, Cushman Lab. Foram. Research Contr., vol. 12, p. 40, pl. 7, figs. 3ę-c, 1936.

Cushman and Todd, idem, vol. 18, p. 37, 1942.

Kline, Mississippi Geol. Survey Bull. 53, p. 47, pl. 7, fig. 8, 1943.

Cushman and Todd, Cushman Lab. Foram. Research Contr., vol. 22, p. 59, pl. 10, fig. 20, 1946.

Bulimina cf. cacumenata Cushman, idem, Special Pub. 16, p. 23, pl. 5, fig. 3, 1946.

Test small, somewhat fusiform, greatest width slightly above the middle, gradually tapering to a long, subacute point, consisting of 6 to 7 whorls; chambers arranged in a slightly twisted series, those of adjacent saries meeting in a zigzag line, those of the last whorl somewhat inflated; sutures distinct in the upper part, obscure in the lower part of the test, very slightly depressed; wall, except for the last whorl and occasionally for the next to the last, covered with irregular, low, closely set costae, last whorl smooth, coarsely perforate; aperture loopshaped, with a slight lip. Length 0.20 to $0.23 \mathrm{~mm}$., diameter 0.10 to $0.11 \mathrm{~mm}$.

The types of the species are from the Paleocene Midway formation, 3 miles above bridge over Cedar Creek, on Austin-Red Rock road, Bastrop County, Texas. We have specimens also from the Eocene, Pit in San Mateo, 
Santa Elena, Ecuador. It has also been recorded from the Paleocene Naheola formation of Alabama.

This species differs from Bulimina semicostata Nuttall in the much smaller, narrow test, the more inflated chambers, and in the shape of the chambers, which are distinctly angled. It is much smaller and more coarsely costate than B. microcostata Cushman and Parker.

\section{Bulimina kugleri Cushman and Renz}

Plate 30 , figure 13

Bulimina kugleri Cushman and Renz, Cushman Lab. Foram. Research Contr., vol. 18, p. 9, pl. 2, figs. 9a-c, 1942.

Test elongate, fusiform, about twice as long as broad, greatest breadth at about the middle; chambers distinct, slightly inflated, elongate; sutures distinct, very slightly depressed; wall smooth; aperture a high, arched, slightly curved opening at the base of the inner margin of the last-formed chamber. Length of holotype $0.50 \mathrm{~mm}$. ; diameter $0.23 \mathrm{~mm}$.

Our species differs from $B$. quadrata Plummer in the more distinctly fusiform shape, subacute at the ends; and the high, curved aperture.-Cushman and Renz.

The types of this species are from-the Paleocene of Soldado Rock, Trinidad.

\section{Bulimina semicostata Nuttall}

Plate 21, figures 28,29

Bulimina semicostata Nuttall, Jour. Paleontology, vol. 4, pp. 274, 285, pl. 23, figs. 15, 16, 1930.

Parker and Bermúdez, Jour. Paleontology, vol. 11, p. 513, pl. 58, figs. 3a-c, 1937.

Bermúdez, Soc. cubana historia nat. Mem., vol. 11, p. 342, 1937.

Renz, 8th Am. Sci. Congress Proc., p. 537 (list), 1942.

Test of medium size, fusiform, 2 or more times as long as broad, initial end pointed, consisting of about 5 whorls; chambers indistinct except for those of last whorl; sutures indistinct except for last whorl, very slightly depressed; wall, except for last whorl, covered with fine, low, irregular costae, last whorl smooth, perforate; aperture loop-shaped, with a slight lip. Length 0.40 to $0.60 \mathrm{~mm}$., diameter 0.28 to $0.32 \mathrm{~mm}$.

The types of the species are from the Eocene Aragon formation of Mexico, Grimsdale 409 (Francia-Aragon), 720 meters S. $70^{\circ} \mathrm{W}$. of La Antigua. Nuttall also describes it as being frequent in the Chapapote formation and rare in the Guayabal. Besides Nuttall's localities it has been reported from the Eocene of $\mathrm{Cuba}$ and Trinidad. A similar form occurs in the Eocene material of the Atlantis core 21-38, taken off the eastern -coast of North America.

This species differs from Bulimina cacumenata Cushman and Parker in its much larger size. It differs from $B$. jarvisi Cushman and Parker in being smaller, more fusiform, less triangular in transverse section, and in having less inflated and less globular chambers that are somewhat morè angled.

\section{Bulimina semicostata Nuttall var. crassicosta Parker and Bermúdez \\ Plate 22, figure 1}

Bulimina semicostata Nuttall var. crassicosta Parker and Bermúdez, Jour. Paleontology, vol. 11, p. 513, pl. 58, figs. 4 a-c, 1937.

Bermúdez, Soc. cubana historia nat. Mem., vol. 11, p. 3+2, 1937.

Variety differing from the typical form in its larger size and the presence of fewer, heavier costae. Length 0.44 to $0.80 \mathrm{~mm}$., diameter 0.24 to $0.38 \mathrm{~mm}$.

The types are from the Eocene Alturas de Almendares quarry, Havana, Cuba. The variety is known only from the Eocene of Cuba.

\section{Bulimina corrugata Cushman and Siegfus}

Plate 22, figure 2

Bulimina corrugata Cushman and Siegfus, Cushman Lab. Foram. Research Contr., vol. 11, p. 92, pl. 14, figs. 7a, b, 1935.

Cushman, idem, vol. 15, p. 64, 1939.

Cushnan and Siegfus, San Diego Soc. Nat. History Trans., vol. 9, no. 34, p. 411, pl. 16, figs. 38a, b, 1942.

Curran, Am. Assoc. Petroleum Geologists Bull., vol. 27, pp. 1378, 1381 (lists), 1943.

Weaver, Washington Univ. [Seattle] Pub. in Geology, vol. 6, no. 1, p. 23 (list), 1944.

Test elongate, slightly tapering, fusiform, greatest breadth above the middle, somewhat triangular in transverse section, angles bluntly rounded; chambers indistinct except for the last 3 which are somewhat inflated, rather low, and only slightly overlapping; sutures indistinct except in the later portion, where they are depressed; wall covered by longitudinal costae, which are high and sharp, running from the initial end to the base of the last-formed chamber, continuous over the sutures; last-formed chamber smooth, distinetly perforate; aperture a rather broad, elongate opening, slightly, if at all, curved, with a slight lip. Length 0.35 to $0.45 \mathrm{~mm}$., diameter $0.25 \mathrm{~mm}$.

The types of the species are from the Eocene Kreyenhagen shale, Lower Garza Creek, California, 573 feet below the top of the Kreyenhegen. Besides the type locality it occurs at Gaviota Canyon, Santa Barlara County, California, about 400 feet stratigraphically below the top of a massive sandstone bed carrying Turritella variata Conrad and other California localities. It also occurs in Eocene material from one of the Atlantis ocres.

This species most closely resembles Bulimina rost'ata H. B. Brady but differs from it in having a bluntly rounded initial end and a more flattened, less pointed apertural end. 


\section{Bulimina bradyi Weinzierl and Applin}

Plate 22, figure 3

Bulimina bradyi Weinzierl and Applin, Jour. Paleontology, vol. 3, p. 404, pl. 43, fig. 7, 1929.

?Bulimina cf. B. sculptilis Cushman and McMasters, Jour. Paleontology, vol. 10, p. 513, pl. 75, figs. 27a, b, 1936.

Test of medium size, $1 \frac{1}{3}$ times as long as broad, tapering fairly rapidly from the widest point approximately one-fifth of the distance from the top of the test, consisting of about 6 whorls; chambers distinct, slightly inflated, those of last whorl composing about three-fifths of the test; sutures distinct, very slightly depressed, showing as dark lines; wall ornamented by 10 , low, regular, platelike costae which extend from the initial end to halfway up the last-formed whorl, finely perforate; aperture loopshaped, with a distinct lip. Length of holotype $0.44 \mathrm{~mm}$., diameter $0.32 \mathrm{~mm}$.

The types of the species are from the Eocene Claiborne group, Rio Bravo Oil Company's well, Deussen B. 1, 4010 feet, South Liberty Dome, Liberty County, Texas. The form recorded by Cushman and McMasters from the Eocene Llajas formation, Ventura County, California, is tentatively placed here.

The species differs from Bulimina jacksonensis Cushman in having a larger number of lower, more regular costae. It is much smaller and more tapering than $B$. sculptilis Cushman, though it seems possible that it might represent an immature specimen of the latter species. The form has been described from the holotype, which is the only specimen we have definitely referable to the species. It is refigured here.

\section{Bulimina mauricensis Howe}

Plate 22, figure 4

Bulimina mauricensis Howe, Louisiana Dept. Cons. Geol. Bull. 14, p. 62, pl. 8, figs. 29, 30, 1939.

Test short-fusiform, pointed at both ends, broadest in the middle, composed of a few elongate, somewhat inflated chambers, smooth; sutures depressed; aperture an oblique slit, subterminal, with a tendency to form a lip on either side of the slit.-Howe.

Length of holotype $0.40 \mathrm{~mm}$., diameter $0.20 \mathrm{~mm}$.

The types are from the Eocene Cook Mountain formation, St. Maurice, Winn Parish, Louisiana. We have no typical material.

The species seems to bear a close resemblance to Bulimina ovata D'Orbigny, which occurs in the Jackson formation.

\section{Bulimina winniana Howe}

Plate 22, figure 5

Bulimina winniana Howe, Louisiana Dept. Cons. Geol. Bull. 14, p. 64, pl. 8, fig. 31, 1939.
Bulimina ovata Cole and Gillespie (not D'Orbigny), Bull. Am. Paleontology, vol. 15, no. 57b, p. 10(132), p1. 2, fig. 5, 1930. ?Bulimina pyrula Ellisor (not D'Orbigny), Am. A ssoc. Petroleum Geologists Bull., vol. 17, pl. 3, fig. 2, 1933.

Test small, ovate, broadest below the middle, with a short, broad initial end and a more tapering apertural end; composed of a few smooth chambers; wall thin, perforate; aperture a high slit extending into the apertural face from the base of the last chamber.-Howe.

Length of holotype $0.33 \mathrm{~mm}$., dianeter $0.20 \mathrm{~mm}$.

The types are from the Eocene Cook Mountain formation sample no 37, St. Maurice, Winn Parish, Louisiana. The species occurs, questionably, in the Eocene Jackson formation of Texas. It occurs in the Oligocene Meson formation of Mexico, and similar forms are found in the Red Bluff clay at Hiwannee, Mississippi.

Howe differentiates this form from Bulimina guayabalensis Cole and separates the Guayal al specimens entirely. He describes the latter as being more elongate, with the chambers tending to be added at greater distances from the initial end. We have, howerer, specimens from the Guayabal formation referable to both species. $B$. winniana is smaller, more fusiform, and has fewer, more ovate chambers.

\section{Bulimina curtissima Cushman and Siegfus}

Plate 22, figure 6

Bulinina curtissima Cushman and Siegfus, Cushrian Lab. Foram. Research Contr., vol. 11, p. 93, pl. 14, fig̨s. 9a, b, 1935; San Diego Soc. Nat. Hist. Trans., vol. 9, p. 412, pl. 17, figs. 2a, b, 1942.

Test short and broad, only slightly longer than broad, fusiform in front view, greatest breadth somewhat below the middle, thence tapering to either end, in tial end acute and spinose; chambers comparatively few, strongly inflated, increasing rapidly in size as added, the last whorl making a very large part of the surface of th: test, greatly overlapping; sutures distinct, slightly depressed; wall ornamented, at the base of the chambers, by a few, short spines, otherwise smooth, finely perforate; aperture elongate, slightly curved, with a slight lip. Length 0.30 to $0.35 \mathrm{~mm}$., diameter 0.22 to $0.25 \mathrm{~mm}$.

The species was described from the Eorene Kreyenhagen shale, Upper Garza Creek, California, 83 feet below the top of the Kreyenhagen. It is known only from the type locality.

This species differs from Bulimina cooporensis Cushman in being much shorter, more fusiform, and in having no costae.

\section{Bulimina garzaensis Cushman and Siegfus}

Plate 22, figure 7

Bulimina garzaensis Cushman and Siegfus, Cushman Lab. Foram. Research Contr.. vol. 11, p. 93, pl. 14, figs. \{a, b. 1935: San 
Diego Soc. Nat. Hist. Trans., vol. 9, no. 34, p. 412, pl. 17, figs. 1a, b, 1942.

Test fusiform, greatest breadth above the middle, nearly circular in transverse section, initial end subacute or acute with a short spine, apertural end usually somewhat truncately rounded; chambers fairly distinct, especially toward the apertural end where they are inflated; sutures of the earlier portion indistinct, later somewhat depressed; wall except for the last whorl of chambers ornamented by longitudinal costae which are largely confined to the individual chamber to form an irregular reticulate pattern of variously shaped, depressed areas; aperture somewhat longer than broad, slightly curved, with a raised lip. Length $0.50-1.00 \mathrm{~mm}$.; diameter 0.30-0.65 mm.-Cushman and Siegfus.

The types are from the Eocene Kreyenhagen shale, Garza Creek, California. We have no other material referable to the species.

A study of the type specimens shows that the holotype differs considerably from the paratypes. The latter have been referred to Bulimina consanguinea Parker and Bermúdez. The holotype bears considerable resemblance to Bulimina corrugata Cushman and Siegfus but has a thicker-walled test with heavier, more irregular costae.

\section{Bulimina adamsi Cushman and Parker}

\section{Plate 22, figure 8}

Bulinina adamsi Cushman and Parker, Cushman Lab. Foram. Research Contr.. vol. 12, p. 41, pl. 7, figs. 6a-c, 1936.

Kelley, Am. Assoc. Petroleum Geologists Bull., vol. 27, p. 11 (list), 1943.

Test small, triangular in transverse section, the angles truncated, not more than $1 \frac{1}{2}$ times as long as broad, consisting of about 5 whorls; chambers somewhat obscured by the surface ornamentation, adjacent series meeting in a very sharply angled, zigzag line; sutures depressed except at the initial end; wall ornamented with 3 irregular, elongate costae at each corner of the triangular test, extending the whole length, the flat sides of the test ornamented with irregular costae, giving a reticulate appearance, coarsely perforate; aperture loop-shaped, with a distinct lip, placed on the flattened top of the test. Length 0.24 to $0.34 \mathrm{~mm}$., width of one side 0.20 to 0.24 $\mathrm{mm}$.

The types of the species are from the Eocene, 225 feet stratigraphically below the Domengine sandstone, Oil Canyon, just east of Oil City, Fresno County, California. It has also been recorded from the Eocene of Santa Barbara County, California.

The species differs from Bulimina truncana Gümbel and $B$. rostrata $\mathrm{H}$. B. Brady in the triangular shape of the test and the irregular reticulation of the costae.

\section{Bulimina microcostata Cushman and Parker}

Plate 22, figure 9

Bulimina microcostata Cushman and Parker, Cushman Lab. Foram. Research Contr., vol. 12, p. 39, pl. 7, figs. 2a-c, 1936.
LeRoy, Natuurk. tijdschr. Ned. Indië, vol. 99, pt. 6, p. 244, pl. 1, figs. 20, 21, 1939.

Kelley, Am. Assoc. Petroleum Geologists Bull., vol. 2\%, p. 11 (list), 1943.

?Bulimina cf. B. semicostata Church (not Nuttall), Mining in California, vol. 27, pl. B, fig. 4(5, 6? $), 1931$.

Test of medium size, more than twice as long as broad, consisting of 6 to 8 whorls, the last-formed whorl forming $1 / 3$ or more of the test; chambers toward the initial end increasingly narrow, arranged in series with a slight offset twist and with the adjacent series joined in a zigzag line, very slightly inflated; sutures distinct, slightly depressed; wall of the lower part of the test covered vith very fine costae, the upper part smooth, finely pe-forate; aperture a long narrow, loop-shaped opening, with a slight lip. Length 0.34 to $0.48 \mathrm{~mm}$., diameter $0.1 \mathrm{~S}$ to $0.24 \mathrm{~mm}$.

The types are from the Eocene Kreyenhagen shale, NE $1 / 4$ sec. 2, T. 1 N., R. 1 E., M.D.M., in center of exposure in abandoned shale quarry, $1 \frac{1}{2}$ miles northeast of Sommersville, Contra Costa County, California. It has also been recorded from Santa Barbara County, Califo"nia and from the Miocene of Sumatra.

This species differs from Bulimina semicostata Nuttall in having finer costae and more numerou's chambers that are arranged in series, are more inflated, and narrover. It differs from $B$. cacumenata Cushman and Parker in its much greater size, more inflated chambers, more uniform width, and finer costae.

\section{Bulimina lirata Cushman and Parker}

Plate 22, figure 10

Bulimina lirata Cushman and Parker, Cushman Lab. Foram. Research Contr., vol. 12, p. 43, pl. 8, figs. 2a-c, 1936.

Curran, Am. Assoc. Petroleum Geologists Bull., vol. 27, pp. 1378, 1381 (lists), 1943.

Kelley, idem, vol. 27, p. 11 (list), 1943.

Martin, Stanford Univ. Publ., -Univ. Ser., Geol. Sci., vcl. 3, no. 3, p. 9 (list), 1943.

Cushman and Simonson, Jour. Paleontology, vol. 18, p. 198, pl. 32, fig. 13, 1944.

Bulimina cf. B. lirata Cushman and Siegfus, San Diego Soc. Nat. History Trans., vol. 9, no. 34, p. 413, pl. 17, fig. 3, 1942.

Test large, usually less than $11 / 2$ times as long as broad, rapidly tapering, consisting of 4 whorls, the last-formed constituting about half the test; chambers indistinct except in the last-formed whorl; last-formed chambers inflated; sutures depressed; wall of last-formed chambers mostly smooth, finely perforate, remainder of test coarsely costate, with thin, plate-like, low costae, 11 or more in number, sometimes extending part way onto the chambers of the last-formed whorl, continuous throughout; aperture loop-shaped, with a slight lip. Length of holotype $0.57 \mathrm{~mm}$., diameter $0.40 \mathrm{~mm}$. 
The types are from the Eocene, gray clay shale, 450 feet stratigraphically above the base of the Avenal sandstone, Coal Mine Canyon, sec. 26, T. 20 S., R. 14 E., M.D.M., Fresno County, California. The species is recorded from several localities in the Eocene and Oligocene of California.

This form differs from Bulimina instabilis Cushman and Parker in the shorter, broader shape of the test, less numerous chambers, and their somewhat different shape. It differs from $B$. jacksonensis Cushman in the shape of the test and the more numerous, lower costae.

\section{Bulimina excavata Cushman and Parker}

Plate 22, figure 11

Bulimina excavata Cushman and Parker, Cushman Lab. Foram. Research Contr., vol. 12, p. 41, pl. 7, figs. ta-c, 1936.

Kelley, Am. Assoc. Petroleum Geologists Bull., vol. 27, p. 8 (list), 1943.

Test of medium size, somewhat triangular in transverse section, about $11 / 2$ times as long as broad, consisting of about 5 whorls; chambers fairly distinct, inflated; sutures distinct, depressed, with small depressions extending from them upward into the chambers, usually 1 to each chamber; wall smooth, finely perforate; aperture loop-shaped. Length 0.26 to $0.34^{\circ} \mathrm{mm}$, diameter 0.21 to $0.22 \mathrm{~mm}$.

The types are from the lower Eocene, about 3 miles N. $45^{\circ}$ E. of Santa Susana, in Poison Oak Canyon, north of Simi Valley, Ventura County, California. They are found 2710 feet stratigraphically above the Cretaceous contact, in brown shale, mapped by Kew as the Martinez formation. It is also recorded from the Eocene Anita shale, Santa Barbara County, California.

This species resembles the Mexican Upper Cretaceous species Bulimina incisa Cushman, but differs from it in the more angled character of the test, the depressed sutures, and the inflation of the chambers. It is known only from the type locality.

\section{Bulimina guayabalensis Cole}

Plate 22, figure 12

Bulimina guayabalensis Cole, Bull. Am. Paleontology, vol. 14, no. 57, p. 24, pl. 1, figs. 1, 2, 1927.

Cushman and Siegfus, San Diego Soc. Nat. History Trans., vol. 9, no. 34, p. 413, pl. 16, fig. 39, 1942.

Bulimina sp. Cushman, Am. Assoc. Petroleum Geologists Bull., vol. 9, p. 301, pl. 7, fig. 9, 1925.

Cushman and Applin, idem, vol. 10, p. 169, pl. 7, figs. 10, 11, 1926.

Bulimina capitata? Cushman and Dusenbury (not Yokoyama), Cushman Lab. Foram. Research Contr., vol. 10, p. 61, pl. 8, figs. 10a, b, 1934.

Kelley, Am. Assoc. Petroleum Geologists Bull,, vol. 27, p. 11 (list), 1943.

Bulimina pupoides Nuttall (not D'Orbigny), Jour. Paleontology, vol. 9, p. 127, pl. 14, fig. 22, 1935.
Bulimina pyrula Coryell and Embich (not D'Orbigny), idem, vol. 11, p. 304, pl. 42, fig. 18, 1937.

Test compact, ovate, broadest near the apertural end, chambers few, large, inflated, smooth; sutures strongly depressed aperturally, very slightly depressed in the initial chambers; aperture long, narrow. Length $0.42 \mathrm{~mm}$. Width $0.26 \mathrm{~mm}$.-Cole.

The types are from the Eocene Guayabal formation of Mexico. Records referable to this species are given from the Eocene Poway conglomerate and Kreyenhagen shale of California; the upper Eocene of Venezuola and Panama; the Eocene, Moctezuma River, Vera Cruz, Mexico; and from the Eocene Jackson formation of Texas.

Cole describes this species as differing from Bulimina pupoides D'Orbigny in the fewer chambers, more compact form, and slightly different arrangement of chambers. The one topotype specimen we have seems to bear out this analysis. It is interesting to note that forms apparently identical with $B$. pupoides occur higher up in the Mexican section which makes it possible that this species represents the ancestral form.

\section{Bulimina guayabalensis Cole var. ampla Cushman and Parker}

Plate 22, figure 13

Bulimina yuaydabalensis Cole var. ampla Cushman and Parker, Cushman Lab. Foram. Research Contr., vol: 12, p. 43, pl. 8, figs. 1a-c, 1936.

Bulimina ampla Bandy, Jour. Paleontology, vol. 18, p. 377, pl. 62, figs. 8a, b, 1944.

Bulimina cf. B. socialis Cushman and Hobson (not Bornemann), Cushman Lab. Foram. Research Contr., vol. 11, p. 62, pl. 9, figs, 2a, b, 1935.

Variety differing from the typical form in the larger test, which is much broader in proportion to its width; and in the chambers, which are somewhat more inflated. Length 0.40 to $0.61 \mathrm{~mm}$., diameter 0.30 to $0.45 \mathrm{~mm}$.

The types of the variety are from the Eocene Kreyenhagen shale, NE $1 / 4$ sec. 2, T. 1 N., R. 1 E., M.D.M., in center of exposure in abandoned shale quarry, $11 / 2$ miles northeast of Sommersville, Contra Costa County, California. It occurs also in the Oligocene San Lorenzo formation of California. It is recorded by Bandy from the Eocene of Cape Blanco, Oregon.

This form is close to Bulimina pupoides D'Orbigny but is shorter and broader and has few⿳r, somewhat more inflated chambers.

\section{Bulimina bradburyi Martin}

Plate 30 , figure 9

Bulimina bradburyi Martin, Stanford Univ. Publ., TJniv. Ser., Geol. Sci., vol. 3, no. 3, p. 19, pl. 6, figs. 4a, b, 1943.

Test small, triserial, tapering, greatest width at next to lastformed whorl just below last chamber; about twice as long as wide; sub-rounded in cross section; wall calcareous smooth, finely 
perforate; periphery round; chambers inflated, increasing rapidly in size as added; sutures distinct, depressed; aperture an elongate, wide, comma-shaped slit extending from just below terminal edge of last chamber to spiral suture. Length $0.52 \mathrm{~mm}$.; greatest width $0.28^{\circ} \mathrm{mm}$.

This species is similar to Bulimina prolixa Cushman and Parker (1935) but differs in its more compactly arranged and more inflated chambers and in its more spiral and oblique sutures.Martin.

The types are from the Eocene Lodo formation of California.

\section{Bulimina debilis Martin '}

Plate 30, figure 10

Bulimina debilis Martin, Stanford Univ. Publ., Univ. Ser., Geol. Sci., vol. 3, no. 3, p. 20, pl. 6, figs. 1a-c, 1943.

Test small, elongate, fusiform, irregularly triserial, greatest width just above middle, about twice as long as broad, subcircular in cross section; wall calcareous, thin, smooth, hyaline, finely perforate; slightly roughened at initial end; periphery round; chambers inflated, increasing rapidly in size as added, somewhat embracing; sutures distinct, slightly depressed; initial end of test bluntly pointed; aperture a comma-shaped opening at top of last-formed chamber, extending to spiral suture, bordered on inner curve by a raised lip. Length $0.37 \mathrm{~mm}$; greatest width $0.2 \mathrm{~mm}$.

This species is similar to Bulimina ovata D'Orbigny of Cushman and Ponton (1932) but differs in being less fusiform, also smaller in size, and in having squarer chambers.-Martin.

The types are from the Eocene Lodo formation of California.

\section{Bulimina whitei Martin}

Plate 30 , figure 11

Bulinina zuhitei Martin, Stanford Univ. Publ., Univ. Ser., Geol. Sci., vol. 3, no. 3, p. 20, pl. 6, figs. 5a, b, 1943.

Test small, tapering, triserial, greatest width across apertural end; cross section triangular, angles bluntly rounded; wall calcareous, hyaline, finely perforate, ornamented with low, sharp, longitudinal costae extending from pointed initial end about halfway up last-formed chamber; generally three to four costae along each blunt angle, occasionally one or more on face of each side; chambers increasing rapidly in size as added; sutures distinct, slightly depressed; aperture an elongate, elliptical, slightly depressed opening at center of inside face of last-formed chamber. Length $0.23 \mathrm{~mm}$. ; greatest width $0.17 \mathrm{~mm}$.

This species is similar to Bulimina corrugata Cushman and Siegfus (1935) but differs in having fewer and lower costae, which continue to the last-formed chamber, and distinctly visible early chambers.-Martin.

The types are from the Eocene Lodo formation of California.

\section{Bulimina jacksonensis Cushman}

Plate 22, figures 14-16

Bulimina jacksonensis Cushman, Cushman Lab. Foram. Reșearch Contr., vol. 1, p. 6, pl. 1, figs. 6, 7, 1925 ; idem, p. 65, 1925.

Cushman and Applin, Am. Assoc. Petroleum Geologists Bull., vol. 10 , p. 168 , pl. 7 , figs. $8 a$, b, 1926.
Howe and Wallace, Louisiana Dept. Cons. Geol. Bull. 2, p. 59, pl. 11, fig. 5, 1932.

Ellisor, Am. Assoc. Petroleum Geologists Bull., vol. 17, pl. 7, fig. 5, 1933.

Cushman, U. S. Geol. Survey Prof. Paper 181, p. 35, pl. 13, figs. 7-9, 1935.

Nuttall, Jour. Paleontology, vol. 9, p. 127, pl. 15, fig. 1, 1935.

?Coryell and Embich, Jour. Paleontology, vol. 11, p. 304, pl. 42, fig. 17, 1937.

Renz, 8th Am. Sci. Congress Proc., p. 541 (list), 1942.

Cushman, Cushman Lab. Foram. Researci Special Pub. 16, p. 23, pl. 5, fig. 1, 1946.

Bulimina? sp. Church, Mining in California, vol. 27, pl. B, firs. $2,3,1931$.

Test elongate, tapering, the initial end acute, apertural end broadly rounded, in the adults somewhat contracted, consisting of as many as 7 or 8 whorls; chambers fairly distinct; sutures flush with the surface or slightly depressed; surface ornamented by 6 to 8 very prominent, plate-like, longitudinal costae, continuous from the apical end to almost the top of the last-formed chambers, the outer margin more or less serrate; aperture elongate, comma-shaped, with a lip. Average length $0.90 \mathrm{~mm}$.

The types are from the upper Eocene yellow clay in the Tantoyuca formation, Palacho Hacienda, south of Panuco-Tampico railroad, Vera Cruz, Mexico. The ho'otype is much smaller than the typical adult specimens from the Eocene of the United States. It is refigured here, together with specimens from the Cocoa sand member of the Jackson formation of Cocoa Post Office, Alabanna. We have specimens from various localities of Jackson age throughout the Gulf Coast region. The species is found also in Eocene material from Gaviota Canyon, Santa Barbara County, California, about 400 feet stratigraphically below the top of a massive sardstone bed carrying Turritella variata Conrad. It has been recorded by Nuttall from the upper Eocene of Venezuala and by Renz from the San Fernando formation of Trinidad. The record of Coryell and Embich from the upper Eocene of Panama is placed here questionably. In addition we have specimens from the middle Eocene of Egypt.

The species differs from Bulimina sculptilis Cushman in having fewer costae, which are higher, more platelike, and more serrate.

\section{Bulimina jacksonensis Cushman var. cuneata Cushman}

\section{Plate 22, figures 17,18}

Bulimina jacksonensis Cushman var. cuneata Cushman, Cushman Lab. Foram. Research Contr., vol. 2, p. 35, 1926; U. S. G:ol. Survey Prof: Paper 181, p. 35, pl. 13, figs. 10, 11, 1935.

Bulimina cuneata Beck, Jour. Paleontology, vol. 17, p. 605, pl. 107, figs. 3, 9, 1943.

Detling, idem, vol. 20 , p. 356 , pl. 49, figs. $13,15,16,1946$.

Variety differing from the typical form in the larger 
number of costae, 10 to 12 , the more tapering form, and the very serrate character of the edges of the costae. Length of holotype $0.80 \mathrm{~mm}$., diameter $0.34 \mathrm{~mm}$.

The types of the variety are from the Eocene, 2 to 3 feet below the base of the Red Bluff formation, half a mile southeast of Melvin, Choctaw County, Alabama. Cushman records the variety in the Cooper marl of South Carolina. Beck records a similar form from the Eocene of Washington.

In some respects this form is closer to Bulimina sculptilis Cushman than to $B$. jacksonensis, especially as regards the shape of the test and the number of costae. The character of the costae, however, and the form and character of the chambers seem to ally it more closely with the latter.

\section{Bulimina cooperensis Cushman}

Plate 22, figure 19

Bulimina cooperensis Cushman, Cushman Lab. Foram. Research Contr., vol. 9, p. 12, pl. 1, figs. 32a, b, 1933; U. S. Geol. Survey Prof. Paper 181, p. 35, pl. 13, figs. 12-14, 1935; Cushman Lab. Foram. Research Contr., vol. 21, p. 8, 1945.

Test elongate, tapering, $21 / 2$ to 3 times as long as broad, greatest breadth toward the apertural end; chambers distinct, inflated, considerably overlapping; sutures deep, distinct; wall of the basal half of the chambers with platelike costae that end in sharp points, the initial end of the test often with a spine; aperture elongate, with a slightly depressed border, and a distinct lip. Length 0.40 to $0.50 \mathrm{~mm}$., diameter 0.18 to $0.20 \mathrm{~mm}$.

The types of the species are from the Eocene Cooper marl, 1 mile south of Moncks Corner, Berkeley County, South Carolina. It also occurs in the Eocene Twiggs Clay of Washington County, Georgia.

This species is easily distinguishable on account of its costate character and numerous, overhanging chambers. It differs from Bulimina arkadelphiana Cushman and Parker var. midwayensis Cushman and Parker in the above characters, the latter having spines but no costae and the chambers, while somewhat undercut, not projecting so far. It is also much larger.

\section{Bulimina instabilis Cushman and Parker}

Plate 23, figure 1

Bulimina instabilis Cushman and Parker, Cushman Lab. Foram. Research Contr., vol. 12, p. 44, pl. 8, figs. 3a-c, 1936.

Test large, about $11 / 2$ times as long as broad, consisting of 6 to 8 whorls; chambers distinct, last-formed chambers inflated, arranged in fairly regular series; sutures distinct, very slightly depressed; wall in the adult with several, thin, plate-like, somewhat jagged costae, with low costae between, extending up to the last-formed whorl; in young forms the costae not well developed, sometimes resembling spines and again almost entirely absent; last-formed chambers smooth, coarsely perforate; aperture loop-shaped, with a slight lip. Length of holotype $0.71 \mathrm{~mm}$., diameter $0.43 \mathrm{~mm}$.

The types are from Eocene material at $20<8$ feet depth in the Lillis Welch well no. 1, drilled by ${ }^{N /} /$ estern Gulf Oil Company, located 680 feet north and 99 ) feet east of southwest corner sec. 26, T. 15 S., R. 12 E., M.D.M., Fresno County, California.

The species is very variable. The arrangement and form of the chambers remains the same, but the costae in some specimens are very definite, whereas in others they appear only intermittently or may even lo completely absent. There seems to be no logical way however, in which the species can be further subdivided. It differs from Bulimina buchiana D'Orbigny in having more chambers and much lower costae. It is longer ard more slender than B. lirata Cushman and Parker, and has more chambers, which are somewhat differently shaped.

\section{Bulimina schencki Beck}

Plate 30 , figure 16

Bulimina schencki Beck, Jour. Paleontology, vol. 17, p. 605, pl. 107 , figs. $28,33,1943$.

Test small, about twice as long as broad, fusiform, greatest width through middle, initial end subacute; chanbers few, last three make up more than one-half of entire test, inflated; sutures distinct, deeply incised; wall smooth; aperture set in broad opening at top of last chamber. Length $0.33 \mathrm{~mm}$; diameter $0.18 \mathrm{~mm}$.

These specimens are identical with Bulimina capitata? of Cushman and Dusenbury (1934) and differ from the original figure of $B$. capitata Yokoyama (1890) in having less inflated chambers that are largest at the apertural end.-Beck.

The types are from the Eocene of Cowlitz River, Lewis County, Washington.

\section{Bulimina ovata D'Orbigny var. cowlitzen «is Beck}

\section{Plate 30, figure 15}

Bulimina ovata D'Orbigny var. cowtitzensis Beck, Jour. Paleontology, vol. 17, p. 605, pl. 107, fig. 22, 1943.

This subspecies differs from the typical form in having more inflated chambers, and a coarsely punctate wall. Length, $0.45 \mathrm{~mm}$.; diameter $0.25 \mathrm{~mm}$.-Beck.

The types are from the Eocene of Cowlitz River, Lewis County, Washington.

\section{Bulimina macilenta Cushman and Pørker}

Plate 23, figures 2, 3

Bulinina macilenta Cushman and Parker, Cushman Lab. Foram. Research Contr., vol. 15, p. 93, 1939.

Cushman and Stainforth, idem, Special Pub. 14, p. 40, pl. 6, fig. 3, 1945.

Cushman, idem, Special Pub. 16, p. 23, p1. 5, fig. 4, 1946 
Bulimina inflata Galloway and Morrey (not Seguenza), Bull. Am. Paleontology, vol. 15, p. 37, pl. 5, fig. 13, 1929.

?Coryell and Embich, Jour. Paleontology, vol. 11, p. 304, pl. 42, fig. 19, 1937.

Bulimina denticulata Cushman and Parker (not B. truncana Gümbel var. denticulata Protescu), Cushman Lab. Foram. Research Contr., vol. 12, p. 42, pl. 7, figs. 7, 8, 1936.

Cushman, Cushman Lab. Foram. Research Contr., vol. 15, p. 64, 1939.

Kelley, Am. Assoc. Petroleum Geologists Bull., vol. 27, p. 8 (list), 1943.

Curran, idem, vol. 27, p. 1379 (list), 1943.

Martin,. Stanford Univ. Publ, Univ. Ser., Geol. Sci., vol. 3, no. 3, p. 9 (list), 1943.

Test of medium size, usually less than $1 \frac{1}{2}$ times as long as broad, rapidly tapering, consisting of about 4 - whorls, the last-formed whorl forming one-half to threefourths of the test; chambers fairly distinct, slightly undercut at the base, much inflated; sutures, in the lastformed whorl, distinct, depressed, obscured in the earlier portion of the test; wall of last whorl smooth, perforate; the margins of the chambers cut into more or less regular flutings or scallops that apparently cover the whole of the bottom of the test because of the narrowness of the chambers, the marginal character of the flutings being plain, however, in the last-formed whorl and often in the preceding one; aperture loop-shaped. Length 0.24 to $0.38 \mathrm{~mm}$., diameter 0.20 to $0.34 \mathrm{~mm}$.

The types of the species are from the Eocene, about 3 miles N. $45^{\circ}$ E. of Santa Susana, in Poison Oak Canyon, north of Simi Valley, Ventura County, California, from brown shale 2710 feet stratigraphically above the Cretaceous contact, in strata mapped as Martinez. There are several other records from the Eocene of California. Similar specimens were found in material collected by Vaughan from Rio Buena Vista, Vera Cruz, Mexico, and called by him Alazan. A single specimen occurs in the Eocene material in the Atlantis core 12-36, 880 meters, N. Lat. $39^{\circ} 50^{\prime}$; W. Long. $70^{\circ} 58^{\prime}$. Galloway and Morrey's species from the upper Eocene(?) of Manta, Ecuador has been placed here questionably, and also that of Coryell and Embich from the Eocene of Panama. It also occurs in the Oligocene Cipero formation of Trinidad.

This form resembles most closely Bulimina spinata Cushman and Campbell but is much smaller and has the fluted margins of the chambers much more sharply defined and coarser. It seems probable that $B$. spinata may be the ancestral form.

\section{Bulimina stalacta Cushman and Parker}

\section{Plate 23, figure $4^{\prime}$}

Bulimina stalacta Cushman and Parker, Cushman Lab. Foram. Research Contr., vol. 12, p. 42, pl. 7, figs. 5a-c, 1936.

?Bulimina inflata Cole (not Seguenza), Bull. Am. Paleontology,. vol. 14 , no. 51 , p. 25 , pl. 3 , fig. $12,1927$.
Test large, about $11 / 2$ times as long as broad, gradually tapering, terminated by a spine; chambers distinct in upper part of test, very slightly inflated; sutures distinct, somewhat depressed; wall of last-formed whorl smooth, finely perforate, lower part ornamented by blunt spines, often alined and appearing as remnants of jagged costce, some specimens having costae as well as spines; aperture loop-shaped, with a slight lip. Length of holotype 0.58 mm., diameter $0.33 \mathrm{~mm}$.

The types are from the Eocene beds in a small canyon, 50 feet stratgraphically above the top of a massive santstone, on the south slope of hill 2217 (Cholame topgraphic sheet), about $11 / 2$ miles east of Tar Canyon, Reef Ridge, Kings County, California. Specimens questionatly referable to this species were found in the Alazan shele of Mexico (collected by T. W. Vaughan) and Eocene material in the Atlantis cores 12-36 and 21-38, collected off the eastern coast of the United States. Similar forms occur in the Eocene at Biarritz, and at Kiscell, Hungary. Cole's species from the Eocene Guayabal formation of Mexico is placed here questionably.

This species differs from Bulimina macilenta Cushman and Parker in the more spinose character of the test and in the more fusiform shape.

\section{Bulimina consanguinea Parker and Bermúdez}

Plate 23, figure 5

Bulimina consanguinea Parker and Bermúdez, Jour. Paleontology, vol. 11 , p. 515 , p1. 59, figs. 2a-c, 1937.

Bermúdez, Soc. cubana historia nat. Mem., vol. 11, p. 342, 1937.

Bulimina garzaensis Cushman and Siegfus (part), Cushman Lab. Foram. Research Contr., vol. 11, p. 93, 1935.

Test large, about $1 \frac{1}{3}$ times as long as broad, tapering evenly, usually with a short, blunt, basal spine, consisting of 4 to 6 whorls; chambers distinct in last-formed whorl only, although frequently distinguishable in portions of the remainder of the test; sutures distinct in last whorl only, very slightly depressed; wall. smooth in the upper part of the last whorl, the remainder ornamented by longitudinal, plate-like costae with jagged edges, 6 to 8 visible on the front of the test, finely perforate; aperture loop-shaped, with a lip. Length $0.80 \mathrm{~mm}$., diameter 0.50 to $0.76 \mathrm{~mm}$.

The types of the species are from the Eocene, north side of Elvador in Noroña, north of Guanajay, on railroad, Pinar del Rio Province, Cuba. We have a single specimen from the Alazan clay, Rio Buena Vista, jist south of crossing of Alazan to Moyutla road, Vera Cri'z, Mexico. Specimens ascribed to Bulimina garzaensis Cushman and Siegfus from the Eocene Kreyenhagen shale of Garza Creek, California belong under this species. In addition it is found in the Eocene of Turin, Italy. 
This form most closely resembles Bulimina sculptilis Cushman var. laciniata Cushman and Parker but differs from it in the shape of the chambers, which are less inflated, less pronounced. and fewer in number, in the costae which are more jagged, and in the basal spine which is more pronounced.

\section{Bulimina impendens Parker and Bermúdez}

Plate 23, figures 6,7

Bulimina impendens Parker and Bermúdez, Jour. Paleontology, vol. 11, p. 514, pl. 58, figs. 7a-c, 8a-c, 1937.

Bermúdez, Soc. cubana historia nat. Mem., vol. 11, p. 342, 1937.

Test small, about $11 / 3$ times as long as broad, very slightly tapering, consisting of 3 to 4 whorls; chambers distinct in last whorl only, those of each whorl overhanging those previously formed to give a decidedly collared effect; sutures distinct in last whorl, slightly depressed, previous sutures obscured by surface ornamentation; wall spinose or fluted at the lower margin of the last 2 whorls, the remainder of the test covered by short, irregular spines; aperture loop-shaped, with a slight lip. Length 0.20 to $0.45 \mathrm{~mm}$., diameter 0.20 to $0.35 \mathrm{~mm}$.

The types are from the Eocene Alturas de Almendares quarry, Havana, Cuba. Besides the type locality, we have a single specimen from the Eocene, in a small canyon, 50 feet stratigraphically above the top of a massive sandstone on the slope of hill 2217, about half a mile east of Tar Canyon, Reef Ridge, Kings County, California.

The species differs from Bulimina curtissima Cushman and Siegfus in being much more spinose, in having more chambers, and in the very marked overhang of the chambers.

\section{Bulimina palmerae Parker and Bermúdez}

Plate 23 , figure 8

Bulimina palmerae Parker and Bermúdez, Jour. Paleontology, vol. 11, p. 514, pl. 59, figs. 1a-c, 1937.

Test of medium size, $11 / 2$ times as long as broad, tapering, with a well developed, blunt, basal spine, consisting of 4 to 6 whorls; chambers distinct, last-formed chambers somewhat inflated; sutures distinct, depressed, incised; wall with blunt spines at the edges of the chambers, remainder of wall smooth, perforate; aperture loopshaped, with a well defined lip. Length 0.48 to $0.80 \mathrm{~mm}$., diameter 0.32 to $0.56 \mathrm{~mm}$.

The types of the species are from the Eocene, one kilometer north of Arroyo Arenas, on road to Jaimanitas (water well), Havana Province, Cuba. It has not been recorded elsewhere.

This species differs from Bulimina arkadelphiana Cushman and Parker var. midwayensis Cushman and Parker in being much larger, having coarser spines and fewer of them. It differs from B. stalacta Cushmen and Parker in its more spinose character, lack of costae, and the slight overhang of the chambers.

\section{Bulimina tarda Parker and Bermúdez}

Plate 23, figure 9

Bulimina tarda Parker and Bermúdez, Jour. Paleontology, vol. 11, p. 514, pl. 58, figs. 6a-c, 1937.

Bermúdez, Soc. cubana historia nat. Mem., vol. 11, p. 342, 1937.

Cushman, Cushman Lab. Foram, Research Contr., vol. 15, p. 64, 1939.

Test small, tapering, consisting of 4 to 5 whorls, the last-formed whorl forming one-third or more of the test; chambers few, those of last whorl slightly inflated; sutures fairly distinct, very slightly depressed, showing as dark lines with occasional small, incised areas; wall smooth, coarsely perforate; aperture loop-shaped, with a slight lip. Length 0.30 to $0.35 \mathrm{~mm}$., diameter 0.21 to $0.23 \mathrm{~mm}$.

The types of the species are from the Eocene, Loma Principe, cut between calle $\mathrm{F}$ and Avenida de los Presidentes, 20 meters west of José M. Gómez monument, Havana, Cuba. Besides the Eocene occurrense in Cuba, it has been recorded from the Eocene material in the Atlantis cores 12-36 and 21-38, taken off the east coast of the United States, and from the Eocene, 3 milos N. $46^{\circ} \mathrm{E}$. of Santa Susana, Poison Oak Canyon, north of Simi Valley, Ventura County, California, from brown shale, $10+0$ feet stratigraphically above the Cretaceous contact, in strata mapped by Kew as Martinez.

This form resembles Bulimina tuxpamensis Cole but is much smaller, more rapidly tapering, and has a smoother wall.

\section{Bulimina jarvisi Cushman and ParJer}

Plate 23, figure 10 ; plate 24 , figure 1

Bulimina jarvisi Cushman and Parker, Cushman Lab. Foram. Research Contr., vol. 12, p. 39, pl. 7, figs. 1a-c, 1936.

Parker and Bermúdez, Jour. Paleontology, vol. 11, p. 513, pl. 58, figs. 2a-c, 1937.

Cushman and Stainforth, Cushman Lab. Fcram. Research Special Pub. 14, p. 41, pl. 6, fig. 5, 1945.

Test large, more than twice as long as broad, tapering throughout, the lower half triangular in transverse section with rounded angles, somewhat twisted, consisting of 6 to 7 whorls; chambers inflated; sutures distinct, depressed; wall of the lower one-half to two-thirds of the test covered with fine, irregular costae, the upper part very coarsely perforate, giving the surface a rough appearance; aperture loop-shaped, with a slight lip. Length 0.80 to $0.96 \mathrm{~mm}$., diameter 0.30 to $0.40 \mathrm{~mm}$.

The types are from the Eocene "Lower Marl", Cipero 
sect. sta. no. 10, Trinidad, B. W. I. The species has been recorded from the Eocene, Alturas de Almendares quarry, Cuba. We have specimens from the Eocene, approximately 5250 feet $\mathrm{N}$. $62^{\circ} \mathrm{W}$. of road intersection at Las Cruces, E1 Jaro Canyon, Santa Barbara County, California. Specimens from the Eocene of Häring in the Tyrol seem identical.

\section{Bulimina heathensis W. Berry}

Plate 24, figure 2

Bulimina heathensis W. Berry, Eclogae geol. Helvetiae, vol. 25, no. 1, p. 28, pl. 3, figs. $6,7,1932$.

Test elongate, nearly uniform diameter for most of its length, about two and one quarter times as long as wide; chambers indistinct; sutures depressed; wall smooth, polished; aperture elongate, irregular. Length $0.53 \mathrm{~mm}$.; diameter $0.24 \mathrm{~mm}$.W. Berry.

The species was described from the Oligocene Heath formation in Quebrada Heath, northwestern Peru.

We have no material referable to this form. Berry's figures are reproduced. It seems possible from the figures that the form may be a Buliminella.

\section{Bulimina tuxpamensis Cole}

Plate 24, figure 6

Bulimina turpamensis Cole, Bull. Am. Paleontology, vol. 14, p. 212, pl. 1, fig. 23, 1928.

Parker and Bermúdez, Jour. Paleontology, vol. 11, p. 513, pl. 58, figs. 1a-c, 1937.

Bermúdez, Soc. cubana historia nat. $M e m$. , vol. 11, p. 342, 1937.

Cushman and Stainforth, Cushman Lab. Foram. Research Special Pub. 14, p. 41, pl. 6, fig. 6, 1945.

Colom, Inst. Invest. Geol., Num. 3 Estudios Geologicas, p. 60, pl. 4, figs. $122,123,1946$

Test stout, tapering, very regular in outline, broadest near the apertural end, very finely perforate; chambers but slightly inflated, numerous; sutures in most specimens relatively wide, limbate; aperture loop-like or comma shaped, extremely terminal, the most extreme specimens having the aperture almost straight across the end of the test. Length $0.75 \mathrm{~mm}$.-Cole.

The types are from the Eocene material in the Huasteca Petroleum Company's well. Cerro Azul no. 75, Tampico, Mexico, at the depth of 1040 feet. We have no typical material. Parker and Bermúdez found specimens in the Eocene of Cuba, 4.5 kilometers west of Guanajay on the road to Mariel, Pinar del Rio Province, which seem to resemble this form closely except that the lower part of the test is somewhat roughened. Similar specimens occur in the Eocene near Siegsdorf, Germany, and at Gassino, near Turin, Italy. It also occurs in the Oligocene Cipero formation of Trinidad.

The species is larger than Bulinina tarda Parker and Bermúdez, less sharply tapered, and has more sharply angled chambers.

\section{Bulimina pupula Stache}

Plate 24, figures 7,8

Bulimina pupula Stache, Novara-Exped., Geol. Theil, vol. 1, pt. 2, p. 265, pl. 24, fig. 13, 1865.

Cushman and Parker, Cushman Lab. Foram. Research Contr., vol. 13, p. 66, pl. 9, figs. 1, 2, 1937.

Curran, Am. Assoc. Petroleum Geologists Bull., vol. 27, p. 1378 (list), 1943.

Bulimina ovata Stache (not D'Orbigny), Novara-Exped., Gecl. Theil, vol. 1, pt. 2, p. 266, pI. 24, fig. $14,1865$.

Chapman, New Zealand Geol. Survey, Paleontology, Bull. 11, p. 39, pl. 5, figs. 13, 14, 1926.

Bulimina aperta Stache, Novara-Exped., Geol. Theil, vol. 1, pt. 2, p. 266, p1. 24, fig. 15, 1865.

Bulimina propinqua Stache, idem, p. 267, pl. 24, fig. 16, 1865.

Bulimina affinis Chapman, New Zealand Geol. Survey, Paleontology, Bull. 11, p. 37, pl. 5, figs. 15, 16, 1926.

Test large, $2 \frac{1}{2}$ times as long as broad, fusiform, greatest breadth at, or above, the middle, initial end subacute or rounded; chambers distinct, only slightly inflated, tend-.. ing to become somewhat biserial in the adult; sutures distinct, slightly depressed, curved; wall smooth, distinctly perforate, thick; aperture narrow, elongate, with a distinct tooth and slight lip. Length up to $1.25 \mathrm{mr}$., diameter $0.50 \mathrm{~mm}$.

The types are from the Eocene, Whaingaroa Bay, Ne'w Zealand. The species occurs at various localities in th: Eocene of New Zealand and has also been recorded from the Miocene there. It is also listed from the Eocene of California.

There seems little doubt that the various species of Stache given in the synonymy refer to the same species. The figures show variations which are within the range of variation of the specimens in our collection. The form is close to Bulimina pupoides D'Orbigny but is larger, has less inflated chambers, and a thicker wall.

\section{Bulimina cylindrica Roemer}

Plate 24, figure 4

Bulimina cylindrica Roemer, Neues Jahrb., 1838, p. 387, pl. 3, fir. 44.

Cylinder-shaped, with 4 whorls and globular chambers.-Roem 9 r (translated).

Roemer described the species from the younger Tertiary "Meersand" of North Germany. We have no material referable to it, but the figure resembles Bulimina elongata D'Orbigny.

\section{Bulimina uva Roemer}

Plate 24, figure 5

Bulimina uva Roemer, Neues Jahrb., 1838, p. 387, pl. 3, fig. 43.

Oval, botryoidal, with many spirally arranged, rounded, archid chambers.-Roemer (translated). 
Roemer described the species from the Tertiary "Meersand" of North Germany. We have no material referable to it and it is somewhat questionable whether the form belongs to this genus. The original figure is reproduced here.

\section{Bulimina socialis Bornemann}

Plate 24, figure 3

Bulimina socialis Bornemann, Deutsche geol. Gesell. Zeitschr., vol. 7, p. 342, pl. 16, fig. 10. 1855.

Cushman and Parker, Cushman Lab. Foram. Research Contr., vol. 13 , p. 36 , pl. 4, figs. 1a-c, 1937.

Galloway and Heminway, New York Acad. Sci., Sci. Survey Porto Rico and Virgin Islands, vol. 3, p. 423, pl. 31, figs, 9a, b, 1941.

Test of medium size, about $11 / 2$ times as long as broad, somewhat oval in shape, with the widest part at about the middle of the test; chambers few, distinct, the last whorl forming the greater part of the test, inflated; sutures distinct, depressed; wall thin, perforate; aperture elongate, loop-shaped, with a slight lip, extending from the margin of the last-formed chamber, well above the suture joining the second and third chambers. Length $0.47 \mathrm{~mm}$., diameter $0.30 \mathrm{~mm}$.

The species was described from the Oligocene of Hermsdorf, near Berlin, Germany. We have only one poorly preserved specimen from that locality, but good material from the middle Oligocene of Ratingen, near Dusseldorf, Germany. One of these specimens is figured. It is recorded from the Ponce formation of Puerto Rico.

The species resembles Bulimina winniana Howe but is larger, with more rounded, inflated chambers. The chambers are more inflated and fewer in number than those of $B$. ovata D'Orbigny.

\section{Bulimina coprolithoides Andreae}

Plate 24, figure 9

Bulimina coprolithoides Andreae, Geol. Specialkarte Elsass-Lothringen Abh., vol. 2, pt. 3, p. 213, pl. 6, figs. 4a-d, 1884.

Cushman, Soc. sci. Seine-et-Oise Bull., ser. 2, vol. 9, p. 52(6), pl. 2, figs. $4 a, b, 1928$.

Cushman and Parker, Cushman Lab. Foram. Research Contr., vol. 13, p. 37, pl. 4, figs. 2a-c, 1937.

Test small, somewhat longer than broad, tapering from the broadest part in the middle of the last whorl, consisting of about 3 whorls, the last-formed composing almost three-fourths of the test; chambers distinct, inflated, arranged in regular series; sutures distinct, depressed; wall polished, translucent, finely perforate; aperture broad, loop-shaped, deepset, with a slight lip, just above the junction of the second and third chambers. Length $0.22 \mathrm{~mm}$., diameter $0.16 \mathrm{~mm}$.
The types are from the Oligocene of Rufach, Alsace. The species occurs also in the Oligocene at Ormoy and Dax, Seine-et-Oise, France.

The species resembles Bulimina simplex Terquem but is less elongate and slender, has fewer whorls, and more inflated chambers. It is broader and shorter than $B$. elongata D'Orbigny and the more globular chambers are arranged in regular series.

\section{Bulimina alsatica Cushman and Parker}

Plate 24, figures 10,11

Bulimina alsatica Cushman and Parker, Cushman Lab. Foram. Research Contr., vol. 13, p. 39, pl. 4, figs. 6, 7, 1937.

Colom, Real Soc. Española Hist. Nat. Bol., vol. 41, p. 419, pl. 27, figs. 10-12, 1943.

?Bulimina buchiana Reuss (not D'Orbigny), Akad. Wiss. Wien Sitzungsber., vol. 62 , pt. 1, p. 484, 1870 (Von Schlicht, Foraminiferen des Septarienthones von Pietzpuhl, p. 66, no. 383, pl. 22, figs. 30-33, Berlin, 1870).

Bulimina inflata Andreae (not Seguenza), Geol. Specialkarte Elsass-Lothringen Abh., vol. 2, pt. 3, p. 119, pl. 9, figs. 6a-c, 7, 1884.

?Cushman, Florida Geol. Survey Bull. 4, p. 43, pl. 8, figs. 6a, b, 1930.

?Cushman and Ponton, idem, Bull. 9, p. 77, 1932.

?Cushman and Cahill, U. S. Geol. Survey Prof. Paper 175-A, p. 24, p1. 8, figs. 1a, b, 1933.

Test small, about $11 / 2$ times as long as broad, tapering, the initial end of the test having 1 or more short spines; chambers indistinct except for those of th $\%$ last whorl; sutures indistinct, depressed; wall of most of the last whorl smooth, the rest of the test with plate-like costae ending in plate-like spines, bent downward to give a hooked appearance, the costae usually not crossing the sutures; aperture loop-shaped with a we'l defined lip, well above the junction of the second and third chambers. Length 0.34 to $0.57 \mathrm{~mm}$., diameter 0.22 to $0.44 \mathrm{~mm}$.

The types of the species are from the Oligocene of Hartmannsweiler, Alsace. It occurs also in the Oligocene at Hermsdorf, near Berlin, Germany. Very similar specimens occur in the Miocene Choctawhatchee marl of Florida, and in the Miocene of San Miniato, Italy. It is also recorded by Colom from the Mioceno of Spain.

This form can be recognized by the hook-like spines. It differs from Bulimina inflata Seguenza in this respect as well as in not having the pronounced, often continuous costae of the latter. It differs frem $B$. stalacta Cushman and Parker in the shorter, more tapered test and in the more projecting, hooked spines It is more spinose and has fewer, much less distinct chambers than $B$. rinconensis Cushman and Laiming. The chambers are less distinct and the costae and spines le:s heavy and pronounced than in B. bleeckeri Hedberg. 


\section{Bulimina sculptilis Cushman}

Plate 24, figure 12

Bulimina sculptilis Cushman, U. S. Geol. Survey Prof. Paper 133, p. 23, pl. 3,-fig. 3, 1923.

Cushman and Schenck, California Univ., Dept. Geol. Sci., Bull., vol. 17, p. 311, pl. 43, fig. 16, 1928.

Cole and Ponton, Florida Geol. Survey Bull. 5, p. 38, pl. 9, fig. 11, 1930.

Nuttall, Jour. Paleontology, vol. 6, p. 19, pl. 5, fig. 1, 1932. Cushman and Parker, Cushman Lab. Foram. Research Contr., vol. 13, p. 37, pl. 4, figs. 3a-c, 1937.

Renz, 8th Am. Sci. Congress Proc., p. 553 (list), 1942.

Howe, Jour. Paleontology, vol. 16, p. 267 (list), 1942.

Franklin, idem, vol. 18, p. 314, pl. 45, fig. 15, $19+4$.

Cushman and Ellisor, iden, vol. 19, p. 562, p1. 75, fig. 14, 1945.

Test elongate, at least twice as long as broad, tapering, subacute at the initial end; chambers numerous, distinct; sutures slightly depressed, distinct; wall finely perforate, ornamented with about 10, thin, low, longitudinal costae, extending from halfway down the lastformed whorl to the base of the test without a break, but often with slight depressions at the sutures, giving a somewhat scalloped effect; aperture long, comma-shaped, with a well developed lip, placed somewhat above the junction of the second and third chambers. Length 0.77 mm., diameter $0.40 \mathrm{~mm}$.

The types are from the Oligocene Red Bluff clay, Hiwannee, Mississippi. The species occurs in the lower Oligocene of the Coastal Plain region of the United States. Specimens recorded by Nuttall from the Alazan clay of Mexico are placed here, although his form has higher, more plate-like costae that somewhat approach those of Bulimina jacksonensis Cushman in character; the shape of the test and character of the chambers, however, seem to ally it more definitely with B. sculptilis. Somewhat similar specimens occur in the Eocene of Häring, in the Austrian Tyrol. It has also been recorded by Howe from the type locality of the Oligocene Glendon formation in Alabama. Other records include the Oligocene and Miocene of Venezuela.

\section{Bulimina sculptilis Cushman var. laciniata Cushman and Parker}

Plate 24, figure 13

Bulimina sculptilis Cushman var. laciniata Cushman and Parker, Cushman Lab. Foram. Research Contr., vol. 13, p. 38, pl. 4, figs. 4a-c, 1937; idem, p. 53.

Variety differing from the typical form in the more tapered test, usually terminated by a blunt spine; in the chambers which are more inflated, especially those of the last whorl; and in the jagged costae. Length 0.56 to 0.80 mm., diameter 0.40 to $0.44 \mathrm{~mm}$.
The types are from the Miocene, south side of Alsea Bay, Lincoln County, Oregon (Loc. A. 198, Schenck, California Univ., Dept. Geol. Sci., Bull., vol. 18, no. 1, p. 33, Nov. 30, 1928). The variety is found also in the Oligocene Bassendorf shale, Coos County, Oregon (Loc. A. 93, idem, p. 18).

\section{Bulimina alazanensis Cushman \\ Plate 24, figures $14-16$}

Bulimina alazanensis Cushman, Jour. Paleontology, vol. 1, p. 161, pl. 25, fig. 4, 1927.

Parker and Bermúdez, Jour. Paleontology, vol. 11, p. 514, p1. 58, figs. 5a-c, 1937.

Bermúdez, Soc. cubana historia nat. Mem., vol. 11, p. 341, 1937.

Cushman and Stainforth, Cushman Lab. Foram. Researct, Special Pub. 14, p. 40, p1. 6, fig. 2, 1945.

?Bulinina presli Reuss var. buchiana Parker and Jones (not D'Orbigny), Philos. Trans., vol. 155, p. 374, pl. 17, fig. 71, 1865.

Test small, somewhat longer than broad, greatest breadth near the apertural end, thence tapering to the initial end; chambers and sutures obscured by the ornamentation which consists of prominent, longitudinal costae terminated at the basal end by somewhat spinose projections; surface often slightly corrugated between the costae; aperture elongate, somewhat comma-shaped. Length $0.50 \mathrm{~mm}$. or less.

The types are from the Alazan clay, Rio Buena Vista, just south of crossing of the Alazan-to-Moyutla road, Vera Cruz, Mexico. The species has been recorded in the Eocene of Cuba and the Oligocene Cipero formation of Trinidad. Similar forms are found in the Pliocene of Lomita Quarry, Palos Verdes Hills, California. The form described as Bulimina rostrata H. B. Brady(?) by Cushman, Stewart and Stewart (San Diego Soc. Nat. History Trans., vol. 6, p. 65, pl. 5, fig. 1, 1930) from the Pliocene of Humboldt County, California, is a somewhat larger form and is questionably referred to this species. We have a few Recent specimens from the north Pacific and from the north Atlantic near Ireland that closely resemble this form.

The species is very close to Bulimina truncana Gümbel. A comparison of suites of specimens, however, shows certain definite differences. B. alazanensis has fewer, somewhat coarser, more irregular costae.

\section{Bulimina alazanensis Cushman var. spatiosa Cushman and Todd}

Plate 30, figure 19

Bulimina alazanensis Cushman var. spatiosa Cushman and Todd, Cushman Lab. Foram. Research Special Pub. 15, p. 40, p!. 6, fig. 12, 1945. 
Variety differing from the typical in the larger size, more prominent basal spine, and higher and somewhat less regular costae.-Cushman and Todd.

The types are from the Miocene, half a mile east of Buff Bay, Jamaica.

\section{Bulimina bicona W. Berry}

Plate 24, figure 19

Bulimina bicona W. Berry, Eclogae geol. Helvetiae, vol. 25, no. 1, p. 28, pl. 3, figs. 13, 14, 1932.

Test nearly fusiform, apical end abruptly rounded, apertural end with a rounded point, bases of chambers appearing above the apex, the last one extending from the apertural end to about half-way back on the test; chambers slightly inflated; sutures depressed; aperture a comma-shaped slit, often broken. Length $0.33 \mathrm{~mm}$.-W. Berry.

The species was described from the Oligocene Heath formation in Quebrada Heath, northwestern Peru.

We have no material referable to the species. Berry says that the form may be recognized by its distinctive shape, which is almost biconical. The original figures are reproduced.

\section{Bulimina jugosa Cushman and Parker}

Plate 25, figure 1

Bulimina jugosa Cushman and Parker, Cushman Lab. Foram. Research Contr., vol. 13, p. 38, pl. 4, figs. 5a-c, 1937.

Test small, rapidly tapering, about $1 \frac{1 / 2}{2}$ times as long as broad, consisting of 3 to 4 whorls; chambers very indistinct; sutures indistinct, slightly depressed; wall coarsely perforate, sometimes slightly translucent, ornamented by numerous longitudinal, low, rounded costae; aperture somewhat deepset, loop-shaped, with a very slight lip, placed just above the junction of the second and third chambers. Length 0.30 to $0.48 \mathrm{~mm}$., diameter 0.20 to $0.30 \mathrm{~mm}$.

The types of the species are from the Oligocene(?) Punta Bianca shales, Sea Cliff, near village of Rio Seco, $1^{\circ} 10^{\prime}$ south of the Equator, 9.25 kilometers southwest of Manta, Ecuador. It is known only from the type locality.

The species differs from Bulimina alazanensis Cushman in its much heavier test, heavier, more rounded costae, and blunt initial end.

\section{Bulimina bleeckeri Hedberg}

\section{Plate 24, figure 17}

Bulimina bleeckeri Hedberg, Jour. Paleontology, vol. 11, p. 675, p1. 91, figs. 12, 13, 1937.

Palmer, Soc. cubana hist. nat. Mem., vol. 14, p. 295, 1940.

Franklin, Jour. Paleontology, vol. 18, p. 314, pl. 46, fig. 14, 1944.

Cushman and Ellisor, idem, vol. 19, p. 562, p1. 75, fig. 16, 1945.
Cushman and Stainforth, Cushman Lab. Foram. Research Special Pub. 14, p. 41, pl. 6, fig. 4, 1945.

?Bulimina inflata Nuttall (not Seguenza), Quart. Jour. Geol. Soc., vol. 84, p. 77, pl. 3, fig. 19, 1928.

Nuttall, Jour. Paleontology, vol. 6, p. 20, p1. 5, fig. 2, 1932.

?Cushman, Cushman Lab. Foram. Research Contr., vol. 5, p. 94, pl. 13, fig. 31, 1929.

Variably top-shaped, with last three chambers usually making angles of at least 30 degrees with axis of test. Chambers numerous; as many as 18 visible on some specimens. Strongly overlapping; chambers of each whorl superimposed exactly above those of preceding whorl. Lower edges of chambers straight, at right angles to axis of test; each with 3 to 6 strong costae or crenulations which extend downward beyond the base of the chamber as blunt spines. On the last three chambers these costae are developed only near the lower margin, but are probal ly more extensive over the earlier chambers though largely concealed by overlap. Sutures distinct. Aperture in a deep embayment of the last chamber margin, near where it overlaps the suture separating the second and third to the last chambers. Holotype from Sample E-4022. Length, $0.38 \mathrm{~mm}$., maximum diameter, $0.28 \mathrm{~mm}$.-Hedberg.

The types are from the Oligocene Carapita formation, District of Libertad, State of Anzoategui, Venezuela. It occurs also in the Oligocene Alazan formetion of Mexico, Cipero formation of Trinidad, Cojimar formation of Cuba, and in the Punta Bianca shale, near Manta, Ecuador.

This form is very close to Bulimina alsatica Cushman and Parker but has heavier, more pronounced costae and spines, and much more distinct chambers. The costae are higher and not arranged in regular lines, as in $B$. inflata Seguenza var. alligata Cushman and Laiming. It is more tapering and not so fusiform as $B$. rinconensis Cushman and Laiming. The costae are heavier and not so regular as in B. subacuminata Cushman and Stewart. Hedberg's figured specimens have been studied, and the holotype is refigured here.

\section{Bulimina rugifera Glaessner}

Plate 24, figure 18

Bulimina rugifera Glaessner, Problems of paloontology, Moscow Univ., vols. 2-3, p. 372, pl. 2, fig. 19, 1937.

Under this name Glaessner has described and figured a specimen from the Tertiary of the Caucasus region. We have no specimens of this species and from the figure alone it is difficult to place it.

\section{Bulimina pyrula D'Orbign! \\ Plate 25, figure 2}

Bulimina pyrula D'Orbigny, Foraminifères fossiles du bassin tertiaire de Vienne, p. 184, pl. 11, figs. 9, 10, 1846.

Terrigi, Com. geol. italiana Mem., vol. 4, pt. 1, p. 71, pl. 1, figs. 18, 19, 1891.

Silvestri, Accad. sci. Acireale Atti e Ren1., vol. 5, p. 12, pl. 5. figs. 74-82, 1893. 
Egger, Naturh. Ver. Passau Jahresber. 16, p. 16, pl. 4, figs. 1a-c, 1895.

?Howe and Wallace, Louisiana Dept. Cons. Geol. Bull. 2, p. 60, pl. 11, fig. 6, 1932.

Cushman and Parker, Cushman Lab. Foram. Research Contr., vol. 13, p. 46, pl. 6, fig. 1, 1937.

LeRoy, Natuurk. tijdschr. Ned-Indië, vol. 99, pt. 6, p. 244, pl. 5, figs. 19, 20, 1939; Colorado School of Mines Quart., vol. 39, no. 3, p. 26, pl. 5, fig. 14, 1944.

Silvestri and Zangheri, Soc. geol. italiana Boll., vol. 61, p. 87, 1942.

Bulimina sp. aff. B. pupoides Schwager (not D'Orbigny), Com. geol. italiana Boll., vol. 9, p. 523, pl. 1, fig. 10a, 1878.

Bulimina pyrula D'Orbigny var. spinescens Amicis (not $\mathrm{H}$. B. Brady), Soc. geol. italiana Boll., vol. 12, pt. 3, p. 59, pl. 3, figs. 8a, b, 1893.

Egger, Naturh. Ver. Passau Jahresber. 16, p. 17, pl. 4, figs. 2, 3, 1895.

Test of medium size, about $11 / 2$ times as long as broad, acuminate at both ends, consisting of 2 to 3 whorls, the last-formed whorl composing about seven-eighths of the test; chambers slightly inflated, early chambers very narrow owing to the great involution; sutures slightly depressed; wall smooth, polished, often translucent, frequently ornamented with one or more small spines at the base, coarsely perforate; aperture loop-shaped, with a well-defined lip and tooth. Length of specimens from Baden 0.36 to $0.6+\mathrm{mm}$., diameter 0.26 to $0.40 \mathrm{~mm}$.

The types are from the Miocene at Baden, Vienna Basin, Austria. The earliest record for the species is from the Eocene Jackson formation of Louisiana. We have material from the Yazoo clay of Mississippi which yields a form very close to D'Orbigny's species though not absolutely identical. It occurs questionably in the Eocene of Biarritz and in the Alazan clay of Mexico. In the Miocene it is found at several localities in the Vienna Basin and in Germany. We have material from the Pliocene of Castel Arquato and Coroncina, Italy, and specimens with a somewhat more rounded base, from gray siltstone 280 feet stratigraphically above the base of the first Pico sandstone, $21 / 10$ miles N. $74^{\circ}$ E. of La Crosse Junction, Cañada de Aliso, Ventura County, California. It is recorded by LeRoy from the Miocene of Sumatra.

Considerable confusion prevails in the literature regarding this species. Many forms that have been recorded, especially from the Recent, belong to the genus Globobulimina, which is an involute form developed from Bulimina, showing only the last three chambers, at least in the adult. Bulimina pyrula approaches the Globobulimina type and it seems probable that it represents an ancestral form of that genus. The early chambers, however, though very narrow are easily seen: The presence of the occasional spines does not seem to be a specific character. The species is easily differentiated from other forms by its highly involute character, which makes the last whorl predominant. It differs from the species of Globobulimina in being acuminate at both ends, with the early whorls visible.

\section{Bulimina pyrula D'Orbigny var. lata Seguenza}

Bulimina pyrula D'Orbigny var. lata Seguenza, R. accad. Lin`ei Atti, ser. 3, vol. 6, p. 147, 1880.

Wider forms with the initial portion not prominent but ratter flattened.-Seguenza (transiated).

Seguenza described the variety from the Miocene Tcrtonian of Calabria, Italy. It was not figured.

\section{Bulimina pupoides D'Orbigny}

Plate 25, figures 3-7

Bulimina pupoides D'Orbigny, Foraminifères fossiles du bassin tertiaire de Vienne, p. 185, pl. 11, figs. 11, 12, 1846.

H. B. Brady, Challenger Rept., Zoology, vol. 9, p. 400, pl. 50, figs. 15a, b, 1884.

Terrigi, Com. geol. italiana Mem., vol. 4, pt. 1, p. 72, pl. 1, fig. 22, 1891.

Egger, Naturh. Ver. Passau Jahresber. 16, p. 14, pl. 4, fiзss. $6 a, b, 7,8,1895$.

Flint, U. S. Nat. Mus. Rept. for 1897, p. 290, pl. 37, fig. 3, 1899.

Nuttall, Jour. Paleontology, vol. 4, p. 285, 1930.

Macfadyen, Egypt. Geol. Survey, 1930, p. 52, pl. 1, fig. 11, 1931 ; ?Geol. Mag., vol. 69, p. 494, pl. 34, fig. 4, 1932.

Nuttall, Jour. Paleontology, vol. 6, p. 19, pl. 2, fig. 9, 1932.

Cushman and Parker, Cushman Lab. Foram. Research Contr., vol. 13, p. 47, pl. 6, figs. 2, 3, 1937.

Ellisor, Am. Assoc. Petroleum Geologists Bull., vol. 24, pp. 439 (list), 444 (list), pl. 4, fig. 5, 1940.

LeRoy, Colorado School of Mines Quart., vol. 36, no. 1, p. 32, pl. 1, figs. 93, 94, 1941.

Coryell and Mossman, Jour. Paleontology, vol. 16, p. 242, pl. 36, fig. 43, 1942.

Bandy, idem, vol. 18, p. 377, pl. 62, fig. 9, 1944.

LeRoy, Colorado School of Mines Quart., vol, 39, no. 3, p. 26, pl. 1, figs. 1, 4; pl. 4, fig. 10 ; p. 84, pl. 2, fig. 2, 1944.

Cushman and Ellisor, Jour. Paleontology, vol. 19, p. 562, p1. 75, fig. 13, 1945.

Bulimina cf. B. pupoides, Parker and Bermúdez, Jour. Paleontology, vol. 11, p. 515, pl. 59, figs. 3a-c, 4a-c, 5a-c, 1937.

Bulimina pitecusana Costa, Accad. pontaniana Atti, vol. 7, pl. 15, fig. $5,1856$.

Bulimina incrassata Karrer, Akad. Wiss. Wien Sitzungsber., vol. 58, p. 177, pl. 4, fig. 12, 1868.

Cushman and Parker, Cushman Lab. Foram. Research Contr., vol. 13, p. 52, 1937.

? Bulimina affinis H. B. Brady (not D'Orbigny), Challenger Reft., Zoology, vol. 9, p. 400, pl. 50, figs. 14a, b, 1884.

Terrigi, Com. geol. italiana Mem., vol. 4, pt. 1, p. 72, pl. 1, fig. 21, 1891.

?Cushman, U. S. Nat. Mus. Bull. 71, pt. 2, p. 79, text fig. 130, 1911 ; idem, Bull. 100, vol. 4, p. 165, 1921.

Bulimina oz'ata Burrows and Holland (not D'Orbigny), Gesl. Assoc. Proc., vol. 15, p. 32, pl. 2, fig. 11, 1897.

?Bulimina elegans Nuttall (no: D'Orbigny), Jour. Paleontology, p. 285 , pl. 23 , fig. $12,1930$. 
Test of medium size, twice as long as broad or less, very slightly tapering, consisting of about 5 whorls; chambers somewhat inflated; sutures distinct, depressed, running at right angles to the vertical axis; wall smooth, often somewhat transparent, perforate; aperture loopshaped, with a well defined lip, and often with a tooth. Length of specimens from Baden 0.30 to $0.80 \mathrm{~mm}$., diameter 0.20 to $0.40 \mathrm{~mm}$.

The types are from the Miocene of Nussdorf and Baden, in the Vienna Basin, Austria. This species has a wide range both vertically and horizontally. The earliest known specimens are from the Eocene of Hungary; Biarritz, France; the Thanet beds of Pegwell Bay in the Isle of Wight; and Cuba. It has been recorded by Nuttall from the Eocene Aragon formation and the Oligocene Alazan clay of Mexico. It occurs in the Miocene of Austria, Hungary, Germany, Egypt, and Texas. In the Pliocene we have material from Coroncina and Castel Arquato, Italy. It has been recorded by Macfayden from the Pliocene and Pleistocene of East Anglia. In the eastern Pacific it occurs from Lat. $32^{\circ} \mathrm{N}$. south to the coast of Patagonia, and we have a few specimens from the vicinity of the Philippine Islands. It has been recorded by Flint from the Gulf of Mexico. His figures seem to represent the form although we have no material to verify the identification.

This is a variable species. Specimens from Baden show a wide range of variation in respect to length, width, number of whorls, etc. The only absolutely fixed characters are the angle that the sutures make with the vertical axis of the test, the shape of the chambers, and the position. of the aperture. The species differs from Bulimina ovata D'Orbigny in the shape of the test, which is slightly tapering, not oval; and in the shape of the chambers, which is more angled. It is more difficult to separate the form from $B$. affinis D'Orbigny, but it differs in the shape of the apertural face, which does not extend so far down the side of the test and is less protuberant; in the shape of the test, which is narrower in proportion to the width; and in the greater number of chambers, the last whorl making up a smaller proportion of the test. It is sometimes difficult, however, to identify definitely certain of the Pacific forms that seem to have some of the characteristics of both groups.

\section{Bulimina ovata D'Orbigny}

Plate 25, figures 8,9

Bulimina ovata D'Orbigny, Foraminifères fossiles du bassin tertiaire de Vienne, p. 185, pl. 11, figs. 13, 14, 1846.

H. B. Brady, Challenger Rept., Zoology, vol. 9, p. 400, pl. 50, figs. 13a, b, 1884. (See Bulimina notovata Chapman).

Terrigi, Com. geol. italiana Mem., vol. 4, pt. 1, p. 72, pl. 1, fig. 20, 1891.

Egger, Naturh. Ver. Passau Jahresber. 16, p. 15, pl. 3, figs. $11 \mathrm{a}, \mathrm{b}, 1895$.
Sidebottom, Royal Micr. Soc. Jour., 1918, p. 122, pl. 3, figs. 1-3.

Cushman, U. S. Nat. Mus. Bull. 100, vol. 4, p. 164, text fig. 4, 1921 ; Cushman Lab. Foram. Research Contr., vol. 2, p. 55, pl. 7, fig. 1, 1926.

Macfadyen, Egypt Geol. Survey, 1930, p. 53, pl. 1, fig. 13, 1931.

?Nuttall, Jour. Paleontology, vol. 6, p. 19, pl. 2, fig. 8, 1932.

?Cushman and Ponton, Cushman Lab. Foram. Research Contr., vol. 8, p. 67, pl. 9, figs. 1, 2, 1932 ; ?Florida Geol. Survey Bull. 9, p. 78, pl. 11, fig. 11, 1932.

Cushman, U. S. Geol. Survey Prof. Paper 181, p. 35, pl. 13, figs. 15, 16, 1935.

Cushman and Parker, Cushman Lab. Foram. Research Contr., vol. 13, p. 47, pl. 6, figs. 4, 5, 1937.

?Kleinpell, Miocene stratigraphy of Califorria, p. 255, pl. 12, figs. 14a, b; ("aff.") pl. 2, fig. 9, Tulsa, 1938.

LeRoy, Colorado School of Mines Quart., vcl. 36, no. 1, p. 32 , pl. 1, figs. 95,96 ; p. 79, pl. 2, fig. 14, 1941.

Toulmin, Jour. Paleontology, vol. 15, p. 597, pl. 80, figs. 25, 26, 1941.

Silvestri and Zangheri, Soc. geol. italiana Boll., vol. 61, p. 88 , 1942.

ten Dam and Reinhold, Geol. Stichting Mededeelingen, ser. C-V, no. 2, p. 80, 1942.

ten Dam, idem, no. 3, p. 111, pl. 3, figs. 10, 11, 1944.

Cushman, Cushman Lab. Foram. Research Contr., vol. 20, p. 24, pl. 4, figs. 21, 22, 1944; idem, Special Pub. 16, p. 23, pl. 5, fig. 2, 1946.

Colom, Inst. Invest. Geol., Num. 3 Estudios Geologicos, p. 158, pl. 10, fig. 151, 1946.

Bulimina cf. B. ovata Israelsky, 6th Pacific Sci. Congress Proc., p. 577, pl. 6, fig. 10, 1939.

Bulimina laevigata D'Orbigny, Annales sci. nat., vol. 7, p. 270, no. $14,1826$.

Fornasini, Soc. geol. italiana Boll., vol. 20, F. 182, text fig. 4 , 1901; Accad. sci. Ist. Bologna Mem., ser. 5, vol. 9, p. 374, 1901 ; idem, vol. 10, p. 154, 1901.

Cushman and Parker, Cushman Lab. Foram. Research Contr., vol. 14, p. 94, pl. 16, fig. 16, 1938.

Bulimina semistriata D'Orbigny, Annales sci. nat., vol. 7, p. 270, no. $15,1826$.

Fornasini, Soc. geol. italiana Boll., vol. 20, p. 200, text fig. 5, 1901.

Cushman and Parker, Cushman Lab. Foram. Research Contr., vol. 14 , p. $61,1938$.

Bulimina ellipsoides Costa, Accad. pontaniana Atti, vol. 8, pt. 2, p. 265 , pl. 15 , fig. $9,1856$.

Cushman and Parker, Cushman Lab. Foram. Research Contr., vol. 14, p. 61, 1938.

Bulimina affinis Rzehak (not D’Orbigny), Naturf. Ver. Brünn Verh., vol. 14, pt. 1, pp. 80, 90, pl. 1, fig. 2, 1885.

Egger, Naturh. Ver. Passau Jahresber. 16, p. 14, pl. 4, figs. 4, 5, 1895.

Bulimina pupoides Cushman (not D'Orbigny), U. S. Nat. Mus. Bull. 100, vol. 4, p. 161, pl. 31, fig. 8, 1921.

Bulimina sp. Cushman and Applin, Am. Assoc. Petroleum Geologists Bull., vol. 10, p. 169, pl. 7, figs. 10, 11, 1926.

Test of medium size, not more than twice as long as broad, oval in shape, the broadest portion about one-third 
of the way down from the apertural end, consisting of 2 or 3 whorls, the last-formed whorl forming one-half or more of the test; chambers somewhat inflated; sutures distinct, depressed; wall smooth, somewhat translucent, perforate, the perforations sometimes arranged in regular lines to give a faintly striate appearance; aperture loop-shaped, with a well defined lip and tooth. Length of specimens from Baden 0.38 to $0.64 \mathrm{~mm}$., diameter 0.26 to $0.34 \mathrm{~mm}$.

The species was described from the Miocene at Nussdorf, in the Vienna Basin, Austria. It is a widely ranging form, occurring in the Eocene of Biarritz, France, and of Hungary, and in the Jackson group of Texas, Salt Mountain limestone of Alabama, and Aquia formation of Virginia. Somewhat questionable forms occur in the Oligocene of Mexico. In the Miocene it is found at several localities in Austria, Hungary and Germany. Cushman records it in the Monterey shale of California, Kleinpell from the Luisian of Reliz Canyon, Monterey County and questionably from many other California Miocene localities. A similar form occurs in the Miocene of Florida. In the Pliocene we have specimens from several localities in Italy and Spain, and similar, though somewhat larger, less inflated specimens were found 300 feet above the base of the Pico sandstone, in Cañada de Aliso, Ventura County, California. It is found in Recent seas at Rimini, Italy and at various localities near the Philippine Islands.

Bulimina semistriata D'Orbigny has been placed in the synonymy under this species, as specimens in the Pliocene of Italy that were referable to it were identical with the forms from the Vienna Basin. They showed very plainly the faint striations caused by the alining of the perforations, a characteristic which may be seen also in the Austrian specimens. The Recent specimens from Rimini, which may be referred to $B$. laevigata D'Orbigny, were also identical with $B$. ovata. B. ellipsoides Costa has been identified with this species. Although his figure is poor, the general characters seem to point very definitely to the same form.

This species is closely related to Bulimina pupoides D'Orbigny but differs from it in the oval form of the test, the angle of the sutures, which curve downward rather than extending at right angles to the vertical axis. This latter character is especially true of the megalospheric form. The specimens at any one locality vary greatly, and this accounts, up to a point, for the variety of figures given in the literature. We have included in the synonymy only such forms as can be checked with a reasonable degree of accuracy, either by a study of topotype material or of material of the same general region and age.

Chapman has given a new name, "Bulimina notovata," to Brady's figured specimens from off New Zealand.

\section{Bulimina arcuata D'Orbigny}

Plate 25, figure 10

Bulimina arcuata D'Orbigny, Annales sci. nat., vol. 7, p. 270, no. 12,1820

Fornasini, Accad. sci. Ist. Bologna Mem., ser. 6, vol. 5, p. 46, pl. 1, figs. 12, 12a, 1908.

Cushman and Parker, Cushman Lab. Foram. Research Contr., vol. 13, p. 53, 1937.

The type is from the Miocene, near Dax, France.

It is impossible to tell definitely from the figure to what genus this species belongs. The only clue we have is in D'Orbigny's description of Bulimina patagonica in which he compares that species to $B$. arcuata, saying that the Recent form has a comma-shaped aperture instead of a round one, and is spinose. Aside from the question of the aperture the species seems to have the characteristirs of a Buliminella.

\section{Bulimina buchiana D'Orbigny}

Plate 25, figures 11,12

Bulimina buchiana D'Orbigny, Foraminifères fossiles du bassin tertiaire de Vienne, p. 186, pl. 11, figs. 15-18, 1846.

Macfadyen, Egypt Geol. Survey, 1930, p. 55, pl. 1, fig. 21, 1931.

Cushman and Parker, Cushman Lab. Foram. Research Contr., vol. 13, p. 48, pl. 6, figs. 6, 7, 1937.

ten Dam and Reinhold, Geol. Stichting Mededeelingen, sar. C-V, no. 2, p. 81, 1942.

Colom, Inst. Invest. Geol., Num. 3 Estudios Geologicos, p. 159, pl. 10, figs. 157, 158, 1946.

Test of medium size, about twice as long as broad, gradually tapering, broadest portion somewhat above the middle, consisting of 5 or 6 whorls in the adult form, sometimes with a well developed basal spine; chambers numerous, distinct in the later portion; sutures in the smooth part of the test distinct, depressed; wall of mcst of the last-formed whorl smooth, perforate, the rest of the test with longitudinal costae usually extending, unbroken across at least 2 chambers, sometimes more; aperture loop-shaped, with a distinct lip. Length of specimens from Baren 0.34 to $0.90 \mathrm{~mm}$., diameter 0.22 to $0.44 \mathrm{~mm}$.

The types of the species are from the Miocene of Nussdorf and Baden, Vienna Basin, Austria, and Boholth, Styria. It occurs also in the Miocene of Bulgaria and Egypt.

This is a larger species than Bulimina costata D'O"bigny, the costae are somewhat finer, more numerous, and more regular. The chambers are not typically underc't at the sutures to give a collared effect to the test, although some forms show a slight tendency in that direction. 


\section{Bulimina buchiana Dorbigny var. calabra Seguenza}

Plate 25, figure 13

Bulimina buchiana D'Orbigny var. calabra Seguenza, R. accad Lincei Atti, ser. 3, vol. 6, p. 146, pl. 13, fig. 34, 1880.

Cushman and Parker, Cushman Lab. Foram. Research Contr., vol. 13, p. 51, pl. 6, fig. 8, 1937.

Bulimina buchiana Terrigi (not D'Orbigny), Pont. accad. sci. Nuovi Lincei Atti, vol. 33, p. 73, p1. 2, fig. 37, 1880.

Variety differing from the typical form in having more whorls and somewhat more overhanging chambers. Length of figured specimen $0.60 \mathrm{~mm}$, diameter $0.30 \mathrm{~mm}$.

The variety was described from the Miocene Tortonian of Calabria, Italy. We have material from the Tortonian of Varpolata, Hungary, the upper Miocene of France, and the Recent deposits of Rimini and Venice, Italy.

This variety approaches the form of Bulimina costata D'Orbigny, but the chambers are not so collared, there are many more whorls, and the test is much larger.

\section{Bulimina elongata D'Orbigny}

Plate 25, figures $14-17$

Bulimina elongata D’Orbigny, Annales sci. nat., vol. 7, p. 269, no. 9, 1826; Foraminifères fossiles du bassin tertiaire de Vienne, p. 187, pl. 11, figs. 19, 20, 1846.

Hantken, K. ungar. geol. Anstalt Mitt. Jahrb., vol. 4, p. 61, pl. 10, figs. 7a, b, 1875.

Terquem, Soc. géol. France Mém., ser. 3, vol. 2, p. 109, pl. 11 (19), figs. 21a, b, 22, 1882.

Egger, K. bayer. Akad. Wiss. Abh., cl. 2, vol. 18, p. 284, pl. 8, figs. 75, 76, 105, 106, 1893; Naturh. Ver. Passau Jahresber. 16, p. 15, pl. 3, figs. 12a, b, 1895.

?Chapman, California Acad. Sci. Proc., ser. 3 (Geology), vol. 1 , p. 243 , pl. 29 , fig. $1,1900$.

?Fornasini (part), Acçad. sci. Ist. Bologna Mem., ser. 5, vol. 9, p. 373, text fig. 5,1901 ; idem, p. 376 , pl. 0 , fig. 10 (not figs. $12,20,37$ ).

?Paalzow, Offenbacher Ver. Naturkunde Ber., 1912-24, p. 15, pl. 1, figs. 8, 9, 1924.

Macfadyen, Egypt Geol. Survey, 1930, p. 54, pl. 1, fig. 17, 1931. Cushman and Parker, Cushman Lab. Foram. Research Contr., vol. 13, p. 49, pl. 7, figs. 1-3, 1937.

ten Dam and Reinhold, Geol. Stichting Mededeelingen, ser. C-V, no. 2, p. E0, pl. 5, fig. 11, 1942.

Bulimina ariminensis D'Orbigny, Annales sci. nat., vol. 7, p. 269, no. 8, 1826.

Fornasini, Soc. geol. italiana Boll., vol. 20, p. 178, text fig. 3, 1901.

Cushman and Parker, Cushman Lab. Foram. Research Contr., vol. 14, p. 92, pl. 16, figs. 11a, b, 1938.

Bulimina inconstans Egger, Neues Jahrb., 1857, p. 283, pl. 12, figs. 1-3, 8, 9 .

?Buliminella inconstans Coryell and Mossman, Jour. Paleontology, vol. 16, p. 243, pl. 36, fig. 45, 1942.

Bulimina pupoides Williamson (not D'Orbigny), Recent Foraminifera of Great Britain, p. 61, pl. 5, figs. 124, 125, 1858.

Terrigi, Pont. accad. sci. Nuovi Lincei Atti, vol. 33, p. 71, pl.
2, figs. 30-34, 1880; R. accad. Lincei Atti, ser. 4, Mem., vol. 6 , p. 110 , pl. 5 , fig. $6,1893$.

Bulimina scabriuscula Reuss, Akad. Wiss. Wien Sitzungsber., vol. 42 , p. 360 , pl. 2 , fig. 13,1860 .

?Bulimina eocena Hantken, K. ungar. geol. Anstalt Mitt. Jahrb., vol. 1 , p. 136 , pl. 2 , fig. $16,1871-72$.

Bulimina elegans Jones (not D'Orbigny), Crag Foraminifera, Palaeont. gr. Soc. Mon., pt. 2, p. 163, pl. 6, fig. 19, 1895.

Bulimina fusiformis Fornasini (not Williamson) (part), Accad. sci. Ist. Bologna Mem., ser. 5, vol. 9, p. 377, pl. 0, figs. 6, 9, 41 (not figs. 1, 3, 4, 16, 18, 21, 23, 27, 36, 40), 1901.

Liebus, K.-k. geol. Reichsanstalt Jahrb., vol. 52, pl. 5, fig. 7, 1902.

Bulimina fusiformis Williamson var. pupoides Fornasini (not D'Orbigny), Accad. sci. Ist. Bologna Men., ser. 5, vol. 9, p. 378, pl. 0, figs. $13,17,1901$.

? Bulimina imbricata Reuss var. procera Liebus, Geol. Bund. Jahrb., vol. 77, p. 368, pl. 13, figs. 8a, b, 1927.

Bulimina gracilis Cushman, Florida Geol. Survay Bull. 4, p. 43 , pl. 8, figs. 5a, b, 1930.

Cushman and Ponton, idem, Bull. 9, p. 76, 1932.

Cushman and Cahill, U. S. Geol. Survey Prof. Paper 175-A, p. 24, pl. 7, figs. 16a, b, 1933.

Cushman, Geol. Soc. America Bull., vol. 47, p. 431, pl. 5, figs. 8a, b, 1936.

Ellisor, Am. Assoc. Petroleum Geologists Bull., vol. 24, p. 439 (list), pl. 5, fig. 18, 1940.

Bulimina schwageri(?) Cushman and Dusent t1ry (not Yokoyama), Cushman Lab. Foram. Research Contr., vol. 10, p. 62, pl. 8, figs. 11a, b, 1934.

Test long and slender, 3 or more times as long as broad, width practically uniform throughout the test except in the microspheric form where the last-formed chambers are inflated, consisting of 5 or 6 whorls; chambers distinct, slightly inflated, angled; sutures distinct, depressed; wall smooth, polished; often translucent, very finely perforate; aperture a long loop-shaped opening, with a well defined lip. Length of specimens from Baden and Nussdorf 0.28 to $0.67 \mathrm{~mm}$, diameter 0.14 to 0.22 $\mathrm{mm}$.

The types of the species are from the Miocene at Nussdorf, in the Vienna Basin, Austria. We have specimens from various localities in the Vienna Basin, including Nussdorf. The species is variable and long ranging, occurring from the Eocene to the Recent. Slight variations can be seen in specimens from difforent localities, but the species is so variable, even at the type locality, that it does not seem expedient to try to subdivide it further. We have material from the Eocene of the Paris Basin and Biarritz, France; from Neustift near Ofen, Hungary; from 480 feet below the base of the Tecuya formation, and from the Poway conglomerate of California ; and from the Alazan(?) shale of Mexico. Paalzow records it from the Oligocene of Germany. We have material from the Miocene of Germany ard France, from the Choctawhatchee formation of Florida, and various localities in Maryland. Chapman records it from the 
Miocene of California and Macfadyen from the Miocene of Eg.ypt. We have specimens from the Pliocene of Belgium, Sicily, Castel Arquato in Italy, near Nice in France, and questionably from the Kalinnen of Australia. Jones records it, as Bulimina elegans, from the Coralline Crag of England. In the Recent seas it is recorded from Zanzibar, Rimini in Italy, Bognor in England, and from the Red Sea. It has been recorded also from about the British Isles, although all our material from there seems to be varietal.

Various species of authors have been placed in the synonymy under this form. Bulimina ariminensis D'Orbigny, although the older name, was a nomen nudum until figured by Fornasini in 1901. Specimens from the Miocene of Dingden in Westphalia, one of the type localities for B. scabriuscula Reuss, were typical B. elongata. Specimens from Ortenburg, Germany, near Egger's locality for $B$. inconstans, were also typical. The specimens from the Miocene of Florida called B. gracilis Cushman are somewhat more slender and attenuated but identical ones may be found in the Vienna Basin material. The specimens from the Miocene of Chesapeake Beach, Maryland, are very typical.

The species may be recognized by its long, narrow test with angled chambers that are not arranged in regular series, and its rounded base.

\section{Bulimina elongata D'Orbigny var. tenera Reuss}

Plate 25, figure 18

Bulimina tenera Reuss (part), Akad. Wiss. Wien Sitzungsber., vol. 55, pt. 1, p. 94, pl. 4, figs. 11a, b, (not fig. 12), 1867.

Bulimina elegans Macfadyen (not d'Orbigny), Egypt Geol. Survey, 1930, p. 53, pl. 1, fig. 14, 1931.

Bulimina elongata D'Orbigny var. tenera Reuss, Cushman and Parker, Cushman Lab. Foram. Research Contr., vol. 13, p. 50, pl. 7, fig. 5, 1937.

Bulimina cf. B. elongata D'Orbigny var. tenera. Cushman and Herrick, idem, vol. 21, p. 64, pl. 10, fig. 16, 1945.

Variety differing from the typical form in that the last-formed whorl constitutes a large proportion of the test, usually about two-thirds, in the more pointed apertural end, and broader aperture.

The types are from the Miocene, Wieliczka, Galicia. We have no topotype material, but specimens from the Miocene of the Vienna Basin, Austria, appear to be identical. The variety occurs also in the Eocene of Germany and Hungary, the Miocene of France, Germany, Egypt, and Florida (Choctawhatchee marl) in the United States. Less typical specimens occur in the Eocene McBean formation of Georgia.

This form is apparently a variety of Bulimina elongata D'Orbigny. The initial portion of the test is identical with that of the latter, the variation coming only in the lastformed whorl.

\section{Bulimina elongata D’Orbigny var. subulata Cushman and Parker}

Plate 26, figures 1, 2

Bulimina elongata D'Orbigny var. subulata Cushman and Parker, Cushman Lab. Foram. Research Contr., vol. 13, p. 51, pl. 7, figs. 6, 7, 1937.

LeRoy, Colorado School of Mines Quart., vol. 36, no. 1, p. 32. pl. 3, figs. 72, 73, 1941.

Cushman, U. S. Nat. Mus. Bull. 161, p. 11, pl. 3, figs. 13a, b. 1942.

Colom, Inst. Invest. Geol., Num. 3 Estudios Geologicos, p 158, pl. 10, figs. 159, 160, 1946.

Bulimina aff. elongata D'Orbigny var. subulata LeRoy, Colorado School of Mines Quart., vol. 39, no. 3, p. 84, pl. 2, fig. 4. 1944.

Bulimina aculeata Reuss (not D'Orbigny), Akad. Wiss. Wien Denkschr., vol. 1, p. 374, pl. 47, fig. 13, 1850.

Egger, Naturh. Ver. Passau Jahresber. 16, p. 17, pl. 3, figs 8, 10,13,14, 1895.

Macfadyen, Egypt Geol. Survey, 1930, p. 55, pl. 1, fig. 19, 1931.

Hofker (part), Sta. Zool. Napoli Pub., vol. 12, pt. 1, p. 121, figs. 33-35, 1932.

Bulimina spinosa Seguenza, Accad. gioenia sci. nat. Atti, ser. 2, vol. 18 , p. 23, pl. 1, figs. 8, 8a, 1862 .

Cushman and Parker, Cushman Lab. Foram. Research Contr., vol. 14, p. $62,1938$.

Bulimina ovata Parker and Jones (not D'Orbigny), Philos. Trans., vol. 155 , p. 374, pl. 17, figs. $67 \mathrm{a}, \mathrm{b}, 1865$.

Bulimina elongata H. B. Brady (not D'Orbigny), ChallengeRept., Zoology, vol. 9, p. 401, pl. 51, figs. 1, 2, 1884.

Bulimina elegans Egger (not D’Orbigny), K. bayer. Akad. Wiss. Abh., cl. 2, vol. 18, p. 284, pl. 8, figs. 66, 67, 1893; Naturh. Ver. Passau Jahresber. 16, p. 16, pl. 3, fig. 9, 1895.

Variety differing from the typical form in having well developed spines at the base of the test, varying in lengtr and number. Length of specimens from Baden 0.32 to $0.57 \mathrm{~mm}$., diameter 0.20 to $0.24 \mathrm{~mm}$.

The types of the variety, are from the Miocene of Baden, Vienna Basin, Austria. It occurs at various other localities in the Vienna Basin. We have material from the Miocene of Hungary, Germany, France, Italy, and Egypt; from the Pliocene of France and Italy; and from Recent material from the Mediterranean Sea, Ireland, northeast coast of the United States, Juan Fernandez Island, Chile, and the Fiji Islands. LeRoy records it from the lat? Tertiary of Borneo and Java.

The variety is easily recognized. It differs from Bulimina gibba Fornasini in its more parallel-sided test, mor? irregular chambers, and rounded base.

\section{Bulimina elongata D'Orbigny var. lappa Cushman and Parker}

Plate 25, figure 19

Bulimina elongata D'Orbigny var. lappa Cushman and Parker, Cushman Lab. Foram. Research Contr., vol. 13, p. 51, pl. 7, fig. 8, 1937. 
Variety differing from the typical form in having a much shorter, broader test, with thicker walls, the initial portion of the test covered with very short, blunt spines. Length 0.30 to $0.54 \mathrm{~mm}$., diameter 0.20 to $0.28 \mathrm{~mm}$.

This variety was described from the Miocene at Nussdorf, Vienna Basin, Austria. We have material from several localities in the Vienna Basin, from the Miocene of Hungary and Egypt, and from the Pliocene of Italy.

The variety is easily distinguished by its short, broad test and its very short spines, which often appear as a roughening of the lower portion of the test.

\section{Bulimina buccinoides Egger}

Plate 26, figure 3

Bulimina buccinoides Egger, Neues Jahrb., 1857, p. 282, pl. 10, figs. 9-11.

Cushman and Parker, Cushman Lab. Foram. Research Contr., vol. 13 , p. 52, 1937.

Test ovate, pointed at both ends, middle portion inflated; consisting of 5 whorls, first chambers narrow, arched, later ones very large, long, arched; aperture thin and pointed. Length $0.75 \mathrm{~mm}$.

A summary of Egger's description of the species from the Miocene of Hausbach is given. We have no material referable to it. The original figures are reproduced.

\section{Bulimina tuberculata Egger}

Plate 26, figures 4,5

Bulimina tuberculata Egger, Neues Jahrb., 1857, p. 284, pl. 12, figs. 4-6 (not fig. 7).

Cushman and Parker, Cushman Lab. Foram. Research Contr., vol. 13, p. 50, pl. 7, figs. 4a-c, 1937.

?Bulimina aff. B. minuta Glaessner (not "Tritaxia minuta Marsson"), Problems of paleontology, Moscow Univ., vols. 2-3, p. 370 , pl. 2, figs. $18 \mathrm{a}, \mathrm{b}, 1937$.

Test small, about twice as long as broad, triangular in transverse section with rounded angles, slightly tapering, consisting of about 5 whorls; chambers fairly distinct, arranged in series with the adjacent chambers joined in a zigzag line, later chambers somewhat inflated; sutures distinct, early sutures flush with the surface, later sutures depressed; aperture a broad, loop-shaped opening. Length of specimens from a locality near Ortenburg, Germany, 0.24 to $0.42 \mathrm{~mm}$., diameter 0.12 to $0.20 \mathrm{~mm}$.

The types are from the Miocene at Hausbach, near Ortenburg, Germany. We have specimens from Egger's Miocene localities in Germany; from Kostej, near Banat, Hungary; from two localities in the Miocene of France; and a single specimen from Nussdorf in the Vienna Basin, Austria. The species appears to be confined to the Miocene.

The last figure given by Egger (pl. 12, fig. 7) does not refer to this species but probably to a Bitubulogenerina which occurs at the same locality. The species differs from Bulimina mimuta (Marsson) in being larger, more elongate, less tapered, with more rounded angles and more inflated chambers.

\section{Bulimina bulbiformis Seguenza}

\section{Plate 26, figure 6}

Bulimina bulbiformis Seguenza, R. accad. Lincei Atti, ser. 3, vol. 6 , p. 146 , pl. 13 , fig. $35,1880$.

Cushman and Parker, Cushman Lab. Foram. Research Contr., vol. 13, p. $52,1937$.

Seguenza describes this species as egg-shaped, rounded at the apertural end, pointed at the initic 1 end, with the sutures very slightly depressed and indistinct.

The types are from the Miocene Tortonian of Calabria, Italy. We have no material referable to it.

\section{Bulimina calcarata Seguenze}

Plate 26, figures 7-9

Bulimina calcarata Seguenza, R. accad. Lincei Atti, ser. 3, vol. 6, p. 146 , pl. 13, fig. $36,1880$.

Bulimina ovata D'Orbigny var. apiculata Egger, Naturh. Ver. Passau Jahresber. 16, p. 17, pl. 3, fig. 15, 1895.

Cushman and Parker, Cushman Lab. Forar. Research Contr., vol. 14, p. 55, pl. 9, fig. 5, 1938.

Test of medium size, somewhat fusiform, short and broad, consisting of about 3 whorls, initial end usually bluntly pointed with 1 or 2 heavy, short soines; chambers distinct, inflated; sutures distinct, depressed; wall smooth, perforate; aperture loop-shaped, with a lip, and well developed tooth. Length of figured specimen $0.60 \mathrm{~mm}$., diameter $0.40 \mathrm{~mm}$.

The species was described from the Miocene Tortonian of Calabria, Italy. We have no topotype material but specimens from several localities in the Miocene of the Vienna Basin, Austria seem typical. Specimens from the Pliocene of Castel Arquato, Italy are more fusiform, with somewhat less inflated chambers, but otherwise appear identical.

The species resembles Bulimina pupoides D'Orbigny but has fewer, more inflated chambers and the short, basal spines. The chambers do not slope downward as in $B$. pyrula D'Orbigny, are more inflated, and the spines are heavier than those occasionally seen in the latter species.

\section{Bulimina triquetra Franzenau}

Bulimina triquetra Franzenau, Termeszetrajzi Füzetek, vol. 15, p. $139,1892$.

Cushman and Parker, Cushman Lab. Foram. Research Contr., vol. 13, p. $52,1937$.

Franzenau in describing this species from the Miocene of Romhány, Hungary, says that it bears more resem- 
blance to the genus Verneuilina than Bulimina. He describes it as elongate, elliptical, pointed at both ends, sharply three-cornered, with somewhat concave sides; the initial chambers distinct, arranged in 3 rows, the youngest chamber composing the whole top of the test; sutures in the initial portion distinct, depressed, later portion indistinct; aperture elongate, comma-shaped, placed vertically on the last chamber; wall finely perforate.

He compares the species to Bulimina arcuata Stache (not D'Orbigny), from the Eocene of Whaingaroa, but says that Stache's form is more textularian in character. $B$. arcuata Stache does not belong to Bulimina, and it seems quite possible, from the description, that $B$. triquetra belongs to the genus Tritaxia or some related genus. As no figures were given, the point cannot be definitely settled.

\section{Bulimina parvula Franzenau}

Bulimirıa parvula Franzenau, Termeszetrajzi Füzetek, vol. 15, p. $139,1892$.

Cushman and Parker, Cushman Lab. Foram. Research Contr., vol. 13, p. 52, 1937.

This species, from the Miocene of Romhány, Hungary, is described as elongate, fusiform, with the apertural end sharply pointed, the initial end bluntly pointed, consisting of 4 rapidly increasing whorls; chambers inflated, with deep sutures; aperture an arched, elongate opening, at the inner margin of the last chamber, surrounded by a bordering ridge.

No figures are given of this species, and the description is too brief to make a definite identification possible.

\section{Bulimina porrecta Franzenau}

Bulimina porrecta Franzenau, Glasnik. hrv. nar. druztva, vol. 7, pt. 6, pl. 5, figs. 1a, b, 1894 .

The figures of this species, described from the Miocene, Marcusevec, Croatia, show a form very similar to Bulimina pupoides D'Orbigny. Lack of any material referable to it, however, makes a positive identification impossible.

\section{Bulimina cuspidata Franzenau}

Bulimina cuspidata Franzenau, Glasnik, hrv. nar. druztva, vol. 7, pt. 6, pl. 5, figs. 2, 3, 1894.

Cushman and Parker, Cushman Lab. Foram. Research Contr., vol. 13 , p. 52, 1937.

The figures of this species from the Miocene of Marcusevec, Croatia, show a form with few whorls, globular chambers, and with a sharp, basal spine. We have no material referable to it.

Bulimina affinis D'Orbigny var. tenuissimestriata Schubert Plate 26, figures 10,11

Bulimina affinis D'Orbigny var. temuissimestriata Schubert, K.-k. geol. Reichsanstalt Jahrb., vol. 53, p. 416, pl. 19, figs. 5a-c, 1903.

Cushman and Parker, Cushman Lab. Foram. Research Contr.. vol. 13, p. 53, 1937.

Schubert differentiates this variety by the fine striations, as well as by the arrangement of the chambers. He. states that it bears a greater resemblance to "Buliminc. ovulum" Reuss, (Bulimina reussi Morrow), than to the typical Recent examples of $B$. affinis.

The species is described from the Miocene "Welser Schlier," in a well-boring near Wels, Austria. We have. no material referable to it. The original figures are reproduced here.

\section{Bulimina rotula Schubert}

Plate 26, figure 12

Bulimina rotula Schubert, K.-k. geol. Reichsanstalt Jahrb., vol. 53, p. 416, pl. 19, figs. 7a, b, 1903.

Cushman and Parker, Cushman Lab. Foram. Research Contr., vol. 13, p. $53,1937$.

Schubert differentiates this species from others by its cylinder-shaped test and compact chambers. He compares it to Bulimina subornata H. B. Brady, from which it differs by the shape and position of the aperture and by the costae, which are much finer and cover the whole. test. He says that in shape it resembles "Bulimina puschi" Reuss (Arenobulimina puschi (Reuss)) and "Buliminc. imbricata" Reuss (Buliminella imbricata (Reuss)) but differs in the construction of the chambers.

The species was described from the Miocene "Welser Schlier," in a well-boring near Wels, Austria. We have no specimens referable to it. The original figures are reproduced here.

\section{Bulimina pseudotorta Cushman}

Plate 26, figure 13

Bulimina pseudotorta Cushman, Cushman Lab. Foram. Researcl Contr., vol. 2, p. 55, pl. 7, fig. 3, 1926.

Cushman, Stewart and Stewart, San Diego Soc. Nat. History Trans., vol. 6, p. 66, 1930.

Kleinpell, Miocene stratigraphy of California, p. 258, Tulsa. 1938.

Test of medium size, rapidly tapering from the broadly rounded, or somewhat truncate, apertural end, initial end narrow, rounded; chambers few, slightly inflated, angular in shape; sutures distinct, depressed; wall smooth, finely perforate; aperture elongate, comma-shaped. Length of holotype $0.90 \mathrm{~mm}$, diameter $0.66 \mathrm{~mm}$.

This species was described from the Miocene Monterey shale, sec. 24, T. 28 S., R. 14 E., M.D.M., San Luis Obispo County, California. It is recorded by Cushman, Stewart and Stewart from the Miocene of Humboldt County, 
California, and by Kleinpell from the upper Relizian and lower Luisian at various Californian localities.

The species most closely resembles Bulimina (Desinobulimina) montereyana Kleinpell but differs from it in being more tapered and in not having the terminal aperture. It seems very probable that it represents the ancestral form of Kleinpell's species.

\section{Bulimina alligata Cushman and Laiming \\ Plate 26, figure 14}

Bulimina inflata Seguenza var. alligata Cushman and Laiming, Jour. Paleontology, vol. 5, p. 107, pl. 11, figs. 17a, b, 1931.

Kleinpell, Miocene stratigraphy of California, p. 254, pl. 7, fig. 1, Tulsa, 1938.

Schenck and Childs, Stanford Univ. Publ., Univ. Ser., Geol. Sci., vol. 3, no. 2, p. 26 (list), 1942.

Weaver, Washington Univ. [Seattle] Pub, in Geology, vol. 6, no. 1, p. 23 (list), 1944 .

Test about twice as long as broad, tapering, consisting of about 6 whorls; chambers indistinct, later chambers slightly inflated, sutures indistinct in early portion of the test, depressed in later portion; wall of most of last whorl smooth, remainder of test ornamented by low costae arranged in straight lines but broken at the sutures, with occasional shorter costae interpolated; aperture loopshaped, with the base practically at the junction of the second and third chambers. Length $0.60 \mathrm{~mm}$., diameter $0.35 \mathrm{~mm}$.

The types are from the Miocene of Los Sauces Creek, Ventura County, California. Kleinpell records the species from the upper and lower Saucesian and questionably from the upper Luisian of California. It occurs in the Pliocene, above the base of the first Pico sandstone, Cañada de Aliso, Ventura County, California : at 210 and 260 feet stratigraphically above the base, $23 / 10$ miles $\mathrm{N}$. $75^{\circ}$ E. of La Crosse Junction; and at 3140 feet stratigraphically above the base, $2 \%$ miles S. $88^{\circ} \mathrm{E}$. of $\mathrm{La}$ Crosse Junction. It has also been recorded from the Miocene Gallaway formation and the Oligocene Sandholdt formation of California.

This form has been given specific rank, as it does not seem to be varietally related to Bulimina inflata Seguenza. The chambers are arranged in more regular series and are more rounded and inflated, the costae are arranged in more definite longitudinal lines and are very definitely broken at the sutures. The costae are more definite and regular than in $B$. rinconensis Cushman and Laiming, the test is less fusiform, and the aperture is placed lower.

\section{Bulimina rinconensis Cushman and Laiming}

\section{Plate 26, figure 15}

Bulimina rinconensis Cushman and Laiming, Jour. Paleontology, vol. 5, p. 107, pl. 11, figs. 18a, b, 1931.
Kleinpell, Miocene stratigraphy of California, p. 258, Tulsa, 1938.

Renz, 8th Am. Sci. Congress Proc., p. 556 (list), 1942.

Weaver, Washington Univ. [Seattle] Pub. in Geology, vol. 6, no. 1, p. 23 (list), 1944.

Bulimina cf. B. rinconensis Cushman and Hobson, Cushman Lab. Foram. Research Contr., vol. 11, p. 62, pl. @, figs. 4a, b, 1935.

Test about twice as long as broad, with the greatest breadth toward the apertural end, somervhat fusiform. consisting of 5 or 6 whorls; chambers fairly distinct except in early portion of the test, arranged in regular series, inflated, somewhat angular; sutures distinct, depressed; wall ornamented by bluntly pointed, low, broad, rounded costae, at the base of the chambors in the lastformed whorls and across the whole chamber in the earlier ones; aperture fairly long, loop-shaped, placed at the apex of the test, well above the junction of the second and third chambers. Length $0.50 \mathrm{~mm}$., diameter $0.25 \mathrm{~mm}$.

The types are from the Miocene on Los Sauces Creek, Ventura County, California. The species occurs in the Oligocene(?) San Lorenzo formation of California. Kleinpell records it from the Miocene, lower Saucesian and upper and lower Zemorrian, of California. In the Pliocene it is found at several localities above the lase of the first Pico sandstone in Cañada de Aliso, Ventura County, California : at 260 feet stratigraphically above the base in brown siltstone, $23 / 10$ miles N. $75^{\circ} \mathrm{E}$. of La Crosse Junction; at 3140 feet stratigraphically above the base in gray siltstone, $22 / 5$ miles S. $88^{\circ} \mathrm{E}$. of La Crosse Junction; and at 8240 feet stratigraphically above the $17.5 e$ in a shaly parting of a conglomerate member, $23 / 4$ miles S. $72^{\circ} \mathrm{E}$. of La Crosse Junction. It occurs also in the Pliocene on the west side of Atlantic Blvd., 1275 feet. N. $13^{\circ} \mathrm{E}$. of northwestern corner of intersection of Harding Ave., Los Angeles, California. The species has been recorded, but without figures, from the Oligocene of Trinidad and Costa Rica, and from the Miocene of Trinidad.

The species differs from Bulimina alligata Cushman and Laiming in the more fusiform test, in the placing of the aperture nearer the apex of the test, and in the less regular, bluntly pointed costae. The costae are more rounded than in Bulimina subacuminata Cushman and R. E. Stewart, and it lacks an initial spine.

\section{Bulimina delreyensis Cushman and Galliher Plate 26, figure 16}

Bulimina delreyensis Cushman and Galliher, Custman Lab. Foram. Research Contr., vol. 10, p. 25, pl. 4, figs. Ea, b, 1934.

Bulimina buchiana Cuslıman and Ponton (not D'Orbigny), Florida Geol. Survey Bull. 9, p. 78, pl. 12, figs. 1a, b, 1932.

Test about twice as long as broad, taparing from the subacute initial end to the greatest breadth at the last whorl, rounded in transverse section; chambers distinct, slightly inflated, increasing uniformly in size as added; 
sutures distinct, very slightly depressed; wall ornamented with a few, distinct, longitudinal costae, independent of the chambers, with secondary costae coming in between the primary costae as growth progresses, the uppermost part. of the last 2 chambers smooth; aperture very narrow, elongate, on the somewhat flattened apex of the test. Length $1.00 \mathrm{~mm}$., diameter $0.50 \mathrm{~mm}$.

The species was described from the Miocene Monterey shale in the diatomite quarry, 4 miles east of Del Monte, south side of Canyon Del Rey, California.

The form from the I'oldia zone of the Choctawhatchee formation of Florida, described by Cushman and Ponton as Bulimina buchiana D'Orbigny is very close to this species except that the test is somewhat more ovate.

The species somewhat resembles Bulimina buchiana D'Orbigny but differs from it in having fewer, more regular costae that extend well up onto the chambers of the last whorl, in having the chambers of the last whorl forming a much smaller proportion of the whole test, and in the flattened character of the apex of the test, which in B. buchiana is somewhat ovate.

\section{Bulimina carnerosensis Cushman and Kleinpell}

Plate 26, figure 17

Bulimina carnerosensis Cushman and Kleinpell, Cushman Lab. Foram. Research Contr., vol. 10, p. 5, pl. 1, figs. 12a, b, 1934.

Kleinpell, Miocene stratigraphy of California, p. 252, Tulsa, 1938.

Weaver, Washington Univ. [Seattle] Pub. in Geology, vol. 6. p. 23 (list), 1944.

Test short, ovate, somewhat compressed, periphery slightly lobulate, greatest breadth toward the apertural end; chambers fairly distinct, somewhat inflated, increasing in height as added; sutures fairly distinct, somewhat depressed, very slightly oblique, becoming nearly horizontal in the last-formed portion; wall ornamented by low, longitudinal, regular costae independent of the individual chambers, lapping over the outer end of the last 2 chambers; aperture elongate, nearly straight, running well into the terminal face. Length $0.40 \mathrm{~mm}$., diameter $0.20 \mathrm{~mm}$.

The species was described from the Miocene on Carneros Creek, California, 295 feet stratigraphically above the base of the Temblor formation. Kleinpell records it from the upper and lower Zemorrian of California and Weaver from Gallaway formation, near Point Arena, California.

This species is, in some ways, similar to Bulimina buchiana D'Orbigny but differs from it in having fewer, heavier costae that are continuous almost to the top of the last-formed whorl. It also resembles Bulimina delreyensis Cushman and Galliher, differing from it in being much smaller and in having a more ovate test.

\section{Bulimina carnerosensis Cushman and Kleinpell var. mahoneyi Cushman and Kleinpell}

Plate 26, figure 18

Bulimina carnerosensis Cushman and Kleinpell var. mahoneyi Cushman and Kleinpell, Cushman Lab. Foram. Research Contr., vol. 10, 'p. 5, pl. 1, figs. 13a, b, 1934.

The variety differs from the typical form in its largesize, greater length in proportion to its width, and in the sutures, which become more oblique in the later portion of the test.

This variety was described from the Miocene on Carneros Creek, California, 310 feet stratigraphically abov: the base of the Temblor formation. It occurs 15 feet above the typical form and evidently represents a development from it.

\section{Bulimina uvigerinaformis Cushman and Kleinpell}

Plate 26, figure 19

Bulimina wvigerinaformis Cushman and Kleinpell, Cushman Lat. Foram. Research Contr., vol. 10, p. 5, pl. 1, figs. 14a, 1 1934.

?Kleinpell, Miocene stratigraphy of California, p. 261, Tulsa. $i y$.

Test fusiform, greatest breadth near the middle, rounded in transverse section, periphery somewhat lobulate; chambers numerous, distinct, inflated, later chambers globular; sutures distinct, depressed; wall ornamented by longitudinal costae, more or less independent on each chamber, somewhat broken at the sutures; aperture in the adult elongate, somewhat curved, with a slight lif: sometimes terminal, not reaching to the base of the chamber. Length $1.10 \mathrm{~mm}$., diameter $0.45 \mathrm{~mm}$.

The types are from the Miocene, 335 feet stratigraphically above the top of a prominent chert bed, 10 feet thick, exposed at base of ocean bluffs, immediately east of mouth of Dos Pueblos Creek, west of Naples, Californic. Kleinpell records somewhat similar specimens, having continuous, more numerous costae, from the Montere: shale near El Toro, California.

This species represents an intermediate form between the genus Uvigerina and Bulimina. In many respects it more closely approaches the former in the shape and arrangement of the chambers and the presence of a terminal aperture. The aperture, however, has no neck, and is elongate and slit-like in shape. This uvigerine character makes it easily separable from other known species.

\section{Bulimina pseudoaffinis Kleinpell}

Plate 26, figure 20

Bulimina pseudoaffinis Kleinpell, Miocene stratigraphy of California, p. 257, pl. 9, fig. 9, Tulsa, 1938. 
Weaver, Washington Univ. [Seattle] Pub. in Geology, vol. 6, p. 23 (list), 1944.

Test of medium size, somewhat tapering, with the broadest portion just above the middle, periphery slightly lobulate; consisting of about 3 whorls, the last-formed whorl forming as much as four-fifths of the test; chambers distinct, inflated; sutures distinct, depressed; wall smooth, finely perforate; aperture elongate, commashaped. Length of holotype $0.64 \mathrm{~mm}$., diameter $0.40 \mathrm{~mm}$.

The species was described from the Miocene, lower Relizian, Reliz Canyon, Monterey County, California (sample C.4, Leland Stanford Junior Univ. loc. 691). Kleinpell also records it from the upper Saucesian, lower and upper Relizian of Reliz Canyon. A study of the plesiotypes of two forms recorded as Bulimina ovula D'Orbigny shows specimens closely related to Kleinpell's species except that they have more tapered tests. They were found in the Monterey shale, San Luis Obispo County, (Cushman, Cushman Lab. Foram. Research Contr., vol. 2, p. 55, pl. 7, fig. 2, 1926) and the Vaqueros formation of Simi Valley, California (Cushman and LeRoy, Jour. Paleontology, vol. 12, p. 125, pl. 22, fig. 18, 1938). Weaver records it from the Point Arena formation of California.

This form is less tapered, with more rounded chambers than Bulimina pseudotorta Cushman. It is much smaller and has more inflated chambers than B. affinis D'Orbigny. It is more tapering, with a more flattened apertural end than $B$. pupoides D'Orbigny. Kleinpell relates it to $B$. ocula D'Orbigny, but the latter species is broadly ovate, very involute, and has a well-developed tooth.

\section{Bulimina delmonteensis Kleinpell}

Plate 26, figure 21

Bulimina montereyana Kleinpell var. delmontcensis Kleinpell, Miocene stratigraphy of California, p. 255, pl. 16, fig. 9, Tulsa, 1938.

Test of medium size, rapidly tapering, somewhat ovate with the broadest portion about one-third of the distance from the apertural end, consisting of 2 to 3 whorls; chambers distinct, those of last-formed whorl slightly inflated; sulures distinct, very slightly depressed; aperture loopshaped, very slightly curved, placed at the apex of the test, with a slight tooth. Length of holotype $0.58 \mathrm{~mm}$., diameter $0.38 \mathrm{~mm}$.

The types are from the Miocene, lower Delmontian, Reliz Canyon (Leland Stanford Junior Univ. loc. 691), California. The species has been recorded by Kleinpell from the Miocene, ranging from the upper Luisian to the lower Delmontian of California. Our material is from the Miocene Tice shale of Contra Costa County. California, at which locality Kleinpell records the species in abundance.
This species seems to have more than a varietal difference from Bulimina (Desinobulimina) montereyana Kleinpell. It shows no sign of having a terminal aperture, has less inflated, somewhat differently shaped chambers, is more tapered, and the apertural end is not truncate. It differs from $B$. pseudotorta Cushman in being much shorter, more ovate, and in having less inflated, less angled chambers.

\section{Bulimina ovula D'Orbigny var. pedroana Kleinpell}

\section{Plate 26, figure 22}

Bulimnina ovula D'Orbigny var. pedroana Kleinpell, Miocene stratigraphy of California, p. 257, pl. 22, fig. 13, Tulsa, 1938.

Variety differing from the typical form in the more tapering, less fusiform test, which has more whorls and a broader base, and in the more inflated chembers and depressed sutures. Length $0.70 \mathrm{~mm}$, diameter $0.56 \mathrm{~mm}$.

The types are from the Miocene, lower Delmontian, Malaga mudstone of San Pedro, California.

This variety is much less involute than th: typical form. The chambers are more inflated and incraase much less rapidly in height as added than those of "Bulimina ovula Cushman and Moyer" from the Recent of San Pedro, California (referred by us to $B$. affinis D'Orbigny), a form which Kleinpell says is close to his variety.

\section{Bulimina microlongistriata, LeK oy}

Plate 30, figure 14

Bulinina microlongistriata LeRoy, Colorado S rhool of Mines Quart., vol. 36, no. 1, p. 32, pl. 1, figs. 97, 98, 1941.

Glaessner, Royal Soc. Victoria Proc., vol. 55 (n. ser.), pt. 1, p. 68 (list), 1943.

LeRoy, Colorado School of Mines Quart., vcl. 39, no. 3, p. 26, pl. 1 , fig. 2 ; pl. 5 , fig. 11 ; p. 84 , pl. 2, fig. 3, 1944.

Test medium, about twice as long as broad, widest in upper twothirds, tapers rather gradually; chambers distinc ${ }^{+}$, slightly inflated toward apertural end; sutures distinct, slightly depressed; wall transparent, covered with very minute longitudinal striae the entire length of test, although on some specimens the last cliamber is smooth; aperture a narrow loop. Length $0.68 \mathrm{~mm}$., height $0.38 \mathrm{~mm}$

In general characteristics and outline this species appears to be closely related to Bulimina subornata Brady but differs from it primarily in that it lacks the basal spine.-LeRoy.

This species was described from the late Tertiary (uppermost Miocene or early Pliocene) of the Sangkoelirang Bay area on the east coast of Borneo. It has been recorded from the Miocene of central Sumatra and west Java.

\section{Bulimina echinata D'Orbigny}

Plate 26, figures 23, 24

Bulimina echinata D'Orbigny, Annales sci. nat., vol. 7, p. 269, no. $5,1826$. 
Fornasini, Soc. geol. italiana Boll., vol. 20, p. 176, text fig. 2, 1901 ; Accad. sci. Ist. Bologna Mem., ser. 5, vol. 9, p. 379, pl. 0, fig. 38, 1901.

Heron-Allen and Earland, Linnean Soc. London Trans., vol. 2, ser. 2, p. 235, pl. 41, fig. 3, 1916.

Cushman, U. S. Nat. Mus. Bull. 104, pt. 3, p. 99, pl. 15, fig. 6, 1922.

Cushman and Parker, Cushman Lab. Foram. Research Contr., vol. 14, p. 54, pl. 9, figs. 3, 4, 1938.

Parr, Min. and Geol. Jour., vol. 1, no. 4, p. 67, pl., fig. 7, 1939.

Test medium in size, elongate, with almost parallel sides in the megalospheric form, shorter and much more tapering in the microspheric, consisting of 4 to 5 whorls; chambers distinct, inflated; sutures distinct, depressed; wall of upper part of test smooth, finely perforate, lower part covered with short, very fine, sharp spines which occasionally extend up to cover all the test except for the upper part of the last-formed whorl, with occasional shaped, with a well defined lip. Length 0.45 to $0.60 \mathrm{~mm}$., longer spines at the initial end; aperture broad, loopdiameter 0.25 to $0.30 \mathrm{~mm}$.

The types are from the Pliocene near Siena, Italy. The species occurs in the Miocene of San Rufillo, near Bologna, Italy; from several localities in the Pliocene of Italy; from the Pliocene of Garrobo, southern Spain, and the Pliocene of Victoria, Australia. It is found in the present ocean off Rimini, Italy, and has been recorded from off the west coast of Scotland.

This species resembles Bulimina elongata D'Orbigny var. lappa Cushman and Parker but is more tapering, has more depressed sutures, and sharper spines, which usually cover a greater part of the test. It is closely related to the $B$. elongata group but is much more spinose in character and has more deeply depressed sutures.

\section{Bulimina costata D'Orbigny}

Plate 27, figures 2, 3

Bulimina costata D'Orbigny, Annales sci. nat., vol. 7 , p. 269 , no. 1 , 1826.

Fornasini, Soc. geol. italiana Boll., vol. 20, p. 174, fig. 1, 1901.

Cushman and Parker, Cushman Lab. Foram. Research Contr., vol. 14, p. 54, pl. 9, figs. 1, 2, 1938.

? Bulimina buchiana Egger (not D'Orbigny), Naturh. Ver. Passau Jahresber. 16, p. 18, pl. 4, figs. 9, 10 (fig. 11 ?), 1895.

Bulimina inflata H. B. Brady (not Seguenza) (part), Challenger Rept., Zoology, vol. 9, p. 406, pl. 51, figs. 11, 13 (not figs. $10,12), 1884$

Macfadyen, Egypt Geol. Survey, 1930, p. 55, pl. 1, fig. 20, 1931.

Test small, about twice as long as broad, microspheric form gradually tapering, megalospheric with the widest portion about halfway up the test, consisting of about 5 whorls in the adult form; chambers fairly distinct, especially in the last-formed whorls, somewhat undercut; sutures distinct, depressed; wall of upper part of last whorl smooth, otherwise ornamented with longitudinal costae, usually broken at the sutures with a sharp poirt, occasionally crossing the sutures, perforate; apertu-e loop-shaped, narrow, with a distinct lip. Length 0.40 to $0.50 \mathrm{~mm}$., diameter 0.22 to $0.28 \mathrm{~mm}$.

The types of the species are from the Pliocene of Coroncina, Italy. It occurs in the Miocene of Hungary, the Vienna Basin, Italy, and Egypt, with similar specimens in the Miocene of Venezuela; in the Pliocenie of Italy, France, and Sicily; in the Pleistocene of Malaga, Spain; and in Recent material from Rimini, Italy, ard near Ireland.

This species is smaller than Bulimina buchiard D'Orbigny and has more irregular, broken costae, which make what D'Orbigny calls a "keeled" effect at the suture. It is more definitely costate than $B$. alsatica Cushman ard Parker. The species is very variable and it is sometimes difficult to separate the non-typical specimens of these three species.

\section{Bulimina acanthia Costa}

Plate 26, figures 25-27; plate 27, figure 1

Bulinina acanthia Costa, Accad. pontaniana Atti, vol. 8, pt. 2, p. 335 , pl. 13, figs. $35,36,1856$.

Cushman and Parker, Cushman Lab. Foram. Research Contr., vol. 14, p. 61, 1938.

Bulimina etnea Seguenza, Accad. gioenia sci. nat. Atti, ser. 2, vol. 18, p. 24, pl. 1, fig. 9, 1862.

Cushman and Parker, Cushman Lab. Foram. Research Contr., vol. 14, p. 59, pl. 10, figs. 6-9, 1938.

Bulimina marginata Terrigi (not D'Orbigny), Pont. accad. sci. Nuovi Lincei Atti, vol. 33, p. 72, pl. 2, figs. 35, 36, 1880.

Test of medium size, tapering, usually terminated by a small spine or spines, about twice as long as broad, consisting of 4 to 7 whorls; chambers distinct, those of last whorl inflated, in the adult forms with a distinct overhan? in the last 1 or 2 whorls in the microspheric form, an 1 sometimes throughout the test in the megalospheric; sutures distinct, depressed; wall smooth, polished, finel." perforate, the overhanging chambers having a very slight scalloping along the edge with occasional small spines; aperture a broad, loop-shaped opening, with a distinct lip. Length up to $0.65 \mathrm{~mm}$., diameter up to $0.30 \mathrm{~mm}$.

The types are from the Pliocene of Lequile and Notaresco, Italy. The species occurs at several localities in the Pliocene of Italy and Sicily. The species described as Bulimina pulchella by Cushman and Moyer (not D'Orbigny) (Cushman Lab. Foram. Research Contr., vol. $\epsilon$. p. 56, pl. 7, fig. 19, 1930) from the Recent off San Pedrc, California is very close to this form.

This species resembles Bulimina marginata D'Orbigny but even the most advanced megalospheric specimens do not show the uniform undercutting of the chambers seen in that species. The chambers are more undercut 
than in B. gibba Fornasini, and the basal portion of the test is not angled. The species is very variable. Several figures are given in an attempt to show some of the variations.

\section{Bulimina pustulosa Costa \\ Plate 27, figure 5}

Bulimina pustuloșa Costa, Accad. pontaniana Atti, vol. 8, pt. 2, p. 268 , pl. 15 , fig. 8 (incorrectly referred to figs. 6,7 , in text), 1856 .

Costa describes this species as ovately conical, more or less elongate, initial end acute, apertural end obtuse, rounded; 5 to 9 chambers, large, inflated, subglobular; wall finely papillate. Length $0.70 \mathrm{~mm}$.

The types are from the Pliocene, near Naples, Italy. The figure and description suggest Dorothia globosa (D’Orbigny).

\section{Bulimina pedunculata Costa}

Plate 27, figure 6

Bulimina pedunculata Costa, Accad. pontaniana Atti, vol. 8, pt. 2, p. 336, p1. 18, fig. 13 (incorrectly referred to fig. 16, in text), 1856.

Cushman and Parker, Cushman Lab. Foram. Research Contr., vol. 14, p. $62,1938$.

Test oval, pointed at the bottom, initial end obtuse; 4 or 5 chambers, the first two separated by a transverse suture, later ones large, involute, the last prolonged into a sort of peduncle, at the end of which is the slit-like aperture. Length $1.00 \mathrm{~mm}$.

A summary of Costa's description of the species from the Pliocene of Cannitello near Naples, Italy, is given. It is doubtful if it belongs in Bulimina.

\section{Bulimina peucetia Costa}

Plate 27, figure 4

Bulimina peucetia Costa, Accad. pontaniana Atti, vol. 8, pt. 2, p. 338, pl. 18, fig. 15 (peucetiae affinis in expl.), 1856.

Bulimina "peucetiae affinis" Cushman and Parker, Cushman Lab. Foram. Research Contr., vol. 14, p. 62, 1938.

Test subovate, somewhat pointed at the initial end, apertural end obtuse or almost truncate; composed of 7 or 8 chambers, inflated, almost biserial but slightly coiled, distinct with deep sutures, last chamber almost covering the two preceding ones; aperture elongate. Length $1.00 \mathrm{~mm}$.

This species was described from the Pliocene of Bari, near Naples, Italy. It is doubtful whether it belongs in Bulimina. A summary of Costa's description is given.

\section{Bulimina subcalva Cushman and K. C. Stewart}

Plate 27, figure 7

Bulimina subcalva Cushman and K. C. Stewart, in Cushman, Stewart and Stewart, San Diego Soc. Nat. History Trans., vol. 6, p. 65, pl. 4, figs. 11a, b, 1930.

Cushman and Parker, Cushman Lab. Foram. Research Contr., vol. 14, p. 55, pl. 9, figs. 8a-c, 1938.

Test slightly longer than broad, rapidly tapering from the greatest width near the apertural end to the acute initial end, with a distinct, basal spine, con isting usually of 4 or 5 whorls; chambers distinct, somewhat inflated, those of successive whorls alined in series; sutures distinct, depressed; wall of the chambers ornamented by distinct, somewhat plate-like costae that do not cross the sutures and are terminated by slightly spinose projections, upper part of last whorl smooth, finely perforate; aperture elongate, loop-shaped, placed above the junction of the second and third chambers, with a slight lip. Length of holotype $0.53 \mathrm{~mm}$., diameter $0.35 \mathrm{~mm}$.

The types are from the Pliocene of Scotia Bluffs, about 160 yards southward from north line of SE $1 / 4$ sec. 5, T. 1 N., R. 1 E., H. M., Humbolt County, California. The species occurs also in the Pliocene of Lomita Quarry, Palos Verdes Hills, California.

The species differs from Bulimina subacuminata Cushman and R. E. Stewart in being typically less fusiform, and in having the costae less pronounced and with somewhat spinose projections. It differs fro'n $B$. alligata Cushman and Laiming in having the spinose projections and a basal spine.

Bulimina subacuminata Cushman and R. E. Stewart

Plate 27, figure 8

Bulimina subacuminata Cushman and R. E. Stewart, in Cushman, Stewart and Stewart, San Diego Soc. Nat. History Trans., vol. 6, p. 65, pl. 5, figs. 2, 3a, b, 1930.

Cushman and Parker, Cushman Lab. Foram. Research Contr., vol. 14, p. 56, pl. 9, fig. 9, 1938.

Hanna and Hertlein, State of Calif., Div. of Mines, Bull. 118 , p. 180 , fig. 67 [plate], fig. 39, 1941.

Test about twice as long as broad, somexhat fusiform, tapering from the broadest portion near the base of the last-formed whorl, with a well developed basal spine, consisting of 6 whorls in the adult; chambers fairly distinct, those of last whorl slightly inflated; sutures fairly distinct, depressed; wall perforate, upper part of lastformed whorl smooth, remainder of test ornamented by thin, high, plate-like costae, usually broker at the sutures but occasionally continuous across them, the lower end of the costae often angled; aperture loop-shaped, placed well above the junction of the second and third chambers. Length $0.50 \mathrm{~mm}$., diameter $0.28 \mathrm{~mm}$. 
The types are from the Pliocene on Bear River, NE 1/4 sec. 20, T. 1 N., R. 2 W., H. M., Humboldt County, Calif. Similar, though more tapered, specimens were found at 1,030 feet and 1,175 feet stratigraphically above the base of the first Pico sandstone, in brown sandy shale near the base of a conglomerate member, and in gray siltstone respectively, $2 \%$ miles $\mathrm{N}$. $77^{\circ} \mathrm{E}$. of La Crosse Junction, Cañada de Ališs, Ventura County, California.

The species differs from Bulimina rinconensis Cushman and Laiming in the thinner, higher costae and in having a basal spine.

\section{Bulimina pagoda Cushman var. hebespinata R. E. and K. C. Stewart}

Plate 27, figures 9, 10

Bulimina pagoda Cushman var. hebespinata R. E. and K. C. Stewart, Jour. Paleontology, vol. 4, p. 63, pl. 8, figs. 3a, b, 1930.

Cushman and Parker, Cushman Lab. Foram. Research Contr., vol. 14, p. 55, pl. 9, figs. 6, 7, 1938.

Variety differing from the typical form in having much heavier, blunter spines that are the continuation of rather indistinct, short costae and that do not project as far as those of the typical form. Length of holotype $0.40 \mathrm{~mm}$., diameter $0.30 \mathrm{~mm}$.

The types are from the Pliocene, lower part of Pico formation, at a drilling depth of 5,348 feet in the Miley H. \& H. no. 1 well of the Richfield Oil Company of California, Rincon Oil Field, sec. 17, T. 3 N., R. 24 W., S. B. M., Ventura County, Calif. The variety occurs also 5,175 feet above the base of the first Pico sandstone, Cañada de Aliso, Ventura County, California, and at the south side of Garvey Blvd., 100 yards west of intersection with Atlantic Blvd., Repetto Hills, Los Angeles, California.

It differs from Bulimina rinconensis Cushman and Laiming in having a more tapered test and projecting spines.

\section{Bulimina fossa Cushman and Parker}

Plate 27, figure 11

Bulimina fossa Cushman and Parker, Cushman Lab. Foram. Research Contr., vol. 14, p. 56, pl. 9, fig. 10, 1938.

Test nearly twice as long as broad, tapering from the greatest breadth at the last-formed whorl to the subacute initial end, apertural end broadly rounded, consisting of 6 or more whorls; chambers slightly inflated, increasing very gradually and rather regularly in size; sutures distinct, only slightly depressed; wall with distinct, longitudinal costae which are only slightly raised, continuous across the sutures from the base to the lower part of the last-formed whorl, divided as growth proceeds; aperture loop-shaped, with a distinct, raised lip. Length of holotype $0.30 \mathrm{~mm}$., diameter $0.18 \mathrm{~mm}$.

$695464-47-5$
The types are from the Pliocene, in brown siltstone, 210 feet stratigraphically above the base of the first Piro sandstone, Cañada de Aliso, 2.3 miles N. $75^{\circ}$ E. of La Crosse Junction, Ventura County, California. It is rot known elsewhere.

The species is more elongate and has finer, more numerous costae than Bulimina alazanensis Cushmen. The chambers are more inflated and the costae are lower than in $B$. truncana Gümbel, and the test is narrower in proportion to the length.

\section{Bulimina marginospinata Cushman and Parker}

Plate 27, figure 12

Bulimina marginospinata Cushman and Parker, Cushman Lab. Foram. Research Contr., vol. 14, p. 57, pl. 9, fig. 11, 1938

Test fusiform, greatest breadth somewhat below the middle, nearly twice as long as broad, initial end acute, consisting of about 5 whorls in the adult; chambers d'stinct, somewhat inflated, the last 3 in the adult making up much the larger part of the test, increasing rapidly in size as added, greatly overlapping; sutures distinct, or ${ }^{-1} y$ slightly depressed; wall mostly sinooth, finely perforate, with a small number of short spines at the basal margin of the chambers; aperture elongate, with a distinct, rais $: d$ lip. Length 0.40 to $0.45 \mathrm{~mm}$., diameter 0.25 to $0.28 \mathrm{~m}$.

The types are from the Pliocene, first gully north of Lomita Quarry, Palos Verdes Hills, Los Angeles County, California. It is found also in the Pliocene of the Repetto Hills, Los Angeles County, California.

This species has more chambers than Bulimina pyrila D'Orbigny, and a more tapered test with shorter, broader chambers than $B$. ovata D'Orbigny.

\section{Bulimina denudata Cushman and Parker}

Plate 27, figures 13,14

Bulimina pagoda Cushman var. denudata Cushman and Parker, Cushman Lab. Foram. Research Contr., vol. 14, p. 57, pl. 10, figs. 1a-c, 2a-c, 1938.

Bulinina marginata Galloway and Wissler (not D'Orbigny), Jo'ır. Paleontology, vol. 1, p. 73, pl. 11, fig. 17, 1927.

Bulimina pulchella Cushman (not D'Orbigny), Scripps Inst. Oceanography Bull., Tech. ser., vol. 1, p. 152, pl. 2, fig. 13, 1927.

Test 2 or more times as long as broad, fusiform in the megalospheric form, tapering from the broadest part ne? $r$ the apex of the test in the microspheric, initial end sometimes with a small basal spine, consisting of as many as 7 whorls; chambers distinct, early chambers not inflated, later chambers inflated, undercut at the margins, not increasing very much in height as added so the last whorl is shallow and often projecting; sutures distinct, flush with the surface in the initial portion, later portion depressed; wall of the margin of the undercut chambers very slightly 
and irregularly toothed, remainder smooth, finely perforate; aperture loop-shaped, at apex of test. Length 0.32 to $0.57 \mathrm{~mm}$., diameter 0.12 to $0.27 \mathrm{~mm}$.

The types are from the Pliocene of Cañada Seca, 2,300 feet stratigraphically above the base of a bluishgray shale, 3.6 miles S. $50^{\circ} \mathrm{E}$. of La Crosse Junction, Ventura County, California. The species is found also in the Pliocene of Cañada de Aliso, Ventura County, California, 2.4 miles S. $88^{\circ} \mathrm{E}$. of La Crosse Junction, in gray siltstone 3,200 feet stratigraphically above the base of the first Pico sandstone, and 2.4 miles N. $77^{\circ} \mathrm{E}$. of La Crosse Junction in brown sandy shale, near base of a conglomerate member, 1,030 feet stratigraphically above base of the first Pico sandstone. It occurs in the Pliocene of San Pedro, California and in the Pleistocene of Lomita Quarry, Palos Verdes Hills, 2 miles south of Lomita, Los Angeles County, California. It is found in Recent material $1 \frac{1}{2}$ miles south of Scripps Institution Pier, La Jolla, California, at a depth of 9 feet.

This species was originally described as a variety of Bulimina pagoda Cushman. There seems, however, to be a specific difference between the two forms. In $B$. denudata the margins of the chambers are undercut sharply so that the chambers overhang, in $B$. pagoda the chambers are undercut so they project but do not overhang the preceding ones. The latter is much shorter in proportion to its length and tapers more rapidly.

Bulimina denudata has many of the characteristics of $B$. marginata D'Orbigny but differs from it in the much shallower character of the last whorl, which projects more and gives a pagoda-like effect, in the lack of undercutting of the early chambers, and in the less regularly toothed margin of the chambers.

\section{Bulimina denudata Cushman and Parker var. deformata Cushman and Parker}

Plate 27, figure 15

Bulimina pagoda Cushman var. deformata Cushman and Parker, Cushman Lab. Foram. Research Contr., vol. 14, p. 58, pl. 10, figs. 3a-c, 1938.

Bulimina pagoda Cushman, Stewart and Stewart (not Cushman), San Diego Soc. Nat. History Trans., vol. 6; p. 66, pl. 5, figs. 6a-c, 1930.

Variety differing from the typical form in the chambers, which are undercut almost throughout the test, have a more crenulated margin with occasional spines, are more projecting, and sometimes somewhat twisted.

The types are from the Pliocene of Charley Hill Gulch (Branch of Ryan's Slough), center of Wr/2 sec. 5, T. 4 N., R. 1 E., H. M., Humboldt County, California. The variety is not known elsewhere.

This variety differs from Bulimina marginata D'Orbigny in the shallow character of the last-formed whorls and having more projecting chambers.

\section{Bulimina inflata Seguenza}

Plate 27, figures 16,17

Bulimina inflata Seguenza, Accad. gioenia sci. net. Atti, ser. 2, vol. 18 , p. 25 , pl. 1, fig. $10,1862$.

?Brady, Parker, and Jones, Zool. Soc. London Trans., vol. 12, p. 220 , pl. 43 , fig. $9,1888$.

Silvestri, Accad. sci. Acireale Atti e Rend., vol 5, p. 12, pl. 5, figs. $68,69,1893$.

Cushman and Parker, Cushman Lab. Foram. Kesearch Contr., vol. 14, p. 58, pl. 10, figs. 4, 5, 1938.

Phleger, Geol. Soc. America Bull., vol. 50, p. 1422, pl. 3, fig. 25, 1939.

Cushman and Henbest, U. S. Geol. Survey Prof. Paper 196-A, pl. 9, fig. 18, 1940.

Valk, in Rutten and Hotz, Geol. Petr. and Pal. Results of Explorations in the island of Ceram, 3d se"., Geol., no. 1, p. 23, 1945.

Bulinina inflata Seguenza var. Schwager, Com. geol. italiana, Boll., vol. 9, p. 529, p1. 1, fig. 19, 1878.

Test of medium size, widest near top, about $11 / 2$ times as long as broad, consisting of 4 to 5 whorls, the lastformed whorl forming at least one-third of the test; chambers fairly distinct, those of last whorl inflated; sutures distinct in upper portion of test, somewhat depressed; wall of uppermost part of last-formed chamber smooth, otherwise costate, with numerous plate-like costae which are sometimes broken at the sutures but are often continuous across them, coarsely perforate; aperture loopshaped, with a distinct lip, either at, or just above, the junction of the second and third chambers. Length 0.45 to $0.55 \mathrm{~mm}$., diameter 0.30 to $0.40 \mathrm{~mm}$.

The types are from the Pleistocene of Catania, Sicily. We have material from the Pliocene of Calabria, Messina, and the clay pit behind the Vatican, Rome, Italy; and from Garrobo, Spain. In the Miocene the species occurs at Niederlies, Austria; on the sea coast near Manta, Ecuador; and in Venezuela. In the Recent seas it occurs at Rimini, Italy, and near Ireland. It has been recorded from the Abrohlos Bank, Brazil, by Brady, Parker and Jones, but this record is subject to question, and it is possible that their form represents Bulimina striata D'Orbigny var. mexicana Cushman. It is also recorded from deep sea cores in the North Atlantic.

This species differs from Bulimina buchiana D'Orbigny and $B$. costata D'Orbigny in its test, which is rapidly tapering instead of fusiform and in the much larger proportion of the test occupied by the last-formed whorl. It differs from $B$. striata D'Orbigny in the lack of a basal spine, in the much less marked break in the costae at the sutures, and in the resulting lack of the effect of marginal overhang of the chambers.

There are numerous other records for this species but the figures given show that the specimens must be restudied before they can be placed with certainty. 


\section{Bulimina striata D'Orbigny}

Plate 28, figures 1-3

Bulimina striata D’Orbigny, Annales sci. nat., vol. 7, p. 269, no. 2, 1826.

Guérin-Ménéville's Cuvier, Iconographie, Mollusques, p. 9, pl. 2, fig. 16, 1829-1843.

Fornasini, Accad. sci. Ist. Bologna Mem., ser. 5, vol. 9, p. 371, fig. 1, 1901.

Cushman and Parker, Cushman Lab. Foram. Research Contr., vol. 14, p. 90, pl. 16, figs. 1-3, 1938.

LeRoy, Colorado School of Mines Quart., vol. 39, no. 3, p. 26, pl. 1, fig. 5, 1944.

Bulimina inflata Flint (not Seguenza) (part), U. S. Nat. Mus. Rept., 1897, p. 291, pl, 37, fig. 5, 1899.

Test medium in size, composed of about 5 whorls, tapering from the widest portion near the top of the lastformed whorl, with a short, stout basal spine; chambers distinct, especially in the last-formed whorl, increasing regularly in size as added, those of each whorl slightly overhanging the previous ones, slightly inflated; sutures distinct in the last whorl, slightly depressed; wall ornamented with heavy, low longitudinal costae that extend up almost to the top of the last-formed whorl and that are broken at the sutures; aperture elongate, loop-shaped, at the junction of the second and third chambers. Length 0.40 to $0.65 \mathrm{~mm}$., diameter 0.30 to $0.50 \mathrm{~mm}$.

The types are from Recent material from Rimini, Italy. The species occurs also in the western Atlantic south of Cape Cod. Le Roy has referred specimens from the Miocene of Sumatra to this species.

This species differs from Bulimina inflata Seguenza in having the costae cut off at the sutures and in the presence of a basal spine.

\section{Bulimina striata D'Orbigny var. mexicana Cushman}

\section{Plate 28, figure 4}

Bulimina inflata Seguenza var. mexicana Cushman, U. S. Nat. Mus. Bull. 104, pt. 3, p. 95, pl. 21, fig. 2, 1922.

Bulimina inflata Flint (not Seguenza) (part), U. S. Nat. Mus. Rept., 1897, p. 291, pl. 37, fig. 5, 1899.

Cushman and Jarvis, Jour. Paleontology, vol. 4, p. 362, pl. 33, fig. 5, 1930.

Bulimina striata D'Orbigny var. mexicana Cushman and Parker, Cushman Lab. Foram. Research Contr., vol. 16, p. 16, pl. 3, fig. 9, 1940.

Cushman and Todd, idem, Special Pub. 15, p. 40, pl. 6, fig. 10, 1945.

Variety differing from the typical form in having the costae terminated by short, sharp spines.

The types are from Recent material, Albatross sta. 2377 , in 210 fathoms, Lat. $29^{\circ} 07^{\prime} 30^{\prime \prime}$ N., Long. $88^{\circ}$ $08^{\prime} \mathrm{W}$. The variety is found in Recent material, from the western Atlantic along the coast of Georgia and south. In the Pacific it is found as far north as Lat. $43^{\circ}$, and in the Philippine region. A somewhat similar form occurs in the Philippine region, near the Fiji Islands, and in th: Pliocene of Kar Nicobar (Bulimina inflata Schwage(not Seguenza), Novara-Exped., Geol. Theil, vol. 2. p. 246, pl. 7, fig. 91, 1866; H. B. Brady, Challenger Rept., Zoology, vol. 9, p. 406, pl. 51, figs. 10-13, 1884; Cushman, U. S. Nat. Mus. Bull. 100, vol. 4, p. 160, pl. 31. fig. 6,1921 ) but it is distinguished by having somewhat less sharp spines. The variety is found also in the Miccene of Buff Bay, Jamaica.

\section{Bulimina marginata D'Orbigny}

Plate 28, figures 5, 6

Bulimina marginata D'Orbigny, Annales sci. nat., vol. 7, p. 269 , no. 4, pl. 12, figs. 10-12, 1826.

Parker and Jones (part), Annals and Mag. Nat. Histor:', ser. 2, vol. 19 , p. 296 , pl. 11, figs. 39, 40 (not figs. 35-38), 1857.

H. B. Brady, Challenger Rept., Zoology, vol. 9, p. 405, pl. $5^{5}$. figs. 3-5, 1884.

H. B. Brady, Parker and Jones, Zool. Soc. London Trans, vol. 12 , p. 220 , pl. 43 , figs. 7, $10,1888$.

Egger, K. bayer. Akad. Wiss. Abh., cl. 2, vol. 18, p. 287, pl. 8, figs. 69, 70, 1893.

Goës, K. svenska vetensk. akad. Handl., vol. 25, no. 9, p. 45, pl. 9, figs. 439-444, 1894.

Jones, Crag Foraminifera, Palaeont. Soc. Pub., pt. 2, p. 165, pl. 3, figs. 5, 6, 1895 .

Reade, Geol. Mag., dec. 4, vol. 7, pp. 100, 101 (lists), pl. 5, fig. 4, 1900.

Fornasini, Accad. sci. Ist. Bologna Mem., ser. 5, vol. 9, p. 372, 1901 ; idem, vol. 10, p. 15, 1902.

Cushman, U. S. Nat. Mus. Bull. 71, pt. 2, p. 83, text fige. 136a, b, 1911.

Applin, Ellisor and Knicker, Am. Assoc. Petroleum Geologists Bull., vol. 9, p. 98, pl. 3, fig. 4, 1925.

Ikari, Suisangaku Zasshi, no. 30, p. 3, pl. 1, fig. 7, 1927.

Cushman and Parker, U. S. Nat. Mus. Proc., vol. 80, art. 3, p. 14, 1931.

Cushman and Ponton, Florida Geol. Survey Bull. 9, p. 77, pl. 11, fig. 12, 1932.

Macfadyen, Geol. Mag., vol. 69, p. 34, fig. 5, 1932.

Cushman, Cushman Lab. Foram. Research Special Pub. 5, pl. 27, figs. 11a, b, 1933.

Cushman and Parker, idem, Contr., vol. 14, p. 91, pl. 16, figs. 5, 6, 1938; idem, vol. 16, p. 9, pl. 2, figs. 8, 9, 1940.

Phleger, Geol. Soc. America Bull., vol. 50, p. 1403, pl. 3, fig. 23, 1939.

Coryell and Rivero, Jour. Paleontology, vol. 14, p. 341, 1940.

Macfadyen, Geol. Mag., vol. 79, p. 135 (list), 1942.

Silvestri and Zangheri, Soc. geol. italiana Boll., vol. 61, p. 88 , 1942.

Cushman, Cushman Lab. Foram. Research Special Pub. 12, p. 27, pl. 3, figs: 45, 46, 1944.

Palmer, Bull. Am. Paleontology, vol. 29, no. 115, p. 46, 1945. Bulimina pulchella D'Orbigny, Voyage dans l'Amérique méridionale, vol. 5 , pt. 5 , Foraminifères, p. 50 , pl. 1, figs. 6 , 7 , 1839. 
Bulimina serrata Bailey, Smithsonian Contr., vol. 2, p. 12, pl., figs. 32-34, 1851.

Bulimina pupoides D'Orbigny var. marginata Williamson, Recent Foraminifera of Great Britain, p. 62, pl. 5, figs. 126, 127, 1858.

Bulimina presli Reuss var. marginata Parker and Jones, Philos. Trans., vol. 155, p. 372, pl. 15, fig. 10, pl. 17, fig. 70, 1865 .

Bulimina elegans D'Orbigny var. marginata Fornasini, Accad. sci. Ist. Bologna Mem., ser. 5, vol. 9, p. 376, pl. 0, figs. 7, 14, 33, 39, 1901.

Bulimina fusiformis Williamson var. marginata Fornasini, idem, p. 378, pl. 0, figs. $24,25$.

Bulimina gibba Fornasini var. marginata Fornasini, idem, p. 379, pl. 0, figs. 15, 19, 22, 26, 35, 42 .

Bulimina patagonica Cushman and Wickenden (not D'Orbigny), U. S. Nat. Mus. Proc., vol. 75, art. 9, p. 8, pl. 3, figs. 11a, b, 1929.

Cushman and Kellett, idem, vol. 75 , art. 25, p. 7, pl. 3, figs. $4 a, b, 1929$.

Test medium to large, tapering from the widest point in the last whorl; chambers numerous, angled, somewhat inflated, undercut at the margin; wall, except for the margins of the chambers, smooth, finely perforate, often partially translucent, margins of the chambers ornamented with tooth-like crenulations which are often extended into short, sharp spines; aperture loop-shaped, near the apex of the test, well above the junction of the second and third chambers, with a well-developed lip. Length of figured specimen $0.70 \mathrm{~mm}$., diameter $0.35 \mathrm{~mm}$.

The species was described from Recent material from Rimini, Italy. It appears to be a very variable form and a study of the abundant material from many parts of the world seems to offer no logical method of subdividing it. Some specimens are much more elongate and slender than others. Some develop long spines at the margins of the chambers whereas others have undercut margins with almost no ornamentation. Many of the variations appear at the same locality, and a few are apparently localized. The species has been recorded from the following: Miocene of Louisiana, Florida (Cancellaria zone of the Choctawhatchee marl), Haiti, and Jamaica. Pliocene of England. Pleistocene of England and cores from the western Atlantic. Recent deposits of Rimini, Italy; eastern Atlantic Ocean near the British Isles, Norway, and Iceland; western Atlantic Ocean off the coast of North and South America, Falkland Islands; Pacific Ocean off the coast of South America, Japan, Philippine region, Australia, New Zealand.

This group can be differentiated from the Bulimina denudata Cushman and Parker group by the larger proportion of the test occupied by the last-formed whorl and the much slighter projection of the chambers, which do not flare outward to the same extent.

\section{Bulimina marginata D'Orbigny var. tessellata Cushman and Todd}

Plate 30 , figure 18

Bulimina marginata D'Orbigny var. tessellata Cushman and Todd,
Cushman Lab. Foram. Research Special Pub. 15, p. 39, pl. 6, fig. 9, 1945.

Variety differing from the typical in the somewhat coarser spines and the wall which has rather large, prominent perforations arranged in linear patterns especially noticeable on the smooth, later portion of the chambers.-Cushmar and Todd.

The types are from the Miocene, half a mile east of Buff Bay, Jamaica.

\section{Bulimina trilobata D'Orbigny}

Plate 28, figure 7

Bulimina trilobata D'Orbigny, Annales sci. nat., vol. 7, p. 269 , no. 6, 1826.

Parker, Jones and Brady, Annals and Mar. Nat. History, ser. 4 , vol. 8 , p. 172 , pl. 11 , fig. $127,1871$.

Fornasini, Accad. sci. Ist. Bologna Mem., ser. 5, vol. 9, p. 373, text fig. 3, 1901.

Polymorpha pineiformia Soldani (part), Testacsa, vol. 1, pt. 2, p. 119, pl. 131, fig. xx, 1791.

The species was described from the Kecent material from Rimini, Italy. It is difficult, either from the figure of Soldani designated by D'Orbigny in 1826 or from the later figure published by Fornasini, to refer any of the Rimini material to this species. It is porsible that the form represents a variation of the species Bulimina aculeata D'Orbigny, in which case the name $B$. trilobata should be given priority. As no definite assertions can be made, however, it would seem best to retain the name aculeata, since it has been used so extensively throughout the literature.

\section{Bulimina aculeata D'Orbigny}

Plate 28, figures 8-11

Bulimina aculeata D'Orbigny, Annales sci. nat., vol. 7, p. 269, no. 7, 1826.

Parker, Jones and Brady, Annals and Mạ̣. Nat. History, ser. 4, vol. 8, p. 172, pl. 11, fig. 128, 1871.

H. B. Brady, Challenger Rept., Zoology, vol. 9, p. 406, pl. 51, figs. 7-9, 1884.

Egger, K. bayer. Akad. Wiss. Abh., cl. 2, vol. 18, p. 28广, pl. 8, figs. 72, 78, 1893.

?Jones, Crag Foraminifera, Palaeont. Soc. P'1b., pt. 2, p. 163, pl. 3, figs. 1, 2, 1895.

Flint, U. S. Nat. Mus. Rept. for. 1897 , p. 2 ?1, pl. 37, fig. 4, 1899.

Fornasini, Accad. sci. Ist. Bologna Mem. ser. 5, vol. 9, p. 373, text fig. 4, 1901 ; idem, ser. 5, vol. 10, p. 17, 1902.

Cushman, U. S. Nat. Mus. Bull. 71, pt. 2, p. 86, text fig. 139, 1911; idem, Bull. 100, vol. 4, p. 161, pl. 31, fig. 5, 1921; idem, Bull. 104, pt. 3, p. 96, pl. 22, figs. 1, 2, 1922.

Hada, Tohoku Imp. Univ. Sci. Repts., ser. 4, Biol., vol. 6, p. 127, text fig. 84, 1931.

Cushman, Cushman Lab. Foram. Research Special Pub. 5, pl. 27, fig. 12, 1933.

Cushman and Parker, idem, Contr., vol. 14, p. 92, pl. 16, figs. 8-10, 1938; idem, Contr., vol. 16, p. 11, pl. 2, fig. 16 
(in explanation of plate as 'Bulimina pupoides D'Orbigny var. spinulosa Williamson”), 1940.

Phleger, Geol. Soc. America Bull., vol. 50, p. 1403, pl. 3, fig. 24, 1939.

Cushman and Henbest, U. S. Geol. Survey Prof. Paper 196-A, pl. 9, fig. 17, 1940.

Chapman, Royal Soc. South Australia Trans., vol. 65, p. 165, 1941.

ten Dam and Reinhold, Geol. Stichting Mededeelingen, ser. C-V, no. 1, p. 55, 1941.

ten Dam, idem, no. 3, p. 111, $19+4$.

Cushman, Cushman Lab. Foram. Research Special Pub. 12, p. 28 , pl. 3, fig. 47,1944 .

Cushman and Todd, idem, Special Pub. 15, p. 39, pl. 6, fig. 11, 1945.

Valk, in Rutten and Hotz, Geol. Petr. and Pal. Results of Explorations in the island of Ceram, 3rd ser. Geol., no. 1, p. 23, 1945.

Colom, Inst. Invest. Geol., Num. 3 Estudios Geologicos, p. 159, pl. 10, figs. 174, 175, 1946.

Polymorpha pineiformia Soldani (part), Testacea, vol. 1, pt. 2, p. 118, pl. 127, fig. I?; pl. 130, fig. vv, 1791.

Bulimina pupoides D'Orbigny var. spinulosa Williamson, Recent Foraminifera of Great Britain, p. 62, pl. 5, fig. 128, 1858.

Bulimina patagonica Heron-Allen and Earland (not D'Orbigny), Discovery Repts., vol. 4, p. 350, pl. 8, figs. 33, 34, 1932.

Test large, tapering from the widest portion in the last whorl, initial end subacute, consisting of 4 to 6 whorls; chambers distinct, regularly triserial, increasing rapidly in size as added, rounded, inflated, especially those of last whorl; sutures distinct, depressed; wall of initial portion ornamented by heavy spines, sometimes only at the base but often extending as much as half way up the test, otherwise smooth, very finely perforate, polished; aperture broadly loop-shaped, in a depression of the apertural face, with a raised lip. Length of specimens from Rimini, Italy, 0.60 to $0.75 \mathrm{~mm}$., diameter 0.40 to $0.50 \mathrm{~mm}$.

The types are from the Recent of Rimini, Italy. The species occurs in the Miocene of Kattowitz, Germany, and Dax, Dept. of Seine-et-Oise, France, and also in the Miocene of Buff Bay, Jamaica. It has been recorded by Jones from the Pliocene Crag of England. In the Recent seas it is found in the Atlantic along the eastern coast of the United States and as far north as Gaspé Bay, and in the Pacific in the Australian, Philippine, Hawaiian and Japanese regions.

D'Orbigny based the species aculeata on part of Soldani's species pineiformia, but gave no characterization nor figure. It would be difficult to refer anything to Soldani's figure, but the publication of D'Orbigny's figure by Fornasini showed clearly what the species is. D'Orbigny's definite designation for the species gives his name priority over Williamson's name published in 1858.

This species has been confused with Bulimina gibba Fornasini. It can be easily differentiated by the globular last-formed chambers, the rounded rather than threecornered initial end and the more rapidly tapering test. The form is very variable as regards the amount and character of ornamentation. Some specimens have almost no spines whereas others may be spinose half way up tho test. The spines are usually heavy and short but at times may be quite sharp and long.

\section{Bulimina caudigera D'Orbigny}

Plate 28, figures 12,13

Bulimina caudigera D'Orbigny, Annales sci. nat., vol. 7, p. 270, no. 16 , Modèles, no. $68,1826$.

Fornasini, Accad. sci. Ist. Bologna Mem., ser. 5, vol. 9, p. 375, 1901.

Cushman and Parker, Cushman Lab. Foram. Research Contr., vol. 14, p. 94, pl. 16, figs. $17,18,1938$.

Test broadly fusiform, the basal end very broadl." rounded, the last-formed whorl forming the greater part of the test; chambers distinct, angled, with almost n? inflation; sutures distinct, slightly depressed; wall smootl. very closely perforate, somewhat translucent; aperture loop-shaped, at apex of test, placed well above the suture joining the second and third chambers. Length 0.60 to $0.70 \mathrm{~mm}$., diameter 0.30 to $0.37 \mathrm{~mm}$.

The types are from Recent material from Rimini, Italy. It has not been found elsewhere.

The species differs from Bulimina affinis D'Orbigny in the more angled character of the chambers and their almost complete lack of inflation. It is also considerably smaller.

\section{Bulimina squammigera D'Orbigny}

Plate 28, figures $14-16$

Bulimina squammigera D'Orbigny, in Barker-Webb and Berthelct, Histoire naturelle des îles Canaries, vol. 2, pt. 2, Foramin:fères, p. 137, pl. 1, figs. 22-24, 1839.

Cushman and Parker, Cushman Lab. Foram. Research Contr., vol. 16 , p. 8 , pl. 2 , figs. $5-7,1940$.

Test elongate, almost cylindrical, smooth and polished, although marked with small, evenly spaced points, very obtuse at the end: Spire elongate, turret-like, composed of 5 slightly swollen whor1; without a deep suture. Chambers elongate, oblong, especially in the younger portion, becoming much more swollen in the adult portion; all somewhat pointed at the basal end, giving tr ? appearance altogether of scales placed in regular rows; th a last chamber entirely convex right up to the edge of the aperture. Aperture virguline, placed at the upper end of the last chamber. Color white. Total length $0.50 \mathrm{~mm}$.-D'Orbigny (translated).

The species was described from Recent material from Teneriffe in the Canary Islands. We have no typical material.

It is possible that this species belongs in the gent's Buliminella. 


\section{Bulimina patagonica D'Orbigny}

Plate 28, figure 17

Bulimina patagonica D'Orbigny, Voyage dans l'Amérique méridionale, vol. 5 , pt. 5 , Foraminifères, p. 50 , pl. 1, figs. 8 , 9 , 1839.

Cushman and Parker, U. S. Nat. Mus. Proc., vol. 80, art. 3, p. 14, pl. 3, fig. 14, 1931; Cushman Lab. Foram. Research Contr., vol. 16, p. 9, pl. 2, figs. 10-12, 1940.

Test oblong, conical, very polished on the last whorls, rough, covered with small spines on the remainder, these projecting all the more as they are at the base and completely conceal the spire, composed of 5 rounded whorls, separated by somewhat depressed sutures. Chambers broader than high, 3 to a whorl, all somewhat inflated and distinct, the last inflated and larger than the rest. Aperture virguline, placed almost in the center of the width of the chamber. Color white. Length $0.66 \mathrm{~mm}$.-D'Orbigny (translated).

D'Orbigny described the species from Recent material from the Bay of San Blas, Patagonia. We have specimens from off Ilha Govenador, Rio de Janeiro Harbor, Brazil, and from the Falklands that are very close to this form. They are very much smaller, however, and apparently represent immature specimens.

D'Orbigny differentiates this species from Bulimina echinata D'Orbigny by its conical shape, and from $B$. aculeata D'Orbigny by its more elongate whorls, less globular chambers, and its much finer spines. The last whorl is more inflated than in $B$. elongata D'Orbigny var. subulata Cushman and Parker, and the test is not so elongate.

\section{Bulimina patagonica D'Orbigny var. glabra Cushman and Wickenden}

Plate 28, figures 18,19

Bulimina patagonica D'Orbigny var. glabra Cushman and Wickenden, U. S. Nat. Mus. Proc., vol. 75, art. 9, p. 9, pl. 4, figs. 1a-c, 1929.

Cushman and Parker, Cushman Lab. Foram. Research Contr., vol. 16, p. 17, pl. 3, figs. 13, 14, 1940.

Variety differing from the typical form in the lack of spines on the basal portion of the test.

The types are from Recent material from Cumberland Bay, Juan Fernandez Island, Chile. The variety is not known elsewhere.

This form is very close to Bulimina elongata D'Orbigny, differing from it in the marked inflation of the last whorl. It is very possible that this variety and the typical form are more closely related to $B$. elongata, but until more material of $B$. patagonica can be obtained for study the relationships of the three cannot be definitely established.

\section{Bulimina ovula D'Orbigny}

Plate 28 , figures $20-22$

Bulimina ovula D'Orbigny, Voyage dans P'Amérique méridionale, vol. 5, pt. 5, Foraminifères, p. 51, pl. 1, figs. 10, 11, 1839.
Cushman, Scripps Inst. Oceanography Bull., Tech. ser., vol. 1, p. 150 , pl. 2, fig. 10, 1927.

Heron-Allen and Earland, Discovery Repts., vol. 4, p. 350, pl. 8, fig. 32, 1932.

?Kleinpell, Miocene stratigraphy of California, p. 256, pl. 7, fig. 2, Tulsa, 1938.

Cushman and Parker (part), Cushman Lab. Foram. Research Contr., vol. 16, p. 10, pl. 2, figs. 13, 14 (not fig. 15), 1940. Bulimina ovata Cushman (not D'Orbigny), U. S. Nat. Mus. Bull. 71, pt. 2, p. 77, text figs. 125a-c, 1911.

Globobulimina pacifica Cushman and Parker (not Cushman), Cushman Lab. Foram. Research Contr., vcl. 7, p. 9, pl. 1, fig, 30, 1931

Test broadly oval, consisting of 2 or 3 whorls, the lastformed whorl composing most of the test, the remaining whorls forming a sharply pointed base in the microspheric form; chambers distinct, those of last whorl very much inflated; sutures distinct, very slightly deoressed; wall smooth, translucent, with medium sized perforations: aperture comma-shaped, with a long curved tooth. Length of figured specimens $0.70 \mathrm{~mm}$., diameter $0.50-0.60 \mathrm{~mm}$.

The species was described from Recent material off the coast of Chile and Peru. We have specinens from off the west coast of America, and it has been recorded from the Falkland Islands. In the Miocene it is found in the lower part of the Temblor formation of the San Joaquin Valley, California. The form recorded by Kleinpell is placed here questionably. Specimens from Reliz Canyon, Monterey County, California, sample C. 4, have a much less predominant last-formed whorl and an aperture that is smaller and lacks the typical larce tooth. These specimens are in a rather bad state of presarvation, however, and the characters do not show as clearly as they do in the Recent specimens.

The species resembles Bulimina pyrula D'Orbigny but is larger, with more inflated chambers, and 1-cks the occasional spines.

\section{Bulimina affinis D'Orbigny}

Plate 28, figures 23-25

Bulimina affinis D'Orbigny, in De la Sagra, Historia física, política y natural de la îsla de Cuba,. Foraminifères, vol. 6, p. 109, pl. 2, figs. 25, 26, 1840.

Flint, U. S. Nat. Mus. Rept., 1897, p. 290, pl. 37, fig. 2, 1899.

Cushman, U. S. Nat. Mus. Bull. 104, pt. 3, p. 103, pl. 20, fig. 6, 1922.

Phleger, Geol. Soc. America Bull., vol. 50, p. 1403, 1939.

Cushman and Parker, Cushman Lab. Foram. Research Contr., vol. 16, p. 7, pl. 2, figs. 1-4, 1940.

Coryell and Rivero, Jour. Paleontology, vol. 14, p. 341, pl. 44, fig. 21, 1940.

Palmer, Soc. cubana hist. nat. Mem., vol. 14, p. 295, pl. 51, fig. 14, 1940.

Macfadyen, Geol. Mag., vol. 79, p. 135 (list), 1942.

Coryell and Mossman, Jour. Paleontology, vol. 16, p. 242, pl. 36, fig. 42, 1942. 
Franklin, idem, vol. 18, p. 314 , pl. 46, fig. 9, 1944.

Renz, 8th Am. Sci. Congress Proc., p. $5+8$ (list), 1942.

Goudkoff and Porter, Am. Assoc. Petroleum Geologists Bull., vol. 26, p. 1652 (list), 1942.

Colom, Inst. Invest. Geol., Num. 3, Estudios Geologicos, p. $159,1946$.

Bulimina pupoides Cushman (not D'Orbigny), U. S. Nat. Mus. Bull. 71 , pt. 2, p. 80 , text fig. 132, 1911; idem, Bull. 104, pt. 3, p. 105, pl. 20, fig. 3, 1922.

Bulimina ovata Cushman (not D'Orbigny), idem, Bull. 104, pt. 3, p. 100 , pl. 21, fig. $3,1922$.

Bulimina ovula Cushman and Moyer (not D'Orbigny), Cushman Lab. Foram. Research Contr., vol. 6, p. 56, pl. 7, fig. 21, 1930.

Test large, composed of 3 to 4 whorls, the last-formed whorl composing three-fifths or more of the test, broadly ovate in the megalospheric form, tapering to a subacute point in the microspheric; chambers distinct, inflated, especially the last-formed, which bulges out over the suture toward the apertural end; sutures distinct, depressed, especially that of the last chamber; wall transparent, coarsely perforate; aperture loop-shaped, with a slight lip and a plate-like tooth. Length of figured specimens 0.82 to $1.00 \mathrm{~mm}$., diameter 0.50 to $0.60 \mathrm{~mm}$.

The species was described from Recent material near Cuba. It occurs in the western Atlantic and in the vicinity of Ireland, in the Pacific at Guide sta. 22(24) Lat. $43^{\circ}$ $12^{\prime} \mathrm{N}$., Long. $125^{\circ} 01^{\prime} \mathrm{W}$. in the Galapagos Islands, and in the vicinity of the Philippine Islands. Many specimens of a somewhat broader, stouter form are found in various parts of the Pacific. In the Pliocene it occurs in Cañada de Aliso, Ventura County, California, 2.1 miles N. $74^{\circ} \mathrm{E}$. of La Crosse Junction, in gray siltstone, 280 feet stratigraphically above the base of the first Pico sandstone. There are numerous records from the Oligocene to Recent that do not seem entirely typical.

Our specimens are larger than that described by D'Orbigny. The figured specimen (pl. 14, fig. 25), however, shows the microspheric form of the species and is apparently identical with D'Orbigny's figure. He compares the species to Bulimina laerigata D'Orbigny (in synonymy of $B$. oz'ata D'Orbigny), differentiating it by the slight depression of the last chamber, and by the whorls, which are less widely separated. A comparison of the form with specimens from Rimini, Italy, and the Miocene of the Vienna Basin shows these same differences. B. affinis, in addition, is a larger form and less ovate in the megalospheric form. It is much larger than $B$. pupoides D'Orbigny and the last-formed whorl makes up a much greater proportion of the test.

\section{Bulimina oceanica Terquem}

Plate 28, figure 26

Bulimina oceanica Terquem, Essai sur le classement des animaux qui vivent sur la plage et dans les environs de Dunkerque, pt. 3, p. 127 , pl. 17, figs. 10a, b, 1881 .
Cushman and Parker, Cushman Lab. Foram. Research Con'r., vol. 16, p. 11, pl. 2, figs. $17 \mathrm{a}, \mathrm{b}, 1940$.

Test elongate, narrow, conical, polished, obtuse at the ends; composed of 4 whorls, with triangular chambers, convex, the 17st rounded; aperture round, lateral, placed at the bottom of an aci ${ }^{+}$, oval depression, with a lip.-Terquem (translated).

Terquem described the species from Recent material from Dunkerque, France. We have no typical material. Bulimina elongata D'Orbigny occurs in this same region and this form may be referable to it. From the figures, however, it appears to be a more slender form with a marked spiral suture, which is typical of the gerus Buliminella.

\section{Bulimina exilis H. B. Brady}

Plate 28, figures 27,28

Bulimina elegans D'Orbigny var. exilis H. B. Brady, Challenger Rept., Zoology, vol. 9, p. 399, pl. 50, figs. 5, 6, 1884.

Sidebottom, Manchester Lit. Philos. Soc. Mem. and Proc., vol. 54 , no. 16, p. 12, p1. 1, fig. 11, 1910.

Cushman, U. S. Nat. Mus. Bull. 71, pt. 2, p. 82, text fig. 135 , 1911.

Heron-Allen and Earland, Linnean Soc. London Trans., vol. 11, ser. 2, p. 234, pl. 41, figs. 4-9, 1916.

Cushman, U. S. Nat. Mus. Bull. 104, pt. 3, p. 106, pl. 17, f.gs. 7-12, pl. 19, figs. 2, 3, 1922.

Buliminella elegans D'Orbigny var. exilis Phleger, Geol. Soc. A $\mathrm{m}$. Bull., vol. 50, p. 1405, pl. 3, fig. 17, 1939.

Bulimina elegans Flint (not D'Orbigny), U. S. Nat. Mus. Rept., 1897, p. 290, pl. 36, fig. 3, 1899.

Bulimina exilis Cushman and Parker, Cushman Lab. Foram. Research Contr., vol. 16, p. 11, pl. 2, figs. 18-21, 1940.

Test elongate, slender, tapering, the length sometimes as much as 5 times the diameter, with a basal spine that is sometimes absent on the megalospheric form; chambars elongate, sharply angled, oblique, very slightly inflated; sutures distinct, usually formed of clear shell material, slightly depressed; wall smooth, polished, finely $\mathrm{p}^{\wedge} \mathrm{r}-$ forate; aperture broad, loop-shaped, placed at the apex of the test, pointing directly downward to meet the junction of the second and third chambers. Length of figured specimens $0.65 \mathrm{~mm}$., $0.80 \mathrm{~mm}$.; diameter $0.15 \mathrm{~mm}$., $0.18 \mathrm{~mm}$.

The types are from Recent material from Porcupine sta. 20 , northwest of Ireland. The species is found in the Pliocene of Castel Arquato, Italy. From the Recent it has been recorded from the Bay of Palermo, Italy; from various localities in the British Isles; from the westirn Atlantic south of Cape Cod; and from various localities in the north Pacific. We have typical material from all these general areas except the Mediterranean. It also occurs in deep sea cores taken in the western Atlantic.

This form is easily recognized by its slender, tapered test with the basal spine, by its polished surface, and by the elongate, angled chambers. 
Bulimina exilis H. B. Brady var. tenuata (Cushman) Cushman and Parker

Plate 28, figure 29

Buliminella subfusiformis Cushman var. tenuata Cushman, Scripps Inst. Oceanography Bull., Tech. ser., vol. 1, p. 149, pl. 2, fig. 9, 1927.

Bulimina elegans Cushman (not D'Orbigny), U. S. Nat. Mus. Bull. 71, pt. 2, p. 82, text fig. 134, 1911; Cushman Lab. Foram. Research Special Pub. 4, pl. 22, fig. 7, 1933.

Buliminella subfusiformis Cushman and Moyer (not Cushman), Cushman Lab. Foram. Research Contr., vol. 6, p. 56, pl. 7, fig. $20,1930$.

Variety differing from the typical form in having the initial end rounded and in lacking a basal spine.

The types are from Recent material from Guide sta. 13, Lat. $33^{\circ} 17^{\prime}$ N., Long. $117^{\circ} 55^{\prime} \mathrm{W}$., in 396 fathoms. The variety occurs at various localities along the west coast of North America.

The form may be easily distinguished by the basal end, which is rounded instead of tapering and has no spine.

\section{Bulimina pyrula D'Orbigny var. spinescens H. B. Brady}

Plate 28 , figures 30,31

Bulimina pyrula D'Orbigny var. spinescens H. B. Brady, Challenger Rept., Zoology, vol. 9, p. 400, pl. 50, figs. 11, 12, 1884.

Cushman, U. S. Nat. Mus. Bull. 71, pt. 2, p. 79, text figs. 128, 129, 1911.

Cushman and Parker, Cushman Lab. Foram. Research Contr., vol. 16, p. 12 , pl. 2, figs. $22-25,19+0$.

Colom, Inst. Invest. Geol, Num. 3 Estudios Geologicos, p. 158, pl. 10, fig. 150, 1946.

Variety differing from the typical form in having the lower part of the test covered with short, sharp spines, not extending above the lowest part of the last-formed chamber.

The types are from Recent material off the Ki Islands, in 480 fathoms, Challenger sta. 191A. The variety is found in the Miocene of San Rufillo, Italy, and in the Recent of the north Pacific.

It differs from Bulimina barbata Cushman in being much more involute. Both $B$. pyrula D'Orbigny and this variety have a partially involute test which approaches, in character, the involute genus Globobulimina.

\section{Bulimina subornata H. B. Brady}

Plate 28, figures 32,33

Bulimina subornata H. B. Brady, Challenger Rept., Zoology, vol. 9, p. 402, pl. 51, figs. $6 a$, b, 1884.

Egger, K. bayer. Akad. Wiss. Abh., cl. 2, vol. 18, p. 286, pl. 8, fig. 79, 1893.

Millett, Royal Micr. Soc. Jour., 1900, p. 276, pl. 2, fig. 3.

Cushman, U. S. Nat. Mus. Bull. 71, pt. 2, p. 88, text fig. 141, 1911.

Cushman and Parker, Cushman Lab. Foram. Research Contr., vol. 16 , p. 12 , pl. 2 , figs. $26-28,1940$.
Test medium in size, fusiform, pointed at the initial end, more rounded at the apertural end, with a short basal spine; chambers distinct, angled, very slig.ttly inflated; sutures distinct, slightly depressed; wall of the lower half of the test covered with irregular, low costae which give the test a roughened appearance, upper part of wall smooth, coarsely perforate; aperture long, narrow, curved, extending over the apex of the test. Length of figured specimens $0.45 \mathrm{~mm} ., 0.55 \mathrm{~mm}$; d diameter $0.25 \mathrm{~mm}$., $0.27 \mathrm{~mm}$.

The types are from the Hyalonema-ground, south of Japan, in 345 fathoms, and off Aru Island, in 800 fathoms. We have material from the Philippina region and the species has been recorded from Australia and the Malay Archipelago.

The species is distinctive and may be easily recognized by the angled chambers and roughened lower part of the test. It differs from Bulimina semicostata Nuttall in having much finer costae that do not cover as much of the test.

\section{Bulimina rostrata $H$. B. Brady}

Plate 28, figure 34

Bulimina rostrata H. B. Brady, Challenger Rept., Zoology, vol. 9, p. 408, p1. 51, figs. 14, 15, 1884.

Cushman, U. S. Nat. Mus. Bull. 71, pt. 2, p. 87, text figs. 140a, b, 1911; Scripps Inst. Oceanography Bıll., Tech. ser., vol. 1, p. 152, pl. 2, fig. 12, 1927.

Cushman and Parker, Cushman Lab. Foram. Research Contr., vol. 16, p. 13, pl. 2, figs. 29-31, 1940.

Cushman and Henbest, U. S. Geol. Survey Prof. Paper 196-A, pl. 9, fig. 19, 1940.

Hanna and Hertlein, State of Calif., Div. of Mines, Bull. 118, p. 180, fig. 67 [plate], fig. 40, 1941.

LeRoy, Jour. Paleontology, vol. 15, p. 623 (list), 1941.

Cushman, U. S. Nat. Mus. Bull. 161, pt. 3, p. 10, pl. 3, fig. 12, 1942.

Bulinina buchiana Cushman '(not D'Orbigny), U. S. Nat. Mus. Bull. 104, pt. 3, p. 95, pl. 20, fig. 4, 1922.

Test small, fusiform, often somewhat curved, broadest near the middle, rounded at the apertural erd, pointed at the initial end; chambers indistinct; sutures indistinct, occasionally showing slightly between the costae, slightly depressed; wall of last chamber smooth, rather coarsely perforate, remainder of test ornamented $\mathrm{k} v 10$ or 11 , regular, plate-like costae, continuous throughout; aperture small, loop-shaped, at the apex of the tert. Length of figured specimen $0.40 \mathrm{~mm}$., diameter $0.20 \mathrm{~mm}$.

The types are from Recent material from the $\mathrm{Ki}$ Islands, in 428 fathoms. The species is found in both the north and south Pacific. A similar, somewhat more slender, form is found at various localities in the western Atlantic both in bottom samples and in de $p$ sea cores. It is also recorded from the Pliocene of California. 


\section{Bulimina notovata Chapman}

Plate 30 , figure 8

Bulimina ovata H. B. Brady (not D'Orbigny, 1846), Challenger Rept., Zoology, vol. 9, p. 400, pl. 50, figs. 13a, b, 1884.

Bulimina notovata Chapman, Royal Soc. South Australia Trans., vol. 65 , p. $166,1941$.

Brady's figured specimens of $B$. "ovata" were obtained east of New Zealand (fide Nuttall). D'Orbigny obtained his fossil type from the Miocene of the Vienna Basin; when the latter is compared with the living form, so familiar in southern waters, the differences are easily seen. $B$. oz'ata, according to the figured type, is a long ovate form, with the segments slightly inflated and prominent and therefore specifically different from the "Challenger" specimen. Goës $(1894,45)$ has placed Brady's ovata in the synonymy of Bulimina ellipsoides Costa, but that form, according to Goës' figures (1894, pl. viii, figs. 31-36), is also distinct from this southern living species.-Chapman.

This species is based on the Challenger figures which are reproduced on our plate.

\section{Bulimina ornata Egger}

Plate 28, figure 35

Bulimina ornata Egger, K. bayer. Akad. Wiss. Abh., cl. 2, vol. 18, p. 286 , pl. 8 , fig. $80,1893$.

Cushman and Parker, Cushman Lab. Foram. Research Contr. vol. 16, p. 13, pl. 2, fig. 32. 1940.

Test cone-shaped, with the initial end a rounded point, consisting of 4 or 5 whorls of 3 rounded chambers each, ending at the apertural end with an offset, rounded, upward-projecting last chamber. Sutures not very depressed; the surface of the chambers covered with papillae of equal size, low, rising above the surface where the perforations pierce the wall, arranged to give the appearance of a closely striped pattern. Length $0.15 \mathrm{~mm}$., diameter $0.09 \mathrm{~mm}$.Egger (translated).

The types are from Gazelle sta. 90, off west Australia, in 359 meters. We have no typical material.

The possible connection between this species and Bulimina fijiensis Cushman has been discussed under the latter form.

\section{Bulimina consobrina Fornasin}

Plate 28, figure 36

Bulimina consobrina Fornasini, Accad. sci. Ist. Bologna Mem., ser. 5, vol. 8, p. 374, text fig. 23, 1900.

Cushman and Parker, Cushman Lab. Foram. Research Contr., vol. 16, p. 14, pl. 2, fig. 33, 1940.

Fornasini describes this form as very elongate, pointed, and graceful in the early portion, composed of numerous, inflated chambers, the early chambers arranged in regular series, the later chambers, which are fewer in number, less regularly arranged.

The types are from Recent material from Porto Corsini, near Ravenna, Italy. We have no specimens referable to the species.

The form shows considerable resemblance to the smoother variations of Bulimina gibba Fornasini, especially in the early portion of the test. Lack of topotype material makes it impossible definitely to combine the two species.

\section{Bulimina gibba Fornasini}

Plate 28, figures 37,38 ; plate 29 , figures $1-5$

Bulimina gibba Fornasini, Accad. sci. Ist. Bologna Mem., ser. 5, vol. 9, p. 378, pl. 0, figs. 32, 34, 1901.

Cushman and Parker, Cushman Lab. Foram. Research Contr., vol. 16, p. 48, 1940.

Bulimina presli Reuss var. aculeata Parker and Jones (not D'Orbigny) (part), Philos. Trans., vol. 155, p. 373, pl. 17, figs. 68,69 (not pl. 15, fig. 11), 1865.

Bulimina elegans H. B. Brady (not D'Orbigny), Challenger Rext., Zoology, vol. 9, p. 398, pl. 50, figs. 1-4, 1884.

Cushman, U. S. Nat. Mus. Bull. 104, pt. 3, p. 105, 1922.

Bulimina elongata D'Orbigny var. ariminensis Fornasini (not D’Orbigny), Accad. sci. Ist. Bologna Mem., ser. 5, vol. 9, p. 377, pl. 0, figs. 8, 11, 1901.

Bulimina fusiformis Fornasini (not Williamson) (part), idem, pp. 377,378 , pl. 0 , figs. $1,3,4,16,18,21,23,27,36,40$ (not figs. 6, 9, 31), 1901.

Bulimina fusiformis Williamson var. baccata Fornasini (not Yokoyama), idem, p. 378, pl. 0, figs. 2, 5, 30, 1901.

Bulimina baccata Cushman and Parker, Cushman Lab. Foram. Research Contr., vol. 16, p. 14, p1. 3, figs. 1-6, 1940.

Bulimina parkerac Thalmann, Am. Midland Naturalist, vol. 28, p. 464, 1942.

Test of medium size, gradually tapering, initial portion somewhat triangular in transverse section, often with a terminal spine, consisting of 5 or 6 whorls; chambers angled, distinct, regularly triserial, sometimes with the chambers sufficiently offset to give a slight twist to the test, increasing regularly in size, slightly inflated; sutures distinct, slightly depressed; wall smooth, polished, finely perforate, usually ornamented at the base with short spines; aperture loop-shaped, broad, with a slight lip. Length 0.33 to $0.58 \mathrm{~mm}$., diameter 0.20 to $0.23 \mathrm{~mm}$.

The species was described from Recent material from the Adriatic Sea. It is found in the Pliocene of Sicily; the Recent of the Mediterranean, the eastern Atlantic near Ireland, and Juan Fernandez Island, Chile, in the Pacific.

This species is close to Bulimina acanthia Costa $k \cdot t$ differs from it in the almost entire absence of marginal overhang of the chambers, this characteristic appearing only occasionally in the basal part of the test. It differs from $B$. elongata D'Orbigny in the more angled chare:ter of the chambers, the angled base, and the typically smaller size.

\section{Bulimina torta Cushman}

Plate 29, figure 6

Bulimina torta Cushman, U. S. Nat. Mus. Bull. 71, pt. 2, p. 81, text figs. 133a-c, 1911. 
Cushman and Parker, Cushman Lab. Foram. Research Contr., vol. 16, p. 15, pl. 3, fig. 8, 1940.

Test elongate, broadest near the apertural end, tapering to the subacute apical end; apertural end broadly rounded; early portion slightly compressed; later portion circular in cross section; chambers several, somewhat inflated; sutures depressed; wall calcareous, perforate, smooth; aperture very long and narrow, curved, broadest at the upper end; color white. Length $0.65 \mathrm{~mm}$.Cushman.

The type is from Albatross sta. H2902, 1,783 fathoms, northeast of the Hawaiian Islands. The species has not been recorded elsewhere.

This species is rendered unique by the long, slit-like aperture that curves over the top of the test. It is questionable whether it actually belongs in Bulimina at all. The number of specimens, however, is so limited that the study of the internal structure must wait until more material is available.

\section{Bulimina subaffinis Cushman}

Plate 29, figure 7

Bulimina șubaffinis Cushman, U. S. Nat. Mus. Bull. 100, vol. 4, p. 166, text figs. 7a, b, 1921.

Cushman and Parker, Cushman Lab. Foram. Research Contr., vol. 16, p. 15, pl. 3, fig. 7, 1940.

LeRoy, Colorado School of Mines Quart., vol. 39, no. 3, p. 27, p1. 5, fig. 9, 1944.

?Bulimina elongata Cushman (not D'Orbigny), U. S. Nat. Mus. Bull. 71, pt. 2, p. 79, text figs. 131a-d, 1911.

Test large, fusiform, apical end sharply pointed, apertural end rounded, the last whorl composing a large proportion of the test; chambers distinct, angled, very slightly inflated, sutures distinct, slightly depressed; aperture long, comma-shaped, with a well developed lip and tooth. Length (of holotype) $1.00 \mathrm{~mm}$., diameter $0.55 \mathrm{~mm}$.

The types are from Albatross sta. D5201, Sogod Bay, southern Leyte, in 554 fathoms. Similar specimens are found in the north Pacific, but they are somewhat more elongate and slender and have more chambers. LeRoy records it from the Miocene of Sumatra.

The species is larger and more pointed at the base than Bulimina ovata D'Orbigny, and is more ovate with less inflated chambers than $B$. affinis D'Orbigny.

\section{Bulimina barbata Cushman}

Plate 29, figure 8

Bulimina barbata Cushman, Scripps Inst. Oceanography Bull., Tech. ser., vol. 1, no. 10, p. 151, pl. 2, fig. 11, 1927.

Cushman and Parker, Cushman Lab. Foram. Research Contr. vol. 16, p. 16, pl. 3, fig. 10, 1940.

Bulimina pyrula D'Orbigny var. spinescens Cushman (not H. B. Brady), U. S. Nat. Mus. Bull. 100, p. 164, text fig. 3, 1921.

Test of medium size, broadly oval, the greatest width at, or below, the middle, the last-formed whorl composing more than half the test; chambers distinct, slightly inflated; sutures distinct, slightly depressed; wall of early portion of the test and the lower margir of the lastformed whorl covered with fine acicular spines, remainder of test smooth, finely perforate, somewhat translucent; aperture narrow, loop-shaped, placed at th: apex of the test well above the suture joining the second and third chambers. Length $0.75 \mathrm{~mm}$., diameter $0.40 \mathrm{~mm}$.

The species was described from Recent material from the west coast of North America, Discoverer sta. 9D, Lat. $36^{\circ} 40^{\prime} \mathrm{N}$., Long. $122^{\circ} 26^{\prime} \mathrm{W}$., at 1,121 fathoms. It has been found at several localities in the same general area and at one locality in the Philippine reg: on.

The species resembles Bulimina pyrula Г'Orbigny var. spinescens $\mathrm{H}$. B. Brady but differs from it in being less involute, having somewhat more inflated chambers, and longer spines.

\section{Bulimina spinifera Cushman}

Plate 29, figure 9

Bulimina spinifera Cushman (part), Scripps Inst. Oceanography Buli., Tech. ser., vol. 1, p. 151, p1. 2, fig. 15, 1927.

Test broadly fusiform or ovate, chambers of the last-formed portion strongly overlapping, initial end pointed and the base of the chambers sparsely spinose. Length $0.50 \mathrm{~mm}$; brec dth, $0.30 \mathrm{~mm}$.Cushman.

The types are from Lydonia sta. 31 , Lat. $7^{\circ}$ N., Long. $81^{\circ} 35.5^{\prime} \mathrm{W}$., in 478 fathoms. Some of the specimens from the west coast of North America that were originally included in this species are very different. They are completely involute, or almost so, and belong in the genus Globobulinina. The species is approaching Globobulimina in character and seems very close to Bulimina pyrula D'Orbigny var. spinescens H. B. Brady. T*e holotype is larger than the typical form of Brady's varioty and shows at least four whorls. In order to learn the true relationship of the two forms, however, more material is needed for study.

\section{Bulimina pagoda Cushman}

Plate 29, figures 10,11

Bulimina pagoda Cushman, Scripps Inst. Oceanogra ohy Bull., Tech. ser., vol. 1, p. 152, pl. 2, fig. 16, 1927.

Cushman and Parker, Cushman Lab. Foram. Research Contr., vol. 16, p. 17, pl. 3, figs. 11, 12, 1940.

Coryell and Mossman, Jour. Paleontology, vol. 16, p. 242, pl. 36, fig. 44, 1942.

Test rapidly tapering, broadest near the apertural end, almost as broad as long; consisting of as many as 5 whorls; chambers distinct, deeply cut under at the base, inflated, especially those of the last who +1 , increasing rapidly in size as added; sutures of last whorl distinct, depressed, the position of the earlier sutures clearly defined 
by the sharp undercutting of the chambers; wall of the periphery of each chamber with a series of large, stout spines projecting outward and curving downward, otherwise smooth, thin, rather coarsely perforate; aperture very slightly comma-shaped, at the apex of the test, well above the junction of the second and third chambers. Length $0.50 \mathrm{~mm}$., diameter $0.40 \mathrm{~mm}$.

The types are from Recent material from Lydonia sta. 30 , Lat. $7^{\circ} 0.1^{\prime}$ N., Long. $81^{\circ} 48.7^{\prime}$ W., south of Panama, in 428 fathoms. It is also found in the Pliocene Charco Azul formation of Panama.

This form differs from Bulimina marginata D'Orbigny in the flaring of the chambers, the much shallower lastformed whorl, and in having the projecting spines.

\section{Bulimina fijiensis Cushman}

Plate 29, figures 14,15

Bulimina fijiensis Cushman, Cushman Lab. Foram. Research Contr., vol. 9, p. 79, pl. 8, figs. 7a-c, 1933

Cushman and Parker, idem, vol. 16, p. 17, pl. 3, figs. 15, 16, 1940.

Cushman, U. S. Nat. Mus. Bull. 161, pt. 3, p. 11, pl. 3, figs. $10,11,1942$

Test small, stout, slightly longer than broad, rounded; chambers distinct, inflated, somewhat globular, comparatively few, increasing rapidly in size as added; sutures distinct, depressed; wall coarsely perforate except about the aperture where it is apparently without perforations; aperture loop-shaped, placed well above the junction of the second and third chambers. Length $0.25 \mathrm{~mm}$., diameter $0.15 \mathrm{~mm}$.

The types are from Recent material from Nairai, Fiji, in 12 fathoms. In addition to the Fiji localities we have one specimen from Zanzibar.

This species is close to Bulimina ornata Egger and possibly should be identified with it. Cushman's species, however, does not have the papillae that are plainly shown in the figure of the latter.

\section{Bulimina brevitrigona Chapman and Parr}

Plate 29, figure 17

Bulimina brevitrigona Chapman and Parr, Australasian Antarctic Exped., ser. C, vol. 1, pt. 2, p. 85, pl. 8, fig. 13, 1937.

Cushman and Parker, Cushman Lab. Foram. Research Contr., vol. 16 , p. 18, pl. 3, fig. $18,1940$.

Test conical; short and broadly trigonal; consisting of a trifacial series of moderately inflated chambers, the last of which are comparatively large and well-inflated; sutures well impressed, aperture a curved slit between the sutures of the last three chambers, the edges of which are delicately toothed. Aboral end somewhat acute. Test hyaline, finely tubulate and polished on the surface. Length, $0.7 \mathrm{~mm}$; width, $0.67 \mathrm{~mm}$.

This species is practically isomorphous with Verneuilina bradyi Cushman, which has a finely arenaceous test.-Chapman and Parr.
The types are from sta. XXII of the Mawson Australasian Antarctic Expedition, Lat. $66^{\circ} 13^{\prime}$ S., Long. 91.0 $15^{\prime} \mathrm{E}$., in 125 fathoms. We have no typical material. It seems questionable whether the form is a true Bulimir $x$, as the aperture is apparently not typical. If the species is isomorphous with Eggerella bradyi (Cushman) as described, this thesis is certainly true, since the aperture in the latter genus is not placed in the same position as in Bulimina, and is differently shaped. In addition, the arenaceous form has five chambers to the whorl in the early portion of the test. A study of the original spe:imens would have to be made before a final analysis of the generic characteristics of the species could be made.

Bulimina buchiana D'Orbigny var. gutta Chapman and Parr Plate 29, figure 16

Bulimina buchiana D'Orbigny var. gutta Chapman and Parr, Australasian Antarctic Exped., ser. C, vel. 1, pt. 2, p. 86, pl. 8, fig. 14, 1937.

Cushman and Parker, Cushman Lab. Foram. Research Contr., vol. 16, p. 19, pl. 3, fig. 17, 1940.

Test elongate, ovate, slightly curved, wider at oral end, poin ${ }^{+}$ed aborally; sides gently convex. Surface ornamented with about ten fine sharp costae persistent to the penultimate chamber; aperture bulimine, situated in a slight concavity. Dimensions: Length, 040 $\mathrm{mm}$; greatest width, $0.19 \mathrm{~mm}$.

This variety has a more slender habit of growth than the specific form. Its narrow and slightly curved test makes it easily distinguishable from typical examples of Bulimina buchiara. Bulimina rostrata, at first sight suggestive of the above variety, differs in the dominant costae, obliterating the suture lines, as well as in the aciculate aboral end.-Chapman and Parr.

The types are from sta. XLVII of the Mawson Australasian Antarctic Expedition, Lat. $42^{\circ} 38.5^{\prime}$ S., Long. $149^{\circ}$ $41.5^{\prime} \mathrm{E}$., in 1,320 fathoms. We have no material referal'!e to the form.

\section{Bulimina clava Cushman and Parker, n.sp.}

Plate 29, figures 12,13

? Bulimina aculeata Brady, Parker and Jones (not D'Orbigny), Zool. Soc. London Trans., vol. 12 , p. 220 , pl. 43, fig. 8 , 1888.

Bulimina inflata Cushman (not Seguenza), U. S. Nat. Mus. Bull. 104, pt. 3, p. 93, pl. 21, fig. 1, 1922.

Test large, tapering, greatest width formed by the last whorl, initial end pointed, typically with a stout spine, three or four whorls in the adult test, the last whorl making up more than half the surface; chambers of the earlier portion obscured by the sculpture of the surface, inflated, those of the last whorl distinct, the basal margin distinctly undercut; sutures of the last whorl distinct, slightly depressed; wall finely but distinctly perforate, in the last chambers nearly smooth on the upper part, becoming costate toward the periphery, each costa extending backward 
into a spinose process, the costae of adjacent chambers in the earlier part often fused; aperture broadly commashaped. Length up to $0.90 \mathrm{~mm}$., diameter up to $0.50 \mathrm{~mm}$.

Holotype (Cushman Coll. No. 35854) from Albatross sta. 2018, Atlantic Ocean, off the mouth of Chesapeake Bay, Lat. $37^{\circ} 12^{\prime} .22^{\prime \prime}$ N., Long. $74^{\circ} 20^{\prime} 04^{\prime \prime}$ W., in 788 fathoms.

The species is found in the western Atlantic north of Cape Hatteras and in the eastern Atlantic in the vicinity of Ireland. A somewhat similar form is found in the Pacific, off the west coast of America, and possibly in the vicinity of Japan (Bulimina inflata Cushman (not Seguenza), U. S. Nat. Mus. Bull. 71, pt. 2, p. 84, text fig. 137, 1911 ; Scripps Inst. Oceanography Bull., Tech. ser., vol. 1, p. 151, pl. 2, fig. 14, 1927).

This species differs from Bulimina striata D'Orbigny var. mexicana Cushman in being much larger, with less regular chambers that increase much more rapidly in size and do not show a uniform collared effect, and in having, typically, a longer, heavier basal spine. The young specimens of the two forms are sometimes difficult to separate.

Subgenus DESINOBULIMINA Cushman and Parker, 1940

Desinobulimina Cushman and Parker, Cushman Lab. Foram. Research Contr., vol. 16, p. 19, 1940.

Subgenoholotype Bulimina auriculata Bailey, 1851.

Test with the early chambers like Bulimina but with the aperture of the last-formed chambers becoming terminal, connected with the earlier apertures by an internal trough, which is joined to one side of the aperture toward the front, and projects above at the back in the form of a tooth.

Many of the smooth species of Bulimina show a tendency to develop in this direction. All forms that have an apertural tooth have at least an incipient trough-like connection between the apertures. As a general rule, however, the apertures themselves are also connected, the lower part of the aperture of the last chamber joining the upper end of the aperture of the previous chamber. Only a few species show the aperture becoming terminal, with the trough as the sole means of communication. In these forms the trough extends down from the final aperture and twists around to join the tooth-like protuberance of the previous aperture.

The earliest known form showing these characteristics is Bulimina quadrata Plummer, from the Paleocene Midway group of Texas. Other known species come from the Miocene and Recent.

\section{Bulimina (Desinobulimina) quadrata Plummer}

Plate 29, figures 18, 19

Bulimina (Ellipsobulimina) quadrata Plummer, Univ. Texas Bull. 2644, p. 72, pl. 4, figs. 4, 5, 1927.
Jennings, Bull. Am. Paleontology, vol. 23, no. 78, p. 30, pl. 3, fig. 19, 1936.

Albritton and Phleger, Jour. Paleontology, vol. 11, p. 352, 1937.

Cushman, Cushman Lab. Foram. Research Contr., vol. 16, p. 67, p1. 11, fig. 21, 1940.

Kline, Mississippi Geol. Survey Bull. 53, p. 48, pl. 4, fig. 20, 1943.

Applin and Jordan, Jour. Paleontology, vol. 19, p. 131 (list), 1945.

Cushman and Todd, Cushman Lab. Foram. Research Contr., vol. 22, p. 60, pl. 10, fig. 19, 1946.

Test medium to large, megalospheric form almost cylindrical, microspheric tapering, consisting of 4 to 5 whorls; chambers sharply angled, very slightly if at all inflated; sutures distinct, very slightly depressed; wall thin, translucent, finely perforate; aperture terminal, with a slight lip and small tooth, in well-preserved specimens the inner connecting trough usually visible. Length of topotype specimens 0.60 to $0.90 \mathrm{~mm}$., diameter 0.26 to $0.34 \mathrm{~mm}$.

The types of the species are from the Paleocene, Midway formation, clay pit of Mexia Brick Works, about 1 mile west of the town of Mexia, Limestone County, Texas. Besides various localities in the Midway formation of Texas we have questionable specim?ns from the Paleocene, about $2 \% 10$ miles N. $44^{\circ}$ E. of Santa Susana, in Poison Oak Canyon, north of Simi Valley, Ventura County, California, from brown shale 2,785 feet stratigraphically above the Cretaceous contact in strata mapped by Kew as Martinez. It has also been recorled from the Paleocene of Alabama and Florida and the Cretaceous of New Jersey.

This species very much resembles Bulimina kickapooensis Cole but may be easily differentiated from it by the terminal aperture. It differs from most of the other smooth species in the almost complete lack of inflation of the chambers and their sharply angled character.

Bulimina (Desinobulimina) illingi Cushman and Stainforth

Plate 30, figure 12

Bulimina (Desinobulimina) illingi Cushman and St`inforth, Cushman Lab. Foram. Research Special Pub. 14, p. 41, pl. 6, figs. 7a, b, 1945.

Test fairly short, less than twice as long as broad, irregularly oval, greatest breadth usually above the middle, initial end rounded in the megalospheric form or subacute in the microspheric; chambers comparatively few, increasing rapidly in size as added, the last whorl making up nearly the whole of the surface of the test; sutures slightly depressed; wall smooth, coarsely perforate; aperture terminal with a slightly projecting lip Length 0.75 $0.93 \mathrm{~mm}$; breadth $0.45-0.52 \mathrm{~mm}$.

This species differs from $B$. (Desinobulimina) auriculata Bailey in the broader form, more inflated chambers, and typically more rounded base.-Cushman and Stainforth. 
The types of this species are from the Oligocene Cipero formation of Trinidad.

\section{Bulimina (Desinobulimina) montereyana Kleinpell}

Plate 29, figures 20, 21

Bulimina montereyana Kleinpell, Miocene stratigraphy of California, p. 254, pl. 13, fig. 13, Tulsa, 1938.

Bulimina pseudotorta Barbat and Johnson (not Cushman), Jour. Paleontology, vol. 8, p. 13, pl. 1, fig. 10, 1934.

Test large, fusiform, with the initial end sometimes prolonged, narrow, apertural end somewhat truncated, consisting of about 4 whorls in the adult; chambers distinct, slightly inflated, angled; sutures slightly depressed; wall smooth, finely perforate; aperture terminal, crescentshaped, with a tooth. Length given by Kleinpell 1.00 to $1.25 \mathrm{~mm}$. or more, diameter 0.65 to $0.70 \mathrm{~mm}$.

The types are from the Miocene of Reliz Canyon, California (Leland Stanford Junior Univ. loc. 691, sample D80). The species has been recorded by Kleinpell from various localities ranging from the upper Luisian to the lower Delmontian in the Miocene of California. We have good material from sta. SPD-4, Tice shale, Contra Costa County, California, a locality at which Kleinpell records the species in abundance.

The species differs from Bulimina pseudotorta Cushman in its more fusiform shape, larger size, and the presence of the terminal aperture. It is larger than Bulimina delmonteensis Kleinpell, has more inflated chambers, is less tapering, and has the terminal aperture.

\section{Bulimina (Desinobulimina) auriculata Bailey}

Plate 29, figures 22-24

Bulimina auriculata Bailey, Smithsonian Contr., vol. 2, p. 12, pl., figs. $25-27,1851$.

Bulimina pyrula Flint (not D'Orbigny), U. S. Nat. Mus. Rept., 1897, p. 290, pl. 36, figs. 4, 5, 1899.

Bulimina (Desinobulimina) auriculata Cushman and Parker, Cushman Lab. Foram. Research Contr., vol. 16, p. 20, pl. 3, figs. 19-21, 1940.

Cushman, idem, Special Pub. 12, p. 28, pl. 3, fig. 48, 1944.

Cushman and Todd, idem, Special Pub. 15, p. 40, pl. 6, fig. 14, 1945.

$1 / l^{\prime} / 1 / 4$

Bulimina (Desinobulimina) cf. auriculata Cushman and Todd, Cushman Lab. Foram. Research Contr., vol. 22, p. 92, 1946.

Test long in the adult form, fusiform, consisting of about 3 whorls; chambers distinct, partially involute so that the last-formed whorl usually forms at least threefourths of the test; sutures distinct, slightly depressed; wall thin, translucent, smooth, with medium sized perforations; aperture terminal, with a large, curved tooth, the connecting internal trough easily visible through the wall of the test. Length up to $0.52 \mathrm{~mm}$., diameter up to $0.92 \mathrm{~mm}$.
The types are from Recent material collected southeast of Montauk Point, Long Island, Lat. $\left.40^{\circ} 21^{\prime} 54^{\prime \prime}\right]^{\top}$., Long. $70^{\circ} 55^{\prime} 35^{\prime \prime} \mathrm{W}$., in 51 fathoms. The species occirs along the eastern coast of the United States north of Cape Hatteras. Specimens from Albatross sta. 2018, Atlantic Ocean, off the mouth of Chesapeake Bay, Lat. $37^{\circ} 12^{\prime} 22^{\prime \prime}$ $\mathrm{N}$., Long. $74^{\circ} 20^{\prime} 04^{\prime \prime} \mathrm{W}$., in 788 fathoms, are very much broader in proportion to their length and probably rep+esent a varietal form of Bailey's species (Bulimina pyrula Cushman (not D'Orbigny), U. S. Nat. Mus. Bull. 104, p. 101, pl. 20, fig. 1, 1922). In the Pacific off the wast coast of North America a form recorded as Bulimina ovata Cushman (not D'Orbigny) (Cushman Lab. Foram. Fesearch Contr., vol. 6, p. 56, pl. 7, fig. 22, 1930) is very similar except that the adults rarely show the terminal aperture. Specimens similar to these occur also in the Pliocene of Timms Point, California.

The species is larger and has less inflated chambers than Bulimina ovata D'Orbigny. It differs also in having the terminal aperture with the trough-like connection with the earlier apertures.

\section{Bulimina (Desinobulimina) turgida Bailey}

Plate 29, figures $25-27$

Bulimina turgida Bailey, Smithsonian Contr., vol. 2, p. 12,. pl., figs. 28-31, 1851.

Bulimina marginata Parker and Jones (not D'Orbigny) (part), Annals and. Mag. Nat. History, ser. 2, vol. 19, p. 296, pl. 11, figs. 36-38 (not figs. 35, 39, 40), 1857.

Bulimina presli Reuss var. pyrula Parker and Jones (not D’Orbigny), Philos. Trans., vol. 155 , p. 372 , pl. 15, figs 8 , 9, 1865.

Bulimina doliolum Terquem and Terquem, Soc. Zool. France Bull., vol. 11, p. 333, pl. 11, figs. 17, 18, 1886.

Bulimina ovoides Terquem and Terquem, idem, p. 334 , pl. 11 , fig. 20.

Bulimina pyrula D'Orbigny var. spinescens Flint (not $H$. B. Brady), U. S. Nat. Mus. Rept., 1897, p. 290, pl. 37, fig. 1, 1899.

Cushman, U. S. Nat. Mus. Bull. 104, pt. 3, p. 102, pl. 20, fig. 2, 1922 .

Bulimina (Desinobulimina) turgida Cushman and Parker, Cushman Lab. Foram. Research Contr., vol. 16, p. 20, pl. 3, f xs. 22-24, 1940.

Test ovate, broadest near the middle, rounded at both ends but with the apertural end narrower and more pointed; chambers distinct, much inflated, giving the test a very irregular appearance; sutures distinct, depressed; wall smooth except for the base, which is usually ornamented with 2 or 3 short spines, finely perforate; aperture curved, terminal in the adult, with a broad tooth. Length of figured specimens $0.75 \mathrm{~mm} ., 0.95 \mathrm{~mm} ., 1.12 \mathrm{~mm}$; diameter $0.50 \mathrm{~mm}$., $0.55 \mathrm{~mm}$., $0.55 \mathrm{~mm}$.

The types are from sta. E no. 9, Lat. $40^{\circ} 21^{\prime} 54^{\prime \prime}$ N., Long. $70^{\circ} 55^{\prime} 35^{\prime \prime} \mathrm{W}$., southeast of Montauk Point, Long 
Island, in 51 fathoms, and sta. $\mathrm{F}$ no. 24 , Lat. $39^{\circ} 52^{\prime} 40^{\prime \prime}$ N., Long. $72^{\circ} 14^{\prime} \mathrm{W}$., southeast of Fire Island Inlet, in 49 fathoms. The species occurs along the eastern coast of the United States and in the vicinity of Norway and the British Isles.

This species is quite variable. The immature specimens are almost completely involute, becoming much more evolute in the aduit. The figure of an immature specimen from Dröbach, Norway, is given to show this characteristic and also to show the species "Bulimina doliolum Terquem". The swollen, inflated chambers and heavy, short spines make it easy to identify the species.

\section{Species originally referred to BULIMINA but not here included}

The following species were originally described as Bulimina but are not included in the present discussion of that genus:

Bulimina acicula Costa, Accad. pontaniana Atti, vol. 8, pt. 2, p. 338, pl. 22, fig. 6, 1856 (= Pyrulina?).

B. acicula Andreae, Specialkarte Elsass-Lothringen Abh., vol. 2, pt. 3 , p. 277 , pl. 12 , fig. $13,188+$ (See Turrilina andreaei Cushman).

B. acuta Costa, Accad. pontaniana Atti, vol. 7, pt. 2, p. 336, pl. 13, fig. 25, 1856 (A homonym of $B$. acuta Reuss 1851 . We have no typical material).

B. andreae Rzehak, K. naturh. Hofmuseums Wien, vol. 6, p. 2, (list), 1891 (nomen nudum).

B. andreaei Schubert, Deutscher. Naturwiss.-med. Ver. Böhmen "Lotos" Sitzungsber., p. 59, pl. 2, 1900 (=Virgulina (Virgulinella) pertusa Reuss, Cushman, Cushman Lab. Foram. Research Special Pub. 9, p. 31, pl. 5, figs. 6-9, 1937).

B. arcuata Stache, Novara-Exped., Geol. Theil, vol. 1, pt. 2, p. 269 , pl. 24, figs. 18a-c, 1865 (homonym of $B$. arcuata D'Orbigny, 1826. = ?).

B. auricula Heron-Allen and Earland, Discovery Repts., vol. 4, p. 351, pl. 9, figs. 1, 2, 1932 (= Buliminella?).

B. auriculata Terquem, Soc. Géol France Mém., ser. 3, vol. 2, p. 115, pl. 12(20), fig. 14, 1882 (homonym of $B$. auriculata Bailey, 1851. = ?).

B. brevicona Perner, Foram. Ceskeho Cenomanu, p. 54, pl. 3, figs. 1a, b, 1892 (= Arenobulimina brevicona (Perner) Cushman).

B. candida Terquem, Soc. Géol. France Mém., ser. 3, vol, 2, p. 111, pl. 11(19), figs. 30, 31, 1882 (= Valvulina candida (Terquem)).

B. chapmani Heron-Allen and Earland, British Antarctic Exped., Zoology, vol. 6, p. 130, pl. 4, figs. 18-20, 1922 (see Pseudobulimina chapmani (Heron-Allen and Earland)).

B. compressa Bailey, Smithsonian Contr., vol. 2, art. 3, p. 12, pl., figs. 35-37, 1851 (= Virgulina compressa (Bailey) Cushman, U. S. Nat. Mus. Bull. 104, pt. 3, p. 116, pl. 24, figs. 2, 3, 1922).

B. compressa Carsey, Texas Univ. Bull. 2612, p. 29, pl. 4, fig. 14, 1926 (see Buliminella carseyae Plummer).

B. conoidea Perner, Foram. Ceskeho Cenomanu, p. 55, pl. 3, figs. 5a, b, 1892 (= Arenobulimina conoidea (Perner) Cushman, Cushman Lab. Foram. Research Special Pub. 8, p. 38, pl. 4, figs. 1, 2, 1937).
B. contorta Gümbel, Anleit. geol. Beob. Alpenreisen, D. O. Alp. Ver. Zeitschr,, Beilage, p. 105, fig. 25 [plate], fig. 22, 1878 $(=?)$.

B. conulus Terquem, Soc. Géol. France Mém., ser. 3, vol. 2, p. 116, pl. $12(20)$, fig. 17, 1882 (see Buliminellc conulus (Terquem)).

B. convoluta Williamson var. dehiscens Heron-Allen and Earland, Royal Micr. Soc. Jour., 1924, p. 143, pl. 8, figs. 26-28 (= Ceratobulimina dehiscens (Heron-Aller and Earland) Cushman and Harris, Cushman Lab. Foram. Research Contr., vol. 3, p. 176, pl. 29, figs. 7a-c, 1927).

B. convoluta Williamson var. nitida Millett, Royal Micr. Soc. Jour., 1900, p. 280, pl. 2, fig. 10 (=Cushmanella?).

B. cuneiformis Terquem, Essai sur le classement des animaux qui vivent sur la plage et dans les environs de Dunkerque, pt. 3 , p. 127 , pl. 16, figs. 11a, b, 1881 (= arenaceous form).

B. cuneiformis Terquem, Soc. Géol. France Mém., ser. 3, vol. 2, p. 112 ; pl. $12(20)$, figs. $2 \mathrm{a}, \mathrm{b}, 1882$ (homonym of $B$. cuneiformis Terquem, 1881. We have no typical material).

B. cylindracea Costa, Accad. pontaniana Atti, vol. 8, pt. 2, p. 269, pl. 15, fig. 10, 1856 (=Virgulina).

B. declivis Reuss, Akad. Wiss. Wien Sitzungsber., vol, 48, pt. 1, p. 55, pl. 6, fig. 70; pl. 7, fig. 71, 1863 (see Robertina declivis (Reuss)).

B. depressa Perner, Foram. Ceskeho Cenomanu, p. 55, pl. 3, figs. 3a, b, 1892 (= Pernerina depressa (Perner) Cushman, Am. Jour. Sci., vol. 36, p. 19, pl. 1, figs. 5-7, 1933).

B. d'orbignyi Reuss, Verstein. böhm. Kreideformation, pt. 1, p. 38, pl. 13, figs. 74a, b, 1845 (= Arenobulimina d'orbignyi (Reuss) Cushman and Parker, Cushman Lab. Foram. Research Contr., vol. 10, p. 30, pl. 5, figs. 13, 14, 1934).

$B$. elegans D'Orbigny, Annales sci. nat., vol. 7, p. 270 , no. 10 , Modèles, no. 9, 1826 (see Buliminella elegans (D'Orbigny)).

$B$. elegans D'Orbigny var. gibba Schubert, K.-k. geol. Reichsanstalt Jahrb., vol. 53, p. 416, pl. 19, figs. 6a-c, 1904 (homonym of $B$. gibba Fornasini, 1901. We have no typical material).

$B$. elegantissima D’Orbigny, Voyage dans l'Amérique méridionale, vol. 5, Foraminifères, p. 51, pl. 7, fgs. 13, 14, 1839 (see Buliminella elegantissima (D’Orbigny)).

B. elegantissima D'Orbigny var. apiculata Chapmen, Linnean Soc. London Jour., Zoology, vol. 30, p. 31, pl. 14, fig. 77, 1908 (see Buliminella madagascariensis (D'Orbigny) var. spicata Cushman and Parker).

B. elegantissima D'Orbigny var. compressa Millett, Royal Micr. Soc. Jour., 1900, p. 277, pl. 2, fig. 5 (see Buliminella parallela Cushman and Parker).

B. elegantissima D'Orbigny var. fusiformis Sidebottom, Royal Micr. Soc. Jour., 1918, p. 23, pl. 3, figs. 8-10 (see Buliminella madagascariensis (D'Orbigny)).

B. elongata D'Orbigny var. cylindrica Grzybowsk', Akad. Umiej., Wydz. mat.-przr. Rozpr., Krakow, vol. 9, p.·189, pl. 2, fig. 14 (pl. 1 in text), 1894 (homonym of $B$. cylindrica Roemer, 1838. We have no typical material).

B. flexa Terquem, Soc. Géol. France Mém., ser. 3, vol. 2, p. 115, pl. 12(20), fig. 15, 1882 (see Buliminella flexa (Terquem)).

B. frons Olszewski, Sprawozd. Kom. Fizyj. Akad. Umiej. Krakowie, vol. 9, p. 121, pl. 2, fig. 1, 1875 (= Arenobulimina frons (Olszewski) Cushman, Cushman Lab. Foram. Research Special Pub. 8, p. 44, pl. 4, fig. 28, 1937).

B. galliheri Kleinpell, Miocene stratigraphy of California, p. 253, 
pl. 17, figs. 2, 5, Tulsa, 1938 (see Globobulimina galliheri (Kleinpell)).

B. gregorii Chapman, Royal Soc. Victoria Proc., vol. 16, p. 187, pl. 22, figs. 3, 3a, $1904(=$ ? Described by Chapman as finely arenaceous).

B. imbricata Reuss, Haidinger's Naturwiss. Abh., vol. 4, pt. 1, p. 38, pl. 3, fig. 7, 1851 (see Buliminella imbricata (Reuss)).

B. imperatrix Karrer, Akad. Wiss. Wien Sitzungsber., vol. 57, pt. 1, p. 176, pl. 4, fig. 11, 1868 (see Robertina imperatrix (Karrer)).

$B$. incrassata Karrer var. elongata Seguenza, R. Accad. Lincei Atti, ser. 3, vol. 6, p. 146, 1880 (homonym of B. elongata D'Orbigny, 1846).

B. inflata Perner, Foram. Ceskeho Cenomanu, p. 55, pl. 3, figs. 4a-c, 1892 (= Arenobulimina brevicona (Perner) Cushman and Parker, Cushman Lab. Foram. Research Contr., vol. 10. pp. 35, 36, pl. 6, figs. 7a, b, 1934).

$B$. intorta Terquem, Soc. Géol. France Mém., ser. 3, vol. 2, p. 115, pl. 12(20), fig. 16, 1882 (see Buliminella intorta (Terquem)).

B. irregularis Terquem, idem, p. 112, pl. 12(20), figs. 1a, b (see Buliminella irregularis (Terquem)).

B. jaekeli Franke, Abh. geol.-paleont. Inst. Greifswald, vol. 6, p. 24, pl. 2, figs, 15a-c, 1925 (= Pernerina depressa (Perner) Cushman and Parker, Cushman Lab. Foram. Research Contr., vol. 10, p. 36, 1934).

B. laevis Beissel, Preuss geol. Landesanstalt Abh., n. ser., vol. 3, p. 66, p1. 12, figs. 39-43, 1891 (see Buliminella laevis (Beissel)).

B. madagascariensis D'Orbigny, Annales sci. nat., vol. 7, p. 270, no. 17, 1826 (see Buliminella madagascariensis (D'Orbigny)).

B. nnadrugaensis Bermúdez, Soc. cubana historia nat. Mem., vol. 12, no. 2, p. 89, text figs. 1-3, 1938 (= Angulogerina?).

B. mammillata Costa, Accad. pontaniana Atti, vol. 7, pt. 2, p. 335, pl. 18, fig. 16, 1856 (=Virgulina?).

B. marginata D'Orbigny var. biserialis Millett, Royal Micr. Soc. Jour., 1900, p. 278, pl. 2, fig. 7 (= Suggrunda?).

B. minutissima Wright, in Reade, Liverpool Geol. Soc. Proc., vol. 9, p. 190, pl. 13, figs. 9-12, 1902 (= Ceratobulimina? Referred by Earland to Robertina).

B. normani Goës, $\mathrm{K}$. svenska vetensk. akad. Handl., vol. 25 , no. 9, p. 47, p1. 9, figs. 437, 438, 1894 (= Robertina?).

$B$. obesa Reuss, Haidinger's Naturwiss. Abh., vol. 4, p. 40, pl. 3, fig. 12, 1851 (= Arenobulimina obesa (Reuss) Cushman and Parker, Cushman Lab. Foram. Research Contr.; vol. 10, p. 31, pl. 5, fig. 20, 1934).

B. obliqua D’Orbigny, Soc. Géol. France Mém., ser. 1, vol. 4, p. 40, pl. 4, figs. 7, 8, 1840 (= Arenobulimina obliqua (D'Orbigny.) Cushman, Cushman Lab. Froram. Research Contr., vol. 7, p. 36, pl. 5, figs. 5a-c, 1931).

B. obliqua Terquem, Soc. Géol. France Mém., ser. 3, vol. 2, p. 118, pl. 12(20), fig. 23, 1882 (see Buliminella semi-nuda (Terquem)).

B. obtusa D’Orbigny, Soc. Géol. France Mém., ser. 1, vol. 4, p. 39, pl. 4, figs. 5, 6, 1840 (see Buliminella obtusa (D'Orbigny)).

B. ovigera Terquem, Soc. Géol. France Mém., ser. 3, vol. 2, p. 108, pl. 11(19), figs. 17-20, 1882 (see Robertina ovigera (Terquem)).

B. ovula Terquem, idem, p. 113, pl. 12(20), fig. 5, 1882 (see Buliminella turbinata (Terquem)).

$\dot{B}$. ovulum Harting, Ver. kon. akad. Wetensch., vol. 10, p. 9, pl. 1, figs. $10 \mathrm{a}, \mathrm{b}, 1864$ (homonym of $B$. ovula D'Orbigny, 183? Figure unrecognizable).

B. parkeri Terquem and Terquem, Soc. Zool. France Bull., vol. 11, p. 334, pl. 11, fig. 9, 1886 (see Robertina parkeri (Terquem and Terquem)).

B. (?) petalifera Howe, Louisiana Dept. Cons. Geol. Bull. 14, p. 63, pl. 9, figs. 22, 23, 1939 (= Discorbis).

B. polystropha Reuss, Verstein böhm. Kreideformation, pt. 2, p. 100 , pl. 24, fig. 53, 1846 (= Vernewilina polystropha (Reuss), Cushman, Cushman Lab. Foram. Research Special Pub. 7, p. 11, pl. 1, figs. 14, 15, 1937).

B. preslii Reuss, Verstein böhm. Kreideformation, pt. 1, p. 3 ? pl. 13, fig. 72, 1845 (= Arenobulimina preslii (Reuss) Cusl man and Parker, Cushman Lab. Foram. Research Contr., vol. 10, p. 29, pl. 5, figs. 12, 13, 1934).

B. preslii Reuss var. sabulosa Chapman, Royal Micr. Soc. Jour., 1892 , p. 7 , pl. 12 , fig. 5 (= Arenobulinina sabulosa (Chapman), Cushman and Parker, Cushman Lab. Foram. Research Contr., vol. 10, p. 32, pl. 6, figs. 6a, b, 1934).

B. pulchra Terquem, Soc. Géol. France Mém., ser. 3, vol. 2, p. 114 , pl. $12(20)$, figs. $8,9,11,12$ (not fig. 10), 1882 (= Buliminella).

B. punctata D'Orbigny, Annales sci. nat., vol. 7, p. 270, no. 11, 1826 (see Buliminella punctata (D'Orbigny)).

B. pupa Terquem, Soc. Géol. France Mém., ser. 3, vol. 2, p. 116, pl. 12(20), figs. 18a, b, 1882 (see Buliminella pupa (Terquem)).

B. pupoides D’Orbigny var. brevis Seguenza, R. accad. Lincai Atti, ser. 3, vol. 6, p. 146, 1880 (homonym of $B$. brevis D'Orbigny, 1826):

B. pupoides D'Orbigny var. convoluta Williamson, Recent Foraminifera of Great Britain, p. 63, pl. 5, figs. 132, 133, 1858 (see Pseudobulimina convoluta (Williamson)).

B. pupoides D'Orbigny var. fusiformis Williamson, idem, p. 63, pl. 5, figs. 129, 130, 1858 (=Virgulina-not $V$. fusiformis Cushman).

B. puschi Reuss, Haidinger's Naturwiss. Abh., vol. 4, p. 37, f1. 3, figs. 6a, b, 1851 (= Arenobulimina puschi (Reuss) Cushman and Parker, Cushman Lab. Foram. Research Contr., vol. 10, p. 30, pl. 5, figs, 18a, b, 1934).

B. pusilla Brotzen, Sveriges geol. undersökning, ser. C, no. 39\}, vol. 30 , no. 3 , p. 127 , pl. 8 , fig. 4; text fig. 44,1936 (see Buliminella pusilla (Brotzen)).

B. pygmaea Egger, Neues Jahrb., 1857, p. 284, pl. 12, figs. 10, 11 $(=$ ?).

B. pyrula D'Orbigny var. perversa Cushman, U. S. Nat. Mus. Bull. 100, vol. 4, p. 163, text figs. 2a-c, 1921 (see Globobulimina perversa (Cushman)).

B. pyrula D’Orbigny var. spinosa Seguenza, R. accad. Lincei At $\uparrow \mathrm{i}$, ser. 3, vol. 6, p. 147, 1880 (homonym of B. spinosa Seguenza, 1862).

B. rhomboidalis Costa, Accad. pontaniana Atti, vol. 8, pt. 2, pl. 13, fig. 24, 1856 (= Uvigerina?).

B. rimosa Marsson, Naturw. Ver. Neu-Vorpommern u. Rügen Mitth., vol. 10, p. 153, pl. 3, figs. 2a, b, 1878 (= Ataxophragminum rimosum (Marsson) Cushman and Parker, Cushman Lab. Foram. Research Contr., vol. 10, p. 32, pl. 6, figs. 3-5, 1934).

B. robertsi Howe and Ellis, in Howe, Louisiana Dept. Cons. Geol. Bull. 14, p. 63, pl. 8, figs. 32, 33, 1939 (see Buliminella robertsi (Howe and Ellis)).

B. scabra Williamson, Recent Foraminifera of Great Britain, p. 
65, pl. 5, figs. 136, 137, 1858 (B. arenace a on expl. of plate) (=-Eggerella scabra (Williamson) Cushman, Cushman Lab. Foram. Research Special Pub. 8, p. 50, pl. 5, figs. $10,11,1937$ ).

B. scalariformis Terquem, Soc. Géol. France Mém., ser. 3, vol. 2, p. 114, pl. 12(20), fig. 13, 1882 (see Buliminella irregularis (Terquem)).

B. sellini Brotzen, Deutschen Palästina-Ver. Zeitschr., Jahrg. 1934, p. 59, pl. 4, fig. 2 (= Discorbis?).

B. semi-nuda Terquem, Soc. Géol. France Mém., ser. 3, vol. 2, p. 117, pl. 12(20), fig. 21, 1882 (see Buliminella semi-muda (Terquem)).

B. striato-punctata Terquem, idem, p. 116, pl. 12(20), fig. 19 (see Buliminella pupa (Terquem)).

B. subbulbiformis Rzehak, K. naturh. Hofmuseums Wien, vol. 6, pp. 2, 9, (list), 1891 (nomen nudum).

B. subcylindrica H. B. Brady, Quart. Jour. Micr. Sci., vol. 21, p. 56, 1881 (see Robertina subcylindrica (H. B. Brady)).

B. subdeclivis Rzehak (no reference or information concerning this species).

B. subsphaerica Reuss, Verstein. Böhm. Kreideformation, pt. 2, p. 109, pl. 24, fig. 53, 1846 (= Arenobulimina subsphaerica (Reuss) Cushman and Parker, Cushman Lab. Foram. Research Contr., vol. 10, p. 30, pl. 5, fig. 16, 1934).

B. subteres H. B. Brady, in Wright, Belfast Nat. Field Club, App. 1880 , p. 180 , pl. 8 , figs. 2, 2a, 1881 (see Robertina subteres (H. B. Brady)).

B. sulcata D'Orbigny, Annales sci. nat., vol. 7, p. 269, no. 3, 1826 (=Uvigerina?).

B. terquemiana Heron-Allen and Earland, Royal Micr. Soc. Jour., 1911, p. 314, pl. 9, figs. 13, 14 (see Buliminella semimuda (Terquem)).

B. textilariformis Stache, Novara-Exped., Geol. Theil, vol. 1, pt. 2, p. 268, pl. 24, figs. 17a-c, 1865 (=?).

B. trigona Chapman, Geol. Soc. London Quart. Jour., vol. 48, p. 514, pl. 15, fig. 8, 1892 (= Arenobulimina? trigonula (Chapman) var. inornata (Chapman) Cushman, Cushman Lab. Foram. Research Special Pub. 8, p. 44, 1937).

B. trigonula Chapman var. inornata Chapman, South African Mus. Ann., vol. 4, no. 10, p. 224, pl. 29, fig. 3, 1904 (= Arenobulimina? trigonula (Chapman) var. inornata (Chapman) Cushman, Cushman Lab. Foram. Research Special Pub. 8, p. 44, 1937).

B. trilobata Franke, Preuss. Geol. Landes. Abh., n. ser., vol. 3, p. 161, pl. 14, fig. 26, 1928 (= Ataxophragmium? Homonym of $B$. trilobata D'Orbigny, 1826).

B. trocheata Terquem, Soc. Géol. France Mém., ser. 3, vol. 2, p. 111, pl. 11(19), fig. 33, 1882 (= Arenobulimina?).

B. truncata Reuss, Verstein. Böhm. Kreideformation, pt. 1, p. 37, pl. 8, fig. 73, 1845 (= Arenobulimina truncata (Reuss) Cushman and Parker, Cushman Lab. Foram. Research Contr., vol. 10, p. 29, pl. 5, figs, 8, 9, 1934).

B. turbinata Terquem, Soc. Géol. France Mém., ser. 3, vol. 2, p. 113, pl. 12(20), figs. 6, 7, 1882 (see Buliminella turbinata (Terquem)).

B. uviformis Terquem, idem, p. 110, pl. 11(19), figs. 27a, b, 1882 $(=$ Valvulina $)$.

B. variabilis D'Orbigny, Soc. Géol. France Mém., ser. 1, vol. 4, p. 40, pl. 4, figs. 9-12, 1840 (= Ataxophragmium variabile (D'Orbigny) Reuss, Models nos. 6 and 7, 1865).

B. williamsoniana H. B. Brady, Quart. Jour. Micr. Sci., vol. 21, p. 56, 1881 (see Buliminoides williamsoniana (H. B. Brady)).

Genus NEOBULIMINA Cushman and Wickenden, 1928

Neobulinina Cushman and Wickenden, Cushman Lab. Foram. Research Contr., vol. 4, p. 12, 1928.

Cushman, idem, Special Pub. 1, p. 247, 192?; idem, Special Pub. 4, p. 220, 1933.

Genotype Neobulimina canadensis Cushman and Wickenden, 1928.

Test in the early stages triserial, as in Eulimina; adult biserial, not compressed; chambers inflated, simple; wall calcareous, perforate, aperture in the triserial stage as in Bulimina, in the adult broader, tending to become subterminal. Cretaceous.

So far as known the species of Neobulimina are all confined to the Cretaceous.

\section{Neobulimina minima Tappan}

Plate 29, figures 28,29

Neobulimina minima Tappan, Jour. Paleontology, vol. 14, p. 117, pl. 19, figs. 5a-c, 6, 1940; idem, vol. 17, p. 597, pl. 81, fig. 16, 1943.

Test minute, early stage triserial, later stage biserial, final pair of chambers forming approximately one-third of the test, slightly twisted, nearly circular in cross-section; chambers inflated, slightly elongate, wall calcareous, surface smooth, apert'ire broad, loopshaped at the base of the last-formed chamber. Length of holotype, $0.26 \mathrm{~mm}$; ; breadth, $0.10 \mathrm{~mm}$; width, $0.08 \mathrm{~mm}$.; length of paratype, $0.21 \mathrm{~mm}$; breadth, $0.09 \mathrm{~mm}$.-Tappan.

The types are from the Lower Cretaceous Grayson formation, middle and top of zone 1, Grayson Bluff, Denton Creek, 31/2 miles northeast of Roanoke, 2 miles by road east of the Fort Worth-Denton highway, $\mathrm{I}$ 'nton County, Texas. The species has also been recorded from the Duck Creek formation of Texas and Oklahoma.

It is somewhat smaller, more slender, and with more gradually increasing chambers than typical specimens of Neobulimina canadensis Cushman and Wickenden. The two forms are undoubtedly closely related, and it is possible that some Upper Cretaceous forms referred to $N$. canadensis are more closely related to $N$. minima

\section{Neobulimina canadensis Cushman and Wickenden}

Plate 29, figures 32,33

Neobulimina canadensis Cushman and Wickenden, Cushman Lab. Foram. Research Contr., vol. 4, p. 13, pl. 1, figs. 1, 2, 1928.

Cushman, Tennessee Div. Geol. Bull. 41, p. $4 \varepsilon$, pl. 8, figs. 1a-c, 1931; Cushman Lab. Foram. Research Sfecial Pub. 4, pl. 22, figs. 24a, b, 1933; idem, Special Pub. 5, pl. 27, figs. $15 \mathrm{a}-\mathrm{c}, 1933$.

Cushman and Parker, iden, Contr., vol. 12, p. 9, pl. 2, figs. 9, 10a, b, 1936. 
Jennings, Bull. Am. Paleontology, vol. 23, no. 78, p. 31, pl. 3, fig. 22, 1936.

Albritton and Phleger, Jour. Paleontology, vol. 11, p. 352, 1937.

Frizzell, idem, vol. 17, p. 350, pl. 57, fig. 3, 1943.

Cushman and Todd, Cushman Lab. Foram. Research Contr., vol. 19 , p. $66,1943$.

Cushman, idem, Contr., vol. 20, p. 93, pl. 14, figs. 12, 13, 1944.

Cushman and Deaderick, Jour. Paleontology, vọl. 18, p. 337, pl. 53, figs. 9, 10, 1944.

Cushman, U. S. Geol. Survey Prof. Paper 206, p. 125, pl. 52, figs. 11, 12, 1946.

Test small, elongate, fusiform, greatest width near the middle, tapering slightly toward either end, about $21 / 2$ times as long as broad in adult specimens, early triserial stage of 12 to 18 chambers, the biserial adult stage of 4 to 6 chambers, each part making about one-half the mass of the test; chambers distinct, subglobular, inflated; sutures very distinct, depressed; wall calcareous, coarsely perforate, in some of the thicker-walled specimens appearing almost reticulate; aperture in the early triserial portion oblique and comma-shaped, in the adult biserial stage broader, the portion at the basal edge of the chamber broad and the elongate axis nearly at right angles to the margin of the chamber, the whole aperture in the adult at the base of a distinct depression. Length $0.30 \mathrm{~mm}$., breadth $0.13 \mathrm{~mm}$., breadth of biserial portion $0.13 \mathrm{~mm}$., thickness $0.09 \mathrm{~mm}$.

The types of the species are from the Upper Cretaceous of Alberta, from Imperial Ribstone Well at a depth of 360-370 feet, Land Subdivision 6, Sec. 6, T. 45, R. 1 W, 4th meridian. The species occurs in the Upper Cretaceous of the United States in formations of Navarro, Taylor and Austin ages of the Gulf Coast area and in the Navesink marl of New Jersey. It is found also in the Bearpaw shale of Alberta, Canada, and is recorded from the Upper Cretaceous of Peru.

The microspheric form is more irregular and twisted than the megalospheric and is usually much less common. The young forms, which occur most commonly, do not show the biserial stage and appear like perfectly normal Bulimina. It differs from Neobulimina irregularis Cushman and Parker in being smaller, with more regular chambers that are less inflated and less globular in character.

\section{Neobulimina spinosa Cushman and Parker}

Plate 29, figure 31

Neobulimina spinosa Cushman and Parker, Cushman Lab. Foram. Research Contr., vol. 12, p. 9, pl. 2, figs. 11a, b, 1936.

Cushman, idem, Contr., vol. 20, p. 12, 1944 ; U. S. Geol. Survey Prof. Paper 206, p. 126, pl. 52, fig. 14, 1946.

Test small, about $1 \frac{1}{2}$ times as long as broad, widest portion of the test at a point about two-thirds of the dis- tance from the initial end, the initial end covered with short spines sometimes as much as one-third of the way up the test; chambers inflated, about 9 in the triserial po-tion, 2 in the biserial; sutures distinct, depressed; wall transparent or partially so, coarsely perforate; apertu-e loop-shaped, with a distinct, slightly flaring lip, nearly terminal. Length 0.16 to $0.25 \mathrm{~mm}$., diameter 0.10 to. $0.17 \mathrm{~mm}$.

The types are from the Upper Cretaceous Selma chal:$11 / 2$ miles west of Sardis, on the Sardis-Henderson road, Henderson County, Tenn. The species occurs in the Upper Cretaceous of the United States in formations of lower Navarro age (below the Nacatoch sand) and of Taylor age in the Gulf Coast Region.

\section{Neobulimina irregularis Cushman and Parker}

Plate 29, figure 30

Neobulimina irregularis Cushman and Parker, Cushman Lah. Foram. Research Contr., vol. 12, p. 9, pl. 2, figs. 8a, b, 1936. Loetterle, Nebraska Geol. Survey, ser. 2, Bull. 12, p. 38, pl. 5 , fig. 12, 1937.

Cushman, U. S. Geol. Survey Prof. Paper 206, p. 125, pl. 52 , fig. 13, 1946.

Test elongate, practically the same width throughout, except for the initial end which is tapering, about 5 tim's as long as broad in the microspheric form, shorter in the megalospheric, about 5 whorls in the triserial stage and 4 in the biserial stage of the adult form; chambers distinct, globular, irregular; sutures distinct, depressed; wall coarsely perforate; aperture broadly loop-shaped, extenting from the base of the last-formed chamber. Length 0.20 to $0.43 \mathrm{~mm}$., diameter 0.08 to $0.20 \mathrm{~mm}$.

The types are from the Upper Cretaceous, Ector tong re of the Austin chalk, about 2.3 miles south of Sherman, Grayson County, Texas. This species occurs in the Upp:r Cretaceous of the United States in the Austin and Eagle Ford formations of Texas and the Niobrara formation of Kansas, Nebraska and South Dakota. It occurs also in the Boyne Beds of Manitoba, Canada.

The species bears considerable resemblance, in form, to Verneuilina schizea Cushman and Alexander but is defnitely calcareous; with a Bulimina type of aperture and has the later chambers biserial. It has more globular, less regularly arranged chambers than Neobulimina canadensis Cushman and Wickenden and a larger biserial portion of the test.

\section{Genus GLOBOBULIMINA Cushman, 1927}

Globobutimina Cushman, Cushman Lab. Foram. Research Contr., vol. 3 , p. $67,1927$.

Galloway and Wissler, Jour. Paleontology, vol. 1, p. 73, 1927.

Cushman, Cushman Lab. Foram. Research Special Pub. 1, p. 248, 1928; idem, Special Pub. 4, p. 220, 1933.

Bulimina (part) of authors.

Genotype Globobulimina pacifica Cushman, 1927. 
Test spiral, triserial, early chambers tending to elongate, later chambers extending backwards, and in the adult becoming involute or nearly so, the last 3 chambers often making up the whole exterior; wall calcareous, finely perforate; aperture loop-shaped, with a tooth or plate and internal tube or trough. Cretaceous (?), Tertiary, Recent.

The early stages of this genus are similar to Bulimina, after which stages the chambers extend backward and, in the megalospheric specimens particularly, enclose the earlier ones. The microspheric specimens alone are often difficult to place.

\section{Globobulimina galliheri (Kleinpell) Cushman and Parker}

Plate 29, figure 38

Bulimina galliheri Kleinpell, Miocene stratigraphy of California, p. 253, pl. 17, figs. 2, 5, .Tulsa, 1938 .

Weaver, Washington Univ. [Seattle] Pub. in Geology, vol. 6, p. 23 (list); 1944.

Globobulimina cf. G. pacifica Cushman and Hobson, Cushman Lab. Foram. Research Contr., vol. 11, p. 62, pl. 9, figs. 3a, b, 1935.

Test large, inflated, pyriform, triserial, the last whorl making up almost the entire test; chambers distinct, inflated; sutures distinct, depressed; wall smooth, finely perforate; aperture terminal, comma-shaped, almost round with surrounding edge slightly raised. Length, up to $0.9 \mathrm{~mm}$.; breadth, $0.64 \mathrm{~mm}$.-Kleinpell.

The species was described from the Miocene Monterey shale of California at the type locality. Kleinpell also records it from the lower Modelo shale near Girard, California. We have some poorly preserved specimens from the latter locality that are adequate for general study. The species occurs also in the San Lorenzo and Gallaway formations of California.

Our specimens, though poor, show very plainly that the species should be placed in the genus Globobulimina. As Kleinpell says, a few early chambers are sometimes seen at the base of the test but with a few exceptions this is not true of the adult specimens. The form differs from G. pacifica Cushman in being broader at the base, with somewhat more inflated chambers, and with the first chamber of the last whorl broader and more rounded.

\section{Globobulimina globosa LeRoy}

Globobulimina globosa LeRoy, Colorado School of Mines Quart., vol. 39, no. 3, p. 27, pl. 1, fig. 3; pl. 5, fig. 13, 1944.

Test ovate globular, nearly as thick as high, initial end broadly rounded, apertural end somewhat pointed; chambers distinct, last three comprise seven-eighths of the test; aperture comma-shaped. Length $0.76 \mathrm{~mm}$., diameter $0.62 \mathrm{~mm}$.

As a general rule this species occurs in small numbers within the Telisa. In the Lower Palembang it is occasionally present.

It differs from Globobulimina pacifica Cushman by being less elongate and by showing a broader base.-LeRoy.

This species was described from Miocene beds of Central Sumatra.

\section{Globobulimina bulbosa LeRoy}

Globobulimina bulbosa LeRoy, Colorado School of Mines Quart., vol. 39, no. 3, p. 85 , pl. 2, fig. 1, 1944 .

Test medium, bulbous, maximum diameter in lower third, base rather flat; chambers distinct, somewhat inflated, strongly overlapping; sutures distinct, slightly depressed; wall smooth; aperture elliptical with distinct lip. Length $0.71 \mathrm{~mm}$., diameter (max.) $0.58 \mathrm{~mm}$.

This species differs from Globobulimina pacifica Cushman by being more bulbous and less elongate. The specios tends to be rather constant in character-LeRoy.

This species was described from Miocene beds of West Java.

\section{Globobulimina glabra Cushman and Parker, n.sp.}

Plate 29, figures 35,36

?Bulimina pyrula H. B. Brady (not D'Orbigny), Challenger Rept., Zoology, vol. 9, p. 399, pl. 50, figs. 7-10, 18:4

Test of medium size, ovate, the megalo pheric form being broader at the base than the microspheric, the earlier whorls often visible in the young forms; chambers distinct, the first-formed chamber of the last whorl not completely enclosed in front view so that it is vibible on both sides of the test, somewhat inflated; sut ares distinct, slightly depressed; wall thin, smooth, with medium sized perforations : aperture comma-shaped, with a lip and high curved tooth. Length 0.45 to $0.55 \mathrm{~mm}$., diameter 0.30 to $0.40 \mathrm{~mm}$.

Holotype (Cushman Coll. No. 35851) from the Pliocene Vatican clay, clay pit behind the Vatican, Rome, Italy.

The species figured by Brady from New Zealand, the $\mathrm{Ki}$ Islands, and the Azores seems to resemble this form. It is probable that the distribution given by Brady includes more than one species. We have not found any specimens outside of the type locality.

The species may be differentiated from Globobulimina pacifica Cushman by the fact that the last two chambers do not enclose the third at the base of the test, hence it is visible from both sides. In many specimens the suture of the last chamber makes a wide angle with the vertical axis instead of curving downward as in $G$. pacifica.

\section{Globobulimina pacifica Cushman}

Plate 29, figure 37

Globobulimina pacifica Cushman, Cushman Lab. Foram. Research - Contr., vol. 3, p. 67, pl. 14, fig. 12, 1927; Scripps Inst. Oceanography Bull., Tech. ser., vol. 1, p. 153, pl. 3, fig. 1, 1927.

Galloway and Wissler, Jour. Paleontology, vol 1, p. 74, pl. 11, fig. 18, 1927.

Cushman and Moyer, Cushman Lab. Foram. Pesearch Contr., vol. 6 , p. $57, ; 1930$. 
?Cushman, Stewart and Stewart, San Diego Soc. Nat. History Trans., vol. 6, p. 66, pl. 5, fig. 4, 1930.

Cushman and Ponton, Florida Geol. Survey Bull. 9, p. 79, pl. 12, fig. 2, 1932.

Cushman, Cushman Lab. Foram. Research Special Pub. 4, pl. 22, figs. 22a, b, 1933; idem, Special Pub. 5, pl. 27, figs. 16a, b, 1933; ?Bernice P. Bishop Mus. Bull. 119, p. 123, pl. 15, fig. 1, 1934.

Campbell, Jour. Entom. and Zool., vol. 27, no. 3, p. 41, text fig. 1, 1935.

Palmer, Soc. cubana hist. nat. Mem., vol. 14, p: 296, 1940.

LeRoy, Colorado School of Mines Quart., vol. 36, no. 1, p. 33, pl. 3, figs. 70, 71, 1941

Schenck and Childs, Stanford Univ, Pub., Univ. Ser., Geol. Sci., vol. 3, no. 2, p. 27 (list), 1942.

Beck, Jour. Paleóntology, vol. 17, p. 606, pl. 107, fig. 16, 1943.

Franklin, idem, vol. 18, p. 314, pl. 46, fig. 19, 1944.

LeRoy, Colorado School of Mines Quart., vol. 39, no. 3, p. 27 , pl. 5, fig. 12, 1944

Weaver, Washington Univ. [Seattle] Pub. in Geology, vol. 6, no. 1, p. 24 (list), 1944.

Test oval, broadest near the bottom and gradually narrowing toward the apertural end; chambers distinct, the first-formed chamber of the last whorl narrow, usually surrounded on both sides by the last 2 chambers in front view, with only 2 chambers showing in rear view, very slightly inflated; sutures distinct, slightly depressed; wall thin, finely perforate, smooth; aperture loop-shaped, with a slight border and a broad apertural tooth. Length up to $1.50 \mathrm{~mm}$., diameter $1.00 \mathrm{~mm}$.

The types are from the eastern Pacific, Lat. $17^{\circ} 18^{\prime}$ $\mathrm{N}$., Long. $102^{\circ} 22^{\prime} \mathrm{W}$., at 1,197 fathoms. The species is common along the west coast of North America. It has been recorded from the Miocene of Florida and California and questionably from the Pliocene of Humboldt County, California, and Vitilevu, Fiji. We have a single specimen from the Pliocene in Cañada de Aliso, Ventura County, California, 2.1 miles N. $74^{\circ}$ E. of La Crosse Junction, in gray siltstone, 280 feet stratigraphically above the base of the first Pico sandstone. The specimen figured by Kleinpell from the Miocene of Reliz Canyon, Monterey County, California (Miocene stratigraphy of California, p. 260, pl. 8, fig. 7, Tulsa, 1938), does not seem to represent this species and we have no material to verify it. The species has been recorded from Eocene age to Recent from widely separated areas and these records need further study.

\section{Globobulimina pacifica Cushman var. scalprata Cushman and Todd.}

Plate 30, figure 17

Globobulimina pacifica Cushman and Jarvis (not Cushman), Jour. Paleontology, vol. 4, p. 362, pl. 33, fig. 6, 1930.

Globobulimina pacifica Cushman var. scalprata Cushman and Todd, Cushman Lab. Foram. Research Special Pub. 15, p. 40, pl. 6, fig. 15, 1945.
Variety differing from the typical in the ornamentation of the test consisting of very fine, numerous, linear costae.

This variety is fairly common and varies somewhat in the re'ative prominence of the ornamentation.-Cushman and Todd.

The types are from the Miocene, half a mile east of Buff Bay, Jamaica.

\section{Globobulimina perversa (Cushman) Cushman and Parker}

Plate 29, figure 34

Bulimina pyrula D'Orbigny var. perversa Cushman, U. S. Nat. Mus. Bull. 100, vol. 4, p. 163, text figs. 2a-c, 1921.

Bulimina pyrula Cushman (not D'Orbigny), idem, p. 162, text figs. 1a-c, 1921.

Macfadyen, Egypt Geol. Survey, 1930, p. 54, pl. 1, figs. 16a, b, 1931.

Test large, pyriform, initial chambers sometimes showing very slightly at the base; chambers distinct, somewhit inflated, first-formed chamber of last whorl broad at the base; sutures distinct, the suture of the last-formed chamber in the portion that extends from the base up to the aperture very much depressed, so the chamber forms a very decided fold above it; aperture slightly curving, in a deep depression caused by the upward bulge of the chamber, with a thick, curving tooth. Length of figured specimen $1.25 \mathrm{~mm}$., diameter $0.95 \mathrm{~mm}$.

The types are from Recent material from Albatross sta. D5591, in 260 fathoms, Sibuko Bay, Borneo. The species occurs in the Miocene of Baden, Vienna Basin, Austria, the Pliocene of Castel Arquato, Italy, and the Recent deposits of the Philippine region.

This is one of the largest known species of Glotobulimina and may be easily differentiated by the $\operatorname{dee}^{-1} \mathbf{y}$ depressed suture of the last chamber.

\section{Globobulimina caribbea Cushman and Bermúdez}

Globobulimina caribbea Cushman and Bermúdez, Cushman Lab. Foram. Research Contr., vol. 21, p. 73, pl. 12, figs. 1-3, 1945.

Test very large for the genus, slightly pyriform, early chanbers slightly visible at the base, sides convex and tapering gradually toward the apertural end; chambers distinct, somewl at inflated, the last two making up a large portion of the surface of the test; sutures distinct, depressed, especially in the last-formed whorl; wall smooth except at the base where in some specimens there is a slight tendency to become spinose; aperture elongate, with a slight lip at one side and a somewhat thickened, curving tooth projecting distinctly above the general outline of the test. Length of adult specimens 1.90-2.45 mm.; diameter 1.13-1.57 mm. -Cushman and Bermude.

This species was described from off southern Cula, Atlantis station 3345 , lat. $21^{\circ} 08^{\prime} \mathrm{N}$., long. $79^{\circ} 56^{\prime} 30^{\prime \prime}$ W., 690-700 fathoms.

This species, the largest of the genus so far known, can be distinguished from Globobulimina perversa (Cush- 
man) by its larger size, slightly more elongate form, and the tendency to spinosity at the base.

\section{Globobulimina sobrina Galloway and Morrey}

Globobulimina sobrina Galloway and Morrey, Jour. Paleontology, vol. 5 , p. 352 , pl. 40 , figs. $12 \mathrm{a}, \mathrm{b}, 1931$.

Test robust, ovate, broadest near the base, oval in cross section; apical end broadly rounded; chambers embracing, only three visible; sutures distinct, slightly depressed; wall smooth, very finely perforate; aperture virguline, with vertical tooth, near the periphery. Length $0.45 \mathrm{~mm}$.

The Tabasco specimens are megaspheric and have a more rounded initial end than $B$. pyrula (D'Orbigny), the apertural end is less pointed, and it is not subtriangular in cross section. The form is shorter than G. pacifica Cushman-Galloway and Morrey.

The types are from the "Cretaceous", near Puenta Piedra, on the Rio Puscatan, 19 kilometers south of Macuspana, Tabasco, Mexico. We have no material referable to the species. 


\section{SUPPLEMENT}

The following species and varieties have become available since this work was completed:

Bulimina abatissae Selli, Annali Mus. Geol. Bologna, 2d ser., vol. 17, 1943-44, p. 58, pl. 1, fig. 15, 1944. Eocene, Italy.

B. bortonica Finlay, Royal Soc. New Zealand Trans., vol. 69, p. 100 , pl. 12, figs. 25, 26, 1939. Middle Eocene, New Zealand.

B. bremneri Finlay, idem, vol. 69, p. 455, pl. 64, figs. 84-86, 1940. Lower to middle Miocene, New Zealand.

B. byramensis Cushman and Todd, Cushman Lab. Foram. Research Contr., vol. 22, p. 91, pl. 15, figs. 25, 26, 1946. Oligocene, Byram marl, Mississippi.

B. forticosta Finlay, Royal Soc. New Zealand Trans., vol. 69, p. 455, pl. 64, figs. 77-81, 1940. Upper middle Eocene to middle Oligocene, New Zealand.

B. mapiria Finlay, idem, vol. 69, p. 454, pl. 64, fig. 72, 1940. Uppermost Miocene, New Zealand.

B. miolaevis Finlay, idem, vol. 69, p. 454, pl. 64, figs. 70, 71, 1940. Lower Miocene, New Zealand.

B. pahiensis Finlay, idem, vol. 69 , p. 455 , pl. 64 , figs. 87,88 , 1940. Upper middle Eocene, New Zealand.

B. petroleana Cushman and Hedberg var. spinca Cushman and Renz, Cushman Lab. Foram. Research Special Pub. 18, p. 37, pl. 6, fig. 13, 1946. Upper Cretaceous, Trinidad.

B. rakauroana Finlay, Royal Soc. New Zealand Trans., vol. 69, p. 454, pl. 64, figs. 75, 76, 1940. Upper Cretaceous (Santonian), New Zealand.

. B. scobinata Finlay, idem, vol. 69, p. 455 , pl. 64, figs. 82, 83, 1940 Middle to upper Oligocene, New Zealand.

B. sculptilis Cushman var. paucicostata Cushman and Ellisor, Jour. Paleontology, vol. 19 , p. 562 , pl. 75 , fig. 15,1945 . Middle Oligocene, Anahuac formation, Texas.

B. senta Finlay, Royal Soc. New Zealand Trans., vol. 69, p. 454, p1. 64, figs. 73, 74, 1940. Lower to upper Miocene, New Zealand.
B. simaensis Makiyama and Nakagawa, Geol. Soc. Japan Jour., vol. 48 , no. 572 , p. 241,1941 . Pleistocene, Japan.

B. stokesi Cushman and Renz, Cushman Lab. Foram. Research Special Pub. 18, p. 37, pl. 6, fig. 14, 1946. Upper Cretace nus, Trinidad.

B. trigonalis ten Dam, Geol. Stichting Mededeelingen, ser.' $\mathrm{C}-\mathrm{V}$, no. 3 , p. 112 , pl. 3 , figs. $16,17,1944$. Paleocene, Netherlands.

B. truncana Gümbel var. aksuatica Morozova, Soc. naturalistes Moscou, Bull., new ser., vol. 47, sect. geol., vol. 17, p. 74, pl. 3, fig. 3, 1939. Eocene, Russia.

B. truncanella Finlay, Royal Soc. New Zealand Trans., vol. 69, p. 455, pl. 64, figs. 89-91, 1940. Middle Eocene to urper Miocene, New Zealand.

B. (Desinobulimina) suteri Cushman and Renz, Cushman I.ab. Foram. Research Special Pub. 18, p. 38, pl. 6, fig. 15, 1946. Upper Cretaceous, Trinidad.

Buliminella beaumonti Cushman and Renz, idem, Special Pub. 18, p. 36, pl. 6, fig. 7, 1946. Upper Cretaceous, Trinidad.

B. browmi Finlay, Royal Soc. New Zealand Trans., vol. 69, p. 321, pl. 27, figs. 85, 86, 1939. Lower middle Eocene, New Zealand.

B. sauria Finlay, idem, vol. 69 , p. 321, pl. 27, figs. 87, 97, 98, 1939. Upper Cretaceous (Santonian), New Zealand.

Globobulimina hannai Cushman and Ellisor, Jour. Paleontology, vol. 19 , p. 562, pl. 76, fig. 1, 1945. Middle Oligocene, Anahuac formation, Texas.

Robertina lornensis Finlay, Royal Soc. New Zealand Trans., vol. 69 , p. 114 , pl. 12 , figs. $27,28,1939$. Lower Oligocene, N'ew Zealand.

R. moodysensis Cushman and Todd, Cushman Lab. Foram. Research Contr., vol. 21, p. 94, pl. 15, figs. 10, 11, 1945 Eocene, Moodys marl member of Jackson formation, Mississippi.

Turrilina brevispira ten Dam, Geol. Stichting Mededeelingen, ser. C-V, no. 3, p. 110, pl. 3, fig. 14, 1944. Eocene (Ypresian), Netherlands. 


\section{PLATES 15-30}




\section{PLATE 15}

Figure 1. Terebralina regularis Terquem. (After Terquem.) Jurassic, France. $\times 50$.

Figure 2. Turriline andreaei Cushman. (After Andreae.) Oligocene, France. $\times 70$. $a$, Front view; $b$, rear view.

FIGURE 3. T. alsatica Andreae. (After Andreae.) Oligocene, France. $\times 70$. $a$, Front view; $b$, rear view; $c$, apertural view.

Figure 4. Buliminella obtusa (D’Orbigny) Cushman and Parker. Cretaceous, Bougival, France. $\times 50$. $a$, Front vi:w; $b$, rear view; c, apertural view.

Frgure 5. B. imbricata (Reuss) Cushman and Parker. Cretaceous, Lemberg, Galicia. $\times$ 115. $a$, Front view; $b$, rear view; $c$, apertural view.

FIgURE 6. B. laevis (Beissel) Cushman and Parker. Cretaceous, Friedrichsberg, near Aachen, Germany. $\times 50 . a$, Front view; $b$, rear view; $c$, apertural view.

Figure 7. B. pusilla (Brotzen) Cushman and Parker. (After Brotzen.) Cretaceous, Sweden. $\times 70$.

Figure 8. B. carseyae Plummer. Cretaceous, Taylor marl, southeast of Del Valle, Texas. $\times 75$, $a$, Front view; $b$, rear view; $c$, apertural view.

Frgure 9. B. carseyae Plummer var. plana Cushman and Parker. Cretaceous, Navarro group, 6 miles east'of Castroville, Texas. $\times$ 75. $a$, Front view; $b$, rear view; $c$, apertural view.

Figures 10, 11. B. cushmani Sandidge. Cretaceous. 10, Kemp clay, 1 mile west-southwest of Noack, Texas. 11, Gotzreuther Graben, near Siegsdorf, Bavaria. $\times 85$.

Figure 12. B. vitrea Cushman and Parker. Cretaceous, Selma chalk, 2 miles west of Guntown, Mississippi. $\times 75$. a, Front view; $b$, rear view; $c$; apertural view.

FIgure 13. B. fabilis Cushman and Parker. Cretaceous, Taylor marl, 14.2 miles east of Hillsboro, Texas. $\times 85 . a$, Front view; $b$, rear view; $c$, apertural view.

Frgures 14,15. B. colonensis Cushman and Hedberg. (After Cushman and Hedberg.) Cretaceous, Venezuela. $\times 75.14 a$, Front view; $b$, apertural view.

FIguRe 16. B. irregularis (Terquem) Cushman and Parker. Eocene, France. $\times 90$. Front view; $b$, rear view; $c$, apertural view.

Figure 17. B. intorta (Terquem) Cushman and Parker. Eocene, France. $\times 90$. $a$, Front view; $b$, rear view; $c$. apertural view.

Figures 18-21. B. turbinata (Terquem) Cushman and Parker. Eocene, France. a, Front view; $b$, rear view; $c$, apertural view. 18, $19, \times 100.20,21, \times 95$, abnormal specimens. 


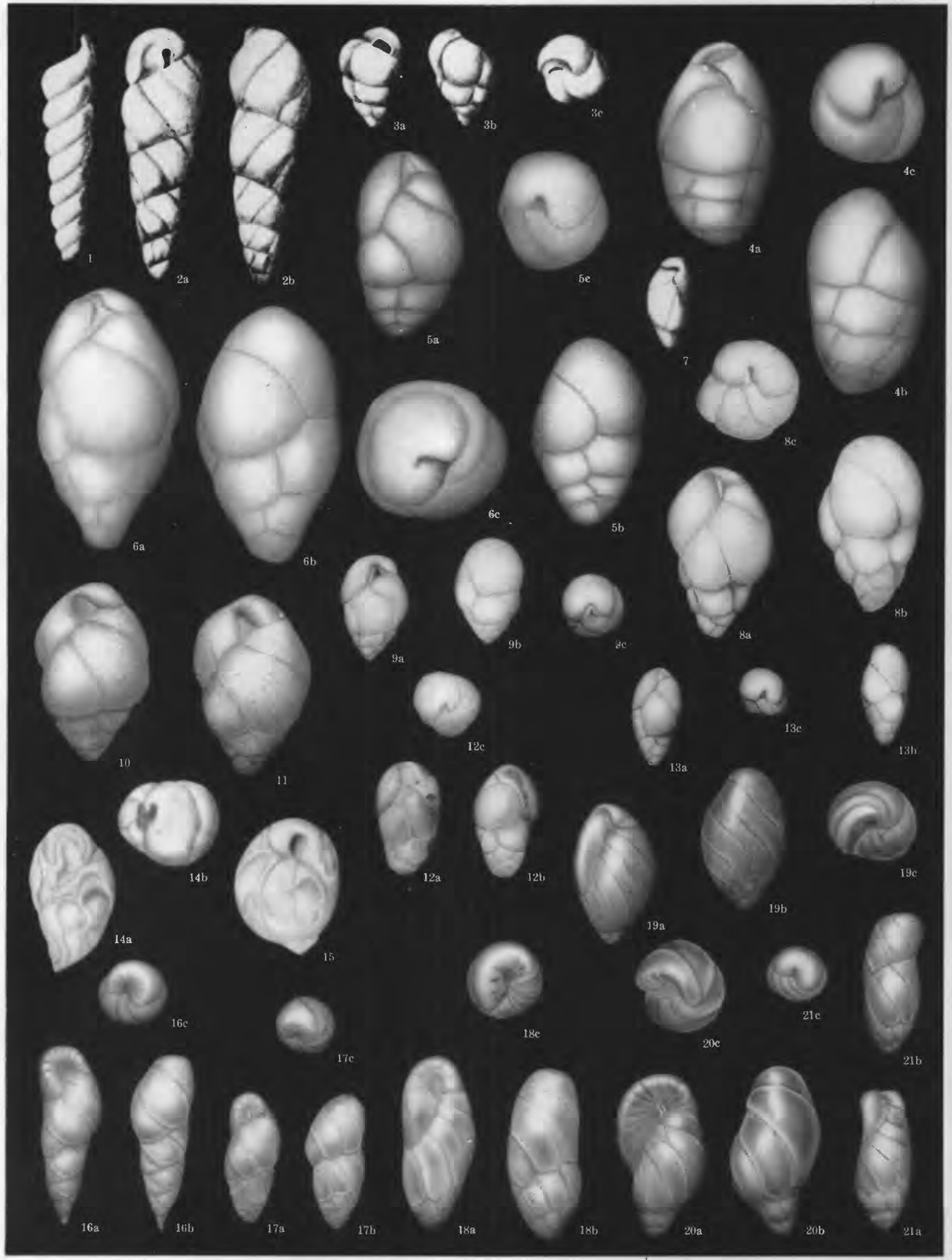

TEREBRALINA, TURRILINA, AND BULIMINELLA 


\section{PLATE 16}

Figure 1. Buliminella flexa (Terquem) Cushman and Parker. Eocene, France. $\times 95$.

Figure 2. B. conulus (Terquem) Cushman and Parker. (After Terquem.) Eocene, France. $\times 30$.

Figure 3. B. pupa (Terquem) Cusiman and Parker. Eocene, France. $\times 95 . a$, Front view; $b$, rear view; $c$, apertural view.

Figures 4, 9. B. semi-nuda (Terquem) Cushman and Parker. Eocene, France. $\times$ 95. $a$, Front view; $b$, rear view; $c$, apertural view.

Figures 5, 6. B. pulchra (Terquem) Cushman and Parker. Eocene, France. $\times 70$. $a$, Front view; $b$, rear view; $c$, apertural view.

Figure 7. B. alabamensis Cushman. (After Cushman.) Eocene, Water Valley, Alabama. $\times 70$. Front view; $b$, side view.

FIGURE 8. B. robertsi (Howe and Ellis) Martin. Eocene, 3 miles north of Branson, Texas. $\times 110$.

Figure 10. B. basistriata Cushman and Jarvis. Eocene, Trinidad. $\times 85$.

Figure 11. B. basistriata Cushman and Jarvis var. nuda Howe and Wallace. Eocene, Danville Landing, Louisiana. $\times 85$.

Figure 12. B. grata Parker and Bermúdez. (After Parker and Bermúdez.) Eocene, Cuba. $\times 65$. $a$, Front view; $b$, rear view; $c$, apertural view.

Figure 13. B. grata Parker and Bernúdez var. spinosa Parker and Bermúdez. (After Parker and Bermúdez.) Eocene, Cuba. $\times 55$. $a$, Front view; $b$, rear view; $c$, apertural view.

Figukes 14, 15. B. westraliensis Parr. (After Parr.) Eocene, Australia. $\times 60$.

Frgures 16,17. B. obtusata Cushman. Oligocene, Byram, Mississippi. $\times 95.17 a$, Front view; $b$, rear view.

Figukes 18, 19. B. choctawensis Cushman and McGlamery. (After Cushman and McGlamery.) Oligocene, Alabama. $\times 85$.

Figure 20. B. madagascariensis (D'Orbigny) var. spicata Cushman and Parker. Oligocene, Australia. $\times 65 . a$, Front view; $b$, rear view.

Figure 21. B. subfusiformis Cushman. Miocene, California. $\times 85$.

Figure 22. B. curta Cushman. Miocene, California. $\times 85$.

Figure 23. B. curta Cushman var. basispinata R. E. and K. C. Stewart. (After R. E. and K. C. Stewart.) Pliocene, California. $\times 65$.

Figure 24. B. brevior Cushman. Miocene, California. $\times 65$. 


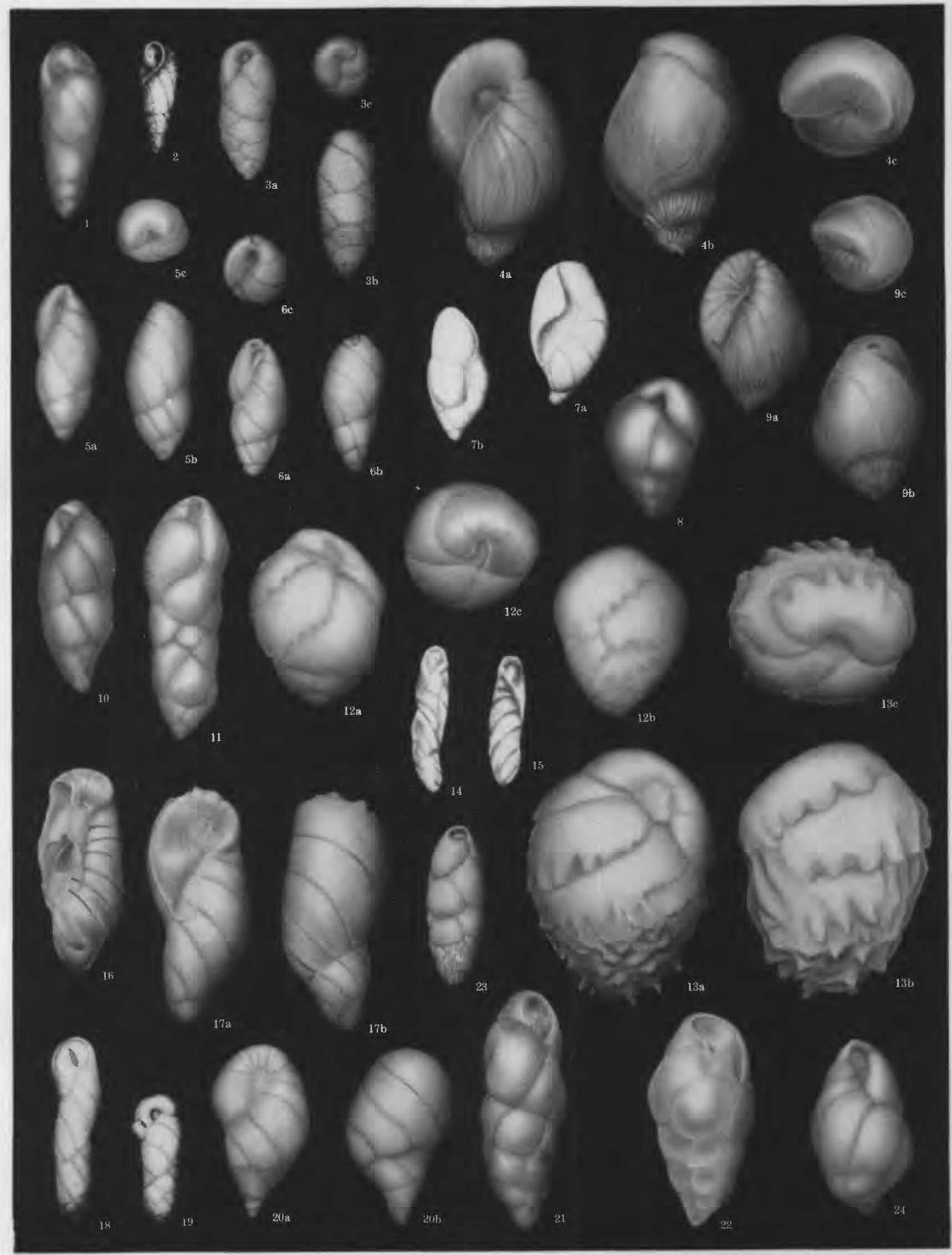




\section{PLATE 17}

Figure 1. Buliminella californica Cushman. Miocene, California. $\times 85$.

Figure 2. B. glomerata Cushman and Parker, n. name (After Tolmachoff.) Miocene, Colombia. $\times 35$.

Figures 3, 4. B. dubia Barbat and Johnson. (After Barbat and Johnson.) Miocene, California. $\times 55$.

Figure 5. B. henryana Cushman and Kleinpell. (After Cushman and Kleinpell.) Miocene, California. $\times 65$. $a$, Front view; $b$, apertural view.

Figure 6. B. bassendorfensis Cushman and Parker. Miocene, Oregon. $\times 65 . a$, Front view; $b$, rear view.

Figure 7. B. semihispida Kleinpell. (After Kleinpell.) Miocene, California. $\times 35, a$, Front view; $b$, rear view; $c$, apertural view.

Figures 8,9. B. multicamera Cushman and Parker. Pliocene, Italy. $\times 70$. $a$, Front view; $b$, rear view.

Figures 10-12. B. elegantissima (D'Orbigny) Cushman. Recent. $\times 100$. 10, Off Peru. 11, 12, Off Brazil.

Figure 13. B. elegantissina (D’Orbigny) Cushman var. cochlea Wiesner. (After Wiesner.) Recent, Antarctic. $\times 25$.

Figure 14. B. elegans (D'Orbigny) Cushman and Parker. Drawn from D'Orbigny's model.

Figures 15-17. B. madagascaricnsis (D’Orbigny) Cushman and Parker. 15, 16, Oligocene, Australia. $\times 65$. $a$, Front view; $b$, rear view. 17, Recent, New Zealand. $\times 85$.

Figures 18, 19. B. spinigera Cushman. Recent, Atlantic. $\times 50$.

Figures 20,21, B. milletti Cushman. (After Cushman.) Recent, Fiji, $\times 65 . a$, Front view; $b$, apertural view.

Figure 22. B. parallela Cushman and Parker. Recent, off Brazil. $\times 135$. $a$, Front view; $b$, rear view; $c$, apertural view.

Figures 23,24. Buliminoides williamsoniana (H. B. Brady) Cushman. (After H. B. Brady.) Recent, Pacific. $\times 50.23 a$, Front view; $23 b$, side view. $24 a$, Front view; $24 b$, apertural view.

Figures 25, 26. Ungulatella pacifica Cushman. (After Cushman.) Recent, Pacific. $\times 40$. $a$, Front view; $b$, side view; $c$, apertural view.

Figure 27. U. peregrina Cushman. (After Cushman.) Recent, Pacific. $\times 105 . a$, Front view; $b$, side view; $c$, apertural view.

Figures 28, 29. U. conoides Cushman. (After Cushman.) Recent, Pacific. $\times 105 . a$, Front view; $b$, side view, $c$, apertural view.

Figure 30. U. capistra Cushman. (After Cushman.) Recent, Pacific. $\times 80 . a$, Front view; $b$, side view, $c$, apertural view.

Figure 31. Buliminella punctata (D'Orbigny) Cushman and Parker. (After Fornasini.) Recent, Mediterranean. $a$. Front view; $b$, rear view. 


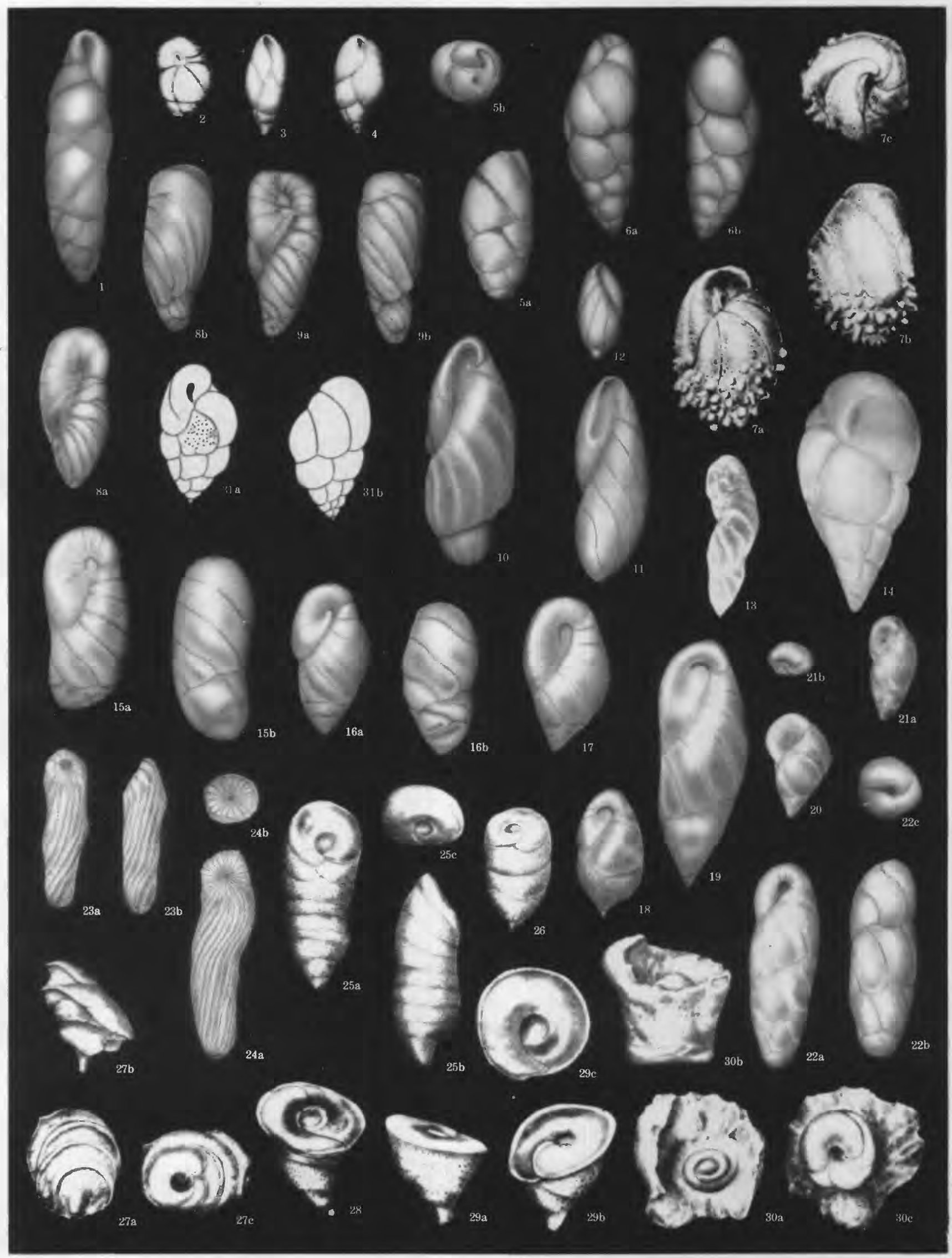




\section{PLATE 18}

Figure 1. Robertina wilcoxensis Cushman and Ponton. Eocene, Wilcox, 1 mile north of Ozark, Alabama. $\times 100 . a$, Front view; $b$, rear view.

Figure 2. $R$. mcguirti Howe. (After Howe.) Eocene, Cook Mountain, St. Maurice, Louisiana. $a$, Front view; $b$, rear view. $\times 80$.

Figure 3. R. plummerae Cushman and Parker. Eocene, Claiborne, Bastrop Co., Texas. $\times 70$. $a$, Front view; $b$, rear view.

Figure 4. $R$. ovigera (Terquem) Cushman and Parker. Eocene, France. $\times 85 . a$, Front view; $b$, rear view.

Frgure 5. $R$. germanica Cushman and Parker. Oligocene, Germany. $\times 40 . a$, Front view; $b$, rear view.

Figure 6. R. angusta (Cushman) Cushman and Parker. Oligocene, Mississippi. $\times 55$. $a$, Front view; $b$, rear view.

Figure 7. $R$, declivis (Reuss) Cushman and Parker. Uligocene, Germany. $\times 85 . a$, Front view; $b$, rear view.

Figures 8,22 . $R$. austriaca Reuss. Miocene, Austria. $\times 65 . a$, Front view; $b$, rear view:

Figures 9, 10. R. imperairix (Karrer) Cushman and Parker. Miocene, Hungary. $\times 65$. $a$, Front view; $b$, rear view.

Figure 11. $R$. californica Cushman and Parker. Pliocene, California. $\times 55$. $a$, Front view; $b$, rear view.

Figure 12. $R$. arctica D'Orbigny. Recent, off Greenland. $\times 65 . a$, Front view; $b$, rear view.

Figure 13. R. subcylindrica (H. B. Brady) Cushman and Parker. Recent, off Brazil. $\times$ 65. $a$, Front view; $b$, rear view.

Figure 14. $R$. charlottensis (Cushman) Cushman, Recent, Queen Charlotte Sound. $\times$ 55. $a$, Front view; $b$, rear view.

Figure 15. R. translucens Cushman and Parker. Recent, off Ireland. $\times 85, a$, Front view; $b$, rear view.

Figure 16. $R$. bradyi Cushman and Parker. Recent, Caribbean Sea. $\times 85$. $a$, Front view; $b$, rear view.

Figure 17. $R$. parkeri (Terquem and Terquem) Cushman and Parker. (After Terquem and Terquem.) Recent, oft Norway.

Figure 18. $R$. oceanica Cushman and Parker, n. sp. Recent, off New Zealand. Holotype. $\times 35$.

Frgure 19. R. subteres (H. B. Brady) Cushman and Parker. Recent, off Ireland. $\times 85 . a$, Front view; $b$, rear view.

Frgure 20. Pseudobulimina chapmani (Heron-Allen and Earland) Earland. (After Heron-Allen and Earland.) Recent, Antarctic. $\times 50$. $a$, Dorsal view; $b$, ventral view; $c$, apertural view.

Frgure 21. P. glaessneri Howe and Roberts. (After Howe.) Eocene, Cook Mountain, St. Maurice, Louisiana. $\times 55 . a$, Dorsal view ; $b$, ventral view; $c$, apertural view. 


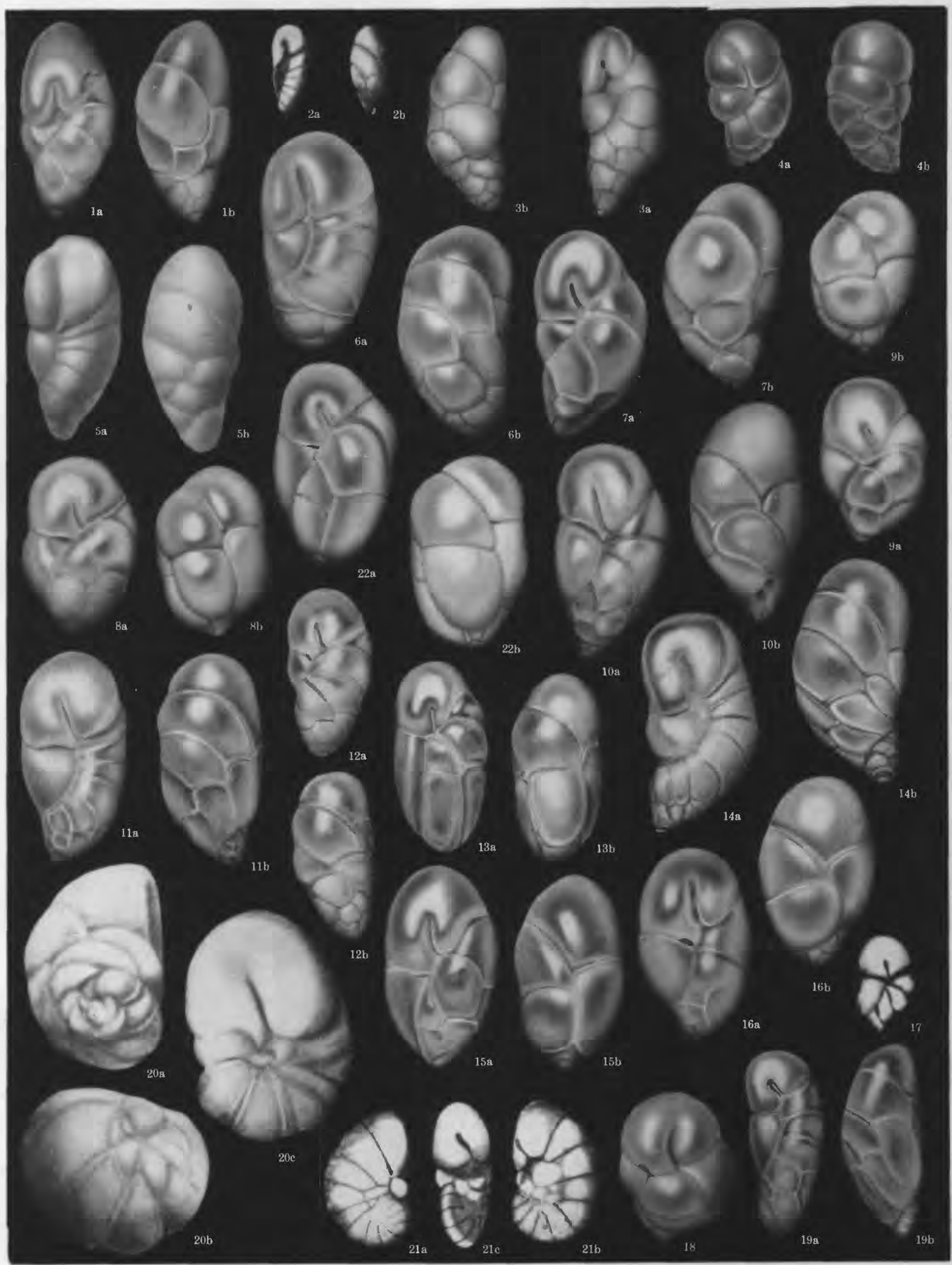




\section{PLATE 19}

Figure 1. Bulimina antiqua Terquem and Berthelin. (After Terquem and Berthelin.) Jurassic, France. $\times 80$.

Figures 2,3. B. incurva Terquem. (After Terquem.) Jurassic, France. $\times 50$.

Figure 4. B. intricata Terquem. (After Terquem.) Jurassic, Franze. $\times 50$.

FigrjRes 5,6. B. muricata Terquem. (After Terquem.) Jurassic, France. $\times 55$.

Figures 7-9. B. prima Terquem. (After Terquem.) Jurassic, France. Fig. 7, $\times$ 50. Figs. 8, 9, $\times 40$.

Figure 10. B. nannina Tappan. (After Tappan.) Lower Cretaceous, Texas. $\times 60$. $a$, Front view; $b$, rear view.

Figure 11. B. murchisoniana D'Orbigny. Cretaceous, Graveșend, England. $\times 35$, Front view; $b$, apertural view.

Figures 12-15. B. intermedia Reuss. 12, 13, Cretaceous, Kosstitz, Bohemia. 14, 15, Cretaceous, Luschitz, Bohemia. Autotypes in Reuss collection at Vienna. $\times 35 . a$ Front view; $b$, apertural view.

Figure 16. B. acuta Reuss. (After Reuss.) Cretaceous, Lemberg, Galicia.

Figure 17. B. parza Franke. Cretaceous, Mersch, near Hamm, Germany. $\times 100$.

Figure 18. B. exigua Cushman and Parker. Cretaceous, Brownstown marl, Texas. $\times 65$. $a$, Front view; $b$, apertural view.

Figures 19,20. B. kickapoocnsis Cole. Cretaceous, 19, Upper part of Taylor marl, Red River Co., Texas, Holutype, negalospheric. $\times$ 55. $a$, Front view; $b$, apertural vicw. 20, Upper part of Taylor marl, Navarro Co., Texas. Paratype, microsplieric. $\times 55$.

Figures 21,22. B. kickapoo'usis Cole var. pinqua Cushman and Parker, Cretaceous, Corsicana marl, Limestone Co., Texas. 21, Holotype. 22 , Paratype. $\times 40, a$, Front view; $b$, apertural view.

Figures 23, 24. B. taylorenis Cushman and Parker. Cretaceous. 23, Upper part of Taylor marl, Red River Co., Texas. a, Front view; $b$, apertural view. $\times 60.24$, Upper part of Taylor marl, Bexar Cu., Texas, $\times 70$.

Figuke 25. B. triangularis Cuslman and Parker. Cretaceous, upper part of Taylor marl, Collin Co., Texas. $\times 60$. a, Front view; $b$, apertural view.

Figure 26. B. rudila Cusliman and l'arker. Cretaceous, upper part of Taylor marl, Red River Co., Texas. $\times 70$. a, Front view; $b$, apertural view.

Figure. 27. B. pectinata Cushman and Parker. Cretaceous, lower part of Taylor marl, Delta Co, Texas. $\times 75 . a$, Front view; $b$, rear view ; $c$, apertural view.

Figukes 28-30. R. usperu Cushman and P'arker. (retaceous. 28, 29. Corsicana marl, Navarro Co., Texas. $\times 40$. 30, Upper part of Taylor marl, Kaufman Co., Texas.

Figure 31. B. reusiri Morrow. Cretaceous, Lemberg, Galicia. $\times 90$. 


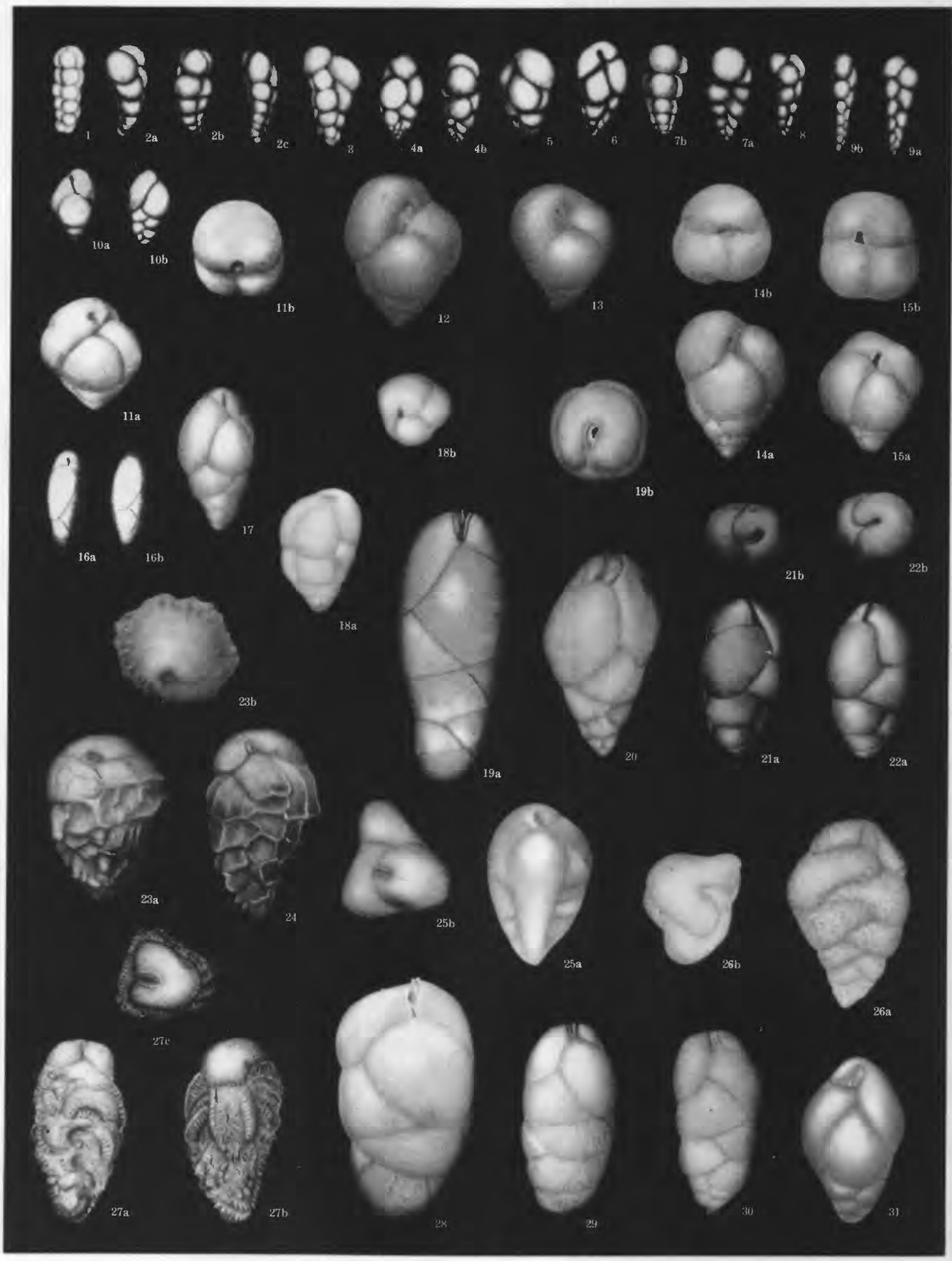

BUIIMINA 


\section{PLATE 20}

FIGUres 1-5. Bulimina reussi Morrow. Cretaceous. 1, Wolfe City sand member of Taylor marl, Collin Co., Texas. 2, Austin chalk, Collin Co., Texas. 3, 4, White Chalk, Antigua, B. W. I. 5, Saratoga chalk, Howard Co., Arkansas. 1, 2, $\times 90.3-5, \times 55$. $a$, Front view; $b$, apertural view.

Figure 6. B. reussi Morrow var. navarroensis Cushman and Parker. Cretaceous, Corsicana marl, Caldwell Co., Texas. $\times 90$. Front view; $b$, apertural view.

Figures 7,8. B. prolixa Cushman and Parker. Cretaceous, Ripley, McNairy Co., Tennessee. 7a, Front view; $b$, apertural view. $\times 90$. $8 a$, Front view; $b$, side view. $\times 55$.

Figures 9, 10. B. arkadelphiana Cushman and Parker. Cretaceous, Arkadelphia marl, Hempstead Co., Arkansas. $\times 65 . a$, Front view; $b$, apertural view.

Figure 11. B. velascoensis (Cushman) White. Cretáceous. Mexico. $\times 65$.

Figures 12, 13. B. incisa Cushman. Cretaceous, Mexico. $12, \times 55.13, \times 80$.

Figure 14. B. tortilis Reuss. (After Reuss.) Cretaceous, New Jersey. $a$, Front view ; $b$, rear view.

Figure 15. B. trihedra Cushman. Cretaceous, Mexico. $\times 55, a$, Front view; $b$, rear view.

Figures 16, 17. B. trinitatensis Cushman and Jarvis. Cretaceous. Trinidad. $\times 50 . a$, Front view; $b$, apertural view.

Figure 18. B. globocapitata Chapman. (After Chapman.) Eocene, New Zealand. $\times 25$, Front view; $b$, rear view.

Figure 19. B. limbata White. Cretaceous, Mexico. $\times 55 . a$, Front view; $b$, apertural view.

Figure 20. B. mendezensis White. Cretaceous, Mexico. $\times 90 . a$, Front view; $b$, rear view.

Figure 21. B. spinata Cushman and Campbell. Cretaceous, California. $\times 65$.

Figures 22, 23. B. callahani Galloway and Morrey. Cretaceous, Mexico. 22, (After Galloway and Morrey) $\times 45.23, \times 50$.

Figure 24. B. tabascoensis Galloway and Morrey. (After Galloway and Morréy.) Cretaceous, Mexico. $\times 45$.

Figure 25. B. ezoensis Yokoyama. (After Yokoyama.) Cretaceous(?), Japan. $\times 20 . a$, Front view; $b$, rear view; $c$, apertural view.

Figures 26-28. B. schwageri Yokoyama. (After Yokoyama.) Cretaceous(?), Japan. $\times$ 70. $a$, Front view; $b$, rear view.

Figure 29. B. baccata Yokoyama. (After Yokoyama.) Cretaceous(?), Japan. $\times 70$. Front view; $b$, rear view; $c$, apertural view.

Figure 30. B. capitata Yokoyama. (After Yokoyama.) Cretaceous(?), Japan. $\times 70$. Front view; $b$, rear view; $c$, apertural view.

Figure 31. B. polymorphinoides Yokoyama. (After Yokoyama.) Cretaceous(?), Japan. $\times 70$, $a$, Front view; $b$, rear view; $c$, side view. 


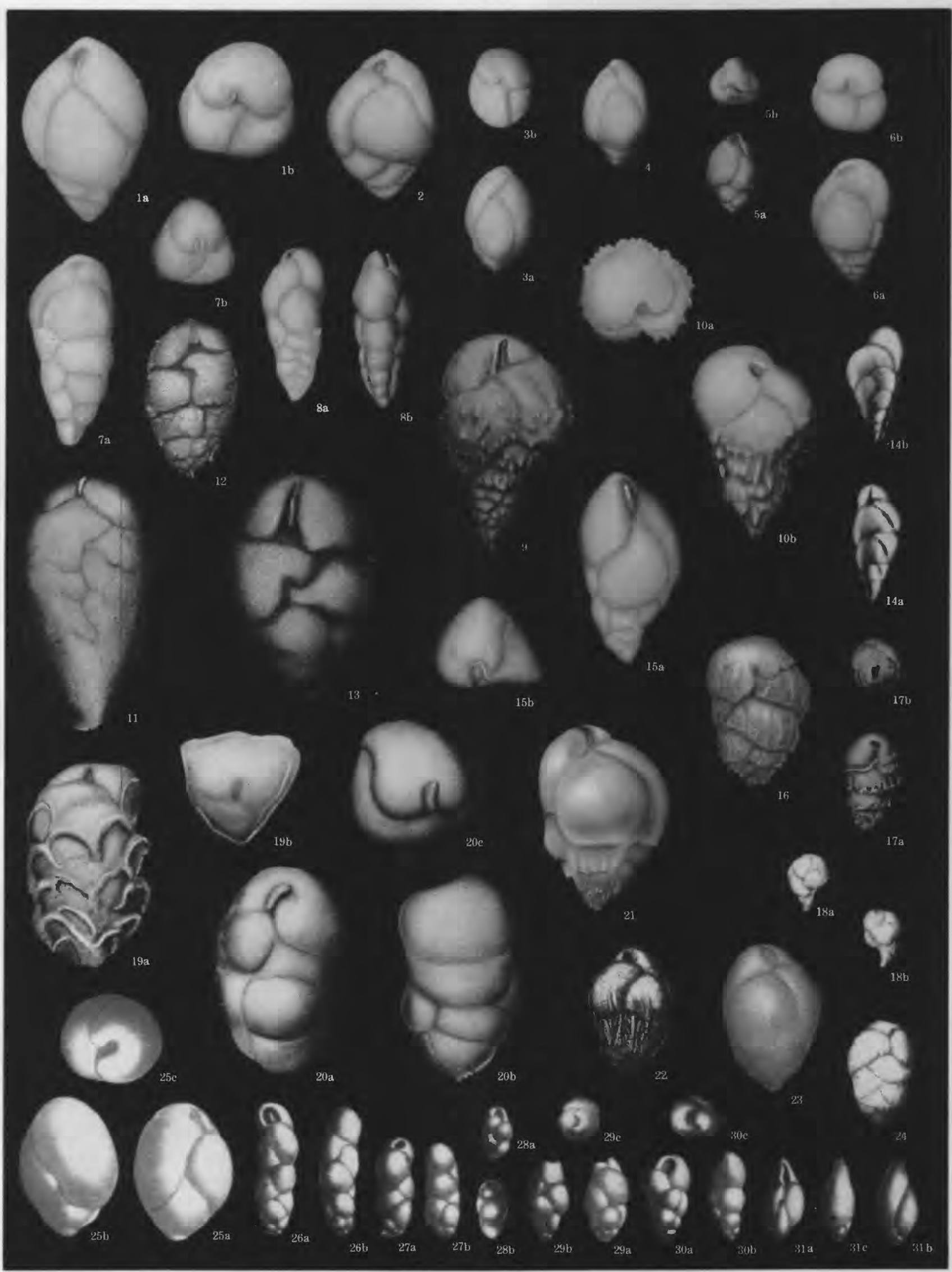




\section{PLATE 21}

Figures 1,2. Bulimina aspera Cushman and Parker. Cretaceous, $\cdot$ Taylor marl, Caldwell Co., Texas. $\times 80$.

Figure 3. B. brevis D'Orbigny. Cretaceous, Gravesend, England. $\times 35$.

Figure 4. B. minuta (Marsson) Cushman. Cretaceous, Rügen, Germany. $\times 50$.

Frgure 5. Buliminella pusilla (Brotzen) Cushman and Parker. Cretaceous, Eriksdal, Sweden. $\times 125$.

Figure 6. Bulimina tabascoensis Galloway and Morrey. Cretaceous, Mexico. $\times 65$.

Figures 7,8. B. truncana Gümbel. Eocene, Budapest, Hungary. $\times 85 . a$, Front view; $b$, rear view; $c$, apertural view.

Figure 9. B. simplex Terquem. Eocene, France. $\times 65 . a$, Front view; $b$, rear view; $c$, apertural view.

Figures 10,11. B. longiscata Terquem. (After Terquem.) Eocene, France. 10, $\times 12.11, \times 28$.

Figure 12. B. obscura Terquem. (After Terquem.) Eocene, France. $\times 25 . a$, Front view; $b$, apertural view.

Figure 13. B. oviformis Terquem. (After Terquem.) Eocene, France. $\times 25$.

Figure 14. B. splendens Terquem. (After Terquem.) Eocene, France. $\times 35$.

Figure 15. B. glanduiformis Terquem. (After Terquem.) Eocene, France. $\times 28$.

Figure 16. B. decorata Terquem. (After Terquem.) Eocene, France. $\times 28$.

Frgure 17. B. tenuistriata Terquem. Eocene, France. $\times 90 . a$, Front view; $b$, rear view; $c$, apertural view.

Figure 18. B. trigona Terquem. Eocene, France. $\times 50$. $a$, Front view; $b$, rear view; $c$, apertural view.

Figures 19, 20. B. selseyensis Heron-Allen and Earland. (After Heron-Allen and Earland.) Eocene, Selsey, England. $\times 70$.

Figures 21,22. B. versa Cushman and Parker. Eocene, France. $\times 75$. $a$, Front view; $b$, rear view; $c$, apertural view.

Figure 23. B. eccentrica Cushman and Parker. Eocene, France. $\times 45$. $a$, Front view; $b$, rear view; $c$, apertural view.

Figures 24, 25. B. arkadelphiana Cushman and Parker var. midwayensis Cushman and Parker. Paleocene, Midway, Texas. $\times 105$. $a$, Front view; $b$, rear view; $c$, apertural view.

Figure 26. B. thanetensis Cushman and Parker, n. sp. Eocene. Thanet Beds, Pegwell Bay, England. Holotype. $\times 85$.

Figure 27. B. cacumenata Cuslman and Parkęr. Paleocene, Midway, Bastrop Co., Texas. $\times 125$. $a$, Front view; $b$, rear view; $C$, apertural view.

Figures 28,29. B. semicostata Nuttall. Eocene. 28, Cuba. (After Parker and Bermúdez.) $\times$ 65. $a$, Front view; $b$, rear view; $c$, apertural view. 29, Mexico. $\times 50$. Paratype. 


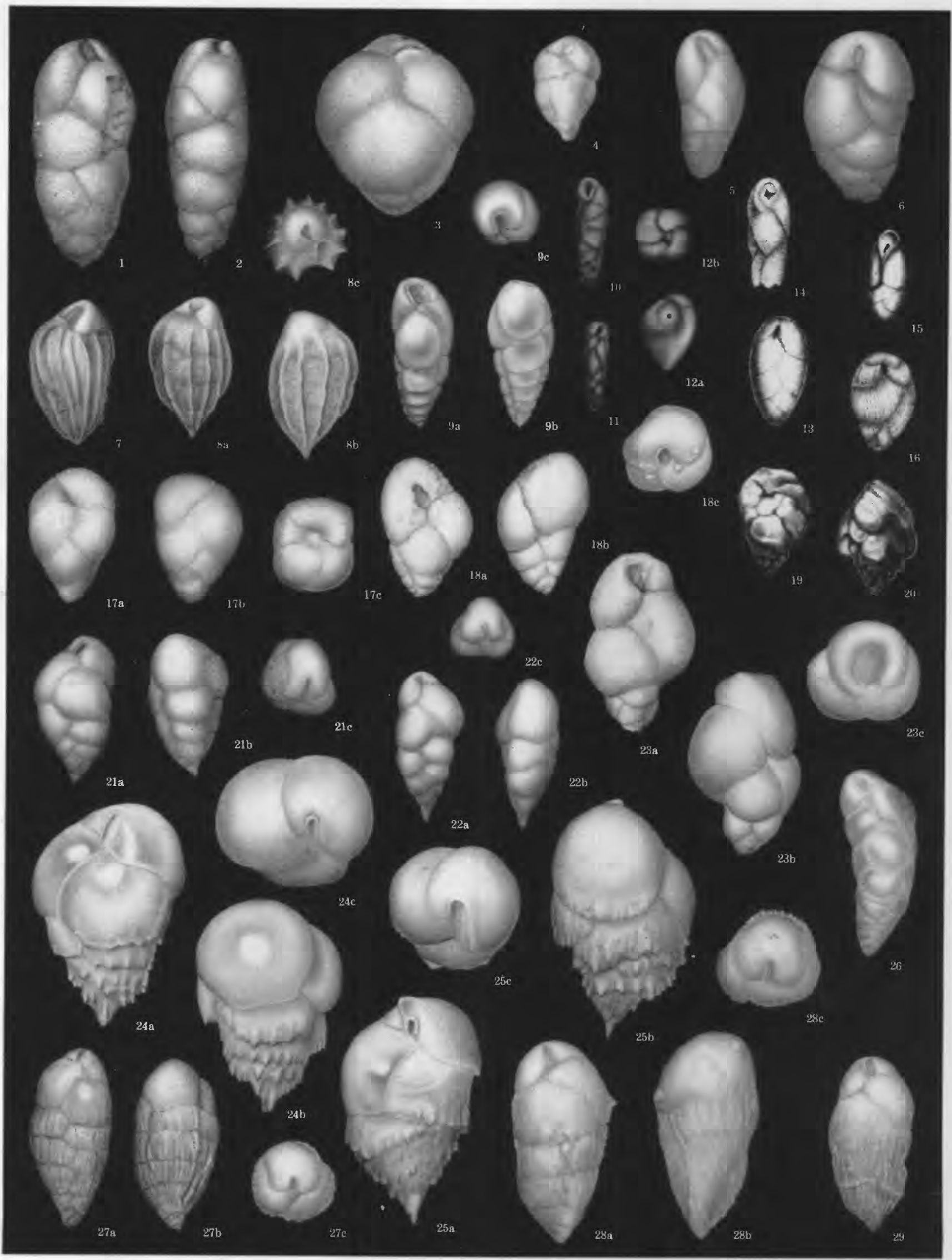

BULIMINA AND BULIMINELLA 


\section{PLATE 22}

Figure 1. Bulimina semicostata Nuttall var. crassicosta Parker and Bermúdez. (After Parker and Bermúdez.) Eocene, Cuba. $\times 85$. $a$, Front view; $b$, rear view ; $c$, apertural view.

Figure 2. B. corrugata Cushman and Siegfus. (After Cushman and Siegfus.) Eocene, California. $\times 85 . a$, Front view; $b$, apertural view.

Figure 3. B. bradyi Wienzierl and Applin. Eocene, Claiborne, South Liberty, Texas. Holotype refigured. $\times 65$.

Frgure 4. B. mauricensis Howe. (After Howe.) Eocene, Claiborne, St. Maurice, Louisiana. $\times 65$. $a$, Front view; $b$, apertural view.

Figure 5. B. winniana Howe. (After Howè.) Eocene, Claiborne, St. Maurice, Louisiana. $\times 70$

Figure 6. B. curtissima Cushman and Siegfus. (After Cushman and Siegfus.) Eocene, California. $\times 90$. $a$, Front view; $b$, apertural view.

Figure 7. B. garzaensis Cushman and Siegfus. (After Cushman and Siegfus.) Eocene, California. $\times 85$. $a$, Front view; $b$, apertural view.

Figure 8. B. adamsi Cushman and Parker. Eocene, California. $\times 85 . a$, Front view; $b$, rear view; $c$, apertural view.

Figure 9. B. microcostata Cushman and Parker. Eocene, California. $\times 85$. $a$, Front view; $b$, rear view; $c$, apertural view.

Figure 10. B. lirata Cushman and Parker. Eocene, California. $\times 65$. $a$, Front view; $b$, rear view; $c$, apertural view.

Figure 11. B. excavata Cushman and Parker. Eocene, California. $\times 85$. $a$, Front view; $b$, rear view: $c$, apertural view.

Figure 12. B. guayabalensis Cole. Eocene, Guayabal, Mexico Topotype. $\times 65$.

Figure 13. B. guayabalensis Cole var. ampla Cushman and Parker. Eocene, California. $\times 60$. $a$, Front view; $b$, rear view, $c$, apertural view.

Figures 14-16. B. jacksonensis Cushman. 14, 15, Eocene, Jackson, Cocoa Post Office, Alabama. $\times$ +5. 16 (After Cushman). Holotype refigured. $\times 65$. Eocene, Mexico.

Figures 17, 18. B. jacksonensis Cushman var. cuneata Cushman. (After Cushman.) Eocene, Jackson, southeast of Melvin, Alabama. $\times 45$.

FIgURE 19. B. cooperensis Cushman. Eocene, Cooper marl, South Carolina. $\times 65$. 


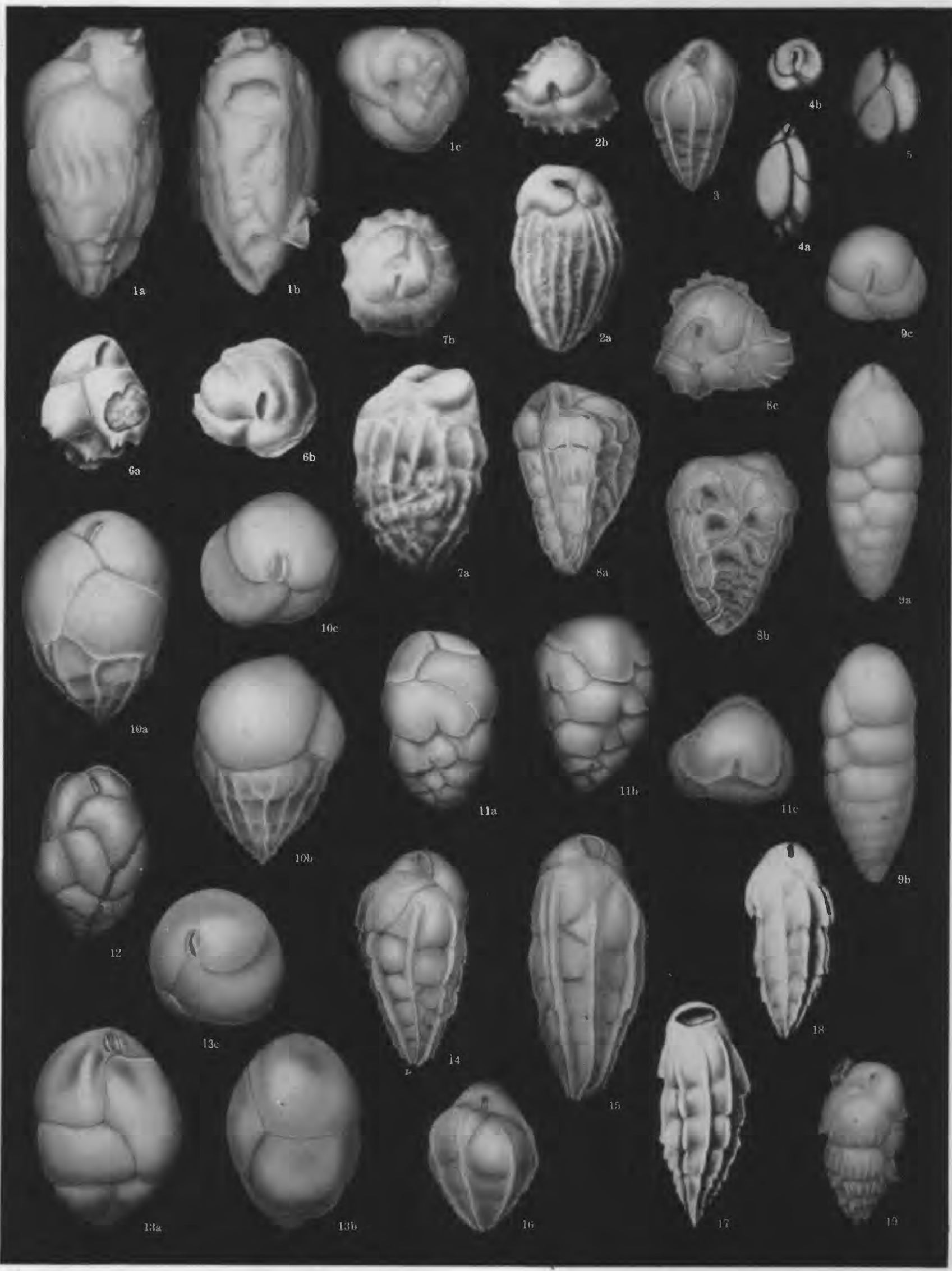


PLATE 23

Figure 1. Bulimina instabilis Cushman and Parker. Eocene, California. $\times 60 . a$, Front view; $b$, rear view; $c$, apertural view.

Figures 2,3. B. macilenta Cushman and Parker. Eocene, California. $\times 85$. $a$, Front view; $b$, rear view; $c$, apertural view.

Figure 4. B. stalacta Cushman and Parker, Eocene, California. $\times 105$. $a$, Front view; $b$, rear view; $c$, apertural view.

Figuke 5. B. consangumea Parker and Bermúdez. (After Parker and Bermúdez.) Eocene, Cuba. $\times 55 . a$, Front view; $b$, rear view; $c$, apertural view.

Frgukes 6, 7. B. impendens Parker and Bermúdez. (After Parker and Bernúdez.) Eocene, Cuba. $\times 85 . a$, Front view; $b$, rear view; $c$, apertural view.

Figure 8. B. palmerae Parker and Bermúdez. (After Parker and Bermúdez.) Eocene, Cuba. $\times 55 . a$, Front view; $b$, rear view; $c$, anertural view.

Figure 9. B. tarda Parker and Bermúdez. (After Parker and Bermúdez.) Eocene, Cuba. $\times 100$. $a$, Front view; $b$, rear view; $c$, apertural view.

Figuke 10. 13. jarvisi Cushman and Parker. Eocene, Trinidad. $\times 80$. $a$, Front view; $b$, rear view; $c$, apertural view. 


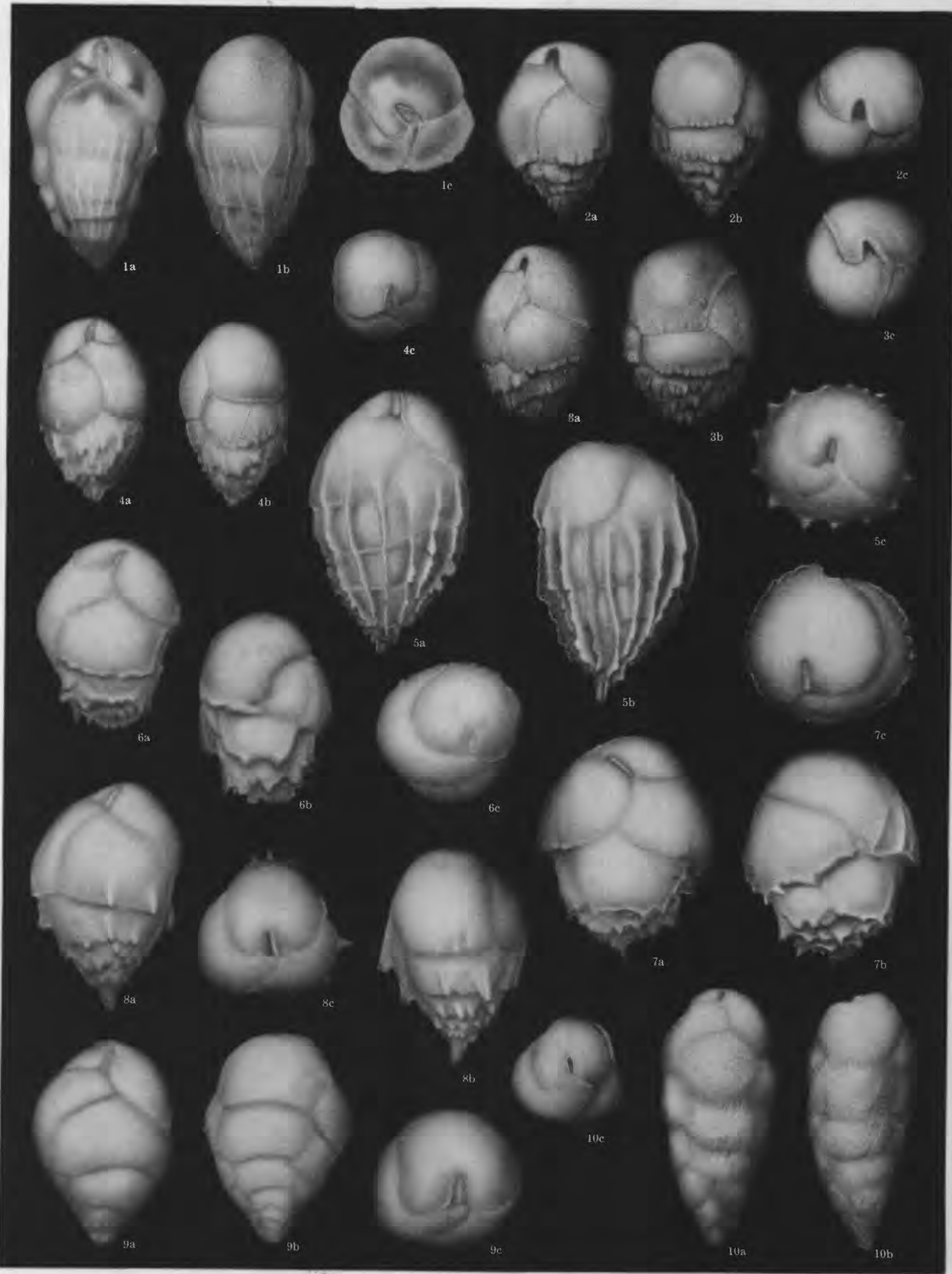




\section{PLATE 24}

Figure 1. Bulimina jarvisi Cushman and Parker. (After Parker and Bermúdez.) Eocene, Cuba. $\times 50 . a$, Front view; $b$, rear view: $c$, apertural view.

Figure 2. B. heathensis W. Berry. (After W. Berry.) Oligocene, Peru. $\times 20, a, b$, Opposite sides.

Figure 3. B. socialis Bornemann. Oligocene, Germany. $\times 65, a$, Front view; $b$, rear view; $c$, apertural view.

Figure 4. B. cylindrica Roemer. (After Roemer.) Oligocene, Germany. $a$, Front view; $b$, apertural view.

Figure 5. B. wva Roemer. (After Roemer.) Oligocene, Germany. $a$, Front view; $b$, apertural view.

Figure 6. B. tuxpamensis Cole. (After Parker and Bermúdez.) Eocene, Cuba. $\times 55, a$, Front view; $b$, rear view; $c$, apertural view.

Figures 7,8. B. pupula Stache. Eocene, New Zealand. $\times 28$. $a$, Front view; $b$, rear view; $c$, apertural view.

Figure 9. B. coprolithoides Andreae. Oligocene, France. $\times 125 . a$, Front view; $b$, rear view; $c$, apertural view.

Figures 10,11. B. alsatica Cushman and Parker. Oligocene, France. $\times 85$. $a$, Front view; $b$, rear view; $c$, apertural view.

Figure 12. B. sculptilis Cushman. Oligocene, Red Bluff, Mississippi. $\times 50$. $a$, Front view; $b$, rear view; $c$, aperlural view.

Figure 13. B. sculptilis Cushman var. laciniata Cushman and Parker. Oligocene, Oregon. $\times 50$. $a$, Front view; $b$, rear view; $c$, apertural view.

Figures 14-16. B. alazanensis Cushman. $\times$ 85. 14, (After Parker and Bermúdez.) Eocene, Cuba. $a$, Front view; $b$, rear view; c, apertural view. 15, Alazan clay, Mexico. 16, Recent, West Indies.

Figure 17. B. bleeckeri Hedberg. Oligocene, Venezuela. $\times 65$.

Figure 18. B. ruqifera Glaessner. (After Glaessner.) Oligocene, Russia. $\times 55$.

Figure 19. B. bicona W. Berry. (After W. Berry.) Oligocene, Peru. $\times 20$. $a$, Front view; $b$, apertural view. 


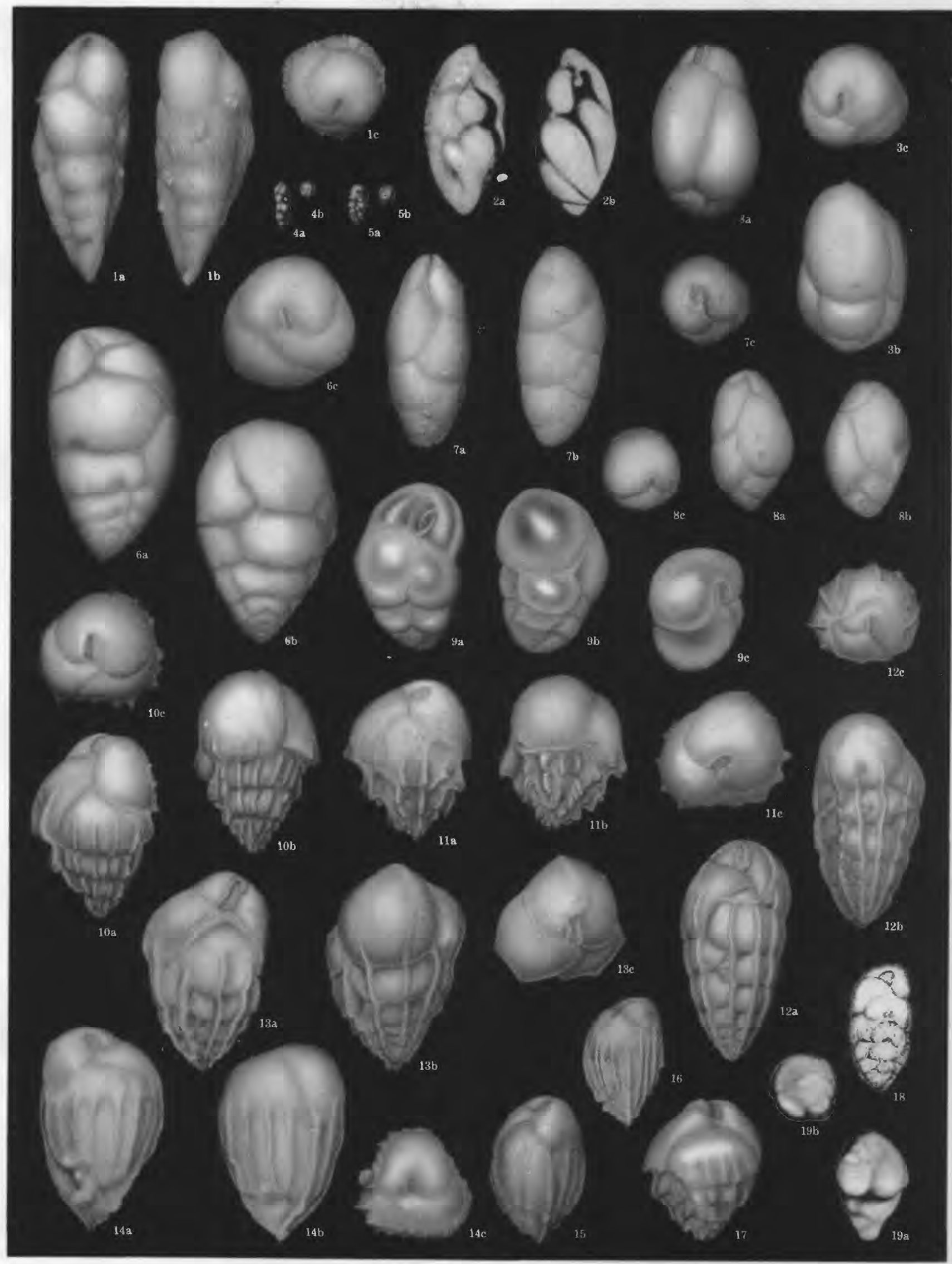




\section{PLATE 25}

Figure 1. Bulimina jugosa Cushman and Parker. Oligocene(?), Ecuador. $\times 90, a$, Front view; $b$, rear view; $c$, apertural view.

Figure 2. B. pyrula D’Orbigny. Miocene, Austria. $\times 35 . a$, Front view; $b$, rear view; $c$, apertural view.

Figures 3-7. B. pupoides D'Orbigny. 3, 4, Miocene, Austria. $\times$ 35. 5-7, (After Parker and Berniúdez.) Eocene, Cuba. $\times 50$. $a$, Front view; $b$, rear view; $c$, apertural view.

Figures 8,9. B. ovata D'Orbigny. Miocene, Austria. $8, \times 35.9, \times 50$. $a$, Front view; $b$, rear view; $c$, apertural view.

Figure 10. B. arcuata D'Orbigny. (After Fornasini.) Miocene, France. $a$, Front view; $b$, rear view.

Figures 11,12. B. buchiana D'Orbigny. Miocene, Austria. $\times$ 35. $a$, Front view; $b$, rear view; $c$, a1lertural view.

Figure 13. B. buchiana D'Orbigny var. calabra Seguenza. Miocene. Hungary. $\times 50$. $a$, Front view; $b$, rear view; $c$, apertural view.

Figures 14-17. B. elongata D'Orbigny. 14, (After Fornasini) Recent. Kimini, Italy. $a$, Side view; $b$, front view. 15-17, Miocene, Austria. $\times 50.15 a$, Front view; $b$, apertural view. $16 a$, Front view; $b$, rear view; $c$, apertural view. 17a, Front view; $b$, apertural view.

Figure 18. B, elongata D'Orbigny var. tenera Reuss. Miocene, Austria. $\times 65 . \quad$, Front view; $b$, rear view; $c$, apertural view.

Figure 19. B. clongata I)'Orbigny var. lappa Cushman and Parker. Mincene, Austria. $\times 50$. $a$, Front view; $b$, rear view; $c$, apertural view. 


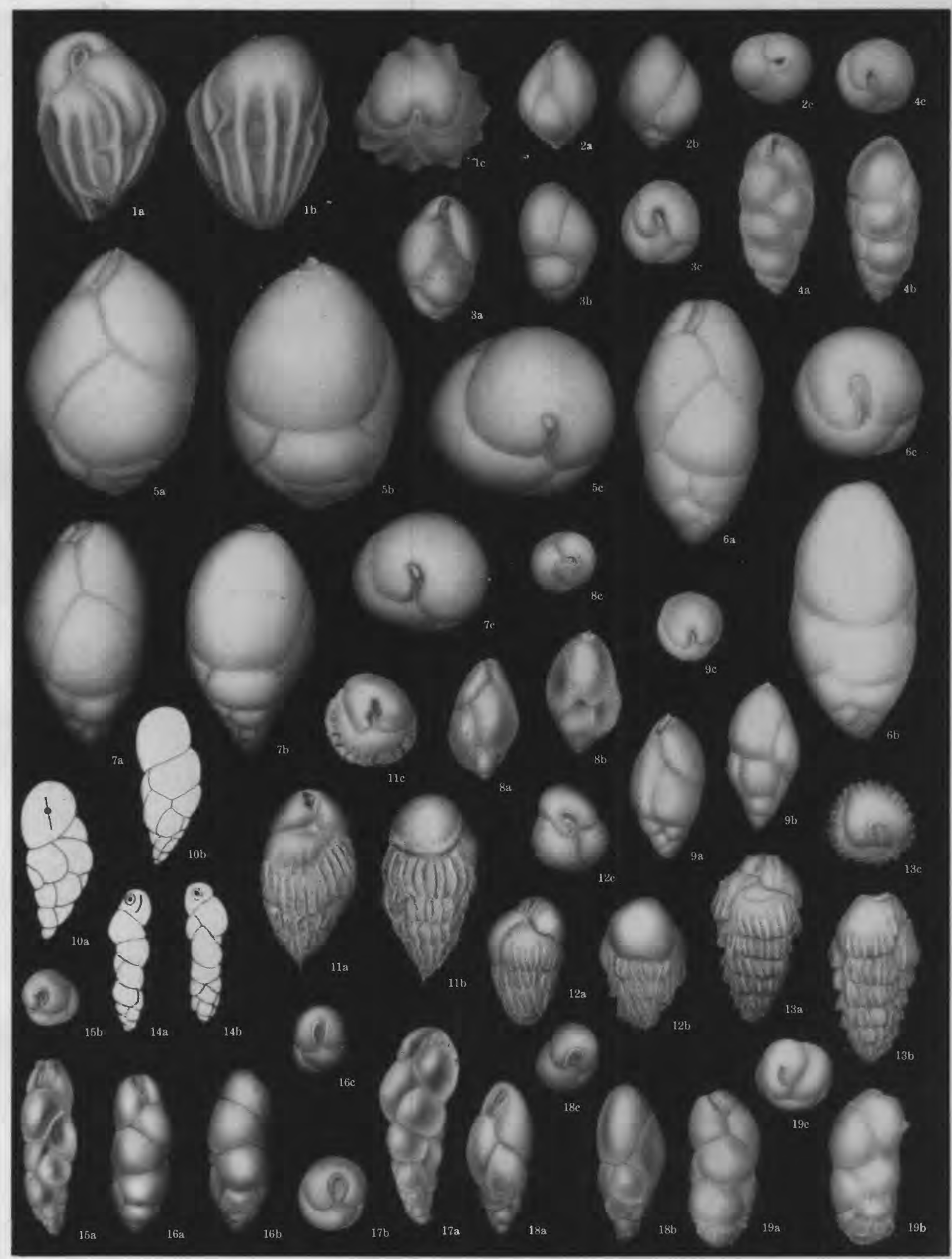




\section{PLATE 26}

Figures 1,2. Bulimina elongata D'Orbigny var. subulata Cushmin and Parker. Miocene, Austria. $\times 50$. $a$, Front view; $b$, rear view; $c$, apertural view.

Figure 3. B. buccinoides Egger. (After Egger.) Miocene, Germany, $a$, Front view; $b$, rear view; $c$, apertural view.

Figures 4,5. B. tuberculata Egger. Miocene, Ortenburg, Germany. $4, \times 85.5, \times 65$. $a$, Front view; $b$, rear view; $c$, apertural view.

Figure 6. B. bulbiformis Seguenza. (After Seguenza.) Miocene, Italy. $\times 35$.

Figures 7-9. B. calcarata Seguenza. 7, (After Seguenza.) Miocene, Italy. $\times 35.8$, Pliocene, Castel Arquato, Italy. $\times 40 . a$, Front view; $b$, rear view; $c$, apertural view. 9, Mioce.ı, Loos, Austria. $\times 50$.

Figures 10,11. B. affinis D'Orbigny var. tenuissimestriata Schubert. (After Schubert.) Miocene, Austria. $a$, Front view; $b$, rear view.

Figure 12. B. rotula Schubert. (After Schubert.) Miocene, Austria. $a$, Front view; $b$, rear view.

Figure 13. B. pseudotorta Cushman. Miocene, California. $\times 35$.

Figure 14. B. alligata Cushman and Laiming. Miocene, California. $\times 50$.

FIgURE 15. B. rinconensis Cushman and Laiming. Miocene, California. $\times 65$.

Figure 16. B. delreyensis Cushman and Galliher. (After Cushman and Galliher.) Miocene, California. $\times 35 . a$, Front view; $b$, apertural view.

Figure 17. B. carnerosensis Cushman and Kleinpell. (After Cushman and Kleinpell.) Miocene, California. $\times 65 . a$, Front view; $b$, apertural view.

FIGURE 18. B. carnerosensis Cushman and Kleinpell var. mahoneyi Cuslman and Kleinpell. (After Cushman and Kleinpell.) Miocene, California. $\times 65 . a$, Front view; $b$, apertural view.

Figure 19. B. uvigerinaformis Cushman and Kleinpell. (After Cushman and Kleinpell.) Miocene, California. $\times 35 . a$, Front view; $b$, apertural view.

FIGURE 20. B. pseudoaffinis Kleinpell. Miocene, California. $\times 50$.

Figure 21. B. delmonteensis Kleinpell. Miocene, California. $\times 50$.

Figure 22. B. ovula D’Orbigny var. pedroana Kleinpell. (After Kleinpell.) Miocene, California. $\times 50$.

Figures 23,24. B. echinata D’Orbigny. Pliocene, Coroncina, Italy. $\times 65$. $a$, Front view; $b$, rear view; $c$, apertural view.

Figures 25-27. B. acanthia Costa. Pliocene. 25, Castel Arquato, Italy. $\times 70.26,27$, Sicily. 26, $\times 45.27, \times 70 . a$, Front view; $b$, rear view; $c$, apertural view. 


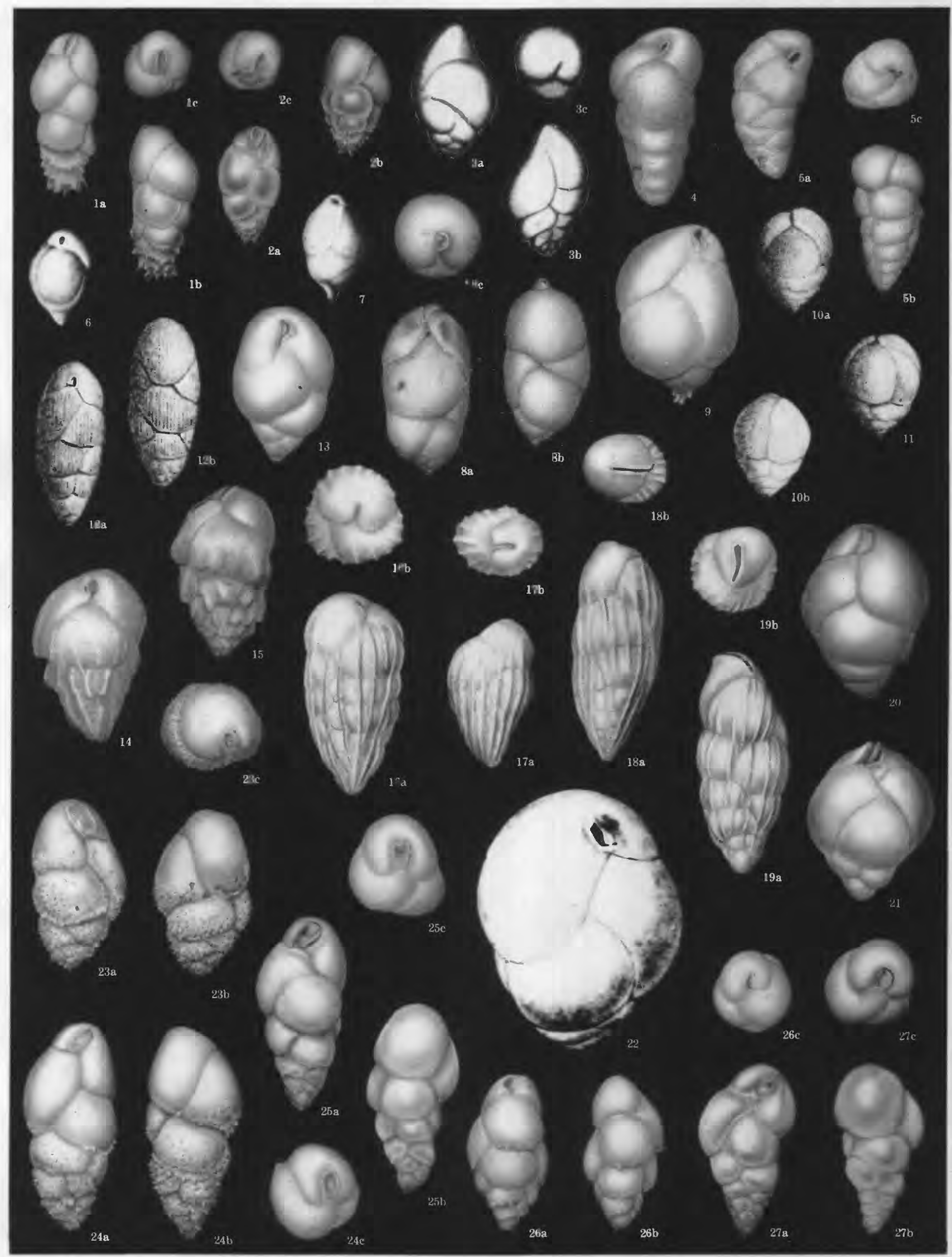




\section{PLATE 27}

Figure 1. Bulimma acanthia Costa. Pliocene, Sicily. $\times 70 . a$, Front view; $b$, rear view; $c$, apertural view.

Figures 2,3. B. costata D'Orbigny. Pliocene, Castel Arquato, Italy. $\times 85$. $a$, Front view; $b$, rear view; $c$, apertural view.

Figure 4. B. peucetia Costa. (After Costa.) Pliocene, Italy. $a$, Front view; $b$, rear view.

Figure 5. B. pustulosa Costa. (After Costa.) Pliocene, Italy.

Figure 6. B. pedunculata Costa. (After Costa.) P'liocene, Italy.

Figure 7. B. subcalva Cushman and K. C. Stewart. Pliocene, California. $\times 50 . a$, Front view; $b$, rear view; $c$, apertural view.

Figure 8. B. subacuminata Cushman and R. E. Stewart. Pliocene, California. $\times 65 . a$, Front view; $b$, rear view; $c$, apertural view.

Figures 9, 10. B. pagoda Cushman var. hebcspinata R. E. and K. C. Stewart. Pliocene, California. 9, (After R. E. and K. C. Stewart.) $\times 85 . a$, Front view; $b$, apertural view. $10, \times 60 . a$, Front view; $b$, rear view; $c$, apertural view.

Figure 11. B. fossa Cushman and. Parker. Pliocene, California. $\times 85$. $a$, Front view; $b$, rear view; $c$, apertural view.

Figure 12. B. maryinospinata Cushman and Parker. I'liocene, California. $\times 65$. $a$, Front view; $b$, rear view; $c$, apertural view.

Figures 13,14 . B. denudata Cushman and l'arker. Pliocene, California. $\times 65$. $a$, Front view; $b$, rear view; $c$, apertural view.

Figure 15. B. denudata Cushman and Parker, var. deformata Cushman and Parker. Pliocene, California. $\times 70 . a$, Front view; $b$, rear view; $c$, apertural view.

Figukes 16,17. B. inflata Seguenza. $\times 70.16$, Pliocene, Southern Spain. 17, Pliocene, Messina, Italy. $a$, Front view; $b$, rear view; $c$, apertural view. 


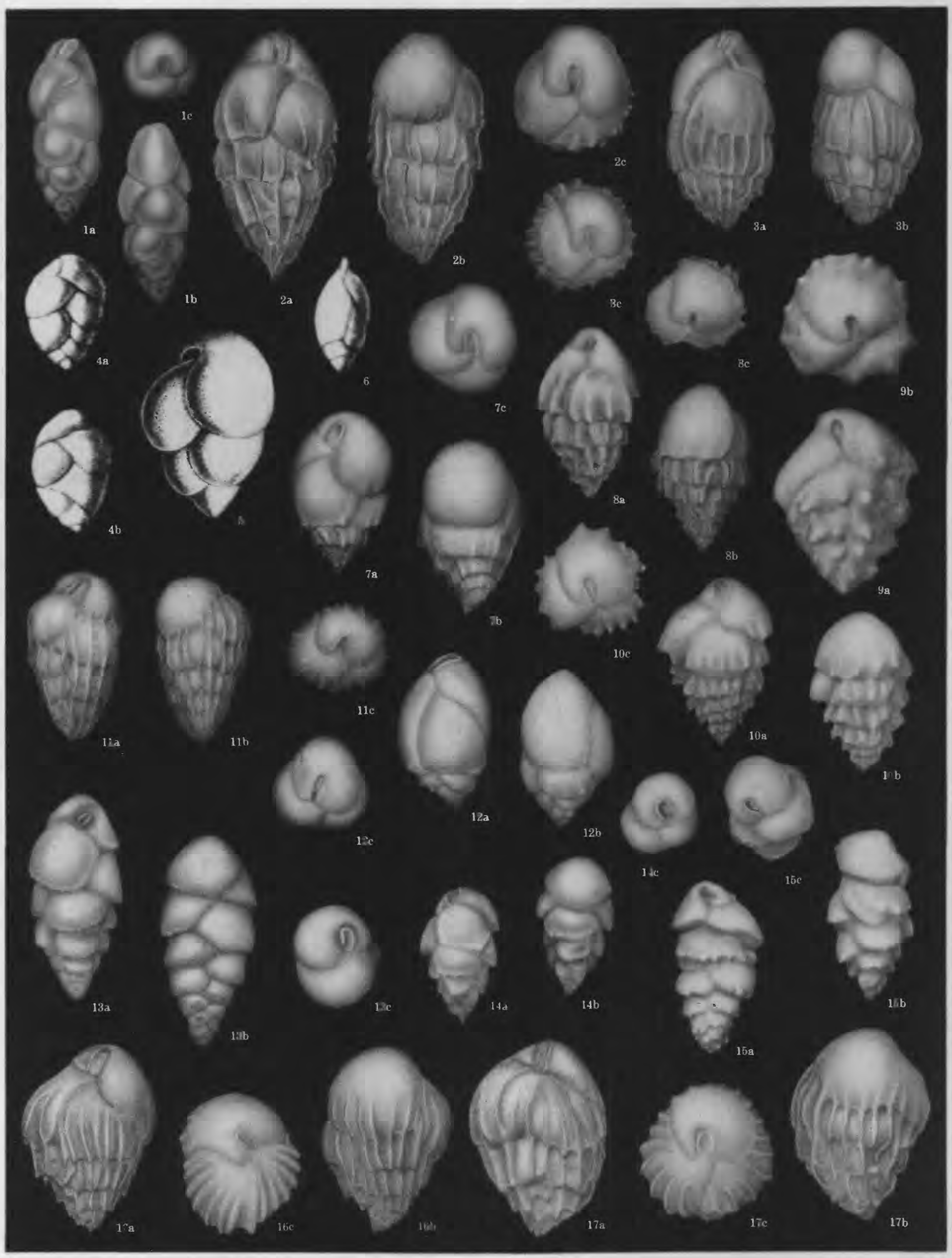




\section{PLATE 28}

Figures 1-3. Bulimina striala D'Orbigny. 1, (After Fornasini). $a$, Front view; $b$, rear view. 2, 3, Recent, Rimini, Italy. $\times 42$.

Figure 4. B. striata D'Orbigny var. mexicana Cushman. Recent, Gulf of Mexico. $\times 35$.

Figures 5,6. B. marginata D'Orbigny. 5, (After D'Orbigny). $a$, Front view; $b$, rear view. 6 , Recent, Rimini, Italy. $\times 45 . a$, Front view; $b$, apertural view.

Figure 7. B. trilobata D'Orbigny. (After Fornasini.) $a$, Front view; $b$, rear view.

Figures 8-11. B. aculeata D’Orbigny. 8, (After Fornasini.) 9-11, Recent, Rimini, Italy. $\times 35 . a$, Front view; $b$, apertural view.

Figures 12,13 . B. candigera D'Orbigny. 12, From D'Orbigny's model. 13, Recent, Rimini, Italy. $\times 35$. $a$, Front view; $b$, apertural view.

Figures 14-16. B. squammigera D'Orbigny. (After D'Orbigny.) Recent, Canary Islands.

Figuke 17. B. patagonica D'Orbigny. Recent, Rio de Janeiro Harbor, Brazil. $\times 65$.

Figures 18, 19. B. patagonica D'Orbigny var, glabra Cushman and Wickenden. Recent, oft Juan Fernandez Island. $\times 65$.

Figures 20-22. B. ovula D'Orbigny. Recent, Pacific. $\times 35$.

Figukes.23-25. B. affinis D'Orbigny. Recent, Western Atlantic. $\times 35 . a$, Front view; $b$, apertural view.

Figure 26. B. oceanica Terquem. (After Terquem.) Recent, Eastern Atlantic. $\times 40 . a$, Front view; $b$, rear view.

Figures 27,28. B. exilis H. B. Brady. Recent, off British Isles. $\times 50$.

Figure 29. B. cxilis H. B. Brady var. tenuala (Cushman) Cushman and Parker. Recent, Eastern Pacific. $\times 42$.

Figukes 30,31. B. pyrula D'Orbigny var. spinescens H. B. Brady. Recent, Philippines. $\times 50$.

Figukes 32,33. B. subornata H. B. Brady. Recent, Philippines. $\times 50$

Figure 34. B. rostrata H. B. Brady. Recent, Eastern Pacific. $\times 85$. $a$, Front view; $b$, rear view.

Figure 35. B. ornata Egger. (After Egger.) Recent, off West Australia.

Figure 36. B. consobrina Fornasini. (After Fornasini.) Recent, Italy. $\times 40$.

Figures 37, 38. B. gibba Fornasini. (After Fornasini.) Recent, Italy. $\times 40$. 


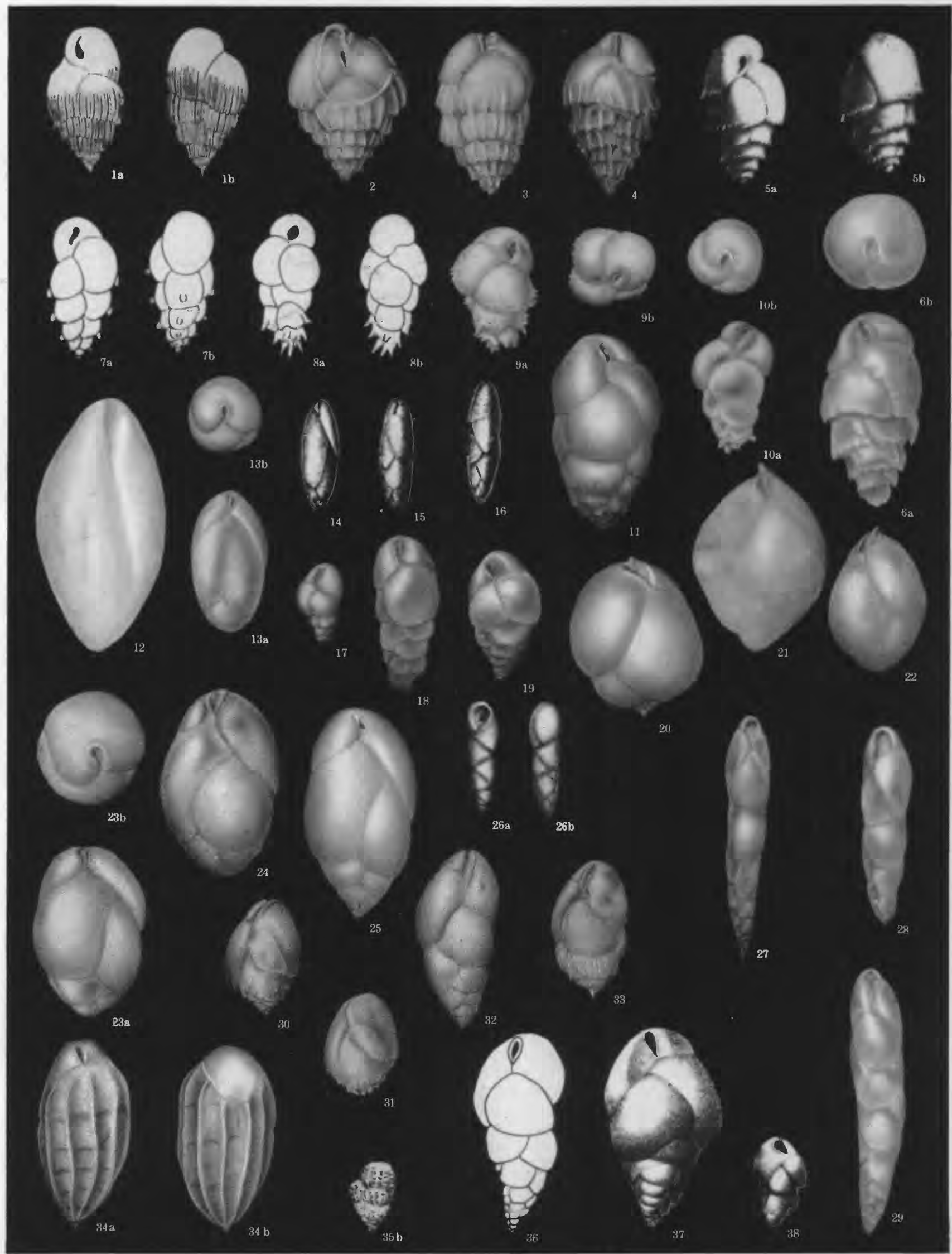




\section{PLATE 29}

Figures 1-5. Bulimina gibba Fornasini. Recent, off Villefranche, France. $\times 50$.

Figure 6. B. torta Cushman. (Holotype refigured.) Recent, Pacific. $\times 50$.

Figure 7. B. subaffinis Cushman. Recent, Philippines. $\times 22$.

Figure 8. B. barbata Cushman. (After Cushman.) Recent, Pacific. $\times 35$.

Figure 9. B. spinifera Cushman. Recent, Pacific. $\times 50$.

Figures 10,11. B. pagoda Cushman. Recent, Eastern Pacific. 10, (After Cushman), Holotype. $\times 35.11$, Paratype. $\times 65$.

Figures 12,13. B. clava Cushman and Parker, n. sp. Recent, Western Atlantic. $\times 35.12$, Holotype. 13, I'aratype.

Figures 14, 15. B. fijicnsis Cushman. (After Cushman.) Recent. 14, Holotype. Nairai, Fiji. $\times 55$. $a$, Side view; $b$, front view; c, apertural view. 15 , Off Zanzibar. $\times 90$.

Figure 16. B. buchiana D'Orbigny var. gutta Chapman and Parr. (After Chapman and Parr.) Recent, Antarctic. $\times 65$.

Figure 17. B. brevitrigona Chapman and Parr. (After Chapman and Parr.) Recent, Antarctic. $\times 65$.

Figukes 18, 19. Bulimina (Desinobulimina) quadrata Plummer. Paleocene, Midway, Texas. $\times 45.18$, Megalospheric. 19, Microspheric.

Figures 20,21. B. (Desinobulinina) montercyana Kleinpell. Miocene, California. $\times 35$. Front view; $b$, apertural view.

Figures 22-24. B. (Desinobulinina) auriculata Bailey. Recent, South of Block Island. 22, 23, $\times 45$. $a$, Front view; $b$, side view. $24, \times 50$. Showing interior.

Fıgukes 25-27. B. (Desinobulimina) turgida Bailey. $\times$ 35. Recent. 25, 26, South of Block Island. 27, Off Dröbach, Norway.

Figures 28, 29. Neobulimina minima Tappan. (After Tappan.) Lower Cretaceous, Texas. $\times 65$. $a$, Front view; $b$, rear view; $c$, apertural view.

Figure 30. $N$. irregularis Cushman and Parker. Cretaceous, Austin chalk, Grayson Co., Texas. $\times 40$. $a$, Front view; $b$, apertural view.

Figure 31. N. spinosa Cushman and Parker. Cretaceous, Ripley formation, Henderson Co., Tennessee. $\times 70 . a$, Front view; $b$, apertural view.

Figures 32,33. N. canadensis Cushman and Wickenden. Cretaceous, Taylor marl, Texas. $\times 70$. $a$, Front view; $b$, apertural view. Figure 34. Globobulimina perversa (Cushman) Cushman and Parker. Recent, Philippines. $\times 23$.

Figures 35,36. G. glabra Cushman and Parker, n. sp. Pliocene, Rome, Italy. $\times 40.35$, Holotype. 36, Paratype.

Figure 37. G. pacifica Cushman. Recent, off California. $\times 28$.

Figure 38. G. galliheri (Kleinpell) Cushman and Parker. (After Kleinpell.) Miocene, California. $\times 35 . a$, Front view; $b$, apertural view. 


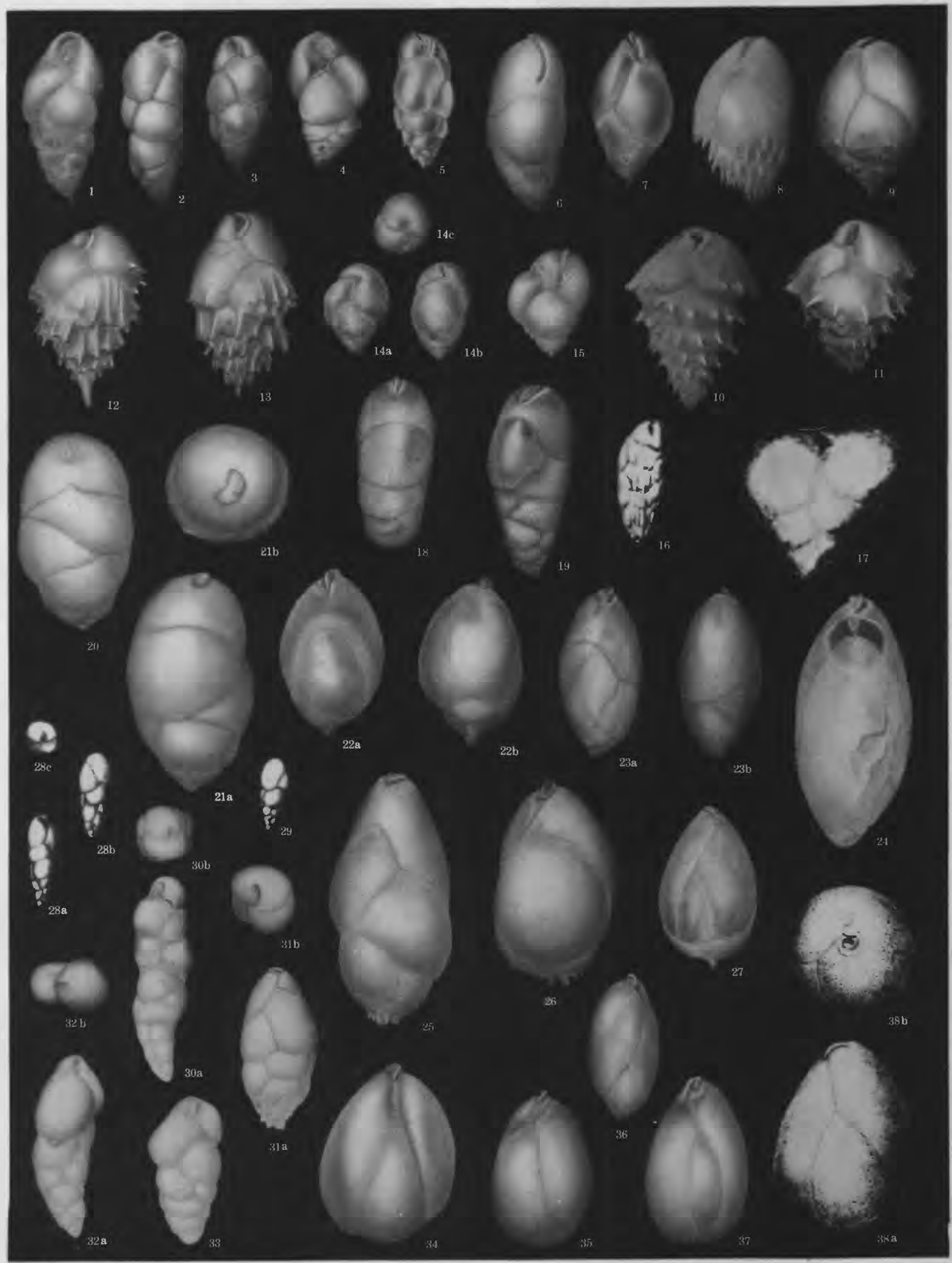

BULIMINA. BULIMINA (DESINOBULIMINA), NEOBULIMINA, GLOBOBULIMINA 


\section{PLATE 30}

Figure 1. Buliminella barbati Cushman and Simonson. (After Cushman and Simonson.) Oligocene, California. $\times 90 . a$, Front view; $b$, rear view; $c$, apertural view.

Figure 2. B. fusiforma Jennings. (After Jennings.) Upper Cretaceous, New Jersey.

Figures 3, 4. Robertina washingtonensis Beck. (After Beck.) Eocnne, Washington. $\times$ 47. 3, Holotype. $a$, Front view; $b$, rear view. 4, Paratype.

Figure 5. Bulimina laddi Cushman and Hedberg. (After Cushman and Hedberg.) Upper Cretaceous, Colombia. $\times 60 . a$, Front view ; $b$, rear view; $c$, apertural view.

Figure 6. B. petroleana Cushman and Hedberg. (After Cushman and Hedberg.) Upper Cretaceous, Colombia. $\times 60 . a$, Front view ; $b$, rear view ; $c$, apertural view.

Figure 7. B. referata Jennings. (After Jennings.) Upper Cretaceous, New Jersey. $a$, Front view; $b$, apertural view.

Figure 8. B. notovata Chapman. (After H. B. Brady, "Bulimina ovata D'Orbigny.") Recent, off New Zealand. $\times 35 . a$, Front view; $b$, rear view.

Figure 9. B. bradburyi Martin. (After Martin.) Eocene, California. $\times 65 . a$, Front view; $b$, apertural view.

Figure 10. B. debilis Martin. (After Martin.) Eocene, California. $\times 65 . a$, Front view; $b$, rear view ; $c$, apertural view.

Figure 11. B. whitei Martin. (After Martin.) Eocene, California. $\times 90 . a$, Front view; $b$, anertural view.

Figure 12. B. (Desinobulimina) illingi Cushman and Stainforth, (After Cushman and Stainforth.) Oligocene, Trinidad. $\times 25$. $a$, Front view; $b$, rear view; $c$, apertural view.

Figure 13. B. kugleri Cushman and Renz. (After Cushman and Renz.) Paleocene, Trinidad. $\times 70$. $a$, Front view; $b$, rear view; $c$, apertural view.

Figure 14. B. microlongistriata LeRoy. (After LeRoy.) Late Tertiary, Borneo. $\times 30$. $a$, Front view; $b$, apertural view.

Figure 15. B. ovata D'Orbigny var. cowlitzensis Beck. (After Beck.) Eocene, Washington. $\times 47$.

Figure 16. B. schencki Beck. (After Beck.) Eocene, Washington. $\times$ 73. $a$, Front view; $b$, rear view.

Figure 17. Globobulimina pacifica Cushman var. scalprata Cushman and Todd. (After Cushman and Todd.) Miocene, Jamaica. $\times 30$.

FIGURe 18. Bulimina marginata D'Orbigny var. tessellata Cushman and Todd. (After Cushman and Todd.) Miocene, Jamaica $\times 65$.

Figure 19. B. alazanensis Cushman var. spatiosa Cushman and Todd. (After Cushman and Todd.) Miocene, Jamaica. $\times 42$. 


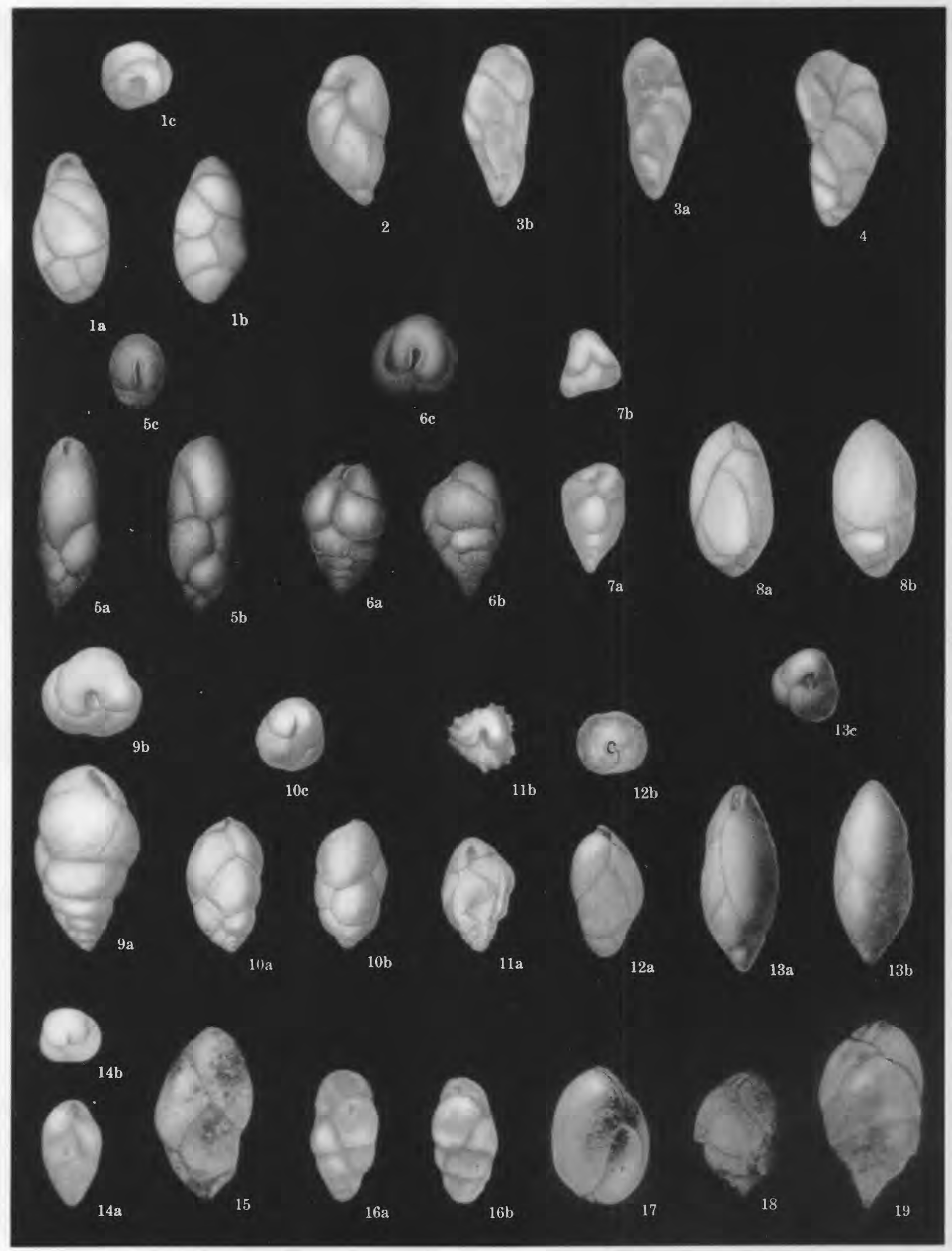

BULIMINELLA, BULIMINA, AND GLOBOBULIMINA 

A

Acknowledgments for aid $\ldots \ldots \ldots \ldots \ldots \ldots \ldots \ldots \ldots \ldots \ldots \ldots \ldots \ldots \ldots, 55$

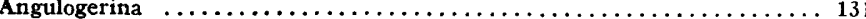

Arenobulimina $\ldots \ldots \ldots, \ldots \ldots \ldots \ldots \ldots \ldots \ldots \ldots \ldots \ldots \ldots \ldots, 132$

brevicona $\ldots \ldots \ldots \ldots \ldots \ldots \ldots \ldots \ldots \ldots \ldots \ldots \ldots \ldots \ldots \ldots \ldots \ldots \ldots \ldots \ldots \ldots \ldots, 131$

conoidea $\ldots \ldots \ldots \ldots \ldots \ldots \ldots \ldots \ldots \ldots \ldots \ldots \ldots \ldots \ldots \ldots \ldots \ldots \ldots, 130$

d'orbignyi $\ldots \ldots \ldots \ldots \ldots \ldots \ldots \ldots \ldots \ldots \ldots \ldots \ldots \ldots \ldots \ldots, 130$

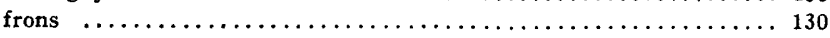

obesa $\ldots \ldots \ldots \ldots \ldots \ldots \ldots \ldots \ldots \ldots \ldots \ldots \ldots \ldots \ldots \ldots \ldots, 131$

obliqua $\ldots \ldots \ldots \ldots \ldots \ldots \ldots \ldots \ldots \ldots \ldots \ldots \ldots \ldots \ldots \ldots, 131$

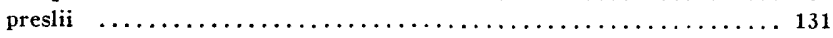

puschi $\ldots \ldots \ldots \ldots \ldots \ldots \ldots \ldots \ldots \ldots \ldots \ldots \ldots \ldots \ldots \ldots \ldots \ldots, 111,131$

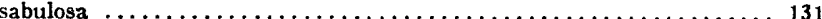

subsphaerica $\ldots \ldots \ldots \ldots \ldots \ldots \ldots \ldots \ldots \ldots \ldots \ldots \ldots \ldots \ldots \ldots \ldots \ldots, 132$

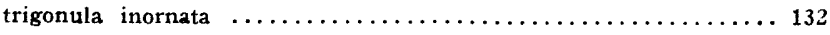

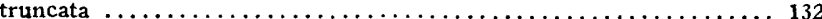

Ataxophragmium $\ldots \ldots \ldots \ldots \ldots \ldots \ldots \ldots \ldots \ldots \ldots \ldots \ldots, 132$

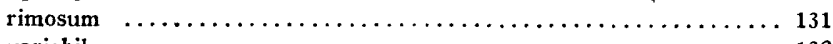

variabile $\ldots \ldots \ldots \ldots \ldots \ldots \ldots \ldots \ldots \ldots \ldots \ldots \ldots \ldots, 132$

B

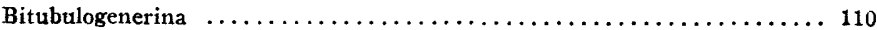

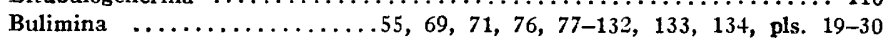

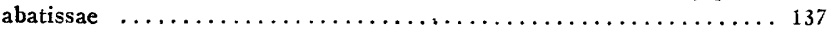
acanthia $\ldots \ldots \ldots \ldots \ldots \ldots \ldots \ldots \ldots \ldots \ldots \ldots \ldots \ldots \ldots \ldots \ldots \ldots \ldots \ldots, 115,125$, pls. 26,27 acicula $\ldots \ldots \ldots \ldots \ldots \ldots \ldots \ldots \ldots \ldots \ldots \ldots \ldots \ldots \ldots \ldots \ldots \ldots \ldots \ldots \ldots \ldots \ldots \ldots, 130$ aculeata $\ldots \ldots \ldots \ldots \ldots \ldots \ldots \ldots \ldots .92,109,120-121,122,127$, pl. 28 acuta $\ldots \ldots \ldots \ldots \ldots \ldots \ldots \ldots \ldots \ldots \ldots \ldots \ldots \ldots, 130$, pl. 19 adamsi $\ldots \ldots \ldots \ldots \ldots \ldots \ldots \ldots \ldots \ldots \ldots \ldots \ldots \ldots \ldots \ldots \ldots \ldots \ldots$, pl. 22 affinis $\ldots \ldots \ldots \ldots \ldots 101,105,106,111,114,121,122-123,126$, pl. 28

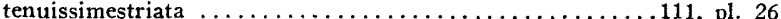
alazanensis $\ldots \ldots \ldots \ldots \ldots \ldots \ldots \ldots \ldots \ldots \ldots 8,103,104,117$, pl. 24 spatiosa $\ldots \ldots \ldots \ldots \ldots \ldots \ldots \ldots \ldots \ldots \ldots \ldots \ldots \ldots . \ldots \ldots+104$, pl. 30

alligata $\ldots \ldots \ldots \ldots \ldots \ldots \ldots \ldots \ldots \ldots \ldots \ldots \ldots \ldots \ldots \ldots \ldots \ldots, 112,116$, pl. 26 alsatica $\ldots \ldots \ldots \ldots \ldots \ldots \ldots \ldots \ldots \ldots \ldots \ldots \ldots \ldots \ldots \ldots \ldots \ldots, 104,115$, pl. 24 amphicona $\ldots \ldots \ldots \ldots \ldots \ldots \ldots \ldots \ldots \ldots \ldots \ldots \ldots \ldots \ldots \ldots \ldots \ldots, 79$

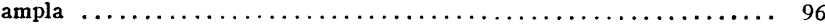

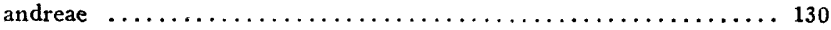
andreaei $\ldots \ldots \ldots \ldots \ldots \ldots \ldots \ldots \ldots \ldots \ldots \ldots \ldots \ldots \ldots \ldots \ldots \ldots \ldots \ldots, 130$ antiqua $\ldots \ldots \ldots \ldots \ldots \ldots \ldots \ldots \ldots \ldots \ldots \ldots \ldots \ldots \ldots \ldots, \ldots \ldots, 19,19$

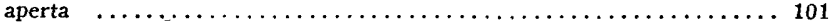
arcuata $\ldots \ldots \ldots \ldots \ldots \ldots \ldots \ldots \ldots \ldots \ldots \ldots \ldots 107,111,130$, pl. 25 arenacea $\ldots \ldots \ldots \ldots \ldots \ldots \ldots \ldots \ldots \ldots \ldots \ldots \ldots \ldots \ldots \ldots \ldots \ldots, 132$ ariminensis $\ldots \ldots \ldots \ldots \ldots \ldots \ldots \ldots \ldots \ldots \ldots \ldots \ldots \ldots \ldots \ldots \ldots \ldots, 109$ arkadelphiana $\ldots \ldots \ldots \ldots \ldots \ldots \ldots \ldots \ldots \ldots \ldots \ldots, 85,87$, pl. 20 midwayensis $\ldots \ldots \ldots \ldots \ldots \ldots \ldots \ldots \ldots \ldots \ldots .92,98,100$, pl. 21 aspera $\ldots \ldots \ldots \ldots \ldots \ldots \ldots \ldots \ldots \ldots \ldots \ldots \ldots \ldots, 81,83$, pls. 19,21 auricula $\ldots \ldots \ldots \ldots \ldots \ldots \ldots \ldots \ldots \ldots \ldots \ldots \ldots \ldots \ldots \ldots \ldots \ldots \ldots \ldots \ldots, 130$ auriculata $\ldots \ldots \ldots \ldots \ldots \ldots \ldots \ldots \ldots \ldots \ldots \ldots \ldots \ldots \ldots \ldots \ldots \ldots \ldots, 129,130$ baccata $\ldots \ldots \ldots \ldots \ldots \ldots \ldots \ldots \ldots \ldots \ldots \ldots \ldots \ldots . \ldots, 89,125, \mathrm{pl} .20$ barbata $\ldots \ldots \ldots \ldots \ldots \ldots \ldots \ldots \ldots \ldots \ldots \ldots \ldots \ldots 124,126$, pl. 29

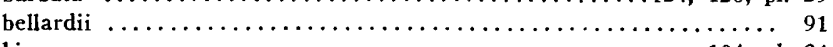
bicona $\ldots \ldots \ldots \ldots \ldots \ldots \ldots \ldots \ldots \ldots \ldots \ldots \ldots \ldots \ldots \ldots, \ldots \ldots \ldots$, pl. 24 bleeckeri $\ldots \ldots \ldots \ldots \ldots \ldots \ldots \ldots \ldots \ldots \ldots \ldots \ldots 102,104$, pl. 24 bortonica $\ldots \ldots \ldots \ldots \ldots \ldots \ldots \ldots \ldots \ldots \ldots \ldots \ldots \ldots \ldots \ldots \ldots \ldots \ldots \ldots, 137$ bradburyi $\ldots \ldots \ldots \ldots \ldots \ldots \ldots \ldots \ldots \ldots \ldots \ldots \ldots \ldots, \ldots \ldots, 97$, pl. 30

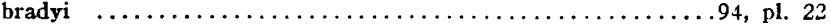

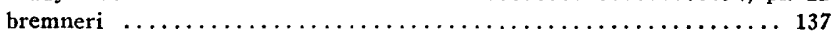
brevicona $\ldots . \ldots \ldots \ldots \ldots \ldots \ldots \ldots \ldots \ldots \ldots \ldots \ldots \ldots \ldots \ldots, 130$ brevis $\ldots \ldots \ldots \ldots \ldots \ldots \ldots \ldots \ldots \ldots \ldots \ldots \ldots \ldots, 79,84,131$, pl. 21 brevitrigona $\ldots \ldots \ldots \ldots \ldots \ldots \ldots \ldots \ldots \ldots \ldots \ldots \ldots \ldots \ldots \ldots \ldots \ldots \ldots \ldots$, pl. 29 buccinoides $\ldots \ldots \ldots \ldots \ldots \ldots \ldots \ldots \ldots \ldots \ldots \ldots \ldots \ldots \ldots \ldots \ldots \ldots \ldots \ldots$, pl. 26 buchiana $\ldots .88,98,102,107,108,112,113,115,118,124,127$, pl. 25 calabra $\ldots \ldots \ldots \ldots \ldots \ldots \ldots \ldots \ldots \ldots \ldots \ldots \ldots \ldots \ldots$, pl. 25 gutta $\ldots \ldots \ldots \ldots \ldots \ldots \ldots \ldots \ldots \ldots \ldots \ldots \ldots \ldots \ldots \ldots \ldots \ldots \ldots$, pl. 29 bulbiformis $\ldots \ldots \ldots \ldots \ldots \ldots \ldots \ldots \ldots \ldots \ldots \ldots \ldots \ldots \ldots$, pl. 26

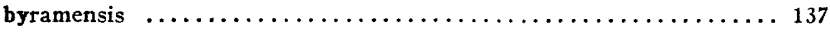
cacumenata $\ldots \ldots \ldots \ldots \ldots \ldots \ldots \ldots \ldots \ldots \ldots \ldots \ldots, 92,93,95$, pl. 21 calcarata $\ldots \ldots \ldots \ldots \ldots \ldots \ldots \ldots \ldots \ldots \ldots \ldots \ldots \ldots \ldots \ldots \ldots$, pl. 26 callahani $\ldots \ldots \ldots \ldots \ldots \ldots \ldots \ldots \ldots \ldots \ldots \ldots \ldots \ldots, 87-88$, pl. 20 candida $\ldots \ldots \ldots \ldots \ldots \ldots \ldots \ldots \ldots \ldots \ldots \ldots \ldots \ldots \ldots \ldots \ldots \ldots \ldots \ldots \ldots, 130$ capitata $\ldots \ldots \ldots \ldots \ldots \ldots \ldots \ldots \ldots \ldots \ldots \ldots \ldots, 88-89,96,98$, pl. 20 carnerosensis $\ldots \ldots \ldots \ldots \ldots \ldots \ldots \ldots \ldots \ldots \ldots \ldots \ldots \ldots \ldots \ldots \ldots \ldots \ldots \ldots, p_{113}, 26$

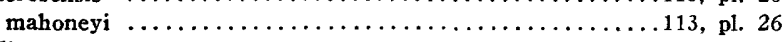
caudigera $\ldots \ldots \ldots \ldots \ldots \ldots \ldots \ldots \ldots \ldots \ldots \ldots \ldots \ldots \ldots \ldots \ldots \ldots \ldots, p l, 28$ $695464-47-9$

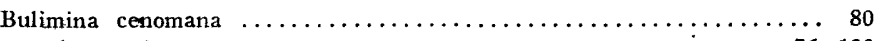
chapmani $\ldots \ldots \ldots \ldots \ldots \ldots \ldots \ldots \ldots \ldots \ldots \ldots \ldots \ldots \ldots \ldots, 130$ clava $\ldots \ldots \ldots \ldots \ldots \ldots \ldots \ldots \ldots \ldots \ldots \ldots \ldots \ldots \ldots \ldots \ldots \ldots \ldots \ldots, 128$, pl. 29 compressa $\ldots \ldots \ldots \ldots \ldots \ldots \ldots \ldots \ldots \ldots \ldots \ldots \ldots \ldots \ldots \ldots . .5,130$

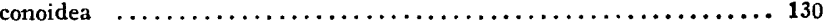
consanguinea $\ldots \ldots \ldots \ldots \ldots \ldots \ldots \ldots \ldots \ldots \ldots \ldots \ldots .95,99-100$, pl. 23 consobrina $\ldots \ldots \ldots \ldots \ldots \ldots \ldots \ldots \ldots \ldots \ldots \ldots \ldots \ldots \ldots \ldots \ldots \ldots$, pl. 28 contorta $\ldots \ldots \ldots \ldots \ldots \ldots \ldots \ldots \ldots \ldots \ldots \ldots \ldots \ldots \ldots \ldots \ldots \ldots \ldots, 130$ conulus $\ldots \ldots \ldots \ldots \ldots \ldots \ldots \ldots \ldots \ldots \ldots \ldots \ldots \ldots \ldots \ldots, 130$

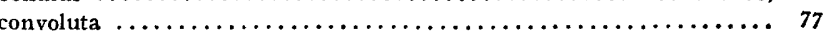
dehiscens $\ldots \ldots \ldots \ldots \ldots \ldots \ldots \ldots \ldots \ldots \ldots \ldots, 130$

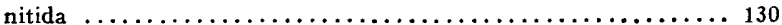
cooperensis $\ldots \ldots \ldots \ldots \ldots \ldots \ldots \ldots \ldots \ldots \ldots \ldots . .65,94,98$, pl. 22 coprolithoides $\ldots \ldots \ldots \ldots \ldots \ldots \ldots \ldots \ldots \ldots \ldots \ldots \ldots \ldots$, 102, pl. 24 corrugata $\ldots \ldots \ldots \ldots \ldots \ldots \ldots \ldots \ldots \ldots \ldots \ldots \ldots 89,93,95,97$, pl. 22 costata $\ldots \ldots \ldots \ldots \ldots \ldots \ldots \ldots \ldots \ldots \ldots \ldots 107,108,115,118$, pl. 27

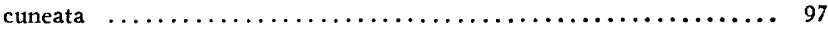
cuneiformis $\ldots \ldots \ldots \ldots \ldots \ldots \ldots \ldots \ldots \ldots \ldots \ldots \ldots \ldots \ldots \ldots, 130$ curtissima $\ldots \ldots \ldots \ldots \ldots \ldots \ldots \ldots \ldots \ldots \ldots \ldots \ldots . \ldots 4,100$, pl. 22 cuspidata $\ldots \ldots \ldots \ldots \ldots \ldots \ldots \ldots \ldots \ldots \ldots \ldots \ldots \ldots \ldots \ldots \ldots \ldots, 111$

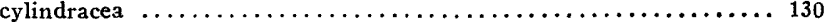
cylindrica $\ldots \ldots \ldots \ldots \ldots \ldots \ldots \ldots \ldots \ldots \ldots \ldots \ldots \ldots \ldots \ldots \ldots \ldots \ldots \ldots, 130$, pl. 24 debilis $\quad \ldots \ldots \ldots \ldots \ldots \ldots \ldots \ldots \ldots \ldots \ldots \ldots \ldots \ldots . \ldots \ldots$, pl. 30 declivis $\ldots \ldots \ldots \ldots \ldots \ldots \ldots \ldots \ldots \ldots \ldots \ldots \ldots \ldots, 73,75,86,130$ decorata $\ldots \ldots \ldots \ldots \ldots \ldots \ldots \ldots \ldots \ldots \ldots \ldots \ldots \ldots, 90-91$, pl. 21 delmonteensis $\ldots \ldots \ldots \ldots \ldots \ldots \ldots \ldots \ldots \ldots \ldots \ldots 114,129$, pl. 26

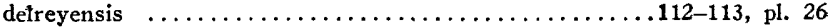

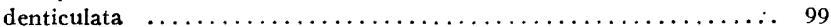
denudata $\ldots \ldots \ldots \ldots \ldots \ldots \ldots \ldots \ldots \ldots \ldots \ldots \ldots \ldots \ldots \ldots \ldots \ldots \ldots \ldots \ldots \ldots, 117,120$, pl. 27

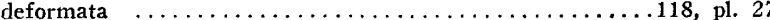

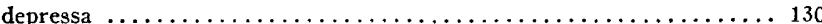
doliolum $\ldots \ldots \ldots \ldots \ldots \ldots \ldots \ldots \ldots \ldots \ldots \ldots \ldots \ldots \ldots \ldots \ldots \ldots \ldots \ldots \ldots \ldots \ldots, 129,130$ d'orbignyi $\ldots \ldots \ldots \ldots \ldots \ldots \ldots \ldots \ldots \ldots \ldots \ldots \ldots \ldots \ldots \ldots \ldots, 130$ eccentrica $\ldots \ldots \ldots \ldots \ldots \ldots \ldots \ldots \ldots \ldots \ldots \ldots \ldots \ldots \ldots, \ldots 2$, pl, 21 echinata $\ldots \ldots \ldots \ldots \ldots \ldots \ldots \ldots \ldots \ldots \ldots \ldots 11+115,122$, pl. 26 elegans $\ldots \ldots \ldots \ldots \ldots \ldots \ldots \ldots 57,68,81,105,108,109,123-125,130$

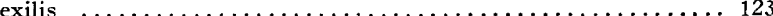

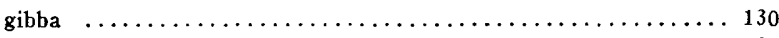
marginata $\ldots \ldots \ldots \ldots \ldots \ldots \ldots \ldots \ldots \ldots \ldots \ldots \ldots \ldots \ldots \ldots, 120$ elegantissima $\ldots \ldots \ldots \ldots \ldots \ldots \ldots \ldots \ldots \ldots \ldots . \ldots, 67,68,69,130$ apiculata $\ldots \ldots \ldots \ldots \ldots \ldots \ldots \ldots \ldots \ldots \ldots \ldots \ldots, 64,130$ compressa $\ldots \ldots \ldots \ldots \ldots \ldots \ldots \ldots \ldots \ldots \ldots \ldots \ldots, 130$ fusiformis $\ldots \ldots \ldots \ldots \ldots \ldots \ldots \ldots \ldots \ldots \ldots \ldots \ldots, 130$ ellipsoides $\ldots \ldots \ldots \ldots \ldots \ldots \ldots \ldots \ldots \ldots \ldots \ldots \ldots \ldots, 107,125$ elongata........... $83,88,90,101,102,108-109,115,122,123,125$, $126,131, \mathrm{pl} .25$ ariminensis $\ldots \ldots \ldots \ldots \ldots \ldots \ldots \ldots \ldots \ldots \ldots \ldots \ldots \ldots \ldots \ldots, 125$ cylindrica $\ldots \ldots \ldots \ldots \ldots \ldots \ldots \ldots \ldots \ldots \ldots \ldots \ldots \ldots \ldots \ldots \ldots \ldots \ldots \ldots, 130$ lappa $\ldots \ldots \ldots \ldots \ldots \ldots \ldots \ldots \ldots \ldots \ldots \ldots \ldots \ldots, 109-110,115$, pl. 25 subulata $\ldots \ldots \ldots \ldots \ldots \ldots \ldots \ldots \ldots \ldots \ldots \ldots \ldots, 109,122$, pl. 26 tenera $\ldots \ldots \ldots \ldots \ldots \ldots \ldots \ldots \ldots \ldots \ldots \ldots \ldots \ldots \ldots \ldots \ldots \ldots \ldots$, pl. 25

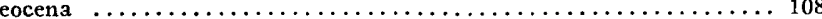

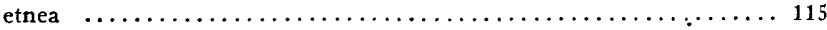
excavata $\ldots \ldots \ldots \ldots \ldots \ldots \ldots \ldots \ldots \ldots \ldots \ldots \ldots \ldots \ldots,{ }^{2}, 22$ exigua $\ldots \ldots \ldots \ldots \ldots \ldots \ldots \ldots \ldots \ldots \ldots \ldots \ldots \ldots \ldots, 81$, pl. 19 exilis $\ldots \ldots \ldots \ldots \ldots \ldots \ldots \ldots \ldots \ldots \ldots \ldots \ldots \ldots \ldots \ldots \ldots \ldots \ldots \ldots \ldots$, pl. 28

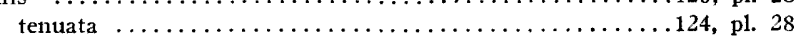

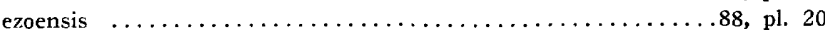
fijiensis $\ldots \ldots \ldots \ldots \ldots \ldots \ldots \ldots \ldots \ldots \ldots \ldots \ldots \ldots \ldots \ldots \ldots \ldots, 127$, pl. 29 flexa $\ldots \ldots \ldots \ldots \ldots \ldots \ldots \ldots \ldots \ldots \ldots \ldots \ldots \ldots \ldots, 130$ forticosta $\ldots \ldots \ldots \ldots \ldots \ldots \ldots \ldots \ldots \ldots \ldots \ldots \ldots \ldots \ldots \ldots \ldots \ldots, 137$ fossa $\ldots \ldots \ldots \ldots \ldots \ldots \ldots \ldots \ldots \ldots \ldots \ldots \ldots \ldots \ldots \ldots \ldots \ldots \ldots \ldots \ldots \ldots \ldots \ldots \ldots \ldots$, pl. 27

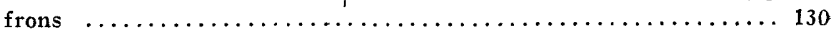
fusiformis $\ldots \ldots \ldots \ldots \ldots \ldots \ldots \ldots \ldots \ldots \ldots \ldots \ldots \ldots \ldots, 108,125$ baccata $\ldots \ldots \ldots \ldots \ldots \ldots \ldots \ldots \ldots \ldots \ldots \ldots \ldots \ldots \ldots \ldots \ldots \ldots, 125$ marginata $\ldots \ldots \ldots \ldots \ldots \ldots \ldots \ldots \ldots \ldots \ldots \ldots \ldots \ldots \ldots \ldots \ldots \ldots \ldots, 120$ pupoides $\ldots \ldots \ldots \ldots \ldots \ldots \ldots \ldots \ldots \ldots \ldots \ldots \ldots \ldots \ldots \ldots \ldots \ldots \ldots, 108$

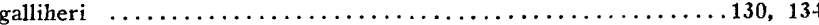
garzaensis $\ldots \ldots \ldots \ldots \ldots \ldots \ldots \ldots \ldots \ldots \ldots \ldots . \ldots \ldots 4-95,99$, pl. 22 gibba $\ldots \ldots \ldots \ldots \ldots \ldots \ldots \ldots \ldots 109,116,121,125,130$, p1s. 28,29 marginata

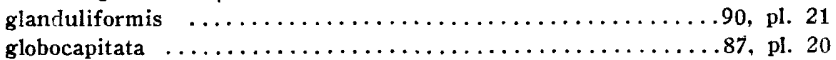
gracilis $\ldots \ldots \ldots \ldots \ldots \ldots \ldots \ldots \ldots \ldots \ldots \ldots \ldots \ldots \ldots \ldots, 108,109$ 


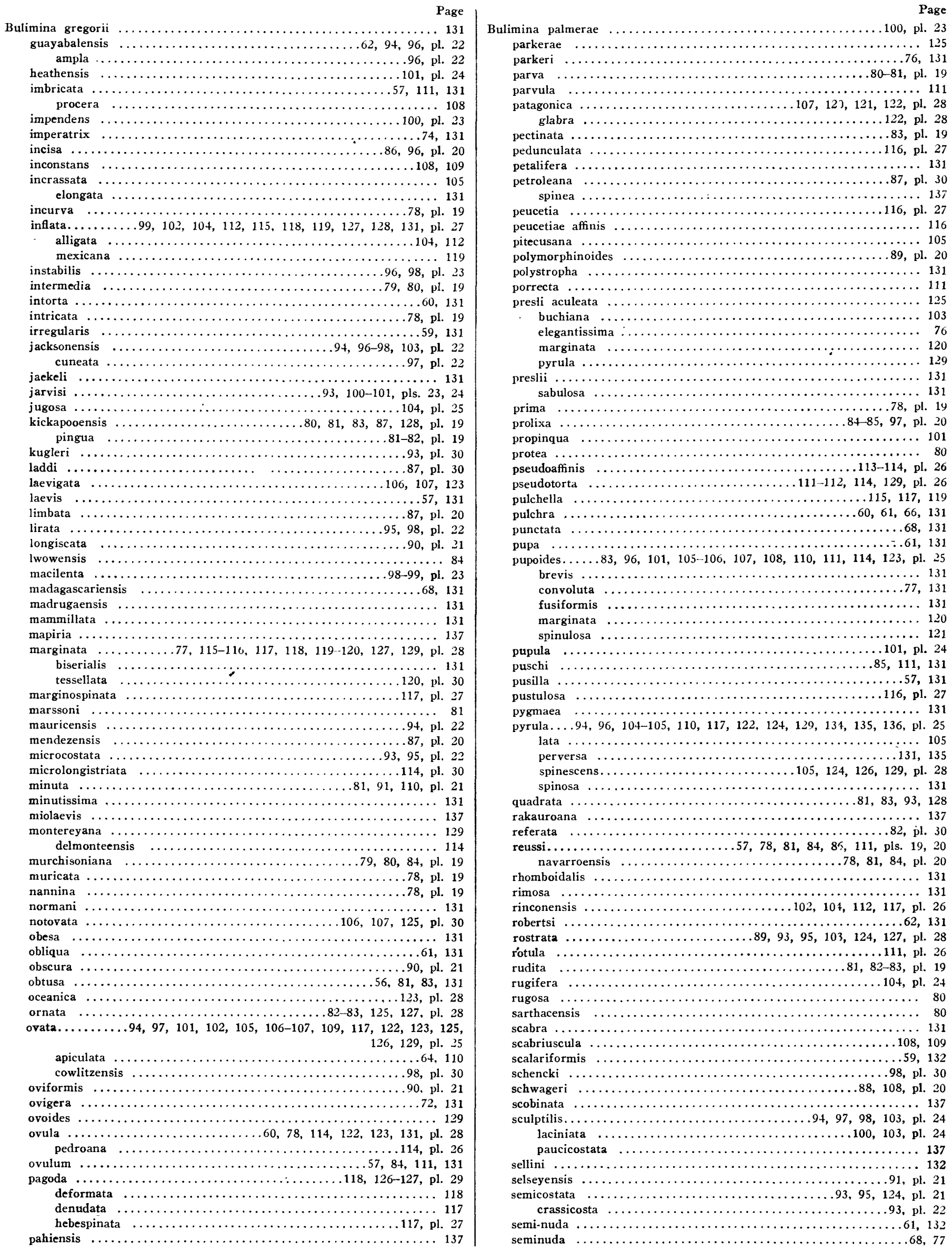


Bulimina semistriata

Page

$$
\text { senta }
$$

serrata

simaensis

simplex

socialis

speciosa

spinata

spinifera

spinosa

splendens

squammiger

stalacta

stokesi

striata

mexicana

striato-punctata

subacuminata

subaffinis

subbulbifotmis

subcalva

subcylindrica

subdeclivis

subornata.

subsphaerica

subteres

sulcata

tabascoensi

tarca

taylorensis

tenera

tenuistriata

terquemiana

textilariformis

thanetensis

torta

tortilis

triangularis

trigona

trigonalis

trigonula inornat

trihedra

trilobata

trinitatensis

triquetra

trocheata

truncana.

aksuatica

angusta

denticulata

truncanella

truncata

tuberculata

tumida

turbinata

turgida

tuxpamensis

uva ........

uvigerinaform

variabilis .

velascoensis

ventricosa

versa

whitei

williamsonian

winniana

(Desinobulimina)

auriculata

illingi

montereyan

quadrata

suteri

turgida

(Ellipsobulimina) quadrata

sp....

Buliminell

alabamensis

.106, 107

. 137

137 $\ldots 96,102, \mathrm{pl} .24$ $86-87,99$, .109, 131 ..121, pl. 28 $99,100,102$, pl. 23 118,119 , pl. 28 $18,119,128$, pl. 28 $\ldots \ldots \ldots \ldots \ldots 61,132$ 17 , pl. 27
26, pl. 29 $\ldots \ldots .132$ $\ldots 75,132$

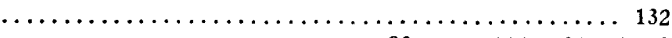
$\ldots \ldots \ldots \ldots \ldots \ldots \ldots, 132$ $74,75,76,132$ $\ldots \ldots \ldots .132$ , pls. 20,21 $.82,86$, pl. 19 $\ldots \ldots .109$ $\ldots 91$, pl. 21 $\ldots 61,132$ $\ldots \ldots 132$ 25-126, pl. 29 .85, pl. 20 ..82, pl. 19 1, 132, pl. 21 $\ldots \ldots \ldots 132$ $.120,132$, pl. 28

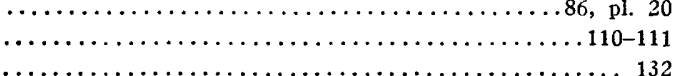
. 137 9, 99 
D

Page

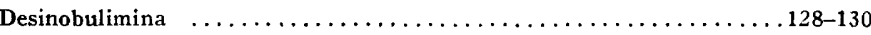

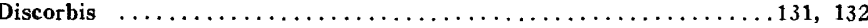

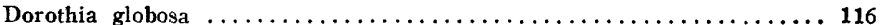

$\mathbf{E}$

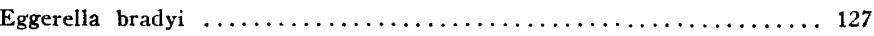

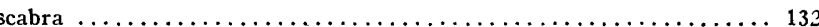

Entosolenia $\ldots \ldots \ldots \ldots \ldots \ldots \ldots \ldots \ldots \ldots \ldots \ldots \ldots \ldots \ldots \ldots \ldots, 77$

Gaudryina velascoensis $\ldots \ldots \ldots \ldots \ldots \ldots \ldots \ldots \ldots \ldots \ldots \ldots \ldots, 85$ Globobulimina.................105, 124, 126, 133-136, pls. 29, 30

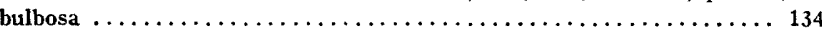

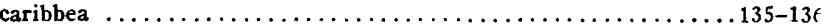

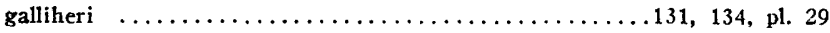

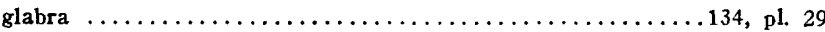

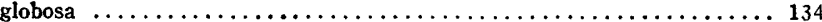

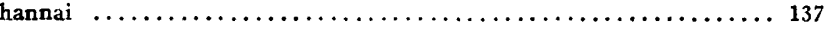
pacifica.................... 29

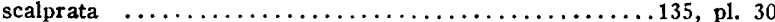

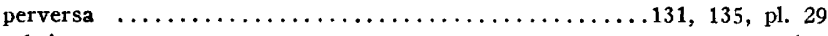

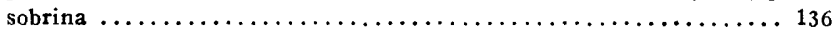

$\mathbf{N}$

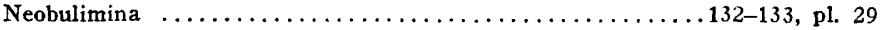
canadensis $\ldots \ldots \ldots \ldots \ldots \ldots \ldots \ldots \ldots \ldots \ldots \ldots \ldots \ldots 132-133$, pl. 29

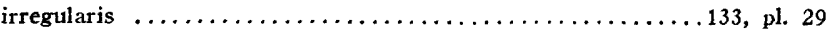

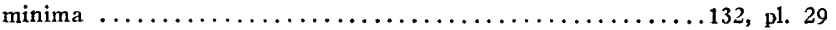
spinosa $\ldots \ldots \ldots \ldots \ldots \ldots \ldots \ldots \ldots \ldots \ldots \ldots \ldots \ldots \ldots \ldots \ldots \ldots \ldots \ldots \ldots \ldots \ldots$, pl. 29

$\mathbf{P}$

Pernerina depressa $\ldots \ldots \ldots \ldots \ldots \ldots \ldots \ldots \ldots \ldots \ldots \ldots \ldots \ldots \ldots \ldots$ 130, 131

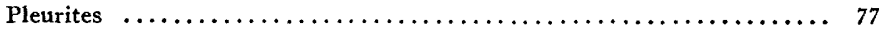

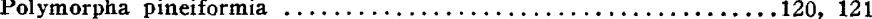

Pseudobulimina $\ldots \ldots \ldots \ldots \ldots \ldots \ldots \ldots \ldots \ldots \ldots \ldots \ldots \ldots \ldots 76-77$, pl. 18 chapmani $\ldots \ldots \ldots \ldots \ldots \ldots \ldots \ldots \ldots \ldots \ldots \ldots \ldots \ldots 76-77,130$, pl. 18 convoluta $\ldots \ldots \ldots \ldots \ldots \ldots \ldots \ldots \ldots \ldots \ldots \ldots \ldots \ldots \ldots \ldots \ldots, 131$

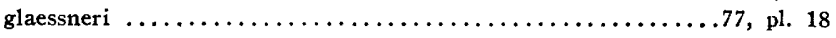

Robertina $\ldots \ldots \ldots \ldots \ldots \ldots \ldots \ldots \ldots \ldots \ldots \ldots \ldots \ldots .71-76,131$, pl. 18 angusta $\ldots \ldots \ldots \ldots \ldots \ldots \ldots \ldots \ldots \ldots \ldots \ldots \ldots \ldots \ldots \ldots \ldots \ldots \ldots \ldots \ldots, 73$, pl. 18 arctica.......................71, 74, 75, 76, pl. 18

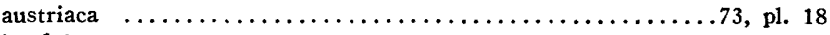
bradyi $\ldots \ldots \ldots \ldots \ldots \ldots \ldots \ldots \ldots \ldots \ldots \ldots \ldots \ldots \ldots \ldots$, pl. 18

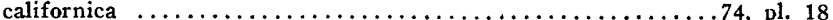

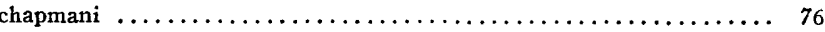
charlottensis $\ldots \ldots \ldots \ldots \ldots \ldots \ldots \ldots \ldots \ldots \ldots \ldots \ldots \ldots \ldots \ldots$, pl. 18

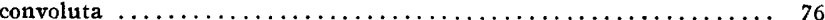

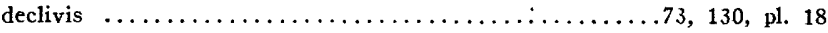

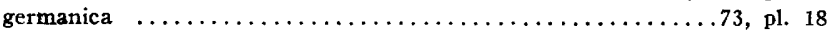
imperatrix $\ldots \ldots \ldots \ldots \ldots \ldots \ldots \ldots \ldots \ldots \ldots \ldots \ldots \ldots, 14,131$, pl. 18
Pagc

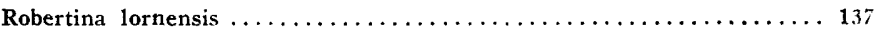
mcguirti $\ldots \ldots \ldots \ldots \ldots \ldots \ldots \ldots \ldots \ldots \ldots \ldots \ldots \ldots \ldots \ldots . \ldots \ldots$, pl. 18

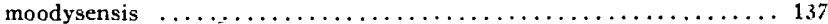

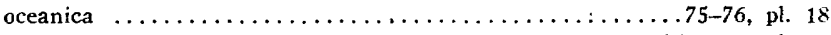

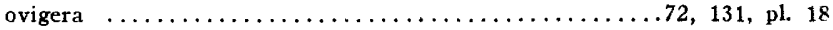
parkeri $\ldots \ldots \ldots \ldots \ldots \ldots \ldots \ldots \ldots \ldots \ldots \ldots \ldots \ldots \ldots, 131$, pl. 18

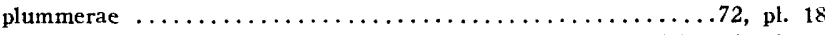
subcylindrica $\ldots \ldots \ldots \ldots \ldots \ldots \ldots \ldots \ldots \ldots \ldots \ldots \ldots \ldots 75,132$, pl. 18 subteres $\ldots \ldots \ldots \ldots \ldots \ldots \ldots \ldots \ldots \ldots \ldots \ldots \ldots \ldots, 76,132$, pl. 18

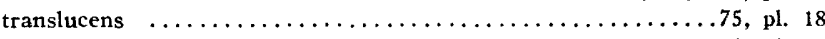

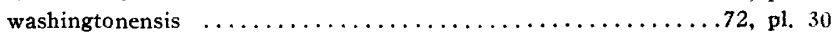
wilcoxensis $\ldots \ldots \ldots \ldots \ldots \ldots \ldots \ldots \ldots \ldots \ldots \ldots \ldots \ldots 71-72,73$, pl. 18

S

Suggrund 1.31

Terebralina $\ldots \ldots \ldots \ldots \ldots \ldots \ldots \ldots \ldots \ldots \ldots \ldots \ldots \ldots \ldots \ldots \ldots 55-56$, pl, 15

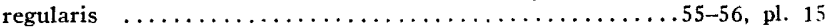

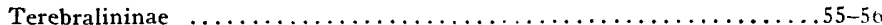

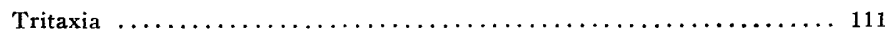
minuta $\ldots \ldots \ldots \ldots \ldots \ldots \ldots \ldots \ldots \ldots \ldots \ldots \ldots \ldots \ldots \ldots \ldots \ldots, 110$

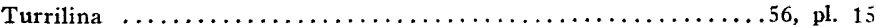

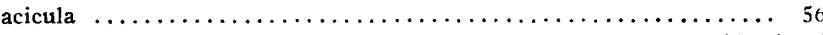

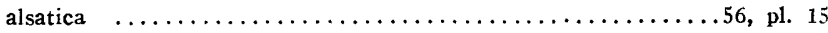

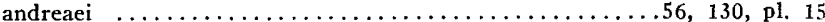

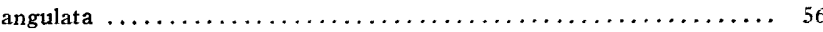

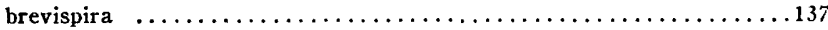

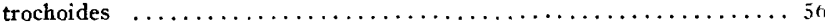

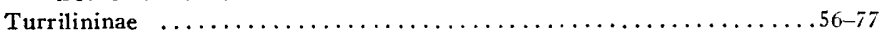

Ungulatella $\ldots \ldots \ldots \ldots \ldots \ldots \ldots \ldots \ldots \ldots \ldots \ldots \ldots \ldots \ldots . \ldots \ldots+71$, pl. 17

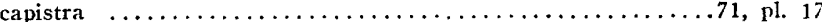

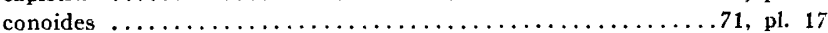

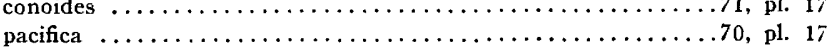

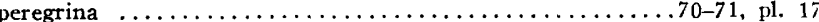

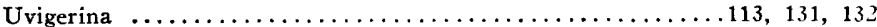

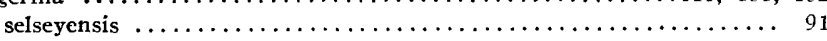

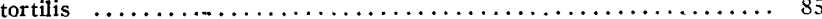

$\mathrm{V}$

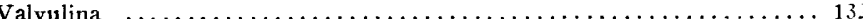

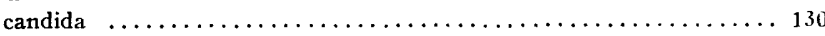

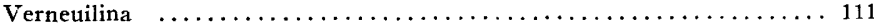

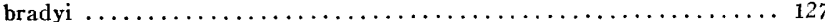

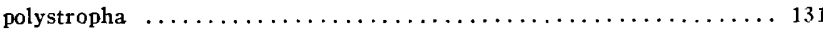

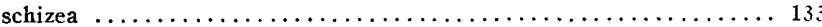

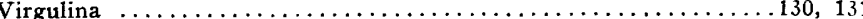

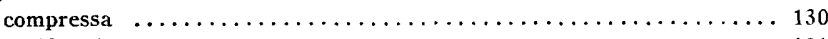

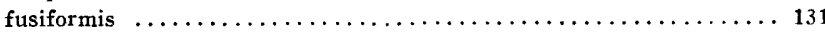

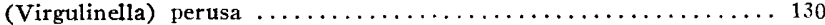


UNITED STATES DEPARTMENT. OF THE INTERIOR

J. A. Krug, Secretary

GEOLOGICAL SURVEY

W. E. Wrather, Director

Professional Paper 210-E

\title{
NEW UPPER CRETACE0US FOSSILS \\ FR0M MISSISSIPPI AND TEXAS
}

\author{
PART 1. FOSSILS FROM TWO DEEP WELLS \\ IN MISSISSIPPI \\ PART 2. A VENERICARDIA FROM UVALDE \\ COUNTY, TEXAS
}

BY

\section{LLOYD WILLIAM STEPHENSON}

Shorter contributions to general geology, 1946

(Pages 161-198)

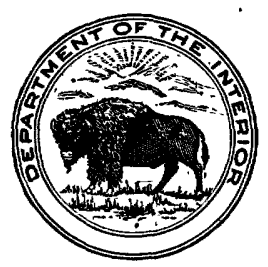

UNITED STATES

GOVERNMENT PRINTING OFFICE

WASHINGTON : 1947

For sale by the Superintendent of Documents, U. S. Government Printing Office, Washing ton 25, D. C. 


\section{CONTENTS}

Abstract (Parts 1 and 2)

Part 1. Fossils from two deep wells in Mississippi...... Introduction . . . . . . . . . .

McRae No. 1 well in Hinds County Location and other pertinent data.......... Fossiliferous cores.......................... List of fossils Correlation . . . . . . . .

Av̀ent No. 1 well in Grenada County Location and other pertinent data...........

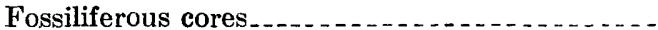

List of fossils...................

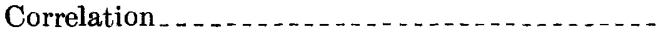

Systematic descriptions ..........................

Fossils from the McRae well ............

Kingdom Animalia....................

Phylum Coelenterata............

Phylum Echinodermata.
Page

161

161

161

161

161

162

162

162

163

163

163

163

164

164

164

164

164

165
Part 1-Continued.

Systematic descriptions-Continued.

Fossils from the McRae well-Continued.

Kingdom Animalia-Continued.

Phylum Molluscoidea..............

Phylum Mollusca........ ..........

Kingdom Plantae......................

Fossils from the Avent well . . . . . . . . . . .

Kingdom Animalia.

Phylum Annelida

Phylum Molluscoidea_............. 170

Phylum Mollusca................. 170

Part 2. A new Venericardia from Uvalde Courty, Tex

Introduction . . . . . . . . . . . . . . . . . 185

Systematic description $\ldots 186$

Venericardia uvaldana ................... 186

Bibliography............... 187

Index _.

\section{ILLUSTRATIONS}

Plate 31. Fossils from the Avent and McRae wells in Mississippi, and a new Venericardia from Uvalde County, Tex

32. Fossils from the Avent well in Mississippi.

33. Fossils from the Avent well in Mississippi 


\title{
NEW UPPER CRETACEOUS FOSSILS FROM MISSISSIPPI AND TEXAS
}

\author{
By Lloyd William Stephenson
}

\begin{abstract}
In Part 1 macrofossils of Upper Cretaceous age found in core samples from two deep wells in Mississippi, one in Hinds County and the other in Grenada County, are described. Two cores taken from depths of 3,931 to 3,937 feet and 3,970 to 3,980 feet in McRae No. 1 well in Hinds County yielded previously undescribed molluscan species as follows: Vetoarca hindsana (n. gen. and n. sp.), Postligata monroei, Anomia microlirae, Venericardia subterrea, and Odostomia meraei. One core from depths of 2,730 to 2,750 feet in Avent No. 1 well in Grenada County yielded the following new molluscan species: Nucula nullu, Postligata aventi, Trigonarca munda, Anomia acutilinearis, Crassatella subterrestris, Cardium (Trachycardium) grenadense, Fulpia? subtrigona, Tellina harrelli, Spisula brevis, Caryocorbula mississippiana, Caryocorbula morsei, Nerita nodosa, Nerita denticulata, Melanella (EuTima?) parva, Turritella toleri, Turritella magnoliana, "Cerithium" imlayi, Pugnellus calcaris, and Paladmete caveola. One previously described species, Hamulus ony Morton (a worm tube), was identified in this well. In the

cores from both wells poorly preserved specimens of several genera, which are specifically unidentified, were obtained. The paleontologic evidence is interpreted to indicate the early Taylor (=early Demopolis) age of the two cores from the McRae well in Hinds County, and the late Austin (=Eutaw) age of the core from the Avent well in Grenada County.

In Part 2 a new bivalve species, Venericardia uvaldana, from the lower part of the Anacacho limestone of Uvalde County, Tex., is described. It is closely related to the species, $V$. subterrea Stephenson, from core samples at depths of 3,931 to 3,937 feet and 3,970 to 3,980 feet in the oil-prospecting well, McRae No. 1, in Hinds County, Miss. Because of the close biologic relationship of the two species and considering the rarity of the genus Venericardia in the American Cretaceous, the evidence is believed to favor the approximate syupchroneity of the bed containing $V$. uvaldana in Uvalde County with the beds cortaining V. subterrea in Hinds County.
\end{abstract}

\section{PART 1. FOSSILS FROM TWO DEEP WELLS IN MISSISSIPPI}

\section{INTRODUCTION}

Upper Cretaceous fossils from two deep wells in Hinds and Grenada Counties, Miss., have been submitted to me for identification and study. They are chiefly mollusks and are in part well-preserved. Preliminary lists of the recognizable forms have been prepared and submitted, through the Geological Survey, to the persons who furnished the materials. The fossils are from core samples and are of particular interest because most of them belong to undescribed species; all but one of the species are referred to previously. described genera, some of them, however, provisionally or questionably. One new genus is described. The assemblage from each well appears to be a heretofore unrecorded facies fauna. Most geologists interested in the subsurface geology of Mississippi have regarded the fossil-bearing cores from the well in Grenada County as of the age of the upper part of the Eutaw formation of the eastern Gulf region and the upper part of the Austin chalk of Texas, and the paleontologic evidence here presented tends to confirm that correlation. There has been less certainty about the age of the fossil-bearing cores from the well in Hinds County, but paleontologic evidence is now available which suggests that they correspond in age to the lower part of the Taylor marl of central Texas and to the lower part of the Anacacho limestone of Uvalde County, Tex.

The cores from these two wells demonstrate the possibilities afforded by core samples for obtaining identifiable macrofossils and suggest that a great amount of valuable stratigraphic data has been and is being overlooked and lost because of failure to have core samples studied by qualified paleontologists. Many micropaleontologists are on the company pay rolls, but only rarely have the services of specialists in macrofossils been used by the companies in subsurface investigations.

\section{McRAE NO. 1 WELL IN HINDS COUNTY}

\section{LOCATION AND OTHER PERTINENT DATA}

The well in Hinds County is known as Baker, Ridgway, et al., McRae No. 1 and is located in SE1/4 SW1/4NW $1 / 4$ sec. 24 , T. 7 N., R. 1 W., about 10 miles nortlnorthwest of the center of Jackson. The elevation above sea level at the mouth of the well is recorded $\varepsilon \mathrm{s}$ 319 feet (plane-table determination). Drilling wes begun on November 9,1933 , and the well was completed December 28, 1933, at a total depth of 3,981 feet. It has been abandoned as a nonproducer. Sedimentary rocks of Tertiary age were penetrated to a depth of 3,456 feet, where the first rock of Cretaceous age was encountered. The latter, generally known as the gas rocl, 
is considered by the company geologists to be of the age of the Navarro group of Texas.

Core samples were taken in the lower part of the hole as follows: $3,360-3,364$ feet; $3,441-3,446$ feet; 3,484 feet (four cores, presumably meaning that four core samples were taken between depths of 3,484 and 3,884 feet) ; 3,884-3,892 feet; and 3,909-3,981 feet. The fossiliferous core samples submitted for study were labeled as coming from depths of 3,931 to 3,937 feet and 3,970 to 3,980 feet; the diameter of each of these samples was about $15 / 8$ inches.

The core taken at a depth of 3,884 to 3,892 feet was logged by the driller as chalk; presumably this is the basal bed of the Selma chalk, as that unit is generally interpreted in this part of the Gulf region by the company geologists and the drillers. The cores taken between depths of 3,909 feet and the bottom of the hole at 3,981 feet were logged as "packed sand," and the two fossiliferous cores fall within the limits of this so-called packed sand. The fossiliferous materials were submitted to the United States Geological Survey by $\mathbf{M r}_{\mathrm{r}}$. George C. Swearingen, State Oil and Gas Supervisor, of Jackson, Miss., in January 1934, through Mr. Watson H. Monroe, of the Federal Survey.

\section{FOSSILIFEROUS CORES}

The fossiliferous core taken between depths of 3,931 and 3,937 feet is a water-laid, tuffaceous, calcareous rock of only moderate hardness and is essentially similar in its lithology to the more richly fossiliferous core at the lower depth. It yielded the following bivalve fossils (U. S. G. S. 18883) : Vetoarca hindsana, Postligata monroei, Venericardia subterrea, and Tenea? sp. All these species are present also in the core from the lower depth $(3,970-3,980$ feet $)$.

The core that yielded the greater number of the fossils was taken between depths of 3,970 and 3,980 feet. This rock is a heterogeneous aggregate of volcanic rock grains, some sharply angular, some rounded in greater or less degree. Scattered through the rock are occasional well-rounded pebbles of altered igneous rock, the largest one measured being $13 \mathrm{~mm}$. long. The rock is calcareous, as evidenced by its active effervescence in cold hydrochloric acid. A piece of the core was examined by Dr. C. S. Ross, of the Geological Survey, who describes it as follows:

Composed largely of igneous rock and mineral grains. The rock grains are in part andesitic in character, but in general they are characterized by a very fine-grained or glassy groundmass, now completely replaced by secondary minerals. Many of them are markedly vesicular, being characterized by abundant rounded gas bubbles. The rock is marked by a larger proportion of ferromagnesian minerals than the Grenada specimen. The indeterminable character of the groundmass and the thorough alteration make the original character of the rock somewhat doubtful, but it seems to have been andesitic and phonolitic materials. The volcanic mineral grains are especially abundant and comprise sodic amphiboles, brown hornblende,- biotite, sphene, and potassic feldspar. Amphiboles have been partly or completely replaced by calcite, and brown hornblende has been partly replaced. All mineral grains are surrounded by rims of a clay mineral, probably a high iron saponite. A little glauconite is present, but quartz and others of the common detrital minerals are almost absent.

\section{IIST OF FOSSILS}

Fossils were obtained from the lower core as listed below (U. S. G. S. 18884) :

Fossils from core sample from depth 3,970-3,980 feet, McRae No. 1 well

Animalia :

Coelenterata :

Fragment of madreporarian coral, ind terminate.

Echinodermata:

Fragments of small unidentified crinoid stems.

Molluscoidea :

Two fragments of a bryozoan of the order Cheilostomata (identified by Dr. R. S. Bassler).

Mollusca :

Pelecypoda :

Barbatia? sp.

Vetoarca hindsana $n$. sp.

Postligata monroei $\mathrm{n}$. sp.

Inoceramus sp.

Anomia microlirae n. sp.

Venericardia subterrea n. sp.

Tenea? sp.

Gastropoda :

Turritella sp.

"Cerithium" sp.

Odostomia meraei n. sp.

Plantae:

Hollow stems believed to belong to a species of marine algae.

\section{CORRELATION}

The fact that the identifiable species in the cores from the two depths, as just recorded, are all new detracts from their value in determining the age of the cores with respect to better-known sections elsewhere. However, two of the forms listed appear to posses some correlative value. Inoceramus sp. belongs to a form of the genus that is not found in beds older than the upper part of the Austin chalk but ranges into higher beds as, for example, the Taylor marl and its age equivalents. $V$ enericardia subterrea is a close analog of $V$. uvaldana Stephenson, a new species from Uvalde County, Tex., described in Part 2 of this report (p. 185). These two forms, though closely related, appear to differ from each other sufficiently to justify their specific separation. $V$. uvaldana is from the Anacacho limestone, probably a basal bed of that formation.

The Anacacho limestone is of Taylor age but has not been deternined to represent all the Taylor of central Texas. So far as it goes the paleontologic evidence seems to favor the early Taylor age (=exrly Demopolis age) of the two fossil-bearing cores in the McRae well, but the evidence is admittedly meager, since the stratigraphic range of Venericardia subterrea is not known. 
If the differences noted between $V$. subterrea and $V$. uvaldana (p. 187) represent evolutionary changes in time rather than provincial differences, then the two species would differ somewhat, although probably not greatly, in age.

Although the fossiliferous core samples from the McRae well resemble those from the Avent well in Grenada County both in lithologic character and in origin, no fossil species are common to the two wells. The paleontologic evidence would seem to indicate that they are not of exactly the same age. Water-laid volcanic rocks resembling one another but differing in age are wellknown in the western Gulf region.

In addition to the fossils from the McRae No. 1 well described in this paper, one species of Foraminifera, Pseudorbitoides israelski Vaughan and Cole, represented by numerous individuals, has been recorded by Vaughan and Cole $(1943$, p. 98) from a slightly shallower position, depth $3,909-3,922$ feet in the same well. The material was submitted for identification by $\mathrm{Mr}$. W. H. Monroe in 1942. Apparently this material also came from the so-called packed sand of the drillers. Data on the occurrence of the same species in the lower part of the Taylor marl in a well in Louisiana, in the lower part of the Anacacho limestone in wells in Zavalla and Uvalde Counties, Tex., at the surface in Kinney County, Tex., and at an equivalent stratigraphic position at the surface in southern Petén, Guatamala, are given by Vaughan and Cole in an earlier paper (1932, pp. 615, 616).

\section{AVENT NO. 1 WELL IN GRENADA COUNTY}

\section{LOCATION AND OTHER PERTINENT DATA}

The well in Grenada County was drilled by the Adams Oil \& Gas Co. and is known as Avent No. 1. It is located in the center of NE $1 / 4 \mathrm{NE}^{1} / 4 \mathrm{NW}^{1} / 4$ sec. $26, \mathrm{~T} .22 \mathrm{~N}$., R. 4 E., about 2 miles southwest of Grenada. The elevation at the mouth of the well is reported to be 304 feet above sea level. The well was completed and abandoned as a nonproducer December 7, 1942, at a total depth of 4,031 feet. No complete log of the well is available, but the geologists of several of the oil companies agree in placing the Cretaceous-Tertiary contact at a depth of 1,840 feet. The companies do not agree as to the exact depth at which the top of the Eutaw formation was encountered, but most of them agree within a range of 5 feet, placing the Eutaw-Selma contact between depths of 2,725 and 2,730 feet, and at least one company places this contact as deep as 2,740 feet.

\section{FOSSILIFEROUS CORES}

The core samples that yielded the fossils listed and described in this paper were $23 / 4$ inches in diameter and were labeled as coming from between depths of 2,730 and 2,750 feet, but their exact position within this range of 20 feet was not indicated. The piece of core (No. 5) from which more than half of the fossils were ol. tained (U. S. G. S. 18894) was presented to the Uniter States Geological Survey by Mr. David Harrell, district geologist of the Carter Oil Co. through Dr. Ralph W. Imlay, geologist of the Federal Survey. This core sample was 8 or 9 inches long and consisted of water-lajd and more or less water-worn fragments of volcanic rock, including scattered smoothly worn igneous pebbles up to half an inch or more in diameter, considerable glauconite, and many shells and fragments of shells. Most of the shells and fragments are water-worn in greater or less degree, though a goodly number were not seriously damaged, and $\dot{a}$ few are nearly perfect. A small samp ${ }^{l_{0}}$. of this rock was examined by Dr. C. S. Ross, who describes it as follows:

Composed dominantly of well-rounded volcanic rock fragments up to 5 millimeters in diameter. These are in general andesitic in character, but others are probably phonolites. The feldspar is nearly fresh, but sparse ferromagnesian minerals are altered to calcite. A few feldspar grains which represent volcanic rock phenocrysts are present, but ferromagnesian mineral grains are sparse or absent. Glauconite is abundant.

Irregularly distributed through the rock and often closely associated with the shells are stringers, sheets, and patches of secondary calcite, which in certain spots has been replaced by silica to form a pale bluish-gray variety of chalcedony; the calcite may commonly be seen coating the exterior or filling the interior cavities of the shells.

A second piece of this core (depth 2,730-2,750 feet.) 4 or 5 inches long was presented by Mr. Frederic T. Mellen through Mr. W. H. Monroe, geologist of the Federal Survey (U. S. G. S. 18930). Though not so prolific as the preceding samples, it nevertheless yielded a goodly number of fossils. Lithologically it is essentially like the first sample; one smoothly rounded igneous pebble, which was cut away at one end by the cors barrel, was originally more than an inch in length.

\section{LIST OF FOSSILS}

The list of fossils given below includes those obtained from both the core samples just described (U. S. G. S. $18894,18930)$.

Fossils from core samples from depth 2,730-2,750 feet, Avent well No. 1

Annelida :

Serpula sp.

Hamulus onyx Morton.

Molluscoidea :

Membranipora sp.

Mollusca :

Pelecypoda :

Nucula nulla n. sp.

Barbatia? sp.

Breviarca sp.

Postligata aventi n. sp.

Trigonarca munda n. s1 
Fossils from core samples from depth 2,730-2,750 feet, Avent well No. 1-Continued

Mollusca-Continued.

Pelecypoda-Continued.

Pteria? sp.

Inoceramus sp.

Ostrea sp.

Exogyra? sp.

Pecten (Camptonectes) sp.

Anomia acutilinearis n. sp.

Volsella sp.

Etea? sp.

Crassatella subterrestris n. sp.

Cardium (Trachycardium) grenadense n. sp.

Fulpia? subtrigona n. sp.

Aphrodina sp.

Tellina harrelli $\mathrm{n}$. sp.

Tellina? sp. $a$.

Tellina? sp. $b$.

Tellina? sp. $c$.

Linearia sp.

Protodonax sp.

Spisula brevis 1. sp.

Caryocorbula mississippiana n. sp.

Caryocorbula morsei n. sp.

Caryocorbula sp. $a$.

Caryocorbula sp. $b$.

Caryocorbula sp. $c$.

Coryocorbula sp. $\boldsymbol{d}$.

Scaphopoda :

Dentalium sp.

Gastropoda :

Nerita nodosa $\mathrm{n}$. sp.

Nerita denticulata $n$. $s p$.

Melanella (Eulima?) parva 11. sp.

Natica sp.

Natica? sp.

Turritella toleri $\mathrm{n}$. sp.

Turritella magnoliana $n$. sp.

"Cerithium" imlayi n. sp.

"Cerithium" sp. a.

"Cerithium" sp. $b$.

Pugnellus calcaris n. sp.

Hercorhyncus? sp.

Paladmete caveola n. sp.

Paladmete? sp.

"Fusinus" sp.

\section{CORRELATION}

Only one of the species obtained from the Avent cores, the marine worm Hamulus onyx Morton, is referred to a previously described species. It has a long range in the Upper Cretaceous series but has not been recorded from beds older than the upper part of the Austin chalk of that series. Nineteen new species of mollusks are described, including 11 pelecypods and 8 gastropods. About 25 genera of mollusks are too poorly preserved to justify giving them specific names. Most of them probably belong to undescribed species.

Certain of the forms listed suggest a close age relationship of the Avent cores to fossiliferous water-laid volcanic rock appearing at the surface in a small outcrop on the west flank of Prothro salt dome in NE1/4 sec. 18 and SE1/4 sec. 7, T. 14 N., R. 6 W., 4 miles northwest of Saline, Bienville Parish, La. (See Spooner, 1926, pp. 245-252.) The fossils from this locelity have had their shell substance replaced by crystalline calcite, which causes them to break and crumble readily along cleavage planes. It is therefore difficult to compare them critically with fossils from the Avent well. One of the forms from the Avent well is Inoceramus sp. (pl. 32 , fig. 37), which is closely analogous to several speciInens from the Prothro dome locality; another is $\mathrm{Car}$ dium (Trachycardium) grenadense (pl. 32, figs. 3436), also closely analogous to a species there; and several poorly preserved specimens of Pugnellus from Prothro dome, though perhaps not specific lly identical, certainly represent a species that is a close analog of Pugnellus calcaris (pl. 33, figs. 25-32).

The specimen of Inoceramus to which reference was made above is a close analog also of a form of the genus found in a hard calcareous, concretionary sandstone at the top of the Tokio formation a mile north of Ben Lomond, Sevier County, Ark. (Dane, 1929, p. 41, pl. 8, fig. 1). Both the fossiliferous. rock at this locality and that at the Prothro dome locality have been correlated with the Blossom sand of northeastern Texas, which in turn is correlated with the upper part of the Austin chalk (Dane, 1929, p. 42; Rusiell, 1941, pp. 32-34).

It would appear, therefore, from the paleontologic evidence that the fossiliferous cores from the Avent well are of the age of the upper part of the Austin chalk. There has been general agreement among the company geologists that the Avent cores are of Eutaw age. The larger fossils do not at present afford a direct paleontologic tie with the Eutaw formation in outcrops, but the upper part of the Eutaw (Tombigbee sand member) has been shown to be of upper Austin age on satisfactory paleontologic grounds (Stephenson and Monroe, 1940, pp. 69, 242).

\section{SYSTEMATIC DESCRIPTIONS}

FOSSILS FROM THE McRAE VTELL

Kingdom ANIMAIIA

Phylum COELENTERATA

Subphylum CNIDARIA

Class ANTHOZOA

Subclass HeXacoRALIA

Order MADREPORARIA.

The Coelenterata are represented in the McRae No. 1 well by one small water-worn fragment of a proportionately rather tall madreporarian ccral. Prior to fossilization it was first subjected to wear on a beach, which destroyed the external features, snd it was subsequently broken, revealing the irregular features of the narrow columella and the arrangement of the tuber- 
cles on the side of one septum (pl. 31, fig. 17). The specimen is too incomplete for generic or specific assignment. The height of the fragment is $6.5 \mathrm{~mm}$.

Occurrence: McRae No. 1 well, Hinds County, depth 3,970-3,980 feet. U. S. N. M. 103984 (U. S. G. S. $1888 \pm$ ).

\section{Phylum ECHINODERMATA}

\section{Subphylum PELMATOZ0A}

\section{Class CRINOIDEA}

The core sample yielded several fragments of the columns of an unclassified crinoid (pl. 31, figs. 18, 19), concerning which Dr. Edwin Kirk, of the Geological Survey, says:

These fragments of columns are not referable to any known genus. They are circular in section, with a circular lumen. The diameter of an average columnal is $1 \mathrm{~mm}$. and its height, $0.17 \mathrm{~mm}$. The side faces are somewhat convex. The joint face is plane and is traversed by strong radiating ridges, some of which increase by dichotomy toward the periphery. There seem to be about 20 primary ridges. Externally tre suture line is somewhat depressed and is marked by a series of sharply incised pits, separated by short vertical ridges. This gives the column a very unusual and characteristic ornamentation.

Occurrence: McRae No. 1 well, Hinds County, depth $3,9 \pi 0-3,980$ feet. U. S. N. M. 103985 and 103986 (U. S. G. S. 18884).

\section{Phylum MOLLUSCOIDEA \\ Class BRYOZOA \\ Order CHEILOSTOMATA}

The core yielded two fragments of a hollow cylindrical bryozoan (pl. 31, figs. 20, 21), which, according to Dr. R. S. Bassler, belongs to the order Cheilostomata, but of a type unknown to him. One of the fragments has a diameter of $3.2 \mathrm{~mm}$. and a length of $5 \mathrm{~mm}$. The wall as seen at the broken end is about $0.5 \mathrm{~mm}$. thick and encloses a matrix of crystalline calcite; at the other end of the fragment the walls dome over and seal the interior space. The other fragment, which affords a view of the inner surface of the wall, reveals some of the structural details of the organism.

Occurrence: McRae No. 1 well, Hinds County, depth 3,970-3,980 feet. U. S. N. M. 103987 (U. S. G. S. 18884).

\section{Phylum Moludsca \\ Class PELECYPODA \\ Family ARCIDAE \\ Genus BARBATIA Gray, 1840}

Barbatia? sp.

Plate 31, figure 22

One juvenile Barbatia-like shell, a left valve, is elongated in outline, moderately inflated, has a well-devel- oped, round-crested umbonal ridge, and is ornamented all over with rather subdued radial costae, coarsest on the dorsal slopes. A broad, shallow depression extends from the beak to the ventral margin. The dentition is like that of Barbatia with the subumbonal teeth smell and vertical, and the teeth away from the umbo becoming successively more oblique to nearly horizontal at the ends. The shell measures: Length $4 \mathrm{~mm}$., height $2 \mathrm{~mm}$., convexity about $0.8 \mathrm{~mm}$.

Occurrence: McRae No. 1 well, Hinds County, depth 3,970-3,980 feet. U. S. N. M. 103988 (U.S. G. S. 18884).

\section{Genus VETOARCA Stephenson, n. gen.}

Type species: Vetoarca hindsana Stephenson.

Etymology: Latin vetus, ancient; Arca, a bivalve mollusern genus.

This new genus is characterized by its small size, its small trigonal ligamental pit, which appears to $h$ ? alivincular, the subcentral position of the beaks with respect to the hinge, the slightly raised platforms supporting the adductor muscles, and the strongly ribbed inner surface. The genus appears to be related to Trigonarca Conrad, the adductor scars of which occupy similar but more pronounced raised platforms, the inner surface of which is marked by short radial riks in a band near the pallial line, and the beak of which is opisthogyrate. The type species of Trigonarca, $T$. maconensis Conrad, is very large, has a very large multivincular ligamental area, and has its beak situated well back of the center of the area and hinge.

Vetoarca hindsana Stephenson, n. sp.

Plate 31, figures 23-26

Shell small, subtrigonal in outline, strongly convex; slightly inequilateral, equivalve. Beaks prominent, ircurved, slightly opisthogyrate, not closely approximate, situated about 0.45 the length of the shell from the anterior extremity. Greatest inflation near the midlength, well above the midheight. Umbonal ridge prominent but well-rounded on the crest. Antero- and posterodorsal slopes steep. The posterior slope of each valve is divided by a radial swell which reaches the posterior margin near its midlength, producing a marginal, wide-obtuse, subangulation. Between this swell and the umbonal ridge is a shallow radial depression. Surface smooth with the exception of fine growth lines. Anterodorsal margin broadly arched; anterior margin rather sharply rounded; ventral margin broadl" rounded; posterior margin sharply rounded below, sul. truncated and inclined forward above, rounding into the dorsal margin.

Dimensions of the holotype, a left valve: Length 10.8 nim., height $8.4 \mathrm{~mm}$., convexity $3.5 \mathrm{~mm}$. The largest paratype, also a left valve, is $11.4 \mathrm{~mm}$. long.

The ligament is set in a small sunken triangular pit below the beak; it appears to be alivincular but is a little 
longer posteriorly than anteriorly; the base of the triangle next to the hinge is a little longer than either of the other two sides. The hinge is narrow, of nearly uniform width from end to end, and somewhat arched in trend. The short, transverse, somewhat irregular teeth may form a continuous row, as in the holotype, or the continuity may be broken by a short toothless gap at the center; away from the center the teeth become a little oblique, and some of them may be angulated in trend. The adductor scars are subequal in size and occupy a high position in the shell; each scar occupies a slightly raised platform which extends from the scar radially back toward the umbonal region. Pallial line simple. The inner surface of the shell between the adductor scars is covered with about 16 pairs of narrow, sharply defined, radial ribs which extend from the inner umbonal region to the pallial line, where each pair ends in a sort of "tack-puller" fork; on the holotype and on some of the paratypes these ribs are somewhat obscured in part by a coating of secondary calcite and in part by corrosion; they are best seen in the paratype shown in plate 31 , figure 24 . The inner margin is smooth.

The shells of this species are present in great numbers in the core sample from a depth of 3,970 to 3,980 feet, many of the specimens being young individuals. The holotype is larger than average but is exceeded in length by the specimen shown in plate 31, figure 23.

Types: Holotype, a left valve, U. S. N. M. $103989 ; 2$ figured paratypes, left valves, U. S. N. M. 103990; 71 selected unfigured paratypes, left valves, and 55 selected unfigured paratypes, right valves, U. S. N. M. 103991.

Occurrence: McRae No. 1 well, depths 3,931-3,937 feet (U. S. N. M. 103993 ; U. S. G. S. 18883) and 3,9703,980 feet (U. S. G. S. 18884, type lot).

\section{Gentis POStLigAtA Gardner, 1916}

Postligata monroei Stephenson, n. sp.

Plate 31, figures 27-29

Shell small, subovate in outline, slightly inflated, a little compressed anteriorly, slightly inequilateral, equivalve. Beaks of moderate prominence, incurved, prosogyrate, separated slightly, situated a little in advance of the midlength. Greatest inflation near the midlength, well above the midheight. Surface smooth. Anterodorsal margin nearly straight, descending; posterodorsal margin broadly arched, descending; anterior and posterior margins rather sharply rounded; ventral margin broadly and regularly rounded. Lunule and escutcheon wanting.

- Dimensions of the holotype, a complete shell: Length $6.8 \mathrm{~mm}$., height $5.9 \mathrm{~mm}$., thickness $3.1 \mathrm{~mm}$.

Ligament opisthodetic, rather long, set in at least 2 grooves, which are oblique to the dorsal margin backward and slightly downward. Hinge taxodont, rela- tively thick, with teeth in 2 series scarcoly separated; the anterior series is the shorter, with 5 or 6 relatively strong transverse teeth, and is gently concave upward in trend; the posterior series is long and gently arched upward in trend with 15 or 16 teeth, which are small, short, and closely spaced in the anterior half of the series and stronger, longer, and more widely spaced in the posterior half. The inner surface of the shell is only partly uncovered in one of the paratypes; it appears to be smooth, and the pallial line is obscure. The inner margin is smooth.

Compared with the nearly circular genotype, Postligata wordeni Gardner (1916, pp. 543, 514, pl. 21, figs. 7-9) from the Monmouth formation of Maryland, the outline of monroe $i$ is more elongated, and the beaks are more prominent and a little farther forward. Postligata greenensis (Stephenson), from the Snow Hill marl member of the Black Creek formation of the Carolinas (Stephenson, 1923, p. 107, pl. 18, figs. 9, 10) is more broadly subovate, more oblique in outline, has nonprominent beaks, and is more compressed. Postligata schalki Stephenson from Georges Bank, Atlantic Ocean (1936, p. 374, pl. 1, fig. 8), is more compressed and is more oblique in the posteroventral direction. Postligata crenata Wade, from the Coon Creek tongue of the Ripley formation, McNairy County, Tenn. (1926, p. 48, pl. 11, figs. 3,6 ), is more compressed, is more nearly circular in outline, has less prominent beaks. and is crenulated on the inner margin.

The species is named in honor of Mr. W. H. Monroe, geologist, U. S. Geological Survey, Was'ington, D. C.

Types: Holotype, U.S: N. M. 103992; one paratype, a right valve, figured, U. S. N. M. 1039?4; five unfigured paratypes, including one adult left valve and four juvenile shells; of the latter, one is a complete shell and three are left valves, U. S. N. M. 103995.

Occurrence : McRae well No. 1, Hinds County, depths $3,93.1-3,937$ feet (U. S. G. S. 18883 ; U. S. N. M. 103996) and 3,970-3,980 feet (U. S. G. S. 18884, type lot).

\section{Family PEDALIONIDAE}

Genus INOCERAMUs J. Sowerby, 1814

Inoceramus sp.

Plate 31, figure 30

The genus Inoceramus Sowerby is represented by one small, incomplete right valve, consisting of the internal mold partly covered with shell. The specimen happened to lie in a position such that the descending core barrel cut off the posterior and ventral parts of the shell in a strip several millimeters wide. The shell is of moderate convexity, fullest in front, and is broadly subovate in outline with the long axis lying parallel to the hinge line. 'The beak is small and nonprominent. and is situated a few millimeters back of the anterior end. The surface is covered with low, nerrow, broadly 
round-crested, concentric ridges separated by shallow, slightly broader interspaces. The anterior margin is subtruncated, the ventral margin broadly rounded, the posterior margin shorter and more evenly rounded than the anterior margin, and the dorsal margin nearly straight.

Dimensions: Length $19+\mathrm{mm}$. , height $18+\mathrm{mm} .$, convexity about $8 \mathrm{~mm}$.

Although this shell is specifically indeterminate in our present somewhat confused state of knowledge of this generic group, its form is that of shells not older than the Austin chalk of Texas and probably not older than the Taylor marl.

Occurrence: McRae No. 1 well, Hinds County, depth 3,970-3,980 feet. U. S. N. M. 103997 (U. S. G. S. 18884).

\section{Family ANOMIIDAE}

Genus ANOMIA (Linné) Müller, 1758, 1776

Anomia microlirae Stephenson, n. sp.

Plate 31, figures 31-33

Shell small, thin, inequivalve, irregular in outline and form, but in general subcircular to broadly subovate in outline; the individuals vary in form from flattish to strongly convex depending on the form of the object to which the right valve was attached. Beak of left valve small, direct, node-like, situated centrally with respect to length of shell and about half a millimeter back from the dorsal margin. Surface covered with closely spaced radiating, almost microscopic lirae, which are delicately wavy in trend. Growth lines fine with an occasional stronger lamina. Resilifer a narrow, elongated, internal amphidetic pit situated well below the dorsal margin.

Dimensions of the holotype: Length $5.6 \mathrm{~mm}$., height $4.6 \mathrm{~mm}$., convexity $2.3 \mathrm{~mm}$.

This species differs from Anomia acutilinearis ( $\mathrm{p}$. 174) in having fine radiating lirae and weaker, finerdeveloped concentric markings.

Types: Holotype, U. S. N. M. 103998; six unfigured paratypes, U. S. N. M. 103999.

Occurrence: McRae well No. 1, Hinds County, depth $3,970-3,980$ feet (U. S. G. S. 18884).

\section{Order TELEODESMACEA}

\section{Family CARDITIDAE}

Genus VENERICARDIA Lamarck, 1801

Type species: Venericardia imbricata (Gmelin) (=Venus imbricata Gmelin), from the Eocene of the Paris Basin, France.

In its relatively small size, rounded outline, numerous noded ribs, and small subumbonal lunule, the species $V$ enericardia subterrea (described on this page), closely resembles the genotype, Venericardia imbricata (Gmelin), from the Eocene of the Paris Basin. As is to be expected there are differences between the two species, 732303-47-2 among which may be mentioned the narrower hinge plate and more oblique cardinal teeth, the smaller lunule, and the sharper and more pronounced ribs and nodes of $T$. imbricata. However, the features that characterize the genotype, though differing in strength of development, seem all to be present in V. subterrea, and the close genetic relationship between the two species seens indisputable.

\section{Venericardia subterrea Stephenson, n. sp. \\ Plate 31, figures 34-37}

Shell of medium size and submedium convexity, subcircular in outline, slightly inequilateral, equival'e. Beaks prominent, incurved, prosogyrate, approximate, situated slightly forward of the midlength. Greatest convexity about midway of the length, well above the midheight, from which place the surface rounds broadly down to the front, rear, and ventral margins, and steeply down to the dorsal margin. Lunule short, deeply impressed, vertically descending, delimited by a deeply incised groove, $\mathbf{V}$-shaped in cross section. Escutcheon wanting. Surface ornamented all over with about 31 radiating ribs of medium strength, broadly curved in trend; these ribs appear to have been worn somewhat before fossilization, are coarsest on the anterior slone, and become progressively narrower and weaker towerd the rear; the interspaces are narrower than the ribs. The crests of the ribs are broken into squarish and rectangular nodes by concentric grooves which are liss deeply incised than the spaces between the ribs.

Dimensions of the holotype, a left valve: Length 20 mm., height $20.4 \mathrm{~mm}$., convexity $6.3 \mathrm{~mm}$.

Ligamental groove long, narrow, deeply incieed, broadly arched in trend. Nymph narrow and deeply submerged. Hinge heavy. Two cardinal teeth in loft valve, the anterior one of medium thickness, trending downward and a little backward, the posterior one prominent, long, narrow, broadly arched in trend; a deep, oblique, elongate, trigonal socket of medium width separates the two cardinals; a very narrow, shallow socket lies in front of the anterior tooth. The sides of the cardinals are finely striated in the direction of movement. A small protuberance lies on the hinge plate just in front of the distal end of the groove delimiting the lunule. The right hinge as seen in a fragment of one young shell presents a thick, long, oblique, slightly arched, trigonal cardinal, bordered behind by a long, narrow, broadly arched socket and in front by a short, trigonal socket; in front of the latter is a feeble, almost obsolete anterior cardinal; back of the posterior socket and closely bordering the nymph is a narrow, relatively weak, oblique, slightly arched posterior cardinal. A small depression on the hinge plate just below the dirtal end of the groove delimiting the lunule receives the corresponding protuberance on the left valve. Adductor scars subequal, the anterior scar subovate, the 
posterior one subtrigonal. Pallial line simple. Inner margin create, each indentation lying immediately be-. low the end of a rib.

In general form, outline, and pattern of ornamentation this species is similar to Venericardia uvaldana (p. 186), but the shell is not so strongly convex, the ribs are much less sharp and prominent, the lunule is markedly more deeply impressed, and the anterior cardinal tooth is proportionately smaller and thinner. The number of ribs is essentially the same in the two species.

Types: Holotype, a left valve, U. S. N. M. 104001; 18 mostly incomplete, in part fragmentary, paratypes, ranging in size from adult to very small, and including 11 left valves ( 2 internal molds), 5 right valves ( 1 hinge figured), and 2 very small, complete individuals with both valves intact. The figured paratype bears the catalog number U. S. N. M. $10 \pm 000$, and the other 17 paratypes U. S. N. M. 104002.

Occurrence: McRae No. 1 well, Hinds County; two examples from depth 3,931 to 3,937 feet (U. S. N. M. 104003 ; U. S. G. S. 18883) ; type specimens from depth 3,970 to 3,980 feet (U. S. G. S. 18884).

\section{Family VENERIDAE \\ Genus TENEA Conrad, 1870}

Tenea? sp.

Plate 31, figure 38

Two small specimens of a smooth pelecypod, one a left and the other a right valve, have a form suggestive of that of the genus Tenea Conrad, but on both a closely adhering matrix of secondary calcite conceals the features of the hinge. The shell is smooth, subcircular in outline, of medium convexity, and the beak is of medium prominence.

Dimensions of the right valve : Length $2.3 \mathrm{~mm}$., height $2.4 \mathrm{~mm}$, convexity about $0.4 \mathrm{~mm}$.

Occurrence: M.Rae well No. 1, Hinds County, left valve, depth 3,931-3,937 feet (U. S. N. M. 104004; U. S. G. S. 18883) ; right valve depth 3,970-3,980 feet (U. S. N. M. 104005 ; U. S. G. S. 18884).

\section{Class GASTROPODA}

\section{Family TURRITELIIDAE}

Genus TURRITELLA Lamarck, 1799

Turritella sp.

Plate 31, figure 39

Two fragments of a small turreted gastropod, both incomplete at both ends, appear to be young shells of an unidentified species of Turritella Lamarck. The larger specimen includes four whorls and part of a fifth whorl and measures: Height $5.7 \mathrm{~mm}$., diameter at large end $2.4 \mathrm{~mm}$. Spiral angle about $18^{\circ}$. Suture closely appressed and sharply but not deeply impressed. Sides of whorls flattish to very gently convex. The body whorl bears about six obscure, narrow primary spirals, with very obscure secondaries in the interspaces. The upper edge of the growing whorl abuts against the lower side of the lowermost primary spiral, leaving it partly exposed just above the suture. Tha lowermost primary marks the periphery of the body whorl, below which the base is sharpy constricted, flattish, and bears numerous very fine, obscure spiral lirae. The spiral ornamentation becomes progressively more obscure on the sides of the younger whorls in the direction of the apex. Aperture apparently subtriangulai. Outer lip partly broken away but apparently thin. Inner lip forming a thin callus over the parietal wall.

This shell probably belongs to the subgrorp of Turritella to which $T$. vertebroides Morton belongs.

Occurrence: McRae well No. 1, Hinds County, depth 3,970-3,980 feet, figured specimen (U. S. N. M. 104006 ; U. S. G. S. 18884) ; one example (U. S. N. M. 104007 ; U. S. G. S. 18881).

\section{Family CERITHIIDAE}

\section{Genus CERITHIUM Bruguière, 1789}

\section{"Cerithium" sp.}

Plate 31, figure 40

Two whorls of a small turreted gastrc pod possess external ornamentation that suggests membership in the family Cerithiidae. In profile the side of each whorl is rather strongly constricted in a band below the upper suture and inflated below toward the lower suture. Four nodose spiral ribs are present, the lowermost one, which follows the crest of the inf ation, being the strongest; the second strongest rib clos?ly parallels the upper suture, and intermediate between the two strong ribs are two weaker ribs, the upper one of which is the smaller. The periphery of the boty whorl is obtusely subangular, the base is constricted and bears only obscure traces of spiral lirae. The anterior end of the aperture bears a short, twisted siphc nal channel, which was broken away and lost during preparation.

Dimensious of the fragment: Height $3+\mathrm{mm}$., diameter $2.5 \mathrm{~mm}$.

Occurrence: McRae well No. 1, Hinds County, depth 3,970-3,980 feet. U. S. N. M. 104008 (U. S. G. S. 18884).

Family PYRAMIDELLIDAE

Genus ODOSTOMIA Jeffreys, 1839

Odostomia meraei Stephenson, n. sp

Plate 31, figures 41,42

Shell small, smooth, with spire about twice as high as the aperture is long; spiral angle about $40^{\circ}$. Proto- 
conch somewhat worn but apparently a low, smooth, trochoid shell. Whorls $31 / 2$ or 4 , moderately and evenly convex on the side. Suture closely appressed, moderately impressed. Body whorl broadly rounded in profile from suture above to base. Through the semiopaque shell of the body whorl may be obscurely seen seven or eight spiral lirae, which apparently traverse the inner surface; closely adhering matrix prevents the observation of these lirae on the inner surface near the aperture. Aperture subovate, angular at the rear, sharply rounded at the front. Outer lip thin, broadly and regularly arched. The upper part of the inner lip forms a thin callus on the parietal wall; below, it forms a ridge of callus bordering a weak umbilical fissure.

Dimensions of the holotype: Height $3.2 \mathrm{~mm}$., diameter $1.8 \mathrm{~mm}$.

The name of the species is derived from the family name McRae.

Type: Holotype, U. S. N. M. $10 t 009$.

Occurrence: McRae well No. 1, Hinds County, depth 3,970-3,980 feet (U. S. G. S. 18884). A smaller, less perfect shell in the same collection is regarded as a questionable example of the species.

\section{Kingdom PLANTAE}

Plate 31, figures $43-46$

The plant kingdom is believed to be represented in one of the cores from the McRae well by 20 fragments of stems interpreted to belong to a species of marine algae. The stems are hollow cylinders and range in diameter from $0.9 \mathrm{~mm}$. to $1.2 \mathrm{~mm}$. The walls are a quarter of a millimeter or less in thickness, and the hollow interior is filled with a matrix mainly of crystalline calcite. The outer surface is densely stippled with tiny tubercles, each of which is perforated in the center. The inner surface also presents a stippled appearance. That the stems are in sections is indicated by the constrictions at the ends of several fragments, and joints connecting the end portions of sections appear on 2 short fragments. Some of the fragments are slightly constricted at both ends, and the terminal edges of their walls are rounded; these may be complete, short sections; one such section is $2.5 \mathrm{~mm}$. long and $1.2 \mathrm{~mm}$. in diameter. A freshly broken end of a tube shows transverse structural markings in the wall which seem to be connected with the stippling on the inner and outer surfaces of the tube; these may be filled pores.

Occurrence: McRae well No. 1, Hinds County, three figured specimens (U. S. N. M. 104010; U. S. G. S. 18884); several unfigured fragments (U. S. N. M. 104011; U. S. G. S. 18884).
FOSSILS FROM THE AVENT WELL

Kingdom ANIMALIA

Phylum ANNELIDA

Family SERPULIDAE

Genus SERPULA Linné, 1758

Serpula sp.

Plate 31, figures 1, 2

Marine worms are represented in the fauna from the Avent core (depth 2,730-2,750 feet) by three fragments of irregular calcareous tubes that appear to belong to the genus Serpula, using that name in a broad sense. The smaller of the two better preserved fragments is $9 \mathrm{~mm}$. in length, $1.7 \mathrm{~mm}$. in diameter at the small end, and $2 \mathrm{~mm}$. in diameter at the large end (U. S. G. S. 18930 , U. S. N. M. 104012) ; in addition to the growth lines, which extend directly around the tube, this specimen bears three narrow longitudinal ribs grouped on one side, the middle one of which is irregular in height but in part prominent, and the other two of which are nonprominent; obscure traces of several other longitudinal markings are present. The larger of these two fragments is $9.5 \mathrm{~mm}$. in length, $3.1 \mathrm{~mm}$. in diameter at the small end, and $3.8 \mathrm{~mm}$. in diameter at the large end (U. S. G. S. 18930, U. S. N. M. 104012) ; it bears four narrow longitudinal ribs, also grouped on one side, two of which are in part prominent and flangelike, and two nonprominent and alternating in position with the other two; several obscure longitudinal markings are present. The tube wall is less than half a millimeter thick, and at the large end bevels from the inside outward to a thin edge, apparently indicating that this was the terminus of the tube at the time of the animal's death. The third fragment (U. S. G. S. 18894, U. S. N. M. 101013) is smaller and much less complete than the other two; it is $6.2 \mathrm{~mm}$. long and bears a pair of narrow, fairly regular nonprominent longitudinal ribs on one side.

\section{Genus HAMULUS Morton, 1834 \\ Hamulus onyx Morton \\ Plate 31, figures 3, 4}

1834. Hamulus onyx Morton, Synopsis of the organic remains of the Cretaceous group of the United States, p. 73, pl. 2, fig. 8 ; pl. 16, fig. 5 .

1905. Hamulus onyx Morton. Johnson, Acad. Nat. Sci. Philadelphia Proc., vol: 57, p. 4.

1916. Hamulus onyx Morton. Gardner, Maryland Geol. Survey, Upper Cretaceous (2 vols.), p. 747.

1921. Hamulus onyx Morton. Wade, U. S. Nat. Mus. Proc., vol. 59 , p. 43 , pl. 9 , figs. $1-3,5,6$. 
1923. Hamulus onyx Morton. Stephenson, North Carolina Geol. and Econ. Survey, vol. 5, p. 76, pl. 10, fig. 11.

1926. Hamulus onyx Morton. Stephenson, Alabama Geol. Survey, Special Rept. 14, p. 250, pl. 92, fig. 2.

1926. Hamulus onyx Morton. Wade, U. S. Geol. Survey Prof. Paper 137, p. 30, pl. 2, figs. 4-7, 12.

1929. Hamulus onyx Morton. Dane, Arkansas Geol. Survey Bull. 1, p. 150, pl. 27, fig. 2.

1941. Hamulus ony $x$ Morton. Steplrenson, Texas Univ. Pub. 4101 , p. 58 , pl. 4 , figs. 8,9 .

1943. Hamulus onyx Morton. Howell, Acad. Nat. Sci. Philadelphia Proc., vol. 95, p. 150, pl. 19, figs. 1-12.

Several fragmentary tubes seem to be essentially like those of the species Hamulus onyx Morton. One fragment, the large end of a medium-sized tube (pl. 31, fig. 3 ), is attached at its smaller end to a small shell fragment; in large suites of tubes of this species from the Upper Cretaceous of the Gulf region only a few have been found attached to extraneous objects. The fragments in the present fauna indicate curved tubes of about the average size, and the same degree of taper, as seen in typical tubes of onyx. Each tube is ornamented with six subangular to rounded, rather rugged longitudinal ribs of subequal size. The first fragment mentioned above is $10 \mathrm{~mm}$. in length, $2 \mathrm{~mm}$. in diameter at its incomplete small end, and $4.4 \mathrm{~mm}$. in diameter at its large end measured on the outside of the ribs. A fragment of another tube, the large end of which is broken away, is $8.4 \mathrm{~mm}$. in length, $1.3 \mathrm{~mm}$. in diameter at the small end, and $3 \mathrm{~mm}$. in diameter at the large end.

Types: Morton (1834, pp. 73, 74, pl. 2, fig. 8; pl. 16, fig. 5) in his original description figured two specimens (cotypes), one from Lynchs Creek, S. C., and one from Erie Bluff, Warrior River, Hale County, Ala. 'The former is lost, and the latter is presumed to be one of four specimens in the collection of the Academy of Natural Sciences of Philadelphia (Acad. Nat. Sci. Philadelphia, Nos. 2303, 14996, 14997, 14998). The one of the four nearest in appearance to Morton's figured specimen from Erie Bluff was figured by Stephenson (1923, pp. $76-79$, pl. 10, fig. 11), and all four of them were figured by Howell (1943, pp. 150-152, pl. 19, figs. 1-8). Howell designates the specimen shown in his figure 1 as holotype (meaning lectotype) and called the other three paratypes. As Morton did not designate a helotype, Howell is mistaken in referring to the Lynchs Creek specimen (his p. 140) as "Morton's holotype," and to the other three specimens as paratypes. In order to clear up the matter, I herewith designate as the lectotype of Hamulus onyx Morton the specimen from Erie figured by Howell as "holotype" (his pl. 19, fig. 1). This specimen appears to be the same as the one figured by Stephenson. (See reference in the synonymy.) Two plesiotypes, one, U. S. G. S. 18894 (U. S. N. M. 104014); the other, U. S. N.M. 104014a. Two unfigured fragments, U. S. N. M. 104015 (U. S. G. S. 18930).
Occurrence: Avent No. 1 well, Grenada County, deptì $2,730-2,750$ feet. U. S. N. M. 104014,104015 (U. S. G. S. 18894, 18930).

\section{Hamulus? sp.}

Plate 31, figures 5-7

A detached serpuloid operculum from one of the core samples (U. S. G. S. 18894; U. S. N. M. 104016) may have come from a tube of Hamulus. It does not agree in detail with the operculum of $H$. ony $x$ Morton, as described and figured by Wade $(1926, \mathrm{pp} .30,31, \mathrm{pl} .2$, figs. 6,12$)$. It has a diameter of $2.3 \mathrm{~mm}$. and a height of $2.7 \mathrm{~mm}$.

No tubes of $H$. ony $x$ with the operculum attached are available in the material from Erie Bluff, Tombigbee River, Hale County, Ala., one of Morton's localities.

\section{Phylum MOLLUSCOIDEA \\ Class BRYOZOA \\ Order CHEILOSTOMATA \\ Family MEMBRANIPORIDAE}

Genus MEMBRANIP0RA Blainville, 1830

Membranipora sp.

Plate 31, figure 8

The Bryozoa are represented by one poorly preserved specimen, which Dr. R. S. Bassler refers to the genus Membranipora Blainville. The zooecia have a thick clublike, probably branching, habit of growth.

Oscurrence: Avent No. 1 well, Grenada County, depth 2,730-2,750 feet. U. S. N. M. 104017 (U. S. G. S. 18930).

Phylum MOLLUSCA

Class PELECYPODA

Family NUCULIDAE

Genus NUCULA Lamarck, 1799

Nucula nulla Stephenson, n. sp.

Plate 31, figures 9, 10

The species is represented in the Avent core samples by 11 individuals, which range in length from $1.4 \mathrm{~mm}$. to $4.3 \mathrm{~mm}$. In view of the number of s recimens it is assumed that the larger ones are adults, an assumption that may not be justified.

Shell small, subelliptical-elongate in outline, strongly inequilateral, equivalve, of medium convexity, the greatest inflation being a little back of the midlength and a little above the midheight. Beaks moderately prominent, incurved, approximate, opistl ogyrate, situated about three-tenths the length of the shell from the posterior extremity. The surface rounds down broadly to the anterior and ventral margins and steeply to the 
anterodorsal and posterior margins. A shallow sulcus extends radially in a curve from the beak to the lower posterior margin on each valve, and between these two sulci the posterodorsal margins of the two valves rise to form a well-defined rostrum. Anterodorsal margin long and, broadly arched; anterior margin sharply rounded; ventral margin long and broadly rounded, rising a little more steeply at each end; posterior margin with a short subtruncation inclined forward; posterodorsal margin short, steep, nearly straight. Surface of shell marked only by very fine, obscure growth lines. The internal features are not clearly uncovered, but the numerous taxodont teeth, numbering six or more to the millimeter, can be obscurely seen through the semitransparent shell of the holotype and of several of the paratypes. Radiating internal shell structure such as is characteristic of the nuculid group can be faintly discerned on one of the paratypes.

Dimensions of the holotype, a shell chosen for its completeness : Length $4.3 \mathrm{~mm}$., height $3.1 \mathrm{~mm}$., thickness $2 \mathrm{~mm}$.

Types: Holotype, U. S. N. M. 104018 (U. S. G. S. 18894 ) ; four unfigured paratypes, U. S. N. M. 104020 (U. S. G. S. 18894) ; seven unfigured paratypes, IT. S. N. M. 104019 (U. S. G. S. 18930).

Occurrence: Avent No. 1 well, Grenada County, depth 2,730-2,750 feet (U. S. G. S. 18894, 18930).

\section{Family ARCIDAE, sensu lato \\ Genus BARBATIA Gray, 1842 \\ Barbatia? sp.}

Plate 31, figure 11

Three shells in the Avent core are questionably referred to Barbatia Gray. None are completely preserved, and none show the hinge; one appears to be adult, and the other two appear to be juvenile, probably all of the same species. The adult, a right valve, is about $17 \mathrm{~mm}$. long and $9 \mathrm{~mm}$. high and bears 25 or more tuberculated, moderately strong ribs, of which a centrally located group are smaller and more closely spaced than those either anterior or posterior to them. The juvenile shells, one a left and the other a right valve, are each about $3+\mathrm{mm}$. long and about $2 \mathrm{~mm}$. high and are similarly ribbed. Figured specimen, U. S. N. M. 104021 ; unfigured, U. S. N. M. 104022.

Occurrence : Avent No. 1 well, Grenada County, depth $2,730-2,750$ feet (U. S. G. S. 18894,18930 ).

\section{Genus BREVIARCA Conrad, 1872}

\section{- Breviarca sp.}

Plate 31, figures 12, 13

One shell, a left valve, in the Avent core is referable to the genus Breviarca Conrad. It is considerably wa- ter-worn and cannot be referred safely to a species. However, it has the outline and form of Breviarca congesta Conrad and is closely allied to that species. Conrad's species came from the Snow Hill calcareous member of the Black Creek formation at Snow Hill, N. C. (Stephenson, 1923, pp. 112-114, pl. 20, figs. 9-13), and is considered to be of upper Taylor age. The shell measures: Length $8.3 \mathrm{~mm}$, height $7.9 \mathrm{~mm}$., convexity $2.5 \mathrm{~mm}$. In outline the shell is broadly subovate, and the surfece is smooth as preserved. The hinge and ligamental aroa are worn, but the dentition appears to be typical, and ligamental striations transverse to the hinge line are present. Other internal features are concealed by hard matrix.

Occurrence : Avent No. 1 well, Grenada County, depth 2,730-2,750 feet. U. S. N. M. 104023 (U. S. G. S. 18894).

\section{Genus TRIgONARCA Conrad, 1862}

Trigonarca munda Stephenson, n. sp.

Plate 31, figures 14-16

This species is represented in the Avent core by one nearly complete left valve, which possesses all the characteristic features of the genus Trigonarca Conred; it is probably a young individual.

Shell small for the genus, moderately inflated, roughly subquadrate in outline, inequilateral. Beak of medium prominence, rather narrow, strongly incurved, approximate, opisthogyrate, situated back of the midlength, about three-fifths the length of the hinge from its anterior end. Umbonal ridge well developad, rounded on the crest. Greatest inflation a little brck of the midlength, well above the midheight, from which point the surface rounds down regularly to the anterior and ventral margins; posterior slope steep and broadly excavated radially from the beak to the posterior margin. Anterodorsal margin short and nearly straight; anterior margin regularly rounded; ventral margin broadly and regularly rounded; posterior margin strongly truncated, inclined forward, rounded at upper and lower ends. The surface bears sharp growth lines of irregular strength; a closely spaced group of 9 or 10 weak radial lines diverges outward from the beak on the anterodorsal slope, fading out before reaching the anterior margin; a similar but much shorter and weaker group of lines passes rearward from the beak on the posterodorsal slope. The most prominent part of the umbo is faintly divided by a radial depression, in which several very faint radial lines may be detected. Lunule and escutcheon wanting.

Dimensions: Length $24 \mathrm{~mm}$., height $21.2 \mathrm{~mm}$., convexity $7.1 \mathrm{~mm}$.

The ligament is amphidetic, but the posterior part is short and covers only a small part of the area; it is sharply defined by impressed grooves. The area of attachment of the ligament is triangular with its 
longest side coinciding with the upper edge of the hinge plate; the markings on the area appear to be the beginnings of rather coarse chevron-shaped grooves, suggesting that this specimen is the young stage of an individual that in its adult stage might be several times larger. The numerous taxodont teeth form a broad asymmetric arch on a narrow hinge plate, curving down more sharply at the rear; centrally the teeth are short, irregular, and vertical; away from the center in each direction they become first longer and successively more oblique, then shorter, continuing to increase their obliquity until the short terminal teeth become horizontal; some of the teeth anterior and posterior to the umbo are obtusely and asymmetrically angulated in trend. Adductor scars large, elongated, the posterior one a little larger; a narrow sharp ridge extends from under the beak radially past the anterior scar; the posterior scar occupies a raised platform, which is bordered on the inner side by a prominent, curved, sharp-edged carina, the posterior part of which extends radially with diminishing strength toward the umbo. Pallial line entire. Inner surface bearing numerous weak radial lines which end distally at the pallial line. Inner margin smooth. Brownish, rather dim spots and zigzag bands, mainly on the posterior half of the surface, appear to be original color patterns.

A small outcrop of water-laid volcanic sandstone exposed on the west flank of Prothro salt dome, Bienville Parish, La., has yielded eight poorly preserved specimens of Trigonarca ranging in size from that of $T$. munda up to a length of $72 \mathrm{~mm}$. The two smaller specimens in the lot agree rather closely in form with $T$. mund $a$ and may be specifically identical with it; they appear to be the young stage of a species, of which the larger specimens are the adults. These shells were mistakenly referred to Cucullaea by me in a paper by W. C. Spooner (1926, p. 248).

Type: Holotype, U. S. N. M. 104024.

Occurrence : A vent No. 1 well, Grenada County, depth 2,730-2,750 feet (U.S. G. S. 18894).

Louisiana, questionably on the west flank of the Prothro salt dome (secs. 7 and 18, T. 14 N., R. 6 W.), Bienville Parish (U.S. G. S. 12950).

Genus PosTligata Gardner, 1916

Postligata aventi Stephenson, n. sp.

Plate 32, figures 31-33

Shell small, compressed, broadly subovate in outline, slightly extended in the posteroventral direction, slightly inequilateral, equivalve. Beaks small, nonprominent, prosogyrate, situated a little in advance of the midlength; in nearly all specimens the beak and hinge are more or less water-worn. Surface marked only by fine growth lines and an occasional concentric groove marking a resting stage. With the exception of a faint subtruncation on the lower anterior margin and the interruption caused by the beak, the margins are evenly curved all the way around. Lunule and escutcheon wanting.

Dimensions of the holotype, a right ralve: Length $10.4 \mathrm{~mm}$, height $9.8 \mathrm{~mm}$., convexity $2 \mathrm{~mm}$.

Ligament opisthodetic, multivincular, set in 3 or 4 grooves oblique to the hinge line backwarl and downward. Taxodont teeth in two series scarcely separated from each other; the anterior series numbers 8 or 9 teeth alined in a nearly straight row; the posterior series numbers 13 or 14 alined in a slightly uparching curve. Inner surface smooth with the exception of 2 narrow, weak ridges extending from under the beak, 1 radially past the inner side of each adductor scar. Adductor scar's slightly impressed, subecual, the anterior one roundish, the posterior one a little elongated in the posteroventral direction. Pallial line entire. Inner margin smooth.

Compared with Postligata monroei (p. 166) from the McRae No. 1 well in Hinds County, this species is more compressed laterally, is less elongated in the direction of the length, and is a little more extended in the posteroventral direction.

The species is named in honor of Dr. J. K. Avent, on whose land the Avent well was drilled.

Types: Holotype, a right valve, U. S. T' . M. 104025 (U. S. G. S. 18930) ; 1 figured paratype, a lefi valve, U. S. N. M. 104026 (U. S. G. S. 18894) ; 16 unfigured paratypes, U S. N. M. 104027 (U. S. G. S. 18930); 25 unfigured paratypes, U. S. N. M. 104028 (U. S. G. S. 18894).

Occurrence : Avent No. 1 well, Grenada County, depth 2,730-2,750 feet (U. S. G. S. 18894, 18930).

\section{Family PTERIIDAE}

Genus PTERIA Scopoli, 1777

\section{Pteria? sp.}

A fragment of a small left valve, which includes the umbonal region and the anterior wing, is too incomplete for specific identification. The surface is smooth, and the wing trigonal and strongly compressed. Part of the hinge is present but is badly worn; it shows a ligamental depression below the beak in front of which a toothlike protrusion bulges slightly inward from the straight hinge line.

Occurrence: Avent No. 1 well, Grenada County, depth 2,730-2,750 feet. U. S. N. M. 104029 (U. S. G. S. 18894).

\section{Family PEDALIONIDAE}

\section{Genus INOCERamus sowerby, 1814}

The status of our present knowledge of the group of American Upper Cretaceous bivalve molluscan fossils to which the name Inoceramus Sowerby is commonly 
applied is discussed by me in two papers (Stephenson, 1923 , pp. 127-131; 1941, pp. 98, 99). Supplemental to those discussions it now appear's that Sowerby's name, Inoceramus cuvierii, appeared in print as early as December 1814. The following is quoted from the proceedings of the Limnaean Society published in the Annals of Philosophy, vol. 4, p. 448, 1814 :

A paper by Mr. [J.] Sowerby was read on a fossil shell which occurs in chalk, very frequently in the flint nodules. Fragments of it had been observed by Cuvier and Brongniart in the chalk near Paris, and from their fibrous texture they were led to consider them as fragments of pinnæ; but from their thickness (near half an inch) they concluded that the shell must have been of enormous size. Mr. Sowerby got specimens of the fossil from various quarters of the chalk country in the south of England. He ascertained, by comparing these specimens with each other, that it was a bivalve shell, having a hinge of a peculiar structure, and constituting a genus apart. To this genus he has given the name inoceramus; and the most common species he calls inoceramus Cuvierii.

What was said about the difficulty of classifying and naming many of the American specimens of Inoceramus, in my two papers cited above, still remains true, for which reason I refrain from giving a specific name to the comparatively well preserved shell shown in plate 32 , figure 37 .

\section{Inoceramus sp.}

Plate 32, figure 37

The material referable to Inoceramus Sowerby in the Avent core includes one fairly well preserved right valve, an incomplete juvenile left valve, and several fragments. The right valve (U. S. G. S. 18894) is subovate in outhine, of medium convexity with the greatest inflation above the midheight and well toward the front, strongly inequilateral. Beak slightly prominent, strongly incurved, prosogyrate, situated only a little back of the anterior extremity. Surface rounding down steeply to the anterior margin and broadly to the ventral margin; there is a suggestion of a weak umbonal ridge, back of which the surface becomes slightly compressed in the posterior and posterodorsal regions. The concentric undulations range in distance apart from less than 1 $\mathrm{mm}$. near the beak to a maximum of about $6 \mathrm{~mm}$. in the posteroventral region; the undulations are rather sharply curved in trend on the anterior slope, broadly curved on the ventral-facing slope as far as the umbonal ridge, where they bend sharply up and pass first in a very gentle curve to the posterodorsal slope, thencein a regular curve forward to the dorsal margin. The anterior, ventral, and posterior margins are not complete but if present would conform to the trend of the concentric ridges. A rather marked subtruncation of the posterior margin is indicated. The dorsal margin is straight.

Dimensions of the large right valve : Length $48+\mathrm{mm}$., height $43 \mathrm{~mm}$., convexity about $11 \mathrm{~mm}$.
This shell belongs to the subgroup of Inoceramus, the valves of which are elongate parallel to the hinge line. The subgroup makes its first appearance in late Austin (= Eutaw) time and is common in marine sediments throughout the remainder of Upper Cretaceous time. Although not specifically identical with Inoceramus barabini Morton, from "Greene County, Ala.," the Avent specimens are closely allied to it. They appear to match closely specimens of Inoceramus from water-laid volcanic rock exposed on the west flank of Prothro salt dome near the north line of NE1/4 sec. 18, T. 14 N., R. 6 E., Bienville Parish, La. It is also closely similar in outline and form to a representative of the genus fornd in the upper part of the Tokio formation near Ben Lomond, Sevier County, Ark. (Dane, 1929, p. 41, pl. 8, fig. 1). Figured, U. S. N. M. 104030; unfigured, L. S. N. M. 104031.

Occurrence : Avent No. 1 well, Grenada County, de pth 2,730-2,750 feet (U. S. G. S. 18894); fragments, C. S. N. M. 104032 (U.S. G. S. 18930).

\section{Family OSTREIDAE}

Genus OSTREA Linné, 1758

\section{Ostrea sp.}

Juvenile shells of Ostrea of a rather'nondescript character, some of them water-worn, are scattered through the Avent core. Some of the fragments are irregularly costate. None of the material is specifically determir ate.

Occurrence: Avent No. 1 well, Grenada County, depth $2,730-2,750$ feet. U. S. N. M. 104033 (U. S. G. S. 18?94, 18930).

\section{Genus EXoGYRA Say, 1820}

\section{Exogyra? sp.}

One incomplete juvenile shell having a maximum dimension of $8.3 \mathrm{~mm}$. is questionably referred to Exody ra Say. It is irregular in form and finely and irregularly costate. The beak and hinge are strongly twisted is in Exogyra.

Occurrence: Avent No. 1 well, Grenada County, depth 2,730-2,750 feet. U. S. N. M. 104034 (U. S. G.S. 188?4).

$$
\text { Family PECTINIDAE }
$$

Genus PECTEN Müller, 1776

Subgenus CAMPTONECTES (Agassiz ms.) Meek, 1864.

Pecten (Camptonectes) sp.

Plate 32, figures $41-43$

The Avent core yielded 10 fragments belonging to Pecten (Camptonectes), none of which is complete enough for specific assignment. The fragments indicate a medium-sized species with very fine, flattish, radi- 
ating costae of the $C$ amptonectes sort. The costae cover both the main body and the ears of the shell.

Occurrence: Avent No. 1 well, Grenada County, depth 2,730-2,750 feet. Figured, U. S. N. M. 104036 (U. S. G. S. 18894), U. S. N. M. 104035 (U. S. G. S. 18930); unfigured, U. S. N. M. 104037 (U. S. G. S. 18894), U.S. N. M. 104038 (U. S. G. S. 18930).

\section{Family ANOMIIDAE}

Genus ANOMIA Linné, 1758

Anomia acutilinearis Stephenson, $n$. sp.

Plate 32, figures 38-40

The species is represented in the Avent core by six left valves, none of which is complete in all features.

Shell small, compressed, subcircular in outline, subequilateral. Beak small, nonprominent, set back about $1 \mathrm{~mm}$. from the dorsal margin. The surface is covered with fine, sharp, slightly overlapping growth lamellae. Radiating lines are wanting. The shells are compressed but variable in details of form and sharpness of lining. The external lining is impressed on the internal mold as fairly regular, concentric grooves, as shown by one specimen from which the shell is missing except in a small area in the dorsal region. Internal features not uncovered.

Dimensions of the holotype, a shell partly broken away along the dorsal margin: Length $8.4 \mathrm{~mm}$., height about $9 \mathrm{~mm}$., convexity about $1 \mathrm{~mm}$.

Types: Holotype, U. S. N. M. 104039; two figured paratypes, U. S. N. M. 104040; three unfigured paratypes, U. S. N. M. 104041.

Occurrence: Avent No. 1 well, Grenada County, depth $2,730-2,750$ feet (U. S. G. S. 18894).

\section{Family MYTILIDAE}

Genus VOLSELLA Scopoli, 1777

Volsella sp.

The genus Volsella Scopoli is represented in the Avent core by one incomplete, water-worn, left valve. The umbonal ridge is obtusely subangular in cross section. the anteroventral slope is moderately steep, and the worn surface shows no radial ribbing. The hinge is worn but appears to be edentulous. As preserved the shell is $9 \mathrm{~mm}$. long, about $7 \mathrm{~mm}$. high, and has a convexity of $2.5 \mathrm{~mm}$.

Occurrence: Avent No. 1 well, Grenada County, depth 2,730-2,750 feet. U. S. N. M. 104042 (U. S. G. S. 18894).

\section{Family PLEUROFLORIDAE}

Genus ETEA Conrad, 1875

Etea? sp.

Plate 32, figure 28

One left valve shows most of the external features of the shell, but the hinge is poorly preserved. The shell is thin, moderately inflated, inequilateral. Beak moderately prominent, incurved, prosogyrate, situated about two-fifths the length of the shell from the anterior extremity. Umbonal ridge sinuous, obtusely angular in cross section, extending from beak to lower posterior extremity. Anterodorsal margin short, slightly excavated; anterior margin sharply rounded; ventral margin very broadly rounded; posterior margin angular below, strongly truncated above; posterodorsal margin long and broadly arched. Concentric growth lines fine and sharp. The teeth appear to have been worn or broken away; ligamental groove long; nerrow.

Dimensions: Length $6.3 \mathrm{~mm}$., height $4.9 \mathrm{~mm}$., convexity $2 \mathrm{~mm}$.

Occurrence : Avent No. 1 well, Grenada County, depth 2,730-2,750 feet. U. S. N. M. 104043 (U. S. G. S, 18930).

\section{Family CRASSATELIIDAE}

Genus CRASSATELLA Lamarck, 17:99

Crassatella subterrestris Stephenson, $\mathbf{n}, \mathbf{s p}$.

Plate 32, figures 21-25

The available material in the Avent core referable to the genus Crassatella consists of 1 nearly complete right valve, small for the genus, possibly a young individual, and 10 very small juvenile shells in different stages of completeness. The description is k ased mainly on the complete shell (holotype), supplemented by the juvenile shells which show the young stage and the beak in sharper detail.

Shell small for the genus, compressed, subtrigonal in outline, inequilateral, equivalve. Umbong 1 ridge low, forming a broad subobtuse angle in cross se tion. Beaks low, slightly prominent, prosogyrate, situated about one-fourth the length of the shell from the anterior extremity. Greatest inflation above the midheight and shightly in advance of the midlength; from the highest point the surface rounds broadly and gently to the beak and to the anterior and ventral margins; the steeper posterodorsal slope forms a flattish, radiating, slightly sinuous band extending from the beak to the posterior margin. Lunule of medium length, narrow, rather deep and roughened by growth lines; escutcheon long, narrow and rather deep. Anterodorsal margin short, slightly excavated; anterior margin a little more 
sharply rounded than a semicircle; ventral margin broadly rounded anteriorly, becoming nearly straight toward the rear; posterior margin subangular below, followed above by a short subtruncation inclined a little forward; posterodorsal margin long, descending, broadly arched. On the young stage, not exceeding $7 \mathrm{~mm}$. in length, the concentric ornamentation is proportionately coarse and strong, except near the tip of the beak, the ridges being separated by interspaces broadly $V$-shaped in cross section and extending uninterrupted beyond the umbonal ridge to the dorsal margin; on later stages the concentric ridges are narrower and closer together as far rearward as the umbonal ridge, where every other ridge fades out, the remaining ones continuing to the margin; very fine, obscure, concentric lining is barely detectable on the surfaces between the ridges.

Dimensions of the holotype: Length $13 \mathrm{~mm}$., height $10.7 \mathrm{~mm}$., convexity $2.3 \mathrm{~mm}$.

The dentition on the right valve includes a prominent, narrow, cardinal tooth, sloping a little forward, below the beak; a narrow, weak, oblique anterior cardinal closely paralleling the inner margin of the lunule; the two cardinals separated by a narrow deep socket. The large cardinal is striated in the direction of movement on the side facing forward. The ligament occupied a broad shallow pit back of the large cardinal; this pit does not reach the inner edge of the hinge plate, but is separated from it by a small more deeply inset socket into which fits the lower end of a cardinal tooth of the left valve. There is no lateral dentition proper, but an inner groove along the anterodorsal margin serves as a pseudosocket into which fits the thin edge of the corres̀ponding margin of the left valve. In like manner the narrow posterolateral edge of the right valve fits into a corresponding groove in the margin of the left valve. Adductor scars rather large, elongated, and subequal. Pallial line entire. Inner margin smooth.

The ligamental characters of this species indicate that it belongs to the subgroup of Crassatella typified by C. vadosa Morton (Stephenson, 1941, pp. 176, 177).

Types: Holotype, U. S. N. M. 104044 (U. S. G. S. 18894) ; five unfigured paratypes, U. S. N. M. 104045 (U. S. G. S. 18894) ; two figured paratypes, U. S. N. M. 104046 (U. S. G. S. 18930); three unfigured paratypes, U. S. N. M. 104047 (U. S. G. S. 18930).

Occurrence: A vent No. 1 well, Grenada County, depth 2,730-2,750 feet (U. S. G. S. 18894, 18930).

\section{Family CARDIIDAE}

\section{Genus CARDrum Linné, 1758}

Cardium (Trachycardium) grenadense Stephenson, n. sp.

Plate 32, figures 34-36

Shell of medium size, subcircular in outline except for the posterior truncation, moderately inflated, sub$732303-47-3$ equilateral, equivalve. Beaks moderately prominent, strongly incurved, nearly direct, approximate, situated slightly in advance of the midlength. Umbonal ridge broadly rounded on the crest. Dorsal slopes steep, the posterior one broadly excavated in the radial direction. Margins regularly rounded except the posterior one which is rather strongly subtruncated, the line of truncation inclining somewhat forward. Surface ornamented with 32 to 34 sharply developed ribs, the coarsest ones of which are on the umbonal inflation from which they decrease regularly in size toward the front; toward the rear the ribs decrease in size, several of them becoming longitudinally bifid. The ribs bear tubercles on their crests; adjacent to the ventral margin on the holotype the tubercles number about 7 in a linear distance of $3 \mathrm{~mm}$.; toward the beak the number increases, and the size decreases; the tubercles are conical to slightly elongated in the concentric direction, and are concentrically alined from one rib to another; the tubercles are most prominent anteriorly and decrease regularly in strength rearward, becoming weak to obscure on the umbonal ridge and posterior slope. In the umbonal region of most specimens the ribs and tubercles are more or less worn.

Dimensions of the holotype, a half-grown left valve chosen because of the well-preserved condition of its surface features: Length $11.8 \mathrm{~mm}$., height $11.7 \mathrm{~mm}$., convexity $3.8 \mathrm{~mm}$. The largest shell in the core, whose surface is considerably worn and corroded measures: Length $23 \mathrm{~mm}$., height about $23 \mathrm{~mm}$., convexity $7 \mathrm{~mm}$.

Ligamental groove opisthodetic, short, narrow. Nymph short and rather stout. Hinge of left valve with two cardinal teeth, the anterior one prominent, trigonal, slightly oblique forward, the posterior one narrow, nonprominent, oblique backward, subparallel to the nymph, the two separated by a deep triangular socket; anterior lateral short, stout, distant; posterior lateral proportionately short and weak and nearer the beak. Hinge of right valve with two cardinal teeth, the anterior one short, weak, and strongly oblique forward, the posterior one stout, trigonal, oblique backward, the two separated by a deep trigonal socket; the posterior lateral dentition consists of a pair of short claspers, the inner element of which is stout, the outer weak and blending with the margin of the shell, the two elements separated by a narrow socket; the anterior lateral dentition presents a similar pair of short claspors. The hinge becomes proportionately thick and rugred in adults. Adductor scars high in the shell, the anterior one subtrigonal in outline, the posterior one larger and somewhat elongated. Pallial line entire. Inner nargin strongly crenulated, the indentations corresponding to the ends of the ribs.

The species is closely related to, possibly specifically identical with, poorly' preserved specimens of Cardium (Trachycardium) from water-laid volcanic sandstone 
exposed in a small area on the west flank of Prothro salt dome, Bienville Parish, La. (U. S. G. S. 12870, 12950). (See Spooner, 1926, p. 248.) ,

Types: Holotype, a half-grown left valve, U. S. N.M. 104048 (U. S. G. S. 18894) ; 2 figured paratypes, U. S. N. M. 104049 (U. S. G. S. 18894); 57 unfigured paratypes, many fragmentary, U. S. N. M. 104050 (U. S. G. S. 18894) ; 17 unfigured paratypes, U. S. N. M. 104051 (U. S. G. S. 18930).

Occurrence: Avent No. 1 well, Grenada County, depth 2,730-2,750 feet (U. S. G. S. 18894, 18930).

\section{Family VENERIDAE \\ Genus FULPIA Stephenson, 1946 \\ Fulpia? subtrigona Stephenson, n. sp.}

Plate 32, figures 29, 30

The core yielded only two examples of this species, one an adult right valve and the other a juvenile shell with both valves present.

Shell small, roughly subtrigowal in outline, moderately convex, inequilateral, equivalve. Umbonal ridge weak, rounded. Beak of moderate prominence, incurved, prosogyrate, situated a little in advance of the midlength. Anterodorsal slope steep, excavated; posterodorsal slope steep, gently rounded both radially and transverse to the margin, ending distally in a short marginal subtruncation. Lunule and escutcheon wanting. Surface ornamented only with fine incremental lines and irregularly distributed, stronger, concentric grooves, which mark brief resting stages.

Dimensions of the holotype: Length $12.5 \mathrm{~mm}$, height $11.7 \mathrm{~mm}$., convexity $3.9 \mathrm{~mm}$.

Ligamental groove external, opisthodetic, about 3 $\mathrm{mm}$. long in the holotype. Hinge of right valve not completely preserved. Cardinal teeth three, the anterior one obscure, weak, apparently fused with the margin of the shell, the medial one nearly direct, of moderate thickness, partly broken away, posterior one long, oblique, strong. Anterior cardinal socket narrow, deep, trigonal; medial socket wide, deep, trigonal; posterior socket long, narrow, oblique, deep. The anterior cardinal socket opens in the forward direction into a long, narrow lateral groove or socket which is poorly preserved anteriorly; presumably this groove serves as a socket for a corresponding long anterior lateral tooth of the left valve. Beginning just back of the distal end of the ligamental groove a long, lateral groove or socket extends rearward, becoming obscure in that direction because of poor preservation. Other internal features not uncovered.

This species, though too poorly preserved for positive identification, appears to possess the generic characters of Fulpia Stephenson, which was first described from the Woodbine formation of Texas. The Texas mate- rial (1946, pp. 68-71, pl. 12) is abundant and wellpreserved.

Types: Holotype, U. S. N. M. 104052 (U. S. G. S. 18894); one unfigured paratype, a nearly complete juvenile shell, U. S. N. M. 104053 (U. S. G. S. 18930).

Occurrence: Avent No. 1 well, Grenada County, depth 2,730-2,750 feet (U. S. G. S. 18894, 18930).

\section{Genius APHRODINA Conrad, 1869}

\section{Aphrodina sp.}

Plate 32, figures 18-20

Three fragmentary specimens in the Avont core are referred to the genus A phrodina Conrad. They include a medium-sized right valve showing most of the hinge, the umbonal region, and part of the exterior, a left valve of a smaller specimen showing part of the hinge, the beak, and part of the exterior, and one very small, incomplete right valve.

The shell is ovate-elongate in outline, smooth, and only moderately inflated. The lunule is long, rather narrowly lanceolate, and bounded by a sharply defined line. Escutcheon wanting. Ligamental groove long, sharply incised, bounded by a well-developed nymph. Beak moderately prominent, prosogyrate. The right hinge bears three cardinal teeth, of which the anterior one is oblique forward, narrow above, and thick distally, the medial one is direct, elongate-trigonal, and prominent, the posterior one is long, oblique rearward, thick, and slightly bifid distally. The anterior and medial sockets are of medium width and depth, and the posterior socket is long, narrow, and shallower than the other two. The anterior lateral dentition consists of a socket of moderate length separating a thick tooth below from a narrow, weak one above. Tha left hinge bears three cardinal teeth, of which the anterior one is thick, trigonal, and slightly bifid, the madial one is moderately thick and entire, and the posterior one is loug, narrow, and weak. Anterior lateral tooth well developed.

Occurrence: Avent No. 1 well, Grenada County, depth 2,730-2,750 feet. U. S. N. M. 104054 (U. S. G. S. 18894).

\section{Family TELIINIDAE}

Genus TELLINA Linné, 1758

Tellina harrelli Stephenson, n. sp.

Plate 32, figures 5-8

Shell small for the genus, elongate-subelliptical in outline, compressed, slightly inequilateral. Beaks small, compressed, nouprominent, nearly direct, situated near the midlength. Greatest inflation above the midheight, near the midlength, from which point the surface curves over gently to the anterior and ventral margins and to 
the weakly defined, broadly rounded umbonal ridge. Back of the ridge the posterodorsal slope steepens and forms a broadly excavated radial band extending from the beak to the posterior margin; this band bears 10 or 12 fine, closely spaced radial riblets. The rest of the outer surface is marked by fine growth lines, the ones on the umbonal area of unworn shells being the sharpest and coarsest. On some shells 2 or 3 obscure radial lines are present on the anterodorsal slope. Anterodorsal margin nearly straight to very gently arched; anterior margin sharply rounded; ventral margin broadly rounded; posterior margin subtruncated, inclined forward; posterodorsal margin broadly excavated.

None of the shells is sufficiently complete around the margins for an accurate measurement. The holotype, a right valve; measures: Length $8.5+\mathrm{mm}$., height $5.8+\mathrm{mm}$., convexity $1.4 \mathrm{~mm}$. One large incomplete left valve must be at least $22 \mathrm{~mm}$. long and is probably $12 \mathrm{~mm}$. or more high.

Ligamental groove long, extending about halfway to the terminus, deeply incised, $\mathbf{V}$-shaped in cross section, bordered within by a narrow but strong nymph. The hinge of the right valve, as seen in the holotype, bears two cardinal teeth, of which the posterior one (broken off in this specimen) is thick, trigonal, slightly oblique to the rear, and presumably bifid; the anterior one is small, narrow, nonprominent, and slightly oblique forward; the two are separated by a deep trigonal socket; behind the large cardinal is a narrow, shallow, oblique socket. About $1 \mathrm{~mm}$. in front of the cardinal area is a pair of short lateral claspers, the outer element of which blends with the margin; the posterior lateral dentition is not clearly seen in the available material. In one of the paratypes, a left valve, the anterior cardinal tooth is prominent, thick, bifid, and slightly oblique forward, and the posterior cardinal is narrow, nonprominent, oblique to the rear, and blends with the margin; the separating socket is wide, deep, and trigonal. The anterior lateral is short and of moderate strength. Posterior lateral not seen. Other internal features not uncovered.

The species is especially characterized by the group of fine radial lines on the posterodorsal slope of both valves.

The species is named in honor of Mr. David Harrell, geologist of the Carter Oil Co., who furnished part of the core material from the Avent well.

-Types: Holotype, U. S. N. M. 104055 (U. S. G. S. 18930 ) ; one figured paratype, U. S. N. M. 104056 (U. S. G. S. 18930); four unfigured paratypes, U. S. N. M. 104057 (U. S. G. S. 18930) ; four unfigured paratypes, U. S. N. M. 104058 (U. S. G. S. 18894).

Occurrence: Avent No. 1 well, Grenada County, depth 2,730-2,750 feet (U. S. G. S. 18894, 18930).

\section{Unidentified specimens of Tellina?}

The Avent core yielded nine specimens of small Tellina-like bivalves (one figured, U. S. G. S. 18\&94, U. S. N. M. 104059 ; six shells unfigured, U. S. G. S. 18894 , U. S. N. M. 104060 ; two unfigured shells, U. S. G. S. 18930 , U. S. N. M. 104061), the largest of which is less than $7 \mathrm{~mm}$. long. None of the hinges was successfully uncovered. The shell is subtrigonal-elongate, rather compressed, and is regularly ornamented with sharp concentric lines, which are coarsest in the umbonal region. No radiating lines present. Beaks situated a little back of the midlength. Ligament short, external, opisthodetic. These shells are designated Tellina? sp. a. One of them, interpreted to be a left valve, is figured (pl. 32, fig. 1).

Another small Tellina-like species is represented by eight specimens (three specimens, U. S. G. S. 18894, U. S. N. M. 10t06t; five specimens, U. S. G. S. 18930 , one figured, U. S. N. M. 104062, four unfigured, U. S. N. M. 104063). One incomplete right valve is $10+\mathrm{rm}$. long. This form is designated Tellina? sp. $b$. The shell is more compressed than in the preceding (sp. $a$ ), and the growth lines are so fine that the surface appears quite smooth. The beak is small, nonprominent, and situc.ted back of the midlength. One right valve is figured (pl. 32 , fig. 2).

Several fragments having a form and outline suggestive of Tellina (U. S. G. S. 18894, one figured, C. S. N. M. 104065 , two unfigured, U. S. N. M. 104066; U. S. G. S. 18930 , U. S. N. M. 104067 , three specimens) are characterized by having the narrow posterodorsal slope cut by a moderately pronounced sulcus extending from the beak to the upper part of the posterior marrin. Otherwise the surface bears only fine growth lines. This is Tellina? sp. $c$. The hinge of the right valve is essentially like that of Tellina with a large trigonal posterior cardinal tooth (broken in the figured specimen), and a weak anterior cardinal; anterior and posterior lateral claspers are well developed. The incomplete right valve shown in the illustration (pl. 32, figs. $3,4)$ is $12+\mathrm{mm}$. long.

\section{Genus IINEARIA Conrad, 1860}

\section{Linearia sp.}

Plate 32, figure 9

One fragment of a right bivalve shell shows the umbonal area, including part of the hinge and part of the anterodorsal slope. The shell is compressed, and the surface bears narrow radiating costae which are conrsest on the anterodorsal slope and become fine to obscure on the side. The posterodorsal slope is broken array. The surface is further marked by pronounced consentric, rather closely spaced ridges, which, on the side, are much stronger than the radiating riblets. Relation- 
ship to the genus Linearia Conrad is definitely shown by the closely spaced, rather long pair of cardinal teeth directed with strong obliquity toward the front. There is also a pair of elongated anterior lateral claspers. The fragment is $5 \mathrm{~mm}$. long, and the complete shell would probably be 8 or $10 \mathrm{~mm}$. long.

Occurrence: Avent No. 1 well, Grenada County, depth 2,730-2,750 feet. U. S. N. M. 104068 (U. S. G. S. 18894).

Family DONACIDAE

Genus PROTODONAX Vokes, 1945

Protodonax sp.'

Plate 32, figure 10

One small, smooth Donax-like left valve is referred to the recently erected genus, Protodonax Vokes (1945, pp. 295-308). The outline is elongate-subtrigonal. The posterior slope is short and steep, and the posterior margin is regularly rounded from the hinge down to the ventral margin. The anterior part of the shell is proportionately very long, and the anterior margin is sharply rounded. The anterodorsal margin is long, descending, and nearly straight, and the ventral margin is very broadly rounded. The hinge is not well preserved.

Dimensions: Length $5.6 \mathrm{~mm}$., height $3.5 \mathrm{~mm}$., convexity about $1.2 \mathrm{~mm}$.

Occurrence: Avent No. 1 well, Grenada County, depth 2,730-2,750 feet. U. S. N. M. 104069 (U. S. G. S. 18894).

\section{Family MACTRIDAE}

Genus SPISULA Gray, 1837

Spisula brevis Stephenson, n. sp.

Plate 32, figures 26, 27

Shell of medium size, short-subtrigonal in outline, moderately inflated, inequilateral, equivalve. Beaks prominent, strongly incurved, slightly prosogyrate, situated somewhat back of the midlength. Umbonal ridge obtusely subangular in cross section, sinuous in trend. Anterodorsal slope steep, moderately descending. Posterodorsal slope steep and steeply descending toward the lower posterior margin. The anterodorsal slope or lunule is outlined by a shallow, radial sulcus, which is bordered on the inner side by a narrow band marked only by fine growth lines, and between this band and the dorsal margin is a band roughened by closely spaced, sharp-crested, concentric ridges. The posterodorsal slope between the umbonal ridge and the dorsal margin is almost equally divided into two radial bands having surfaces respectively similar to the radial bands on the anterodorsal slope. The main or lateral surface of the shell between the two dorsal slopes is marked only by fine growth lines. .
The incomplete holotype, a right valve, is $11+\mathrm{mm}$. long, is about $11 \mathrm{~mm}$. high, and has a convexity of about $4 \mathrm{~mm}$. One paratype is the internal mold of the anterior part of a left valve about twice as large as the holotype, with several fragments of shell attached to it.

The ligament appears to have been quite small and has left no certainly recognizable mark of attachment qn the margin of the shell; the resilium was large and occupied a very shallow pit on the hinge plate; the ligament and resilium were not separated by a shelly septum and were probably closely associated. There are two cardinal teeth in the right valve, the posterior one of which (broken away in the holotype) is thick, tabular, rather prominient, and closely borders the resilium on its anterior side; at its upper end it coalesces with the end of the shell margin (spur of Dall), and it appears to be separated by a narrow space from the upper end of the anterior cardinal. The anterior cardinal is thin, nonprominent, oblique, and is coaloscent with the inner wall of the shell margin; between the two cardinals is a wide trigonal socket. Students of Recent mactroid shells usually treat these two cardinal teeth as the two arms of a compound cardinal tooth; there seems to be no reason in the present species, however, why they should not be regarded as separate cardinal teeth, as the socket separating them receiver a cardinal tooth of the left valve. A deep anterior lateral socket separates a pair of claspers, the inner element of which is of medium thickness and fairly prominent, and the outer element of which is weak and coalescent with the shell margin; this lateral socket lies closely in front of the anterior cardinal tooth and is connected with the cardinal socket by a narrow channel below the end of the tooth. From just back of the resilifer a pronounced groove passes posteriorly along the hinge plcte merging distally into a deep lateral socket between a pair of claspers which are comparable in strength and relationships to the anterior claspers; the posterior end of these claspers is broken away. Other internal features are not uncovered.

This species differs from the genotype, Spisula solida (Linné), from the Recent seas of Europe, in several details, the most important of which is the strong development of the posterior cardinal tooth in the right valve (= posterior arm of compound cardinal tooth of authors). In the genotype and other Recent species the posterior cardinal has been reduced to a thin, short remnant attached to the upper end of the anterior cardinal by the expanding development of the resilium; there is a more intimate relationship of the latersl dentition of $S$. brevis to the cardinal dentition and to the resilifer; and the resilifer is more deeply sunken in the hinge plate. These differences probably warrant a sectional name for the species here under consideration, but a new section should be based on more complete material than is now available. 
Types: Holotype, U. S. N. M. 104070; two unfigured paratypes, U. S. N. M. 104071.

Occurrence: Avent No. 1 well, Grenada Connty, depth 2,730-2,750 feet (U. S.G. S. 18894).

\section{Family CORBULIDAE}

\section{Genus CARYoCORBULA Gardner, 1926}

Type species: Corbula alabamiensis Isaac Lea

Caryocorbula mississippiana Stephenson, n. sp.

Plate 32, figures 11-13

Shell of medium size, subtrigonal, moderately inflated, strongly inequilateral, inequivalve. Beaks of moderate prominence, strongly incurved, prosogyrate, approximate, situated a little back of the midlength; the right beak is more prominent than the left and more strongly incurved. The right valve is most inflated in a curved area extending from the midheight a little back of the umbo forward and downward toward the anterior extremity; from this inflated area the surface rounds down steeply toward and overhangs the anterodorsal margin, less steeply to the ventral margin, and steeply to the posterodorsal margin. The left valve is much less inflated than the right. Anterodorsal margin gently arched, descending; anterior margin sharply rounded; ventral margin broadly rounded; posterior margin short, squarely truncated; posterodorsal margin short, broadly concave. Umbonal ridge sinuous, sharply and obtusely angular in cross section. In front of the ridge on the right valve is a broad, shallow radial sulcus, and back of the ridge the posterodorsal slope is sinuous in the radial direction and broadly excavated on either side of a low central ridge or carina; a corresponding ridge is feebly developed on the left valve. The surfaces of the two valves are about equally marked by fine, somewhat irregular growth lines and irregular ridges, which may become fairly coarse toward the ventral margin of adults. One fragmentary left valve shows a neatly outlined nepionic-like shell capping the umbo, but this may be a fortuitous feature determined by a resting stage in the growth of the animal.

The holotype is an incomplete right valve, the posterior part of which is partly broken away from the internal mold. Its dimensions are: Length about 13.5 $\mathrm{mm}$., height about $11 \mathrm{~mm}$., convexity $4.2 \mathrm{~mm}$.

The hinge of the right valve, as seen in the holotype, presents one prominent, trigonal, slightly upturned cardinal tooth, bordered in front by a round-bottomed trench of medium width and depth, which opens inward and into which the margin of the left valve fits; behind this tooth is a profound pit that receives the chondrophore of the left valve; the right end of the resilium is attached in the upper part of this pit under the overhanging umbo. The left valve bears a partly submerged chondrophore, which protrudes inward and 732303-47-4 slightly rearward; the surface of this chondrophore includes an elongated, spoon-shaped pit bordered behind by a narrow, shallow groove opening inward in a flaring notch, and in front by a slightly prominent, bicarinate ridge about half as wide as the pit. In front of the chondrophore is a deep triangular socket, which receives the cardinal tooth of the right valve. The inner surface of the shell is smooth with the exception of the slightly impressed adductor scars.

This species is similar in form and size to Corbula subgibbosa Conrad from the Snow Hill calcaresus member of the Black Creek formation in North Cr.rolina but is shorter in proportion to the height (Stephenson, 1923 , pp. 343 , 344, pl. 86, figs. 6-12).

Compared with Caryocorbula alabamiensis (Lea), the genotype of Caryocorbula Gardner (1926, p. 46), this species is shorter in outline but is similar in its surface features and in essential ligamental and hinge characters. Compared with Corbula (Corbula) sulcata Lamarck, Vokes ${ }^{1}$ finds that the ligament of the true Corbula differs in important respects from that of Caryocorbula.

Types: Holotype, U. S. N. M. 104072; one figured paratype, U. S. N. M. 104073 ; four unfigured paratypes, U. S. N. M. 104074 .

Occurrence: Avent No. 1 well, Grenada County, depth 2,730-2,750 feet (U. S. G. S. 18894).

\section{Caryocorbula morsei Stephenson, n. sp.}

Plate 32, figures 14-16

The species is represented in the Avent core by four shells, two of which are juvenile.

Shell of medium size, subtrigonal in outline, moderately inflated, inequilateral. Beak prominent, strongly incurved, slightly prosogyrate, centrally located. Anterodorsal slope steep, overhanging near the beak; anterior and ventral-facing slopes rounding down with moderate steepness. Umbonal ridge sharp, sinuous, obtusely angular in cross section. Posterodorsal slope a proportionally narrow, sinuous, broadly excavated band ending distally at the posterior truncation. Between this band and the margin is a well-defined lanceolate, escutcheon-like area bounded by a dull-crested carina. The umbonal part of the shell surface (socalled nepionic shell) is ornamented with fine, closely spaced, concentric ridges. From this area outward the rest of the surface is covered with progressively coarser concentric ridges, those nearest the margin being about half a millimeter wide; approaching the umbonal ridge these concentric ridges fade out somewhat erraticelly to mere growth lines and are wanting on the posterodorsal slope.

Dimensions of the incomplete holotype: Length $11+$ $\mathrm{mm}$., height about $9 \mathrm{~mm}$., convexity about $4 \mathrm{~mm}$.

\footnotetext{
1 Vokes, H. E., oral communication.
} 
The hinge of the right valve includes a large trigonal cardinal tooth curving upward at the end, a wide channel opening inward in front of this tooth, and a deep pit back of the tooth for the reception of the chrondrophore of the left valve. A groove just within and paralleling the margin of the shell, best seen on the paratype, indicates that the right valve is a little larger than and slightly overlaps the left valve.

Compared with Corbula mississippiana this species is shorter, is more pointed posteriorly, and has a coarser concentric ribbing.

The species is named in honor of Prof. William Clifford Morse.

Types: Holotype, U. S. N. M. 104075 (U. S. G. S. 18930) ; one figured paratype, U. S. N. M. 104076 (U. S. G. S. 18930); two unfigured paratypes, U. S. N. M. 104077 (U. S. G. S. 18894).

Occurrence : Avent No. 1 well, Grenada County, depth 2,730-2,750 feet (U. S. G. S. 18894, 18930).

\section{Caryocorbula sp. $a$}

One large left valve (Caryocorbula sp. $a$, pl. 32, fig. 17) resembles $C$. oxynema (Conrad) in form and is of comparable size to that species (Stephenson, 1923, pp. 341,342 , pl. 86, figs. 13-17). The surface and hinge are considerably worn, and the posterior end is broken away. The shell is elongate-subtrigonal in outline and is laterally somewhat compressed.

Dimensions : Length $14+$ mm., height about $10.5 \mathrm{~mm}$., convexity $4 \mathrm{~mm}$.

Occurrence: Avent No. 1 well, Grenada County, depth 2,730-2,750 feet. U. S. N.M. 104078 (U. S. G. S. 18894).

\section{Caryocorbula sp. $b$}

One small incomplete right valve (Caryocorbula sp. b) may be a juvenile individual of a larger species. It appears to be a relatively short, high shell with fine, fairly pronounced concentric ribbing, a little sinuous in trend, and becoming coarser ventrally. It has a distinct umbonal ridge, obtusely subangular in cross section. The posterodorsal slope is steep and broadly excavated. The hinge and other internal features are not well preserved.

Dimensions as preserved: Length $2.7+\mathrm{mm}$., height $2.2 \mathrm{~mm}$., convexity $1.2 \mathrm{~mm}$.

Occurrence : Avent No. 1 well, Grenada County, depth 2,730-2,750 feet. U. S. N. M. 104079 (U. S. G. S. 18894).

\section{Caryocorbula sp. $c$}

Two small, incomplete specimens (Caryocorbula sp. $c)$, one a right valve and the other a left valve, pertain to a short, very plump species. They may be juvenile. The form and dentition are typically corbuloid, but the preservation is too poor for accurate specific assignment. The right valve measures: Length $4.4+\mathrm{mm}$., height $3.2+$ mm., convexity $1.9 \mathrm{~mm}$.
Occurrence : Avent No. 1 well, Grenada Co'unty, depth 2,730-2,750 feet. Left valve, U. S. N. M. $10^{4080 ~(U . ~ S . ~}$ G. S. 18894) ; right valve, U. S. N. M. 104081 (U. S. G. S. 18930).

\section{Caryocorbula sp. $d$}

One fragment of a right valve indicates a somewhat elongated, somewhat depressed species (Caryocorbula sp. $d)$. It is characterized by a short, steep, anterodorsal slope and a long, wide, and broadly excavated posterodorsal slope. The cardinal tooth is proportionately large and prominent. The fragment is ak sut $6 \mathrm{~mm}$. long.

Occurrence: Avent No. 1 well, Grenada Co'unty, depth 2,730-2,750 feet. U.S. N. M. 104082 (U.S. G. S. 18930).

\section{Class SCAPHOPODA}

Family DENTALIIDAE

Genus DENTALruM Linné, 1758

\section{- Dentalium sp.}

Several fragments of smooth, gently tapering, gently curved tubes appear to pertain to a small Dentalium. The smallest fragment measures $0.7 \mathrm{~mm}$. in diameter at the small end, and the maximum diameter of the largest fragment is $1.8 \mathrm{~mm}$. The tubes appear to be broadly subovate in cross section, the longert, diameter being at right angles to the plane of curvature of the tube.

Occurrence: A vent No. 1 well, Grenada County, depth 2,730-2,750 feet. Eight specimens, U. S. N. M. 104083 (U. S. G. S. 18894); one specimen, U. S. N. M. 104084 (U. S. G. S. 18930).

\section{Class GASTROPODA}

Family NERITIDAE

Genus NERITA Linné, 1758, sensu lat?

Nerita nodosa Stephenson, n. sp.

Plate 33, figures 1-3

Shell small, closely involute, with very low spire. Protoconch very small, beadlike, somewhat worn in the available specimens, but apparently a smooth, simple trochoid shell. Whorls about 2 , rapidly expanding. Shoulder weakly defined, broadly convex, rounding over to the broadly convex side below. Surface of holotype ornamented with 14 strongly noded primary spiral ribs, with 3 intercalated small secondary ribs appearing in the early stages of the body whorl, 2 on the side, and 1 on the shoulder. The nodes on the spirals are circular in plan and stand up as sharply defined low domes, forming regular rows on each primary spiral; the ribs and nodes are coarsest on the shoulders and upper part of the whorl and on the base. Aperture 
subovate with a shallow but rather long, well-defined anal canal curving from the posterior end upward and to the left as seen from in front; anterior end of aperture regularly rounded. Outer lip thick and forming an approximate semicircle slightly modified at the intersection of the shoulder subangle; inner surface of outer lip apparently smooth. Inner lip forming a thick callus, which thins and spreads forward and upward on the parietal wall; the anal canal follows the upper edge of this callus to its upper terminus; inner edge of callus smooth, or with 1 weak tooth near the upper end as seen in 1 paratype.

Dimensions of the holotype: Height about $5 \mathrm{~mm}$., diameter about $4.5 \mathrm{~mm}$.

The species differs from Nerita dentioulata in the simplicity and more sunken configuration of its inner lip, in the absence of denticulations on the inner surface of the outer lip, and in the greater strength and coarseness of the surface ornamentation.

Types: Holotype, U. S. N. M. 104085 (U. S. G. S. 18894) ; nine unfigured paratypes, U. S. N. M. 104086 (U. S. G. S. 18894); three unfigured paratypes, U. S. N. M. 104087 (U. S. G. S. 18930).

Occurrence: Avent No. 1 well, Grenada County, depth 2,730-2,750 feet (U. S. G. S. 18894, 18930).

\section{Nerita denticulata Stephenson, n. sp. \\ Plate 33, figures 4-6}

Shell small, semisubglobose, closely involute, with very low spire. Protoconch badly worn. Whorls 2 or $21 / 2$, rapidly expanding. Body whorl plumply rounded with a mere trace of a shoulder angulation. Surface covered with about 17 spiral ribs, which are rather badly worn or corroded but which in places show weak tubercles. Aperture subcrescentic with a shallow anal canal curving to the left and upward; anterior margin rounded. Outer lip strongly and asymmetrically arched, thin at the edge, thickening rearward; inner surface a little back of outer lip set with a row of 8 or 9 distinct, spirally elongated denticulations. Inner lip plumply callused, the callus spreading forward and thinning to an edge on the parietal wall; inner edge of lip with 3 strong teeth or plications, the upper one of which is a little thicker than the other 2 .

Dimensions: Height about $4 \mathrm{~mm}$., diameter about 5 $\mathrm{mm}$.

This species differs from Nerita nodosa in its plump, strongly denticulate inner lip, its more rotund profile, and its weaker and somewhat finer surface ornamentation.

Type: Holotype, U. S. N. M. 104088.

Occurrence: Avent No. 1 well, Grenada County, depth 2,730-2,750 feet (U. S. G. S. 18894).
Family MELANELLIDAE

Genus MELaNelia Bowdich, 1822

Melanella (Eulima?) parva Stephenson, n. sp.

Plate 33, figures 1.1, 12

Shell very small, smooth, straight, high-turreted with apical angle of about $25^{\circ}$, decreasing somewhat on the larger whorls of the spire below. Protoconch small, smooth, trochoid. Suture line sharp and very shallow. Whorls six or seven, very gently convex, almost flat on the sides. Periphery and base of body whorl brordly rounded. Aperture broadly lanceolate, acutely angular at the rear, sharply rounded in front. Outer lip thin, broadly arched. Inner lip broadly excavated.

Dimensions of the one available shell : Height 3.6 mm., diameter $1.1 \mathrm{~mm}$.

A small smooth shell of this sort affords a very menger basis for generic assignment. It may be juvenile but it is nearly complete and is therefore given a specific name.

If curvature of the spire, which characterizes the genotype, Melanella dufresnii Bowdich, be accepted as of genetic value the name Eulima Risso, 1826, may be used with subgeneric rank for straight-spired slolls, such as the one here described, as suggested by Vokes (1939, p. 177).

Holotype: U. S. N. M. 104089.

Occurrence: Avent No. 1 well, Grenada County, depth 2,730-2,750 feet (U. S. G. S. 18894).

\section{Family NATICIDAE}

\section{Genus NATICA Scopoli, 1777, sensu lato}

Unidentified specimens of Natica?

One medium-sized shell from Avent No. 1 well, Grenada County, depth 2,730-2,750 feet, has a low spire, and three and a half or four rapidly expanding whorls (pl. 33, figs. 7, 8). Protoconch worn away. The surface is smooth with the exception of rather pronounced growth lines. A narrow, weakly developed should or is present and is limited outwardly by an obtuse subangulation. The side of the body whorl is broadly rounded in profile. Umbilicus deep, narrow. Inner lip forming an expanded callus on the parietal wall. Dimensions: Height about $10 \mathrm{~mm}$., diameter $7+\mathrm{mm}$. U. S. N. M. 104090 (U. S. G. S. 18894).

One small shell from the same source, referred questionably to Natica (pl. 33, figs. 9, 10), has a small protoconch partly worn away and lacks a shoulder. It is plump in profile and has a small umbilicus. Dimensions: Height $2.7 \mathrm{~mm}$., diameter $2.4 \mathrm{~mm}$. U. S. I'. M. 104091 (U. S. G. S. 18894). 


\section{Family TURRITELLIDAE}

\section{Genus TURRITELLA Lamarck, 1799}

Turritella toleri Stephenson, n. sp.

Plate 33, figures 13-15

Shell small for the genus, high-turreted, with spiral angle of about $18^{\circ}$. Protoconch not preserved. Suture closely appressed, moderately impressed. Whorls 11 in the holotype, with 2 or 3 of the apical ones missing, flattish to very gently convex on the side. The sides of the whorls are ornamented with 3 primary and 4 secondary spiral ribs; the lower and middle primaries are a little closer together than the middle and upper ones; the primaries are very feebly noded. In each of the interspaces between the suture below and the suture above is a secondary spiral, all of which are fine and weak except the uppermost one just below the upper suture, which is a little stronger than the others. The secondaries fade out apically and are not seen on the smaller whorls of the spire. The primaries maintain their identity practically to the apex. The periphery of the body whorl bears a pair of spiral ribs separated by a shallow depression, the upper one of which is stronger; as the growing body whorl advanced it covered the lower rib of this pair, and its upper edge rests against the upper rib whose crest remains slightly exposed as a low narrow ridge bordering the suture. The flattish base below the pair of spirals is covered with a series of very fine, obscure spiral lines. From below upward the growth lines on the side of the whorl trend with strong obliquity backward to a point well above the middle, thence curve forward to the suture above; the antispiral sinus is therefore high on the whorl, and the growth-line angle is to the left of the axis instead of to the right, as it is in all the examples figured by Merriam (1941, p. 36, fig. 5). Aperture subcircular. Outer lip and part of the body whorl of the holotype broken away for several millimeters back of the aperture. Inner lip forming a thin callus over the base.

Dimensions of the holotype: Height $19.5 \mathrm{~mm}$., diameter about $6.3 \mathrm{~mm}$.

One fragment consisting of parts of three whorls (maximum diameter $4.3 \mathrm{~mm}$.) has the pattern of ornamentation of the holotype of this species, except that the secondary spiral ribs are decidedly stronger; whether it is a distinct variety or merely an individual variant cannot be determined without a larger suite of specimens for comparison; for the present it is retained in the species.

The species is named in honor of Mr. Henry N. Toler, first president of the Mississippi Geological Society.

Types: Holotype, U. S. N. M. 104092; one unfigured paratype, U. S. N. M. 104093; one unfigured example (var.?), U. S. N. M. 104094.

Occurrence: Avent No. 1 well, Grenada County, depth 2,730-2,750 feet (U. S. G. S. 18894).
Turritella magnoliana Stephenson, n. s\}. Plate 33, figures 16-18

Shell small for the genus, turreted, with spiral angle of about $20^{\circ}$. Protoconch not preserved. Siture closely appressed, deeply impressed. Whor's broadly rounded on the side; four of the larger whorls preserved on the holotype. On the smallest whorl on the holotype (diameter about $3 \mathrm{~mm}$.) are seven somewhat unequal spiral ribs of primary strength; between the second and third primaries from the top, and between the two lowermost primaries, are small secondaries that gradually increase in strength on the succeeding larger whorls but fall short of attaining primary streng ${ }^{+} h$; a third secondary makes its appearance between the third and fourth primaries on the antepenultimate whorl, and it too gains slowly in strength but remains conparatively small. An eighth primary spiral is present on the rounded periphery of the body whorl, but its crest appears only as a low ridge just above the suture on the earlier whorls; a narrow, shallow depressicn parallels the lower side of this rib on the body whorl. Base strongly constricted, very gently convex, smooth with the exception of very obscure spiral lining. Growth lines obscure. Shell broken away for about $5 \mathrm{~mm}$. back of the outer lip of the aperture, which presumably is subcircular.

The preceding description is based mainly on the holotype, the largest and best preserved of four fragmentary specimens. The three paratypes exhibit individual variations, such as are common among the shells of turritelloid species. The largest of the paratypes is flattish on the upper part of the whorl and presents a stronger and more numerous development of secondary and tertiary spirals. There are seven primary spiral ribs, of which the second and fifth ones below the top are the strongest, and the las, one below just above the suture is the weakest; secondaries are present in all the interspaces, and several very weak tertiaries can barely be discerned. The priphery is rounded, and the alternation of primary and secondary spirals continues over on to the base with diminishing strength, dying out a little more than half way across. The advancing callus of the growing shell covers these weaker spirals.

Dimensions of the incomplete holotype : J eight $14+$ mm., diameter $6+\mathrm{mm}$.

Compared with Turritella toleri this species has more deeply impressed sutures, the whorls are more convex on the sides, and the spiral ribs are more numerous and offer no suggestion of noding.

The name of this species is derived from "Magnolia," one of the nicknames of the State of Missis sippi.

Types: Holotype, U. S. N. M. 104095 (T. S. G. S. 18894); one figured paratype, U. S. N. M. 104096 (U. S. G. S. 18894) ; one unfigured paratype, U. S. N. M. 
104097 (U. S. G. S. 18894) ; one unfigured paratype, U. S. N. M. 104098 (U.S. G. S. 18930).

Occurrence: Avent No. 1 well, Grenada County, depth 2,730-2,750 feet (U. S. G. S. 18894, 18930).

\section{Family CERITHIIDAE}

\section{Genus CERITHrUM Bruguière, 1789}

“Cerithium” imlayi Stephenson, n. sp.

Plate 33, figures 19-22

Shell of medium size, high-turreted, with spiral angle of about $13^{\circ}$. Protoconch not preserved. Suture closely appressed, deeply impressed. Whorls probably 15 or more, flattish on the side, descending gently to the sutural depression above and steeply to the depression below. Each whorl bears 2 primary spiral lirae of medium strength and a third weak spiral just below the upper suture. The spirals are crossed by regularly spaced axials of medium strength, which number 20 or 21 on the largest whorl (diameter $5.1 \mathrm{~mm}$.) and decrease to about 16 on the smallest whorl preserved (diameter $1.8 \mathrm{~mm}$.). At each intersection of a primary spiral with an axial there is a prominent roundish beadlike node; at each intersection of the third weak spiral with an axial is a small node elongate in the direction of the spiral; the strength of the third spiral, including the nodes, varies somewhat on different individuals. The periphery of the body whorl, as seen on one of the paratypes, bears a prominent, thick, rugged spiral ridge; the upper edge of the growing body whorl rests against the crest of this ridge with the result that the suture does not follow the bottom of the sutural depression but lies well up its lower side. Base of shell strongly constricted, broadly excavated, crossed by rugged growth lines whose trend is rather strongly convex toward the aperture. On the side of the whorl above the base the growth lines trend obliquely upward and backward to the lower primary spiral, thence directly upward to the upper primary spiral, thence obliquely forward to the upper suture line; this indicates a deep wide notch in the outer lip of the aperture. The aperture appears to be broadly lanceolate with an obtuse anal angulation at the rear and a sharply rounded anterior margin. Outer lip broken away; inner lip forming a thin callus, which spreads forward a little on the excavated base.

Dimensions of the holotype, which is incomplete at both ends: Height $12+\mathrm{mm}$., diameter at large end 4.4 mm., diameter at small end $2.6 \mathrm{~mm}$.

The species is named in honor of Dr. Ralph W. Imlay, geologist, U. S. Geological Survey.

Types: Holotype,-U. S. N. M. 104099 (U. S. G. S. 18894) ; two figured paratypes, U.S. N. M. 104100 (U.S. G. S. 18894); two unfigured paratypes, U. S. N. M. 104101 (U. S. G. S. 18894); one unfigured paratype, U. S. N. M. 104102 (U. S. G. S. 18930).
Occurrence : Avent No. 1 well, Grenada County, denth 2,730-2,750 feet (U. S. G. S. 18894, 18930).

\section{"Cerithium" sp. a}

Plate 33, figure 23

One fragment of a fairly large whorl appears to belong to some member of the Cerithiidae. The sculpture consists of regularly spaced, rather weak axials crossed by four heavily noded spirals, the uppermost one, bordering the suture, being a little thicker and heavier than the others. The trend of the growth lines is concave toward the aperture.

Occurrence: Avent No. 1 well, Grenada County, depth 2,730-2,750 feet. U. S. N. M. 104103 (U. S. G. S. 18930).

\section{“Cerithium" sp. b}

Plate 33, figure 24

Shell small, turreted, with spiral angle of $25^{\circ}$. Suture closely appressed, slightly impressed. Whorls six or seven (estimated), gradually expanding, flat on the sides. Body whorl subobtusely angulated at the periphery. Base steep, broadly convex. Body wl orl with five rather strong primary spiral ribs, and one secondary rib lies between the two uppermost primaries; the three uppermost primaries and the secondary rib are distinctly noded, the coarseness of the noding be ing proportional to the thickness; the two lowermost primaries are weakly noded. The upper edge of the growing body whorl rests against the lower flank of the lowermost primary. The outer area of the base bears six closely spaced spiral ribs, which are smaller than the primaries above and the successive ones of wl ich decrease in strength inward and die out before res.ching the center. Growth lines sinuous, being conver in trend toward the front on the base and strongly concave in the same direction on the side of the whorl above the periphery; the greatest depth of the latter curve is a little above the middle of the side.

Dimensions of the one available incomplete shell: Height $7+\mathrm{mm}$., diameter $3.7 \mathrm{~mm}$.

Occurrence: Avent No. 1 well, Grenada County, depth 2,730-2,750 feet. U. S. N. M. 104104 (U. S. G. S. 18894).

\section{Family STROMBIDAE}

Genus PUGNELLUS Conrad, 1860

Pugnellus calcaris Stephenson, n. sp.

Plate 33, figures 25-32

Shell medium to large, some fragments indicating a size probably twice that of the selected holotype, smooth, plump-fusiform in stage immediately preceding that of the adult. Spire of medium height, spiral angle on the larger whorls about $65^{\circ}$; apical angle about $72^{\circ}$. Protoconch a simple smooth trochoid shell of not more 
than two turns. Whorls six, evenly and regularly convex on the side. Suture closely appressed, moderately impressed. Body whorl elongated, with a slight, narrow constriction just below the suture, broadly excavated on the base. Growth lines sinuous, being gently sinuous low on the body whorl, strongly convex toward the aperture higher up toward the periphery, and concave in the same direction between the periphery and the suture above. Aperture at stage of growth shown in plate 33 , figure 31 , elongate, about three-fifths the height of the shell, asymmetrically lanceolate, with an acute angle at the rear and an open siphonal canal at the front. At this stage the outer lip is broadly arched above, becoming broadly concave below. Inner lip broadly excavated centrally and forming a thin callus on the parietal wall; remnants of this callus present on different parts of the shell indicate a general spread of the mantle over the exterior. At a shortly subsequent stage the outer lip thickens abruptly and puts out a short, thick, upturned, slightly twisted, spurlike projection, which bears a thick, round-crested, longitudinal ridge on the exterior above its lower border, and a narrow, longitudinal channel on its inner surface just below its upper border. Some fragments in the collection indicate that adult shells become much larger, perhaps twice as large as the holotype. Although the figured specimens do not show an excessive development of callus over the exterior of the shell, some fragments presumably of this species show a strong growth of callus extending up over and completely enveloping the spire.

Dimensions of the paratype shown in plate 33 , figures 30,31 : Height about $36 \mathrm{~mm}$., diameter $20 \mathrm{~mm}$.

The species is not closely similar to any described species in the American Upper Cretaceous. However, one gastropod from water-laid volcanic sandstone exposed in a small area on the west flank of the Prothro salt dome, Bienville Parish, La., appears to be specifically identical with this one.

Types: Holotype, U. S. N. M. 104105; 4 figured paratypes, U. S. N. M. 104106 ; 30 unfigured rather incomplete paratypes, including also numerous uncounted fragments, U. S. N. M. 104107. All these are from the part of the core numbered 18894. About a dozen fragments were obtained from the part of the core numbered 18930 (U. S. N. M. 104108).

Occurrence: Mississippi, Avent No. 1 well, Grenada County, depth 2,730-2,750 feet (U. S. G. S. 18894 , 18930).

Louisiana, questionably in water-laid volcanic sandstone exposed on west flank of Prothro salt dome. Bien'ville Parish (U. S. G. S. 11227, 12870).
Family PYROPSIDAE

Genus HERCORHYNCUS Conrad, 1869

Hercorhyncus? sp.

Plate 33, figures 41,42

This species is represented by 1 very incomplete shell, which includes part of the body whorl and a small part of the penultimate whorl. The shell is fusiform with an elongated body whorl and a spire of moderate height. Collar well developed, below which the body whorl bears an estimated 9 or 10 short, thick axials, which from below upward are slightly oblique toward the rear; they end above at the shoulder in a blunt, illdefined node and die out downward on the upper part of the basal slope. The base bears 4 ratl or strongly flattish-topped spirals separated by wider interspaces; above these spirals are several weaker spirals which become progressively more obscure upward and can barely be detected on the upper part of the body whorl; below the strong spirals are 2 or 3 obscure spirals. Growth lines sinuous, following the trend of the ribs to the edge of the shoulder, thence bending strongly forward across the shoulder and collar to the suture. Aperture rather wide above, passing anteriorly into a moderately long, somewhat twisted canal. Outer lip thin, arched, subangular at the intersection with the shoulder. Inner lip broadly excavated, forming a thin callus on the parietal wall. Columella smooth.

Occurrence: Avent No. 1 well, Grenada County, depth 2,730-2,750 feet. U. S. N. M. 104109 (U. S. G. S. 18894).

\section{Family PALADMETIDAE}

Genus PALADMETE Gardner, 1916

Paladmete caveola Stephenson, n. sF.

Plate 33, figures $33-36$

This species is based on four specimens, one, the holotype, a medium-sized, nearly complete shell, one an incomplete adult, and two young individus.ls.

Shell of medium size, plump, low spire, with spiral angle of about $70^{\circ}$. Protoconch not preserved. Suture closely appressed, deeply impresed. Whorls 5 in the adult, broadly rounded on the side, with narrow, slightly excavated shoulder dipping gently invard to the suture and rounding sharply over to the steop side. Periphery of body whorl rounding over to the constricted base, with a weak suggestion of an obtuse angulation. Body whorl of adult ornamented with ${ }^{\bullet} 15$ round-crested axials, which, from below upward, cross tho side of the whorl to the edge of the shoulder, thence bending sharply forward die out quickly about halfway across the 
narrow shoulder; the axials fade out rather abruptly below where they intersect the periphery. The axials number 14 on the penultimate and 12 on the antepenult whorl; the number of axials on the body whorl of the large adult is estimated to be 23 . The body whorl of the holotype bears about 10 small, obscure spirals, which are smallest and most closely spaced above near the shoulder; on and just below the periphery is a group of 4 spirals, which are stronger and more widely spaced than those above; the base below this group is smooth. Aperture broadly sublanceolate, with a very wide subobtuse angle at the rear, and a short, slightly twisted, wide open siphonal canal in the front.

The nearly complete holotype measures: Height $10.3+\mathrm{mm}$., diameter $7 \mathrm{~mm}$. The best preserved of the two young shells measures: Height $3.7+\mathrm{mm}$., diameter $2.8 \mathrm{~mm}$. The diameter of the large, incomplete adult is about $12 \mathrm{~mm}$.

Compared with Paladmete cancellaria (Conrad), the genotype, this species has a more twisted and narrower siphonal canal, a much weaker development of spiral ribs, more numerous and more regularly spaced axial ribs, and a narrower and less steeply sloping shoulder; there is also only a slight tendency toward the development of varices in this species.

Types: Holotype, U. S. N. M. 104110 (U. S. G. S. 18894); one figured paratype, U. S. N. M. 104111 (U. S. G. S. 18894) ; one unfigured paratype, U. S. N. M. 104112 (U. S. G. S. 18894); one figured paratype, U. S. N. M. 104113 (U. S. G. S. 18930).

Occurrence : Avent No. 1 well, Grenada County, depth $2,730-2,750$ feet (U. S. G. S. 18894, 18930).

Paladmete? sp.

Plate 33, figures 37,38

One small, well-preserved gastropod, apparently a very young individual, questionably referred to Paladmete, has a spire of medium height, plump, evenly rounded whorls, and an aperture about equal in length to the height of the spire. Protoconch small, smooth, trochoid. Suture moderately impressed. The upper part of the body whorl bears 25 or more closely spaced axial ribs of uniform size, and the penultimate whorl is similarly ribbed. No spirals observed. Perimeter of

\section{Part 2. A NEW VENERICARDIA}

\section{INTRODUCTION}

The new species of bivalve mollusk here described under the name Tenericardia uvaldana is part of an unrecorded fauna mainly of pelecypods and gastropods, but including echinoids, bryozoans, and other organisms, from a locality on Nueces River about 0.3 mile upstream from the Southern Pacific R. R. bridge, body whorl broadly rounded. Aperture acutely angular at rear, broadly rounded on front margin.

Dimensions : Height $1.5 \mathrm{~mm}$., diameter $0.9 \mathrm{~mm}$.

Occurrence: Avent No. 1 well, Grenada County, depth 2,730-2,750 feet. U. S. N. M. 104114 (U. S. G. S. 18894).

\section{Family FUSIDAE \\ Genus FUSINUS Rafinesque, 1815 \\ "Fusinus" sp.}

Plate 33, figures 39,40

One small gastropod exhibits shell characters that would seem to justify its reference to a new genus. It is, however, incomplete and is probably juvenile and is therefore hardly adequate to serve as the type of either a genus or a species.

Spire rather low with spiral angle of about $68^{\circ}$. Protoconch not preserved. Whorls about 3 , rapidly expanding. Body whorl with 2 prominent, unexual spiral ribs, the smaller one at the periphery and the larger one, which is high and sharp-crested, about ralfway between the periphery and the suture above. The small rib is engulfed by the upper border of the advancing body whorl and is not exposed on the earlier whorls. Between, above, and below the 2 ribs the surface is covered with small obscure lirae. The sjace between the 2 prominent spirals is crossed by submerged fairly regular axials (estimated 16 on the body whorl), which are inclined slightly forward and are separatel by wider interspaces; these axials ascend the lower slope of the large spiral rib and form low nodes on its crest. On the base the growth lines are slightly convex toward the front in trend. Between the spirals they follow the trend of the axials, and above the upper spiral they trend obliquely forward to the suture. Aperture rather broadly lanceolate, obtusely subangular at the rear; the anterior part of the shell is broken away, but the nearly straight columella suggests either a short siphonal canal or a sharply rounded or angular terminus. Outer lip broadly arched, angular at the intersection of the large spiral. Inner lip broadly excavated abore at the parietal wall. Dimensions of the incomplete sl $9 l 1$ : Height 3.5 $+\mathrm{mm}$., diameter $2.6 \mathrm{~mm}$.

Occurrence: Avent No. 1 well, Grenada County, depth 2,730-2,750 feet. U. S. N. M. 104115 (U. S. G. S. 188?4).

\section{FROM UVALDE COUNTY, TEXAS}

7 miles northwest of Uvalde, Uvalde County; Tex. (U. S. G. S. $15340,16152,16172,16177$ ). When the first collection was made in May 1930 the fossil-bearing rock was well-exposed low in the left bank and in the immediately adjacent dry bed of the River. In 1932 the rock was still exposed essentially as it was in 1930 . When the locality was visited again in 1941, stream 
erosion had cut the bank back toward the east a distance of fully 75 feet, and the site of the fossil-bearing rock had become covered by the shifting gravel of the river bed.

The rock that yielded Venericardia uvaldana and its numerous associated fossils consists of soft brownishyellow marl and limestone; samples of the marl are highly calcareous and react vigorously to cold dilute hydrochloric acid. This rock formed part of a jumbled mass of marl, limestone, and weathered, tuffaceous water-laid volcanic material at that time poorly exposed to a height of 3 or 4 feet above the bed of the river along a linear distance of 200 feet or more. Some of the fossil shells are partly or wholly silicified as the result of the circulation of silica-bearing waters within the mass; the silica that replaced the calcium carbonate has taken the form of closely packed rosettes of chalcedony. The fauna is interpreted to indicate that the containing rock formed part of the Anacacho limestone (Upper Cretaceous): A few fossils found in chalky limestone indicate that part of the mass belonged to the Austin chalk (Upper Cretaceous), and there was inconclusive fossil evidence that the Grayson marl (Del Rio) of the upper part of the Comanche series might be represented in the mixture. These Cretaceous rocks were overlain by 25 feet or more of alluvial terrace gravel and loam of Pleistocene age.

The Anacacho age of the brownish-yellow marl and limestone, which yielded the major portion of the fauna, was at first not suspected. It seemed from the geographic and hypsographic position of the exposed mass that it should not include rocks younger than the Austin chalk. The fauna is made up mainly of undescribed species. However, certain species that appear to be identical with species in the Anacacho limestone, notably two undescribed echinoids, are accepted as indicating the Anacacho age of the fauna. One of the Anacacho echinoids is a Hemiaster from a locality on the Grosenbacher road 1.2 miles southeast of Potranco school, Bexar County (U. S. G. S. 17990), and the other is an Echinobrissus (U. S. G. S. 7709) from Sabinal River a few hundred yards downstream from the Southern Pacific R. R. bridge, a mile west of Sabinal, Uvalde County (U. S. G. S. 7709).

The geologic conditions in Uvalde County and ad- jacent areas have been described by Vaughan (1900, pp. 1-7, maps) and later by Lonsdale (1927, pp. 15-35, 103-110, 124-126, pl. 1), Getzendaner (1931, pp. 93-111, fig. 10), and Sayre (1936, pp. 21-32, 53-58, pl.1). These writers have shown that during and following Cretaceous time a broad area in the vicinity of Uvalde, frequently spoken of as the Uvalde uplift (see geologic map of Texas, 1937), was uplifted and subjected to intensive intrusive and extrusive volcanic activity. This is indicated at many places by sills, stocks, larger masses of basic igneous rocks, and water-laid tuffaceous rock, and by many faults which cut and displace the sedimentary rocks of the area; columnar lava is well-developed in some of the stocks. If there had not been disturbances of this sort one would not expect to find an exposure of the Anacacho limestone at the locality on Nueces River described above. However, in view of the known dislocations in the area, some of rhich have operated to raise the rocks above and some to lower them below their otherwise normal positions, the presence of the Anacacho at the place indicated may be readily accounted for by downfaulting, by collapse of the rocks in sinks connected with limestones of the Comanche series, which underlie the Uvalde area, or by other structural disturbances associated with the igneous activity. The exact stratigraphic position of the fossiliferous brownish-yellow limestone within the Anacacho limestone is not determined, but it probably belongs near the base of that unit.

- My purpose in describing the species, Venericardia uvaldana, at this time is to facilitate comparison with the closely analogous species, V. subterrea, from depths of 3,931 to 3,937 feet and 3,970 to 3,980 feet in the well of Baker, Ridgway, et al., McRae No. 1, in Hinds County, Miss. (See p. 167.) The two speries are so closely similar in form and ornamentation as to suggest approximate, though not necessarily exact, synchroneity of the containing rocks at the two widely separated localities.

\section{SYSTEMATIC DESCRIPTION}

Phylum MOLIUSCA

Class PELECYPODA

Order TELEODESMACEA

Family CARDITIDAE

Genus VENERICARDIA Lamarck, 1801

Venericardia uvaldana Stephenson, n. sp.

Plate 31, figures $\mathbf{4 7 - 5 0}$

Shell of medium size and inflation, thick-rvalled, subcircular in outline, subequilateral, equivalve; a broad, gentle radial swell passes from the beak to the middle of the ventral margin. Beaks prominent, incurved, prosogyrate, approximate, situated a little in advance of the midlength. Greatest inflation about midway of the length, above the midheight, from which point the surface rounds off broadly to the margins in all directions, except toward the dorsal slopes, which, near the beaks, are steep and overhanging. Lumule small, short, outlined by a deeply incised groove, which widens noticeably toward the distal end. Escutcheon wanting. Surface cancellated by radial ribs and concentric grooves. The radial ribs number 32 on the holotype ànd are broadly curved in trend with the concave side toward the front; they are flattish-topped and are ssparated by 
deep, much narrower interspaces; the ribs are coarsest on the anterior half of the surface and become progressively narrower and more crowded toward the rear. The concentric grooves are much narrower and shallower than the radial interspaces and are so spaced as to cut the surface into squarish and rectangular, flattishtopped nodes.

Dimensions of the holotype, a left valve: Length 25 $\mathrm{mm}$., height $27 \mathrm{~mm}$., convexity $9 \mathrm{~mm}$. A smaller specimen measures: Length $19.6 \mathrm{~mm}$., height $20 \mathrm{~mm}$., convexity $6.8 \mathrm{~mm}$.

The ligamental groove is narrow and is rather deeply submerged beneath a sharp, overhanging margin. The nymph is very narrow and deeply submerged. The hinge is heavy for the size of the shell. On the left valve are two cardinal teeth; the anterior cardinal is short, thick, trigonal, prominent, and faintly striated in the direction of movement on the anterior and posterior faces; the posterior cardinal is long, narrow, strongly oblique, broadly arched in trend, finely striated on the sides in the direction of movement; the cardinals are separated by a wide, deep, oblique, elongated trigonal socket. A squeeze made from the hinge of the left valve indicates the presence of a large medial cardinal in the right valve with the anterior and posterior cardinals so much reduced as to be practically obsolete. On the hinge plate just below the distal end of the groove delineating the lunule is a short, distinct protuberance which may function as a weak pseudolateral. Adductor scars of medium size, subequal, situated high in the shell. Pallial line entire. Inner margin strongly crenulated, the indentations marking the ends of the radial ribs.

Compared with Venericardia subterrea (p. 167, pl. 31, figs. $34-37$, of this paper), the species is a little more convex, has a stronger development of the surface ornamentation, a somewhat larger lunule, and a broader and less oblique anterior cardinal tooth in the left valve; the lunule, though larger and less steep, is of the same sort as in subterrea. The two species are closely related.

Types: Holotype, a left valve, U. S. N. M. 103981; nine paratypes, including a medium-sized left valve, three juvenile left valves, four internal molds, two of which are of right and two of left valves, and one incomplete external mold of a right valve, U. S. N. M. 103982.

Occurrence: Bed of Nueces River, 0.3 mile upstream from the bridge of the Southern Pacific R. R., Uvalde County, Tex. (U. S. G. S. 15340).

\section{BIBLIOGRAPHY}

DANe, C. H., Upper Cretaceous formations of southwestern Arkansas: Arkansas Geol. Survey Bull. 1, 215 pp., 29 pls., 1929.
GARDNER, JULIA A., The nomenclature of the superspecific groups of Corbula in the lower Miocene of Florida: Nautilus, vol. 40, No. 2, pp. 41-47, 1926.

Getzendaner, F. M., Uvalde County : [Texas Univ., Bur. Econ. Geology ], Min. Res. Texas, pp. 93-111, figs. 10, 11, 1931.

HoweLr, B. F., Hamulus, "Falcula," and other Cretaceous Tubicola of New Jersey: Acad. Nat. Sci. Philadelphia Proc., vol. 95, pp. 139-166, pls. 19, 20, 1943.

Huld, J. P. D., Prothro salt dome, Bienville Parish, La.: Am. Assoc. Petroleum Geologists Bull., vol. 9, No. 5, pp. 904-906, 1925.

LoNsDate, J. R., Igneous rocks of the Balcones fault region of Texas: Texas Univ. Bull. 2744, 178 pp., 9 pls., 1927.

Monroe, W. H., Pre-Tertiary rocks from deep wells at Jackson, Miss.: Am. Assoc. Petroleum Geologists Bull., vol. 17, No. 1, pp. 38-51, 1933.

Monroe, W. H., and ToLer, H. N., The Jackson gas field ard the State deep test well : Mississippi Geol. Survey Bull. 36, 52 pp., frontispiece, 1 pl., 5 figs., 1937.

Monton, S. G., Synopsis of the organic remains of the Cretareous group of the United States, 88 pp., 19 pls., 1834.

Ross, C. S., MISER, H. D., and STEPHEN Son, L. W., Water-lai canic rocks of early Upper Cretaceous age in southwe wtern Arkansas, southeastern Oklahoma, and northeastern $\mathbf{T}: \mathbf{X a s}$ : U. S. Geol. Survey Prof. Paper 154-F, pp. 175-202, 1929.

Russer., R. D., Cretaceous outcrops in Louisiana: Oil, vol. 1, No. 2, pp. 32-34, 1941.

SAYRE, A. N., Geology and ground-water resources of Uvalde and Medina Counties, Tex.: U. S. Geol. Survey Water-Supply Paper 678, 146 pp., 11 pls., 1936.

SpooNer, W. C., Interior salt domes of Louisiana: Am. Assoc. Petroleum Geologists Bull., vol. 10, No. 3, pp. 217-292, 1 ?26.

StEPhenson, L. W., Cretaceous formations of North Carolina, with supplemental chapter on decapod crustaceans, by Mary J. Rathbun: North Carolina Geol. Survey, vol. 5, 604 pp. ' 102 pls., 1923.

- - Upper Cretaceous fossils from Georges Bank (including species from Banquereau, Nova Scotia): Geol. Soc. America Bull., vol. 47, pp. 367-412, 5 pls., 1936.

- - The larger invertebrate fossils of the Navarro group of Texas: Texas Univ. Pub. 4101, 641 pp., 95 pls., 1941.

—, Fulpia, a new Upper Cretaceous bivalve mollusk from ...exas and Maryland: Jour. Paleontology, vol. 20, No. 1, pp. fR-71, pl. 12, 1946.

Stephenson, L. W., and Monrok, W. H., The Upper Cretaseous deposits: Mississippi Geol. Survey Bull. 40, 266 pp., 15 pls., 1940.

Vaughan, T. W., U. S. Geol. Survey Geol. Atlas, Uvalde folio (No. 64), 7 pp., maps, 1900.

Vaughan, T. W., and Cole, W. S., Cretaceous orbitoidal Foraminifera from the Gulf States and Central America: Nat. Acad. Sci. Proc., vol. 18, No. 10, pp. 609-616, 2 pls., 1932.

- A restudy of the foraminiferal genera Pseudorbitoide? and Vaughanina: Jour. Paleontology, vol. 17, No. 1, pp. 97-100, pls. $17,18,1943$.

Vokes, H. E., Molluscan faunas of the Domengine and Arroyo Hondo formations of the California Eocene: New York Acad. Sci. Annals, vol. 38, 246 pp., 22 pls., 1939.

- Protodonax, a new Cretaceous molluscan genus: Jour. Paleontology, vol. 19, No. 3, pp. 295-308, pls. 46, 47, 1945.

WADE, BRUCE, The fauna of the Ripley formation on Coon C"eek, Tenn. : U. S. Geol. Survey Prof. Paper 137, 272 pp., 72 pIs., 1926. 
, 


\section{PLATES 31-33}




\section{PLATE 31}

\section{Fossils from the Avent well, Grenada County, Miss.}

Figures 1, 2. Serpula sp. (p. 169). Tubes, X 2 (U. S. G. S. 18930; U. S. N. M. 104012).

Figures 3, 4. Hamulus onyx Morton (p. 169).

3. Incomplete tube, $\times 2$ (U. S. G. S. 18894 ; U. S. N. M. 104014),

4. Incomplete tube, $\times 2$ (U. S. G. S. 18930 ; U. S. N. M. 104014a).

FIgURES 5-7. Hamulus? sp. (p. 170). Operculum, $\times 2$ (U. S. G. S. 18894; U. S. N. M. 104016).

FIGURe 8. Membranipora sp. (p. 170). A poorly preserved speci men, $\times 3$ (U. S. G. S. 18930; U. S. N. M. 104017).

FTGUREs 9, 10. Nucula nulla n. sp. (p. 170). Holotype, $\times 3 \frac{1}{1} 2$ (U. S. G. S. 18894 ; U. S. N. M. 104018 ).

Figure 11. Barbatia? sp. (p. 171). A poorly preserved right valve, $\times 11 / 2$ (U. S. G. S. 18894; U. S. N. M. 104021).

FIGURES 12, 13. Breviarca sp. (p. 171). Exterior and interior of left valve, X 2 (U. S. G. S. 18894; U. S. N. M. 104023 ).

FIgURĖs 14-16. Trigonarca munda n. sp. (p. 171).

14. Holotype, a left valve, $\times 1$ (U. S. G. S. 18894 ; U. S. N. M. 104024).

15, 16. Top and interior views of holotype, $\times 1 \frac{1}{2}$.

Fossils from the McRae well, Hinds County, Miss. (U. S. G. S. 18884)

FIGURe 17. Madreporaria (p. 164). A fragment, $\times 4$ (U. S. N. M. 103984).

Figures 18, 19. Crinoidea (p. 165).

18. Fragment of column, $\times 5$ (U. S. N. M. 103985).

19. Cross section of same column, $\times 10$.

Figures 20, 21. Bryozoa (Cheilostomata) (p. 165).

20. Fragment, $\times 4$ (U. S. N. M. 103987).

21. Inner surface of wall, $\times 4$ (U. S. N. M. 103987)

Figure 22. Barbatia? sp. (p. 165). Left valve, $\times 5$ (U. S. N. M. 103988).

Figures 23-26. Vetoarca hindsana n. sp. (p. 165).

23, 24. Exterior and interior of paratypes, left valves, $\times 2$ (U. S. N. M. 103990).

25, 26. Exterior and interior of holotype, a left valve, $\times 2$ (U. S. N. M. 103989).

FIgUkes 27-29. Postligata monroei n. sp. (p. 166).

27. Right valve of holotype, $\times 3$ (U. S. N. M. 103992).

28. Top view of holotype, $\times 3$.

29. Interior of a paratype, a right valve (U. S. N. M. 103994).

FIGURe 30. Inoceramus sp. (p. 166). Right valve, $\times 11 \frac{1}{2}$ (U. S. N. M. 103997).

Figures 31-33. Anomia microlirae n. sp. (p. 167). Views of the holotype, $\times 3$ and $\times 6$ (U. S. N. M. 103998).

FIgUREs 34-37. Venericardia subterrea n. sp. (p. 167).

34-36. Views of the holotype, a left valve, $\times 1 \frac{1}{2}$ (p. 167) (U. S. N. M. 104001).

37. Hinge of the right valve of a paratype, $\times 3$ (p. 167) (U. S. N. M. 104000).

FIGURe 38. Tenea? sp. (p: 168). Right valve, $\times 7$ (U. S. N. M. 104005).

FigURE 39. Turritella sp. (p. 168). A fragment, $\times 6$ (U. S. N. M. 104006).

Figure 40. "Cerithium" sp. (p. 168). A small fragment, $X 5$ (U. S. N. M. 104008).

Figures 41, 42. Odostomia micraei n. sp. (p. 168). Holotype, back and front views, $X 6$ (U. S. N. M. 104009).

FIGURES 43-46. Undetermined species of algae (p. 169).

43, 44. Fragments of stems showing tubercles, $\times 12$ (U. S. N. M. 104010)

45, 46. Views of a fragment showing constriction at joint, and cross section, $\times 10$; part below joint subsequently broken off and lost (U. S. N. M. 104010).

\section{A new Venericardia from Uvalde County, Tex. (U. S. G. S. 15340)}

FIguRes 47-50. Venericardia uvaldana n. sp. (p. 186).

47-49. Views of the holotype, a left valve, $\times 11 / 2$ (U. S. N. M. 103981).

50. A squeeze made from the hinge of the holotype, $\times 1 \frac{1}{2}$ (U. S. N. M. 103983). 

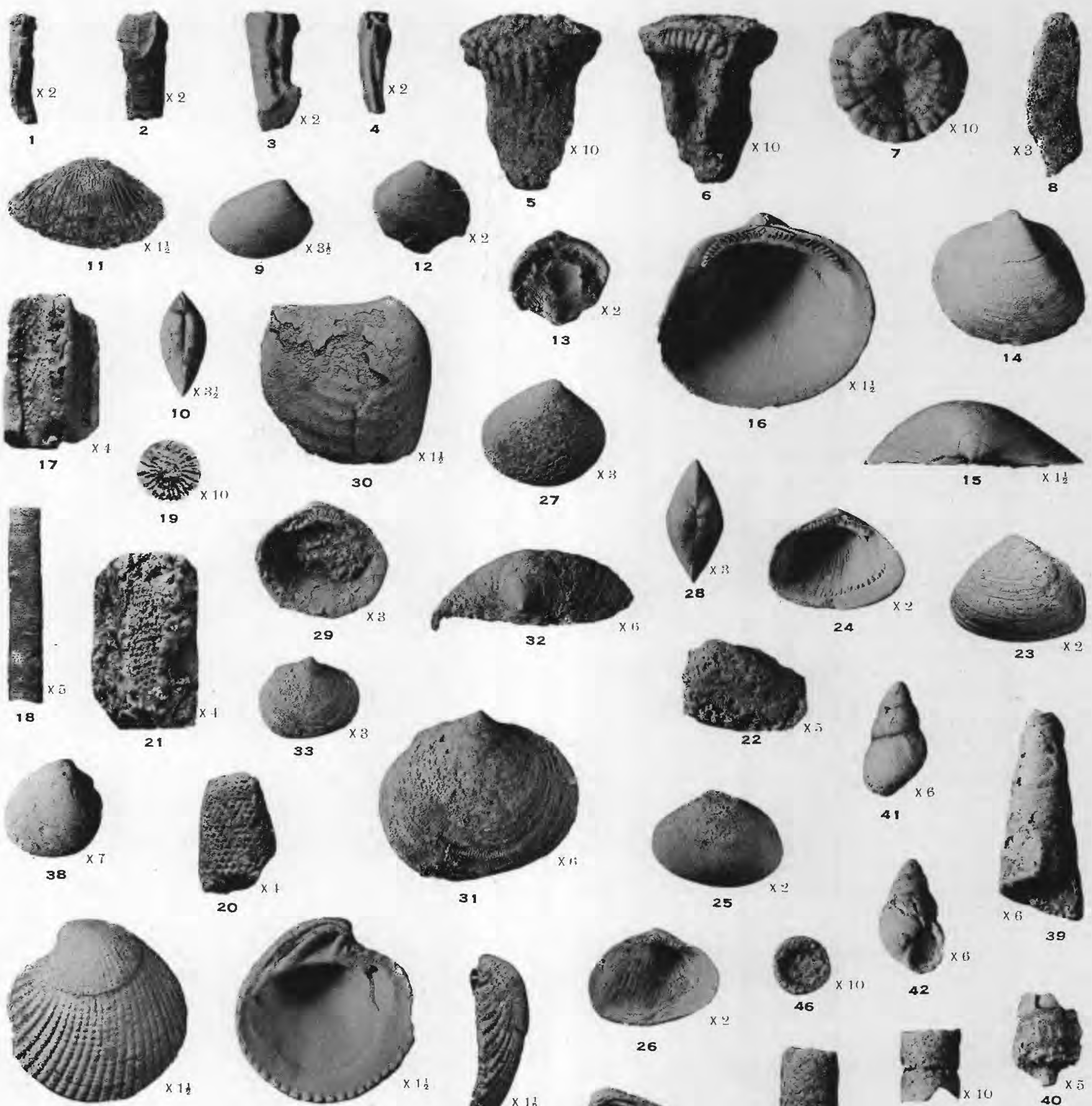

20
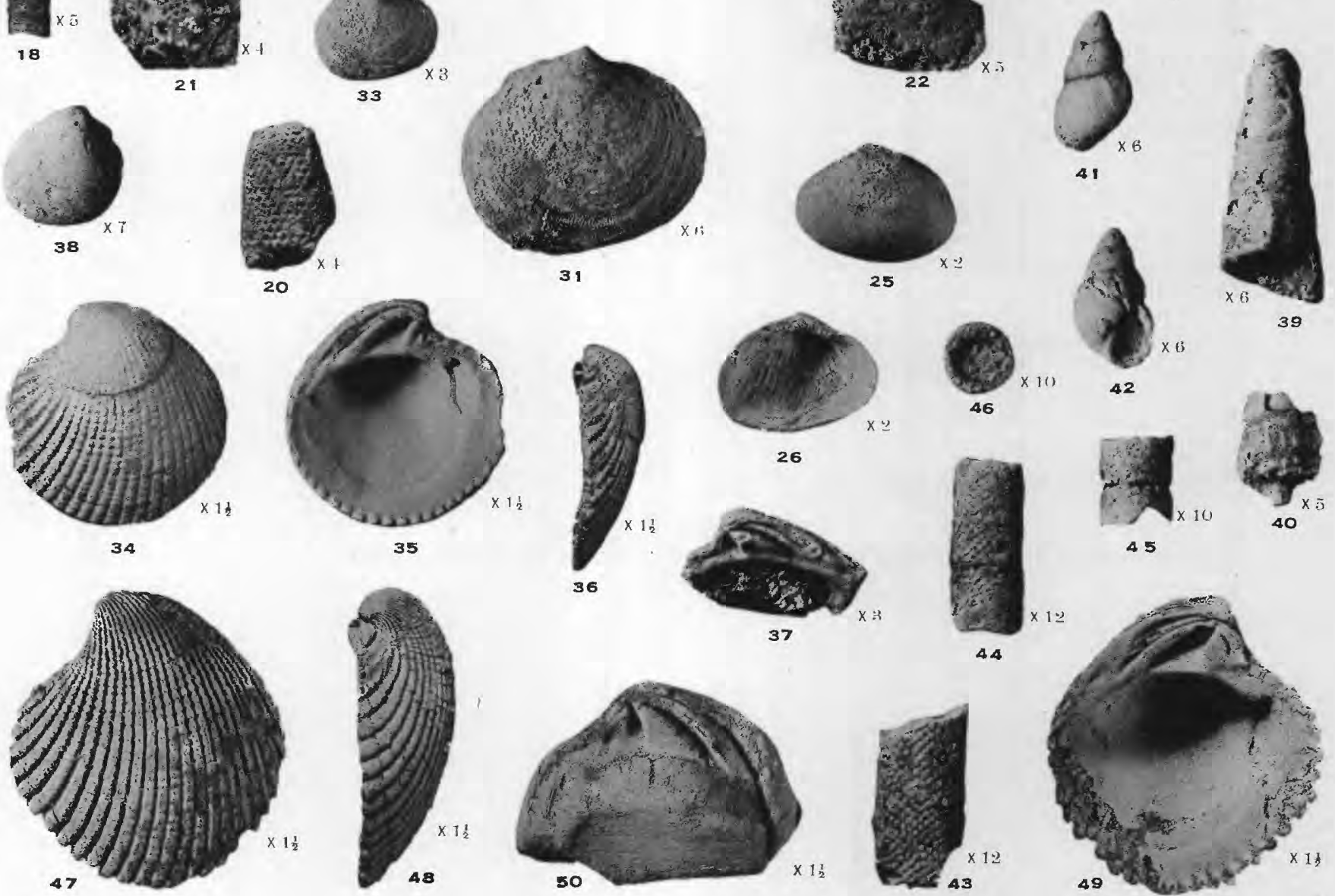

FOSSILS FROM THE AVENT AND MCRAE WELLS IN MISSISSIPPI, AND A NEW VFNERICARDIA FROM UYALDE COU \TY, TEX. 


\section{PLATE 32}

Figure 1. Tellina? sp. $a$ (p. 177). Left valve, $\times 4$ (U. S. G. S. 18894 ; U. S. N. M. 104059 ).

Figure 2. Tellina sp. $b$ (p. 177). Right valve, $\times 3$ (U. S. G. S. 18930 : U. S. N. M. 104062).

Figures 3, 4. Tellina sp. $c$ (p. 177). Right valve, $\times 2$ (U. S. G. S. 18894; U. S. N. M. 104065).

Figures 5-8. Tellina harrelli n. sp. (p. 176).

5, 6. Holotype, a right valve, $\times 3$ (p. 176) (U. S. G. S. 18930; U. S. N. M. 104055).

7, 8. Incomplete paratype, a left valve, $\times 3$ (p. 176) (U. S. G. S. 18930 ; U. S. N. M. 104056).

Figure 9. Linearia $s p$. (p. 177). Incomplete right valve, $\times 4$ (U. S. G. S. 18894; U. S. N. M. 104068).

FIgURe 10. Protodonas sp. (p. 178). Left valve, $\times 4$ (U. S. G. S. 18894; U. S. N. M. 104069).

FiquRes 11-13: Caryocorbula mississippiana n. sp. (p. 179).

11, 12. Holotype, a right valve, $\times 2$ (U. S. G. S. 18894 ; U. S. N. M. 104072).

13. A paratype, a right valve, $\times 2$ (U. S. G. S. 18894 ; U. S. N. M. 104073).

Figures 14-16. Caryocorbula morsei n. sp. (p. 179).

14, 15. Holotype, a right valve, $\times 2$ (U. S. G. S. 18930 ; U. S. N. M. 104075).

16. Paratype, a right valve, $\times 3$ (U. S. G. S. 18930 ; U. S. N. M. 104076).

FIgURe 17. Caryocorbula sp. $a$ (p. 180). Left valve, $\times 2$ (U. S. G. S. 18894; U. S. N. M. 104078).

Figures 18-20. Aphrodina sp. (p. 176).

18, 19. Incomplete right valve, $\times 1$ (U. S. G. S. 18894 ; U. S. N. M. 104054).

20. Incomplete left valve showing hinge, $\times 3$ (U. S. G. S. 18894; U. S. N. M. 104054).

FigUREs 21-25. Crassatella subterrestris n. sp. (p. 174).

21, 22. Holotype, a right valve, $\times 2$ (U. S. G. S. 18894 ; U. S. N. M. 104044).

23. A paratype, a young right valve, $X 3$ (U. S. G. S. 18930; U. S. N. M. 104046).

24, 25. Views of a complete young shell, $\times 5$ (U. S. G. S. 18930; U. S. N. M. 104046).

FIgURes 26, 27. Spisula brevis n. sp. (p. 178). Holotype, an incomplete right valve, $\times 3$ (U. S. G. S. 18894; U. S. N. M. 104070)

Figure 28. Etea? sp. (p. 174). Left valve, $\times 3$ (U. S. G. S. 18930 ; U. S. N. M. 104043).

Figures 29, 30. Fulpia? subtrigona n. sp. (p. 176). Holotype, a right valve, $\times 2$ (U. S. G. S. 18894; U. S. N. M. 104052 ).

Figures 31-33. Postligata aventi n. sp. (p. 172).

31, 32. Holotype, a right valve, $\times 2$ (U. S. G. S. 18930 ; U. S. N. M. 104025)

33. A paratype, a left valve, $\times 4$ (U. S. G. S. 18894; U. S. N. M. 104026).

Figures 34-36. Cardium (Trachycardium) grenadense n. sp. (p. 175).

34. Holotype, a left valve, $\times 2$ (p. 175) (U. S. G. S. 18894; U. S. N. M. 104048).

35, 36. Paratypes, left and right valves to show hinges, $\times 2$ (p. 175) (U. S. G. S. 18894; U. S. N. M. 104049).

Figure 37. Inoceramus sp. (p. 173). Right valve, $\times 1$ (U. S. G. S. 18894; U. S. N. M. 104030).

FigUREs 38-40. Anomia acutilinearis n. sp. (p. 174).

38. Holotype, a left valve, $\times 3$ (U. S. G. S. 18894 ; U. S. N. M. 104039).

39, 40. Paratypes, $\times 3$ and $\times 5$ (U. S. G. S. 18894; U. S. N. M. 104040).

Figures 41-43. Pecten (Camptonectes) sp. (p. 173).

41. Fragment of left valve, $\times 3$ (U. S. G. S. 18930 ; U. S. N. M. 104035).

42, 43. Fragments of a right and a left valve, $\times 3$ (U. S. G. S. 18894; U. S. N. M. 104036). 

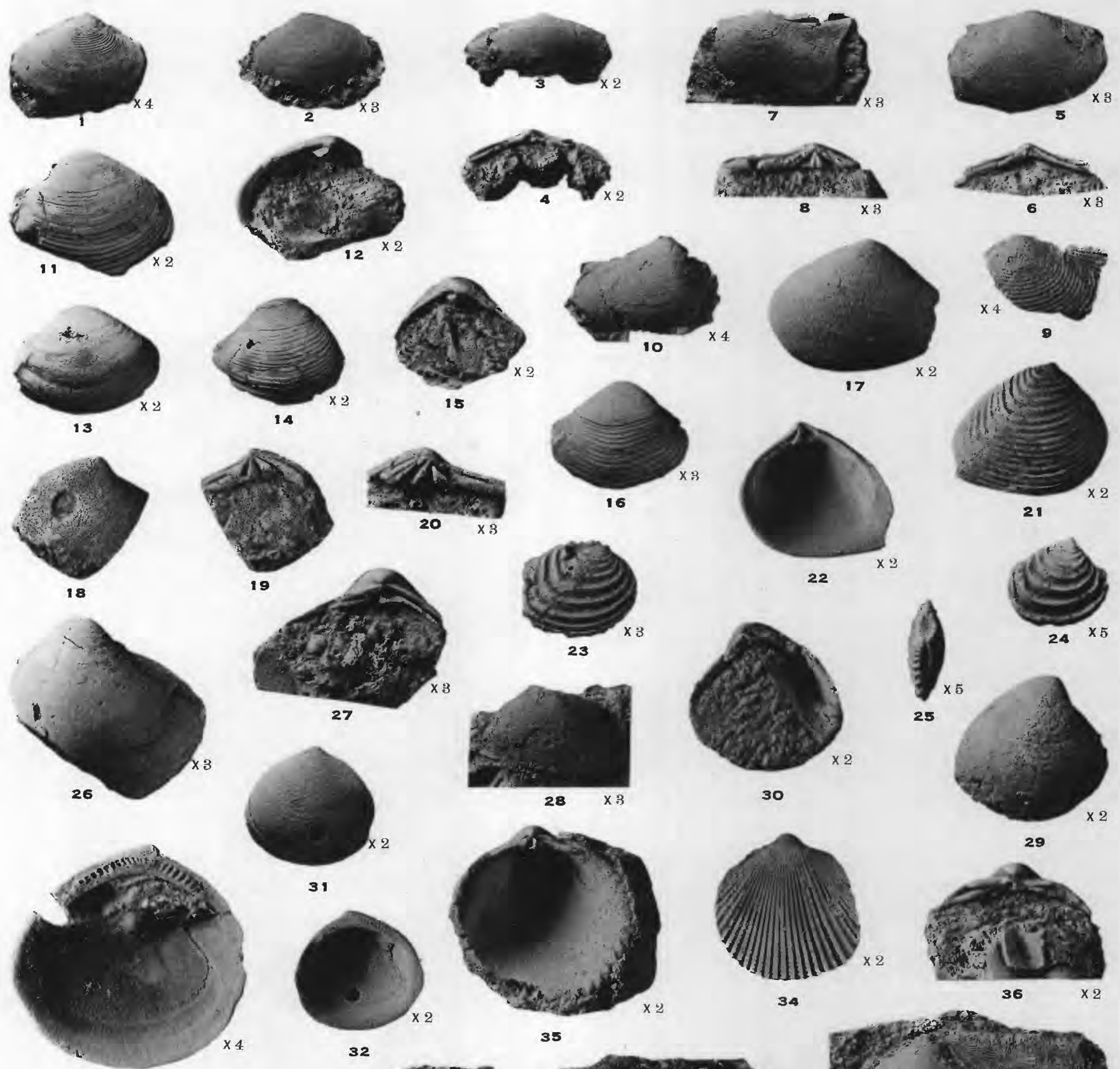

34
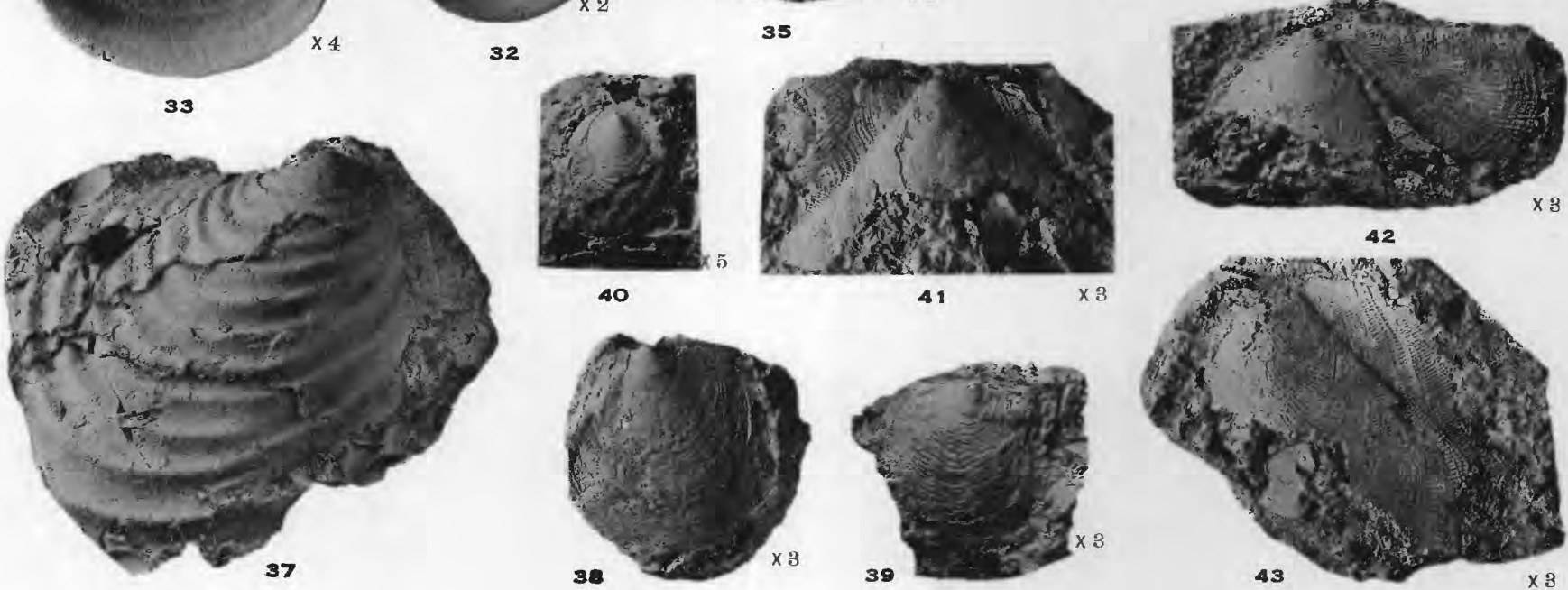

FOSSILS FROM THE AVENT WELL IN MISSISSIPPI. 


\section{PLATE 33}

Figures 1-3. Nerita nodosa n. sp. (p. 180). Views of the holotype, $\times 4$ (U. S. G. S. 18894 ; U. S. N. M. 104085 ).

Figures 4-6. Nerita denticulata n. sp. (p. 181). Views of the holotype, $\times 4$ (U. S. G. S. 18894; U. S. N. M. 104088).

Figures 7, 8. Natica sp. (p. 181). Back and front views, $\times 2$ (U. S. G. S. 18894 ; U. S. N. M. 104090).

Figures 9, 10. Natica? sp. (p. 181). Rack and front views, $\times 6$ (U. S. G. S. 18894; U. S. N. M. 104091 ).

Figures 11, 12. Melanella (Eulima?) parva n. sp. (p. 181). Back and front views of the holotype, X 5 (U. S. G. S. 18894 ; N. S. N. M. 104089).

Figures 13-15. Turritella toleri n. sp. (p. 182). Views of the hol otype, $\times 3$ (U. S. G. S. 18894; U. S. N. M. 104092).

Figures 16-18. Turritella magnoliana n. sp. (p. 182).

16, 17. Back and front views of the holotype, $\times 3$ (U. S. G. S. 18894; U. S. N. M. 104095).

18. Fragment of a paratype, $\times 3$ (U. S. G. S. 18894; U. S. N. M. 104096).

Figures 19-22. "Cerithium" imlayi n. sp. (p. 183).

19. Holotype, $\times 3$ (U. S. G. S. 18894 ; U. S. N. M. 104099).

20-22. Views of two paratypes, X 3 (U. S. G. S. 18894; U. S. N. M. 104100).

Figtre 23. "Cerithium" sp. $a$ (p. 183). A fragment, $\times 4$ (U. S. G. S. 18930 ; U. S. N. M. 104103).

Figure 24. "Cerithium" sp. $b$ (p. 183). A soung incomplete speci men, $X 4$ (U. S. G. S. 18894; U. S. N. M. 104104 ).

FigCrias 25-32. Pugnellus caloaris n. sp. (p. 183).

25, 26. Front and back views of the holotype, $\times 1$ (U. S. G. S. 18894 ; U. S. N. M. 104105).

27-32. Paratypes (U. S. G. S. 18894; U. S. N. M. 104106).

27. Back view of an adult, $\times 1$.

28 , 29. Front anil back views of expanded lip and spur, $\times 1$.

30,31 . Front and back views of a shell at stage just preceding the expansion of the outer lip, $\times 1$.

32. Apex of a young shell, $\times 5$.

Figures 33-36. Paladmete caveola n. sp. (p. 184).

33, 34. Back and front views of the holotype, $\times 3$ (U. S. G. S. 18894 ; U. S. N. M. 104110).

35. A larger incomplete paratype, $\times 2$ (U. S. G. S. 1\&894; U. S. N. M. 104111).

36. A young paratype, $\times 5$ (U. S. G. S. 18930 ; U. S. N. M. 104113).

Figures 37, 38. Paladmete? sp. (p. 185). Back and front views, $\times 10$ (U. S. G. S. 18894 : U. S. N. M. 104114).

Figures 39, 40. "Fusinus" sp. (p. 185). Front and back views, $X 6$ (U. S. G. S. 18894; U. S. N. M. 104115).

Figures 41, 42. Hercorhyneus? sp. (p. 184). Front and back views, X 3 (U. S. G. S. 18894; U. S. N. M. 104109). 

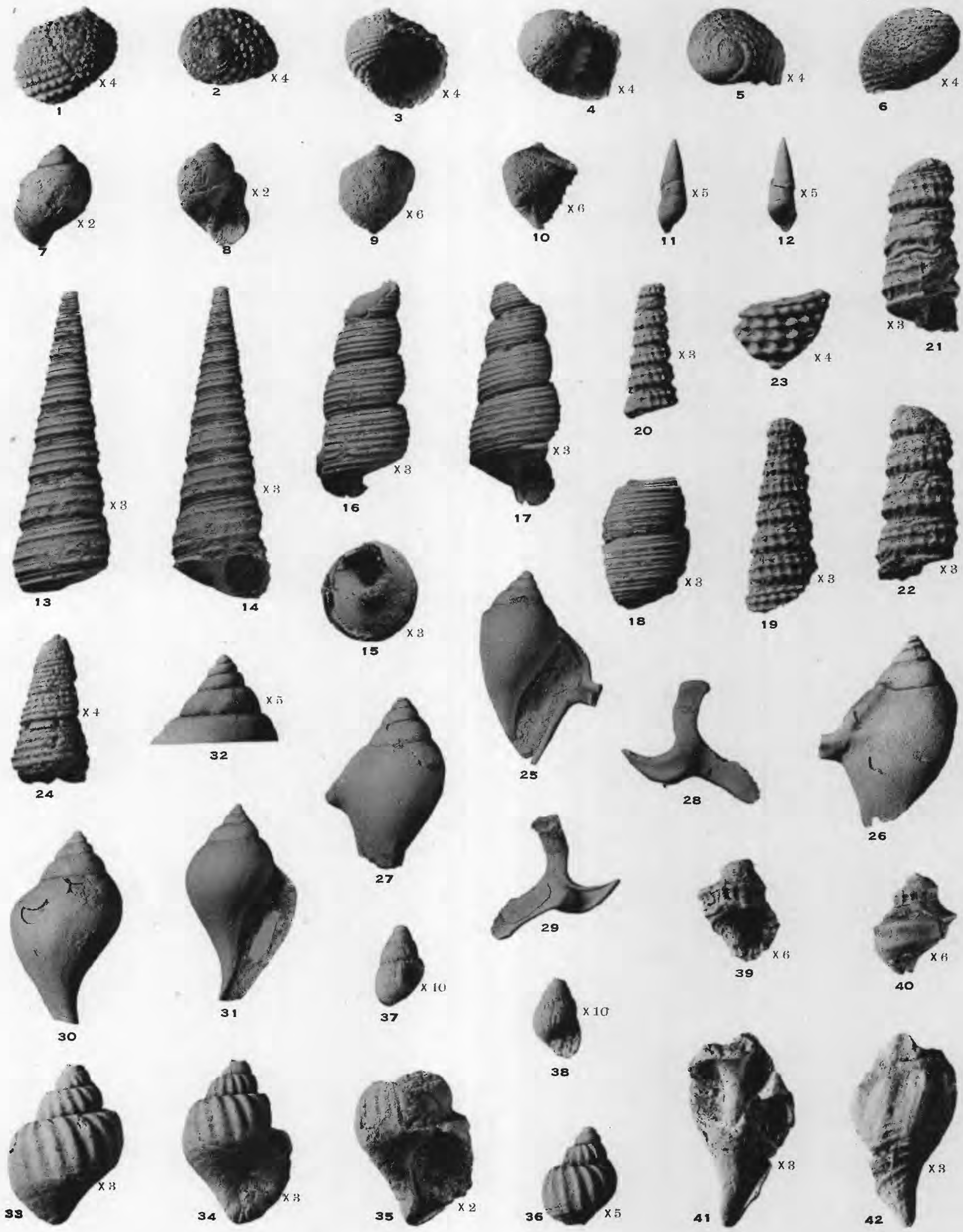

FOSSILS FROM THE AVENT WELL IN MISSISSIPPI. 



\section{INDEX}

acutilinearis n. sp., Anomia alabamiensis, Caryocorbula

Corbula.

Anomia acutilinearis n. sp

Anomiidae..

Anthozon-

Arcidae.

aventi n. sp., Postligata

barabini, Inoceramus

Barbatia? sp.....-

Breviarca congesta

sp.

brevis n. sp., Spisula

Bryozoa . microlirae $n . s p$

Aphrodina sp

Page 167,174, pl. 32 179

179
179

67,174, pl. 32 167, pl. 31

167, 174

.. 164-165

176, pl. 32 65-166, 171-172 - 172, pl. 32

B

173

165,171 , pl. 31

$171, \mathrm{pl} .31$

178-179, pl. 32

.. 165,170

C

calcaris n. sp., Pugnellus

$164,183-184$, pl. 33

Camptonectes

cancellaria, Paladmete

$173-174$

Cardiidae.

Carditidae

$175-176$

Cardium (Trachycardium) grenadense $n$. sp $\ldots 164,175-176$, pl. 32

Caryocorbula alabamiensis . mississippiana n. sp morsei n. sp. ....... 32

oxynema $\ldots . . . \ldots 180$

sp. $a_{\ldots} \ldots \ldots \ldots \ldots$

sp. $b$

sp. $c$ c 180

neola n. sp., Paladmete

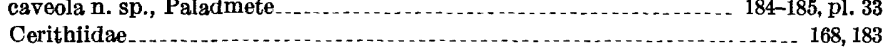

"Cerithium" imlayi n. sp ............................................ 183, pl, 33

sp

sp. $a$.

sp. $b \ldots \ldots$. 33

Cheilostomata

Cnidaria _ 164-165

congesta, Breviarca

Corbula alabamiensis........

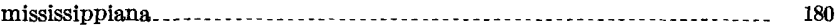

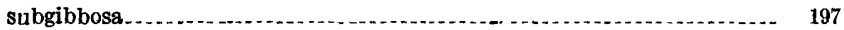

(Corbula) sulcata

Corbulidae.

Crassatella subterrestris n. sp_...........

vadosa $\ldots \ldots \ldots$

Crassatellidae . . . .

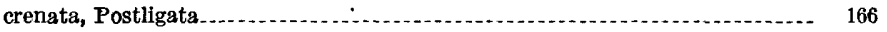

Crinoidea

Cucullaea

cuvierii, Inoceramus

D

Dentaliidae

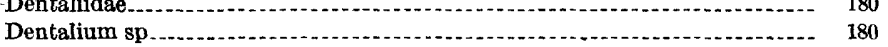

denticulata n. sp., Nerita..... 181, 33

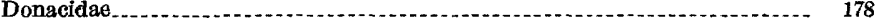

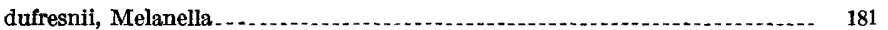

Echinobrissus 186

Etea? sp.

Exogyra? sp. 173

Fulpia? subtrigona n. sp

176, pl. 32

Fusidae

"Fusinus" sp.

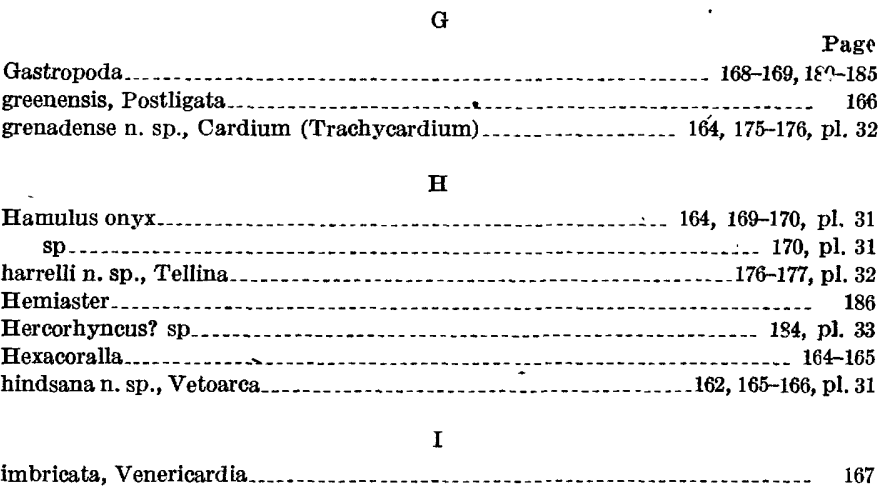

Venus.

mlayi n. sp., "Cerithium"-_...... 183, pl. 33

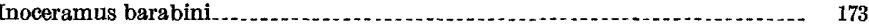

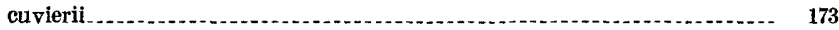
sp ........... 162, 164, 166-167, 173, pls. 31,32

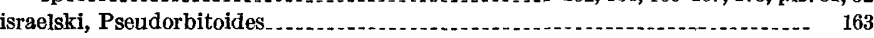

K

Kirk, Edwin, cited

165

Linearia sp.

L

177-178, pl. 32 Linnaean Society, proceedings, quotation from .............................. 173 M

maconensis, Trigonarca

Mactridae .......... 17? 179

Madreporaria

magnoliana n. sp., Turritella ............................... 33

mcraei n. sp., Odostomia $\ldots$

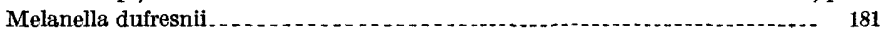

(Eulima?) parva n. sp

Melanellidae _... 181

Membranipora sp........................... 170, pl. 31

Membraniporidae........ 170

microlirae n. sp., Anomia

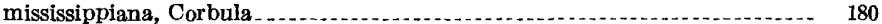

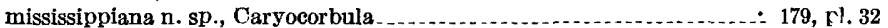

monroei n. sp., Postligata ............ 162, 166, 172, r. 31

morsei n. sp., Caryocorbula ........ 179-180, l. 32

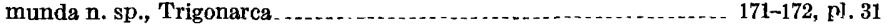

Mytilidae

$\mathbf{N}$

"Natica" unidentified specimens of

Naticidae $\ldots . . . \ldots 1$

Nerita denticulata n. sp......... Fl. 33

nodosa n. sp ........ 180-181, Fl. 33

Neritidae ................ 18C-181

nodosa n. sp., Nerita:

Nucula nulla n. sp............................................... 170-171, Fl. 31

Nuculidae .

nulla n. sp., Nucula

marai n. sp _.......... 168-169, rl. 31

onyx, Hamulus................ 164, 169-170, pl. 31

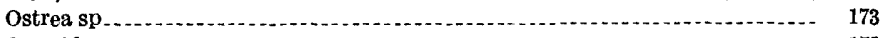

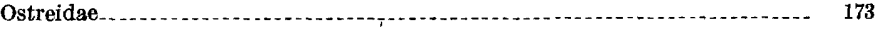

oxynema, Caryocorbula

Paladmete cancellaria

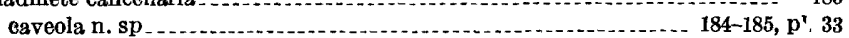

?sp........... 185, , pl. 33 
Page

Paladmetidae

parva n. sp., Melanella (Eulima?)

184-185

181, pl. 33

Pecten (Camptonectes) sp

Pectinidae

Pedalionidae . .................. 166-167, 172-173

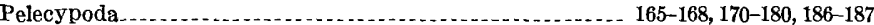

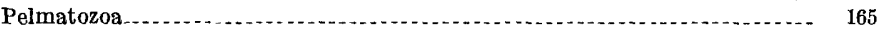

Pleurofloridae

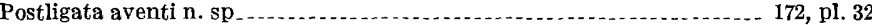

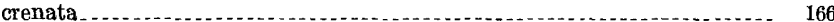

greenensis_. . . .

monroei n. sp . . ...... 162, 166, 172, pl. 31

schalki.

wordeni . . . . .

Protodonax sp.................... 178, pl, 32

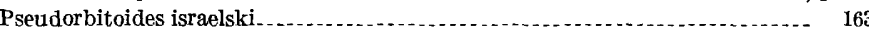

Pteria" sp . . .

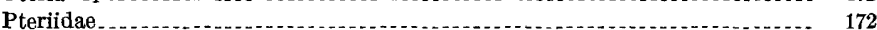

Pugnellus calcaris n. sp

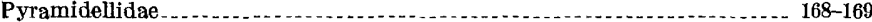

184

$\mathbf{R}$

162,163

Ross, C. S., cited

$\mathbf{S}$

Scaphopoda

schalki, Postligata

180

(69, pl. 31

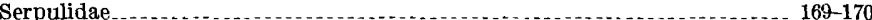

solida, Spisula $\ldots$

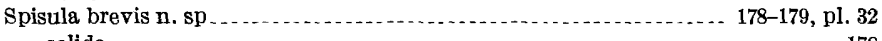
solida

Strombidae

178

(183-184

subgibbosa, Corbula subterrea n. sp., Venericardia.

subterrestris n. sp., Crassatella

subtrigona n. sp., Fulpia?

sulcata, Corbula (Corbula)

Tellina harrelli $\mathrm{n} . \mathrm{sp}$

unidentified specimens

tolen. sp., Turritella

munda n. sp............. 31

Turritella magnoliana n. sp ..................................... 182-183, pl. 33 sp.

toleri n. sp

vertebroides

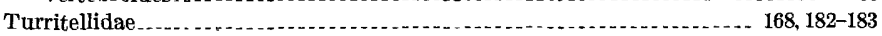

$\mathrm{U}$

uvaldana n. sp., Venericardia _.................... 162, 163, 168, 185, 186-187, pl. 31

V

vadosa, Crassatella.

Venericardia imbricata

subterrea $\mathrm{n} . \mathrm{sp}$

uvaldana n. sp

Veneridae. .

Vetoarca hindsana n. sp . . . .

Volsella sp

wordeni, Postligata

W

$\mathrm{O}$ 